\title{
Nationale parlementen in de Europese Unie
}

\author{
Citation for published version (APA):
}

Wolf, S. P. M. (2022). Nationale parlementen in de Europese Unie: Een juridische vergelijking tussen het Nederlandse en Duitse parlement in Europese aangelegenheden. [, Maastricht University]. Boom Juridisch. https://doi.org/10.26481/dis.20220203sw

Document status and date:

Published: 01/01/2022

DOI:

10.26481/dis.20220203sw

Document Version:

Publisher's PDF, also known as Version of record

\section{Please check the document version of this publication:}

- A submitted manuscript is the version of the article upon submission and before peer-review. There can be important differences between the submitted version and the official published version of record.

People interested in the research are advised to contact the author for the final version of the publication, or visit the DOI to the publisher's website.

- The final author version and the galley proof are versions of the publication after peer review.

- The final published version features the final layout of the paper including the volume, issue and page numbers.

Link to publication

\footnotetext{
General rights rights.

- You may freely distribute the URL identifying the publication in the public portal. please follow below link for the End User Agreement:

www.umlib.nl/taverne-license

Take down policy

If you believe that this document breaches copyright please contact us at:

repository@maastrichtuniversity.nl

providing details and we will investigate your claim.
}

Copyright and moral rights for the publications made accessible in the public portal are retained by the authors and/or other copyright owners and it is a condition of accessing publications that users recognise and abide by the legal requirements associated with these

- Users may download and print one copy of any publication from the public portal for the purpose of private study or research.

- You may not further distribute the material or use it for any profit-making activity or commercial gain

If the publication is distributed under the terms of Article $25 \mathrm{fa}$ of the Dutch Copyright Act, indicated by the "Taverne" license above, 
Nationale parlementen in de Europese Unie 
Omslagontwerp: Textcetera, Den Haag

Opmaak binnenwerk: Ambrac, Deventer

(C) 2022 S.P.M. Wolf | Boom juridisch

Behoudens de in of krachtens de Auteurswet gestelde uitzonderingen mag niets uit deze uitgave worden verveelvoudigd, opgeslagen in een geautomatiseerd gegevensbestand, of openbaar gemaakt, in enige vorm of op enige wijze, hetzij elektronisch, mechanisch, door fotokopieën, opnamen of enige andere manier, zonder voorafgaande schriftelijke toestemming van de uitgever.

Voor zover het maken van verveelvoudigingen uit deze uitgave is toegestaan op grond van artikel $16 \mathrm{~h}$ Auteurswet of de reprorechtregeling van Stichting Reprorecht dient daarvoor een billijke vergoeding te worden voldaan aan Stichting Reprorecht (Postbus 3051, 2130 KB Hoofddorp, www.reprorecht.nl). Voor het verveelvoudigen en openbaar maken van (een) gedeelte(n) uit deze uitgave als toelichting bij het onderwijs, bijvoorbeeld in een (digitale) leeromgeving of een reader (art. 16 Auteurswet), dient een regeling te worden getroffen met Stichting Uitgeversorganisatie voor Onderwijslicenties (Postbus 3060, 2130 KB Hoofddorp, www.stichting-uvo.nl).

No part of this book may be reproduced in any form, by print, photoprint, microfilm or any other means without written permission from the publisher.

De handelseditie van dit boek wordt uitgegeven door Boom juridisch.

ISBN 978-94-6290-702-7

ISBN 978-94-6094-240-2 (e-book)

NUR 823

www.boomjuridisch.nl 


\title{
NATIONALE PARLEMENTEN IN DE EUROPESE UNIE
}

\author{
EEN JURIDISCHE VERGELIJKING TUSSEN HET NEDERLANDSE EN \\ DUITSE PARLEMENT IN EUROPESE AANGELEGENHEDEN
}

\author{
Proefschrift
}

ter verkrijging van de graad van doctor aan de Universiteit Maastricht, op gezag van de Rector Magnificus, prof. dr. Pamela Habibović volgens het besluit van het College van Decanen, in het openbaar te verdedigen op donderdag 3 februari 2022 om 13.00 uur

door

Sofie Petra Marij Wolf 


\section{Promotor}

Prof. mr. dr. A.W. Heringa

\section{Copromotor}

Dr. S. Hardt

\section{Beoordelingscommissie}

Prof. dr. B.H. van den Braak (voorzitter)

Prof. dr. J.Th.J. van den Berg

Prof. mr. dr. A. van den Brink (Universiteit Utrecht)

Prof. mr. dr. W. van der Woude (Rijksuniversiteit Groningen) 
Voor mijn ouders 



\section{N H O U D S O P G AVE}

$\begin{array}{lr}\text { Hoofdstuk } 1 \text { Inleiding } & 13\end{array}$

$\begin{array}{lll}1.1 & \text { Aanleiding } & 13\end{array}$

$\begin{array}{ll}1.2 & \text { Landenkeuze } 20\end{array}$

1.3 Periodekeuze 22

1.4 Onderzoeksvraag 22

$\begin{array}{lll}1.5 & \text { Onderzoeksmethode } & 25\end{array}$

$\begin{array}{lll}1.6 & \text { Opbouw } & 26\end{array}$

Hoofdstuk 2 Van Europees naar nationaal 29

$\begin{array}{ll}2.1 & \text { Inleiding } \\ 2.29\end{array}$

2.2 Nationale parlementen in de Europese Unie 30

$\begin{array}{lll}2.2 .1 & \text { Europees perspectief } & 30\end{array}$

$\begin{array}{ll}\text { 2.2.2 Nationaal perspectief } & 33\end{array}$

2.3 Welke documenten worden verstrekt? 33

2.4 Parlementaire invloed op Europese ontwerpwetgeving 36

2.4.1 Het Barroso-initiatief en de politieke dialoog 36

$\begin{array}{lll}2.4 .1 .1 & \text { Nieuwe Europese wetgeving } & 37\end{array}$

$\begin{array}{lll}2.4 .1 .2 & \text { Nationale parlementen } & 38\end{array}$

2.4.1.3 Beoordeling van de politieke dialoog $\quad 40$

2.4.2 Gelekaartprocedure 44

2.4.2.1 'Groene' en 'rode' kaart 47

2.4.2.2 Tweede Kamer en Eerste Kamer 50

2.4.2.3 Bundestag en Bundesrat $\quad 51$

2.4.2.4 Drie gele kaarten $\quad 52$

2.5 Interparlementaire samenwerking 56

2.5.1 Het Europees Parlement $\quad 57$

2.5.2 Conferentie van Voorzitters van de parlementen van de Europese Unie $\quad 59$

$\begin{array}{lll}2.5 .3 & \text { COSAC } & 60\end{array}$

2.5.4 Interparlementaire Commissiebijeenkomsten $\quad 62$

2.5.5 Gezamenlijke Commissiebijeenkomsten 63

2.5.6 Gezamenlijke parlementaire bijeenkomsten 63

2.5.7 Gezamenlijke parlementaire controlegroep EUROPOL 64

2.5.8 Artikel 13-conferentie 64

2.5.9 Europese Parlementaire Week 65 
2.5.10 Interparlementaire Conferentie voor gemeenschappelijk buitenlands en veiligheidsbeleid en het gemeenschappelijk veiligheids- en defensiebeleid $\quad 66$

$\begin{array}{ll}2.6 & \text { Alternatieve bronnen van informatie }\end{array}$

$\begin{array}{lll}2.6 .1 & \text { IPEX } & 67\end{array}$

$\begin{array}{lll}2.6 .2 & \text { ECPRD } & 68\end{array}$

$\begin{array}{llr}2.7 & \text { Tussenconclusie } & 69\end{array}$

$\begin{array}{ll}\text { Hoofdstuk } 3 \text { Nederland } & 75\end{array}$

$\begin{array}{lll}3.1 & \text { Inleiding } & 75\end{array}$

$\begin{array}{ll}3.2 & \text { Nederland en de Europese Unie }\end{array}$

$\begin{array}{lll}3.3 & \text { Controle } & 78\end{array}$

3.3.1 Verhouding tussen de Staten-Generaal en de regering 78

$\begin{array}{ll}\text { 3.3.2 Parlementaire controlemiddelen } & 80\end{array}$

$\begin{array}{lll}\text { 3.3.2.1 Inlichtingenplicht } & 81\end{array}$

3.3.2.2 Recht van interpellatie, debat en vragen $\quad 82$

3.3.2.3 Enquêterecht 83

3.3.2.4 Ministeriële verantwoordelijkheid en de vertrouwensregel $\quad 84$

3.3.3 Tweede Kamer $\quad 84$

$\begin{array}{lll}\text { 3.3.4 Eerste Kamer } & 91\end{array}$

3.3.5 Overige controle-instrumenten 94

3.3.5.1 Algemeen Overleg Tweede Kamer 94

$\begin{array}{lll}\text { 3.3.5.2 Notaoverleg } & 101\end{array}$

3.3.5.3 Debat over de Europese Raad 101

$\begin{array}{lll}\text { 3.3.5.4 Afspraken } & 104\end{array}$

3.3.5.5 Overleg Eerste Kamer 108

$\begin{array}{lll}3.4 & \text { Wetgeving } & 108\end{array}$

$\begin{array}{lll}3.4 .1 & \text { BNC-fiches } & 109\end{array}$

3.4.2 Behandeling commissievoorstellen door de Tweede
Kamer

3.4.2.1 Wetgevings- en werkprogramma 113

$\begin{array}{lll}3.4 .2 .2 & \text { Consultaties } & 113\end{array}$

3.4.2.3 Rapporteur 116

3.4.3 Behandeling Commissievoorstellen door de Eerste Kamer 119

$\begin{array}{ll}\text { 3.4.3.1 Wetgevings- en werkprogramma } & 120\end{array}$

3.4.4 Nieuwe nationale bevoegdheden na Lissabon 127

$\begin{array}{lll}3.4 .4 .1 & \text { Instemmingsrecht } & 127\end{array}$

$\begin{array}{ll}\text { 3.4.4.2 Parlementair behandelvoorbehoud } & 130\end{array}$ 
$\begin{array}{lll}3.4 .5 & & 135\end{array}$

3.4.5.1 Tweede Kamer $\quad 135$

3.4.5.2 Eerste Kamer 136

3.5 Het parlement en de Europese Unie $\quad 137$

3.5.1 De parlementaire vertegenwoordiging van de Staten-Generaal bij de Europese Unie 137

$\begin{array}{ll}\text { 3.5.2 Staat van de Europese Unie } & 138\end{array}$

3.5.3 Begrotingsrecht en Europees Semester 141

3.5.4 Wet informatiepositie Staten-Generaal inzake de Europese Unie

3.5.5 Voorstel tot verandering van de Grondwet strekkende tot toevoeging van bepalingen inzake het lidmaatschap van de Europese Unie

$\begin{array}{ll}3.6 & \text { Tussenconclusie } \\ \end{array}$

Hoofdstuk 4 Duitsland $\quad 151$

$\begin{array}{lll}4.1 & \text { Inleiding } & 151\end{array}$

$\begin{array}{lll}4.2 & \text { Staatsstructuur } & 154\end{array}$

$\begin{array}{lll}\text { 4.2.1 Bundestag } & 156\end{array}$

4.2.2 Bundesrat en Länder 159

4.2.2.1 Vertegenwoordiger Länder bij de EU 162

4.2.3 Bondsregering; bondskanselier en de bondsministers 162

4.2.4 Verhouding tussen de Bundestag en de regering 164

$\begin{array}{ll}\text { 4.2.5 Bondspresident } & 166\end{array}$

$\begin{array}{ll}\text { 4.2.6 Bundesverfassungsgericht } & 167\end{array}$

4.2.6.1 Het Bundesverfassungsgericht en de Europese Unie 169

$\begin{array}{lll}\text { 4.2.7 Ondersteuning } & 175\end{array}$

$\begin{array}{lll}4.3 & \text { Wetgevingsproces } & 177\end{array}$

$\begin{array}{ll}4.4 & \text { Controle van de regering } \\ & 180\end{array}$

$\begin{array}{ll}\text { 4.4.1 Controlebevoegdheden } & 182\end{array}$

4.4.1.1 Kleine und Große Anfragen 183

4.4.1.2 Schriftliche Fragen, Mündliche Fragen en Fragestunden 184

4.4.1.3 Aktuelle Stunde 186

$\begin{array}{lll}\text { 4.4.1.4 Regierungsbefragung } & 188\end{array}$

4.4.1.5 Aanwezigheidsplicht 188

$\begin{array}{lll}4.4 .1 .6 & \text { Overzicht } & 189\end{array}$

$\begin{array}{lll}\text { 4.4.2 Kamercommissies } & 191\end{array}$ 
4.4.2.1 Permanente commissies $\quad 191$

4.2.2.2 Controlecommissies 195

4.4.2.3 Onderzoekcommissies 195

4.5 Duitsland en de Europese Unie 196

4.5.1 Artikel 23 Grundgesetz für die Bundesrepublik Deutsch-

land 198

4.5.2 Gesetz über die Zusammenarbeit von Bundesregierung und

Deutschem Bundestag in Angelegenheiten der Europäischen

Union 205

4.5.3 Gesetz über die Wahrnehmung der Integrationsverantwortung des Bundestages und des Bundesrates in Angelegenheiten der Europäischen Union

4.5.4 Gesetz über die Zusammenarbeit von Bund und Ländern in Angelegenheiten der Europäischen Union $\quad 212$

$\begin{array}{lll}\text { 4.5.5 Stellungnahme } & 214\end{array}$

$\begin{array}{lll}4.5 .6 & \text { Overzicht } & 218\end{array}$

$\begin{array}{lll}4.6 & \text { Tussenconclusie } & 219\end{array}$

Hoofdstuk 5 Nederland en Duitsland vergeleken $\quad 225$

$\begin{array}{lll}5.1 & \text { Inleiding } 225\end{array}$

5.2 Van Europees naar nationaal 226

5.2.1 Het Barroso-initiatief en de politieke dialoog 226

$\begin{array}{ll}\text { 5.2.2 De gelekaartprocedure } & 228\end{array}$

$\begin{array}{lll}5.3 & \text { Nationale bevoegdheden } & 230\end{array}$

$\begin{array}{lll}\text { 5.3.1 Controlebevoegdheden } & 231\end{array}$

5.3.1.1 Inlichtingenplicht 231

5.3.1.2 Recht van interpellatie, debat en vragen 231

5.3.1.3 Enquêterecht 234

5.3.1.4 Parlementair voorbehoud 235

5.3.1.5 Artikel 23 Duitse Grondwet en verwante wetten 236

5.3.1.6 Gewone controlebevoegdheden vs. bijzondere controlebevoegdheden 238

$\begin{array}{ll}5.4 & \text { Overige elementen van controle } \\ & 239\end{array}$

$\begin{array}{lll}\text { 5.4.1 Bundesverfassungsgericht } & 239\end{array}$

5.4.2 Overleg voorafgaand aan vergadering van de Raad en Europese Raad 241

$\begin{array}{lll}\text { 5.4.3 Kamercommissies } & 242\end{array}$

5.4.4 Ambtelijke ondersteuning 242

5.4.5 Interparlementaire samenwerking 244 
Hoofdstuk 6 Conclusie

249

$\begin{array}{ll}6.1 & \text { Bevindingen } \\ 6.251\end{array}$

$\begin{array}{ll}6.2 & \text { Aanbevelingen } \\ & 6.2 .167\end{array}$

6.2.1 Verzamelen en vastleggen van bevoegdheden 267

6.2.2 Betere procedures voor inzetten en beëindigen bevoegd$\begin{array}{ll}\text { heden } & 270\end{array}$

6.2.2.1 Rapporteur $\quad 270$

$\begin{array}{lll}\text { 6.2.2.2 Subsidiariteitstoets } & 271\end{array}$

6.2.2.3 Parlementair behandelvoorbehoud 272

6.2.3 Leden Europees Parlement zitting in Kamercommissie Europese Zaken 272

6.2.4 Parlementaire betrokkenheid bij handelsverdragen 273

6.2.5 Uitbreiding van het ambtenarenapparaat 274

6.2.6 Openbare statistieken Tweede Kamer 275

6.2.7 Betere samenwerking tussen nationale parlementen 275

7 Bibliografie $\quad 279$

$\begin{array}{lll}7.1 & \text { Literatuur } & 279\end{array}$

$\begin{array}{lll}7.2 & \text { Jurisprudentie } & 288\end{array}$

$\begin{array}{lll}7.3 & \text { Wetgeving } & 289\end{array}$

$\begin{array}{lll}\text { 7.3.1 Nederlandse wetgeving } & 289\end{array}$

$\begin{array}{lll}\text { 7.3.2 Duitse wetgeving } & 289\end{array}$

$\begin{array}{lll}\text { 7.3.3 Europese wetgeving } & 290\end{array}$

7.4 Officiële documenten 293

$\begin{array}{lll}7.5 & \text { Parlementaire stukken } & 296\end{array}$

7.5.1 Tweede Kamer 296

$\begin{array}{lll}7.5 .2 & \text { Eerste Kamer } & 298\end{array}$

7.5.3 Tweede Kamer en Eerste Kamer 299

$\begin{array}{lll}7.5 .4 & \text { Bundestag } & 299\end{array}$

7.5.5 Bundesrat 299

$\begin{array}{lll}7.6 & \text { Websites } & 300\end{array}$

$\begin{array}{lll}\text { 7.6.1 } & \text { Europese websites } & 300\end{array}$

$\begin{array}{ll}\text { 7.6.2 Nederlandse websites } & 301\end{array}$

$\begin{array}{lll}7.6 .3 & \text { Duitse websites } & 305\end{array}$

$\begin{array}{lll}7.6 .4 & \text { Overige } & 307\end{array}$

$\begin{array}{lll}7.7 & \text { Overige bronnen } & 308\end{array}$ 
Bijlage I. Procedure behandeling Europese voorstellen in de Eerste Kamer

Bijlage II. Prioritaire voorstellen uit wetgevings- en werkprogramma 2010 van de Europese Commissie

Bijlage III. Overzicht van voor de Tweede Kamer prioritaire voorstellen uit het wetgevings- en werkprogramma voor 2011 van de Europese Commissie

Bijlage IV. Kleine Anfrage

Bijlage V. Antwoord regering op Kleine Anfrage 331

Summary 347

Impactparagraaf 353

$1 \quad$ Inleiding

2 Onderzoek

3 Relevantie

4 Doelgroep

356

5 Activiteit

356

Dankwoord 359

Curriculum Vitae 361 


\section{HOOFDSTUK 1 INLEIDING}

\subsection{Aanleiding}

'Maybe not formally speaking, but at least politically speaking, all national parliaments have become, in a way, European institutions', aldus Herman van Rompuy. ${ }^{1}$

De rol van nationale parlementen in Europese aangelegenheden ${ }^{2}$ is een veel besproken onderwerp, met name in het debat over de democratische legitimiteit van de Europese Unie (EU). ${ }^{3}$ Door het vele onderzoek op dit gebied en het academisch debat sinds de jaren negentig is het mogelijk om een goed beeld te geven van de huidige positie van nationale parlementen in de Europese Unie. ${ }^{4}$ Sinds lange tijd wordt gesproken over een democratic deficit, een tekort aan democratische legitimiteit, van de EU. ${ }^{5}$ Dit tekort wordt in de preambule van het Verdrag van Lissabon erkend doordat de wens wordt uitgesproken '(...) om het door het Verdrag van Amsterdam en het Verdrag van Nice op gang gebrachte proces te voltooien teneinde de doeltreffendheid en de democratische legitimiteit van de Unie te versterken $(. . .)^{\prime}{ }^{6}$ Een reden van dit tekort was het feit dat nationale parlementen geen of slechts een kleine rol spelen in de EU. Nationale parlementen werden daarom ook

1 H. Van Rompuy, 'Speech by President Herman Van Rompuy to the Interparliamentary Committee Meeting on the European Semester for Economic Policy Coordination', Brussel, 27 februari 2012, EUCO 31/12.

2 In dit boek worden de termen 'Europese aangelegenheden' en 'EU-aangelegenheden' door elkaar gebruikt maar ermee wordt hetzelfde bedoeld, namelijk aangelegenheden met een link naar de Europese Unie.

3 Zie onder andere: K. Auel \& Th. Christiansen, 'After Lisbon: National Parliaments in the European Union', West European Politics 2015, 38(2), p. 261-281; D. Jančić, 'The Legacy of an Evolving Polity: Democracy, National Identity, and the Good Functioning of the EU', in: D. Jančić, National Parliaments after the Lisbon Treaty and the Euro Crisis. Resilience or Resignation?, Oxford: Oxford University Press 2017; C. Sprungk, 'A New Type of Representative Democracy? Reconsidering the Role of National Parliaments in the European Union', Journal of European Integration 2013, 35(5), p. 547-563.

4 Zie onder andere: P.J. Cardwell \& D. Jančić, 'The European Parliament and development cooperation: democratic participation in the 'low politics' of EU external relations', Journal of European Integration 2019, 41(3), p. 365-381; M. Sorace, 'The European Union democratic deficit: Substantive representation in the European Parliament at the input stage', European Union Politics 2018, 19(1), p. 3-24; C. Hefftler e.a. (eds.), The Palgrave Handbook of National Parliaments and the European Union, Londen: Palgrave Macmillan 2015; P. Kiiver, The National Parliaments in the European Union. A Critical View on EU ConstitutionBuilding, The Hague: Kluwer Law International 2006; A. Maurer \& W. Wessels, National Parliaments on their Ways to Europe: Losers or Latecomers?, Nomos: Baden-Baden 2001; O. Tans, C. Zoethout \& J. Peters (eds.), National Parliaments and European Democracy: A Bottom-up Approach to European Constitutionalism, Groningen: Europa Law Publishing 2007.

5 K. Auel \& Th. Christiansen, 'After Lisbon: National Parliaments in the European Union', West European Politics 2015, 38(2), p. 261.

6 Preambule Verdrag van Lissabon. 
wel gezien als slachtoffers van het Europese integratieproces. ${ }^{7}$ Dit hadden de nationale parlementen zelf pas laat door maar sinds ze zich meer bewust zijn van hun positie en rol in de Europese Unie, is de controle op Europese aangelegenheden via de eigen regering, als ook via hun eigen bevoegdheden uit de Europese verdragen, toegenomen. ${ }^{8}$ Met betrekking tot het verkleinen van het democratic deficit is dit een positieve ontwikkeling aangezien de democratische verantwoordingsplicht ten aanzien van het besluitvormingsproces in de Raad en de Europese Raad wordt versterkt door de ministers te dwingen tot het afleggen van verantwoording (voor en na de onderhandelingen) en hun standpunten en onderhandelingsposities toe te lichten aan het nationale parlement. ${ }^{9}$ Er lijkt een algemene overeenstemming te zijn over het feit dat de Europese integratie, die in de jaren vijftig van de vorige eeuw begon door de verschillende Europese en internationale samenwerkingsverbanden, heeft geleid tot de zogenoemde deparliamentarization (vrij vertaald: ontparlementarisatie). ${ }^{10}$ Hiervoor zijn een tweetal oorzaken. Ten eerste: sinds het begin van de Europese samenwerkingsverbanden hebben nationale parlementen (delen van) hun wetgevings- en controlebevoegdheden verloren. Doordat parlementen instemden met wijzigingen en herzieningen van Europese verdragen accepteerden zij dat een deel van hun bevoegdheden naar de Europese Unie verhuisde. ${ }^{11}$ Ten tweede: het zijn de nationale regeringen die de lidstaten in Europese onderhandelingen vertegenwoordigen en niet de parlementen, waardoor een informele asymmetrie bestaat tussen de regeringen en de parlementen. De nationale parlementen hebben hierdoor een (kennis)achterstand op de rege-

$7 \quad$ Ibid.

8 K. Auel, O. Eisele \& L. Kinski, 'What Happens in Parliament Stays in Parliament? Newspaper Coverage of National Parliaments in EU Affairs', Journal of Common Market Studies 2018, 56(3), p. 628-645, op p. 629; K. Auel \& T. Raunio, 'Introduction: Connecting with the Electorate? Parliamentary Communication in EU Affairs', The Journal of Legislative Studies 2014, 20(1), p. 1-12, op p. 2.

9 E. Miklin, 'EU Politicisation and National Parliaments: Visibility of Choices and Better Aligned Ministers?', The Journal of Legislative Studies 2014, 20(1), p. 78-92, op. p. 81-83; T. Raunio, National Parliaments and European Integration. What we know and what we should know, Working Paper No. 2, January 2009, ARENA Centre for European Studies University of Oslo, p. 17.

10 A.L. Högenauer \& G. Abels, 'Conclusion: regional parliaments - a distinct role in the EU?', The Journal of Legislative Studies 2017, 23(2), p. 260-273, op p. 260; D. Whelan, 'Assessing the Reasons and Options for Brexit: A Defence of the UK's Decision to Leave the EU', North East Law Review 2018, 6, p. 1-5 op p. 1-2; T. Raunio, National Parliaments and European Integration. What we know and what we should know, Working Paper No. 2, January 2009, ARENA Centre for European Studies University of Oslo, p. 15; O. Tans, 'Introduction: National Parliaments and the European Union; In Search of Common Ground', in: O. Tans, C. Zoethout \& J. Peters (eds.), National Parliaments and European Democracy: A Bottom-up Approach to European Constitutionalism, Groningen: Europa Law Publishing 2007, p. 3.

11 A.L. Högenauer \& G. Abels, 'Conclusion: regional parliaments - a distinct role in the EU?', The Journal of Legislative Studies 2017, 23(2), p. 260-273, op p. 260; R. Senninger, 'Issue expansion and selective scrutiny how opposition parties used parliamentary questions about the European Union in the national arena from 1973 to 2013', European Union Politics 2017, 18(2), p. 283-306, op p. 284; A. Maurer, 'National Parliaments in the European Architecture: From Latecomers' Adaptation towards Permanent Institutional Change?', in: A. Maurer \& W. Wessels, National Parliaments on their Ways to Europe: Losers or Latecomers?, Nomos: Baden-Baden 2001, p. 29. 
ringen. Daarnaast is het voor nationale parlementen moeilijk om hun regeringen (gedetailleerde) toezeggingen te laten doen alvorens de onderhandelingen op Europees niveau beginnen. Enerzijds door het toenemend gebruik van stemmen met een gekwalificeerde meerderheid in de Raad aangezien dit de controle van nationale parlementen op het handelen van hun ministers in de Raad verzwakt, anderzijds omdat er tijdens die onderhandelingen standpunten en inzichten kunnen wijzigen waarop de regering flexibel moet kunnen inspelen. $^{12}$

Een van de oorzaken van het democratic deficit en de deparliamentarization is, zoals reeds gezegd, overdracht van wetgevende bevoegdheden van nationaal naar Europees niveau. Het Europees Parlement, hét democratisch gelegitimeerde orgaan van de Europese Unie, volledig medewetgever maken zou een oplossing moeten zijn geweest voor het democratic deficit en de deparliamentarization. De invloed van het Europees Parlement is echter te klein omdat het parlement zijn wetgevende bevoegdheid samen met de Raad moet uitoefenen. ${ }^{13}$ Dit betekent dat het Europees Parlement afhankelijk is van de Raad (andersom natuurlijk ook), wat wel wordt gezien als een verzwakking van de democratische legitimiteit van het Europees besluitvormingsproces. ${ }^{14}$ Ook wanneer men kijkt naar de klassieke rol van parlementen valt op dat het Europees Parlement geen recht van initiatief heeft. Dit is wellicht het belangrijkste argument waarom het Europees Parlement geen goede vervanging is van nationale parlementen. Dit argument speelt echter geen rol wanneer het gaat om controle van en de rol bij de totstandkoming en de vertrouwensrelatie met de Europese Commissie aangezien het Europees Parlement daarbij wel betrokken is. Wat

12 Ch. Rauh \& P. de Wilde, 'The opposition deficit in EU accountability: Evidence from over 20 years of plenary debate in four member states', European Journal of Political Research 2018, 57(1), p. 194-216, op p. 196; D. Whelan, 'Assessing the Reasons and Options for Brexit: A Defence of the UK's Decision to Leave the EU', North East Law Review 2018, 6, p. 1-5, op p. 2; T. Raunio, National Parliaments and European Integration. What we know and what we should know, Working Paper No. 2, January 2009, ARENA Centre for European Studies University of Oslo, p. 15; G. Majone, "Europe's "Democratic Deficit": The Question of Standards', European Law Journal 1998 4(1), p. 7.

13 Op Nederlands nationaal niveau zijn de regering en het parlement tezamen wetgever en bestaat er een vertrouwensrelatie tussen de regering en het parlement. Wanneer er geen vertrouwen meer is, dient de regering af te treden. Tussen het Europees Parlement en de Raad bestaat een dergelijke vertrouwensband niet, waardoor het Europees Parlement de Raad niet tot aftreden kan dwingen. Hierdoor is het Europees Parlement, als wetgever, verzwakt. Bovendien kan de Raad wetgeving maken zonder het Europees Parlement daarbij te betrekken. Voorbeelden hiervan zijn het Fiscal Compact en het ESM-verdrag. In dergelijke gevallen kan men zeker spreken van een verzwakking van de postitie van het Europees Parlement.

14 Ch. Rauh \& P. de Wilde, 'The opposition deficit in EU accountability: Evidence from over 20 years of plenary debate in four member states', European Journal of Political Research 2018, 57(1), p. 194-216, op p. 194; Th. Winzen, Ch. Roederer-Rynning \& F. Schimmelfennig, 'Parliamentary co-evolution: national parliamentary reactions to the empowerment of the European Parliament', Journal of European Public Policy 2015, 22(1), p. 75-93, op p. 77; M. Horspool \& M. Humphreys, European Union Law, Oxford: Oxford University Press 2012, p. 58-59; O. Tans, 'Introduction: National Parliaments and the European Union; In Search of Common Ground', in: O. Tans, C. Zoethout \& J. Peters (eds.), National Parliaments and European Democracy: A Bottom-up Approach to European Constitutionalism, Groningen: Europa Law Publishing 2007, p. 3 . 
daarnaast geldt als een verzwakking van het Europees Parlement is dat het Europees Parlement niet de Raad weg kan sturen zoals op nationaal niveau wel mogelijk is (het parlement kan de regering naar huis sturen). Tot slot heeft de Raad op bepaalde beleidsgebieden de mogelijkheid om regelgeving buiten het Europees Parlement om te maken, in de vorm van internationale verdragen. ${ }^{15}$ Het monopolie dat de Europese Commissie heeft op het voorstellen van nieuwe wetgeving heeft als gevolg dat het Europees Parlement voor het uitoefenen van zijn bevoegdheden afhankelijk is van de Commissie. ${ }^{16}$ Hierdoor heeft het Europees Parlement een te kleine rol om te kunnen spreken van een volwaardige democratische legitimatie terwijl het juist een prominente rol zou moeten hebben vanuit het perspectief van democratische legitimatie van het Europees Parlement en het feit dat het Europees Parlement de Europese Commissie dient te controleren. ${ }^{17}$ Het is ook zo dat het Europees Parlement de Europese Commissie controleert maar desondanks blijft het Europees Parlement afhankelijk van de Commissie voor nieuwe wetgeving en daardoor heeft de Commissie een prominentere rol dan het Europees Parlement. Gezien de democratische legitimatie van het Europees Parlement (en het ontbreken daarvan bij de Europese Commissie) zou dit - de prominente rol en het initiatiefrecht - omgedraaid moeten zijn: het recht om wetgeving te initiëren behoort namelijk aan parlementaire stelsels. De controletaak van het Europees Parlement en zijn rol bij de benoeming en het ontslag van de Commissie, geven een hoogstens indirecte legitimatie aan de Europese Commissie, maar in het wetgevingsproces waar de Europese Commissie het exclusieve recht heeft om wetgeving te initiëren, is dit onvoldoende. Zo is er bijvoorbeeld geen reële parlementaire controle door het Europees Parlement op nalaten in geval van geen of onvoldoende wetgevingsinitiatief door de Europese Commissie en ondanks het vereiste van toestemming van het Europees Parlement bij de benoeming van de Europese Commissie, is het keuzeproces van met name de voorzitter van de Europese Commissie niet democratisch. Dit is ook niet democratischer geworden door het loslaten van het zogenoemde Spitzenkandidaten-principe.

Een ander gevolg van de Europese integratie is dat nationale parlementen wetgevende bevoegdheden hebben overgedragen aan de Europese Unie en zij daarmee ook invloed op hun eigen regeringen kwijtgeraakt zijn. Deelname aan het (nationale) wetgevingsproces behoort tot de mogelijkheden om invloed uit te oefenen op de regering omdat nationale

15 Er ontstaat dan een zogenoemd 'executief federalisme', zoals bij het ESM en het Fiscal Compact en het Coronafonds.

16 N. Nugent \& M. Rhinard, 'Is the European Commission Really in Decline?', Journal of Common Market Studies 2016, 54(5), p. 1205; M. Horspool \& M. Humphreys, European Union Law, Oxford: Oxford University Press 2012, p. 60; G. Majone, 'Europe's “Democratic Deficit”: The Question of Standards', European Law Journal 1998 4(1), p. 8.

17 N. Nugent \& M. Rhinard, 'Is the European Commission Really in Decline?', Journal of Common Market Studies 2016, 54(5), p. 1206-1208; P. Kiiver, The National Parliaments in the European Union. A Critical View on EU Constitution-Building, The Hague: Kluwer Law International 2006, p. 170. 
parlementen (in veel lidstaten) (mede)wetgever zijn. Het gaat dan over de invloed die nationale parlementen kunnen uitoefenen op hun regeringen in het wetgevingsproces. Deze is in sommige gevallen verdwenen aangezien bepaalde onderwerpen niet meer op nationaal maar op Europees niveau geregeld worden. ${ }^{18}$ Opgemerkt moet worden dat het wetgevingsproces in Nederland een bijzonder geval is. In de meeste (Europese) landen is het parlement juridisch gezien de wetgever en maakt de regering daar geen deel van uit, tenzij de leden van de regering ook lid zijn van het parlement zoals in Duitsland het geval is. Feitelijk is dat vaak anders en speelt de regering wel een rol. In Nederland is de jure de wetgever een combinatie van het parlement en de regering en heeft de regering het voortouw. In Duitsland is dat het parlement maar onder erkenning van de vooraanstaande rol daarin van de regering. In dit onderzoek wordt daarom uitgegaan van een feitelijk wetgevingsstelsel waarin wetgeving tot stand komt door regering en parlement.

Sinds het midden van de jaren negentig ontvangt het onderwerp 'nationale parlementen in de Europese Unie' veel aandacht en wordt hierover ook veel gedebatteerd. Voor die tijd waren de algemene opvatting en werkelijkheid dat nationale parlementen thuishoorden in de lidstaten en dat ze op nationaal niveau belangrijk waren, maar geen rol speelden in de Europese arena. ${ }^{19}$ De uitzondering daarop was het goedkeuren van verdragen en verdragswijzigingen door nationale parlementen. Thans is de opvatting dat nationale parlementen wel degelijk een rol spelen in de Europese Unie. De betrokkenheid van nationale parlementen in Europese aangelegenheden en hun rol in de Europese Unie kent een ontwikkeling van indirecte naar directe betrokkenheid. ${ }^{20}$ Tot 2006, toen de nationale parlementen nog niet alle documenten van de Commissie ontvingen, waren nationale parlementen nauwelijks betrokken bij de totstandkoming van Europese wetgeving. De nationale parlementen opereerden nationaal en oefenden controle en invloed uit op Europese aangelegenheden via hun nationale regeringen, met andere woorden, er was sprake van een indirecte betrokkenheid. Doordat nationale parlementen vanaf 2006 Europese voorstellen rechtstreeks ontvangen, is deze parlementaire betrokkenheid vergroot. Nationale parlementen ontvangen namelijk sinds het zogenoemde Barroso-initiatief alle documenten die de Commissie opstelt. De bedoeling was dat daarmee ook de democratische basis van de Europese Unie zou worden vergroot. Het grote voordeel van het Barroso-initiatief is dat nationale parlementen niet langer volledig afhankelijk zijn van hun regeringen met betrekking tot het verkrijgen van informatie. De directe betrokkenheid van nationale

18 K. Auel, O. Rozenberg \& A. Tacea, 'To Scrutinise or Not to Scrutinise? Explaining Variation in EU-Related Activities in National Parliaments', West European Politics 2015, 38(2), p. 283-284.

19 K. Auel \& Th. Christiansen, 'After Lisbon: National Parliaments in the European Union', West European Politics 2015, 38(2), p. 261.

20 Tot 2004 bestond er wel een directe betrokkenheid tussen nationale parlementen en het Europees Parlement door het bestaan van het dubbelmandaat. Dit hield in dat de leden van het Europees Parlement tevens lid waren van de nationale parlementen. 
parlementen is verder uitgebreid bij de totstandkoming van het Verdrag van Lissabon in 2009, waarbij enkele controlemiddelen zijn geïntroduceerd. Hierdoor wordt het Verdrag van Lissabon ook wel aangehaald als het 'Verdrag van de parlementen'. ${ }^{21}$ Sindsdien kunnen nationale parlementen een subsidiariteitstoets uitvoeren bij nieuwe Europese wetgevingsvoorstellen. Dit 'systeem voor vroegtijdige waarschuwing' (Early Warning System) staat in Nederland bekend als de gelekaartprocedure. Tot slot zijn er nog de bevoegdheden zoals die zijn vastgelegd in nationale wetgeving. Met deze bevoegdheden kunnen parlementen hun regeringen controleren op hun handelen op Europees niveau. Ook via deze lijn kunnen nationale parlementen een rol spelen op Europees niveau.

Deze (nieuwe) bevoegdheden zijn gecreëerd om het democratisch tekort te verkleinen, de representatieve democratie in de EU te versterken en het Europese wetgevingsproces dichter bij de burger te brengen. Met dezelfde reden is het Europees Parlement volledig medewetgever gemaakt. Of het gelukt is om met deze maatregelen het democratisch tekort (volledig) weg te werken is maar de vraag. Er bestaat immers (nog altijd) geen recht voor het Europees Parlement of de nationale parlementen om nieuwe Europese wetgeving te initiëren. Ook heeft het een en ander te maken met de inzet en activiteiten van de nationale parlementen. Zij moeten een rol op Europees niveau willen spelen. Nationale parlementen dienen in te zien dat er een rol voor nationale parlementen is weggelegd op Europees niveau en dat het verkleinen van het democratisch tekort niet enkel in het belang van de Europese Unie is en aan het Europees Parlement, maar ook in het belang van en aan de nationale parlementen.

De eerste reden is dat controle van de eigen regering en ministers een van de klassieke taken van een nationaal parlement is. Het maakt daarbij niet uit of het gaat om een nationale of Europese aangelegenheid. Daarnaast hebben nationale parlementen weliswaar wetgevende bevoegdheden overgedragen maar dat betekent niet dat ze deze geheel kwijt zijn. Althans, het blijft de taak van nationale parlementen om toe te zien op (de uitoefening van) deze bevoegdheden. Dat nationale parlementen een rol dienen te spelen in de Europese Unie heeft uiteindelijk geresulteerd in verwijzingen naar nationale parlementen in de verdragen en protocollen. In deze verdragen en protocollen worden nationale parlementen niet enkel erkend vanwege de rol die ze op nationaal niveau spelen, maar hierin zijn ook bevoegdheden voor nationale parlementen neergelegd. Het is daarom dan ook dat nationale parlementen niet alleen een rol in de Europese Unie kúnnen spelen maar ook móeten spelen. Het waren de opstellers van de verdragen, de lidstaten (en daarmee ook de EU zelf) die het nodig vonden om nationale parlementen een grotere rol te geven. Dit werd gerealiseerd door enerzijds, zoals hiervoor aangegeven, de nationale parlementen bevoegdheden

21 I. Cooper, 'Deliberation in the multileverl parliamentary field: the seasonal workers directive as a test case', in: B. Crum \& J. Fossum (eds.), Practices of Interparliamentary Coordination in International Politics: The European Union and Beyond, Colchester: ECPR Press 2013, p. 51. 
toe te kennen in de Europese verdragen en protocollen, en anderzijds door controle van de nationale regeringen ten aanzien van hun activiteiten in de Europese Raad en de Raad een táák te maken van de nationale parlementen. Artikel 12 van het Verdrag betreffende de Europese Unie (VEU) bepaalt dat 'de nationale parlementen actief bij[dragen] tot de goede werking van de Unie (...)'. Met andere woorden, het is dus niet geheel vrijblijvend of nationale parlementen zich bemoeien met Europese wetgeving en beleid.

Artikel 12 VEU spreekt niet over 'mogen bijdragen' of 'kunnen bijdragen'. Dit betekent dat artikel 12 geen discretionaire bevoegdheid voor nationale parlementen schept om het goede functioneren van de Europese Unie te monitoren maar veel eerder een opdracht om er actief aan bij te dragen. En die opdracht wordt gefaciliteerd doordat in een tweetal protocollen de gelekaartprocedure is gecreëerd alsmede de informatie naar de nationale parlementen is geregeld.

Wat mogen we eigenlijk verwachten van een parlement als het op controle op Europese aangelegenheden aankomt?

In dit onderzoek wordt uitgegaan van de gedachte dat de rol van nationale parlementen in de Europese Unie een taak is van nationale parlementen, neergelegd in artikel 12 VEU, en dat deze taak mede in feite door hen zelf is opgelegd. Nationale parlementen hebben immers mogelijkheden gehad om dit te voorkomen indien ze het er niet mee eens waren. Niet alleen door de eigen regering aan te spreken of door in gesprek te gaan met de leden van het Europees Parlement, maar ook door het VEU al dan niet goed te keuren. Tot slot is deze taak een uitkomst van samenwerking tussen de Europese Commissie, het Europees Parlement en de Raad (en dus de ministers van de lidstaten), wat met zich brengt dat deze instituten niet enkel de taak hebben gecreëerd, maar dat de taak van nationale parlementen vereist dat deze Europese instituten gehouden zijn om naar de nationale parlementen te luisteren. De instellingen dienen in de geest van artikel 12 VEU te handelen en de taak van nationale parlementen niet te frustreren maar te faciliteren. Concreet betekent dit voor een parlement dat het zich moet bemoeien met Europese aangelegenheden. Verwacht mag worden dat het parlement deze taak serieus uitoefent. De mogelijkheden daarvoor zijn in eerste instantie de gelekaartprocedure en de politieke dialoog. Het eerbiedigen van het beginsel van subsidiariteit betekent dat een parlement nieuwe Europese wetgeving dient te controleren. Alleen als je controleert weet je of een wetsvoorstel voldoet aan het beginsel van subsidiariteit. Krijgt het parlement een nieuw wetsvoorstel en meent het dat het voorstel, na bestudering, geen goed voorstel is omdat het bijvoorbeeld niet uitvoerbaar is, schort aan evenredigheid of aan motivatie dan dient het parlement dit te bespreken met de Europese Commissie door gebruik te maken van de politieke dialoog. Een parlement kan dan niet achteroverleunen en denken dat een ander nationaal parlement of het Europees Parlement het wel zal oppakken. 
Samen sta je sterker. Nationale parlementen dienen samen te werken. Het platform hiervoor zijn de interparlementaire conferenties. Het is dus ook nodig dat leden van de alle parlementen hieraan deelnemen. Ook dit valt onder de taak van het parlement uit artikel 12 VEU.

Tot slot mag ook van een parlement verwacht worden dat het controle uitoefent op de eigen regering wanneer het gaat om Europees beleid. Controleren van regeringsbeleid is een van de kerntaken van parlementen en dan niet alleen wanneer het gaat om nationaal beleid. Het bevragen van de minister (die naar de Raad in Brussel gaat), moties indienen om de minister te sturen, debatteren om de minister het standpunt van de Kamer over te brengen behoren tot de dagelijkse taken van Kamerleden. Wederom, niet alleen wanneer het om nationaal beleid gaat maar zeer zeker ook wanneer het om Europees beleid gaat. In aanmerking genomen dat er ook een Europees Parlement bestaat kan het voorkomen dat nationale parlementen bepaalde zaken overlaat aan het Europees Parlement. Desondanks dienen nationale parlementen hun eigen regeringen te controleren want controle van de Raad wordt bijvoorbeeld niet gedaan door het Europees Parlement.

Kortom, we verwachten van een nationaal parlement dat het zijn taak, zich bemoeien met Europese aangelegenheden, uitvoert. Voor de uitvoering zijn er dus nationale en Europese mogelijkheden.

\subsection{LANDENKEUZE}

Waarom is in dit onderzoek ervoor gekozen om de landen Nederland en Duitsland te vergelijken ten aanzien van hun activiteiten die als EU-aangelegenheden kunnen worden beschouwd? Het Europese integratieproces is begonnen in de jaren vijftig van de vorige eeuw. Zowel Nederland als Duitsland behoort tot de zes oprichters van de Europese gemeenschappen. Hierdoor zijn beide landen vanaf het begin betrokken bij het Europese integratieproces. Dit proces heeft in beide landen op nationaal niveau veranderingen teweeggebracht. Niet alleen zijn bepaalde wetgevende bevoegdheden overgeheveld van nationaal naar Europees niveau, maar meer concreet moesten de landen gaan bepalen hoe zij een rol konden spelen op Europees niveau. De processen die daarvoor in de lidstaten zijn gecreëerd verschillen per lidstaat. Zo heeft Duitsland duidelijke bevoegdheden en procedures ontwikkeld en deze vastgelegd in wetgeving. In Nederland is dit in veel mindere mate gebeurd. Ook heeft Duitsland een Constitutioneel Hof dat van groot belang is voor de ontwikkeling van het Duitse staatsrecht en dat van invloed is op (de uitoefening van) de bevoegdheden door het Duitse parlement. In Nederland bestaat een dergelijk hof niet en is de rechter niet bevoegd om wetten in formele zin te toetsen aan de Grondwet. Er zijn nog andere verschillen te vinden tussen Duitsland en Nederland die een rol spelen in dit onderzoek. Data en statistieken over het parlement zijn in Duitsland beter toegankelijk 
dan in Nederland, waar bepaalde data niet dan wel niet op een systematische manier worden bijgehouden. Dit is niet alleen van belang voor vergelijkend onderzoek maar ook voor de parlementen zelf. Op basis van die data is namelijk af te leiden wat een parlement precies doet. Antwoorden op de vragen Welke bevoegdheden worden gebruikt? Hoe vaak worden deze gebruikt? Waarvoor? en Door wie? geven inzicht in het functioneren van nationale parlementen. Verder is het zo dat bepaalde landen in de Europese Unie meer invloed hebben op Europese wetgeving en beleid dan andere landen. Voor de keuze voor Nederland en Duitsland is ook de invloed die een lidstaat heeft in de stemming binnen de Raad van de Europese Unie (hierna: de Raad) van belang. Binnen de Raad heeft elke lidstaat één stem. Artikel 238 lid 3 sub a van het Verdrag betreffende de werking van de Europese Unie (VWEU) geeft aan dat '(o)nder gekwalificeerde meerderheid wordt verstaan ten minste 55 procent van de leden van de Raad die deelnemende lidstaten vertegenwoordigen waarvan de bevolking ten minste 65 procent uitmaakt van alle deelnemende staten'. Duitsland heeft meer dan 82 miljoen inwoners, Nederland heeft er iets meer dan 17 miljoen. ${ }^{22}$ Om een meerderheid binnen de Raad te behalen is niet alleen van belang dat lidstaten vóór stemmen maar ook is het aantal inwoners van die voorstemmende lidstaten van belang. Hoe groter het aantal inwoners van een lidstaat dat voor stemt, hoe groter de kans dat de 65 procent-grens wordt behaald. Hieruit volgt dat het belang van de stem van Duitsland zwaarder weegt dan de stem van Nederland. De stem van Duitsland vertegenwoordigt 16,2 procent van de bevolking van de Europese Unie terwijl de stem van Nederland 'slechts' 3,4 procent vertegenwoordigt. Duitsland kan hierdoor meer invloed uitoefenen binnen de (Raad van de) EU dan Nederland. In dit onderzoek wordt daarom een land met veel invloed (Duitsland) met een land met een gemiddelde invloed (Nederland) vergeleken. Ook is de economische macht van Duitsland vele malen groter dan die van Nederland. ${ }^{23}$ Daarnaast telt het Europees Parlement veel meer Duitse leden dan Nederlandse leden, 96 respectievelijk 29 leden. Uit het gegeven dat Duitsland een grotere speler is dan Nederland en de Duitse stem in de Raad zwaarder weegt dan die van Nederland, volgt de hypothese dat het Nederlandse parlement de behoefte heeft om zijn stem op een andere manier te laten gelden. Is het bijvoorbeeld zo dat het Nederlandse parlement vaker gebruikmaakt van de bevoegdheden die zijn vastgelegd in Europese verdragen en protocollen? Of controleert het Nederlandse parlement de regering vaker op Europees beleid dan dat het Duitse parlement doet? Juist om ervoor te zorgen dat op die manier de invloed van Nederland kan worden vergroot?

22 Website Eurostat 2017.

23 Zo draagt Duitsland jaarlijks net iets meer dan $€ 25$ miljard bij aan de begroting van de EU en Nederland net geen $€ 5$ miljard; Website Europese Commissie, EU expenditure and revenue 2014-2020. 


\subsection{Periodekeuze}

Deze studie richt zich op de periode 2010 tot en met 2016. De periode na 2010 wordt ook wel de 'post-Lissabon periode' genoemd. In artikel $12 \mathrm{VEU}$ is de taak van nationale parlementen neergelegd om actief bij te dragen aan de goede werking van de Europese Unie. In dit onderzoek wordt gekeken of hier ook daadwerkelijk sprake van is en in hoeverre de nationale parlementen bijdragen aan de goede werking van de Unie. Om bij te dragen aan de goede werking van de EU hebben de nationale parlementen bevoegdheden nodig. De bevoegdheden die nationale parlementen bezitten op basis van Europees recht zijn neergelegd in Protocol 1 betreffende de rol van de nationale parlementen in de Europese Unie en Protocol 2 betreffende de toepassing van de beginselen van subsidiariteit en evenredigheid. Beide protocollen horen bij het Verdrag van Lissabon.

Daarnaast werden in Nederland bij de Rijkswet houdende goedkeuring van het Verdrag van Lissabon tot wijziging van het Verdrag betreffende de Europese Unie en het Verdrag tot oprichting van de Europese Gemeenschap twee nieuwe nationale bevoegdheden voor het Nederlandse parlement gecreëerd, te weten het parlementair behandelvoorbehoud en het instemmingsrecht. Het laatste recht bestond al wel, maar dan in een andere vorm. Bij de Goedkeuringswet zijn bepaalde beleidsterreinen waarop het parlement instemmingsrecht had, geschrapt. Het huidige instemmingsrecht is een afgeslankte vorm van wat het was voor de Goedkeuringswet en pre-Lissabon.

Nieuwe bevoegdheden en daarbij een nieuwe werkwijze hebben tijd nodig om goed tot hun recht te komen. Een korte onderzoeksperiode van bijvoorbeeld twee of drie jaar zou geen goed beeld kunnen geven omdat Kamerleden nog niet vertrouwd zijn met de nieuwe bevoegdheden of omdat de interne werkwijze nog niet optimaal is. De praktijk wijst uit dat bij de invoering van nieuwe bevoegdheden in de beginperiode de toepassing toeneemt of fluctueert totdat deze stabiliseert. ${ }^{24}$

\subsection{ONDERZOEKSVRAAG}

Het doel van dit onderzoek is het achterhalen van de verschillen en overeenkomsten tussen het Nederlandse en het Duitse parlement waar het hun activiteiten in Europese aangelegenheden betreft. Anders geformuleerd mondt dit uit in de volgende onderzoeksvraag: In welke mate maakt het Nederlandse parlement van de hem toekomende bevoegdheden naar nationaal en Europees recht gebruik voor wat betreft Europese aangelegenheden? Nadat

24 Zie bijvoorbeeld het rapport 'Evaluatie strafrechtelijke aanpak eergerelateerd geweld', WODC 28 juni 2012, p. 40; rapport 'Evaluatie Wet wederzijdse erkenning en tenuitvoerlegging vrijheidsbenemende en voorwaardelijke sancties (Wets)', WODC 1 juni 2018, p. 38; rapport 'Op doel? Evaluatie van de Wet maatregelen bestrijding voetbalvandalisme en ernstige overlast', WODC 22 juni 2012, p. 51. 
deze vraag ook voor het Duitse parlement is beantwoord kan ook de centrale vraag beantwoord worden, namelijk: Kan het Nederlandse parlement zijn controle ten aanzien van Europese aangelegenheden verbeteren, al dan niet naar Duits voorbeeld, teneinde recht te doen aan het VEU, en de eigen nationale rol die het heeft ten aanzien van controle en vertegenwoordiging?

Betrokkenheid van nationale parlementen is tweeledig. Enerzijds controleert het nationale parlement de nationale regering. De regering c.q. de ministers dienen verantwoording af te leggen aan het parlement en wanneer dit niet naar tevredenheid van het parlement gebeurt, kunnen daar consequenties aan worden verbonden. Er dient een vertrouwensrelatie te bestaan tussen de regering en het parlement. Zonder vertrouwen kan de regering niet regeren. Anderzijds kunnen nationale parlementen ook invloed uitoefenen. Dat kan op de eigen regering maar ook op de Europese Commissie. Er bestaat weliswaar geen vertrouwensrelatie tussen de Europese Commissie en de nationale parlementen en er kunnen dus ook geen sancties worden opgelegd door de nationale parlementen, maar het is wel mogelijk om betrokken te zijn bij nieuwe Europese wetgeving en Europees beleid door invloed uit te oefenen op de Europese Commissie via onder andere de politieke dialoog en de gelekaartprocedure, twee instrumenten die later in dit onderzoek aan bod komen.

Parlementen in beide landen kunnen een rol spelen in Europese aangelegenheden door gebruik te maken van hun bevoegdheden. De bevoegdheden die zijn neergelegd in Europese wetgeving, zijn gelijk voor beide parlementen. Hoe, op welke manier en hoe vaak gebruik wordt gemaakt van deze bevoegdheden is een nationale aangelegenheid en is aan het nationale parlement. Die uitoefening kan wisselen al naar gelang relevante nationale omstandigheden zoals politieke cultuur, beschikbare kennis en capaciteit, en de wijze van organisatie van het parlement. Daarnaast zijn er nog de nationale bevoegdheden van beide parlementen die kunnen verschillen qua omvang en toepassing. Deze nationale bevoegdheden zijn al dan niet vastgelegd in nationale Grondwet of wetgeving.

In dit onderzoek wordt een vergelijking gemaakt tussen beide parlementen en wordt nagegaan hoe actief beide parlementen zijn in Europese aangelegenheden. Na deze vergelijking kan worden geconstateerd welk parlement meer gebruikmaakt van de bestaande mogelijkheden en actiever is in Europese aangelegenheden. Zoals in de aanleiding van dit onderzoek wordt aangegeven spelen nationale parlementen een kleine rol op Europees niveau. Ze kunnen een rol spelen door gebruik te maken van de bevoegdheden die ze hebben gekregen.

In dit onderzoek wordt uitgegaan van de hypothese dat Duitsland een grotere rol speelt in de EU dan Nederland. Dat komt zoals aangegeven door haar grote economische omvang en macht en de stemverhoudingen in de Raad. Verder moet onder andere opgemerkt worden dat de inrichting van de Duitse staat anders is dan de Nederlandse. De Duitse rol 
in de EU wordt, anders dan in Nederland het geval is, in de Duitse Grondwet geregeld. In artikel 23 zijn de rechten van de Bundestag ${ }^{25}$ en Bundesrat opgenomen in Europese aangelegenheden. Verder bestaat er gedetailleerde Duitse wetgeving met uitwerkingen van deze bevoegdheden en procedures van artikel 23. Ook het Duitse Bundesverfassungsgericht speelt een rol. Het hof geeft namelijk invulling aan de bevoegdheden door over de constitutionaliteit van wetgeving en ander overheidshandelen, ook waar het de EU betreft, desgevraagd zijn oordeel te kunnen geven.

Het is niet de bedoeling van het onderzoek dat Duitse instituties of concepten of regelingen, zoals het Bundesverfassungsgericht, een-op-een worden overgenomen, maar gekeken wordt naar de elementen die in het Nederlandse systeem zouden kunnen passen en waardoor het Nederlandse parlement een grotere rol zou kunnen spelen in de EU, mits de Duitse ervaringen überhaupt verbeteringen gevonden worden. De uitkomst van het onderzoek kan wellicht ook zijn dat juist Duitsland beste praktijken van Nederland kan overnemen.

In deze vergelijking wordt niet enkel gekeken naar de formele bevoegdheden van beide parlementen. Informele processen, afspraken, de grootte van het ambtenarenapparaat, de instelling van Kamercommissies en het al dan niet vastleggen van bevoegdheden in wetgeving worden eveneens betrokken in dit onderzoek. Met betrekking tot dit laatste, het vastleggen van bevoegdheden in wetgeving, is een groot verschil te zien tussen beide landen. Duitsland heeft in de Grondwet een verwijzing naar de Europese Unie en heeft in formele wetgeving de bevoegdheden van het parlement vastgelegd. In Nederland is dit niet het geval. Aangezien dit voorafgaand aan het onderzoek duidelijk was, kan ook de vraag gesteld worden of parlementen die hun bevoegdheden in (grond)wetten hebben neergelegd ook meer en beter gebruikmaken van deze bevoegdheden. Meer specifiek is dan de vraag of Nederland, naar Duits voorbeeld, ook zijn bevoegdheden ten aanzien van Europese aangelegenheden vast moet leggen in de Grondwet en/of andere nationale wetgeving. Het onderzoek is echter niet beperkt tot alleen deze vraag omdat er wellicht nog andere zaken zijn die het Nederlandse parlement niet doet en het Duitse wel. Daarom is als centrale vraag opgesteld: Kan het Nederlandse parlement zijn controle ten aanzien van Europese aangelegenheden verbeteren, al dan niet naar Duits voorbeeld, teneinde recht te doen aan het VEU, en de eigen nationale rol die het heeft ten aanzien van controle en vertegenwoordiging?

Deze vraag zal uiteindelijk beantwoord worden in de conclusie en de aanbevelingen die gedaan worden.

25 In dit onderzoek is ervoor gekozen om de Duitse termen 'Bundestag', 'Bundesrat' en 'Bundesverfassungsgericht' aan te houden. Voor alle andere organen en functies, zoals de Bondskanselier, zal de Nederlandse naam worden gebruikt. 
In dit rechtsvergelijkend onderzoek wordt naar twee landen gekeken maar aangezien het onderzoek is opgesteld in de Nederlandse taal wordt bij de aanbevelingen de nadruk gelegd op het Nederlandse parlement.

\subsection{ONDERZOEKSMETHODE}

Voor dit onderzoek is gekozen voor de gangbare rechtswetenschappelijke onderzoeksmethode. Dit betreft bestudering van literatuur, ${ }^{26}$ wetgeving, parlementaire documenten en (waar gepast) jurisprudentie. Het verzamelen van data voor beide landen heeft op de volgende manieren plaatsgevonden. Voor het hoofdstuk Van Europees naar nationaal is gebruikgemaakt van het platform IPEX (ipex.eu) en de website van de Europese Commissie (ec.europa.eu). Op deze websites is te vinden hoe vaak het Nederlandse en het Duitse parlement met redenen omklede adviezen hebben ingediend in het kader van de gelekaartprocedure en hoe vaak de parlementen een politieke dialoog hebben gevoerd met de Europese Commissie. Ook documenten en verslagen van de interparlementaire conferenties zijn te vinden via IPEX. Aanvullende informatie werd gevonden via de websites van de nationale parlementen. ${ }^{27}$

Voor het hoofdstuk over Nederland heeft het verzamelen van data op verschillende manieren plaatsgevonden. De Tweede Kamer houdt geen (openbare) overzichten bij van de keren dat controlebevoegdheden (in EU-aangelegenheden) worden ingezet. Voor het achterhalen van de benodigde data is gebruikgemaakt van een combinatie van onderzoeksystemen. Ten eerste is het interne zoeksysteem voor mij door een van de medewerkers van de Tweede Kamer geraadpleegd. De resultaten hiervan zijn vergeleken met de resultaten die via de website www.overheid.nl zijn gevonden. Daarnaast heeft het Parlementaire Documentatie Centrum (PDC) in Den Haag zijn overzichten met mij gedeeld. Het PDC houdt via het systeem Parlementaire Monitor bij hoe vaak bepaalde bevoegdheden door het parlement zijn gebruikt. Deze resultaten van het interne zoeksysteem van de Tweede Kamer, van www.overheid.nl en van het PDC zijn met elkaar vergeleken. Het merendeel van de resultaten kwam overeen en is waar nodig samengevoegd om een zo compleet mogelijk overzicht te krijgen. Via deze manier zijn de resultaten voor wat betreft de Tweede Kamer tot stand gekomen.

26 Voor onderzoek naar de mogelijkheden en zin van 'constitutional transplants' zie onder andere W.J.M. Voermans, 'From Legal Imposition to Legal Invitation: From Transplants to Mutual Learning, Benchmarks and Best-Practice-Inspiration', European Journal of Law Reform 2018, 20, p. 8-19; V. Perju. 'Constitutional Transplants, Borrowing and Migrations', in: M. Rosenfeld \& A. Sajo (eds.), Oxford Handbook of Comparative Constitutional Law, Oxford: Oxford University Press 2012; F. Jacobs, 'Comparative Law and European Union Law', in: M. Reinmann \& R. Zimmermann, The Oxford Handbook of Comparative Law, Oxford: Oxford University Press 2019.

27 Website Tweede Kamer; website Eerste Kamer; website Bundestag; website Bundesrat. 
De Eerste Kamer publiceert haar data op haar eigen website www.eerstekamer.nl. Via deze website is dus te achterhalen hoe vaak de Eerste Kamer haar bevoegdheden inzet. Daarnaast zijn de data die niet via de website verkregen konden worden opgevraagd bij de Eerste Kamer. De resultaten zijn via e-mail ontvangen.

De Duitse Bundestag en Bundesrat houden ieder hun activiteiten bij en deze kunnen worden gevonden op de websites bundestag.de en bundesrat.de. Daarnaast zijn via e-mail overzichten opgevraagd bij beide organen. Deze overzichten bevatten het aantal ingediende met redenen omklede adviezen, het aantal gevoerde politieke dialogen, het aantal Stellungnahmen op grond van artikel 23 van de Grondwet en de aantallen ingezette controlebevoegdheden. Daarnaast zijn overzichten opgevraagd en ontvangen van de concrete inzet van de bevoegdheden. Dit was echter niet mogelijk voor de Stellungnahmen van artikel 23 van de Grondwet. Concrete Stellungnahmen op grond van artikel 23 van de Grondwet in combinatie met de daaruit voortvloeiende wetten zijn gevonden via de websites van de Bundestag en de Bundesrat. ${ }^{28}$

Het onderzoek heeft een nationale focus wat betekent dat uiteindelijk wordt onderzocht wat het Nederlandse parlement zou kunnen verbeteren aan zijn controle.

\subsection{Opbouw}

Dit proefschrift bevat zes hoofdstukken. In hoofdstuk 2 wordt gekeken naar de plaats van nationale parlementen binnen de Europese Unie. In het kader hiervan wordt allereerst uiteengezet welke documenten aan nationale parlementen worden verstrekt in het kader van de informatievoorziening vanuit de Europese Unie aan de nationale parlementen. Daarna worden de politieke dialoog en de gelekaartprocedure behandeld. Beide instrumenten zijn direct gericht tot de Europese Commissie. Tot slot wordt ingegaan op interparlementaire samenwerking. Deze samenwerking tussen nationale parlementen en het Europees Parlement kan de invloed van nationale parlementen in de EU vergroten en zou wellicht kunnen bijdragen aan een betere democratische legitimiteit van de Europese Unie. Het doel van dit hoofdstuk is ten eerste om uiteen te zetten welke bevoegdheden alle nationale parlementen hebben op basis van Europese regels; in het bezit daarvan zullen het Nederlandse en het Duitse parlement niet verschillen. Ten tweede wordt bepaald welke waarde deze bevoegdheden hebben voor Duitsland en Nederland. Worden deze bevoegdheden gebruikt en zo ja, hoe vaak worden ze gebruikt?

Hoofdstuk 3 is geheel gewijd aan het Nederlandse parlement. Dit hoofdstuk begint met enkele korte historische opmerkingen. Daarna is het hoofdstuk verdeeld in drie delen: controle, wetgeving, en het parlement en de EU. Het eerste gedeelte is gericht op de parle- 
mentaire middelen die het parlement kan inzetten om de regering te controleren in de nationale context. Hiermee wordt bedoeld dat alleen gekeken wordt naar de middelen die vastgelegd zijn in Nederlandse wetgeving of door Nederlandse gewoonten zijn ontstaan en dus niet naar de middelen die vastgelegd zijn in Europese verdragen. De middelen die zijn onderzocht, zijn onder andere het recht van interpellatie en het vragenrecht. Per controlemiddel zal worden aangegeven of en hoe vaak het middel door de Tweede Kamer dan wel de Eerste Kamer is ingezet om controle uit te oefenen op Europees beleid van de regering. In het gedeelte 'wetgeving' wordt ingegaan op de processen in beide Kamers voor wat betreft de behandeling van nieuwe commissievoorstellen. Ook zal in dit gedeelte aandacht worden besteed aan de twee (nieuwe) bevoegdheden van het parlement, te weten het instemmingsrecht en het behandelvoorbehoud, die zijn neergelegd in de Goedkeuringswet van het Verdrag van Lissabon. In het laatste gedeelte van dit hoofdstuk ligt de focus op de meer politieke manieren van invloed uitoefenen. Denk hierbij aan de parlementaire vertegenwoordiging bij de EU, de Staat van de Europese Unie, het begrotingsrecht en het Europees Semester.

In hoofdstuk 4 is getracht hetzelfde te doen als in hoofdstuk 3, maar dan voor Duitsland. Aangezien de staatsstructuur van Duitsland anders is dan die van Nederland zal deze kort worden uitgelegd aan het begin van het hoofdstuk. Het doel hiervan is inzicht geven in de voor dit onderzoek belangrijkste staatsorganen en de verhouding tussen de organen. Vervolgens wordt het wetgevingsproces behandeld. Ook in Duitsland wordt de regering gecontroleerd door het parlement. Met welke bevoegdheden het parlement dit doet en hoe vaak deze middelen worden ingezet voor Europese aangelegenheden wordt besproken in de vijfde paragraaf. Anders dan in Nederland bestaan er in Duitsland wetten met daarin specifieke rechten van het parlement om mee te werken aan Europese aangelegenheden. Deze wetten vloeien voort uit artikel 23 van de Duitse Grondwet met daarin de rechten van de Bundestag en de Bundesrat om standpunten in te nemen in Europese aangelegenheden.

In hoofdstuk 5 wordt een vergelijking gemaakt tussen Nederland en Duitsland. Hier wordt aansluiting gezocht bij de opbouw van de vorige twee hoofdstukken over de beide landen.

Het onderzoek wordt afgesloten met het hoofdstuk 'Conclusie' waarin antwoord wordt gegeven op de onderzoeksvragen en aanbevelingen worden gedaan voor het Nederlandse parlement. 



\title{
HoOfDSTUK 2 VAN EUROPEES NAAR
}

\author{
NAT I O NA A L
}

\subsection{INLEIDING}

Vanuit de Europese Unie is getracht de rol van nationale parlementen in de EU te vergroten teneinde het eerder besproken democratic deficit tegen te gaan. Dit begon al bij het Barrosoinitiatief in 2006. De toenmalige voorzitter van de Europese Commissie, José Manuel Barroso, stelde voor om voortaan alle stukken van de Commissie direct aan de nationale parlementen te sturen. Zo zouden de nationale parlementen daarvoor niet langer afhankelijk zijn van hun regeringen. Zo geschiedde. Het gevolg van het Barroso-initiatief was de politieke dialoog. De nationale parlementen kregen de mogelijkheid om met de Commissie in dialoog te gaan. Elk onderwerp is met de Commissie te bespreken. Dat kan nieuwe conceptwetgeving zijn waar een nationaal parlement kritiek op heeft, maar ook kan een simpel compliment aan de Commissie worden gestuurd. Deze politieke dialoog heeft als doel de betrokkenheid van nationale parlementen te vergroten.

Sinds het Verdrag van Lissabon kunnen nationale parlementen met redenen omklede adviezen aan de Commissie sturen in het kader van de gelekaartprocedure. Hiermee kunnen nationale parlementen hun stem laten horen voor wat betreft nieuwe wetgevingsvoorstellen van de Commissie. Om via deze weg effectieve invloed te hebben op Europees niveau dienen nationale parlementen wel samen te werken. Het Nederlandse en Duitse parlement maken immers deel uit van de Europese Unie, waarin verder nog 25 parlementen bestaan. Deze parlementen kunnen een één- of tweekamerstelsel hebben. Zowel het Nederlandse als het Duitse parlement bestaat uit twee kamers. ${ }^{1}$ In de EU bestaan, exclusief de twee laatstgenoemde parlementen, nog tien tweekamerstelsels en vijftien eenkamerstelsels. In totaal zijn dat 39 kamers. Doordat er 39 kamers bestaan, is het voor een enkel parlement of een enkele kamer van een parlement moeilijk om invloed uit te oefenen. ${ }^{2}$ Het is in de context van de gelekaartprocedure noodzakelijk dat meerdere nationale parlementen een gemotiveerd advies aan de Commissie sturen waarin bezwaar wordt gemaakt tegen nieuwe wetgeving. Hoe meer nationale parlementen een gemotiveerd advies sturen,

$1 \quad$ Formeel is de Bundesrat geen kamer maar hij wordt voor EU-doeleinden wel als kamer gezien. Voor dit onderzoek wordt naar Bundesrat verwezen als kamer, hoewel het naar Duits constitutioneel recht geen kamer is (BVerfGE 37, 363 ff., 380).

2 S. Hölscheidt, 'Die Mitwinkungsrechte des Deutschen Bundestages in europapolitischen Angelegenheiten', in: K. Böttger \& M. Jopp (Hrsg.), Handbuch zur deutschen Europapolitik, Baden-Baden: Nomos Verlagsgesellschaft 2017, p. 105-114, op p. 106. 
hoe groter de kans is dat een gele of zelfs een oranje kaart getrokken wordt en de Commissie haar wetgevingsvoorstel dient te heroverwegen of in te trekken. Voor een effectieve gele kaart doen de nationale parlementen er verstandig aan samen te werken aangezien de procedure vereist dat minimaal een bepaald aantal nationale parlementen een gemotiveerd advies stuurt voordat de Commissie haar wetgevingsvoorstel dient te heroverwegen.

In dit hoofdstuk wordt onderzocht of het Nederlandse en het Duitse parlement de bevoegdheden die zij op basis van Europees recht bezitten, uitoefenen en hoe vaak zij dit doen. Deze bevoegdheden zijn voor alle nationale parlementen gelijk. Hoe de uitoefening van deze bevoegdheden op nationaal niveau wordt georganiseerd is echter een aangelegenheid van de lidstaten/de nationale parlementen zelf. Allereerst zal in dit hoofdstuk worden gekeken naar de plaats van nationale parlementen in de Europese Unie alvorens wordt uiteengezet welke documenten precies worden verstrekt in het kader van de informatievoorziening vanuit de Europese Unie aan nationale parlementen. Daarna worden de voornoemde politieke dialoog en de gelekaartprocedure behandeld. Tot slot wordt in dit hoofdstuk ingegaan op wenselijkheid en bestaan van parlementaire samenwerking tussen de parlementen van de 27 lidstaten teneinde hun inbreng en invloed zo effectief mogelijk te laten zijn.

\subsection{Nationale parlementen in de Europese Unie}

Langs twee lijnen kunnen nationale parlementen zich mengen in EU-aangelegenheden. De eerste weg is via de naar nationaal recht geregelde controle van de executieve (en haar handelen in de Europese Raad en de Raad). Het Nederlandse en Duitse parlement controleren hun eigen regeringen. De tweede weg is een Europese en gaat via de politieke dialoog en de gelekaartprocedure en is gericht op invloed uitoefenen op (nieuwe wetgeving van) de Europese Commissie. In de paragrafen hieronder wordt allereerst ingegaan op deze laatste route. Onder het gedeelte Europees perspectief wordt de rol van nationale parlementen in de Europese Unie uitgewerkt, als ook de mogelijkheden van nationale parlementen om de Europese Commissie te beïnvloeden. In het tweede gedeelte genaamd nationaal perspectief, wordt kort aangestipt hoe de nationale parlementen het Europees beleid van hun eigen regeringen controleren. Dit wordt vervolgens meer in detail uitgewerkt in de hoofdstukken over Nederland en Duitsland.

\subsubsection{Europees perspectief}

Nationale parlementen worden sinds 2007 voor het eerst als zodanig genoemd in Europese verdragen. Hiermee wordt duidelijk dat de nationale parlementen een belangrijk element vormen in Europese aangelegenheden, niet alleen binnen de wetgevingsprocedure maar 
binnen de Europese Unie als geheel. Volgens het Verdrag van Lissabon dragen nationale parlementen actief bij aan de goede werking van de Europese Unie. Hiertoe hebben zij onder het verdrag enkele bevoegdheden en rechten gekregen. Genoemd is al de gelekaartprocedure waarbinnen parlementen een met redenen omkleed advies kunnen sturen, en verder is er de mogelijkheid een zaak bij het Hof van Justitie van de Europese Unie aanhangig te maken en het recht rechtstreeks Europese documenten te ontvangen. Nationale parlementen kunnen daarmee onafhankelijk van hun regeringen op Europees niveau handelen. Parlementariërs zijn daarmee niet enkel vertegenwoordigers van de burgers van hun lidstaat, maar ook spelers binnen de Europese Unie. ${ }^{3}$

De rol van nationale parlementen in de EU wordt wel geduid aan de hand van een onderscheid tussen directe en indirecte betrokkenheid bij Europese besluitvorming. Directe betrokkenheid ligt bij het direct gekozen Europees Parlement en als vertegenwoordiging van de lidstaten bij de Raad. Deze instellingen nemen direct deel aan het wetgevingsproces op EU-niveau. Nationale parlementen zijn (slechts) indirect betrokken via de controle die zij uitoefenen op hun regeringen in hun hoedanigheid als lid van de Raad (of Europese Raad). Dit wordt gezien als de traditionele rol van nationale parlementen in de EU en hoort bij het idee dat Europese besluitvorming kan worden gescheiden van het nationale gebeuren. ${ }^{4}$ Sinds het Verdrag van Lissabon hebben nationale parlementen echter een prominente(re) plaats gekregen en worden zij in het Verdrag expliciet genoemd en erkend als onderdeel van de democratische legitimiteit. Artikel 12 VEU, dat geplaatst is onder de nieuwe titel 'Bepalingen inzake de democratische beginselen', geeft aan dat 'de nationale parlementen actief bij[dragen] tot de goede werking van de Unie (...)'. Op grond van het sub a vermelde worden parlementen door de instelling van de Unie geïnformeerd over ontwerpen van wetgevingshandelingen van de Unie, met andere woorden, nieuwe wetgevingsvoorstellen worden direct aan nationale parlementen toegestuurd. Dit kan worden gezien als de codificatie van het Barroso-initiatief. Daarnaast moet de Commissie erop toezien dat het beginsel van subsidiariteit wordt geëerbiedigd; wanneer dat niet het geval is, kunnen nationale parlementen op grond daarvan bezwaar maken tegen wetgevingsvoorstellen. Van een strikte scheiding tussen Europese besluitvorming en nationale bemoeienis kan niet (meer) worden gesproken.

Het zijn echter nog altijd de staatshoofden en regeringsleiders en ministers die, volgens het VEU, de lidstaten in de Europese Raad en de Raad vertegenwoordigen. ${ }^{5}$ De staatshoof-

3 L. Besselink, 'EU Constitutionalism and National Parliaments. Insiders or Outsiders?', in: C. Fasone \& N. Lupo, Interparliamentary Cooperation in the Composite European Constitution, Oxford: Hart Publishing 2016, p. 27.

4 A. Groen \& T. Christiansen, 'National Parliaments in the European Union: Conceptual Choices in the European Union's Constitutional Debate', in: C. Hefftler e.a. (eds.), The Palgrave Handbook of National Parliaments and the European Union, Londen: Palgrave Macmillan 2015, p. 45.

5 Art. 10 lid 2 VEU. 
den en regeringsleiders zijn wel verantwoording schuldig aan hun parlementen en hun burgers. Op basis van het voorgaande wordt op het niveau van de Europese Unie erkend dat nationale parlementen een controlerende taak hebben ten opzichte van hun eigen regeringen voor Europese handelingen en optreden. ${ }^{6}$

De mogelijkheid om invloed uit te oefenen in de Europese Unie ligt vooral, maar niet uitsluitend, in de Europese wetgevingsprocedure. Het is met name in deze procedure dat nationale parlementen hun bevoegdheden kunnen inzetten. Dat kan al in een vroeg stadium door te reageren op groen- of witboeken, of in een later stadium door een met redenen omkleed advies aan de Commissie te sturen in het kader van de gelekaartprocedure.

Nieuwe Europese wetgeving ontstaat niet ad hoc. Initiatieven voor nieuwe Europese wetgeving worden ten eerste geplaatst in het jaarlijkse wetgevings- en werkprogramma van de Europese Commissie. Dit programma wordt ieder najaar aan het Europees Parlement aangeboden en gepubliceerd op de website van de Commissie. Voordat de Commissie een initiatief uitwerkt, consulteert zij geïnteresseerden zoals nationale overheden, belangengroeperingen, non-gouvernementele organisaties (ngo's), vertegenwoordigers van het maatschappelijk middenveld en politieke groeperingen in Europa. Dit wordt gedaan om een zo groot mogelijk draagvlak te creëren voor het uiteindelijke wetsvoorstel. Na deze informele consultatierondes volgt doorgaans een groenboek in een officiële consultatieronde. ${ }^{7}$

In een groenboek wordt een maatschappelijk probleem of onderwerp geanalyseerd en worden aanbevelingen gedaan voor het te ontwikkelen beleid. Ook wordt bekeken of de bestaande instrumenten toereikend zijn of dat er nieuwe instrumenten ontwikkeld moeten worden. Een vraag die dan (met uitzondering van de exclusieve EU-bevoegdheden) volgt, is op welk niveau, nationaal of Europees, maatregelen moeten worden getroffen om het probleem zo effectief mogelijk aan te pakken. Daarbij geldt dat de Unie alleen wetgevend mag optreden als de beoogde maatregelen aan het in artikel 5 lid 3 VEU en in Protocol nr. 2 neergelegde beginselen van subsidiariteit en evenredigheid voldoen. Het onderwerp van een groenboek kan betrekking hebben op alle terreinen waarop de Europese Unie bevoegdheden heeft. Geïnteresseerden zoals overheden, organisaties en bedrijven kunnen op groenboeken binnen een bepaalde termijn reageren, doorgaans door antwoord te geven op de in het groenboek gestelde vragen. $\mathrm{Na}$ een groenboek kan een witboek volgen. Een witboek wordt doorgaans opgesteld voor een discussie over meer concrete voorstellen. Het bevat een voorstel en daarbij een actieplan voor een bepaald concreet beleidsterrein. Ook via een witboek vraagt de Europese Commissie om input voor nieuwe Europese

6 De basis daarvoor zijn art. 10 en 12 VEU.

7 Rapport Tweede Kamer, 'Bovenop Europa: Evaluatie van de versterkte EU-ondersteuning van de Tweede Kamer 2007-2011, Den Haag: Tweede Kamer 2011, p. 5. 
wetgevingsvoorstellen. Wederom kunnen geïnteresseerden (bedrijven, organen, organisaties, individuen, enzovoort) een reactie sturen. Ook nationale parlementen kunnen een reactie naar de Commissie sturen. Hoe eerder een parlement actief is binnen Europa, hoe groter de kans dat werkelijk invloed kan worden uitgeoefend. Het is daarom van belang dat niet pas actie wordt ondernomen na ontvangst van wetgevingsdocumenten maar ook al bij consultatiedocumenten.

\subsubsection{Nationaal perspectief}

De erkenning van nationale parlementen in de EU houdt geen overdracht van bevoegdheden aan de EU in. Bij het Verdrag van Lissabon hebben nationale parlementen juist bevoegdheden gekregen. Hieronder wordt duidelijke welke bevoegdheden nationale parlementen kunnen inzetten om invloed uit te oefenen in de EU. Of, en hoe deze bevoegdheden uitgeoefend worden is aan de nationale parlementen zelf. De uitvoering van Europese bevoegdheden wordt daarmee nationaal geregeld. Dit kan zijn in de Grondwet, wetten, regelingen als ook door gewoonte. Dit verklaart dan ook het verschil van de wijze en mate van controle en invloed op EU-aangelegenheden tussen de nationale parlementen c.q. lidstaten. Niet alle parlementen zijn op dezelfde manier ingericht. Bij het ene parlement (het Duitse parlement) zijn de 'Europese' bevoegdheden terug te vinden in de Grondwet en uitgebreid uitgewerkt in andere nationale wetten, bij het andere parlement (het Nederlandse parlement) is de nationale wetgeving over 'Europese' bevoegdheden heel summier. Maar ook verschilt de politieke cultuur, de mate van ondersteuning, de wijze van organisatie van parlementaire werkzaamheden, dan wel de mate van 'monisme' tussen regering en (meerderheid van het) parlement.

\subsection{WELKE DOCUMENTEN WORDEN VERSTREKT?}

Tot aan het Verdrag van Lissabon werd nieuwe Europese wetgeving op EU-niveau geregeld, met andere woorden, nationale parlementen speelden geen rol in het Europese wetgevingsproces. Het Verdrag van Lissabon bracht daarin verandering. De lidstaten zijn meer geïntegreerd in de Europese wetgevingsprocedure en andere EU-aangelegenheden. Daarbij hoort ook een actieve houding van de nationale parlementen. Voor het Verdrag van Lissabon bestond er slechts een marginale betrokkenheid van nationale parlementen bij Europese wetgeving, alleen via de indirecte manier van ministeriële verantwoordelijkheid en de op gewoonte gebaseerde politieke dialoog. Nationale parlementen konden hun ministers voorafgaand aan een vergadering van de Raad van Ministers van de Europese Unie aanwijzingen geven en hen achteraf ter verantwoording roepen. Daarnaast ontvingen nationale parlementen informatie via hun regeringen. Deze indirecte betrokkenheid bestaat nog 
steeds maar daarnaast zijn op Europees niveau instrumenten gecreëerd om nationale parlementen meer betrokken te maken.

De bevoegdheden die nationale parlementen bezitten op basis van Europees recht zijn onder andere neergelegd in Protocol 1 betreffende de rol van de nationale parlementen in de Europese Unie en Protocol 2 betreffende de toepassing van de beginselen van subsidiariteit en evenredigheid behorende bij het Verdrag van Lissabon. Alle nationale parlementen hebben op basis van Europees recht dezelfde bevoegdheden; dit betekent echter niet dat ook alle parlementen de bevoegdheden op dezelfde manier of met dezelfde intensiteit uitoefenen. ${ }^{8}$ Een essentiële voorwaarde voor het kunnen uitoefenen van de bevoegdheden zoals die in deze protocollen zijn neergelegd is dat nationale parlementen op de hoogte worden gesteld van nieuwe ontwerpwetgeving van de Commissie. In het Verdrag van Lissabon is daarvoor een informatievoorziening aan nationale parlementen vastgelegd. Het recht op informatie is te vinden in Protocol 1 bij het verdrag van Lissabon. Een van de doelen hiervan was het wegwerken van het zogenoemde 'informatietekort' dat heerste onder vorige verdragen. ${ }^{9}$ Op basis van het Protocol betreffende de rol van de nationale parlementen in de Europese Unie bij het Verdrag van Amsterdam waren nationale parlementen afhankelijk van hun regeringen voor wat betreft de informatievoorziening inzake Europese wetgevingsvoorstellen. Niet alle parlementen kregen alle documenten die de regeringen wel hadden ontvangen. Het Verdrag van Amsterdam schreef voor dat voorstellen van de Commissie tijdig beschikbaar werden gesteld zodat de regering van elke lidstaat ervoor kon zorgen dat nationale parlementen ze, indien bruikbaar, zouden ontvangen. ${ }^{10}$ Het was daarbij niet in elke lidstaat gebruik dat de regering de voorstellen van de Commissie doorstuurde naar het parlement. Hierdoor ontstond een 'informatietekort'. Om effectieve controle uit te oefenen is het echter van belang dat nationale parlementen tijdig correcte en volledige informatie ontvangen.

Thans, op basis van Protocol 1 bij het Verdrag van Lissabon, ontvangen nationale parlementen discussiedocumenten (groenboeken, witboeken en mededelingen) en het jaarlijks wetgevingsprogramma van de Europese Commissie, als ook alle andere instrumenten voor wetgevingsprogrammering en beleidsstrategie. ${ }^{11}$ Daarnaast ontvangen de nationale parlementen wetgevingsontwerpen. ${ }^{12}$ Hieronder worden verstaan de voorstellen van de Europese Commissie, de initiatieven van een groep lidstaten, de initiatieven van het

8 H.T. Nguyen, An uneven balance? A legal analysis of power asymmetries between national parliaments in the EU, The Hague: Eleven International Publishing 2018, p. 50.

9 A. Groen \& T. Christiansen, 'National Parliaments in the European Union: Conceptual Choices in the European Union's Constitutional Debate', in: C. Hefftler e.a. (eds.), The Palgrave Handbook of National Parliaments and the European Union, Londen: Palgrave Macmillan 2015, p. 8, 46-47.

10 Art. 2 Protocol nr. 1 betreffende de rol van de nationale parlementen in de Europese Unie.

11 Art. 1 Protocol nr. 1.

12 Art. 2 Protocol nr. 1. 
Europees Parlement, de verzoeken van het Hof van Justitie, de aanbevelingen van de Europese Centrale Bank en de verzoeken van de Europese Investeringsbank. ${ }^{13}$ Ook ontvangen de parlementen van de Europese Commissie een aankondiging dat de Commissie voornemens is een van de verdragen te wijzigen. ${ }^{14}$ Van de Raad ontvangen de parlementen de agenda's en de resultaten van de Raadszittingen, waaronder begrepen de notulen van de Raadszittingen waarin over ontwerpen van een wetgevingshandeling is beraadslaagd. ${ }^{15}$ Tevens ontvangen de parlementen het jaarverslag van de Rekenkamer. ${ }^{16}$

Een andere grote vooruitgang sinds het Verdrag van Lissabon is dat documenten sindsdien in alle officiële talen van de EU beschikbaar worden gesteld. ${ }^{17}$ Dit zorgt voor een hechte(re) band tussen de nationale parlementen en de Europese instellingen. Bij schending van deze verplichtingen is het mogelijk een zaak aanhangig te maken bij het Hof van Justitie van de EU op grond van een vormgebrek dat leidt tot onverbindendheid van het betreffende Europese besluit. ${ }^{18}$ Zover kan worden nagegaan heeft geen nationaal parlement hierover ooit een zaak aanhangig gemaakt. Verder is grote vooruitgang geboekt met betrekking tot het aantal documenten dat nationale parlementen ontvangen en de manier waarop. ${ }^{19}$

Wanneer de informatieverstrekking uit het Verdrag van Lissabon wordt vergeleken met die uit het Verdrag van Amsterdam zijn twee grote punten van vooruitgang te zien. Ten eerste valt het aantal documenten dat nationale parlementen ontvangen op. Thans ontvangen nationale parlementen meer documenten dan voorheen aangezien ze tegenwoordig eenvoudigweg alle documenten ontvangen. Hierdoor worden alle nationale parlementen geïnformeerd en beschikken ze allemaal over dezelfde informatie. Ten tweede, zoals eerdergenoemd, worden tegenwoordig alle consultatiedocumenten en wetgevingsvoorstellen aan de nationale parlementen gestuurd in de officiële talen. ${ }^{20}$ Door het Verdrag van Lissabon zijn nationale parlementen daarmee in een betere positie gekomen, al moet worden opgemerkt dat, ondanks de positieve ontwikkelingen voor nationale parlementen, Protocol 1 bij het Verdrag van Lissabon ervan uitgaat dat nationale parlementen met name

13 Art. 2 Protocol nr. 1.

14 Subsidiarity, National Parliaments and the Lisbon Treaty, House of Commons European Scrutiny Committee, HC 563, 2007-2008, p. 4.

15 Art. 5 Protocol nr. 1.

16 Art. 7 Protocol nr. 1.

17 Art. 1 en 4 Protocol nr. 1; P. Kiiver, 'The early-warning system for the principle of subsidiarity: the national parliament as a Conseil d'Etat for Europe', European Law Review 2011, 36(1), p. 98-108, op p. 99.

18 H.R.B.M. Kummeling, B. van Mourik \& R. Nehmelman, Enkele staatsrechtelijke reflecties op de positie van de Eerste Kamer in het kader van de Europese Unie, Eerste Kamer 2009, p. 9 (zie www.eerstekamer.nl/eu/ publicatie/20090201/bijlage_europese_herbezinning/document).

19 A. Cygan, 'The parliamentarisation of EU decision-making? The impact of the Treaty of Lisbon on national parliaments', European Law Review 2011, 36(4), p. 480-499, op p. 493.

20 Art. 1 en 4 Protocol nr. 1. 
een rol spelen op nationaal niveau. ${ }^{21}$ Maar ook daarbij is de ontvangen informatie vanzelfsprekend van groot belang. De grote vraag is wel of parlementen die kennis ook benutten en daadwerkelijk in staat en bereid zijn deze te verwerken en gebruiken.

\subsection{Parlementaire invloed op Europese ONTWERPWETGeVing}

Parlementen kunnen met de hun toekomende Europese en nationale bevoegdheden invloed uitoefenen in het Europese besluitvormingsproces. In deze paragraaf zullen de twee Europese middelen worden beschreven die parlementen hiervoor tot hun beschikking hebben. Dat zijn de politieke dialoog, gebaseerd op het Barroso-initiatief, en de gelekaartprocedure.

\subsubsection{Het Barroso-initiatief en de politieke dialoog}

Om parlementen in staat te stellen invloed uit te oefenen in het Europese besluitvormingsproces, is het essentieel dat zij voldoende worden geïnformeerd. Er bestaan meerdere manieren waarop nationale parlementen geïnformeerd kunnen worden. De informatieverschaffing door de Europese Commissie is het belangrijkst. De Commissie zendt sinds 2006 al haar wetsvoorstellen en discussiedocumenten, het jaarlijkse wetgevings- en werkprogramma en andere beleidsplannen aan de nationale parlementen. ${ }^{22}$ Zoals eerder beschreven deed de Commissie dit aanvankelijk op initiatief van voormalig voorzitter Barroso. Het doel hiervan is het verbeteren van de uitwisseling van informatie en standpunten over beleid, wetgeving en andere initiatieven tussen de Europese Commissie en de nationale parlementen. ${ }^{23}$ Deze verbetering was nodig omdat er een informatietekort heerste onder nationale parlementen. Tot 2009 deed de Commissie dit vrijwillig, vanaf 2009 is deze informatieverschaffing verplicht nadat deze is neergelegd in Protocol nr. 1 bij het Verdrag van Lissabon. ${ }^{24}$

Nadat nationale parlementen ${ }^{25}$ zijn geïnformeerd, kunnen zij zich een mening vormen over hetgeen van de Commissie afkomstig is, of het nu gaat om wetgevingsvoorstellen,

21 Zie de eerste alinea van de preambule: '(...) dat de wijze waarop de nationale parlementen de controle uitoefenen op hun regering met betrekking tot de activiteiten van de Europese Unie, onder de eigen constitutionele inrichting en praktijk van de lidstaten valt'.

22 Subsidiarity, National Parliaments and the Lisbon Treaty, House of Commons European Scrutiny Committee, HC 563, 2007-2008, p. 4.

23 Website Europese Commissies, Betrekkingen met nationale parlementen.

24 Art. 1 Protocol nr. 1.

25 Daar waar 'nationaal parlement' staat, kan ook 'kamer van een nationaal parlement' worden gelezen zoals de Tweede Kamer, de Eerste Kamer, de Bundestag of de Bundesrat. De bevoegdheden in de politieke dialoog en de gelekaartprocedure gelden voor alle kamers afzonderlijk en niet per se voor het parlement als geheel. 
groenboeken, witboeken of mededelingen. Het doel van het Barroso-initiatief was het bewerkstelligen van een dialoog tussen de Commissie en de nationale parlementen om de parlementen meer te betrekken bij de EU en om de parlementaire en democratische dimensie van de EU te versterken. Deze dialoog is er gekomen en heet, heel toepasselijk, de politieke dialoog. ${ }^{26}$ De politieke dialoog komt neer op een uitwisseling van informatie tussen nationale parlementen en de Europese Commissie. De nationale parlementen vragen onder andere naar de beweegredenen van de Commissie, het doel van het voorstel, de uitwerking van het voorstel, enzovoort. In mindere mate is de politieke dialoog een manier om invloed uit te oefenen op de Commissie. Nationale parlementen geven argumenten mogelijk in de hoop dat de Commissie deze overneemt en veranderingen aanbrengt. Het gaat erom dat nationale parlementen worden betrokken in het Europese besluitvormingsproces, dat ze kunnen reageren op wetgevingsvoorstellen en andere documenten. Dit laatste zegt overigens nog niets over de mate van invloed die nationale parlementen op dat proces kunnen uitoefenen.

\subsubsection{Nieuwe Europese wetgeving}

Wanneer nationale parlementen conceptwetgeving van de Europese Commissie ontvangen, kan deze door de nationale parlementen getoetst worden op strijd met enkele beginselen. Het beginsel van bevoegdheidsverdeling wordt getoetst om te verzekeren dat de Commissie de bevoegdheid heeft om deze conceptwetgeving te maken. Nationale parlementen kunnen beoordelen of de Commissie gebruikmaakt van de juiste juridische basis. Daarnaast kunnen de beginselen van subsidiariteit en evenredigheid worden bezien om ervoor te zorgen dat de Commissie met haar nieuwe voorstel ook op dat punt in lijn handelt met de Europese verdragen. Met betrekking tot de subsidiariteit wordt bekeken of een bepaald onderwerp, dat onder de gedeelde bevoegdheden van de EU valt, daadwerkelijk beter door de Commissie c.q. de EU geregeld kan worden omdat het doel dat nagestreefd wordt met het voorstel niet onvoldoende op nationaal niveau geregeld kan worden. Bij evenredigheid wordt bekeken of de vorm en inhoud van het optreden van Commissie niet ruimer zijn dan nodig om de te behalen doelen uit de Europese verdragen te bereiken. ${ }^{27}$ In het kader van de politieke dialoog moet de Commissie haar handelingen (kunnen) verantwoorden aan nationale parlementen. De Commissie moet kunnen uitleggen, ophelderen en beredeneren waarom ze handelt en op welke manier ze handelt. ${ }^{28}$ Verder kunnen nationale parlementen het voorstel op elk ander politiek of juridisch punt beoordelen; daarbij kan gedacht worden aan de wenselijkheid of politieke opportuniteit van de nieuwe wetgeving.

26 D. Jančić, 'The Barroso Initiative: Window Dressing or Democracy Boost?', Utrecht Law Review 2012, 8(1), p. 80 .

27 Art. 5 lid 4 VEU.

28 D. Jančić, 'The Barroso Initiative: Window Dressing or Democracy Boost?', Utrecht Law Review 2012, 8(1), p. 80 . 
Wanneer nationale parlementen het voorstel strijdig achten met een of meer beginselen kunnen zij een met redenen omkleed advies aan de Commissie sturen met daarin argumenten waarom zij een of meer beginselen geschonden achten. Alleen als het gaat om strijd met het subsidiariteitsbeginsel dan valt dat advies binnen de gelekaartprocedure. Indien en voor zover het advies ingaat op een ander beginsel of op andere (politieke) vragen rondom het voorstel, dan valt het advies binnen de politieke dialoog. In dit laatste geval kan een nationaal parlement wel op alle punten van het voorstel commentaar geven en alle vragen stellen die het heeft. Het is ook toegestaan om een positieve reactie aan de Commissie te sturen over het voorstel.

De Commissie reageert doorgaans op alle adviezen binnen de politieke dialoog en probeert dit binnen drie maanden te doen. Positieve reacties krijgen geen antwoord of enkel een ontvangstbevestiging. De Commissie is niet verplicht te reageren en er is geen juridisch instrument om haar te sanctioneren wanneer zij niet reageert. Ook is de Commissie niet verplicht haar voorstel aan te passen na ontvangst van adviezen van nationale parlementen. ${ }^{29}$ Alle adviezen worden gepubliceerd op de website van de Commissie. ${ }^{30}$ Zowel het Europees Parlement als de Raad wordt op de hoogte gehouden van de dialoog. ${ }^{31}$ Het Europees Parlement heeft nationale parlementen gevraagd om de adviezen die zij aan de Commissie sturen tevens aan het Europees Parlement te sturen. Zo beschikt het Europees Parlement in een vroeg stadium over informatie over de standpunten van nationale parlementen. Daarnaast worden ook de antwoorden van de Commissie ter informatie doorgegeven aan het Europees Parlement en de Raad. ${ }^{32}$

Buiten het schriftelijk contact via de politieke dialoog heeft de Commissie ook contact met nationale parlementen in de vorm van vergaderingen en contacten op politiek en administratief niveau. Leden van de Commissie komen dan samen met leden van de nationale parlementen. Dit gebeurt zowel in Brussel als in de lidstaten. Daarnaast zijn Europarlementariërs ook vaak aanwezig bij interparlementaire vergaderingen en conferenties. ${ }^{33}$ Hier zal later in dit onderzoek bij worden stilgestaan.

\subsubsection{Nationale parlementen}

De manieren waarop nationale parlementen Europese bevoegdheden uitoefenen, verschillen.

De inhoud van de bevoegdheden is voor elk nationaal parlement hetzelfde, maar de uitoefening wordt nationaal geregeld en kan daarom van parlement tot parlement verschil-

29 D. Jančić, 'The Barroso Initiative: Window Dressing or Democracy Boost?', Utrecht Law Review 2012, 8(1), p. 81 .

30 Website Europese Commissie, Adviezen van nationale parlementen en antwoorden van de Commissie.

31 Website Europese Commissie, Dienst secretariaat-generaal.

32 Verslag van de Commissie. Jaarverslag 2007 over de contacten tussen de Europese Commissie en de nationale parlementen, $\operatorname{COM}(2008) 237$, p. 3.

33 Website Europese Commissie, Dienst secretariaat-generaal. 
len. De verschillen hebben hun oorsprong in een verschillende uitwerking van het parlementair stelsel van de lidstaten, maar ook in praktische parameters zoals de hoeveelheid parlementsleden, het aantal fracties binnen een parlement, en de grootte van het ondersteunende apparaat. In het kader van dit onderzoek wordt ingegaan op de uitoefening van bevoegdheden door het Nederlandse parlement en het Duitse parlement.

\subsection{Tweede Kamer en Eerste Kamer}

In de Tweede Kamer nemen de Kamercommissies het initiatief om met redenen omklede adviezen in het kader van de politieke dialoog aan de Europese Commissie te sturen. Het voeren van de dialoog gebeurt veelal schriftelijk. De Nederlandse regering ontvangt een kopie van de brief die de Kamercommissie aan de Europese Commissie stuurt. ${ }^{34}$ Naast een schriftelijke dialoog gaan Tweede Kamerleden ook met commissarissen in gesprek. Met enige regelmaat bezoeken Kamerleden en Nederlandse ambtenaren de Europese Commissie. Andersom gebeurt dit ook. Commissarissen (en hun ambtenaren) nemen deel aan vergaderingen van de Tweede Kamer(commissies). ${ }^{35}$ Zo bracht Eurocommissaris Věra Jourová van Justitie, Consumentenrechten en Gendergelijkheid op 4 juni 2015 een bezoek aan Nederland. Zij sprak allereerst met de toenmalige voorzitter van de Tweede Kamer, Anouchka van Miltenburg, waarna een gesprek met de Kamercommissie voor Veiligheid en Justitie volgde. Een van de onderwerpen waarover werd gesproken was het Europees Openbaar Ministerie. ${ }^{36}$ Van dergelijke ontmoetingen en gesprekken worden geen verslagen gemaakt. Het is daardoor niet te achterhalen wat er tijdens een gesprek is besproken en of deze gesprekken invloed hebben op het handelen van, in dit geval, Eurocommissaris Jourová.

De Eerste Kamer kiest ervoor om een schriftelijke dialoog te voeren met de Commissie. Wanneer een Eurocommissaris een bezoek brengt aan de Tweede Kamer zal de Eerste Kamer hier vaak aansluiting zoeken maar zij zal zelf, om praktische redenen, zelden aansturen op een bezoek van een Eurocommissaris. ${ }^{37}$ De Eerste Kamer is overigens eerder geneigd haar vragen aan de regering te zenden dan aan de Commissie. De Eerste Kamer is namelijk van mening dat de beantwoording door de Commissie te wensen overlaat. De Eerste Kamer is niet tevreden over de kwaliteit van de beantwoording en evenmin over de tijdigheid van beantwoording. Beide zijn ook wel voor verbetering vatbaar. De Commissie streeft naar een beantwoording binnen drie maanden, terwijl de regering binnen vier tot zes weken antwoordt op een brief van de Eerste Kamer. Het is dan ook niet vreemd dat

34 Website Tweede Kamer, Vaste commissie voor Justitie en Veiligheid.

35 Website Europese Commissies, Betrekkingen met nationale parlementen.

36 Website Tweede Kamer, Eurocommissaris Justitie spreekt met Kamerleden.

37 F. Bergman \& I. van den Driessche, 'De Eerste Kamer en "Europa"', Internationale Spectator 2015, nr. 8, p. 5 . 
controle op Europese aangelegenheden door de Eerste Kamer grotendeels via de regering loopt, tenzij het gaat om specifieke keuzes die de Commissie heeft gemaakt. In dat geval wordt de brief aan de Commissie gestuurd. ${ }^{38}$

\subsection{Bundestag en Bundesrat}

In Duitsland worden zowel in de Bundestag als in de Bundesrat binnenkomende documenten toegewezen aan de Kamercommissies waartoe het document naar onderwerp thuishoort. Deze toewijzing wordt gedaan door de Kamercommissie voor Europese Zaken. Daarnaast legt deze commissie de basis voor een eventuele correspondentie met de Europese Commissie. Het merendeel van de correspondentie van het Duitse parlement is schriftelijk. Daarnaast brengen Bundestag en Bundesrat meer adviezen uit aan de Europese Commissie over niet-wetgevingsdocumenten dan over wetgevingsdocumenten. ${ }^{39}$ Net zoals in Nederland brengen Eurocommissarissen ook bezoeken aan het Duitse parlement. Zo ging op 25 september 2014 Eurocommissaris Günther Oettinger in gesprek met de Kamercommissie voor aangelegenheden van de Europese Unie van de Bundestag. In dit gesprek werden onder andere de doelstellingen van de Europese Commissaris op het gebied van digitale economie en samenleving besproken als ook de samenwerking van de nationale parlementen en de Europese Commissie. ${ }^{40}$

\subsubsection{Beoordeling van de politieke dialoog}

In het algemeen hebben de nationale parlementen binnen de Europese Unie diverse prioriteiten en aandachtsgebieden die veelal niet overeenkomen. De Commissie maakt elk jaar de balans op over de door haar ontvangen adviezen en geeft aan welke onderwerpen in dat jaar meerdere adviezen hebben ontvangen, de zogenoemde belangrijkste onderwerpen. ${ }^{41}$ Er zijn slechts weinig documenten binnen de politieke dialoog waarover de Commissie meer dan vier of vijf adviezen van Kamers heeft ontvangen. Met betrekking tot de belangrijkste onderwerpen zijn er een paar onderwerpen die meerdere jaren terugkomen. Het meerjarig financieel kader 2014-2020 en de Europa 2020-strategie zijn twee concrete onderwerpen die de afgelopen jaren veel binnen de politieke dialoog werden besproken. Daarnaast zijn de terreinen justitie, binnenlandse zaken, de Economische Monetaire Unie (EMU) en de interne markt onderwerpen die ieder jaar veelvuldig worden behandeld en die daarom tot de belangrijkste onderwerpen behoren.

38 Ibid., p. 6.

39 Verslag van de Commissie. Jaarverslag 2010 over de betrekkingen tussen de Europese Commissie en de nationale parlementen. $\operatorname{COM}(2011) 345$, p. 7.

40 Website Bundestag, EU-Ausschuss diskutiert mit Kommissar Oettinger.

41 Deze jaarverslagen, getiteld 'Jaarverslag XXXX', over de betrekking tussen de Europese Commissie en de nationale parlementen zijn te vinden op de website van de Europese Commissie, Jaarverslagen. 
De meeste belangrijkste onderwerpen verschillen echter van die van het voorgaande jaar of de voorgaande jaren. In 2010 waren de belangrijkste onderwerpen het Europees burgerinitiatief, ${ }^{42}$ de Richtlijn inzake seizoenarbeiders, ${ }^{43}$ de Richtlijn inzake depositogarantiestelsels, ${ }^{44}$ het Groenboek over pensioenstelsels, ${ }^{45}$ economische governance ${ }^{46}$ en Europa $2020 .^{47,48}$ In 2013 waren de belangrijkste onderwerpen het voorstel tot oprichting van het Europees Openbaar Ministerie, ${ }^{49}$ de Richtlijn over de productie, de presentatie en de verkoop van tabaks- en aanverwante producten, ${ }^{50}$ de Richtlijn over maritieme ruimtelijke ordening en geïntegreerd kustbeheer, ${ }^{51}$ de Verordening over de toegang tot de markt voor havendiensten en de financiële transparantie van haven ${ }^{52}$ en de Verordening betreffende het Agentschap van de Europese Unie voor samenwerking en opleiding op het gebied van rechtshandhaving (Europol). ${ }^{53}$ In 2016 waren de belangrijkste onderwerpen de Richtlijn betreffende de terbeschikkingstelling van werknemers met het oog op het verrichten van diensten, ${ }^{54}$ de mededeling inzake het werkprogramma van de commissie voor 2016: Tijd

42 Groenboek over een Europees burgerinitiatief, COM(2009)622 en Voorstel voor een Verordening over het burgerinitiatief, $\operatorname{COM}(2010) 119$.

43 Richtlijn 2014/36/EU van het Europees Parlement en de Raad van 26 februari 2014 betreffende de voorwaarden voor de toegang en verblijf van onderdanen van derde landen met het oog op seizoenarbeid, $P b E U$ 2014, L 94/375.

44 Richtlijn 2014/49/EU van het Europees Parlement en de Raad van 16 april 2014 inzake de depositogarantiestelsels, PbEU 2014, L 173/149.

45 Groenboek naar adequate, houdbare en zekere Europese pensioenstelsels COM(2010)365.

46 Mededeling 'Naar een intensivering van de economische beleidscoördinatie', COM(2010)250, Mededeling 'Naar een intensivering van de economische beleidscoördinatie ten behoeve van stabiliteit, groei en werkgelegenheid - Instrumenten voor een krachtigere economische governance van de EU', COM(2010)367.

47 Werkdocument van de Commissie - Raadpleging over de toekomstige 'EU 2020' strategie, COM(2009)647 en Mededeling 'EUROPA 2020. Een strategie voor slimme, duurzame en inclusieve groei', COM(2010)2020.

48 Verslag van de Commissie. Jaarverslag 2010 over de betrekkingen tussen de Europese Commissie en de nationale parlementen, $\operatorname{COM}(2011) 345$, p. 6 .

49 Voorstel voor een Verordening tot instelling van het Europees Openbaar Ministerie, COM(2013)534.

50 Richtlijn 2014/40/EU van het Europees Parlement en de Raad van 3 april 2014 betreffende de onderlinge aanpassing van de wettelijke en bestuursrechtelijke bepalingen van de lidstaten inzake de productie, de presentatie en de verkoop van tabaks- en aanverwante producten tot intrekking van Richtlijn 2001/37/EG, PbEU 2014, L 127/1.

51 Voorstel voor een Richtlijn tot vaststelling van een kader voor maritieme ruimtelijke ordening en geïntegreerd kustbeheer, $\operatorname{COM}(2013) 133$.

52 Verordening (EU) 2017/352 van het Europees Parlement en de Raad van 15 februari 2017 tot vaststelling van een kader voor het verrichten van havendiensten en gemeenschappelijke regels inzake de financiële transparantie van havens, PbEU 2017, L 57/1.

53 Voorstel voor een Verordening betreffende het Agentschap van de Europese Unie voor samenwerking en opleiding op het gebied van rechtshandhaving (Europol) en tot intrekking van Besluiten 2009/371/JBZ en 2005/681/JBZ, COM(2013)173; Verslag van de Commissie. Jaarverslag 2013 over de betrekkingen tussen de Europese Commissie en de nationale parlementen. COM(2014)507, p. 6.

54 Voorstel voor een Richtlijn tot wijziging van Richtlijn 96/71/EG van het Europees Parlement en de Raad van 16 december 1996 betreffende de terbeschikkingstelling van werknemers met het oog op het verrichten van diensten, COM(2016)128. 
voor verandering, ${ }^{55}$ de Verordening inzake de behandeling van een verzoek om internationale bescherming door een onderdaan, ${ }^{56}$ de Richtlijn over aspecten van overeenkomsten voor de levering van digitale inhoud en de Richtlijn over bepaalde aspecten van overeenkomsten voor de onlineverkoop en andere verkoop op afstand van goederen. ${ }^{57}$ Aan de hand van deze drie willekeurig gekozen jaren uit het tijdbestek van dit onderzoek is te zien dat de nationale parlementen verschillende onderwerpen belangrijk vinden en dat dit ook elk jaar weer verschilt. Alle andere jaren binnen dit onderzoek zien er net zo versplinterd uit qua belangrijkste onderwerpen. Elk ander jaar had gekozen kunnen worden om het verschil in belangrijkste onderwerpen te laten zien.

Uit de antwoorden van de Commissie blijkt dat het insturen van een advies binnen de politieke dialoog weinig effectief is. In vele gevallen geeft de Commissie met vage bewoordingen als 'in aanmerking nemen' aan wat zij met de adviezen zal doen. Concrete veranderingen worden niet genoemd. Doorgaans wordt nog eens extra uitgelegd wat de standpunten van de Commissie zijn en verantwoordt zij nogmaals waarom het onderwerp op Europees niveau geregeld zou moeten worden. De politieke dialoog moet dus letterlijk gezien worden als een dialoog waar de nationale parlementen hun meningen, zorgen en complimenten kunnen uiten en waarop de Commissie kan reageren. Het moet niet gezien worden als een instrument voor nationale parlementen om sterke of daadwerkelijke invloed uit te oefenen op de activiteiten van de Commissie. De Commissie is bereid om haar standpunten nogmaals uit te leggen, te verduidelijken of te verantwoorden maar is niet (snel) geneigd haar standpunten aan te passen naar aanleiding van een advies van een nationaal parlement. De Commissie geeft aan dat de politieke dialoog zich door de jaren heen ontwikkeld heeft tot 'algemene bilaterale en multilaterale debatten en discussies $(\ldots){ }^{58}$ De meerwaarde van de politieke dialoog voor nationale parlementen zit in de vroegtijdige informatievoorziening en het rechtstreeks contact tussen de parlementen en de Europese Commissie. Parlementen kunnen op een relatief eenvoudige manier snel informatie ontvangen of vragen stellen aan de Commissie (de bron) en hoeven dit dus niet via een omweg (de nationale regering) te doen. ${ }^{59}$ Binnen de politieke dialoog worden met

55 Mededeling 'Het werkprogramma van de Commissie voor 2016. Tijd voor verandering', COM(2015)610.

56 Voorstel voor een Verordening tot vaststelling van de criteria en instrumenten om te bepalen welke lidstaat verantwoordelijk is voor de behandeling van een verzoek om internationale bescherming dat door een onderdaan van een derde land of een staatloze bij een van de lidstaten wordt ingediend (herschikking), $\operatorname{COM}(2016) 270$.

57 Voorstel voor een Richtlijn betreffende bepaalde aspecten van overeenkomsten voor de levering van digitale inhoud, COM(2015)634 en Voorstel voor een Richtlijn betreffende bepaalde aspecten van overeenkomsten voor de online-verkoop en andere verkoop op afstand van goederen, COM(2015)635; Verslag van de Commissie. Jaarverslag 2016 over de betrekkingen tussen de Europese Commissie en de nationale parlementen, $\operatorname{COM}(2017) 601$, p. 3.

58 Verslag van de Commissie. Jaarverslag 2013 over de betrekkingen tussen de Europese Commissie en de nationale parlementen. $\operatorname{COM}(2014) 507$, p. 2.

Ibid. 
name adviezen gestuurd wanneer een nationaal parlement het niet eens is met de Europese Commissie. Doorgaans is dit een reactie op een wetgevingsdocument. Slechts enkele malen stuurt een nationaal parlement een advies over een niet-wetgevingsdocument. De Tweede Kamer stuurt af en toe ook een brief aan de Commissie om haar te laten weten dat zij het eens is met de Commissie. Hierop reageert de Commissie niet. ${ }^{60}$

Meer concreet wordt in dit onderzoek gekeken naar de activiteiten van het Nederlandse en het Duitse parlement. In onderstaande tabel 1 zijn de aantallen ingediende adviezen in het kader van de politieke dialoog van het Nederlandse en Duitse parlement te zien.

Tabel 1 Adviezen aan de Commissie van het Nederlandse en het Duitse parlement

\begin{tabular}{llllllll}
\hline Politieke dialoog & \multicolumn{2}{l}{ Nederland } & \multicolumn{2}{c}{ Duitsland } & $\begin{array}{l}\text { Totale aantal } \begin{array}{l}\text { Gemiddelde } \\
\text { adviezen van } \\
\text { alle parle- } \\
\text { menten in de } \\
\text { Europese } \\
\text { zen per } \\
\text { Unie }\end{array} \\
\text { nationaal } \\
\text { parlement }\end{array}$ \\
\hline $\mathbf{2 0 1 0}$ & 1 & 3 & 2 & 6 & 23 & 387 & 14 \\
\hline $\mathbf{2 0 1 1}$ & 1 & 6 & 3 & 6 & 31 & 622 & 22 \\
\hline $\mathbf{2 0 1 2}$ & 3 & 7 & 1 & 2 & 53 & 633 & 23 \\
\hline $\mathbf{2 0 1 3}$ & 7 & 10 & 0 & 0 & 38 & 621 & 22 \\
\hline $\mathbf{2 0 1 4}$ & 10 & 6 & 0 & 2 & 24 & 506 & 18 \\
\hline $\mathbf{2 0 1 5}$ & 6 & 2 & 0 & 2 & 20 & 350 & 12,5 \\
\hline $\mathbf{2 0 1 6}$ & 8 & 7 & 0 & 5 & 47 & 620 & 22 \\
\hline
\end{tabular}

Onder Nederland is naast de kolommen 'TK' (Tweede Kamer) en 'EK' (Eerste Kamer) ook een kolom 'TK\&EK' (Tweede Kamer en Eerste Kamer) opgenomen. De Tweede Kamer en Eerste Kamer kunnen ieder afzonderlijk van elkaar adviezen sturen aan de Europese Commissie, maar niets staat eraan in de weg om dit gezamenlijk te doen. In de beginjaren (2010-2012) van dit onderzoek hebben de Kamers gezamenlijk opgetreden. In 2012 zijn zij hiermee gestopt. ${ }^{61}$

Het totale aantal ingediende adviezen in 2015 ('slechts' 350 adviezen) wijkt af van andere jaren en dat heeft te maken met de daling van het aantal nieuwe initiatieven van de commissie in verband met verkiezingen van het Europees Parlement en de aanstelling van een nieuwe Commissie. Dit leidde echter niet tot een aanzienlijke daling van adviezen van het Nederlandse en Duitse parlement.

60 Zie bijvoorbeeld de brief naar aanleiding van voorstel COM/2010/0521 via Website Europese Commissie, brief voorzitter Tweede Kamer.

61 Dit had, kort gezegd, ermee te maken dat de Eerste Kamer geen toegevoegde waarde zag in de Tijdelijke Gemengde Commissie Subsidiariteitstoets. Voor meer uitleg zie par. 3.4.3.1. 
In de laatste kolom is het gemiddelde aantal adviezen per nationaal parlement opgenomen. ${ }^{62}$ Hieruit is af te leiden dat het aantal ingediende adviezen door het Nederlandse parlement net iets hoger is dan het gemiddelde aantal. Door de jaren heen is er een lichte stijging te zien. De meeste adviezen gaan over wetgevingsdocumenten; doorgaans is één advies per jaar gericht op een niet-wetgevingsdocument. De onderwerpen waarover de Tweede Kamer en Eerste Kamer adviezen sturen aan de Commissie zijn verschillend. Zo zijn er adviezen gestuurd over seizoenarbeiders, overdracht van passagiersgegevens, het recht tot toegang tot een advocaat in strafprocedures, geluidsreductie bij vliegvelden, bescherming van persoonsgegevens, belastingfraude, het Europees Openbaar Ministerie, Europa 2020 en het investeren in de jongeren van Europa. Er is dus niet één onderwerp zo belangrijk voor (een van) de Kamer(s) dat het vaker terugkeert.

Het Duitse parlement, en dan met name de Bundesrat, is een actieve speler binnen de politieke dialoog, zoals in tabel 1 is te zien. Met een gemiddelde van 34 adviezen per jaar zit de Duitse Bundesrat (ver) boven het gemiddelde van negentien adviezen per parlement per jaar. Het feit dat de Bundesrat zo actief is binnen de politieke dialoog ligt aan de druk die de regeringen en parlementen van de Länder (de deelstaten) uitoefenen. Als deze het niet eens zijn met nieuwe Europese (concept)wetgeving of ander beleid vanuit de EU dan is de politieke dialoog dé manier voor de regeringen en parlementen van de Länder om invloed dan wel druk uit te oefenen. Zoals eerder aangegeven brengt het Duitse parlement met name adviezen uit over niet-wetgevingsdocumenten, vooral naar aanleiding van mededelingen en groenboeken. De onderwerpen die het parlement belangrijk acht, zijn net zo divers als in Nederland maar het Duitse parlement zet met name in op onderwerpen die gedurende langere tijd een rol spelen. Denk bijvoorbeeld aan Europa 2020 en het Financial Framework 2014-2020. Dit zijn projecten die een aantal jaren lopen. Ook reageert het parlement op vele algemene documenten zoals de jaarlijkse groeianalyse binnen het Europees Semester en het jaarlijkse wetgevings- en werkprogramma van de Europese Commissie. Andere belangrijke onderwerpen voor het parlement waren het (Europese) budgetrecht, pensioen, privacybescherming en de interne markt. Sinds 2010 heeft het parlement bijna jaarlijks een advies over deze onderwerpen aan de Commissie gestuurd.

\subsubsection{Gelekaartprocedure}

Naast de hiervoor besproken politieke dialoog bestaat er ook de gelekaartprocedure. Zoals eerder aangegeven kunnen nationale parlementen via de politieke dialoog commentaar

62 Het gemiddelde aantal adviezen per nationaal parlement is het totale aantal adviezen van de parlementen in de Europese Unie gedeeld door 28 (het aantal lidstaten in de periode 2010-2016). 
leveren op het gehele besluitvormingsproces van de EU, dus zowel op wetgeving als op niet-wetgeving. Naast deze politieke dialoog kunnen nationale parlementen via de gelekaartprocedure betrokken zijn bij het Europese wetgevingsproces. De gelekaartprocedure is een middel dat specifiek gericht is op controle van nieuwe Europese wetgeving. Nationale parlementen kunnen hierin een met redenen omkleed advies indienen bij de Europese Commissie wanneer zij van mening zijn dat het wetgevingsvoorstel niet strookt met het subsidiariteitsbeginsel. ${ }^{63}$ Met het versturen van een met redenen omkleed advies aan de Commissie geeft een nationaal parlement uiteraard ook een signaal af aan de eigen regering. Het advies is dan weliswaar gericht aan de Europese Commissie maar daarmee zegt een nationaal parlement tevens dat het wil dat de eigen minister in de Raad in lijn met het advies handelt. Het is als het ware een 'dubbel wapen'.

De nationale parlementen hebben acht weken nadat het voorstel is vertaald in alle officiële talen van de Europese Unie, om een advies in te dienen. ${ }^{64}$ Elk parlement krijgt twee stemmen ${ }^{65}$ en indien een derde van alle stemmen (met redenen omklede adviezen) is uitgebracht, dan is de zogenoemde 'gele kaart' getrokken en dient de Europese Commissie haar voorstel opnieuw in overweging te nemen. Indien het voorstel betrekking heeft op de ruimte van vrijheid, veiligheid en recht is de grens een vierde van de stemmen ${ }^{66}$ Indien de adviezen een gewone meerderheid vertegenwoordigen van alle stemmen die aan de nationale parlementen zijn toebedeeld, wordt de zogenoemde 'oranje kaart' getrokken. In dat geval dient de Commissie het voorstel te heroverwegen en te besluiten het voorstel te handhaven, te wijzigen of in te trekken. Het verschil met de gele kaart zit in de procedure na dit besluit. Indien de Commissie het voorstel handhaaft nadat een oranje kaart is getrokken, zal zij dit gemotiveerd moeten verantwoorden en aangeven waarom het voorstel niet in strijd is met het subsidiariteitsbeginsel. Dit gemotiveerde advies van de Commissie gaat samen met de adviezen van de lidstaten naar de wetgever van de Unie, te weten de Raad en het Europees Parlement. Indien ten minste 55 procent van de Raad of een meerderheid van de uitgebrachte stemmen in het Europees Parlement van oordeel is dat het voorstel in strijd is met het subsidiariteitsbeginsel, wordt het voorstel niet verder in behandeling genomen. ${ }^{67}$

Er zijn enkele gebieden waarop de gelekaartprocedure niet van toepassing is. Dit zijn de gebieden waarop de Unie exclusief bevoegd is om wetgeving te maken. Artikel 3 VWEU geeft een limitatieve opsomming van deze gebieden: de douane-unie, de vaststelling van mededingingsregels die voor de werking van de interne markt nodig zijn, het monetair

63 Art. 6 Protocol nr. 2 betreffende de toepassing van de beginselen van subsidiariteit en evenredigheid (Verdrag van Lissabon).

64 Art. 4 Protocol nr. 2.

65 In een bicameraal parlement krijgt elke kamer één stem.

66 Art. 7 lid 2 Protocol nr. 2.

67 Art. 7 lid 3 Protocol nr. 2. 
beleid voor de lidstaten die de euro als munt hebben, de instandhouding van biologische rijkdommen van de zee in het kader van het gemeenschappelijk visserijbeleid en de gemeenschappelijke handelspolitiek. ${ }^{68}$ De exclusiviteit houdt in dat nationale parlementen geen invloed kunnen uitoefenen op (nieuwe) Europese wetgeving via het subsidiariteitsbeginsel zodat op de voornoemde terreinen de gele- en oranjekaartprocedures niet van toepassing zijn. ${ }^{69}$ Indien een nationaal parlement een met redenen omkleed advies aan de Commissie stuurt als reactie op een wetgevingsvoorstel waarop de Commissie exclusief bevoegd is, wordt dit advies behandeld in de politieke dialoog. Het is aan de Commissie om te bepalen of een ingestuurd advies valt onder de gelekaartprocedure. Het kan dus zijn dat een parlement de intentie heeft een met redenen omkleed advies binnen de gelekaartprocedure te sturen maar dat de Commissie dit niet zo opvat.

De adviezen van nationale parlementen op wetgevingsvoorstellen kunnen naast of in plaats van de politieke dialoog worden ingezet. Voor een reactie van de Commissie is dit om het even. Wanneer namelijk de grens voor een gele dan wel oranje kaart niet wordt bereikt of de termijn hiervan is verstreken, beantwoordt de Commissie de adviezen met betrekking tot het subsidiariteitsbeginsel in het kader van de politieke dialoog. De politieke dialoog kan aldus overlappen met de subsidiariteitstoets. In bepaalde gevallen is alleen een politieke dialoog mogelijk aangezien de gele- en oranjekaartprocedure uitsluitend van toepassing zijn wanneer het gaat om wetgevingsvoorstellen en uitsluitend bij gedeelde bevoegdheden. Bij discussiedocumenten zoals de groenboeken, witboeken en mededelingen kan geen gele of oranje kaart worden getrokken en is communicatie met de Europese Commissie alleen mogelijk via de politieke dialoog.

Het aantal adviezen dat de Commissie heeft ontvangen in zowel de gelekaartprocedure als in de politieke dialoog is sinds de werking van het Verdrag van Lissabon sterk toegenomen. De reden hiervoor is dat parlementen meer tijd en aandacht hebben voor Europese aangelegenheden en daardoor vaker dan voorheen een subsidiariteitstoets uitvoeren en gebruikmaken van de mogelijkheid om in dialoog te treden met de Commissie. Het grote aantal reacties maakt het voor de Commissie moeilijk om binnen drie maanden te antwoorden; desalniettemin houdt de Commissie vast aan deze termijn. ${ }^{70}$ Hoewel de Commissie haar best doet om alle adviezen van nationale parlementen zo concreet en compleet mogelijk te beantwoorden is dit niet altijd mogelijk gebleken, bijvoorbeeld omdat de Commissie nog geen besluit heeft genomen over de inhoud van het advies of omdat er onderhandelingen plaatsvinden tussen de EU-instellingen. ${ }^{71}$

68 Art. 3 lid 1 sub a t/m e VWEU.

69 Art. 5 lid 3 VEU.

70 Reply of the European Commission to the Contribution of the XLVIII COSAC Nicosia, 14-16 oktober 2012, p. 2.

71 Ibid. 
Het verschil tussen de politieke dialoog en de gele- en oranjekaartprocedure is dat de dialoog bilateraal wordt gehouden tussen de Commissie en ieder nationaal parlement apart. De gelekaartprocedure is echter vooral effectief wanneer parlementen samenwerken of althans dezelfde opvattingen hebben. Daarnaast is de gelekaartprocedure gebaseerd op Europese verdragen. Het Barroso-initiatief en, meer specifiek, de politieke dialoog zijn gebaseerd op gewoonte. De omvang van de politieke dialoog is breder dan die van de geleen oranjekaartprocedure. De laatste ziet enkel op het beginsel van subsidiariteit.

\subsubsection{1 'Groene' en 'rode' kaart}

De gele kaart en de oranje kaart zijn de enige kaarten die officieel bestaan. Het in het leven roepen van een groene en rode kaart is door nationale parlementen besproken. Het idee voor een rode kaart werd eerder geopperd door het Verenigd Koninkrijk. De afspraak tussen het Verenigd Koninkrijk en de Europese Unie was dat wanneer 'Brexit' niet door zou gaan er een rode kaart zou komen. Deze kaart hield in dat wanneer minimaal 55 procent van de nationale parlementen bezwaren zou hebben tegen een wetgevingsvoorstel, het voorstel gestopt zou worden door de nationale ministers in de Raad. Nu Brexit heeft plaatsgevonden is dat idee voor een rode kaart tot nader order van tafel, ${ }^{72}$ al staat het de Raad uiteraard vrij om in de praktijk in het geval van 55 procent bezwaren de behandeling van het desbetreffende voorstel te stoppen.

Naast de rode kaart werd al eerder een groene kaart voorgesteld. Ook dit voorstel kwam uit het Verenigd Koninkrijk. De EU-commissie van het Britse House of Lords deed het voorstel daartoe. ${ }^{73}$ Dat werd tijdens de COSAC-bijeenkomst van november 2014 door vele nationale parlementen gesteund (COSAC is de Conferentie van in Europese zaken gespecialiseerde commissies van nationale parlementen). De bedoeling van de groene kaart was dat nationale parlementen voorstellen kunnen doen aan de Commissie tot het maken van nieuwe wetgeving, niet-wetgeving-initiatieven (beleid) en wijzigingen en intrekken van bestaande wetgeving. ${ }^{74}$ Het was niet de bedoeling om een formeel recht van initiatief voor de nationale parlementen te creëren. ${ }^{75}$ Lord Boswell van het Britse House of Lords werkte het voorstel uit in een discussion paper. ${ }^{76}$ Volgens Boswell diende het doel van de groene kaart te zijn het vergroten van de invloed van nationale parlementen op Europese wetgeving

72 K. Auel \& Ch. Neuhold, 'Multi-arena players in the making? Conceptualizing the role of national parliaments since the Lisbon Treaty', Journal of European Public Policy 2017, 24(10), p. 1555.

73 EU Committee's report on The Role of National Parliaments in the EU, 9th Report of Session 2013-14, March 2014.

74 K. Auel \& Ch. Neuhold, 'Multi-arena players in the making? Conceptualizing the role of national parliaments since the Lisbon Treaty', Journal of European Public Policy 2017, 24(10), p. 1555; EU Committee's report on The Role of National Parliaments in the EU, 9th Report of Session 2013-14, March 2014, p. 20.

75 EU Committee's report on The Role of National Parliaments in the EU, 9th Report of Session 2013-14, March 2014, p. 20.

76 Lord Boswell of Aynho, House of Lords The 'Green Card': discussion paper, 19 januari 2015. 
en Europees beleid en een versterking van de politieke dialoog tussen de nationale parlementen en de Commissie. ${ }^{77}$ Deze doelen dienden bereikt te worden zonder wijziging van de verdragen. ${ }^{78}$ De nationale parlementen werden via COSAC aangespoord om constructieve, niet bindende aanbevelingen te doen aan de Commissie over beleid of wetgeving. Deze aanbevelingen mochten en konden uiteraard het recht van initiatief van de Commissie niet ondermijnen. ${ }^{79}$

Formele regels met betrekking tot de groene kaart bestaan (nog) niet maar tot nu toe is het de bedoeling dat elk parlement, dan wel elke Kamer, een initiatief tot een groene kaart kan nemen. Hoe een parlement tot die beslissing komt, wordt nationaal geregeld. Volgens Boswell dient elk initiatief bepaalde onderdelen te bevatten, namelijk: een samenvatting van de redenen voor het nemen van het initiatief, de waarschijnlijke voordelen, welk type wetgeving de voorkeur heeft (bijvoorbeeld een richtlijn) en indien mogelijk de juridische basis hiervoor. Een mogelijke drempel voor het trekken van een groene kaart zou volgens Boswell een vierde van het aantal stemmen kunnen zijn. Dit ligt in lijn met de drempel voor een gele kaart. ${ }^{80}$ Tijdens de COSAC-bijeenkomst van 6 mei 2015 werd de groene kaart uitvoerig besproken. ${ }^{81}$ De drempel voor de groene kaart was wel een discussiepunt. Niet elk parlement was het eens met de door Boswell voorgestelde drempel van 25 procent. Het idee dat parlementen voorstellen voor nieuwe wetgeving kunnen doen of voorstellen om bestaande wetgeving te wijzigen werd unaniem gedeeld. De verdeeldheid ging ook over het intrekken van bestaande wetgeving en het doen van voorstellen om zogenoemde delegated acts (gedelegeerde handelingen) en implementing acts (uitvoeringsbesluiten) in te trekken of te wijzigen, zoals Boswell voorstelde. Niet elk parlement kon zich daarin vinden. ${ }^{82}$ Zoals gezegd was ook de drempel een punt van discussie. Er zijn parlementen die een drempel van een derde van de stemmen, zoals de drempel voor de gele kaart, passender vonden. ${ }^{83}$ Tot op heden zijn er formeel geen regels vastgelegd. Dat heeft te maken met het simpele feit dat de parlementen het nog niet eens zijn over de regels. $\mathrm{Na}$ het initiatief van Boswell is geen ander parlement met een concreet voorstel van regels gekomen. Dit zou in de toekomst wel kunnen gebeuren aangezien veel nationale parlementen achter dit initiatief staan. ${ }^{84}$

\section{Ibid., p. 2.}

78 COSAC, 22nd Bi-annual Report: Developments in European Union Procedures and Practices Relevant to Parliamentary Scrutiny, Rome 4 november 2014, p. 6.

79 Contribution of the LIII COSAC, Riga 31 mei-2 juni 2015, p. 2.

80 Lord Boswell of Aynho, House of Lords The 'Green Card': discussion paper, 19 januari 2015, p. 2.

81 COSAC, 23rd Bi-annual Report: Developments in European Union Procedures and Practices Relevant to Parliamentary Scrutiny.

82 COSAC, 23rd Bi-annual Report: Developments in European Union Procedures and Practices Relevant to Parliamentary Scrutiny, p. 34.

83 Ibid., p. 35.

84 K. Auel \& Ch. Neuhold, 'Multi-arena players in the making? Conceptualizing the role of national parliaments since the Lisbon Treaty', Journal of European Public Policy 2017, 24(10), p. 1555. 
Hoewel er geen formele regels bestaan omtrent de groene kaart is de eerste al getrokken, op initiatief van het Engelse House of Lords. Boswell, voorzitter van de EU-commissie van de House of Lords, wist vijftien (van in totaal 41) andere voorzitters van EU-commissies zo ver te krijgen de brief voor een groene kaart te ondertekenen. ${ }^{85}$ Hierin verzochten de parlementen de Commissie een voorstel op te stellen om voedselverspilling binnen de Europese Unie tegen te gaan. Dit zou de Commissie kunnen doen in haar pakket 'circulaire energie'. Dit is een pakket van maatregelen dat bedrijven moet ondersteunen in de overgang naar een economie waarin hulpbronnen op duurzamere wijze gebruikt worden. ${ }^{86}$ In haar reactie dankte de Commissie de zestien Kamers van parlementen die het voorstel hebben ondertekend. ${ }^{87}$ Aangezien het pakket 'circulaire energie' op het moment van de groene kaart werd opgesteld kon de Commissie nog geen inhoudelijke reactie geven. De Commissie was wel van plan om de suggesties in de groene kaart mee te nemen bij het opstellen van het pakket. De Commissie sloot haar reactie af met de positieve woorden dat ze de brief van de (Kamers van) nationale parlementen waardeerde en dat deze gezien werd als een teken dat nationale parlementen klaar zijn om op een proactieve en opbouwende manier mee te werken aan beleidsvorming op Europees niveau en dat de Commissie aan haar kant werkt aan verbetering van de dialoog en relatie met nationale parlementen zodat nationale parlementen een sterke rol kunnen vervullen in Europese beleid vorming. ${ }^{88}$

In december 2015 presenteerde de Commissie haar pakket 'circulaire energie' met daarin geen directe verwijzingen naar de groene kaart. Wel kwamen enkele suggesties uit de groene kaart terug in de aanbevelingen in het pakket 'circulaire energie'. ${ }^{89} \mathrm{Na}$ slechts één groene kaart is het te vroeg om iets over het effect van een dergelijke kaart te zeggen.

85 Eerste Groene Kaart, advies van Lord Boswell, House of Lords 22 juli 2015 raadpleegbaar via website House of Lords.

86 Website Europese Commissie, 'Naar een circulaire economie'.

87 Brief Europese Commissie van 17 november 2015, C(2015)7982 final.

88 Ibid.

89 A. Gostyńska-Jakubowska, The role of national parliaments in the EU: Building or stumbling blocks, Centre for European Reform, juni 2016, p. 5. 
Tabel 2 Met redenen omklede adviezen in de gelekaartprocedure

\begin{tabular}{llllllll}
\hline Gele kaart & \multicolumn{2}{l}{ Nederland } & \multicolumn{2}{l}{ Duitsland } & $\begin{array}{l}\text { Totaal aantal } \begin{array}{l}\text { Gemiddelde } \\
\text { adviezen van } \\
\text { alle parle- } \\
\text { menten in de } \\
\text { Europese } \\
\text { Zen per } \\
\text { Unie }\end{array} \\
\text { nationaal } \\
\text { parlement }\end{array}$ \\
\hline $\mathbf{2 0 1 0}$ & 1 & 0 & 2 & 1 & 1 & 34 & 1,2 \\
\hline $\mathbf{2 0 1 1}$ & 1 & 0 & 2 & 1 & 1 & 64 & 2,3 \\
\hline $\mathbf{2 0 1 2}$ & 3 & 1 & 1 & 1 & 5 & 70 & 2,5 \\
\hline $\mathbf{2 0 1 3}$ & 5 & 3 & 0 & 0 & 3 & 88 & 3,1 \\
\hline $\mathbf{2 0 1 4}$ & 2 & 0 & 0 & 0 & 0 & 21 & 0,8 \\
\hline $\mathbf{2 0 1 5}$ & 1 & 0 & 0 & 0 & 0 & 8 & 0,3 \\
\hline $\mathbf{2 0 1 6}$ & 3 & 1 & 0 & 0 & 0 & 65 & 2,3 \\
\hline Totaal & $\mathbf{1 6}$ & $\mathbf{5}$ & $\mathbf{5}$ & $\mathbf{3}$ & $\mathbf{1 0}$ & $\mathbf{3 5 0}$ & $\mathbf{1 2 , 5}$ \\
\hline
\end{tabular}

\subsubsection{Tweede Kamer en Eerste Kamer}

Hierboven is in tabel 2 opgenomen hoeveel met redenen omklede adviezen in de gelekaartprocedure zijn ingediend door het Nederlandse en het Duitse parlement. ${ }^{91}$ Allereerst zal worden ingegaan op het Nederlandse parlement waarna bespreking van het Duitse parlement volgt in de volgende paragraaf.

Over het algemeen is het Nederlandse parlement, en dan met name de Tweede Kamer, meer dan gemiddeld actief. Nederland staat bijna alle jaren van dit onderzoek boven in de lijst van actieve parlementen, waar de Zweedse Riksdag bovenaan staat. ${ }^{92}$ Desondanks heerst onder de Nederlandse parlementariërs teleurstelling over de effectiviteit van de gelekaartprocedure aangezien het tot nu toe 'slechts' driemaal gelukt is een gele kaart te trekken. Daarnaast zijn parlementariërs niet tevreden over de late en lakse reacties van de Commissie. ${ }^{93}$ Een andere klacht van parlementariërs is dat nationale parlementen in de gelekaartprocedure enkel bezwaar kunnen maken over subsidiariteit en niet ook over proportionaliteit of andere bezwaren. Of dit de redenen zijn voor het dalende aantal met redenen omklede adviezen in de jaren 2014 en 2015 is moeilijk te zeggen. Ook zijn parle-

90 De Tweede Kamer en Eerste Kamer kunnen ieder afzonderlijk van elkaar adviezen sturen aan de Europese Commissie. Zij kunnen dit ook gezamenlijk doen alhoewel ze daarmee in 2012 zijn gestopt.

91 De jaren na 2016 laten een vergelijkbaar beeld zien met uitzondering van 2017: toen heeft zowel het Nederlandse als het Duitse parlement meerdere met redenen omklede adviezen ingestuurd.

92 Zie de jaarverslagen van 2010 tot en met 2016 over de betrekkingen tussen de Europese commissie en de nationale parlementen.

93 E. Mastenbroek e.a., Gericht op Europa. Nationale parlementaire controle op Europese besluitvorming na het Verdrag van Lissabon, Institute for Management Research Radboud Universiteit Nijmegen 2014, p. ii. 
mentariërs niet tevreden over de termijn waarbinnen een advies moet worden ingediend. Acht weken wordt gezien als een veel te korte termijn.

Binnen de Eerste Kamer neemt de Commissie voor immigratie en Asiel/JBZ-Raad het indienen van de met redenen omklede adviezen voor haar rekening. In de periode van dit onderzoek heeft de Eerste Kamer, als zelfstandige Kamer, vijf met redenen omklede adviezen ingediend. Deze lagen op het gebied van periodieke controles op rijvaardigheid van motorvoertuigen en aanhangers, binnenlands personenvervoer op het spoor, maritieme ruimtelijke ordening en geïntegreerd kustbeheer, Europees Openbaar Ministerie en vennootschapsbelasting. Alle adviezen ingediend als een met redenen omkleed advies werden als zodanig gezien door de Commissie en werden ook allemaal beantwoord. In geen van de gevallen was de Commissie het eens met de Eerste Kamer. De zestien met redenen omklede adviezen die de Tweede Kamer aan de Commissie heeft gestuurd, hadden onder andere betrekking op de volgende onderwerpen: Europees Agentschap voor netwerk- en informatiebeveiliging, vennootschapsbelasting, grenstoezicht, Europees fonds voor aanpassing aan de globalisering 2014-2020, openstellen van de markt voor binnenlands passagiersvervoer per spoor, Eurojust, Europees Openbaar Ministerie, genetisch georganiseerde organismen en hybride mismatches met derde landen. De vijf voorstellen waar de Kamers gezamenlijk een advies over hebben uitgebracht waren toegang en verblijf onderdanen derde landen met het oog op seizoenarbeid, verstrekken levensmiddelen aan de meest behoeftigen in de Unie, herinvoering grenstoezicht aan de binnenlandse grenzen in uitzonderlijke situaties, Europees globaliseringsfonds en gendergelijkheid bij ondernemingen. In tegenstelling tot de Eerste Kamer ontvangt de Tweede Kamer niet altijd een reactie op haar advies. Het is niet duidelijk waarom dit is.

\subsubsection{Bundestag en Bundesrat}

Zoals in tabel 2 is te zien heeft het Duitse parlement dertien met redenen omklede adviezen aan de Commissie gestuurd in de periode van dit onderzoek. ${ }^{94}$ Van deze dertien adviezen zijn er drie afkomstig van de Bundestag. Deze gingen over het depositogarantiestelsel (2010), het gemeenschappelijk Europees kooprecht (2011) en het Fonds voor Europese hulp aan de meest behoeftigen (2012). De Bundesrat is actiever (geweest) in het sturen van adviezen en heeft in de periode die wordt onderzocht tien adviezen gestuurd. In 2010 stuurde de Bundesrat een advies, net zoals de Bundestag, naar aanleiding van het depositogarantiestelsel. In de jaren die volgden, stuurde de Bundesrat met redenen omklede adviezen over voorstellen over bescherming van persoonsgegevens, geluidgerelateerde exploitatiebeperking op EU-luchthavens, gunning van concessieopdrachten, alternatieve beslechting van consumentengeschillen, maritieme ruimtelijke orde en geïntegreerd

94 Alle dertien adviezen zijn door de Commissie als dergelijk gekwalificeerd, ze werden dus allemaal als een met redenen omkleed advies in de gelekaartprocedure gezien en niet in de politieke dialoog. 
kustbeleid, Europol en het gemeenschappelijk stelsel van belastingen. Het Duitse parlement heeft geen advies ingediend op de voorstellen die uiteindelijk leidden tot een van de drie gele kaarten. Alle door de Bundestag en de Bundesrat gestuurde adviezen zijn beantwoord door de Commissie. ${ }^{95}$

\subsubsection{Drie gele kaarten}

Aangezien de drempels voor de gele en oranje kaart vrij hoog zijn, met andere woorden voor een succesvolle gelekaartprocedure dienen veel (kamers van) parlementen een gemotiveerd advies te sturen, is het tot nu toe nog niet vaak voorgekomen dat er daadwerkelijk een gele kaart is getrokken. Een oranje kaart is tot op heden nog niet aan de orde geweest; de gele kaart drie keer. De eerste effectieve gele kaart deed zich voor bij een verordening over het stakingsrecht (2012). ${ }^{96}$ Twaalf met redenen omklede adviezen werden uitgebracht die samen voor negentien stemmen stonden (zeven parlementen hebben een eenkamerstelsel waardoor hun advies voor twee stemmen telt). De meeste bezwaren zagen op de rechtsgrond van artikel 352 VWEU. Dit artikel wordt gebruikt als basis voor wetgeving waarvoor in de verdragen geen grondslag is, maar waarvoor wel optreden vanuit de EU nodig is om de Europese doelstelling te halen. De Commissie heeft naar aanleiding van de gele kaart het voorstel nogmaals bekeken maar vond dat er geen strijdigheid bestond met het subsidiariteitsbeginsel. De Commissie heeft het voorstel uiteindelijk wel ingetrokken omdat het naar alle waarschijnlijkheid niet de benodigde politieke steun zou krijgen in het Europees Parlement en de Raad. Het voorstel sneuvelde dus na de gele kaart, weliswaar niet op basis van subsidiariteit maar vanwege draagvlak en steun.

De tweede gele kaart betrof het voorstel voor een verordening tot oprichting van een Europees Openbaar Ministerie (2013). ${ }^{97}$ Ten aanzien van dit voorstel werd met achttien stemmen bezwaar gemaakt door elf (kamers van) nationale parlementen. Dat was dus ruim meer dan de benodigde veertien stemmen die nodig waren voor een gele kaart aangezien het hier om een voorstel ging binnen de ruimte van vrijheid, veiligheid en recht. Ook hier besloot de Commissie na zorgvuldige bestudering dat het voorstel in overeenstemming was met het subsidiariteitsbeginsel en handhaafde het voorstel. In de Raad kwam men daarna niet tot overeenstemming over het voorstel waarop zestien lidstaten besloten een nauwere samenwerking aan te gaan voor de instelling van een Europees Openbaar Ministerie. ${ }^{8}$ Het Europees Openbaar Ministerie is op die wijze tot stand gekomen, wel

95 In de jaren na 2016 hebben beide Kamers nog enkele gemotiveerde adviezen gestuurd.

96 Voorstel voor een Verordening betreffende de uitoefening van het recht om collectieve actie te voeren in de context van de vrijheid van vestiging en de vrijheid van dienstverrichting, $\operatorname{COM}(2012) 130$.

97 Voorstel voor een Verordening tot instelling van het Europees Openbaar Ministerie, COM(2013)534.

98 Website Europese Raad en Raad van de Europese Unie, Europees Openbaar Ministerie. 
met vele wijzigingen ten opzichte van het oorspronkelijke voorstel. Duitsland maakt vanaf het begin deel uit van deze nauwere samenwerking, Nederland niet. ${ }^{99}$

\section{Nauwere samenwerking}

Wanneer geen overeenstemming bereikt kan worden over een voorstel van een niet-exclusieve bevoegdheid van de Unie, kunnen minimaal negen lidstaten een nauwere samenwerking aangaan. Deze groep lidstaten voert dan onderling de maatregelen uit het voorstel in. Elke andere lidstaat kan ieder moment aansluiten. Het is niet mogelijk om de bevoegdheden uit de verdragen hiermee te verruimen of nieuwe bevoegdheden te creëren. ${ }^{100}$ De machtiging om nauwere samenwerking aan te gaan dient, op voorstel van de Commissie en na goedkeuring door het Europees Parlement, door een gekwalificeerde meerderheid binnen de Raad gesteund te worden. Alleen de deelnemende lidstaten mogen stemmen. ${ }^{101}$ Wanneer het machtigingsbesluit is aangenomen dient de Commissie een conceptverordening of -richtlijn in voor de nauwere samenwerking. Voor het aannemen van dit voorstel wordt de gewone wetgevingsprocedure gevolgd met dien verstande dat in de Raad alle lidstaten mogen deelnemen aan de beraadslaging, maar dat alleen de lidstaten die deelnemen aan de nauwere samenwerking mogen stemmen. ${ }^{102}$

De derde gele kaart werd getrokken in verband met een herziening van de Detacheringsrichtlijn (2016). ${ }^{103}$ Elf lidstaten dienden veertien met redenen omklede adviezen in. Deze veertien adviezen waren samen goed voor 22 stemmen waardoor de gele kaart werd getrokken. Tien van de lidstaten waren Oost-Europese landen aangezien de richtlijn met name (de onderdanen van) deze landen negatief zou raken. Door de richtlijn zouden werknemers die door hun werkgevers naar een ander landen werden gezonden, het minimumloon van het gastland ontvangen in plaats van het minimumloon van het land van herkomst. De angst was dat werknemers uit deze landen inkomsten zouden missen door deze richtlijn. Ook dit voorstel werd door de Commissie zorgvuldig bestudeerd en daarna gehandhaafd. ${ }^{104}$ Uiteindelijk bereikten de Raad, het Europees Parlement en de Commissie tezamen (in een triloog ${ }^{105}$ ) een compromis met betrekking tot dit voorstel. Gedetacheerde

99 Ibid.; Nederland is in een later stadium ook toegetreden tot de nauwere samenwerking.

100 Website Europese Commissie, Enhanced cooperation.

101 Art. 20 VEU; art. 329 lid 1 VWEU; art. 330 VWEU.

102 Art. 326-334 VWEU.

103 Voorstel voor een Richtlijn tot wijziging van Richtlijn 96/71/EG van het Europees Parlement en de Raad van 16 december 1996 betreffende de terbeschikkingstelling van werknemers met het oog op het verrichten van diensten, $\operatorname{COM}(2016) 128$.

104 Website Europese Commissie, De subsidiariteitscontrole.

105 Ook wel 'trialoog' genoemd. 
werknemers zouden pas na twaalf maanden (met een mogelijke verlenging tot achttien maanden) in aanmerking komen voor betaling naar de standaard van het gastland. De verschillen tussen de lidstaten en de uiteenlopende belangen zijn uiteindelijk opgelost via een compromis. ${ }^{106}$

\subsection{Beoordeling van het aantal kaarten}

Het feit dat er tot op heden drie gele kaarten getrokken zijn en niet meer heeft ermee te maken dat (kamers van) nationale parlementen niet genoeg met redenen omklede adviezen insturen om de drempel te halen die nodig is. Dit heeft meerdere oorzaken. Een daarvan is het feit dat de Commissie er niet in slaagt om bij elk nieuw wetgevingsvoorstel een zogenoemd effectbeoordelingsverslag (meer bekend als het impact assessment report) mee te zenden dat voldoet aan de eisen van artikel 5 Protocol nr. 2 bij het Verdrag van Lissabon. Een dergelijk effectbeoordelingsverslag vormt de basis voor parlementaire controle van subsidiariteit. Artikel 5 van Protocol nr. 2 verlangt dat effectenbeoordelingsverslagen ' (...) elementen bevatten waarmee de financiële gevolgen van het ontwerp kunnen worden beoordeeld, alsook - in het geval van een richtlijn - het effect ervan op de door de lidstaten vast te stellen regelgeving, inclusief - waar toepasselijk - de regionale regelgeving' ${ }^{107}$ Daarnaast worden de redenen waarom dit onderwerp beter door de Unie geregeld kan worden dan door de lidstaten afzonderlijk, op 'kwalitatieve en, zo mogelijk, kwantitatieve indicatoren gestaafd'. ${ }^{108}$ Tot slot dient een omschrijving gegeven te worden van '(...) alle, financiële of administratieve, lasten voor de Unie, de nationale regeringen, de regionale of lokale overheden, het bedrijfsleven en de burgers [moeten] tot een minimum worden beperkt en [moeten] in verhouding staan tot het te bereiken doel'. ${ }^{109}$ Het zijn deze zojuist genoemde eisen die vaak niet terug te vinden zijn in de effectbeoordelingsverslagen. ${ }^{110}$ Verder blijkt dat de Commissie laat reageert op de met redenen omklede adviezen van de nationale parlementen en dat de adviezen weinig effectief zijn, noch worden meegenomen in het Europese wetgevingsproces, tenzij de drempel wordt gehaald en daadwerkelijk een gele kaart wordt getrokken. In dat laatste geval wijzen de drie gele kaarten uit dat deze van invloed zijn geweest op het (lot van het) voorstel. ${ }^{111}$ Ook hebben nationale parlementen weinig tijd om een met redenen omkleed advies op te stellen. Acht weken blijkt hiervoor

106 A.W. Heringa, Europees Nederlands Staatsrecht. Het Nederlands staatsrecht beïnvloed door internationaal en Europees recht, Den Haag: Boom juridisch 2019, p. 110.

107 Art. 5 Protocol nr. 2 bij het Verdrag van Lissabon.

108 Art. 5 Protocol nr. 2.

109 Art. 5 Protocol nr. 2.

110 C. Fasone \& N. Lupo, 'Constitutional Review and the Powers of National Parliaments in EU Affairs. Erosion or Protection?', in: D. Jančić, National Parliaments After the Lisbon Treaty and the Euro Crisis. Resilience or Resignation?, Oxford: Oxford University Press 2017, p. 66.

111 Zie par. 2.7. 
een (te) korte termijn te zijn. ${ }^{112}$ Nationale parlementen hebben (te) weinig budget en menskracht om de subsidiariteitscontrole uit te voeren binnen de gestelde acht weken. ${ }^{113}$ Een andere zwakte van de gelekaartprocedure is dat de met redenen omklede adviezen niet bindend zijn en minimaal een derde ${ }^{114}$ van het aantal stemmen c.q. adviezen moet worden uitgebracht. Als dit het geval is dan betekent dit niet dat de Commissie haar voorstel moet intrekken of wijzigen. ${ }^{115}$ Tot slot blijkt dat nationale parlementen verschillende prioriteiten hebben waardoor de drempel vaak niet wordt gehaald. Nationale parlementen reageren op vele verschillende onderwerpen c.q. voorstellen. Het ene onderwerp mag dan voor een nationaal parlement van groot belang zijn, maar dat betekent niet dat dat ook geldt voor andere parlementen. Als men kijkt naar de onderwerpen waarover de verschillende nationale parlementen een met redenen omkleed advies insturen, is te zien dat nationale parlementen niet op één lijn zitten qua prioriteiten.

Naast deze negatieve punten is er ook iets positiefs te zeggen over de gelekaartprocedure. Deze is daadwerkelijk een middel om invloed uit te oefenen op de Commissie, of die invloed nu groot of klein is. De gelekaartprocedure dient ook meer in het grotere geheel van controlemogelijkheden c.q. invloedmogelijkheden gezien te worden. Wanneer genoeg met redenen omklede adviezen aan de Commissie worden gestuurd, geven de nationale parlementen een politiek signaal af dat de Commissie niet kan negeren. De kans is groot dat wanneer de Commissie niet adequaat reageert op dit signaal, zij de klachten via de ministers in de Raad terug zal krijgen, zoals bij alle drie de gele kaarten is gebeurd. ${ }^{116}$

In tabel 2 is het aantal ingediende met redenen omklede adviezen opgenomen. De adviezen die zijn ingestuurd maar die door de Commissie niet als een met redenen omkleed advies in de gelekaartprocedure werden beoordeeld, zijn niet opgenomen. De onderzoeksperiode bedraagt zeven jaar, 2010 tot en met 2016. Voor Nederland is een verdeling gemaakt tussen de Tweede Kamer, de Eerste Kamer en gezamenlijk optreden door de Tweede en Eerste Kamer. Hoewel iedere Kamer een eigen, zelfstandige stem heeft in de gelekaartprocedure staat niets eraan in de weg om binnen een lidstaat (of daarbuiten) samen te werken. Zoals eerder vermeld hebben de Nederlandse Kamers dit gedaan maar zijn ze daarmee na 2012 gestopt. Voor Duitsland is een onderverdeling gemaakt tussen de Bundestag en de

112 K. Granat, The Principle of Subsidiarity and its Enforcement in the EU Legal Order. The Role of National Parliaments in the Early Warning System, Oxford: Hart Publishing 2018, p. 50.

113 C. Fasone \& N. Lupo, 'Constitutional Review and the Powers of National Parliaments in EU Affairs. Erosion or Protection?', in: D. Jančić, National Parliaments After the Lisbon Treaty and the Euro Crisis. Resilience or Resignation?, Oxford: Oxford University Press 2017, p. 66.

114 Een vierde van de stemmen indien het voorstel betrekking heeft op de ruimte van vrijheid, veiligheid en recht; art. 7 lid 2 Protocol nr. 2.

115 K. Granat, The Principle of Subsidiarity and its Enforcement in the EU Legal Order. The Role of National Parliaments in the Early Warning System, Oxford: Hart Publishing 2018, p. 51.

116 E. Miklin, 'Beyond subsidiarity: the indirect effect of the Early Warning System on national parliamentary scutiny in European Union affairs', Journal of European Public Policy 2017, 24(3), p. 369. 
Bundesrat. Deze twee Kamers hebben niet zoals in Nederland gezamenlijke adviezen opgesteld. De laatste kolom in de tabel geeft aan hoeveel met redenen omklede adviezen de Europese Commissie in het desbetreffende jaar heeft ontvangen van alle lidstaten. In 2015 is daarin een behoorlijke daling te zien. In dat jaar werden acht met redenen omklede adviezen ingediend door de lidstaten. Dat is veel minder dan de jaren ervoor en het jaar erna. De daling van het aantal adviezen had te maken met de daling van het aantal nieuwe initiatieven van de commissie in verband met verkiezingen van het Europees Parlement en de aanstelling van een nieuwe Commissie.

\subsection{INTERPARLEMENTAIRE SAMENWERKING}

Om invloed uit te oefenen op Europees niveau is het van belang dat de verschillende nationale parlementen in de Europese Unie samenwerken. Voor het trekken van een gele kaart is het immers nodig dat een groot aantal van de nationale parlementen een met redenen omkleed advies indient. Deze samenwerking vindt met name plaats via interparlementaire conferenties. Volgens de richtlijnen voor interparlementaire samenwerking in de Europese Unie, opgesteld en aangenomen door de Conferentie van Voorzitters van de parlementen van de Europese Unie in 2008, hebben parlementaire conferenties drie doelen. ${ }^{117}$ Ten eerste het bevorderen van het uitwisselen van informatie en beste praktijken tussen nationale parlementen en het Europees Parlement met als doel parlementaire controle, invloed en toezicht te versterken. Ten tweede dienen de conferenties te zorgen voor de uitoefening van de parlementaire bevoegdheden in Europese aangelegenheden en dan met name in het kader van het subsidiariteitsbeginsel en het proportionaliteitsbeginsel. Ten derde wordt de samenwerking met parlementen van derde landen bevorderd. ${ }^{118}$ Hoewel parlementaire samenwerking het doel heeft om deelname van nationale parlementen aan het EU-besluitvormingsproces te verbeteren wijst onderzoek uit dat de samenwerking tussen nationale parlementen binnen deze interparlementaire verbanden vooral consultatief is en er met name uitwisseling van informatie plaatsvindt in plaats van samenwerking in het kader van bijvoorbeeld de gelekaartprocedure. ${ }^{119}$

Binnen de EU bestaan vier belangrijke conferenties op het gebied van interparlementaire samenwerking. Dit zijn de COSAC, de artikel 13-conferentie, de Conferentie van Voorzitters

117 Conference of Speakers of the European Union Parliaments, Guidelines for Inter-Parliamentary Cooperation in the European Union (2008), via ipex.eu.

118 Ibid., p. 3.

119 A. Groen \& T. Christiansen, 'National Parliaments in the European Union: Conceptual Choices in the European Union's Constitutional Debate', in: C. Hefftler e.a. (eds.), The Palgrave Handbook of National Parliaments and the European Union, Londen: Palgrave Macmillan 2015, p. 46. 
van de parlementen van de Europese Unie en de Interparlementaire Conferentie voor gemeenschappelijk buitenlands en veiligheidsbeleid en het gemeenschappelijk veiligheidsen defensiebeleid. Tijdens deze conferenties komen leden van nationale parlementen en leden van het Europees Parlement samen om informatie uit te wisselen, van elkaar te leren en samenwerking tussen parlementen te vergroten en te versterken. Voor deze conferenties zijn de afgelopen jaren wettelijke bases gecreëerd om het belang van deze samenwerking te benadrukken. Zo bepaalt artikel 10 van Protocol nr. 1 bij het Verdrag van Lissabon dat interparlementaire conferenties over aangelegenheden van de Unie kunnen worden georganiseerd. De COSAC is een van de interparlementaire conferenties die hier wordt bedoeld. Daarnaast bepaalt artikel 10 van Protocol nr. 1 dat ook conferenties over specifieke onderwerpen, met name vraagstukken op het gebied van het gemeenschappelijk buitenlands en veiligheidsbeleid, waaronder het gemeenschappelijk veiligheids- en defensiebeleid kunnen worden georganiseerd. Artikel 13 van het begrotingspact geeft een grondslag voor interparlementaire samenwerking op economisch en budgettair gebied. De verschillende conferenties zullen hieronder afzonderlijk worden behandeld.

\subsubsection{Het Europees Parlement}

Interparlementaire samenwerking bestaat niet enkel uit de samenwerking tussen nationale parlementen. Ook het Europees Parlement is hierbij betrokken. Bovendien speelt het Europees Parlement een belangrijke rol in de Europese Unie als medewetgever en controleur van de Europese Commissie. Om die reden zal allereerst uitgebreider worden stilgestaan bij het (ontstaan van het) Europees Parlement.

Het Europees Parlement heeft sinds zijn ontstaan in 1952 een aantal wijzigingen ondergaan. Het Parlement heeft zich ontwikkeld van een instelling zonder al te veel bevoegdheden naar een belangrijk instituut binnen de Europese Unie. De 'Gemeenschappelijke Vergadering van de Europese Gemeenschap voor Kolen en Staal' zoals het Europees Parlement in het begin heette, ${ }^{120}$ had enkele adviserende en toezichthoudende taken bij de oprichting maar speelde geen rol in het Europese wetgevingsproces. Met de invoering van de 'codecisieprocedure' in het Verdrag van Maastricht kreeg het Europees Parlement een rol in het Europese wetgevingsproces. Deze rol is in het latere Verdrag van Amsterdam en in het Verdrag van Nice versterkt zodat het parlement tegenwoordig wetgevende, budgettaire en toezichthoudende taken heeft. ${ }^{121}$ Een van de grote wensen van het Parlement was de invoering van directe verkiezingen. Pas in 1976 werd daartoe besloten door de lidstaten. In 1979 werden de eerste directe verkiezingen gehouden. Voor die tijd werden de

120 In 1962 omgedoopt tot Europees Parlement.

121 P. Craig \& G. de Burca, EU Law, Text, Cases and Materials, Oxford: Oxford University Press 2015, p. 75. 
leden van het Europees Parlement benoemd door en uit de nationale parlementen van de lidstaten. Leden van het Europees Parlement waren tegelijkertijd ook leden van de nationale parlementen. Vanaf 1979 bestond het Europees Parlement uit directe vertegenwoordigers van alle burgers van de Europese Unie. ${ }^{122}$ Het dubbelmandaat werd echter in 2003 verboden. De Akte betreffende de verkiezing van de leden van het Europees Parlement door middel van rechtstreekse algemene verkiezingen bepaalt in artikel 7 lid 2: 'Met ingang van de verkiezing van het Europees Parlement in 2004 is de hoedanigheid van lid van het Europees Parlement onverenigbaar met die van lid van een nationaal parlement. ${ }^{123}$ Tot 2004 was het dus mogelijk om het lidmaatschap van de Tweede of Eerste Kamer te combineren met het lidmaatschap van het Europees parlement. In Nederland kwam het dubbelmandaat na de invoering van directe verkiezingen in 1979 niet vaak voor omdat uit de praktijk bleek dat het combineren van beide functies bijna onmogelijk was. Na 1981 heeft geen Nederlandse parlementariër een dubbelmandaat gehad. ${ }^{124}$ Door de directe verkiezingen en het verbod op een dubbelmandaat werd de directe band tussen het Europees Parlement en de nationale parlementen verbroken waardoor er gedurende een tiental jaren geen directe connectie bestond tussen de parlementen. Al snel werd echter duidelijk voor beide parlementen dat deze band hersteld moest worden. Beide parlementen kunnen namelijk voor elkaar van meerwaarde zijn, met name in het Europese besluitvormingsproces. Dit is een manier voor de leden van het Europees Parlement om de nationale standpunten over nieuwe wetgeving te weten te komen. Voor het herstel van de band tussen het Europees Parlement en de nationale parlementen was het belangrijk dat nationale parlementen erkend werden binnen de Europese Unie. Deze erkenning vond formeel plaats bij het Verdrag van Lissabon. In hetzelfde verdrag werden niet alleen de nationale parlementen erkend maar ook interparlementaire samenwerking. Hiermee wordt niet alleen samenwerking tussen nationale parlementen van EU-lidstaten bedoeld maar ook de samenwerking tussen het Europees Parlement en nationale parlementen. Artikel 12 VEU benadrukt 'de interparlementaire samenwerking tussen de nationale parlementen en het Europees parlement, overeenkomstig het protocol betreffende de rol van de nationale parlementen in de Europese Unie'. ${ }^{125}$ Het Europees Parlement kan samen met de nationale parlementen bepalen hoe het een efficiënte en regelmatige samenwerking kan organiseren en stimuleren. $^{126}$

122 Destijds nog de Europese Gemeenschap.

123 Trb. 1976, 175.

124 J.H. Klok \& H.M.B. Breunese, 'Het dubbelmandaat: tussen droom en daad...', TvCR 2014, afl. 4, p. 304.

125 Art. 12 sub f VEU.

126 Art. 9 Protocol nr. 1 betreffende rol van de nationale parlementen in de Europese Unie. 
De Conferentie van Voorzitters van de parlementen van de Europese Unie (in het Engels Conference of Speakers of the European Union Parliaments) is een conferentie waaraan de voorzitters van de (kamers van de) nationale parlementen en de voorzitter van het Europees Parlement deelnemen. Kandidaat-lidstaten mogen vertegenwoordigers afvaardigen die de conferentie mogen observeren. Artikel 9 van Protocol nr. 2 bepaalt: 'Het Europees Parlement en de nationale parlementen bepalen samen hoe binnen de Unie een efficiënte en regelmatige samenwerking tussen de verschillende parlementen kan worden georganiseerd en gestimuleerd.' De Conferentie van Voorzitters van de parlementen van de Europese Unie neemt hierin het voortouw. De conferentie vindt elk voorjaar plaats in het land dat voorzitter van de EU was in het tweede semester van het voorgaande jaar. ${ }^{127}$ In het voorjaar van 2017 kwamen bijvoorbeeld de leden bijeen in Slowakije aangezien dit land voorzitter van de EU was in het najaar van 2016.

De eerste bijeenkomst vond plaats in Rome in 1963. Dit makkt de Conferentie van voorzitters de oudste conferentie. ${ }^{128}$ Vanaf 1975 werden de bijeenkomsten regelmatig gehouden op jaarlijkse basis. Sinds de Lissabon Top in 1999 bestaat de Conferentie als een autonoom forum voor interparlementaire samenwerking. ${ }^{129}$ Het doel van de conferentie is het beschermen, benadrukken en promoten van (het belang van) de rol van nationale parlementen en het uitvoeren en stimuleren van interparlementaire activiteiten. ${ }^{130}$ De Conferentie biedt instrumenten voor het uitwisselen van standpunten, informatie en ervaringen tussen de vertegenwoordigers, om te discussiëren, en voor de uitwisseling en ondersteuning van onderzoek. ${ }^{131}$ Een van deze instrumenten is IPEX, dat is ontstaan na aanbevelingen tijdens de Conferenties in Rome (2000) en Den Haag (2004). Voor Nederland nemen de voorzitters van beide Kamers deel en zij worden ondersteund door de griffiers van beide Kamers samen met de EU-adviseur van de vaste commissie voor Europese Zaken van de Tweede Kamer. ${ }^{132}$

127 Website Europese Commissies, Betrekkingen met nationale parlementen.

128 C. Hefftler \& K. Gattermann, 'Interparliamentary Cooperation in the European Union: Patterns, Problems and Potential', in: C. Hefftler e.a. (eds.), The Palgrave Handbook of National Parliaments and the European Union, Londen: Palgrave Macmillan 2015, p. 96.

129 Website Hongaars parlement.

130 Art. 2 lid 1 The Stockholm Guidelines for the Conference of Speakers of EU; C. Hefftler \& K. Gattermann, 'Interparliamentary Cooperation in the European Union: Patterns, Problems and Potential', in: C. Hefftler e.a. (eds.), The Palgrave Handbook of National Parliaments and the European Union, Londen: Palgrave Macmillan 2015, p. 96.

131 Art. 2 lid 2 The Stockholm Guidelines for the Conference of Speakers of EU.

132 Het verslag van de bijeenkomst wordt als Kamerstuk 30180 gedrukt; Deelname aan de Conferentie op 21-23 april 2013 vond op ambtelijk niveau plaats in verband met de beëdiging en inhuldiging van koning Willem-Alexander op 30 april 2013. 


\subsubsection{COSAC}

De COSAC oftewel de Conferentie van de commissies voor EU-aangelegenheden van de nationale parlementen van de lidstaten van de Europese Unie en van het Europees Parle$m e n t^{133}$ is een samenwerkingsverband tussen de nationale parlementen. De COSAC werd in mei 1989 in Madrid opgericht door de voorzitters van de parlementen van de lidstaten van de Europese Gemeenschap. Het doel van dit samenwerkingsorgaan is de rol van de nationale parlementen in de EU te versterken door de uitwisseling van informatie en expertise te intensiveren en van gedachten te wisselen over gemeenschappelijke belangen. Tweemaal per jaar wordt een bijeenkomst georganiseerd in het land dat op dat moment voorzitter is van de EU. ${ }^{134}$ Geregeld worden experts uitgenodigd zoals leden van de Europese Commissie. $^{135}$

De formele erkenning van de COSAC kwam in 1997 toen ze werd opgenomen in het Protocol betreffende de rol van de nationale parlementen in de Europese Unie bij het Verdrag van Amsterdam. De COSAC vindt tegenwoordig haar grondslag in artikel 10 van het Protocol betreffende de rol van de nationale parlementen in de Europese Unie bij het Verdrag van Lissabon. Dit artikel luidt:

'Een conferentie van de organen van de parlementen die gespecialiseerd zijn in de aangelegenheden van de Unie kan iedere door haar passend geachte bijdrage ter attentie van het Europees Parlement, de Raad en de Commissie leveren. Deze conferentie bevordert voorts de uitwisseling van informatie en beste praktijken tussen de nationale parlementen en het Europees Parlement, alsook tussen hun respectieve gespecialiseerde commissies. Zij kan ook interparlementaire conferenties over specifieke onderwerpen organiseren, met name om vraagstukken op het gebied van het gemeenschappelijk buitenlands en veiligheidsbeleid, waaronder het gemeenschappelijk veiligheids- en defensiebeleid, te bespreken. De besluiten, aanbevelingen of conclusies van de conferentie binden de nationale parlementen niet en laten hun standpunten onverlet.'

De conclusies van de bijeenkomsten worden naar de nationale parlementen, de Raad, het Europees Parlement en de Commissie gestuurd. De COSAC blijkt een belangrijk middel te zijn om samen te werken bij het indienen van met redenen omklede adviezen in het

133 De afkorting COSAC staat voor Conférence des Organes Spécialisés dans les Affaires Communautaires et Européennes des Parlements de l'Union Européenne.

134 Eerste Kamercommissie Europese Zaken, Introductiedossier, Den Haag: Eerste Kamer 12 juni 2015, p. 23.

135 C. Hefftler \& K. Gattermann, 'Interparliamentary Cooperation in the European Union: Patterns, Problems and Potential', in: C. Hefftler e.a. (eds.), The Palgrave Handbook of National Parliaments and the European Union, Londen: Palgrave Macmillan 2015, p. 96. 
kader van de gele- en oranjekaartprocedure en de politieke dialoog, waarbij de eerste gele kaart tegen het Monti II-voorstel van de Commissie als voorbeeld kan dienen. Deze werd voorbereid tijdens de $47^{\text {ste }}$ COSAC-bijeenkomst in Denenmarken. ${ }^{136}$ COSAC draait om uitwisseling van informatie en beste praktijken met als doel van elkaar te leren. Artikel 1.1 van het reglement van de COSAC formuleert het als volgt: 'De COSAC is een forum voor geregelde gedachtewisselingen zonder dat daarbij afbreuk wordt gedaan aan de bevoegdheden van de parlementaire organen in de Europese Unie. ${ }^{137}$ Geen besluit van de COSAC is bindend, dit betekent dat de COSAC louter een adviesorgaan is. Het expliciet opnemen van het gebied van het gemeenschappelijk buitenlands en veiligheidsbeleid inclusief het gemeenschappelijk veiligheids- en defensiebeleid in het artikel heeft te maken met het intergouvernementele karakter van dit beleid. De controle van dat beleid vindt plaats in de nationale parlementen waardoor de Europese Raad van Nice heeft besloten om de onderlinge samenwerking van nationale en Europese parlementariërs te versterken in het kader van de COSAC. ${ }^{138}$ Het resultaat was dus dat dit beleid expliciet vermeld werd in het artikel met de bedoeling dat de COSAC hier meer aandacht aan zou schenken.

De COSAC komt tweemaal per jaar bijeen. De plenaire bijeenkomst wordt tijdens de bijeenkomst voor de commissievoorzitters voorbereid. Aan de plenaire bijeenkomst kunnen per parlement zes vertegenwoordigers uit de commissie(s) voor EU-aangelegenheden deelnemen. Daarnaast kunnen ook zes vertegenwoordigers van het Europees Parlement deelnemen. Kandidaat-lidstaten mogen drie waarnemers sturen. Doorgaans stuurt Nederland twee afgevaardigden uit de Eerste Kamer en vier uit de Tweede Kamer. De voorbereiding voor de plenaire vergadering vindt plaats in de politieke voorbereidingsgroep COSAC. Deze commissie bestaat uit leden van de Commissie Europese Zaken van zowel de Tweede Kamer als de Eerste Kamer en vergadert achter gesloten deuren. De schriftelijke verslagen van de plenaire bijeenkomst van de COSAC krijgen de vorm van Kamerstuk (in de serie 22660). ${ }^{139}$

De COSAC kan bijdragen voorleggen aan het Europees Parlement, de Raad en de Commissie. Goedkeuring daarvan vindt plaats door middel van een ruime consensus. Wanneer dit niet mogelijk is, worden de bijdragen goedgekeurd met een gekwalificeerde meerderheid van minimaal drie vierde van de uitgebrachte stemmen. Deze meerderheid van de uitgebrachte stemmen moet overeenkomen met minimaal de helft van alle stemmen. Elke delegatie vanuit nationale parlementen beschikt over twee stemmen. ${ }^{140}$

136 Ibid., p. 97.

137 Art. 1.1 Reglement van de Conferentie van de commissies voor EU-aangelegenheden van de parlementen van de Europese Unie (2011/C 229/01).

138 Kamerstukken II 2003/04, 21501-02, nr. 560, p. 2; Kamerstukken II 2002/03, 28604, nr. 3, p. 8.

139 Eerste Kamercommissie Europese Zaken, Introductiedossier, Den Haag: Eerste Kamer 12 juni 2015, p. 23.

140 Art. 7.1 en 7.5 Reglement van de Conferentie van de commissies voor EU-aangelegenheden van de parlementen van de Europese Unie (2011/C 229/01). 
De COSAC wordt door parlementariërs gezien als een netwerkbijeenkomst en zij zijn er positief over. ${ }^{141}$ Met name ten tijde van de eerste gele kaart bleek de netwerkfunctie goed te werken. ${ }^{142}$ Uit onderzoek blijkt dat wanneer een COSAC-bijeenkomst plaatsvindt in de controleperiode van een nieuw wetgevingsvoorstel (in de periode dat nationale parlementen een met redenen omkleed advies kunnen indienen) dit de kans op het behalen van het minimaal aantal adviezen voor een gele kaart vergroot. ${ }^{143}$ Negatief aan COSAC is volgens parlementariërs de kwaliteit van de debatten, de dominantie van het Europees Parlement en het feit dat van bepaalde parlementen geen afgevaardigden aanwezig zijn. Doorgaans hebben de afgevaardigden geen mandaat en kunnen geen formele beslissingen genomen worden. De effectiviteit hangt daarnaast af van de toevallige persoonlijke contacten. ${ }^{144}$

\subsubsection{Interparlementaire Commissiebijeenkomsten}

De Interparlementaire Commissiebijeenkomsten worden georganiseerd door verschillende commissies van het Europees Parlement met de verschillende Kamercommissies van de nationale parlementen. Tijdens bijeenkomsten van de Interparlementaire Commissiebijeenkomsten worden concrete zaken of wetgevingsvoorstellen besproken die onder de gewone wetgevingsprocedure vallen. ${ }^{145}$ Het doel van deze bijeenkomsten tussen leden van nationale parlementen en leden van het Europees Parlement, is de uitwisseling van standpunten waardoor leden van nationale parlementen invloed uitoefenen op de standpunten van leden van het Europees Parlement over concrete wetsvoorstellen. ${ }^{146}$ Interparlementaire commissie-bijeenkomsten worden ongeveer tien keer per jaar georganiseerd, wat betekent dat er behoefte bestaat tot het uitwisselen van informatie tussen de commissies van de parlementen. ${ }^{147}$

141 E. Mastenbroek e.a., Gericht op Europa. Nationale parlementaire controle op Europese besluitvorming na het Verdrag van Lissabon, Institute for Management Research Radboud Universiteit Nijmegen 2014, p. 25.

142 Ibid.

143 Zie D8.4 Report: 'Do National Parliaments use their Rights to involve Themselves in EU Decision Making? What, if any, are the Constraints? A Comparison of Five EU Member States', 21 april 2016, van Petr Kaniok, Masaryk University, via website Beucitizen.

144 E. Mastenbroek e.a., Gericht op Europa. Nationale parlementaire controle op Europese besluitvorming na het Verdrag van Lissabon, Institute for Management Research Radboud Universiteit Nijmegen 2014, p. 25 26.

145 C. Hefftler \& K. Gattermann, 'Interparliamentary Cooperation in the European Union: Patterns, Problems and Potential', in: C. Hefftler e.a. (eds.), The Palgrave Handbook of National Parliaments and the European Union, Londen: Palgrave Macmillan 2015, p. 98.

146 D. Jančić, 'Representative Democracy across Levels? National Parliaments and EU Constitutionalism', Croatian Yearbook of European Law and Policy (8) 2012, p. 242-243.

147 C. Hefftler \& K. Gattermann, 'Interparliamentary Cooperation in the European Union: Patterns, Problems and Potential', in: C. Hefftler e.a. (eds.), The Palgrave Handbook of National Parliaments and the European Union, Londen: Palgrave Macmillan 2015, p. 98. 
Ook de Gezamenlijke Commissiebijeenkomsten worden georganiseerd door het Europees Parlement in Brussel. Het Europees Parlement doet dit samen met de lidstaat die op dat moment voorzitter is van de Europese Unie. De Gezamenlijke Commissiebijeenkomsten zijn er om de dialoog tussen parlementariërs van nationale parlementen onderling en de dialoog tussen nationale parlementariërs en Europarlementariërs te bevorderen binnen bepaalde sectoren en onderwerpen van algemeen belang. In tegenstelling tot de interparlementaire commissiebijeenkomsten worden gezamenlijke commissiebijeenkomsten niet vaak georganiseerd. ${ }^{148}$ Dit laat zien dat er meer behoefte is aan uitwisseling van informatie en standpunten over concrete voorstellen en onderwerpen en minder over onderwerpen van algemeen belang.

\subsubsection{Gezamenlijke parlementaire bijeenkomsten}

Net zoals de Gezamenlijke Commissiebijeenkomsten worden de Gezamenlijke parlementaire bijeenkomsten georganiseerd in Brussel door het Europees Parlement in samenwerking met de lidstaat die voorzitter is van de Europese Unie op dat tijdstip. De gezamenlijke interparlementaire bijeenkomsten zijn regelmatig terugkerende bijeenkomsten. Het doel van deze bijeenkomsten is de interparlementaire dialoog over grote en belangrijke onderwerpen te bevorderen. De onderwerpen die besproken worden zijn onderwerpen van gemeenschappelijk belang. In tegenstelling tot de bovenstaande twee bijeenkomsten, die onderwerpen bespreken op een bepaald beleidsterrein, hebben de Gezamenlijke parlementaire bijeenkomsten een bredere opzet en kunnen in principe alle onderwerpen besproken worden. ${ }^{149}$ De nadruk ligt op de gebieden ten aanzien waarvan de Unie geen wetgeving opstelt maar wel beleid voert, zoals economisch en monetair beleid, energiebeleid, klimaatverandering en gemeenschappelijk buitenlands en veiligheidsbeleid. ${ }^{150}$

148 C. Hefftler \& K. Gattermann, 'Interparliamentary Cooperation in the European Union: Patterns, Problems and Potential', in: C. Hefftler e.a. (eds.), The Palgrave Handbook of National Parliaments and the European Union, Londen: Palgrave Macmillan 2015, p. 98.

149 C. Hefftler \& K. Gattermann, 'Interparliamentary Cooperation in the European Union: Patterns, Problems and Potential', in: C. Hefftler e.a. (eds.), The Palgrave Handbook of National Parliaments and the European Union, Londen: Palgrave Macmillan 2015, p. 97.

150 D. Jančić, 'Representative Democracy across Levels? National Parliaments and EU Constitutionalism', Croatian Yearbook of European Law and Policy (8) 2012, pp. 242. 


\subsubsection{Gezamenlijke parlementaire controlegroep EUROPOL}

Sinds het Verdrag van Lissabon ${ }^{151}$ en de nieuwe EUROPOL-verordening (EU) 2016/794 bestaat de verplichting voor nationaal parlementair toezicht op EURPOL en in april 2017 werd de Gezamenlijke parlementaire controlegroep EUROPOL (GPCE) opgericht. ${ }^{152}$ Volgens artikel 51 lid 1 van de verordening houdt de GPCE politiek toezicht op de activiteiten van Europol, inclusief de gevolgen van de activiteiten op fundamentele rechten en fundamentele vrijheden van natuurlijke personen. Ook enkele rechten van de GPCE zijn opgenomen in de verordening. De GPCE kan de voorzitter van de raad van bestuur, de uitvoerend directeur of hun plaatsvervangers verzoeken voor de raad te verschijnen. Ook wordt de GPCE geraadpleegd over de meerjarige programmering van EUROPOL. Voor de uitvoering van de taken heeft de GPCE enkele informatierechten gekregen. ${ }^{153}$ De GPCE bestaat uit vier leden per nationaal parlement en zestien leden van het Europees Parlement. ${ }^{154}$ De conclusies die de GPCE neemt, worden aan het Europees parlement, de nationale parlementen, de Raad, de Commissie en EUROPOL gestuurd. ${ }^{155}$ Gezien het feit dat de GPCE pas sinds kort bestaat, is het nog niet mogelijk om iets over het effect van de GPCE te zeggen.

\subsubsection{Artikel 13-conferentie}

Als reactie op de economische en financiële crisis is in april 2013 door de Conferentie van Voorzitters van de parlementen van de Europese Unie op Cyprus besloten om een nieuwe interparlementaire conferentie te creëren. Dit is de Interparlementaire conferentie onder Artikel 13 van het Begrotingspact. ${ }^{156}$ De volledige naam is de Interparlementaire Conferentie over Stabiliteit, Economische Coördinatie en Bestuur in de Europese Unie (Interparliamentary Conference on Stability, Economic Coordination and Governance in the European Union), maar de gangbare naam is de Artikel 13-conferentie. De eerste bijeenkomst vond plaats op 16 en 17 oktober 2013 in Vilnius, Litouwen. Artikel 13 van het begrotingspact bepaalt dat

151 Art. 12 VEU.

152 V. Kreilinger (ed.), A Watchdog for Europe's Policemen: The Joint Parliamentary Scrutiny Group for Europol (Policy Paper), Berlijn: Jacques Delors Institute 2017, p. 3.

153 D. Fromage, 'The New Joint Parliamentary Scrutiny Group for Europol: Old Wine in New Bottles?', EU TARN, Blog 17 juni 2017.

154 V. Kreilinger (ed.), A Watchdog for Europe's Policemen: The Joint Parliamentary Scrutiny Group for Europol (Policy Paper), Berlijn: Jacques Delors Institute 2017, p. 16.

155 D. Fromage, 'The New Joint Parliamentary Scrutiny Group for Europol: Old Wine in New Bottles?', EU TARN, Blog 17 juni 2017.

156 Het begrotingspact wordt ook wel Fiscal Compact genoemd en vormt een onderdeel van het Verdrag inzake stabiliteit, coördinatie en bestuur in de economische en monetaire unie. 
'(...) het Europees Parlement en de nationale parlementen van de verdragsluitende partijen samen beslissen over de organisatie en de promotie van een conferentie van vertegenwoordigers van de desbetreffende commissies van het Europees parlement en vertegenwoordigers van de desbetreffende commissies van de nationale parlementen, om het begrotingsbeleid en andere onder dit Verdrag vallende kwesties te bespreken'.

De onderwerpen die tijdens de Artikel 13-conferentie aan bod komen, zijn gerelateerd aan de Economische en Monetaire Unie (EMU). De Conferentie van Voorzitters van de parlementen van de Europese Unie was van mening dat het EMU-beleid van dermate belang was, dat dit beter en meer gecontroleerd zou moeten worden. Hierdoor zou de EMU meer geïntegreerd worden in de lidstaten. De Artikel 13-conferentie wordt, net zoals de COSAC, tweemaal per jaar georganiseerd. In het voorjaar ligt de organisatie in handen van het Europees Parlement en vindt de conferentie in Brussel plaats, in het najaar wordt de conferentie door het parlement van de lidstaat die voorzitter is van de EU georganiseerd en vindt de conferentie aldaar plaats. Het aantal afgevaardigden van de nationale parlementen wordt door de nationale parlementen zelf bepaald. De Artikel 13-conferentie maakt deel uit van de door het Europees Parlement georganiseerde Europese Parlementaire Week (EPW). ${ }^{157}$ Een groot nadeel van de Artikel 13-conferentie is het feit dat geen bindende aanbevelingen kunnen worden gedaan richting EU-organen of nationale regeringen. Het is een platform voor discussie en uitwisseling van informatie en beste praktijken over economisch en financieel bestuur. Controle of invloed uitoefenen op Europees niveau op economisch of financieel gebied gebeurt dus niet via de Artikel 13-conferentie. ${ }^{158}$

\subsubsection{Europese Parlementaire Week}

De EPW wordt in januari of februari georganiseerd door het Europees Parlement samen met de lidstaat die het voorzitterschap van de EU in handen heeft. De bedoeling was om een debat te organiseren tussen het Europees Parlement en de nationale parlementen over de jaarlijkse groeianalyse van de Europese Commissie en daaraan verwante onderwerpen. ${ }^{159}$ Tijdens deze week, die feitelijk maar twee dagen duurt, komen leden van de nationale parlementen samen met leden van het Europees Parlement. De leden debatteren over het

157 Website Tweede Kamer, Artikel 13-conferentie.

158 V. Kreilinger, The new inter-parliamentary conference for economic and financial government (Policy Paper), Berlijn: Jacques Delors Institute 2013.

159 C. Hefftler \& K. Gattermann, Interparliamentary Cooperation in the European Union: Patterns, Problems and Potential, in: C. Hefftler e.a. (eds.), The Palgrave Handbook of National Parliaments and the European Union, Londen: Palgrave Macmillan 2015, p. 99. 
Europees Semester en over stabiliteit, economische coördinatie en bestuur in de Europese Unie. Dit wordt gedaan tijdens de Interparlementaire conferentie inzake het Europees Semester en de artikel 13-conferentie. Naast deze twee conferenties vinden ook bijeenkomsten plaats tussen leden van nationale parlementen en leden van het Europees Parlement uit dezelfde politieke fracties. Ook enkele interparlementaire commissiebijeenkomsten vinden tijdens deze week plaats. De commissies Economische en Monetaire Zaken, Werkgelegenheid en Sociale Zaken en Begroting, de commissies die het initiatief namen voor de EPW, organiseren tijdens elke EPW-bijeenkomst de mogelijkheid voor Europarlementariërs om met hun collega's van de nationale parlementen in debat te gaan. De EPW zorgt voor een kader waarbinnen deze bijeenkomsten en conferenties kunnen plaatsvinden. $^{160}$

Toen het Verdrag inzake Stabiliteit, Coördinatie en Bestuur in de Economische en Monetaire Unie tot stand kwam als reactie op de economische en financiële crisis was het Europees Parlement van mening dat interparlementaire samenwerking op het economische en monetaire terrein van groot belang was. De EPW is ontstaan als reactie op het Europees Semester. Er moest volgens het Europees Parlement een platform bestaan waar nationale parlementen ideeën en beste praktijken konden uitwisselen. Op initiatief van de commissies Economische en Monetaire Zaken (ECON), Werkgelegenheid en Sociale Zaken (EMPL) en Begroting (BUDG) van het Europees Parlement, in samenwerking met de Conferentie van Voorzitters van de parlementen van de Europese Unie, organiseerde het Europees Parlement in februari 2012 een interparlementaire bijeenkomst inzake het Europees Semester. Sinds 2012 wordt deze conferentie elk jaar georganiseerd en wordt deze bijeenkomst georganiseerd als onderdeel van de EPW. ${ }^{161}$ Vanaf 2014 maakt ook de Artikel 13conferentie deel uit van de EPW. ${ }^{162}$

\subsubsection{Interparlementaire Conferentie voor gemeenschappelijk buitenlands en veiligheidsbeleid en het gemeenschappelijk veiligheids-en defensiebeleid}

In april 2012 werd tijdens de Conferentie van Voorzitters van de parlementen van de Europese Unie in Warschau, Polen de Interparlementaire Conferentie voor gemeenschappelijk buitenlands en veiligheidsbeleid en het gemeenschappelijk veiligheids- en defensiebeleid (GBVB/GVDB) opgericht. Enkele maanden later, in september 2012, werd de Conferentie voor het eerste gehouden, op Cyprus. Het doel van deze conferentie is het versterken van de rol van nationale parlementen en het Europees Parlement krachtens het Verdrag van

160 Zie de agenda's van de EPW's via Ipex.eu.

161 Website Europees Parlement, Relations with national parliaments.

162 Ibid. 
Lissabon en meer specifiek Protocol nr. 1 bij dat verdrag. Dit wordt gedaan door informatie en beste praktijken uit te wisselen op het gebied van gemeenschappelijk buitenlands en veiligheidsbeleid en het gemeenschappelijk veiligheids- en defensiebeleid zodat nationale parlementen en het Europees Parlement volledig geïnformeerd zijn wanneer zij in een van deze gebieden handelingen verrichten. ${ }^{163}$ De samenstelling van de conferentie bestaat uit zes vertegenwoordigers per nationaal parlement en zestien vertegenwoordigers van het Europees Parlement. Kandidaat-lidstaten mogen vier vertegenwoordigers sturen die de conferentie mogen observeren. ${ }^{164}$ Deze vertegenwoordigers komen elk half jaar bijeen in het land van de voorzitter van de EU of in het Europees Parlement in Brussel. De conferentie wordt voorgezeten door de voorzitter van de EU in nauwe samenwerking met het Europees Parlement. ${ }^{165}$

\subsection{Alternatieve bronnen VAn informatie}

Er zijn meerdere manieren waarop nationale parlementen informatie uitwisselen en samenwerken met andere nationale parlementen en EU-instellingen. Zo is er een officiële interparlementaire databank genaamd IPEX, waarbinnen op formele wijze op politiek en administratief niveau wordt samengewerkt. Daarnaast bestaat het netwerk ECPRD, dat breder is dan de Europese Unie omdat ook leden van de Raad van Europa deelnemen aan dit netwerk.

\subsubsection{IPEX}

IPEX staat voor Interparliamentary EU Information Exchange. Deze databank is ontstaan in 2000 tijdens de Conferentie van Voorzitters van de parlementen van de Europese Unie. Op de website wordt informatie geplaatst over de behandeling van Europese wetgevingsen beleidsvoorstellen in de nationale parlementen van de Europese Unie. Het doel is interparlementaire samenwerking mogelijk te maken door het uitwisselen van informatie tussen nationale parlementen onderling en met het Europees Parlement. ${ }^{166}$ De website, www.ipex.eu, bevat een databank met ontwerpwetgeving, consultatie- en informatiedocumenten van de Europese Commissie. Daarnaast zijn er ook parlementaire documenten te vinden die de nationale parlementen zelf uploaden. Verder bevat IPEX een kalender met

163 Kamerstukken I en II 2012/13, 33130, A/nr. 2, p. 1.

164 Art. 2 Rules of Procedure of the Inter-Parliamentary Conference for the Common Foreign and Security Policy and the Common Security and Defence Policy.

165 Website Europees Parlement, Relations with national parliaments.

166 Eerste Kamercommissie Europese Zaken, Introductiedossier, Den Haag: Eerste Kamer 12 juni 2015, p. 17. 
de data waarop interparlementaire bijeenkomsten worden gehouden. ${ }^{167}$ IPEX probeert een actueel overzicht te bieden van de standpunten van nationale parlementen in de geleen oranjekaartprocedure. Daarbij is het van groot belang dat de nationale parlementen de benodigde informatie leveren. ${ }^{168}$

Het aantal documenten in IPEX is over de jaren toegenomen maar IPEX is niet goed te gebruiken voor actuele zaken. Zowel het Nederlandse als het Duitse parlement is actief in het plaatsen van documenten. Deze documenten worden doorgaan pas geplaatst nadat de nationale procedure is afgelopen dan wel enige tijd nadat de documenten nationaal zijn gebruikt. IPEX is voor andere lidstaten dus geen actuele bron van informatie en is niet of nauwelijks te gebruiken in de gelekaartprocedure waarbij immers binnen acht weken gereageerd dient te worden. Daarnaast is er een taalkundig probleem. De meeste documenten worden geplaatst in de officiële taal van de lidstaat waardoor de documenten voor andere lidstaten moeilijk te gebruiken zijn. Aan dit probleem is enigszins tegemoetgekomen door de lidstaten zelf, nu steeds meer lidstaten ook een vertaling in het Engels plaatsen. De Bundesrat gaat soms zo ver om naast een Engelse vertaling ook een Franse vertaling te uploaden. ${ }^{169}$

\subsubsection{ECPRD}

The European Centre for Parliamentary Research and Documentation (ECPRD) is net zoals IPEX gecreëerd door de Conferentie van Voorzitters van de parlementen van de Europese Unie. Dit netwerk bestaat sinds 1977 en is gecreëerd voor nationale parlementen van de leden van de Raad van Europa, de Parlementaire Vergadering van de Raad van Europa, de onderzoeksafdelingen van het Europees Parlement en de leden en observerende leden van de Raad van Europa. Omdat parlementariërs van de leden van de Raad van Europa lid van het ECPRD zijn, is dit een groter netwerk dan netwerken waarbij alleen parlementariërs van EU-lidstaten betrokken zijn. Het ECPRD heeft als doel het bevorderen van parlementaire samenwerking op de gebieden van informatie, parlementair onderzoek en documentatie. Verder zet het ECPRD zich in voor het uitwisselen van informatie, ideeën en ervaringen. Het ECPRD is net zoals IPEX een documentatiesysteem. De effectiviteit is hierdoor moeilijk tot niet vast te stellen.

167 Ipex.eu.

168 C. Hefftler \& K. Gattermann, Interparliamentary Cooperation in the European Union: Patterns, Problems and Potential, in: C. Hefftler e.a. (eds.), The Palgrave Handbook of National Parliaments and the European Union, Londen: Palgrave Macmillan 2015, p. 101.

169 V. Knutelská, 'Cooperation among national parliaments: an effective contribution to EU legitimation?', in: B. Crum \& J. Fossum (eds.), Practices of Interparliamentary Coordination in International Politics: The European Union and Beyond, Colchester: ECPR Press 2013, p. 41-43. 
Nationale parlementen hebben op basis van Europees recht meerdere bevoegdheden om invloed uit te oefenen op Europese aangelegenheden. Deze parlementaire middelen om invloed uit te oefenen en de participatierechten zijn geïntroduceerd om het democratisch tekort te verkleinen. De vraag die in de inleiding is gesteld, is of nationale parlementen, in het bijzonder het Duitse en het Nederlandse parlement, deze bevoegdheden gebruiken en in welke mate, en of het democratisch tekort hierdoor daadwerkelijk verkleind is.

Om te beginnen is er het Barroso-initiatief. Dit initiatief was een stap in de goede richting, zeker toen het werd gecodificeerd in het Verdrag van Lissabon. Zonder adequate en volledige informatie kunnen nationale parlementen geen invloed uitoefenen. Men kan op basis hiervan niet stellen dat de betrokkenheid van nationale parlementen is vergroot. Nationale parlementen zijn nu wel op de hoogte van alles wat in de Europese Unie speelt en zijn niet langer afhankelijk van hun regeringen, maar dat maakt de nationale parlementen nog niet direct betrokken of actief. Ook is de invloed van nationale parlementen op de Europese Unie hiermee nog niet vergroot, wederom omdat puur door het ontvangen van informatie de nationale parlementen geen invloed kunnen uitoefenen.

De politieke dialoog die samenhangt met het Barroso-initiatief, is in principe een goed middel voor direct contact tussen de nationale parlementen en de Europese Commissie. Of de politieke dialoog daadwerkelijk werkt, hangt natuurlijk af van activiteiten van de nationale parlementen (zij moeten adviezen insturen), en van de Europese Commissie, die een deugdelijk en tijdelijk antwoord moet sturen. Het Nederlandse parlement, en dan met name de Tweede Kamer, is redelijk actief binnen de politieke dialoog. De Eerste Kamer is niet of nauwelijks actief binnen de politieke dialoog aangezien zij liever een brief aan de regering stuurt dan aan de Europese Commissie. Het Duitse parlement geeft een enigszins omgekeerd beeld. De Bundestag is nauwelijks actief binnen de politieke dialoog, de Bundesrat is zeer actief. De aantallen zeggen echter niet zo veel als de inhoud niet goed is. De politieke dialoog zou de rol van de nationale parlementen in de EU vergroten wanneer de Europese Commissie daadwerkelijk actie zou ondernemen op basis van de adviezen die zij krijgt van de nationale parlementen. Niets is minder waar. De antwoorden van de Commissie zijn matig en soms slechts een herhaling van de standpunten van de Commissie. Op basis van de adviezen die de nationale parlementen sturen, komt de Commissie niet tot andere inzichten waardoor gesteld kan worden dat de invloed van nationale parlementen in de EU niet wordt vergroot door de politieke dialoog. Dit is ook niet het doel van de politieke dialoog. Het is namelijk bedoeld als middel om informatie uit te wisselen tussen de Europese Commissie en nationale parlementen. Dit doel wordt wel bereikt. Nationale parlementen kunnen vragen stellen, hun zorgen uiten, hun standpunten overbrengen en aangeven wat ze graag anders zien en de Commissie beantwoordt die vragen en reageert 
op de zorgen en de standpunten van de nationale parlementen en zo ontstaat er een dialoog. Nationale parlementen kan overigens niet verweten worden dat ze proberen om de Commissie op andere gedachte te brengen en te overtuigen van hun eigen standpunten.

De gelekaartprocedure heeft als doel de nationale parlementen een stem te geven in het Europese wetgevingsproces. Waar de politieke dialoog minder dwingend is voor de Europese Commissie, is de gelekaartprocedure dat juist meer. Zodra een derde van de nationale parlementen een met redenen omkleed advies heeft ingediend bij de Commissie naar aanleiding van een wetsvoorstel dient de Commissie hier iets mee te doen. In het minste geval dient de Commissie het wetsvoorstel nogmaals te bekijken. Het is echter de Commissie die bepaalt of het gaat om een met redenen omkleed advies en niet de lidstaten. Wat dat betreft heeft de Commissie de touwtjes in de handen en kan de Commissie (ten minste in theorie) voorkomen dat een gele kaart wordt getrokken door te bepalen dat adviezen niet worden gezien als met redenen omklede adviezen in het kader van de gelekaartprocedure. Aangezien alle met redenen omklede adviezen met betrekking tot subsidiariteit afkomstig van het Nederlandse en het Duitse parlement behandeld zijn in de gelekaartprocedure, dus door de Commissie bestempeld als subsidiariteitsbezwaren, bestaat er geen reden om aan te nemen dat de Commissie misbruik maakt van haar positie. Tot nu toe is het de nationale parlementen drie keer gelukt een gele kaart te trekken. Wordt er geen gele kaart getrokken dan worden alle met redenen omklede adviezen binnen de politieke dialoog behandeld. Het Nederlandse parlement is nauwelijks actief binnen de gelekaartprocedure. Wederom is de Tweede Kamer actiever dan de Eerste Kamer. Het Duitse parlement heeft in de eerste jaren na het Verdrag van Lissabon enkele met redenen omklede adviezen ingestuurd maar na 2013 niet meer. Alle adviezen die het Nederlandse en het Duitse parlement hebben ingestuurd als een met redenen omkleed advies, zijn als zodanig aangemerkt. Het is dus niet zo dat beide parlementen actiever zijn dan dat de cijfers laten zien.

De gelekaartprocedure, de politieke dialoog als ook de groene kaart kunnen (in theorie) de betrokkenheid van nationale parlementen in de Europese Unie vergroten. In de praktijk is het echter zo dat die betrokkenheid (nog) niet veel voorstelt. Men kan niet stellen dat de nationale parlementen een stem hebben die gehoord wordt op Europees niveau. Een politieke dialoog tussen de Commissie en een parlement geeft de Commissie doorgaans geen aanleiding om haar (wetgevings)plannen te wijzigen, haar standpunten aan te passen of standpunten van een nationaal parlement over te nemen. Eén keer is duidelijk te zien dat de Commissie het standpunt van de nationale parlementen heeft overgenomen. Dat was bij de eerste groene kaart. Aangezien het om slechts één kaart gaat, kan op basis daarvan niet de conclusie getrokken worden dat de politieke dialoog de daadwerkelijke betrokkenheid van nationale parlementen in de EU echt vergroot. Het is eerder zo dat de politieke dialoog in de praktijk geen verandering brengt en dat nationale parlementen via 
de politieke dialoog geen grote(re) rol spelen op Europees niveau, maar het zou wel zo kunnen zijn dat nationale parlementen een grotere rol spelen op nationaal niveau ten opzichte van de eigen regeringen. De politieke dialoog zorgt ervoor dat nationale parlementen beter geïnformeerd zijn, ten minste voor wat betreft hetgeen ze in dialoog met de Europese Commissie hebben besproken. Bovendien geeft het ook een signaal af aan de regering dat het parlement aan een bepaald onderwerp extra aandacht besteedt. De politieke dialoog helpt de nationale parlementen om een beter debat te voeren met de regering omdat de kennis aanwezig is in het parlement.

Voor wat betreft de gelekaartprocedure kan nog het volgende worden opgemerkt. Deze procedure is in het leven geroepen om de betrokkenheid van nationale parlementen te vergroten. In de praktijk kan ook wel geconcludeerd worden dat dit het geval is. Er zijn tot op heden drie gele kaarten getrokken en geen oranje kaart. Die gele kaarten hebben niet meteen geleid tot een wijziging van het voorstel of het intrekken van het voorstel, maar zij hebben wel degelijk invloed gehad op het voorstel. Het voorstel waarvoor de eerste gele kaart is getrokken, is ingetrokken door de Commissie. Dat gebeurde weliswaar niet meteen omdat er strijd bestond met het subsidiariteitsbeginsel, maar later wel, op basis van de haalbaarheid. Het voorstel zou waarschijnlijk niet genoeg steun krijgen in de Raad. Aangezien de juridische grondslag van het voorstel artikel 352 VWEU was, diende de Raad met unanimiteit in te stemmen en dat zat er (volgens de Commissie) niet in.

Het tweede voorstel is in eerste instantie na de gele kaart gehandhaafd maar ook dit voorstel kon niet op genoeg steun rekenen in het Europees Parlement en de Raad. Dit voorstel is uiteindelijk, na vele wijzigingen, voorgezet als een nauwere samenwerking.

Het derde voorstel is ook na de gele kaart gehandhaafd door de Commissie. Op dit voorstel hadden niet enkel nationale parlementen bezwaren maar ook nationale regeringen (overigens net zoals bij de eerste twee gele kaarten) waardoor er wederom weinig draagvlak bestond. De Commissie is daarna samen met de Raad en het Europees parlement in een triloog tot een compromis gekomen waar de bezwaren van de verschillende nationale parlementen zijn meegenomen. Het is wellicht moeilijk om alles een-op-een toe te schrijven aan de gelekaartprocedure maar niet ontkend kan worden dat deze van invloed is geweest. Zo is de 'nauwere samenwerking' een oplossing geworden voor het feit dat niet alleen nationale parlementen tegen het voorstel waren maar ook enkele regeringen. Het is niet vreemd dat wanneer een nationaal parlement problemen heeft met een voorstel, de nationale regering deze ook heeft. Bij het tweede voorstel was unanimiteit vereist binnen de Raad en al snel werd duidelijk dat dat niet haalbaar was. Opmerkelijk is dat in dat geval ook het voorstel drastisch is gewijzigd waardoor verschillende lidstaten die eerst tegen het voorstel waren, waaronder Nederland, zich daarna toch hebben aangesloten bij de nauwere samenwerking.

Er kan dus gesteld worden dat de gelekaartprocedure de betrokkenheid van nationale parlementen bij het Europese besluitvormingsproces heeft vergroot. De drie gele kaarten 
hebben uiteindelijk, misschien via een omweg of als een katalysator, geleid tot intrekking of grondige wijziging van de voorstellen.

Naast de vraag of de rol van nationale parlementen in de Europese Unie is vergroot, is nog een open kwestie of de legitimiteit van de EU door de gelekaartprocedure is vergroot. Gezien de resultaten van drie gele kaarten kan in ieder geval gezegd worden dat het idee van de duale legitimiteit (door EP en nationale parlementen) levensvatbaar is en dat nationale parlementen nationale sentimenten kunnen laten doorklinken. Het is weliswaar zo dat de drempel om een gele kaart te trekken vaker niet dan wel wordt gehaald maar als deze wordt gehaald dan gebeurt er ook daadwerkelijk iets. Zo laten de drie gele kaarten zien hoe de wetsvoorstellen zijn ingetrokken of aanzienlijk zijn gewijzigd. Wat we niet weten, is of dit ook was gebeurd indien er geen gele kaarten waren getrokken of die procedure niet had bestaan, maar men kan ook niet ontkennen dat de gele kaarten van invloed zijn geweest op Europese besluitvorming.

Ook de politieke dialoog draagt bij aan de legitimiteit van de Europese Unie omdat nationale parlementen via die dialoog direct het gesprek aan kunnen gaan met de Commissie en dus hun zegje kunnen doen over Europese wetgeving en andere documenten. Hiervan wordt dan ook gebruikgemaakt. Niet bepalend is of de Commissie de standpunten en dergelijke van nationale parlementen overneemt en haar voorstellen wijzigt, want dat is niet het doel van de politieke dialoog. Wat wel meespeelt, is dat door de politieke dialoog de nationale parlementen meer informatie hebben om hun eigen ministers voor hun optreden in de Raad ter verantwoording te roepen. Door die informatie kunnen nationale parlementen wellicht op een effectievere manier invloed uitoefenen op Europese besluitvorming omdat ze geen informatieachterstand meer hebben en dus beter weten wat ze moeten en kunnen doen.

Om de politieke dialoog maar met name de gelekaartprocedure doeltreffender te maken is meer samenwerking tussen nationale parlementen nodig zodat er vaker gele kaarten getrokken worden en er meer dialogen gevoerd worden over hetzelfde onderwerp. Dit is nodig aangezien de Commissie eerder geneigd is om iets in haar standpunten aan te passen wanneer een grote groep nationale parlementen van zich laat horen. Dit heeft ook ermee te maken dat wanneer nationale parlementen het oneens zijn met de Commissie, de nationale regeringen dit waarschijnlijk ook zullen zijn. Die regeringen zullen dan in de Raad hun bezwaren uiten waardoor de kans bestaat dat het wetsvoorstel in de Raad niet genoeg steun zal krijgen. Het probleem is dat, zoals in de inleiding beschreven, de Europese Unie niet uit één volk bestaat met één mening. De standpunten, meningen, doelen en belangen van de lidstaten zijn veelal verschillend waardoor het niet altijd mogelijk is om een grote groep nationale parlementen achter één standpunt te krijgen. 
Tot slot zijn er nog de vele mogelijkheden van parlementaire samenwerking. De ontmoetingen tussen de nationale parlementen zijn nodig om kennis uit te wisselen, te leren van elkaar en om daadwerkelijk samen te werken in bijvoorbeeld de gelekaartprocedure. Met name dit laatste is van groot belang maar gebeurt te weinig. Door de vele vormen van samenwerking en door de omvang van de informatie bestaat wel het gevaar dat parlementariërs door de bomen het bos niet meer zien. De kans dat er nog vele nieuwe parlementaire conferenties of groepen bijkomen, is klein. Wellicht zijn er nu al te veel en dient de transparantie daarbinnen te worden bevorderd.

Ten slotte is van belang dat nationale parlementen nationaal de expertise en kennis en faciliteiten en menskracht moeten hebben om effectief met de Europese bevoegdheden en met de nationale controle van ministers inzake EU-aangelegenheden om te gaan. Hoe dat het geval is in Nederland en Duitsland zal in de volgende hoofdstukken ook aan de orde komen. 



\section{HoofdSTK 3 NEDERLAND}

\subsection{INLEIDING}

Dit hoofdstuk gaat over de Nederlandse parlementaire werkzaamheden ten aanzien van en invloed op Europese besluitvorming en aangelegenheden. Voor het Verdrag van Lissabon werden nationale parlementen niet erkend, ten minste niet als een onderdeel dan wel relevante entiteit, ten aanzien van Europese Unie-kwesties. Zoals in het vorige hoofdstuk is beschreven, worden de nationale parlementen tegenwoordig wel erkend als van belang voor de representativiteit en legitimiteit van de EU en hebben zij daartoe specifieke bevoegdheden tot hun beschikking gekregen. Na de behandeling van de EU-bevoegdheden en rol van nationale parlementen wordt in dit hoofdstuk vanuit het nationale perspectief onderzocht welke nationale bevoegdheden het Nederlandse parlement ter beschikking heeft en hoe het deze gebruikt en hoe nieuwe Europese wetgeving wordt behandeld in het parlement. Tot slot wordt ingegaan op overige activiteiten van het parlement met betrekking tot de EU-aangelegenheden.

Het parlement heeft twee hoofdfuncties: (1) tot stand brengen van wetgeving en (2) ondersteunen en controleren van de regering. De controle strekt zich uit over al het beleid van de regering. Dat betreft zowel nationaal beleid als Europees en internationaal beleid. Omdat ministers lid zijn van de Raad van ministers van de EU en de ministerpresident zitting heeft in de Europese Raad speelt de regering een rol op Europees niveau ten aanzien van Europese wetgeving en bepaalt de regering mede het beleid van de EU. Naar nationaal recht kan en moet het parlement de activiteiten van de ministers/regering op Europees niveau controleren, zowel als nationale taak van het parlement en als zijn rol zoals beschreven in het VEU. De controle van de regering door het parlement hoort bij het parlementaire stelsel en de in het staatsbestel opgenomen checks and balances. Geen enkele macht mag overheersend of bepalend zijn. Via het controleproces kan het parlement invloed en zeggenschap uitoefenen aangaande de executieve.

Om de regering te controleren beschikt het parlement naar nationaal recht over enkele specifieke controlebevoegdheden. Met behulp van deze controlebevoegdheden probeert het parlement ook invloed uit te oefenen op Europese besluitvorming. De controle op het Europese beleid wordt immers vooral gedaan door het gebruik van nationale bevoegdheden. In het gedeelte Controle wordt hierna ingegaan op de controlebevoegdheden van het parlement. Het gaat dan om de nationale controlemiddelen die het parlement kan inzetten. De weg van het politieke controle- en verantwoordingsproces is een indirecte manier om invloed uit te oefenen op Europese besluitvorming. Het gaat immers altijd via de regering en over dat wat de regering op EU-niveau kan en mag. Naast deze weg bestaat ook een 
directe weg om invloed uit te oefenen op Europese besluitvorming. Het parlement beschikt, zoals in het vorige hoofdstuk staat beschreven, over instrumenten om Europese instellingen, en dan met name de Europese Commissie, te beïnvloeden. Wanneer het parlement nieuwe ontwerpwetgeving rechtstreeks van de Europese Commissie ontvangt, heeft het enkele mogelijkheden om hierop te reageren en daarmee invloed uit te oefenen op deze Europese wetgeving. In het gedeelte Wetgeving van dit hoofdstuk wordt aandacht besteed aan de werkwijze van beide Kamers aangaande nieuwe Europese wetgeving. Hoe wordt de wetgeving ontvangen en daarna behandeld? Welke bevoegdheden heeft het parlement om invloed uit te oefenen en welke bevoegdheden en procedures bestaan er (op nationaal en EUniveau) en maakt het ook gebruik van deze nationale en Europese bevoegdheden? Tot slot wordt in dit hoofdstuk aandacht besteed aan taken van het parlement die niet onder controle of wetgeving vallen. Dit gedeelte, Het parlement en de EU, gaat onder andere in op de Staat van de Europese Unie, het jaarlijkse stuk van de regering waarin zij terugkijkt op de belangrijkste ontwikkelingen in de Europese Unie van het afgelopen jaar en probeert om lijnen naar de toekomst uit te zetten. Dit gedeelte valt onder de noemer controle en vooral ook beleidsbeïnvloeding. Het is een manier voor het parlement om grip te krijgen op beleid(sontwikkeling) van de regering ter zake van de Europese Unie, onder het motto 'meedenken met de regering en de EU' want als het parlement in een vroeg stadium standpunten kenbaar maakt, kan het meer invloed uitoefenen dan wanneer het pas achteraf een standpunt laat weten.

Tot slot volgt een conclusie waarin de bevindingen van dit hoofdstuk worden samengevat.

\subsection{Nederland en de Europese Unie}

Nederland kent, in tegenstelling tot andere Europese landen, geen 'Europawet'. ${ }^{1}$ Er is geen wet, regeling of dergelijke waarin alle bevoegdheden en rechten van het parlement staan opgenomen met betrekking tot Europese aangelegenheden. Het is niet zo dat het parlement geen rechten en bevoegdheden heeft om Europese aangelegenheden, zoals nieuwe Europese wetgeving en beleid, te beïnvloeden of te controleren. Zoals in het vorige hoofdstuk beschreven heeft elk parlement een beperkt aantal bevoegdheden krachtens het Verdrag van Lissabon. Het is voor parlementen mogelijk om bezwaar te maken tegen nieuwe besluiten van de Commissie door een met redenen omkleed advies inzake subsidiariteit aan de Commissie te zenden. Daarnaast bestaat de mogelijkheid voor parlementen om met de Commissie in debat te gaan via de politieke dialoog. Het Nederlandse parlement heeft echter niet enkel nieuwe bevoegdheden uit Europa gekregen. Bij de goedkeuring van

1 Op de Duitse 'Europawetten' zal in het volgende hoofdstuk uitvoerig worden ingegaan. 
het Verdrag van Lissabon zijn twee nieuwe nationale bevoegdheden in de Goedkeuringswet opgenomen: een instemmingsrecht en een behandelvoorbehoud. ${ }^{2}$

Naast deze twee nieuwe nationale en Europese bevoegdheden heeft het parlement uiteraard de al bestaande nationale bevoegdheden die het kan uitoefenen om Europese wetgeving en beleidsontwikkeling te beïnvloeden en de activiteiten van de nationale regering dienaangaande te controleren. Nu nationale parlementen een sterkere institutionele positie binnen de Europese Unie hebben gekregen rijst de vraag of nationale parlementen daadwerkelijk een actieve en doeltreffende rol hierin spelen en die sterkere institutionele positie volledig benutten. Alleen het toekennen van bevoegdheden aan nationale parlementen is niet voldoende, het gaat er tenslotte om wat de parlementen met die bevoegdheden doen. Worden ze ingezet, op welke wijze en met welke frequentie?

Zoals aangegeven kent Nederland geen zelfstandige wet met alle rechten, bevoegdheden en plichten van het parlement ten aanzien van Europese aangelegenheden. Een compleet overzicht is in de wet- of regelgeving niet te vinden. In de Grondwet komt de Europese Unie niet expliciet voor. Wel zijn de artikelen 91 en 92 van de Grondwet over internationale verdragen van toepassing op de EU. Deze artikelen bepalen dat het Koninkrijk niet aan verdragen, dus ook niet aan EU-verdragen, kan worden gebonden zonder voorafgaande toestemming van het parlement. Daarnaast is het volgens artikel 92 mogelijk dat bevoegdheden tot wetgeving, bestuur en rechtspraak worden overgedragen op volkenrechtelijke organisaties, maar dit kan wederom alleen met toestemming van het parlement. ${ }^{3}$ Er zijn enkele voorstellen gedaan om de Grondwet te wijzigen en daarin een verwijzing naar de Europese Unie op te nemen. ${ }^{4}$

De reeds genoemde Goedkeuringswet bevat een tweetal bevoegdheden van het parlement. Ook in het Reglement van Orde van de Tweede Kamer wordt niet veel vermeld over de Europese Unie. In slechts twee artikelen wordt verwezen naar de EU. Artikel 16 spreekt over het bestaan van de vaste Kamercommissie voor Europese Zaken en artikel 55a maakt het mogelijk voor in Nederland gekozen leden van het Europees Parlement om deel te nemen aan de beraadslaging van de Tweede Kamer. Hetgeen echter meer opvalt, is dat het reglement, buiten deze twee artikelen, zwijgt over Europa en de Europese Unie. Het

2 Art. 3 en 4 Rijkswet houdende goedkeuring van het Verdrag van Lissabon tot wijziging van het Verdrag betreffende de Europese Unie en het Verdrag tot oprichting van de Europese Gemeenschap.

3 A.L. Högenauer, 'The Dutch Parliament and EU Affairs: Decentralizing Scrutiny', in: C. Hefftler e.a. (eds.), The Palgrave Handbook of National Parliaments and the European Union, Londen: Palgrave Macmillan 2015, p. 253.

4 Zo heeft de Staatscommissie Grondwet in 2010 voorgesteld om de volgende bepaling op te nemen: 'De regering bevordert de ontwikkeling van de internationale en Europese rechtsorde'. Dit is echter tot op heden niet gebeurd; in 2019 dienden de Tweede Kamerleden Verhoeven en Jetten (beiden D66) een voorstel in om het Nederlandse lidmaatschap van de Europese Unie op te nemen in de Grondwet. Het voorstel werd echter in januari 2021 verworpen. 
reglement van de Eerste Kamer spreekt geheel niet over Europese aangelegenheden, ook niet over een Commissie voor Europese Zaken.

\subsection{Controle}

Zoals in de inleiding kort is aangestipt beschikt het parlement over bevoegdheden om de regering te controleren. Denk dan aan onder andere het vragenrecht of het recht van enquête. Deze bevoegdheden komen aan bod nadat eerst in algemene zin kort de verhouding tussen het parlement, de Staten-Generaal en de regering is besproken.

\subsubsection{Verhouding tussen de Staten-Generaal en de regering}

Naar geldend Nederlands staatsrecht komt het parlement tal van bevoegdheden toe om de regering te controleren. De regering voert de centrale bestuursfuncties uit en op die uitoefening kan en wordt dan door de Staten-Generaal controle uitgeoefend. In het Nederlands parlementair stelsel wordt de regering gecontroleerd door beide Kamers, en de Tweede Kamer neemt hierin het voortouw. Dit kan worden gedaan doordat de StatenGeneraal moeten in- of toestemmen met bepaalde besluiten. ${ }^{5}$ Of doordat het parlement een minister dan wel een staatssecretaris ter verantwoording roept naar aanleiding van een concreet besluit of concrete gebeurtenis. Ook kunnen bewindspersonen ter verantwoording worden geroepen voor het gevoerde beleid in het algemeen.

Het politieke controle- en verantwoordingsproces bestaat uit drie fases: de inlichtingenfase, de debatfase en de sanctioneringsfase. ${ }^{6}$ Om invloed uit te oefenen hebben de StatenGeneraal enkele bevoegdheden en rechten. Dit zijn het recht op inlichtingen uit artikel 68 Grondwet, de ministeriële verantwoordelijkheid uit artikel 42 Grondwet, de vertrouwensregel, het recht van interpellatie en het enquêterecht uit artikel 70 Grondwet.

De eerste fase van het controle- en verantwoordingsproces betreft de inlichtingenfase. Zonder informatie kan het parlement niet controleren. Hoe meer en beter de informatieverstrekking is, hoe beter er gecontroleerd kan worden. Hier komt het inlichtingenrecht van artikel 68 Grondwet naar voren als belangrijkste middel van de Tweede Kamer om informatie te ontvangen. De minister dient beide Kamers in te lichten over zijn of haar

5 Denk daarbij onder andere aan de EU-besluiten op het gebied van Justitie en Binnenlandse Zaken die instemming behoeven van het Nederlandse parlement op grond van art. 3 Rijkswet houdende goedkeuring van het Verdrag van Lissabon of aan de toestemming van de Staten-Generaal om het Koninkrijk in oorlog te verklaren op grond van art. 96 Grondwet.

6 D.J. Elzinga, 'De politieke ministeriële verantwoordelijkheid', in: D.J. Elzinga (red.), Ministeriële verantwoordelijkheid in Nederland, Zwolle: W.E.J. Tjeenk Willink 1994, p. 42. 
beleid. ${ }^{7}$ Wanneer de minister dit niet doet, kan dit (vergaande) politieke gevolgen hebben voor de minister. ${ }^{8}$

De gedachte achter artikel 68 Grondwet is dat beide Kamers de informatie die zijn nodig hebben bij de uitoefening van hun taken verkrijgen van de regering. Het niet of verkeerd informeren wordt dan ook als een doodzonde gezien omdat het de kern van het functioneren van de parlementaire democratie ondermijnt. Het stellen van beperkingen aan de inlichtingenplicht dient dan ook met grote terughoudendheid te worden gedaan. Artikel 68 Grondwet bepaalt dat enkel op grond van 'strijd met het belang van de staat' inlichtingen onthouden mogen worden. Tevens dienen de regering en de Kamers gezamenlijk tot een werkbare informatievoorziening te komen. In de afgelopen decennia heeft deze informatievoorziening een bijzondere vorm aangenomen waarbij in eerste instantie gevraagde inlichtingen geweigerd kunnen worden zonder een beroep te doen op het verschoningsgrond 'strijd met het belang van de staat'. Dit betekent dus dat ministers en staatssecretarissen meer vrijheid hebben gekregen dan grondwettelijk is bepaald. Deze vorm van het weigeren van de gevraagde inlichtingen is een beroep op de vragensteller om (vooralsnog) geen gebruik te maken van het inlichtingenrecht omdat bijvoorbeeld op korte termijn het onderwerp in een ander verband in de Kamer aan de orde komt. Stemt de vragensteller hier niet mee in dan heeft de minister of staatssecretaris geen andere mogelijkheid dan de inlichtingen toch te verstrekken of een expliciet beroep te doen op 'strijd met het belang van de staat'.

Het verschoningsrecht 'het belang van de staat' is een open begrip, maar het moet beperkt worden uitgelegd. Het moet dus gaan om uitzonderlijke gevallen.

Indien informatie dient te worden verstrekt op grond van de Wet openbaarheid van bestuur (Wob) dan dient de minister of staatssecretaris deze informatie zeker ook aan de Kamers te verstrekken op basis van artikel 68 Grondwet. Mocht het verstrekken van gegevens op basis van de Wob kunnen worden geweigerd dan kunnen deze in veel gevallen wel aan het parlement, eventueel vertrouwelijk achter gesloten deuren, worden verstrekt. ${ }^{10}$ Zo is bijvoorbeeld bij de aanschaf van de vervanging van de F-16 straaljagers van Defensie

7 Inlichtingen kunnen worden gevraagd maar dienen ook ongevraagd en dus op initiatief van de minister te worden gegeven.

8 Er zijn verschillende voorbeelden in de geschiedenis te vinden waar de minister de Kamer(s) niet heeft ingelicht of onjuist heeft ingelicht met als gevolg dat de minister moest opstappen. Zo moest minister Zijlstra van Buitenlandse Zaken na onjuiste uitspraken over een ontmoeting met president Poetin opstappen (Handelingen II 2017/18, 51, item 24); minister Opstelten en staatssecretaris Teeven van Veiligheid en Justitie traden beiden op 9 maart 2015 af nadat ze de Tweede Kamer verkeerd hadden ingelicht over de zogenoemde Teevendeal.

9 P. Bovend'Eert, H. Kummeling, S. Munneke \& W. Voermans, Factsheet Reikwijdte van artikel 68 Grondwet, Den Haag: Tweede Kamer der Staten-Generaal 2020, p. 2-3.

10 Raad van State, Ministeriële verantwoordelijkheid. Een ongevraagd advies van de Afdeling advisering, Den Haag: juni 2020, p. 24. 
de Tweede Kamer vertrouwelijk geïnformeerd omdat een openbare informatievoorziening de onderhandelingspositie van de regering zou kunnen schaden. ${ }^{11}$

De tweede fase is de debatfase. Nadat het parlement is ingelicht wordt doorgaans de betrokken minister uitgenodigd voor een debat in de Kamer. Op grond van artikel 69 lid 2 Grondwet zijn ministers verplicht te verschijnen bij de plenaire vergadering van een van de Kamers of de Verenigde Vergadering wanneer zij zijn uitgenodigd. Tijdens dit debat zal de minister zijn beleid moeten uitleggen en verdedigen. Daarnaast wordt in de verschillende Kamercommissies overleg gevoerd met de betrokken bewindspersoon. ${ }^{12}$

De derde en laatste fase in het politieke controle- en verantwoordingsproces is de sanctioneringsfase. Er bestaan meerdere manieren om het proces af te ronden, als ook meerdere consequenties die aan het optreden van de minister verbonden kunnen worden. Wanneer de vorige fases volgens de Tweede Kamer of de Eerste Kamer tot een zeer teleurstellend en onacceptabel resultaat hebben geleid, kan de vertrouwenskwestie worden ingezet. Deze ultieme sanctie wordt in de praktijk niet vaak gebruikt. Daarnaast zijn ook andere politieke consequenties mogelijk zoals het verwerpen van wetsvoorstellen van de regering. Wat ook als consequentie aan het optreden van de bewindspersoon kan worden verbonden, is het niet terugkeren als bewindspersoon in het nieuwe kabinet. Er zijn niet enkel negatieve consequenties. Wanneer fases een en twee naar tevredenheid van de Tweede Kamer of Eerste Kamer worden afgerond kan dit leiden tot goedkeuring of ondersteuning van het regeringsbeleid. De fases worden niet per definitie alle drie doorlopen. Zo kan het voorkomen dat het parlement wordt ingelicht maar dat er geen debat volgt omdat daar vanuit de Kamers geen behoefte aan is. ${ }^{13}$

\subsubsection{Parlementaire controlemiddelen}

Zoals aangegeven heeft het parlement specifieke middelen om de regering te controleren. Deze rechten zijn terug te vinden in de Grondwet en zijn nader uitgewerkt in de Reglementen van Orde van beide Kamers. Hieronder worden de verschillende middelen afzonderlijk besproken.

11 Kamerstukken II 2008/09, 26488, nr. 169.

12 D.J. Elzinga, 'De politieke ministeriële verantwoordelijkheid', in: D.J. Elzinga (red.), Ministeriële verantwoordelijkheid in Nederland, Zwolle: W.E.J. Tjeenk Willink 1994, p. 42 en 43.

13 B. Van Mourik, Parlementaire controle op Europese besluitvorming. Een rechtsvergelijkend onderzoek naar mandaatsystemen en parlementaire behandelingsvoorbehouden, Nijmegen: Wolf Legal Publishers 2012, p. 26. 


\subsubsection{Inlichtingenplicht}

Een belangrijk, misschien wel het belangrijkste, controlemiddel van het parlement is de inlichtingenplicht, ook wel het parlementaire recht op inlichtingen genoemd. Zonder de inlichtingenplicht heeft de ministeriële verantwoordelijkheid weinig betekenis. Wanneer de Kamer niet wordt ingelicht kan zij de regering niet controleren. De relatie tussen de Staten-Generaal en de regering wordt grotendeels beheerst door de inlichtingenplicht van de regering. Artikel 68 van de Grondwet luidt als volgt: 'De ministers en de staatssecretarissen geven de Kamers elk afzonderlijk en in verenigde vergadering mondeling of schriftelijk de door een of meer leden verlangde inlichtingen waarvan het verstrekken niet in strijd is met het belang van de staat.'

Reeds in 1848 bevatte de Grondwet een bepaling over het inlichten van het parlement door de regering. Artikel 89 van de Grondwet 1848 luidde:

'De hoofden der ministeriële departementen hebben zitting in de beide Kamers. Zij hebben alleen eene raadgevende stem, ten ware zij tot leden der vergadering mogten benoemd zijn.

Zij geven aan de Kamers, het zij mondeling, het zij schriftelijk, de verlangde inlichtingen, waarvan het verleenen niet strijdig kan worden geoordeeld met het belang en de zekerheid van het Rijk, de koloniën en bezittingen van het Rijk in andere werelddeelen.

Zij kunnen door elke der Kamers worden uitgenoodigd om te dien einde ter vergadering tegenwoordig te zijn.'

De eerste alinea is als geheel artikel terug te vinden in de Grondwet van $1815 .{ }^{14}$ De uitgebreide versie, dus met de twee nieuwe alinea's, stamt uit de Grondwet van 1848.

Zoals valt te lezen moeten 'de hoofden der ministeriële departementen', de ministers dus, inlichtingen verstrekken wanneer daarom door Kamerleden wordt gevraagd; er staat immers dat het gaat om verlangde inlichtingen. In de jaren 1922, 1983 en 1987 is het artikel gewijzigd tot het artikel dat in onze huidige Grondwet staat. De belangrijkste wijziging is dat 'hoofden der ministeriële departementen' is gewijzigd in ministers en daarbij zijn ook de staatssecretarissen toegevoegd aan het artikel. Ministers en staatssecretarissen zijn dus verplicht om inlichtingen te verstrekken wanneer een Kamer of Kamerlid hierom vraagt. Het inlichtingenrecht wordt als zodanig genoemd sinds de Grondwet van $1983 .{ }^{15}$ Weigeren de gevraagde inlichtingen te verstrekken kan slechts in het belang van de Staat. Daaronder

14 Art. 91 Grondwet 1815.

15 P.P.T. Bovend'Eert \& H.R.B.M. Kummeling, Het Nederlandse parlement, Deventer: Kluwer 2017, p. 286. 
kan van alles vallen. Er bestaat dan ook geen concrete beschrijving wat wel en niet valt onder 'in het belang van de staat'. ${ }^{16}$

Het recht op inlichtingen is een verzamelnaam voor een aantal individuele rechten en is te vinden in artikel 68 Grondwet. Het Reglement van Orde van de Tweede Kamer (RvO II) bevat in dat verband het recht van interpellatie (art. $133 \mathrm{RvO}$ II) waaronder het dertigledendebat valt, het schriftelijke vragenrecht (art. 134 en $135 \mathrm{RvO}$ II) en het mondelinge vragenuur (art. $136 \mathrm{RvO}$ II). Het Reglement van Orde van de Eerste Kamer (RvO I) onderscheidt het recht van interpellatie (art. $139 \mathrm{RvO}$ I) en het schriftelijke vragenrecht (art. 140 RvO I). Hieronder zullen deze parlementaire controlemiddelen worden besproken.

\subsubsection{Recht van interpellatie, debat en vragen}

Beide Kamers hebben het recht van interpellatie (art. 68 Grondwet jo. art. 133 RvO II en art. $139 \mathrm{RvO}$ I). Dit recht houdt in dat een Kamerlid een debat met een of meer ministers kan aanvragen over een onderwerp dat 'vreemd is aan de orde van de dag', dat wil zeggen: een onderwerp dat niet al op de agenda van de Kamer staat (art. 133 lid 1 RvO II). De Kamer beslist door stemming of het verzoek om een interpellatie wordt toegestaan. Dit gebeurt wanneer minstens dertig Kamerleden het verzoek steunen (art. 133 lid 2 RvO II). Gezien het feit dat het interpellatierecht slechts door een minderheid van de Kamer moet worden gesteund, wordt een verzoek vrij zelden geweigerd. Hoewel het interpellatierecht ook voor leden van de Eerste Kamer geldt, komen interpellaties daar vrij weinig voor, overigens ook in de Tweede Kamer. Wanneer in de Eerste Kamer een verzoek wordt ingediend moet de meerderheid van de Kamer het verzoek steunen. Naast het interpellatierecht kent de Tweede Kamer ook een dertigledendebat, voor 2011 ook wel spoeddebat genoemd (art. 54a RvO II). Wat de naam al doet vermoeden: ook hiervoor is steun van dertig Kamerleden nodig. Het verschil tussen beide debatten zit in het aantal termijnen. Bij een interpellatie mag alleen de aanvrager van de interpellatie twee keer het woord voeren (art. 133 lid 5 RvO II). Bij een dertigledendebat mogen alle woordvoerders dit (art. $63 \mathrm{RvO}$ II). Het verbaast dus niet dat dertigledendebatten vaker voorkomen dan interpellaties omdat alle woordvoerders graag de mogelijkheid krijgen om twee keer het woord te voeren. Interpellaties zijn na de invoering van het dertigledendebat zeldzaam geworden in de Tweede Kamer. Naast deze twee varianten om in debat te treden met één of meer ministers bestaat ook de mogelijkheid om vragen te stellen (art. 134 jo. art. 136 RvO II en art. 140 RvO I). Dit gebeurt in beide Kamers vooral schriftelijk. In de Tweede Kamer kan dit ook mondeling plaatsvinden tijdens het zogenoemde vragenuur. Dit vindt

16 Uit de praktijk kunnen echter enkele onderwerpen worden aangewezen die gelden als een weigeringsgrond. Zie daarvoor: P.P.T. Bovend'Eert \& H.R.B.M. Kummeling, Het Nederlandse parlement, Deventer: Kluwer 2017, p. 290. 
wekelijks plaats op dinsdag aan het begin van de vergadering. Op grond van artikel 68 van de Grondwet zijn ministers verplicht antwoord te geven op de vragen, tenzij dit in strijd is met het belang van de Staat. ${ }^{17}$

\subsubsection{Enquêterecht}

Het in artikel 70 van de Grondwet geregelde recht van enquête (onderzoek) komt zowel toe aan beide Kamers afzonderlijk als gezamenlijk in de Verenigde Vergadering. Dit recht valt onder het recht van parlementair onderzoek. Het enquêterecht is het zwaarste middel van de Tweede Kamer om zelfstandig onderzoek in te stellen. Mildere vormen van het recht van parlementair onderzoek zijn het houden van hoorzittingen of rondetafelgesprekken. Het enquêterecht wordt nader geregeld in de Wet op de parlementaire enquête en in de Reglementen van Orde (art. 140-147 RvO II en 128-138 RvO I). Dit recht is verwant aan het hiervoor behandelde recht op inlichtingen. Bij het recht op inlichtingen speelt de regering een actieve rol door de inlichtingen te verstrekken. Bij het recht van enquête kunnen de Kamers informatie verzamelen zonder tussenkomst of hulp van de regering. Het recht werd in 1848 aan de Tweede Kamer toegekend en in 1887 ook aan de Eerste Kamer. In de Wet op de parlementaire enquête worden uitzonderlijke bevoegdheden toegekend aan een daarvoor ingestelde parlementaire commissie. Deze enquêtecommissie heeft onder andere de ingrijpende bevoegdheid om burgers te dwingen om te verschijnen en te antwoorden op vragen van de commissie. Daarnaast kan de commissie inzage vorderen in schriftelijke stukken. Om haar bevoegdheden kracht bij te zetten kunnen dwangmiddelen of strafrechtelijke sancties worden ingezet, zoals het betalen van een dwangsom of het gijzelen van een getuige of deskundige die weigert een verklaring af te leggen. ${ }^{18}$ Sinds 2016 bestaat er binnen het recht van enquête een nieuw instrument, de parlementaire ondervraging. ${ }^{19}$ Volgens artikel 1 van het Tijdelijk protocol parlementaire ondervraging is een parlementaire ondervraging ' (...) een kortlopende parlementaire enquête als bedoeld in artikel 2 van de wet, gericht op het verkrijgen van mondelinge inlichtingen door middel van het horen van personen onder ede'.

De bedoelde wet is de Wet op de parlementaire enquête 2008. In tegenstelling tot een enquête, waar schriftelijke inlichtingen en documenten kunnen worden gevorderd, is een parlementaire ondervraging een volledig mondeling verhoor. De personen die worden verhoord, hebben wel de mogelijkheid een zogenoemd position paper in te sturen waarin zij voorafgaand aan het verhoor hun zienswijze over het onderwerp naar voren kunnen brengen. ${ }^{20}$ Personen die worden opgeroepen voor een parlementaire enquête zijn verplicht

17 Ibid., p. 187 en 188.

18 S.C. Loeffen, Parlementair onderzoek. Een studie van het onderzoeksrecht in Nederland, het Verenigd Koninkrijk en de Verenigde Staten, Den Haag: Sdu Uitgevers 2013, p. 45, 75-76.

19 Tijdelijk protocol parlementaire ondervraging, Kamerstukken II 2015/16, 34400, nr. 2 (bijlage 3).

20 Ibid., p. 6. 
hieraan gehoor te geven en worden onder ede gehoord. ${ }^{21}$ Voor het instellen van een parlementaire enquête is een meerderheidsbesluit van de desbetreffende Kamer nodig. Zoals in het volgende hoofdstuk zal worden beschreven is het enquêterecht in Duitsland een minderheidsrecht, waar een vierde van de leden van de Bundestag een parlementaire enquête kan beginnen. Anders dan in Nederland vinden daardoor in Duitsland meer enquêtes plaats over zaken die onder de verantwoordelijkheid vallen van de nog zittende regering.

\subsubsection{Ministeriële verantwoordelijkheid en de vertrouwensregel}

De vertrouwensregel is een regel van ongeschreven staatsrecht. Hij vormt een van de belangrijkste regels van het Nederlands staatsrecht; dat de vertrouwensregel niet in rechte afdwingbaar is, doet daar niet aan af. In een parlementair stelsel, zoals Nederland heeft, is de legitimatie van de regering afhankelijk van het parlement. De vertrouwensregel zorgt hiervoor. Deze houdt in dat een minister die niet langer op het vertrouwen van de meerderheid van het parlement kan rekenen zijn ontslag moet indienen. ${ }^{22}$ De betekenis van de vertrouwensregel is door de jaren uitgebreid. Waar de regel in het begin zag op de verhouding tussen de ministers en de Koning, ziet de regel nu ook op de verhouding tussen de ministers en hun ambtenaren. Een andere belangrijke stap werd genomen bij de grondwetsherziening van 1848 toen de politieke ministeriële verantwoordelijkheid werd ingevoerd. Hiermee werd vastgelegd dat de handelingen van de Koning voortaan als handelingen van de ministers golden en zij daar ook voor verantwoordelijk werden. Voor deze handelingen dienden de ministers verantwoording af te leggen aan het parlement. Dit is tegenwoordig nog in de Grondwet te vinden in artikel 42 lid 2: 'De Koning is onschendbaar; de ministers zijn verantwoordelijk. ${ }^{23}$

\subsubsection{Tweede Kamer}

De Tweede Kamer maakt continu gebruik van haar controlebevoegdheden. De vraag in dit onderzoek is of deze controlebevoegdheden ook worden ingezet voor controle op Europees beleid en daarmee op een indirecte wijze ook voor controle op Europees niveau. Tabel 3 geeft weer hoe vaak de Tweede Kamer de hiervoor beschreven bevoegdheden inzet bij EU-aangelegenheden.

21 Ibid., p. 4.

22 A.W.Heringa, J. van der Velde, L.F.M. Verhey \& W. van der Woude, Staatsrecht, Deventer: Wolters Kluwer 2018, p. 206-207.

23 A.W. Heringa, J. van der Velde, L.F.M. Verhey \& W. van der Woude, Staatsrecht, Deventer: Wolters Kluwer 2018, p. 208. 
Tabel 3 Controlebevoegdheden van de Tweede Kamer

\begin{tabular}{llll} 
Tweede Kamer & Totale aantal & $\begin{array}{l}\text { Over/verwant aan de } \\
\text { Europese Unie }\end{array}$ & $\begin{array}{l}\text { Percentrage EU van } \\
\text { totaal }\end{array}$ \\
\hline Interpellatie & 9 & 0 & 0 \\
\hline Dertigledendebat & 201 & 9 & 4,5 \\
\hline Schriftelijke vragen & 18627 & 718 & 3,9 \\
\hline Mondelinge vragen & 1131 & 25 & 2,2 \\
\hline Enquêtes/ondervragingen & 6 & 0 & 0 \\
\hline $\begin{array}{l}\text { Totaal alle controlebevoegd- } \\
\text { heden }\end{array}$ & 19974 & 752 & 3,8
\end{tabular}

Laten we beginnen bij de interpellaties. Zoals hiervoor beschreven komen deze nauwelijks nog voor omdat doorgaans wordt gekozen voor een dertigledendebat. In de periode 2008 tot 2010 hebben zeventien interpellaties plaatsgevonden. In de periode 2010 tot 2016 waren dat er negen. Het is duidelijk te zien dat de Kamer steeds minder gebruikmaakt van interpellaties. Geen van deze negen interpellaties had betrekking op de Europese Unie dan wel besluitvorming binnen de Unie. Elk van deze negen interpellaties werd gebruikt om de regering te controleren met betrekking tot een nationale aangelegenheid. ${ }^{24}$

Het zwaarste controlemiddel van de Tweede Kamer, het recht van enquête, werd in de afgelopen dertig jaar tien keer ingezet. Het komt niet vaak voor dat de Kamer besluit om een parlementaire enquête te houden. In de periode 2010 tot 2016 is drie keer een parlementaire enquête gehouden. ${ }^{25}$ In 2011-2012 vond een onderzoek plaats naar het financieel stelsel, ${ }^{26}$ in 2013-2014 naar woningcoöperaties ${ }^{27}$ en in 2013 naar de Fyra. ${ }^{28}$ De laatste twee waren puur nationaal. Het onderzoek was gericht op een nationale kwestie. De parlementaire enquête naar het financieel stelsel had een Europees tintje. Het Nederlandse financiële stelsel raakte in een financiële crisis. Dit had te maken met de Europese economische en financiële crisis. De parlementaire enquête naar het financieel stelsel was, zoals het eindrapport aangeeft, '(...) gericht op de beoordeling van de crisismaatregelen die de Nederlandse overheid in een hectische periode heeft genomen om de acute problemen in het Nederlandse financiële stelsel te bestrijden'. ${ }^{29}$ Een van de actoren in dit onderzoek was de Europese Commissie die een oordeel gaf over de gesloten overeenkomsten en maatregelen in verband

24 Veel van de interpellaties gingen over de volksgezondheid dan wel de zorg. De interpellaties zijn te vinden op de website Tweede Kamer (kamerstukken > kamervragen > interpellatievragen).

25 Voor de periode van 2010 tot 2016 is gekozen in verband met het Verdrag van Lissabon dat in 2009 in werking is getreden. De periode na 2010 staat ook wel bekend als de 'post-Lissabon-periode'.

26 Kamerstukken II 2011/12, 31980, nr. 61 (Eindrapport Parlementaire Enquête Financieel Stelsel).

27 Kamerstukken II 2014/15, 33606, nr. 4 (Hoofdrapport Parlementaire enquête Woningcorporaties).

28 Kamerstukken II 2015/16, 33678, nr. 11 (Parlementaire enquêtecommissie Fyra-rapport).

29 Kamerstukken II 2011/12, 31980, nr. 61, p. 11. 
met mededinging. De Nederlandse minister van Financiën was degene die werd gecontroleerd. Hij was namelijk diegene die verantwoordelijk was voor het verlenen van vergunningen, voor het toetsen van bepaalde criteria en voor het nemen van vele andere besluiten. Het onderzoek had echter niet het doel om via de Nederlandse regering controle uit te oefenen op Europese besluitvorming. Ondanks het Europese tintje aan deze parlementaire enquête kan niet gezegd worden dat de Kamer haar recht van enquête gebruikt om controle uit te oefenen op Europese aangelegenheden.

In de Tweede Kamer zijn er tot op heden, zomer 2021, drie parlementaire ondervragingen geweest. De eerste was de 'parlementaire ondervraging fiscale constructies' die werd ingesteld naar aanleiding van de Panama Papers. De commissie bood op 5 juli 2017 haar verslag aan en sloot daarmee de parlementaire ondervraging af. ${ }^{30}$ Deze parlementaire ondervraging werd niet ingezet ter controle van Europese aangelegenheden maar er werd onderzoek gedaan naar 'het doorsluizen van kapitaal via in Nederland gevestigde ondernemingen met niet of nauwelijks reële economische activiteiten' en 'het wegsluizen van particuliere vermogens naar buitenlandse doelvennootschappen' ${ }^{31}$ De tweede parlementaire ondervraging ging over ongewenste beïnvloeding uit onvrije landen. ${ }^{32}$ De commissie die deze ondervraging uitvoerde, is op 2 juli 2019 ingesteld. Deze commissie onderzocht de ongewenste beïnvloeding van maatschappelijke en religieuze organisaties binnen Nederland uit onvrije landen en hoe deze invloed doorbroken kan worden. ${ }^{33}$ Over deze laatste ondervraging is zelfs geprocedeerd. Het gerechtshof Den Haag heeft in hoger beroep beslist dat de stichting die het hoger beroep had aangespannen, de door de parlementaire ondervragingscommissie gevorderde schriftelijke inlichtingen en documenten diende aan te leveren. ${ }^{34}$ De derde parlementaire ondervraging betrof het onderzoek naar de kinderopvangtoeslagaffaire. ${ }^{35}$ Deze parlementaire ondervragingscommissie Kinderopvangtoeslag onderzocht de aanpak van fraude binnen de Belastingdienst met betrekking tot de kinderopvangtoeslag. ${ }^{36}$ Het rapport 'Ongekend onrecht' van deze parlementaire ondervraging leidde in de Eerste Kamer tot de oprichting van een werkgroep op voorstel van het lid

30 Kamerstukken II 2016/17, 34566, nr. 3.

31 Website Tweede Kamer, debat fiscale constructies.

32 Deze parlementaire ondervraging is afgerond en op 26 januari 2021 werd het evaluatieverslag van de Parlementaire ondervragingscommissie ongewenste beïnvloeding uit onvrije landen (POCOB) gepubliceerd; Kamerstukken II 2020/21, 35228, nr. 35 (evaluatieverslag van de Parlementaire ondervragingscommissie ongewenste beïnvloeding uit onvrije landen).

33 Kamerstukken II 2018/19, 35228, nr. 1; dit onderzoek vond plaats in het najaar van 2019 en het voorjaar van 2020.

34 Gerechtshof Den Haag 24 maart 2020, ECLI:NL:GHDHA:2020:509.

35 Deze parlementaire ondervraging is afgerond en op 17 december 2020 is het Verslag 'Ongekend onrecht' gepubliceerd; Kamerstukken II 2020/21, 35510, nr. 2 (Verslag Parlementaire ondervragingscommissie Kinderopvangtoeslag 'Ongekend onrecht').

Website Tweede Kamer, Parlementaire ondervragingscommissie kinderopvangtoeslag. 
Recourt (PvdA) om een manier te onderzoeken waarop de Eerste Kamer zich rekenschap kan geven van de uitkomsten van dit rapport. ${ }^{37}$

Geen van deze drie parlementaire ondervragen had betrekking op controle van Europese aangelegenheden.

Het aantal dertigledendebatten over Europese aangelegenheden in de periode 2010-2016 bedroeg negen. In totaal zijn in diezelfde periode 201 dertigledendebatten gehouden. Dit betekent dat 4,5 procent van de dertigledendebatten in de periode 2010-2016 over Europese aangelegenheden ging.

Dertigledendebatten kunnen over elk onderwerp gaan. Er zijn dertigledendebatten geweest over Europese kerncentrales, over het Europese draagvlak voor de immigratieen asielplannen van het kabinet, over het bericht dat Europese ambtenaren gaan staken, over in Egypte verdwenen EU-gelden en over een mogelijk EU-lidmaatschap voor Turkije. ${ }^{38}$ In de meeste gevallen lopen de gemoederen niet hoog op en willen de Kamerleden antwoorden op hun vragen. In dat opzicht zijn dertigledendebatten niet anders dan andere debatten zoals bijvoorbeeld algemene overleggen (AO's). Het gaat erom dat de Kamerleden antwoorden krijgen op hun vragen en dat ze hun zorgen en kritiek kunnen uiten. Het ene debat gaat er heftiger aan toe dan het andere. Tijdens het dertigledendebat over een mogelijk EU-lidmaatschap voor Turkije werd er een stuk feller gedebatteerd dan tijdens andere dertigledendebatten. In dit debat waren vrijwel alle fracties kritisch en uitten ze hun grote zorgen over een eventueel lidmaatschap van Turkije van de EU. Er werden daarom tijdens de eerste termijn veel vragen gesteld. Toenmalig minister van Buitenlandse Zaken Koenders en de Kamerleden lagen met enige regelmaat niet op dezelfde lijn. Niet met betrekking tot de inhoud, maar wel over de procedure. Er waren enkele partijen die nog niet eens willen spréken over een eventueel lidmaatschap van Turkije terwijl de minister vond dat daar juist wél over gesproken diende te worden. Ook over het gebruik van woorden verschilden de Kamerleden met de minister. SP-lid Van Bommel vroeg de minister: 'Mag ik deze minister toch vragen of hij zich ervoor wil inzetten om van de regering betrokkenheid bij die herdenking [van de Armeense genocide] te krijgen, die passend is?. ${ }^{39}$ De minister vatte dit veel directer op dan bedoeld was en reageerde als volgt: 'Om nu een regering te dwingen om al dan niet daarheen te gaan, is volgens mij niet de juiste methode. ${ }^{40}$ Het gevolg hiervan was dat in het debat veel werd herhaald en het een lang debat is geworden en het maar de

37 Zie hiervoor ook Kamerstukken II 2020/21, 35510 (op de website van de Eerste Kamer); de werkgroep is in het voorjaar van 2021 ingesteld en bevindt zich thans, zomer 2021, nog in de beginfase waarin een inventarisatie wordt gemaakt van de werkzaamheden van de werkgroep.

38 Handelingen II 2012/13, 58, item 14, Handelingen II 2010/11, 99, item 9, Handelingen II 2012/13, 88, item 7, Handelingen II 2013/14, 43, item 23, Handelingen II 2014/15, 42, item 5.

39 Handelingen II 2014/15, 42, item 5, p. 15.

40 Handelingen II 2014/15, 42, item 5, p. 16. 
vraag is of de Kamerleden en de minister het debat verlaten hebben met een voldaan gevoel en of het iets heeft opgelost.

Het aantal schriftelijke vragen in de periode 2010 tot en met 2016 is aanzienlijk, namelijk 18.627. Dat zijn er gemiddeld 2661 per jaar. Van de 18.627 schriftelijke vragen die zijn gesteld gaan er 718 over Europa; dat is net geen vier procent van het totaal. De ministeries van Buitenlandse Zaken, Justitie en Veiligheid en Economische Zaken ontvangen de meeste schriftelijke vragen over Europa. Mondelinge vragen over Europa komen nog minder voor. In de onderzoeksperiode van zeven jaar gingen 25 mondelinge vragen over Europa. Dat is iets meer dan twee procent van alle mondelinge vragen en een gemiddelde van drie mondelinge vragen per jaar. Al deze vragen worden gesteld naar aanleiding van berichten die in de Nederlandse of buitenlandse media zijn verschenen. Deze vragen worden niet gesteld naar aanleiding van parlementaire documenten die Kamerleden ontvangen.

Het aandeel vragen over Europa in het geheel van vragen laat zien dat de Tweede Kamer de regering, via vragen, niet actief controleert op Europese aangelegenheden. Zowel de schriftelijke als de mondelinge vragen kunnen in twee categorieën worden onderverdeeld. Ten eerste de vragen die gesteld worden om (meer) informatie te krijgen. Het gaat hier dan om vragen waarmee Kamerleden de regering om meer uitleg vragen over bepaalde onderwerpen. Zo wilden VVD-Kamerlid Azmani en CDA-Kamerlid Heerma van de toenmalige minister van Sociale Zaken en Werkgelegenheid Asscher weten of hij van plan was met een wetsvoorstel te komen dat het mogelijk makt een bijstandsuitkering te weigeren aan burgers uit andere EU-landen. ${ }^{41}$ PvdA-Kamerlid Maij vroeg staatssecretaris Teeven van Veiligheid en Justitie: 'Klopt het dat Denemarken momenteel tijdelijk geen gezinnen met minderjarige kinderen meer aan Italië overdraagt, in afwachting van de bodemprocedure bij het EHRM in de zaak Tarakhelt tegen Zwitserland? Welke rechtsvraag staat in die zaak centraal?' ${ }^{42}$ De Rouwe en Oskam, beiden Kamerlid voor het CDA, stelden minister van Veiligheid en Justitie Opstelten de vraag of hij een overzicht kon geven van vijf jaar van alle aantallen overtredingen, uitgesplitst per jaar, land van herkomst, kenteken en soort overtreding, die zijn waargenomen door flitsapparatuur en die zijn begaan met voertuigen met een buitenlands kenteken, die afkomstig zijn uit EU-lidstaten anders dan België, Duitsland en Zwitserland. ${ }^{43}$ Deze vragen illustreren dat sommige Kamervragen

41 Vragen van de leden Azmani (VVD) en Heerma (CDA) aan de minister van Sociale Zaken en Werkgelegenheid over het bericht 'Duitsland mag EU-burgers uitkering weigeren', d.d. 22 mei 2014, Aanhangsel Handelingen II 2013/14, nr. 2316.

42 Vragen van het lid Maij (PvdA) aan de staatssecretaris van Veiligheid en Justitie over het terugsturen van minderjarige kinderen naar Italië op grond van de Dublin-verordening, d.d. 5 juni 2014, Aanhangsel Handelingen II 2013/14, nr. 2420.

43 Vragen van de leden De Rouwe en Oskam (beiden CDA) aan de ministers van Veiligheid en Justitie en van Infrastructuur en Milieu over overtredingen met voertuigen voorzien van buitenlandse kentekens d.d. 8 mei 2014, Aanhangsel Handelingen II 2013/14, nr. 2140. 
(weliswaar een heel klein percentage), een puur informatief karakter hebben. Doorgaans hebben deze vragen een vervolg; dat kan een debat zijn, een brief of wellicht nog meer schriftelijke of mondelinge vragen, waarin informatie wordt gevraagd en een punt wordt gemaakt.

Kamerleden hebben logischerwijs eerst genoeg informatie nodig om een eigen standpunt te formuleren. Als dat op een gegeven moment is gedaan volgt de fase waarin de Kamer de regering probeert te overtuigen van haar standpunt wanneer dit afwijkt van het standpunt van de regering. Hierbij is de tweede categorie van vragen van toepassing. Dit zijn namelijk de vragen waarmee de Kamer invloed wil uitoefenen op het regeringsbeleid. De meerderheid van de gestelde vragen valt in deze categorie. In deze vragen wordt naast informatie, zoals bij de vorige categorie, ook een poging gedaan om de regering te sturen c.q. invloed uit te oefenen. Kamerleden gebruiken in deze vragen vaak de termen 'verzoeken' of 'veranderen' of de zinsneden 'Is de minister bereid (...)' of 'Is de minister het eens met (...)'. ${ }^{44}$ Ook komt het voor dat partijen aan het einde van de vraag nog eens het standpunt van de eigen partij benadrukken: 'Wat de [partij] betreft (...)'. ${ }^{45}$ Een goed voorbeeld waar de Kamer via een (mondelinge) vraag invloed probeert uit te oefenen op het handelen van de minister is de vraag van Kamerlid Van Dijk (SP) op 25 oktober 2016. ${ }^{46}$ Het Kamerlid stelt aan de minister voor Buitenlandse Handel en Ontwikkelingssamenwerking een vraag over het Comprehensive Economic and Trade Agreement (CETA-verdrag) tussen Canada en de Europese Unie waarmee de heffingen op handel in goederen en diensten worden afgeschaft.

'Begrijpt de minister het brede verzet tegen deze foute verdragen, niet alleen van de dappere Walen, maar van miljoenen mensen die in Europa de straat op gaan? Erkent de minister dat dit niet eventjes gerepareerd kan worden met een aanvullende verklaring die neerkomt op een zoethouder?

Is de minister bereid om terug te gaan naar de tekentafel en de onderhandelingen over dit soort bedragen te resetten, zoals zij dit zelf noemt?

44 Zie o.a. de volgende Kamervragen: het lid Fritsma (PVV) aan de staatssecretaris van Veiligheid en Justitie over het bericht 'Aantal asielzoekers EU groeit sterk' (ANP, 20 maart 2015), d.d. 24 maart 2015, Handelingen II 2014/15, 66, item 3; vragen van het lid Jasper van Dijk aan de minister voor Buitenlandse Handel en Ontwikkelingssamenwerking over het bericht 'Het CETA-verdrag' (de Volkskrant 20 oktober 2016), d.d. 25 oktober 2016, Handelingen II 2016/17, 13, item 3.

45 Het lid Visser (VVD) aan de staatssecretaris van Infrastructuur en Milieu, bij afwezigheid van de minister, over het bericht 'EU-verkeerscommissaris broedt op tolplan' (De Telegraaf 26 januari 2015), d.d. 27 januari 2015, Handelingen II 2014/15, 46, item 3.

46 Vragen van het lid Jasper van Dijk aan de minister voor Buitenlandse Handel en Ontwikkelingssamenwerking over het bericht 'Het CETA-verdrag' (de Volkskrant 20 oktober 2016), d.d. 25 oktober 2016, Handelingen II 2016/17, 13, item 3 . 
Als Brussel niet luistert naar het protest, zal een aangepast CETA-verdrag opnieuw aan de parlementen van de lidstaten moeten worden voorgelegd. Is de minister het daarmee eens?

Is de minister bereid om te tekenen voor een referendum over CETA, zodat wij kunnen zien of er werkelijk draagvlak is voor dit wurgakkoord?'

De vragen van het Kamerlid gaan niet zozeer over de inhoud van het verdrag of over uitleg van de materie die het verdrag regelt maar over de totstandkoming van het verdrag, de onderhandelingen en het feit dat er een verdrag tot stand komt. Het is duidelijk dat het Kamerlid probeert de minister zover te krijgen om de onderhandelingen op Europees niveau over te doen, dan wel te vervolgen, en hierin de standpunten van de Kamer mee te nemen. Daarnaast wordt een statement van de minister uitgelokt door te vragen of zij het eens is met de Kamer dat het aangepaste verdrag goedgekeurd moet worden door de nationale parlementen. Indien de minister hierin meegaat, is dit een sterk middel om de minister op een later moment verantwoordelijk te houden voor haar acties. De reactie van de minister (Ploumen, PvdA) op deze vraag is positief voor de Kamer. De minister geeft aan reeds eerder met de Kamer over het verdrag te hebben gesproken en ook de 'to-dolijstjes' die de Kamer haar gegeven heeft te hebben uitgevoerd in Brussel. De wensen en standpunten van de Kamer zijn, volgens de minister, tijdens de hele procedure meegenomen en ook uitgevoerd. Dat had ook daarmee te maken dat de minister de mening van de Kamer deelt. Toch blijven de minister en de Kamer op sommige punten verdeeld en dan met name over de vraag of er überhaupt een verdrag tussen de Europese Unie en Canada tot stand moet komen. De Kamer vindt van niet, de minister van wel. De minister gaat dan ook niet mee met de Kamer als deze vraagt om te stoppen met dit 'ongelooflijke circus' (woorden Kamerlid Grashoff, GroenLinks). ${ }^{47}$

De percentages in tabel 3, die enige pagina's hiervoor te vinden is, worden in de literatuur uitgelegd als lage percentages die betekenen dat de Tweede Kamer het Europees beleid van de regering nauwelijks controleert. Van Keulen meent dat de Kamer de regering niet of nauwelijks controleert op Europese zaken en dat zou kunnen liggen aan te geringe (ambtelijke) ondersteuning van de Kamerleden en de kennisachterstand van de Kamer. Volgens Van Keulen is deze achterstand enorm. De regering wordt ondersteund door vele duizenden ambtenaren, adviesraden, ambassades en commissies, terwijl de Kamerleden het moeten doen met een handvol adviseurs. Wel kunnen Kamerleden 'voorlichting vragen' aan de Raad van State, de Wetenschappelijke Raad voor het Regeringsbeleid (WRR) en andere adviesraden maar zij doen dit weinig. ${ }^{48}$ Auel en Christiansen menen dat nationale

47 Handelingen II 2016/17, 13, item 3, p. 3.

48 M. van Keulen, 'Kamerleden moeten hun kennistekort durven toegeven en agenderen', de Volkskrant 2 mei 2018. 
parlementen aanlopen tegen het hoge technische karakter en de complexiteit van EUaangelegenheden, gebrek aan transparantie van onderhandelingen op EU-niveau, gebrek aan tijd en middelen om de informatie uit Brussel te verwerken en gebrek aan aandacht voor EU-aangelegenheden. ${ }^{49}$

\subsubsection{Eerste Kamer}

De Eerste Kamer heeft dezelfde controlebevoegdheden als de Tweede Kamer, maar oefent deze niet of zeer sporadisch uit. Zoals eerder aangegeven komen interpellaties zelden voor. De afgelopen vijftig jaar zijn in de Eerste Kamer 'slechts' vijftien interpellaties gehouden. Van deze vijftien interpellaties is er geen enkele direct te relateren aan EU-wetgeving zoals verdragen, richtlijnen of verordeningen of aan enige andere gebeurtenis in de EU. ${ }^{50}$ Er is ook geen directe link met het Europese beleid van de regering. Indirect kunnen twee vragen gekoppeld worden aan Europese richtlijnen. In één geval wordt gevraagd of processtukken, in casu de processen-verbaal ten aanzien van verhoren van een verdachte, op basis van een richtlijn kunnen worden overhandigd door Duitsland aan Nederland. ${ }^{51}$ In de tweede interpellatie gaat het over een wijziging van de Waarborgwet 1986 die weer gebaseerd is op een richtlijn. ${ }^{52}$ Benadrukt moet worden dat beide interpellaties zeer indirect gelinkt zijn aan Europese aangelegenheden en dat niet gezegd kan worden dat de Eerste Kamer haar interpellatierecht gebruikt om het Europese beleid van de regering te controleren of te beïnvloeden.

Het gemiddelde aantal schriftelijke vragen per jaar is negen. Het aantal schriftelijke vragen in de periode 2010-2016 bedraagt 63. Acht van deze vragen hebben betrekking op Europa. ${ }^{53}$ Deze vragen hadden betrekking op verschillende beleidsterreinen. Geen van

49 K. Auel \& Th. Christiansen, 'After Lisbon: National Parliaments in the European Union', West European Politics 2015, 38(2), p. 263.

50 Wel zijn twee interpellaties direct gerelateerd aan verdragen van de Raad van Europa. Aangezien dit geen EU-verdragen zijn, wordt hiervan slechts in deze voetnoot melding gemaakt. Op 25 september 2001 werd de minister van Justitie geïnterpelleerd over een wetsvoorstel inzake strafrechtelijke opvang van verslaafden. Gevraagd werd om de betreffende wet op het punt van de toegang van een veroordeelde tot de rechter in overeenstemming te brengen met het Europees Verdrag voor de Rechten van de Mens. De tweede interpellatie, van 18 maart 2008, ging over de opzegging van deel VI (Uitkeringen en verstrekkingen bij arbeidsongevallen en beroepsziekten) van de Europese Sociale Code na een uitspraak van de Centrale Raad van Beroep.

51 Handelingen I 1986/87, 30 september 1986, p. 21-31.

52 Handelingen I 2001/02, nr. 24, p. 1210-1213; de Waarborgwet 1986 geeft waarborgen voor de handel in edelmetalen zoals goud, zilver en platina. Het is op grond van deze wet bijvoorbeeld verboden om edelmetalen te verkopen of in voorraad te hebben die niet voorzien zijn van de in de wet vereiste keurmerken.

53 Aanhangsel Handelingen I 2010/11, 2; Aanhangsel Handelingen I 2010/11, 7; Aanhangsel Handelingen I 2011/12, 4; Aanhangsel Handelingen I 2011/12, 5; Aanhangsel Handelingen I 2011/12, 6; Aanhangsel Handelingen I 2013/14, 3; Aanhangsel Handelingen I 2013/14, 6; Aanhangsel Handelingen I 2014/15, 7. 
deze beleidsterrein viel op door een hoog aantal vragen. Integendeel, er is geen rode draad te ontdekken in de resultaten. De Eerste Kamer heeft nog nooit gebruikgemaakt van het recht van enquête. Een van de redenen hiervoor is gebrek aan tijd. Eerste Kamerleden hebben een deeltijdbaan als Kamerlid waarbinnen ze geen tijd hebben voor een parlementaire enquête. Bovendien bevat de Eerste Kamer de helft van het aantal leden van de Tweede Kamer. De Tweede Kamer heeft het politieke primaat en niet de Eerste Kamer. De Eerste Kamer concentreert zich op de juridische en constitutionele toetsing van wetsvoorstellen en maakt daarom minder gebruik van haar controlebevoegdheden dan de Tweede Kamer. ${ }^{54}$ Daarbij moet wel worden vermeld dat ook de Eerste Kamer politiek bedrijft en zich dus niet altijd terughoudend opstelt. Wel voert de Eerste Kamer parlementair onderzoek uit. Dit verschilt van het recht van enquête, dat bij het enquêterecht gebruikgemaakt kan worden van dwangbevoegdheden uit de Wet op de parlementaire enquête. Bij een parlementair onderzoek is dit niet mogelijk. In 2011 en 2012 deed de Eerste Kamer onderzoek naar het Nederlandse beleid op het gebied van privatisering en verzelfstandiging. ${ }^{55}$ Uit dit onderzoek kwam naar voren dat privatisering of verzelfstandiging soms werd opgelegd of juist werd verboden door de EU, maar dat in de meeste gevallen het een eigen beslissing was van de Nederlandse regering niet gebaseerd op Europese regels. ${ }^{56}$ Een tweede, recenter, onderzoek is ingesteld op 23 maart 2021. Dit onderzoek naar de effectiviteit van antidiscriminatiewetgeving is momenteel, zomer 2021, gaande. ${ }^{57}$

\section{Tabel 4 Controlebevoegdheden van de Eerste Kamer}

\begin{tabular}{llll} 
Eerste Kamer & Totale aantal & $\begin{array}{l}\text { Over/verwant aan de } \\
\text { Europese Unie }\end{array}$ & $\begin{array}{l}\text { Percentage EU van } \\
\text { totaal }\end{array}$ \\
\hline Interpellaties & 2 & 0 & 0 \\
\hline Schriftelijke vragen & 63 & 8 & 13 \\
\hline Enquêtes/onderzoeken & 2 & 0 & 0 \\
\hline $\begin{array}{l}\text { Totaal alle controlebevoegd- } \\
\text { heden }\end{array}$ & 67 & 8 & 11,9
\end{tabular}

Het verschil tussen de Tweede Kamer en de Eerste Kamer heeft te maken met de posities van beide Kamers. De staatsrechtelijke positie van de Tweede Kamer ten opzichte van de Eerste Kamer is vastgelegd in artikel 51 van de Grondwet. Lid 1 van dit artikel luidt: 'De Staten-Generaal bestaan uit de Tweede Kamer en de Eerste Kamer'. Het feit dat de Tweede

54 S.C. Loeffen, Parlementair onderzoek. Een studie van het onderzoeksrecht in Nederland, het Verenigd Koninkrijk en de Verenigde Staten, Den Haag: Sdu Uitgevers 2013, p. 153-154.

55 Kamerstukken I 2012/13, C, A.

56 Kamerstukken I 2012/13, C, A, p. 45 e.v.

57 Kamerstukken I 2020/21, CXLIII. 
Kamer in het artikel vóór de Eerste Kamer wordt genoemd geeft aan dat het politieke primaat bij de Tweede Kamer ligt. Dat blijkt ook uit het feit dat de Eerste Kamer een zwakkere democratische legitimatie heeft dan de Tweede Kamer. De leden van de Eerste Kamer worden niet zoals die van de Tweede Kamer direct gekozen door de bevolking, maar indirect via de leden van Provinciale Staten. ${ }^{58}$ Daarnaast worden kabinetten primair geformeerd op basis van de samenstelling van de Tweede Kamer en niet op basis van de samenstelling van de Eerste Kamer. Tot slot zijn het de fractievoorzitters uit de Tweede Kamer die worden betrokken bij de totstandkoming van regeerakkoorden en spelen de fractievoorzitters uit de Eerste Kamer hierin geen rol. ${ }^{59}$ Het is de Tweede Kamer die het voortouw moet nemen in de controle van de regering. De Eerste Kamer is een Kamer van heroverweging en zij maakt niet veelvuldig gebruik van haar controlebevoegdheden. Dit zou namelijk kunnen leiden tot politiek conflict met bewindslieden en de Tweede Kamer. ${ }^{60}$ Opgemerkt dient te worden dat de Tweede Kamer weliswaar kan worden beschouwd als de Kamer met het politieke primaat maar dat dit niet automatisch inhoudt dat de Eerste Kamer de Tweede Kamer volgt. De Eerste Kamer velt ook een politiek oordeel over nieuwe wetgeving of beleid van de regering en dat oordeel kan afwijken van dat van de Tweede Kamer. Daarnaast bestaat er geen conflictenregeling tussen de Kamers. Wanneer de Kamers van mening verschillen, ontbreekt een regeling om het conflict op te lossen. De praktijk laat zien dat de Eerste Kamer zich dan terughoudend opstelt. Geregeld worden op een informele manier brieven tussen de Kamer en de regering gewisseld. Via deze brieven kan een Kamer of een Kamercommissie punten onder de aandacht van de regering brengen zonder de regering een mening op te dringen. Deze manier van communiceren met de regering heeft de voorkeur van de Eerste Kamer, boven het indienen van moties tijdens debatten. Dit is in lijn met de positie van de Kamer. Zij wordt gezien als de Kamer waar gereflecteerd wordt. ${ }^{61}$ Wel moet worden vermeld dat de Eerste Kamer niet altijd respecteert dat de Tweede Kamer het primaat heeft. Het politieke primaat van de Tweede Kamer en de terughoudende opstelling van de Eerste Kamer is geen geschreven recht maar veeleer politieke praktijk. Doorgaans geldt deze terughoudende positie voor de coalitiefracties in de Eerste Kamer. Deze fracties gaan in het algemeen mee met de regering. De oppositie-

58 H.R.B.M. Kummeling, B. van Mourik \& R. Nehmelman, Enkele staatsrechtelijk reflecties op de positie van de Eerste Kamer in het kader van de Europese Unie, Den Haag: Eerste Kamer, p. 2.

59 B. van Mourik, Parlementaire controle op Europese besluitvorming. Een rechtsvergelijkend onderzoek naar mandaatsystemen en parlementaire behandelingsvoorbehouden, Nijmegen: Wolf Legal Publishers 2012, p. 33 .

60 H.R.B.M. Kummeling, B. van Mourik \& R. Nehmelman, Enkele staatsrechtelijk reflecties op de positie van de Eerste Kamer in het kader van de Europese Unie, Den Haag: Eerste Kamer, p. 3.

61 A.L. Högenauer, 'The Dutch Parliament and EU Affairs: Decentralizing Scrutiny', in: C. Hefftler e.a. (eds.), The Palgrave Handbook of National Parliaments and the European Union, Londen: Palgrave Macmillan 2015, p. 257-258. 
fracties laten zich leiden door de politiek en hebben meer vrijheid om af te wijken van de fractiepositie. ${ }^{62}$

Kortom, algemene controlebevoegdheden worden met name ingezet voor nationale aangelegenheden. Wanneer ze worden ingezet voor Europese aangelegenheden dan is er vrijwel geen verschil tussen de inzet van de verschillende bevoegdheden. Wat daarmee wordt bedoeld is dat vrijwel elke bevoegdheid in eerste instantie wordt ingezet om meer informatie van de regering te verkrijgen. Het maakt niet uit of het gaat om schriftelijke of mondelinge vragen, dertigledendebatten of een enquête. Het komt erop neer dat de Kamerleden vragen stellen aan de regering. Het verschil zit in de snelheid waarmee de Kamerleden antwoord willen en de omvang van de vraag. Gaat het om een korte en kleine vraag dan is het vragenuur het meest voor de hand liggend. Gaat het om een complexere vraag en ook meerdere vragen dan biedt een dertigledendebat een uitkomst. In een dergelijk debat kunnen meerdere vragen worden gesteld, kan er langer over een onderwerp worden gesproken en dit debat kan snel op de agenda van de Kamer worden gezet.

\subsubsection{Overige controle-instrumenten}

De hiervoor besproken instrumenten kunnen worden ingezet voor controle op zowel nationaal als Europees beleid van de regering. Er bestaan echter nog andere controleinstrumenten van het parlement die kunnen worden ingezet voor controle op Europese aangelegenheden en nationale aangelegenheden. Het gaat dan om het algemeen overleg ( $\mathrm{AO})$, het notaoverleg $(\mathrm{NO})$ en het debat met de minister-president voorafgaand aan een vergadering van de Europese Raad. Het AO en NO zijn, samen met het wetgevingsoverleg (WO) en het begrotingsoverleg (BO), gecreëerd met de bedoeling om de plenaire vergadering te ontlasten. Tot slot wordt ingegaan op enkele toezeggingen en afspraken. Er zijn meerdere toezeggingen gedaan door verschillende ministers of afspraken met de Kamer gemaakt om de Kamer nader te informeren over specifieke nieuwe wetgeving.

\subsubsection{Algemeen Overleg Tweede Kamer}

Het algemeen overleg (art. $41 \mathrm{RvO}$ II) is een openbaar overleg dat plaatsvindt in de commissiezalen van het parlement. Het gaat om een overleg tussen een Kamercommissie en een minister of staatssecretaris over zaken die betrekking hebben op het beleidsterrein van de commissie en de minister of staatssecretaris. ${ }^{63}$ In een dergelijk overleg komt een specifiek

62 B. van den Braak, De Eerste Kamer. Geschiedenis, samenstelling en betekenis 1815-1995, Den Haag: Sdu Uitgevers 1998, p. 406-409.

63 J. Kester \& M. van Keulen, “'De Tweede Kamermethode”: versterkte parlementaire invloed op Europese besluitvorming', RegelMaat 2011, afl. 6, p. 304. 
onderwerp in de Raad op het gemeenschappelijk beleidsterrein aan bod. ${ }^{64}$ Voorafgaand aan dit overleg stuurt de minister een geannoteerde agenda aan de Kamer. Hierin vermeldt de minister de positie waarmee hij of zij de Raadsvergadering in gaat. Ministers worden formeel via AO's niet gemandateerd om op een bepaalde wijze op te treden in de Raad, maar het is wel mogelijk om de minister in het debat door middel van moties en vragen aan te sporen om op een bepaalde manier te handelen. Tijdens de behandeling van het Europees voorstel voor een Europees Openbaar Ministerie is zelfs een motie aangenomen die de minister opdroeg niet in te stemmen met de tekst van het voorstel voordat de Kamer haar volledige oordeel over het voorstel had kunnen geven. ${ }^{65}$ De minister reageerde toen dat hij de motie zal opvolgen aangezien deze volgens hem het regeringsbeleid ondersteunt. ${ }^{66}$ Het is ondenkbaar dat een minister zonder voorafgaand AO deelneemt aan een Raadsvergadering. Dit is niet juridisch afdwingbaar, maar er kunnen wel politieke gevolgen zijn wanneer de minister niet in lijn met de wensen van de Kamer handelt. ${ }^{67}$

Sinds 1996 is een AO voor een raadsvergadering vast gebruik. In het begin vond het overleg plaats tussen de commissie voor Europese Zaken en de staatssecretaris voor Europese Zaken. Al snel werd deze procedure gewijzigd in overleggen tussen een Kamercommissie en vakminister op hetzelfde beleidsterrein. ${ }^{68}$ Het feit dat alle Kamercommissies deelnemen aan de AO's maakt Nederland tot een uitzondering. In de meeste andere EUlidstaten voert de commissie voor Europese Zaken overleg met de regering voor wat betreft Europese aangelegenheden. ${ }^{69}$ Een $\mathrm{AO}$ vindt mondeling plaats maar indien dit niet mogelijk is, bijvoorbeeld door een reces, wordt het AO vervangen door een schriftelijk overleg (SO). Dit wordt gedaan om te voorkomen dat een minister deelneemt aan beraadslagingen van de Raad zonder voorafgaand overleg met de Tweede Kamer. ${ }^{70}$

Doorgaans wordt een AO gevoerd in twee termijnen waarbij in de eerste termijn de verschillende woordvoerders van de politieke partijen het woord krijgen en vragen worden gesteld aan de aanwezige minister. De minister is daarna aan zet en zal deze vragen beantwoorden. In de tweede termijn kunnen de commissieleden aanvullende vragen stellen

64 Website Tweede Kamer, Brochure Europese besluitvorming in de Tweede Kamer.

65 Kamerstukken II 2014/15, 32317, nr. 302.

66 Handelingen II 2014/15, 95, item 7, p. 5-6.

67 J. Kester \& M. van Keulen, “De Tweede Kamermethode”: versterkte parlementaire invloed op Europese besluitvorming', RegelMaat 2011, afl. 6, p. 304.

68 Tweede Kamer, 'Bovenop Europa: Evaluatie van de versterkte EU-ondersteuning van de Tweede Kamer 2007-2011', Den Haag: Tweede Kamer 2011, p. 12.

69 Zie bijlage 2 van het rapport 'Bovenop Europa. Evaluatie van de versterkte EU-ondersteuning van de Tweede Kamer 2007-2011', uitgevoerd door de Kamerleden Ten Broeke en Schouw, p. 27.

70 Tweede Kamer, 'Bovenop Europa: Evaluatie van de versterkte EU-ondersteuning van de Tweede Kamer 2007-2011’, Den Haag: Tweede Kamer 2011, p. 13. 
naar aanleiding van de antwoorden van de minister in eerste termijn. ${ }^{71}$ Indien een Kamercommissielid een motie wil indienen naar aanleiding van het algemeen overleg, wordt het verslag algemeen overleg (VAO) op de plenaire agenda geplaatst. Om ervoor te zorgen dat het standpunt van de Kamer, met de eventuele moties, in acht wordt genomen door de minister, wordt over dergelijke moties nog voorafgaand aan de Raadsvergadering gestemd. ${ }^{72}$

Het is niet de bedoeling dat het $\mathrm{AO}$ plenair wordt overgedaan dus er gelden enkele restricties. Tijdens het plenaire debat kan elk lid dan slechts eenmaal het woord voeren. Daarnaast geldt een maximumspreektijd per fractie van twee minuten. ${ }^{73}$ Gezien dit laatste wordt de plenaire behandeling van een AO ook wel een 'tweeminutendebat' genoemd. Omdat een AO een duidelijke procedure kent en voor élke Raadsvergadering een AO wordt gehouden, blijkt dit een goed en vast instrument te zijn voor de Kamer om betrokken te zijn bij het Europese wetgevingsproces. ${ }^{74}$ Wanneer een Raadsvergadering heeft plaatsgevonden over ontwerpwetgeving ontvangt het parlement de notulen van deze zitting. ${ }^{75}$ Ook rapporteert de minister na de Raadsvergadering aan de Tweede Kamer over (de uitkomst van) de onderhandelingen en er kan, indien gewenst, mondeling overleg over gevoerd worden met de desbetreffende Kamercommissie. ${ }^{76}$ Met betrekking tot controle op Europees beleid wordt doorgaans vergaderd in de vorm van een AO. Dit is dan ook de reden dat met betrekking tot AO's data zijn verzameld.

\section{Tabel 5 Algemeen Overleg ${ }^{77}$}

\begin{tabular}{ll} 
Jaartal & Aantal AO's over EU \\
\hline 2010 & 82 \\
\hline 2011 & 120 \\
\hline 2012 & 93
\end{tabular}

71 B. van Mourik, Parlementaire controle op Europese besluitvorming. Een rechtsvergelijkend onderzoek naar mandaatsystemen en parlementaire behandelingsvoorbehouden, Nijmegen: Wolf Legal Publishers 2012, p. 32.

72 Tweede Kamer, 'Bovenop Europa: Evaluatie van de versterkte EU-ondersteuning van de Tweede Kamer 2007-2011', Den Haag: Tweede Kamer 2011, p. 13.

73 Art. 44a RvO II.

74 Tweede Kamer, 'Bovenop Europa: Evaluatie van de versterkte EU-ondersteuning van de Tweede Kamer 2007-2011', Den Haag: Tweede Kamer 2011, p. 12.

75 Art. 5 Protocol nr. 1.

76 A.L. Högenauer, 'The Dutch Parliament and EU Affairs: Decentralizing Scrutiny', in: C. Hefftler e.a. (eds.), The Palgrave Handbook of National Parliaments and the European Union, Londen: Palgrave Macmillan 2015, p. 255

77 De AO's zijn handmatig geteld via de website van de Tweede Kamer. In het zoekvak is gezocht naar 'Algemeen Overleg'. De resultaten zijn vervolgens verfijnd naar de periode van 1 januari 2010 tot 31 december 2016. Vervolgens zijn de AO's over Europa handmatig geteld en de AO's die zijn geannuleerd of uitgesteld afgetrokken van het totaal. 


\begin{tabular}{ll} 
Jaartal & Aantal AO's over EU \\
\hline $\mathbf{2 0 1 3}$ & 112 \\
\hline $\mathbf{2 0 1 4}$ & 91 \\
\hline $\mathbf{2 0 1 5}$ & 93 \\
\hline $\mathbf{2 0 1 6}$ & 94 \\
\hline Totaal EU & $\mathbf{6 8 5}$
\end{tabular}

In de periode 2010-2016 hebben 3156 AO's plaatsgevonden. Uit tabel 5 is af te lezen dat van deze 3156 AO's 685 AO's een Europees onderwerp hadden. Dit betekent dat 21,7 procent van alle AO's over Europa ging. De meest voorkomende Europese AO's zijn die over een raadsvergadering, waarbij de top drie wordt gevormd door de Raad Buitenlandse Zaken, de Ecofin Raad en de Raad Justitie en Binnenlandse Zaken (JBZ-Raad).

In de praktijk hebben de AO's eenzelfde opzet als plenaire debatten. De woordvoerders van de verschillende politieke partijen krijgen eerst het woord waarbij geïnterrumpeerd kan worden. Wanneer alle woordvoerders het woord hebben gehad krijgt de aanwezige minister of staatssecretaris het woord. Aan de spreektijd van de woordvoerders zit doorgaans een limiet, aan de spreektijd van de minister niet. Veelal wordt voor een AO twee uur uitgetrokken en in verband met een limiet op de spreektijd van de woordvoerders duren AO's dan ook niet langer dan deze twee uur.

De AO's zijn in een drietal categorieën in te delen: AO's voorafgaand aan een bijeenkomst van de Europese Raad, AO's voorafgaand aan een bijeenkomst van de Raad en AO's over andere zaken dan geplande bijeenkomsten van de Raad of Europese Raad. De laatste categorie zal voor dit onderzoek 'ad hoc AO's' worden genoemd.

Ten eerste zal worden ingaan op de AO's ten aanzien van een bijeenkomst van de Europese Raad. Wat daarbij opvalt, is dat tot en met 2010 gedebatteerd werd met de minister-president in de vorm van een $\mathrm{AO}$ en dat vanaf 2011 is overgestapt naar plenaire debatten. Enigszins vreemd is dat in 2010 het verslag van de Europese Raad, dus de uitkomsten van de bijeenkomst in Brussel, wel al plenair werd behandeld. Wellicht is dat ook de reden dat vanaf 2011 plenair wordt vergaderd voorafgaand aan een bijeenkomst van de Europese Raad. Het voeren van een plenair debat in plaats van het houden van een Algemeen Overleg was een van de aanbevelingen van de toenmalige Tweede Kamerleden Ten Broeke en Schouw in hun evaluatie 'Bovenop Europa' ${ }^{78}$ In een brief bij deze evaluatie laat het presidium van de Tweede Kamer weten deze aanbeveling al sinds begin 2011 te hebben overgenomen. $^{79}$

78 Tweede Kamer, 'Bovenop Europa: Evaluatie van de versterkte EU-ondersteuning van de Tweede Kamer 2007-2011', Den Haag: Tweede Kamer, p. 24, aanbeveling 7.

79 Kamerstukken II 2010/11, 32726, nr. 1. 
Hoe ziet zo'n AO er nu uit? Als voorbeeld wordt het AO van 26 oktober 2010 genomen over de Europese raadsvergadering van 28 en 29 oktober $2010 .^{80}$ De onderwerpen die werden besproken zijn de Europese begroting, het Stabiliteits- en Groeipact, de eventuele sancties die kunnen volgen wanneer lidstaten zich niet aan dit pact houden als ook andere Eurocrisismaatregelen en de toetreding van Servië tot de Europese Unie. De Kamerleden zijn mild tegen de minister-president. Op de vraag van de minister-president om hem wat onderhandelingsruimte te geven - '(...) ik vraag de Kamer om mij daarin enige manoeuvreerruimte te laten behouden op donderdag en vrijdag' - wordt door de Kamerleden nauwelijks gereageerd. ${ }^{81}$ De milde opstelling van de Kamerleden wordt gespiegeld door de minister-president. Er wordt hem verder niet gevraagd iets te doen maar er wordt voortdurend naar zijn standpunt gevraagd. Dit kan ermee te maken hebben dat het kabinet nog maar juist was aangetreden en de Kamerleden nog niet meteen heel hard debat wilde voeren. Verder is er geen verschil te ontdekken tussen de oppositiepartijen en de coalitiepartijen voor wat betreft de inhoud van de termijn en interrupties. De verwachting is dat coalitiepartijen minder hard optreden dan de oppositiepartijen maar dit is niet waarneembaar. Zowel de leden van de VVD als de leden van het CDA treden in dezelfde mate op als de leden van de oppositiepartijen. ${ }^{82}$ Ten slotte wordt door de minister-president een toezegging gedaan maar die hield niet meer in dan een extra en vertrouwelijk overleg tussen de Kamercommissie en de minister-president. Het was dus geen inhoudelijke toezegging over bijvoorbeeld de onderhandelingspositie in Brussel. Al met al was het een mild debat zonder hevige emoties en winsten of verliezen voor de Kamerleden of de minister-president. Als dit debat wordt vergeleken met andere debatten, dan is te concluderen dat dit debat niet anders is dan andere debatten. Met andere woorden, debatten met de minister-president voorafgaand aan een bijeenkomst van de Europese Raad zijn geen debatten waar een hevige strijd wordt gevoerd. Het gaat met name om informatievoorziening aan de Kamer over de standpunten van de minister-president en de onderhandelingen op Europees niveau.

Met betrekking tot de AO's voorafgaand aan raadsvergaderingen is het volgende beeld te zien. AO's worden veelal tussen de minister en meerdere Kamercommissies gevoerd. Zo is het niet ongebruikelijk dat de Kamercommissie voor Europese Zaken aansluit bij bijvoorbeeld de Kamercommissies voor Economische Zaken of Financiën.

Elk AO voorafgaand aan een raadsvergadering begint met een zogenoemde geannoteerde agenda. Dit houdt in dat de minister per onderwerp dat besproken zal worden in de Raad ongeveer twee A4'tjes uitleg geeft. Deze uitleg is echter veelal vaag en niet concreet. In de geannoteerde agenda voor de Eurogroep en Ecofinraad van 5 en 6 december 2016 in

\footnotetext{
80 Kamerstukken II 2010/11, 21501-02, nr. 490.

81 Kamerstukken II 2010/11, 21501-02, nr. 490, p. 18.

82 Ten tijde van dit AO bestond de regering uit de VVD en het CDA en ontvingen zij gedoogsteun van de PVV.
} 
Brussel schrijft minister van financiën Dijsselbloem bijvoorbeeld: 'Zo is het additionaliteitscriterium in het voorstel verder verduidelijkt', maar hij geeft daarbij niet aan hoe dit criterium is verduidelijkt. ${ }^{83}$

$\mathrm{Nu}$ is het natuurlijk niet mogelijk om precies van tevoren te weten hoe het een en ander in een raadsvergadering besproken en besloten zal worden, dus daar kan de minister ook niet concreet over zijn. In een dergelijke geannoteerde agenda neemt de minister echter ook zaken op die al zijn onderhandeld en waarover is besloten. Een voorbeeld daarvan is zojuist geciteerd. Het gevolg hiervan is dat in het $\mathrm{AO}$ dat volgt in mindere mate campagne wordt gevoerd door Kamerleden maar dat AO's met name worden gebruikt om veel vragen te stellen aan de minister.

In tegenstelling tot de AO's voorafgaand aan de Europese Raad wordt in AO's voorafgaand aan de Raad veel meer debat gevoerd. Meer vragen, meer voorstellen aan de minister om op een bepaalde manier te handelen en meer interrupties. De Kamerleden zijn ook stelliger in de woorden die worden gebruikt. Zo zei SP-Kamerlid Merkies tijdens een AO Eurogroep/Ecofinraad met staatssecretaris Wiebes van Financiën: 'De staatssecretaris houdt zichzelf en ons hier een beetje voor de gek' en 'Dat is dus gewoon voor de show'. ${ }^{84}$ De staatssecretaris reageert daarop met hetzelfde verhaal als hij net daarvoor heeft verteld en herhaalt nog eens de resultaten die zijn geboekt over de jaren. Kamerlid Merkies is het niet eens met de reactie van de staatssecretaris en kondigt aan in een al gepland VAO een motie in te dienen om nogmaals het standpunt van de Kamer duidelijk te maken dat volgens hem dus niet overeenkomt met het standpunt van de staatssecretaris. ${ }^{85}$ De motie is uiteindelijk met een meerderheid van één stem aangenomen. ${ }^{86}$ Kortom, AO's voorafgaand aan raadvergaderingen worden met name gebruikt voor meer informatie van de minister dan wel staatssecretaris. In minder mate wordt de minister 'opgelegd' hoe hij of zij in die raadsvergadering dient te handelen. Men kan dus ook niet zeggen dat het duidelijk is dat in dergelijke AO's de Kamerleden grote invloed hebben op het Europees beleid van het kabinet.

Tot slot is er nog de categorie 'ad hoc AO's' waarin alle AO's vallen die niet verbonden zijn aan een vergadering van de Europese Raad of de Raad. De onderwerpen van deze AO's lopen uiteen van behandelvoorbehouden tot uitbreiding van de Europese Unie en van nieuwe commissievoorstellen tot het jaarverslag van de Europese Rekenkamer.

Het hangt helemaal van het onderwerp af of het AO een verhit debat is of een vraagen-antwoordmoment tussen de Kamer en de minister. Het $\mathrm{AO}$ over de uitbreiding van de

83 Kamerstukken II 2016/17, 21501-07, nr. 1406, p. 8.

84 Kamerstukken II 2016/17, 21501-07, nr. 1408, p. 14.

85 Kamerstukken II 2016/17, 21501-07, nr. 1408, p. 14.

86 Kamerstukken II 2016/17, 34604, nr. 10; Handelingen II 2016/17, 30, item 11. 
Europese Unie waaraan vier commissies deelnamen, was een pittig debat. De uitbreiding van de EU valt niet bij alle partijen in goede aarde waardoor sommige partijen stevige woorden gebruiken om hun visies duidelijk te maken. ${ }^{87}$ Het gaat zo ver dat de voorzitter een Kamerlid vraagt om zijn toon te matigen en de beleefdheidsvormen in acht te nemen. ${ }^{88}$ De opbouw van het $\mathrm{AO}$ is gelijk aan die voorafgaand aan een bijeenkomst van de Europese Raad. Partijen delen in hun inbreng met name hun eigen standpunten en ontvangen daarop interrupties en in mindere mate worden vragen gesteld aan de minister. In die inbreng van de verschillende partijen wordt met name kritiek geuit op de minister, die op sommige punten ingaat. De minister heeft van tevoren natuurlijk ook al zijn inbreng opgesteld waarin niet op elk kritiekpunt geanticipeerd is. Tijdens de termijn van de minister komen er interrupties. Hierin worden veel vragen gesteld. Concrete vragen van CDA-lid Omtzigt aan de minister om bepaalde zaken onder de aandacht te brengen worden door minister Timmermans niet geaccepteerd. Zijn woorden: 'Ik houd niet van boodschappenlijstjes zoals de heer Omtzigt ze kennelijk voor mij heeft ${ }^{39}$ Dit geeft volgens mij aan hoe moeilijk het is om een minister te sturen. De minister wordt iets vrij eenvoudigs gevraagd, enkel het onder de aandacht brengen van bepaalde zaken, en daartoe is de minister niet bereid. Een vergaande sturing zoals bijvoorbeeld de minister vragen om in de Raad voor of tegen te stemmen lijkt hierdoor onmogelijk.

Er zijn ook mildere AO's in de categorie 'ad hoc AO's'. Neem bijvoorbeeld het AO over 'Nieuwe commissievoorstellen en initiatieven van de lidstaten van de Europese Unie'. ${ }^{90}$ Op de agenda stond het voorstel voor een meststoffenverordening. Voor een dergelijke AO over nieuwe voorstellen wordt doorgaans één uur uitgetrokken. In dit geval had de Kamer een behandelvoorbehoud geplaatst op dit voorstel, dus er was al veelvuldig contact tussen de Kamer en staatssecretaris over dit voorstel waarbij veel informatie was uitgewisseld. Dit AO was dan ook onderdeel van dat behandelvoorbehoud. De Kamerleden zijn in hun inbreng heel concreet, wat betekent dat ze weinig eigen campagne voeren maar veel vragen stellen. Die vragen gaan niet alleen over de verordening maar er worden ook vragen gesteld aan de staatssecretaris om op een bepaalde manier te handelen. Zo stelde CDA-Kamerlid Geurts de vraag: 'Is de Staatssecretaris bereid om te pleiten voor een langere invoeringsperiode dan drie jaar?'. ${ }^{11}$ Op de vragen over de verordening gaat de staatssecretaris uitgebreid in. Aangezien er tijdens de inbreng van de staatssecretaris geen interrupties zijn gepleegd, beantwoordt de staatssecretaris de vragen naar tevredenheid van de Kamerleden. Op vragen om op een bepaalde manier te handelen geeft de staatssecretaris echter geen antwoord, en omdat de Kamerleden daar zelf niet op terugkomen is dit verder

87 Kamerstukken II 2012/13, 23987, nr. 127.

88 Kamerstukken II 2012/13, 23987, nr. 127, p. 2.

89 Kamerstukken II 2012/13, 23987, 127, p. 22.

90 Kamerstukken II 2015/16, 22112, 2177.

91 Kamerstukken II 2015/16, 22112, 2177, p. 3. 
geen struikelpunt voor hen. Ook de tweede termijn wordt gekenmerkt door het stellen van vragen over de verordening. Uiteindelijk wordt er nog een toezegging door de staatssecretaris gedaan om op Europees niveau te pleiten voor een drempelwaarde van 1 procent in de verordening maar daarbij geeft hij ook meteen aan dat die ene procent in de praktijk niet veel voorstelt. Met andere woorden, de toezegging 'kost' de staatssecretaris niks. ${ }^{92}$

Kortom, AO's zijn met name een vraag-en-antwoordmoment tussen de Kamercommissies en de minister of staatssecretaris. Het hangt van het onderwerp af in hoeverre er een verhit debat wordt gevoerd, maar in het algemeen kan gezegd worden dat de verhitte debatten in de minderheid zijn. Verder zijn de ministers niet of nauwelijks bereid om toezeggingen te doen. Die worden wel gedaan maar zijn dan niet van dien aard dat gezegd kan worden dat de Kamercommissie (grote) invloed heeft uitgeoefend op het beleid van het kabinet. Samengevat, AO's worden met name ingezet voor het uitwisselen van informatie.

\subsubsection{Notaoverleg}

Naast het algemeen overleg bestaat ook het notaoverleg (art. 40 RvO II). Een notaoverleg (NO) gaat over een stuk dat in handen is gesteld van een Kamercommissie. Het verschil met een $\mathrm{AO}$ is dat aan een $\mathrm{NO}$ alle Kamerleden deel kunnen nemen. Daarnaast is het mogelijk om tijdens een $\mathrm{NO}$ een motie in te dienen. ${ }^{93}$

Naast AO's en NO's organiseren Kamercommissies ook rondetafelgesprekken en houden ze hoorzittingen. Deze zijn echter niet gericht op het verkrijgen van informatie van de minister. Deze bijeenkomsten worden georganiseerd door de commissies om zich te laten voorlichten door experts op bepaalde onderwerpen. Een hoorzitting kan door burgers gebruikt worden om hun mening te ventileren over (aankomend) beleid. Ook in de Eerste Kamer kunnen hoorzittingen worden gehouden, maar die zijn daar vrij zeldzaam. ${ }^{94}$ Aangezien de controletaak van de Kamers met name via het algemeen overleg en het notaoverleg wordt uitgeoefend wordt niet verder ingegaan op rondetafelgesprekken en hoorzittingen.

\subsubsection{Debat over de Europese Raad}

Eenzelfde procedure als het Algemeen Overleg wordt gevolgd wanneer een bijeenkomst van de Europese Raad van staatshoofden en regeringsleiders staat gepland. Voordat de minister-president deelneemt aan een beraadslaging van de Europese Raad bespreekt hij deze beraadslaging met de Kamer. Zoals hierboven is aangegeven gebeurt dit sinds 2011

92 Kamerstukken II 2015/16, 22112, nr. 2177, p. 9.

93 Art. 40 RvO II.

94 P.P.T. Bovend'Eert \& H.R.B.M. Kummeling, Het Nederlandse parlement, Deventer: Kluwer 2017, p. 518. 
plenair. ${ }^{95}$ Gezien het feit dat de agenda voor de beraadslaging van de Europese Raad in een laat stadium wordt afgerond stelt de voorbespreking van deze beraadslaging weinig voor; desondanks gaat de minister-president voor elke bijeenkomst in debat met de Kamer. Dit heeft onder andere te maken met het feit dat tijdens het debat doorgaans enkele moties worden ingediend en aangenomen waarvan verwacht wordt dat de minister-president deze uitvoert. De conceptagenda wordt op grond van de procedureregeling van de Europese Raad een maand voor de bijeenkomst van de Europese Raad opgesteld. ${ }^{96}$ De Nederlandse regering stuurt deze ongeveer zes kalenderdagen voorafgaand aan de bijeenkomst naar de Kamer. ${ }^{97}$ Een enkele keer komt het voor dat de agenda twee weken voorafgaand aan de bijeenkomst wordt gestuurd, maar een termijn van slechts drie dagen komt ook voor. ${ }^{98} \mathrm{Er}$ blijft dan weinig tijd over om het debat voor te bereiden; bovendien is de agenda summier opgesteld waardoor er tijdens het debat over hoofdlijnen wordt gesproken en niet over details. Om die reden worden de beraadslaging en de uitkomsten van de 'Europese Top' na afloop uitvoering plenair besproken. Niet alleen de minister-president zal aanwezig zijn en verantwoording afleggen over zijn optreden, ook de minister van Buitenlandse Zaken en de staatssecretaris voor Europese Zaken (deze laatste indien het kabinet een dergelijke staatsecretaris heeft). De minister en de staatssecretaris ondersteunen de minister-president tijdens de Europese Raad. ${ }^{99}$

In de praktijk zijn dit lange debatten die uren kunnen duren en waarin de vergaderingen van de Europese Raad uitvoerig worden besproken. Dit zijn debatten waar ook echt een debat wordt gevoerd. Sprekers krijgen in eerste termijn tot wel tien minuten spreektijd. Debatten gaan gepaard met veel interrupties tussen de Kamerleden onderling maar ook tijdens de termijn van de minister-president. Als voorbeeld wordt de Europese Raad van 26 en 27 juni 2014 genomen. De korte geannoteerde agenda van nog geen drie pagina's laat zien dat er acht onderwerpen op de agenda staan voor de bijeenkomst in Brussel. ${ }^{100}$ Het zal onder andere gaan over de kandidaat-voorzitter van de Europese Commissie, klimaat- en energiebeleid, het Europees Semester, de toekenning van kandidaat-lidstatus aan Albanië en het verzoek van Litouwen om de euro in te voeren. In de geannoteerde agenda wordt in grote lijnen uiteengezet wat er per onderwerp besproken zal worden. Op 25 juni 2014 volgde het debat met de minister-president over de Europese Raad. ${ }^{101}$ Het is geen

95 J. Kester \& M. van Keulen, “De Tweede Kamermethode”: versterkte parlementaire invloed op Europese besluitvorming', RegelMaat 2011, afl. 6, p. 304.

96 Art. 2 sub 2 Reglement van Orde van de Europese Raad.

97 Elk document met betrekking tot de Europese Raad krijgt Kamernummer 21501-20.

98 Zie bijvoorbeeld Kamerstukken II 2014/15, 21501-20, nr. 920 en Kamerstukken II 2013/14, 21501-20, nr. 908.

99 P.P.T. Bovend'Eert \& H.R.B.M. Kummeling, Het Nederlandse parlement, Deventer: Kluwer 2017, p. 385.

100 Kamerstukken II 2013/14, 21501-20, nr. 895.

101 Handelingen II 2013/14, 98, item 8. 
mild debat. In de eerste termijn van de Kamerleden worden veel interrupties geplaatst. Deze gaan niet enkel over de inhoud van de Europese Raad, maar ook over opmerkingen waardoor Kamerleden zich beledigd voelen. ${ }^{102}$ Het gevoeligste onderwerp is de toekenning van kandidaat-lidstatus aan Albanië. Daarover wordt het meest gedebatteerd door alle partijen, niet alleen de partijen waarvan verwacht wordt dat ze daarop kritiek zouden hebben. Het komt erop neer dat in de eerste termijn de Kamerleden campagne voeren en weinig vragen stellen aan de minister-president. In zijn eerste termijn gaat de ministerpresident uitgebreid in op de agendapunten van de Europese Raad en op de weinige vragen die zijn gesteld door de Kamerleden. Daarbij worden behoorlijk wat interrupties geplaatst en dat is dan ook het begin van het debat. De meeste interrupties gaan over de kandidaatvoorzitter van de Europese Unie en over de Europese begrotingsregels. De minister-president is stellig over de standpunten van het kabinet. Zo is er gesuggereerd, in onder andere de media, dat er een deal bestaat waarbij Juncker naar voren wordt geschoven als nieuwe voorzitter van de Europese Commissie in ruil voor een afzwakking van het Stabiliteits- en Groeipact (SGP). De minister-president is niet op de hoogte van een dergelijke deal en verzekert de Kamer dat het kabinet niet zal instemmen met voorstellen om het SGP te veranderen. ${ }^{103}$ De Kamerleden zijn blij om te horen dat er dus geen deal bestaat waar het kabinet aan meewerkt. Dat blijkt ook uit de inbreng van de Kamerleden in de tweede termijn. Zo dankt VVD-kamerlid Verheijen de minister-president voor de beantwoording van de vragen door te stellen: 'Hij heeft naar mijn idee een kraakhelder antwoord gegeven over de Europese begrotingsregels, waarover in deze Kamer grote zorg bestaat'. ${ }^{104}$

In die tweede termijn worden tien moties ingediend. Veel van die moties zijn volgens de minister-president ondersteuning van het kabinetsbeleid. Aangezien er binnen de Kamer de wens bestaat om minder moties in te dienen, zal de minister-president de moties die het beleid ondersteunen en daarmee overbodig zijn, formeel ontraden. Uiteindelijk ontraadt de minister-president alle moties, sommige omdat ze overbodig zijn, andere omdat hij het er niet mee eens is. ${ }^{105}$ Tijdens de stemming worden negen moties verworpen en wordt één motie aangehouden. ${ }^{106}$ Enkele dagen na dit debat stuurt de minister van Buitenlandse Zaken, mede namens de minister-president, het verslag van de Europese Raad aan de Tweede Kamer. ${ }^{107}$ In het eerstvolgende wekelijkse vragenuur worden hierover vragen gesteld. ${ }^{108}$ VVD-Kamerlid Verheijen wil bevestiging van de minister-president dat de bestaande begrotingsregels en -afspraken niet worden gewijzigd. De minister-president

102 Handelingen II 2013/14, 98, item 8, p. 12.

103 Handelingen II 2013/14, 98, item 8, p. 20.

104 Handelingen II 2013/14, 98, item 8, p. 30.

105 Handelingen II 2013/14, 98, item 8, p. 37-38.

106 Handelingen II 2013/14, 98, item 9.

107 Kamerstukken II 2013/14, 21501-20, nr. 897.

108 Handelingen II 2013/14, 100, item 2. 
geeft aan dat in de Europese Raad is besloten dat de regels van het SGP vaststaan en er niets aan veranderd is. Op die vraag over de begrotingsregels en -afspraken wordt door enkele Kamerleden ingehaakt met een vijftal vragen. ${ }^{109}$ De minister-president beantwoordt deze vragen naar tevredenheid van de Kamerleden, wetende dat over de uitkomsten van de Europese Raad nog een debat zal worden gevoerd. Dat debat vond plaats op 4 september 2014 en ging niet alleen over de Europese Raad van 26 en 27 juni maar ook over de buitengewone en bijzondere bijeenkomsten van de Europese Raad van 16 juli en 30 augustus $2014 .{ }^{110}$ In dit debat blijkt wederom het Stabiliteits- en Groeipact het belangrijkste onderwerp. ${ }^{111}$ Aan het begin van het debat deelde de minister-president mede dat het kabinet minister Frans Timmermans als Nederlandse kandidaat voor het lidmaatschap van de Europese Commissie had voorgedragen. ${ }^{112}$ Deze voordracht werd daarmee een tweede onderwerp waarover de Kamerleden vele vragen stelden. De Kamerleden willen dan met name weten hoe de nieuwe Europese Commissie zal worden ingericht, wat de rolverdeling zal zijn en dan met name wat de rol van de vicepresident zal inhouden. De minister-president kan daarover niet meer zeggen dan hetgeen Juncker eerder in het openbaar hierover heeft gezegd. In de tweede termijn worden twee moties ingediend waarvan één wordt aangehouden en de tweede wordt verworpen. ${ }^{113}$

Kortom, Kamerleden grijpen meerdere mogelijkheden aan om met de minister-president in debat te gaan over de Europese Raad. In tegenstelling tot AO's, die met name een vraagen-antwoordmoment zijn, wordt het debat over de Europese Raad veeleer als mogelijkheid gezien om de standpunten van de Kamer c.q. van de verschillende partijen, kenbaar te maken en de minister-president hiervan te overtuigen. Dit komt niet alleen tot uiting in de inbreng van de Kamerleden en de interrupties maar ook door middel van moties. In hoeverre de minister-president het standpunt van de Kamer echt meeneemt in zijn overwegingen en onderhandelingen in de Europese Raad is moeilijk te zeggen.

\subsubsection{Afspraken}

Nergens in de Nederlandse wet staat dat ministers en staatssecretarissen afspraken kunnen maken met het parlement, maar dat betekent niet dat deze mogelijkheden niet bestaan. Het is niet zo dat er veelvuldig afspraken worden gemaakt maar sporadisch komt het voor. In het geval van Europese aangelegenheden gaat het dan met name om afspraken om de Tweede Kamer meer, langer en gedetailleerder te informeren over een Europees wetsvoorstel, en vooral afspraken omtrent de rol van het parlement in Europese besluitvorming.

109 Handelingen II 2013/14, 100, item 2.

110 Handelingen II 2013/14, 103, item 9.

111 Handelingen II 2013/14, 103, item 11.

112 Handelingen II 2013/14, 103, item 9, p. 1.

113 Handelingen II 2013/14, 103, item 11, p. 14; Handelingen II 2013/14, 106, item 11. 
Dus afspraken waardoor het parlement meer zeggenschap krijgt. Deze afspraken hebben geen formele status maar indien ze niet door de regering worden nagekomen kunnen hieraan politieke gevolgen worden verboden.

Een viertal afspraken is gevonden. Omdat van deze afspraken geen algemeen register wordt bijgehouden, tenminste geen register waarin naar afspraken met betrekking tot Europese aangelegenheden gezocht kan worden, is het mogelijk dat er meer afspraken zijn dan dat gevonden zijn. ${ }^{114}$ Opgemerkt moet worden dat een minister of staatssecretaris met enige regelmaat een toezegging doet, een afspraak maakt, in een debat, vaak als reactie op een motie. In de meeste gevallen gaat het dan om een concrete handeling zoals het toezenden van een document voor een bepaalde datum of de toezegging om met de Kamer nogmaals in debat te gaan. Dit zijn niet de afspraken waar het in deze paragraaf om gaat. De afspraken die abstracter zijn, 'groter' van aard en vaak langer werken en herhaaldelijk van toepassing zijn, worden hieronder behandeld.

Tijdens het AO Landbouw- en Visserijraad op 15 maart 2011 heeft de staatssecretaris van Economische Zaken, Landbout en Innovatie (EL\&I) de volgende toezegging gedaan: de staatssecretaris van EL\&I zal de Kamer voortaan tijdiger informeren over de visserijakkoorden en de inzet van Nederland hierbij. ${ }^{115}$ De afspraak die gemaakt is, is uitgebreider dan alleen het informeren van de Kamer. In deze afspraak gaat het namelijk om het volgende. SP-Kamerlid Van Gerven merkt tijdens het debat op dat het niet alleen de bedoeling is dat de Kamer tijdiger geïnformeerd wordt, maar ook dat het standpunt dat in de Kamer ontwikkeld wordt, door de staatssecretaris ingebracht wordt in de Raad. ${ }^{116}$ De staatssecretaris geeft als reactie: 'Wij zullen de Kamer tijdiger informeren over de voorbereiding, zodat wij de gevoelens kunnen meenemen bij het bepalen van het standpunt in de Landbouw- en Visserijraad. ${ }^{, 17}$ Er wordt ook afgesproken dat de staatssecretaris het standpunt van de Kamer meeneemt in de Raad. Wat precies 'meenemen' betekent in dit geval is niet bepaald.

Een andere afspraak die tussen de regering en de Tweede Kamer gemaakt is, betreft het Comprehensive Economic and Trade Agreement (CETA) met Canada. In dit geval werd de afspraak gemaakt door de minister voor Buitenlandse Handel en Ontwikkelingssamenwerking. Zij liet de Tweede Kamer in een brief van 20 april 2016 het volgende weten: 'Voorafgaand aan het innemen van een standpunt in de Raad kan de Kamer zich vanzelfsprekend uitspreken

114 De afspraken zijn opgevraagd bij de Tweede Kamer. Een staflid van de Kamer heeft de vraag naar afspraken uitgezet bij andere stafleden en daarop zijn de genoemde afspraken binnengekomen.

115 Kamerstukken II 2010/11, 21501-32, nr. 473, p. 39.

116 Kamerstukken II 2010/11, 21501-32, nr. 473, p. 39, p. 35.

117 Kamerstukken II 2010/11, 21501-32, nr. 473, p. 39, p. 38 
over de Nederlandse positiebepaling inzake de ondertekening en voorlopige toepassing van het akkoord door de EU. ${ }^{\text {,18 }}$ Deze afspraak is van belang omdat het parlement zo betrokken wordt bij Europese besluitvorming in de gevallen waarin de gelekaartprocedure, het instemmingsrecht en het behandelvoorbehoud niet van toepassing zijn. Op handelsverdragen zijn deze bevoegdheden en procedures namelijk niet van toepassing.

Ten derde zijn er de afspraken omtrent het Europees Stabiliteitsmechanisme (ESM). Allereerst moet worden opgemerkt dat het bij ESM-besluiten, dus besluiten om financiële steun te bieden aan landen die in moeilijkheden verkeren door de financiële crisis, niet gaat om EU-besluiten, wat betekent dat ook hierop de gelekaartprocedure, het instemmingsrecht en andere bevoegdheden van nationale parlementen in de Europese wetgevingsprocedure, niet van toepassing zijn. Hoewel het behandelvoorbehoud niet van toepassing was op deze ESMbesluiten zijn er soortgelijke afspraken gemaakt. Per brief doet de minister van Financiën een aantal voorstellen voor afspraken. Ten eerste zegt de minister toe om de Tweede Kamer zo vroeg mogelijk en zo snel mogelijk op de hoogte te stellen van nieuwe steunaanvragen en voorgenomen besluiten, destijds. ${ }^{119}$ Destijds ging het nog om besluiten van de Europese Faciliteit voor financiële stabiliteit (EFSF), maar omdat de opvolger, het ESM, sterk leek op het EFSF, werd voorgesteld om alle afspraken ook meteen op ESM-besluiten van toepassing te laten zijn. ${ }^{120}$ Verder stelt de minister in het voorstel voor om in bepaalde gevallen een parlementair voorbehoud in te zetten met als doel dat wanneer een dergelijk voorbehoud is ingezet de minister geen onomkeerbare besluiten kan nemen. ${ }^{121}$ Op dit voorstel volgt enige tijd later een nader uitgewerkt protocol van de minister. ${ }^{122}$ Tot slot komt de minister in december 2014 met een definitief informatieprotocol waarin 'de parlementaire betrokkenheid bij inzet van middelen uit en controle op de Europese noodfondsen nauwkeurig wordt vastgelegd'. ${ }^{123}$ De eerder gedane voorstellen en gemaakte afspraken worden niet gewijzigd. Het uitgangspunt blijft bestaan dat alle maatregelen zo veel mogelijk vooraf in het openbaar met de Tweede Kamer besproken zullen worden. Er wordt zo veel mogelijk aansluiting gezocht bij de behandeling van de artikel 100-procedure, die wordt ingezet bij het verstrekken van inlichtingen over de inzet van de krijgsmacht. Van belang is dat er wordt afgesproken dat

118 Kamerstukken II 2015/16, 31985, nr. 27, p. 3, brief van 20 april 2016.

119 Kamerstukken II 2011/12, 21501-07, nr. 877.

120 Kamerstukken II 2011/12, 21501-07, nr. 877, p. 1.

121 Kamerstukken II 2011/12, 21501-07, nr. 877, p. 2.

122 Kamerstukken II 2011/12, 21501-07, nr. 942.

123 Kamerstukken II 2014/15, 21501-07, nr. 1217, p. 1. 
niet alleen de regering de Tweede Kamer tijdig en zo nauwkeurig mogelijk informeert, maar dat de minister en de Kamer in debat gaan over het Nederlandse standpunt alvorens er op Europees niveau besluiten worden genomen. In bepaalde situaties is, om te voorkomen dat de minister door tijdgebrek een standpunt inneemt zonder voorafgaand overleg met de Kamer, besloten dat de minister op Europees niveau een parlementair behandelvoorbehoud maakt zodat de minister geen onomkeerbare besluiten kan nemen voordat er overleg is geweest met de Tweede Kamer. Zoals eerder aangegeven is het parlementair behandelvoorbehoud strikt genomen niet van toepassing op ESM-besluiten. Toch is besloten om deze procedure mogelijk te maken bij ESM-besluiten.

Tot slot is nog een vierde afspraak gemaakt met betrekking tot het instemmingsrecht van het parlement. ${ }^{124}$ Wederom wordt aangesloten bij het parlementair behandelvoorbehoud. In dit geval wordt op elk voorstel dat instemming van het parlement behoeft een parlementair behandelvoorbehoud geplaatst. Dit zorgt voor een betere informatievoorziening dan wanneer enkel het instemmingsrecht van toepassing is omdat bij het parlementair behandelvoorbehoud altijd een debat plaatsvindt tussen de regering en het parlement. Ook werd afgesproken dat de verantwoordelijke minister de finale tekst van een Europees wetsvoorstel waarvoor unanimiteit in de Raad is vereist op grond van artikel 81 lid 3 VWEU, aan de Kamer voorlegt met het verzoek om schriftelijke instemming.

Deze afspraken laten zien hoe aangesloten wordt bij bestaande mogelijkheden. In de eerste drie afspraken wordt aangesloten bij het parlementair behandelvoorbehoud, bij de vierde afspraak wordt afgesproken om het parlementair behandelvoorbehoud in te zetten. In het eerste geval zou een parlementair behandelvoorbehoud mogelijk zijn maar dat moet dan voor elk afzonderlijk Europees voorstel gemaakt worden. In dit geval is afgesproken dat het voor ieder voorstel geldt. De Kamer wil bij elk visserijakkoord tijdiger geïnformeerd worden. Niet is afgesproken dat de minister een voorbehoud maakt in de Raad maar aangezien wel is afgesproken dat de minister het standpunt van de Kamer meeneemt, is het nodig dat de minister eerst met de Kamer in debat gaat alvorens hij een standpunt kan innemen in de Raad. Ook bij het CETA-verdrag gaat het erom dat de minister de Kamer betrekt bij Europese besluitvorming. De minister zal geen voorbehoud maken in de Raad maar zal wel eerst met de Tweede Kamer in overleg gaan voorafgaand aan de Raad. Niet is afgesproken, zoals wel bij de visserijakkoorden, dat de minister het standpunt meeneemt in de Raad.

124 Kamerstukken I 2015/16, 32317, FY, p. 3, brief van 4 maart 2016. 
Bij alle afspraken is het echter wel de vraag of deze in het geheugen zitten van zowel de minister als de Kamerleden. De afspraken worden namelijk niet formeel geregistreerd waardoor de uitvoering ervan (helaas) afhangt van een goed geheugen van griffie of Kamerleden.

\subsubsection{Overleg Eerste Kamer}

In de Eerste Kamer voeren de commissies zelden mondeling overleg met de minister. Overleg in de commissie is met name gericht op de uitvoering van de wetgevende taak van de Eerste Kamer en staat niet in het teken van controle van het regeringsbeleid. ${ }^{125}$ De Tweede Kamer heeft een sterk ontwikkeld systeem met betrekking tot controle voorafgaand aan de Raadvergadering. Een dergelijk systeem heeft zich niet in de Eerste Kamer ontwikkeld. De Eerste Kamer heeft wel het recht om vragen te stellen en het recht van interpellatie maar deze worden zeer zelden ingezet. Het een en ander heeft te maken met het feit dat de Eerste Kamer 'slechts' één keer per week, op dinsdag, bijeenkomt, hetgeen het organiseren van debatten en overleggen tussen ministers en de Eerste Kamer(commissies) bemoeilijkt. ${ }^{126}$ Hoewel de Eerste Kamer geen vast systeem van AO's kent, ontvangt zij wel de geannoteerde agenda van de regering voorafgaand aan een Raadvergadering en een rapportage van de onderhandelingen. ${ }^{127}$

\subsection{WETGEVING}

Het politieke controle- en verantwoordingsproces is een manier om indirect, via de regering, invloed uit te oefenen op Europese wetgeving. Er bestaat ook een directe weg om invloed uit te oefenen. Zoals in het vorige hoofdstuk beschreven ontvangt het parlement op basis van het Barroso-initiatief uit 2006 nieuwe ontwerpwetgeving direct van de Europese Commissie, dus zonder tussenkomt van de regering. ${ }^{128}$ Vóór het Barroso-initiatief ontving het parlement nieuwe commissievoorstellen via de regering door middel van de zogenoemde BNC-fiches (zie par. 4.4.1 hierna). Ondanks de invoering van het Barroso-initiatief bestaan de fiches nog steeds en worden deze gebruikt om het parlement te informeren, met name over het standpunt van de regering. Wanneer de Kamers nieuwe Europese ontwerpwetgeving hebben ontvangen wordt die door beide Kamers afzonderlijk in behandeling genomen.

125 B. van Mourik, Parlementaire controle op Europese besluitvorming. Een rechtsvergelijkend onderzoek naar mandaatsystemen en parlementaire behandelingsvoorbehouden, Nijmegen: Wolf Legal Publishers 2012, p. 32.

126 A.L. Högenauer, 'The Dutch Parliament and EU Affairs: Decentralizing Scrutiny', in: C. Hefftler e.a. (eds.), The Palgrave Handbook of National Parliaments and the European Union, Londen: Palgrave Macmillan 2015, p. 256.

127 Ibid., p. 257.

128 Art. 4 Protocol nr. 2. 
Enige tijd heeft de Tijdelijke Gemengde Commissie Subsidiariteitstoets bestaan maar sinds de opheffing hiervan in 2009 wordt de behandeling apart uitgevoerd. Hieronder wordt de behandeling van nieuwe ontwerpwetgeving van de Commissie beschreven, waarbij de bevoegdheden van de Tweede en Eerste Kamer aan bod komen.

\subsubsection{BNC-fiches}

Per jaar zendt de Europese Commissie tientallen nieuwe voorstellen aan de Raad en het Europees Parlement. ${ }^{129}$ Deze commissievoorstellen en consultatiedocumenten, zoals groenboeken en witboeken, worden niet alleen aan de nationale parlementen gezonden, maar in eerste instantie ook aan de nationale regeringen. In Nederland komen deze documenten terecht bij de interdepartementale werkgroep Beoordeling Nieuwe Commissievoorstellen (werkgroep BNC). De werkgroep BNC, die in 1989 is opgericht, bestaat uit vertegenwoordigers van alle ministeries (van de directie Internationale en/of EU-zaken) en wordt voorgezeten door het ministerie van Buitenlandse Zaken. Sinds september 2001 zijn ook de decentrale overheden vertegenwoordigd in de werkgroep door middel van vertegenwoordigers van de Vereniging van Nederlandse Gemeenten en Interprovinciaal Overleg. ${ }^{130}$ Voordat de commissievoorstellen rechtstreeks aan de nationale parlementen werden gestuurd was het BNC-fiche het enige middel dat de Kamers hadden met betrekking tot controle van de regering voorafgaand aan een vergadering van de Raad. ${ }^{131}$ Het fiche vormde het startpunt van de betrokkenheid van de Kamers bij een Europees voorstel.

Thans zijn de Kamers niet meer afhankelijk van de regering en gaan zij zelfstandig aan de slag met Europese voorstellen. ${ }^{132}$ Dit betekent niet dat BNC-fiches hun waarde daardoor hebben verloren. Het blijft een instrument waarmee de regering de Kamers informeert over haar oordeel over het Europese voorstel en leidt regelmatig tot een debat tussen de regering en het parlement. Eens per week komt de werkgroep bijeen om alle voorstellen te bespreken en bij elk voorstel een eerstverantwoordelijk departement aan te wijzen. ${ }^{133}$ Naar aanleiding van ongeveer de helft van alle voorstellen stelt de werkgroep een BNCfiche op dat, na goedkeuring van de ministerraad, ${ }^{134}$ naar beide Kamers wordt gezonden. ${ }^{135}$ Sinds het voorjaar van 2012 worden de fiches rechtstreeks naar de Eerste Kamer gezonden.

129 Website De Nederlandse Grondwet, BNC-fiche.

130 Website Europa NU, BNC.

131 Zie het rapport 'Bovenop Europa. Evaluatie van de versterkte EU-ondersteuning van de Tweede Kamer, 2007-2011', uitgevoerd door de Kamerleden Ten Broeke en Schouw, p. 8.

132 Ibid.

133 Onderzoek nieuwe Europese regelgeving: 'impact assessment' Eindrapport, KPMG, 5 oktober 2010.

134 Website De Nederlandse Grondwet, BNC-fiche.

135 BNC-fiches worden gepubliceerd onder Kamerstuknummer 22112. 
Voorheen kreeg de Eerste Kamer de fiches als afschrift van de brief aan de Tweede Kamer. ${ }^{136}$ De Eerste Kamer wenst enkel een BNC-fiche van de regering te ontvangen van de voorstellen die de Kamer op haar prioriteitenlijst heeft staan. Ad hoc kan een fiche worden gevraagd van de voorstellen die niet als prioriteit zijn aangemerkt. ${ }^{137}$ In een dergelijk fiche wordt het eerste Nederlandse standpunt bepaald en het vormt de basis voor het Nederlandse optreden in de Raadswerkgroepen ${ }^{138}$ en hoe de Nederlandse regering zal onderhandelen op Europees niveau. ${ }^{139}$

Een fiche bevat standaard een samenvatting van het Europees voorstel, een oordeel over de subsidiariteit en de proportionaliteit van dat voorstel en een oordeel of de Commissie het voorstel op de juiste rechtsgrondslag heeft gebaseerd. Daarna volgt een analyse van de Nederlandse belangen en de financiële en juridische gevolgen van het voorstel. ${ }^{140}$ Tot slot worden de uitvoerbaarheid en de handhaafbaarheid van het voorstel beoordeeld, de implicaties voor ontwikkelingslanden en uiteindelijk volgt een analyse van de Nederlandse belangen en een eerste algemeen Nederlands standpunt. De regering hanteert een termijn van zes weken na de publicatie van het Commissievoorstel voor het toezenden van de fiches aan de Tweede en Eerste Kamer. ${ }^{141}$

Nadat de Kamercommissie die voor het beleidsterrein waarover het fiche gaat verantwoordelijk is, het fiche heeft ontvangen, besluit die commissie het fiche al dan niet te agenderen voor een overleg met de minister voorafgaande aan de betreffende vergadering van de Raad van Ministers. Niet van elk voorstel wordt een fiche opgesteld. De werkgroep kan zelfstandig besluiten geen fiche op te stellen, bijvoorbeeld wanneer het gaat om standaardrapportages van de Commissie: men denke aan jaarrapporten en voortgangsrapportages. Ook wanneer informatievoorziening aan het parlement op een andere manier wordt gewaarborgd kan het opstellen van een fiche achterwege blijven. De fiches worden door de regering ook aangeboden aan de Ministerraad en aan de Nederlandse leden van het Europees Parlement. ${ }^{142}$

136 Website Eerste Kamer, Parlementaire bevoegdheden Eerste Kamer met betrekking tot de Europese Unie.

137 Kamerstukken I 2011/12, 22112, FJ, p. 2.

138 In de Raadswerkgroepen worden de onderhandelingsrichtlijnen en -instructies voor de Nederlandse vertegenwoordigers opgesteld.

139 Website Eerste Kamer, BNC.

140 Website Eerste Kamer, BNC.

141 Handelingen I 2007/08, 37, p. 1588. Indien de Tweede Kamer een behandelvoorbehoud plaatst of subsidiariteitstoets uitvoert bij een voorstel, geldt een termijn van drie weken. De termijn van zes weken geldt ook in recesperiodes met uitzondering van de vier weken in augustus die overeenkomen met het zomerreces van de Europese instellingen.

142 Website Europa NU, BNC. 
Onderstaande tabel 6 geeft weer hoeveel BNC-fiches de regering aan de Kamers heeft gestuurd in de onderzoekperiode van 2010 tot en met $2016 .{ }^{143}$ Gemiddeld stuurde de regering in die periode 145 BNC-fiches per jaar aan de Tweede en Eerste Kamer.

De Eerste Kamer behandelde doorgaans alleen de BNC-fiches over de voorstellen die zij als prioriteit had aangemerkt. De Tweede Kamer nam de meeste BNC-fiches ter kennisname aan. Een enkele keer volgt een overleg met de minister of staatssecretaris over het BNC-fiche. Zo had de commissie voor Onderwijs, Cultuur en wetenschap in het najaar van 2012 een schriftelijk overleg met de staatssecretaris van Buitenlandse Zaken over het Fiche 'Besluit Culturele Hoofdsteden van Europa 2020 tot 2033'. ${ }^{144}$ De commissie voor Financiën had in het voorjaar van 2016 een schriftelijk overleg met de minister van Financiën over het fiche inzake 'het Actieplan ter versterking van de strijd tegen terrorismefinanciering' ${ }^{145}$ Het zijn doorgaans enkele vragen die de leden van de commissies hebben. Het gaat dan om vragen die niet al te technisch of veel details bevatten zodat ze goed schriftelijk te beantwoorden zijn. Denk daarbij aan vragen over het verloop van de onderhandelingen op Europees niveau, de inzet van het kabinet, welke rol andere Europese instituten spelen of hoe efficiënt en effectief de genomen maatregelen tot nu toe zijn geweest.

Niet alle fiches werden binnen de zeswekentermijn aan het parlement aangeboden. Ongeveer 75 fiches werden uitgesteld, wat betekent dat ze na zes weken na de publicatie van het voorstel door de Commissie aan de Kamers zijn gestuurd. Dit kan problematisch zijn wanneer (een van) de Kamers een met redenen omkleed advies inzake de gelekaartprocedure wil sturen. De termijn daarvoor is acht weken. De Kamers kijken voordat ze het advies sturen altijd naar het standpunt van de regering. Wanneer de regering het BNCfiche niet binnen zes weken of zelfs na acht weken stuurt, heeft de Kamer nauwelijks tot geen tijd meer om het fiche mee te nemen in haar advies. Het ministerie van Veiligheid en Justitie en het ministerie van Economische Zaken spanden de kroon met (te) laat aangeboden fiches. Daarbij moet worden vermeld dat de meeste BNC-fiches in het algemeen afkomstig zijn van juist deze twee ministeries. Hoewel het BNC-fiche niet meer het startpunt is van betrokkenheid voor de Kamers bij Europese voorstellen blijkt het toch nog van waarde te zijn. Door het fiche worden de Kamers op de hoogte gebracht van de standpunten van de regering over het betreffende voorstel en daarnaast wordt het gebruikt bij het opstellen van met redenen omklede adviezen in de gelekaartprocedure.

143 Via 'Officiële Bekendmakingen' op de website overheid.nl zijn alle BNC-fiches te vinden. Via deze website zijn ze per jaar geteld. Mogelijk zijn enkele BNC-fiches gemist omdat niet altijd het gebruikelijke Kamernummer 22112 aan de fiches wordt toegekend.

144 Kamerstukken II 2012/13, 22112, nr. 1498.

145 Kamerstukken II 2015/16, 22112, nr. 2124. 


\section{Tabel 6 BNC-fiches}

\begin{tabular}{ll} 
Jaar & Aantal geleverde BNC-fiches \\
\hline $\mathbf{2 0 1 0}$ & 104 \\
\hline $\mathbf{2 0 1 1}$ & 167 \\
\hline $\mathbf{2 0 1 2}$ & 206 \\
\hline $\mathbf{2 0 1 3}$ & 181 \\
\hline $\mathbf{2 0 1 4}$ & 127 \\
\hline $\mathbf{2 0 1 5}$ & 101 \\
\hline $\mathbf{2 0 1 6}$ & 128 \\
\hline Totaal & 1014
\end{tabular}

\subsubsection{Behandeling commissievoorstellen door de Tweede Kamer}

Sinds 2005, na een 'nee' tegen het voorstel voor een Europese Grondwet, werkt de Tweede Kamer aan een versterking van haar positie en prioriteiten door meer oog te hebben voor Europese aangelegenheden. De Tweede Kamer wil meer aandacht besteden aan Europese aangelegenheden en wil in een vroeg stadium betrokken zijn. Er moest een proactieve houding ontstaan. Hiervoor zijn betere processen en rolverdelingen ontwikkeld. Waar voorheen de Vaste Kamercommissie voor Europese Zaken (EUZA) verantwoordelijk was voor de behandeling van Europese zaken, wordt nu een vorm van gedecentraliseerde controle aangehouden waar de taken verdeeld worden onder alle Kamercommissies naar hun expertise. ${ }^{146}$ De uiteindelijke stemmingen vinden plenair plaats. ${ }^{147} \mathrm{Wel}$ is EUZA verantwoordelijk voor de algemene coördinatie van EU-gerelateerde zaken. ${ }^{148}$

Het systeem dat de Tweede Kamer handhaaft voor EU-coördinatie wordt gezien als een sterk en compleet systeem. Er wordt niet alleen gekeken naar de documenten die vanuit Brussel afkomstig zijn, maar, zoals eerder beschreven, er wordt ook met de ministers overlegd voorafgaand aan een vergadering van de Raad van Ministers. De Kamer probeert van begin tot eind betrokken te zijn.

146 J. Kester \& M. van Keulen, “'De Tweede Kamermethode”: versterkte parlementaire invloed op Europese besluitvorming', RegelMaat 2011, afl. 6, p. 303.

147 A.L. Högenauer, 'The Dutch Parliament and EU Affairs: Decentralizing Scrutiny', in: C. Hefftler e.a. (eds.), The Palgrave Handbook of National Parliaments and the European Union, Londen: Palgrave Macmillan 2015, p. 254.

148 Ibid. 


\subsubsection{Wetgevings- en werkprogramma}

Het startpunt van de Kamer met betrekking tot de betrokkenheid bij nieuwe Europese wetgeving is het jaarlijkse wetgevings- en werkprogramma (WWP) van de Europese Commissie. In het WWP presenteert de Europese Commissie haar plannen voor het komend kalenderjaar. Sinds 2007 wordt het WWP op gestructureerde wijze door de Tweede Kamer behandeld. Samen met de staatssecretaris voor Europese Zaken dan wel de staatssecretaris of minister van Buitenlandse Zaken, bespreekt de vaste Kamercommissie voor Europese Zaken het WWP. Daarnaast wordt ook het oordeel van de regering over de plannen van de Commissie besproken.

Gezien het grote aantal documenten dat door de Commissie wordt opgesteld is de Kamer niet in staat om alle documenten te toetsen. Uit het WWP worden daarom door elke Kamercommissie die dossiers geselecteerd die betrekking hebben op haar beleidsterrein en waaraan zij prioriteit wil geven. Deze dossiers zullen na publicatie op de agenda van de desbetreffende Kamercommissie worden geplaatst. Op de lijst wordt ook aangegeven of de Kamer(commissie) van plan is een behandelvoorbehoud te plaatsen op het betreffende Europese voorstel en of zij voornemens is een subsidiariteitstoets uit te voeren. Ook voorstellen die niet in het WWP zijn opgenomen of waaraan niet in eerste instantie prioriteit is gegeven kunnen op de agenda van de Kamercommissie worden geplaatst. Elke Kamercommissie is vrij om te bepalen welke voorstellen parlementair getoetst moeten worden. Deze voorstellen worden geplaatst op de Lijst van prioritaire voorstellen die daarna plenair wordt vastgesteld. Zodra een voorstel van de Commissie dat door de Kamer als prioritair is bestempeld aan de Kamer is verzonden, wordt het voorstel geagendeerd voor de procedurevergadering van de desbetreffende Kamercommissie. In deze vergadering wordt besloten hoe het voorstel verder zal worden behandeld in de Kamer, op basis van een voorstel van de EU-staf van de Kamer. De vaste commissie voor Europese Zaken van de Kamer stelt een stafnotitie op over het voorstel. Deze notitie wordt aangeboden aan de griffie van de betreffende vakcommissie. Voor 2007 werden de notities naar aanleiding van een BNC-fiche gemaakt maar thans vormt het fiche niet meer het startpunt. De Kamer start zelfstandig met de behandeling van Europese voorstellen en wacht niet meer op de regering. ${ }^{149}$

\subsubsection{Consultaties}

Naast het WWP van de Commissie besteedt de Tweede Kamer aandacht aan consultaties door de Commissie. Voorafgaand aan nieuwe belangrijke Europese wetgeving vraagt de Europese Commissie om een reactie op haar voorstel. Dit doet ze via consultatiedocumenten, doorgaans groenboeken of witboeken genaamd, waarop iedereen vrij is te reageren.

149 Zie het rapport 'Bovenop Europa. Evaluatie van de versterkte EU-ondersteuning van de tweede Kamer, 2007-2011', uitgevoerd door de Kamerleden Ten Broeke en Schouw, p. 5. 
Wanneer er sprake is van dringende gevallen houdt de Commissie geen consultaties. De reden om dit niet te doen motiveert zij dan in het voorstel. ${ }^{150}$ De Nederlandse regering reageert standaard op ieder groen- of witboek. Voordat de regering haar reactie aan de Commissie stuurt, stuurt zij minimaal dertig dagen voorafgaand hieraan de Tweede Kamer haar reactie. De Tweede Kamer maakt gebruik van deze praktijk door commentaar te leveren op en/of aanpassingen voor te stellen in de reactie van de regering. ${ }^{151}$

De Commissie maakt steeds minder gebruik van groenboeken en witboeken. ${ }^{152}$

In tabel 7 is te zien dat de Kamers op de meeste groen- en witboeken reageren. Voor 2006 reageerde de Tweede Kamer op twee derde van de groen- en witboeken. Sinds 2007 heeft de Tweede Kamer op bijna alle groen- en witboeken gereageerd. ${ }^{153}$ Dit geeft aan dat er aandacht is voor de consultaties van de Europese Commissie. Dat er aandacht is voor de consultaties is belangrijk. Hoe eerder een parlement namelijk actief is binnen Europa, hoe groter de kans op invloed kan zijn. Het is daarom van belang dat niet pas actie wordt ondernomen na ontvangst van wetgevingsdocumenten maar vooral ook al bij consultatiedocumenten.

Tabel 7 Reacties Eerste en Tweede kamer op groen- en witboeken

\begin{tabular}{lllllll} 
Jaar & $\begin{array}{l}\text { Groenboe- } \\
\text { ken }\end{array}$ & Witboeken & $\begin{array}{l}\text { Reacties } \\
\text { aan EC } \\
\text { Tweede } \\
\text { Kamer } \\
\text { Groenboek }\end{array}$ & $\begin{array}{l}\text { Reacties } \\
\text { aan EC } \\
\text { Tweede } \\
\text { Kamer Wit- } \\
\text { boek }\end{array}$ & $\begin{array}{l}\text { Reacties } \\
\text { aan EC } \\
\text { Kamer } \\
\text { Groenboek }\end{array}$ & $\begin{array}{l}\text { Reacties } \\
\text { aan EC Eer- } \\
\text { ste Kamer } \\
\text { Witboek }\end{array}$ \\
\hline $\mathbf{2 0 1 0}$ & 10 & 1 & 10 & 1 & 6 & 1 \\
\hline $\mathbf{2 0 1 1}$ & 13 & 1 & 12 & 1 & 5 & 0 \\
\hline $\mathbf{2 0 1 2}$ & 5 & 1 & 4 & 1 & 2 & 0 \\
\hline $\mathbf{2 0 1 3}$ & 7 & 0 & 6 & 0 & 2 & 0 \\
\hline $\mathbf{2 0 1 4}$ & 3 & 1 & 1 & 0 & 2 & 0 \\
\hline $\mathbf{2 0 1 5}$ & 2 & 0 & 2 & 0 & 1 & 0 \\
\hline $\mathbf{2 0 1 6}$ & 0 & 0 & 0 & 0 & 0 & 0
\end{tabular}

De Eerste Kamer reageert op minder dan de helft van de gepubliceerde groen- en witboeken. Dit heeft wederom te maken met het feit dat het lidmaatschap van de Eerste Kamer een deeltijdfunctie betreft. Het feit dat beide Kamers niet bij elk groenboek of witboek een

150 Art. 2 Protocol nr. 2.

151 Tweede Kamer, 'Bovenop Europa: Evaluatie van de versterkte EU-ondersteuning van de Tweede Kamer 2007-2011, Den Haag: Tweede Kamer 2011, p. 4.

152 De groen- en witboeken zijn te vinden op eur-lex.europa.eu.

153 Tweede Kamer, 'Bovenop Europa: Evaluatie van de versterkte EU-ondersteuning van de Tweede Kamer 2007-2011, Den Haag: Tweede Kamer 2011, p. 5. 
reactie aan de Europese Commissie sturen, heeft er ook mee te maken dat ze in plaats daarvan met de regering over het groenboek of witboek in debat gaan. Via deze indirecte manier proberen de Kamers dan invloed uit te oefenen op de Europese wetgeving en beleidsvorming.

Als we de reacties naar de Europese Commissie en de debatten met de regering bij elkaar optellen, blijkt dat beide Kamers op vrijwel alle groenboeken en witboeken richting de Europese Commissie dan wel de regering reageren. Dat is een zeer goede score. Daarbij moet wel een kanttekening worden geplaatst. Wanneer de Kamers in debat gaan met de regering over een groenboek of witboek komt dit vaak neer op een brief waarin enkele vragen gesteld worden, die vervolgens in een enkele brief ook weer beantwoord worden. Het betreft geen lange schriftelijke debatten. Er worden geen andere opties gebruikt zoals mondelinge vragen. Ook worden sommige witboeken en groenboeken ter kennisname aangenomen, wat betekent dat er verder niets mee wordt gedaan. Zo koos de Eerste Kamer er naar aanleiding van witboek COM(2011)144 'Stappenplan voor een interne Europese vervoersruimte - werken aan een concurrerend en zuinig vervoerssysteem' voor om in debat te gaan met de minister van Infrastructuur en Milieu in plaats van een reactie te sturen aan de Europese Commissie. De commissie Verkeer en Waterstaat besloot een schriftelijk debat te voeren met de minister. Na de verkiezingen van 2011 nam de commissie Infrastructuur, Milieu en Ruimtelijke Ordening dit dossier over. De commissie stuurde een brief aan de minister waarin zij laat weten geïnteresseerd te zijn in het standpunt van de regering ten aanzien van het door de Europese Commissie opgestelde stappenplan. Ook wilde de commissie weten of de regering het onderwerp van het witboek besprak met de verschillende relevante organisaties en welke punten tijdens deze besprekingen naar voren waren gebracht. De belangrijkste vraag van de Kamercommissie was ten slotte de vraag of en hoe de regering de standpunten op Europees niveau naar voren zou brengen. De minister liet daarop de commissie per brief weten dat er daadwerkelijk overleg werd gevoerd, dat er veel gemeenschappelijke punten waren, met andere woorden dat de maatschappelijke organisaties en de regering op een lijn zaten. De antwoorden van de minister en de kabinetsreactie op het witboek werden besproken door de commissie Infrastructuur, Milieu en Ruimtelijke Ordening en voor kennisgeving aangenomen. ${ }^{154}$

Uit het gegeven dat de meeste reacties kort zijn - het gaat om slechts enkele vragen in een brief - en daarnaast op een deel van de groen- en witboeken niet wordt gereageerd, blijkt dat deze consultaties niet als prioriteit worden gezien door de Kamers. Ze zijn daarmee niet overbodig of nutteloos aangezien de groen- en witboeken een goed beeld geven van de plannen die de Commissie heeft en die de Kamers dus kunnen verwachten zodat ze zich daar ook op kunnen voorbereiden.

154 Website Eerste Kamer, Witboek stappenplan. 


\subsubsection{Rapporteur}

In de Tweede Kamer hebben commissies de mogelijkheid om een of meer van hun leden te benoemen tot rapporteur. ${ }^{155}$ Deze mogelijkheid bestaat niet in de Eerste Kamer. Een rapporteur zal voorbereidende werkzaamheden uitvoeren en zich meer verdiepen in een dossier om daarna de commissie te kunnen informeren. Er worden met enige regelmaat rapporteurs benoemd met betrekking tot Europese aangelegenheden; met betrekking tot nationale dossiers gebeurt dit veel minder vaak. Het is hun taak om Europese dossiers in de gaten te houden en te behandelen namens de Tweede Kamer. Er zijn rapporteurschappen geweest over onderwerpen als het Europees Openbaar Ministerie, democratische legitimiteit en Brexit. De Kamercommissie voor Europese Zaken heeft - gezien het belang van dit onderwerp - de afgelopen jaren steeds een rapporteur benoemd voor het algemeen overleg Informatievoorziening. Wanneer de Kamer tijdig en goed wordt geïnformeerd over belangrijke EU-dossiers kan zij haar controlerende taak het best vervullen en heeft zij invloed op de Nederlandse inzet bij onderhandelingen die in Europa worden gevoerd. De rapporteur zorgt voor de inbreng van de leden van de commissie voor Europese Zaken in het jaarlijks overleg tussen de commissie en de minister van Buitenlandse Zaken over de tijdigheid en kwaliteit van de informatievoorziening over EU-dossiers van het kabinet aan de Kamer. De tijdens dit overleg gemaakte afspraken worden vastgelegd in een brief aan de minister. Ieder jaar worden de afspraken geëvalueerd en wordt dus bekeken of de afspraken worden nageleefd. ${ }^{156}$

Sinds 2010 zijn er tien rapporteurs voor een Europees dossier benoemd.

\section{Tabel 8 Onderwerpen rapporteurschap}

\begin{tabular}{ll} 
Kamercommissie & Onderwerp \\
\hline Infrastructuur en Milieu & - Circulaire economie (2014) \\
& - Energie-unie (2015) \\
& - Begrotingscyclus (2015) \\
& - Single European Sky (2015) \\
\hline Veiligheid en Justitie & - Europees Openbaar Ministerie (2015) \\
& - Slimme grenzen (2015) \\
\hline Europese Zaken & - Europees Semester (2014) \\
& - Democratische controle en invloed op \\
& - Europese besluitvorming (2014) \\
& - Brexit (2016)
\end{tabular}

155 Art. 27 sub h jo. 30a RvO II.

156 Website Tweede Kamer, Bovenop Europa. 
Zoals tabel 8 weergeeft, kan het rapporteurschap over veel verschillende onderwerpen gaan. In 2015 werden Kamerleden Belhaj (D66) en Van Helvert (CDA) aangesteld als rapporteur voor het onderwerp Single European Sky, met andere woorden een gemeenschappelijk Europees luchtruim, waartoe de Europese Commissie in 2013 enkele wetgevingsvoorstellen had gedaan. In opdracht van de Kamercommissie voor Infrastructuur en Milieu werd onderzoek gedaan naar de (on)mogelijkheden om tot één gemeenschappelijk Europees luchtruim te komen. Hierdoor zou het versnipperde Europese luchtruim beter georganiseerd worden en daartoe zouden de luchtverkeersleidingsdiensten hervormd worden. Bij het uitvoeren van dit onderzoek hebben de rapporteurs verschillende bijeenkomsten bijgewoond en georganiseerd, en gedebatteerd met de Kamercommissie voor Infrastructuur en Milieu. Ook hebben de rapporteurs een inventarisatie gemaakt van de pijnpunten bij de verschillende nationale parlementen met betrekking tot de implementatie van de wetsvoorstellen die de Europese Commissie hieromtrent heeft gemaakt. ${ }^{157}$ Het rapporteurschap leidde tot enkele aanbevelingen en conclusies. ${ }^{158}$ Een van de conclusies was dat de meerderheid van de lidstaten van de EU vóór een gemeenschappelijk Europees luchtruim is. Dit betekent dus dat de rapporteurs onder andere de opdracht hebben gekregen om te inventariseren hoe andere lidstaten over dit onderwerp denken. Dit werd gedaan via vragenlijsten die aan de andere nationale parlementen werden gestuurd. Ook vond er een zogenoemd 'side-event' plaats binnen de COSAC om dit onderwerp met andere nationale parlementen te bespreken. De conclusies op basis van het rapporteurschap zijn met name gericht aan de staatssecretaris. Volgens de rapporteurs is de staatssecretaris aan zet om de nationale belangen te behartigen en niet zozeer het parlement. De rapporteurs doen in dit geval geen aanbevelingen aan het eigen parlement terwijl ook het parlement zelf in actie zou kunnen komen tegen de voorstellen. Bij een subsidiariteitsbezwaar zouden de Kamers een met redenen omkleed advies inzake de gelekaartprocedure kunnen sturen en voor alle niet-wetgevingsdocumenten een bezwaar binnen de politieke dialoog.

In juli 2013 publiceerde de Europese Commissie haar voorstel voor het oprichten van een Europees Openbaar Ministerie. Zowel de Tweede Kamer als de Eerste Kamer heeft naar aanleiding van dit voorstel een met redenen omkleed advies inzake de gelekaartprocedure aan de Commissie gestuurd. De Tweede Kamer besloot om ook een rapporteur aan te stellen bij dit voorstel. Op 20 februari 2014 werd Van der Steur (VVD) aangesteld als rapporteur. Het rapporteurschap werd in april 2015 overgenomen door Recourt (PvdA) aangezien Van der Steur in maart 2015 minister van Veiligheid en Justitie was geworden. ${ }^{159}$ Dit rapporteurschap begon helaas vele maanden later dan de publicatie van het voorstel.

157 Website Tweede Kamer, Rapporteurs Europees luchtruim.

158 Verslag rapporteurs over gemeenschappelijk Europees luchtruim bij brief d.d. 15 september 2016 aan de vaste Commissie voor Infrastructuur en Milieu van de Tweede Kamer, p. 4.

159 Website Tweede Kamer, Rapporteurs. 
Het doel van het rapporteurschap was om informatie in te winnen over de onderhandelingen over dit voorstel. De Tweede Kamer had reeds een subsidiariteitsbezwaar opgesteld en ingestuurd. De standpunten en argumenten van de Kamer werden daarna ook in een position paper neergelegd. ${ }^{160}$ Ook bevatte deze position paper een alternatief voorstel voor een Europees Openbaar Ministerie. De rapporteur heeft de standpunten vervolgens met de Europese wetgever (de Europese Commissie, het Europees Parlement en de Raad van Ministers) gedeeld, en ook met andere lidstaten binnen de EU. ${ }^{161}$ Daarnaast hebben beide rapporteurs bezoeken afgelegd aan andere nationale parlementen en aan Brussel om de standpunten van de Tweede Kamer en het alternatieve voorstel toe te lichten. ${ }^{162}$ Het rapporteurschap eindigde op 10 oktober 2016 toen de rapporteur zijn laatste voortgangsrapportage presenteerde. In deze laatste rapportage gaf de rapporteur aan wat de stand van zaken was voor wat betreft het voorstel. Het voorstel werd destijds in de Raad behandeld.

Enigszins vreemd is dus dat het rapporteurschap werd afgesloten voordat de Europese wetgevingsprocedure was afgerond. Over het einde, wellicht de belangrijkste fase van het voorstel, is niet gerapporteerd en dit is dus niet extra in de gaten gehouden. Zoals in het vorige hoofdstuk staat beschreven wordt het voorstel voor een Europees Openbaar Ministerie voortgezet in de vorm van een nauwere samenwerking. Nederland stond toen voor de belangrijke keuze om mee te doen of niet. Wellicht was juist in deze fase een rapporteur over het voorstel van belang om de Tweede Kamer te informeren over de voortgang van het voorstel, de lidstaten die meedoen en de argumenten voor Nederland om al dan niet deel te nemen aan de nauwere samenwerking.

Als men kijkt naar de andere rapporteurschappen valt het volgende op. Het rapporteurschap circulaire economie werd beëindigd voordat de onderhandelingen over de nieuwe (herziene) richtlijn waren afgerond in de Raad en het Europees Parlement. De rapporteur gaf aan dat zij na de nieuwe verkiezingen niet terug zou komen zodat het rapporteurschap daarom beëindigd werd. ${ }^{163}$ Een nieuwe rapporteur ten aanzien van circulaire economie is niet aangesteld. Ook het rapporteurschap met betrekking tot het dossier slimme grenzen werd beëindigd voordat het wetgevingsvoorstel van de Commissie het hele wetgevingsproces had doorlopen. In februari 2013 publiceerde de Europese Commissie het wetgevingspakket slimme grenzen waarin maatregelen stonden die het beheer van de Europese buitengrenzen moesten verbeteren met onder andere nieuwe ICT-systemen. In maart 2015, dus meer dan twee jaar later, werd de rapporteur aangesteld. Zowel de Raad als het Europees Parlement had vele vragen bij het wetgevingspakket waarop de Commissie besloot het pakket

160 Website Tweede Kamer, Rapporteur bespreekt in Parijs bezwaren Kamer tegen Europees OM.

161 Website Tweede Kamer, Rapporteurs.

162 Website Tweede Kamer, Rapporteur bespreekt in Parijs bezwaren Kamer tegen Europees OM.

163 Eindverslag rapporteur EU-pakket circulaire economie, 13 februari 2017. 
eind 2016 in te trekken. ${ }^{164}$ De bezwaren werden door de Commissie in acht genomen en meegenomen in het nieuwe voorstel. Op 6 mei 2016 publiceerde de Commissie het nieuwe wetgevingspakket: Verordening slimme grenzen: EU-inreis/uitreissysteem. ${ }^{165}$ Een week later schreef de rapporteur een korte brief aan de Kamer over het voorstel en de beëindiging van het rapporteurschap. Het rapporteurschap eindigde omdat dit strikt genomen alleen over het eerste wetgevingspakket ging. $\mathrm{Nu}$ het nieuwe, tweede, pakket gepresenteerd was, was het mandaat voor het rapporteurschap vervuld.

Het doel van elk rapporteurschap is het versterken van de informatievoorziening aan de Kamer om zo optimaal gebruik te kunnen maken van de mogelijkheden om invloed uit te oefenen op het voorstel en de regering. Dat rapporteurschappen worden beëindigd terwijl de Europese wetgevingsprocedure nog niet ten einde is, is wellicht vreemd en vaak niet doelmatig. Aan elk mandaat voor een rapporteurschap wordt echter een termijn gebonden. Het ziet ernaar uit dat deze termijn allesbepalend is. Is de termijn ten einde dan loopt het rapporteurschap af. Het is vreemd dat niet het voorstel dat een versterkte informatievoorziening nodig heeft, bepaalt hoelang een rapporteurschap duurt, maar dat het einde van tevoren wordt vastgelegd. Daarmee wordt aan het doel van een dergelijk rapporteurschap voorbijgegaan.

\subsubsection{Behandeling Commissievoorstellen door de Eerste Kamer}

Voorafgaand aan de inwerkingtreding van het Verdrag van Lissabon heeft de Eerste Kamer een nieuwe werkwijze voor wat betreft de behandeling van nieuwe Europese wetgevingsvoorstellen ontwikkeld. Zij heeft zich bezonnen op haar rol in de Europese context. Daarbij is zij tot de conclusie gekomen dat zij meer aandacht moet hebben voor Europese aangelegenheden en haar rol in de Europese context. Van belang was dat niet enkel de Eerste Kamer als geheel meer aandacht voor Europese aangelegenheden moest hebben, maar ook de Kamercommissies. Het gevolg was dat de behandeling van nieuwe Europese wetgevingsvoorstellen in de Eerste Kamer nagenoeg hetzelfde werd als in de Tweede Kamer. Omdat de Eerste Kamerleden parttimeparlementariërs zijn, hebben zij een hoofdfunctie buiten de Eerste Kamer en er is slechts één effectieve vergaderdag per week. Tijdens deze

164 Position Paper House of Representatives of the States General in The Netherlands with regard to EU proposals regarding Smart Borders, position paper Slimme Grenzen, 29 oktober 2015.

165 Voorstel voor een Verordening tot instelling van een inreis-uitreissysteem (EES) voor de registratie van inreis- en uitreisgegevens en van gegevens over weigering van toegang ten aanzien van onderdanen van derde landen die de buitengrenzen van de Europese Unie overschrijden en tot vaststelling van de voorwaarden voor toegang tot het EES voor rechtshandhavingsdoeleinden en tot wijziging van Verordening (EG) nr. 767/2008 en Verordening (EU) nr. 1077/2011, COM(2016)194; Voorstel voor een Verordening tot wijziging van Verordening (EU) 2016/399 in verband met het gebruik van het inreis-uitreissysteem (EES), $\operatorname{COM}(2016) 196$; Mededeling 'Krachtigere en slimmere informatiesystemen voor grenzen en veiligheid', $\operatorname{COM}(2016) 205$. 
dag moet alle nationale, Europese en internationale ontwerpwetgeving worden getoetst en behandeld. Deze praktische grens brengt mee dat Eerste Kamerleden zich met name richten op die dossiers waarvan zij verwachten dat ze daarin een verschil kunnen maken en hun politieke invloed het grootst is. Dit betekent dat nationale wetsontwerpen soms meer prioriteit hebben dan Europese wetsontwerpen.

\subsubsection{Wetgevings- en werkprogramma}

Ook in de Eerste Kamer worden door de Kamercommissies dossiers geselecteerd op basis van het jaarlijkse wetgevings- en werkprogramma van de Commissie. Het selecteren van Europese voorstellen door de Kamercommissies kan op twee manieren. Ten eerste via het jaarlijkse wetgevings- en werkprogramma van de Europese Commissie, dat elk najaar wordt gepubliceerd. Na publicatie wordt dit programma in elke Kamercommissie geagendeerd. De tweede manier is via het overzicht van aangeboden voorstellen door de Europese Commissie. Dit overzicht, dat wekelijks wordt aangeboden aan de Eerste Kamer, is verwerkt in de Europese nieuwsbrief 'EUpdate'. ${ }^{166}$ Wanneer alle Kamercommissies een selectie hebben gemaakt worden de geselecteerde dossiers op één lijst geplaatst, het jaarlijkse Europese werkprogramma van de Eerste Kamer. Deze lijst is niet definitief. Kamerleden kunnen door het jaar heen dossiers aan de lijst toevoegen. Van elk uitgekozen voorstel dat op dit Europese werkprogramma van de Eerste Kamer wordt geplaatst, wordt een elektronisch dossier aangemaakt, het Edossier. Het Europese werkprogramma wordt nadat het is opgesteld geagendeerd voor het College van Senioren waarna het wordt doorgeleid voor de plenaire vaststelling door de Eerste Kamer. Op het jaarlijkse Europese werkprogramma van de Eerste Kamer staan niet enkel verordeningen en richtlijnen. Kamercommissies kunnen ook besluiten groenboeken, witboeken of andere Europese documenten op de lijst te plaatsen om dit na publicatie te toetsen. De Kamer wacht niet langer op de regeringsappreciatie van het wetgevings- en werkprogramma maar neemt haar eigen verantwoordelijkheid. ${ }^{167}$ Wanneer een Europees voorstel niet wordt aangemerkt als prioritair, dus wanneer het voorstel niet is opgenomen in het jaarlijkse Europese werkprogramma van de Eerste Kamer, wordt het voorstel 'voor kennisgeving aangenomen' en is daarmee de behandeling afgerond. ${ }^{168}$

De behandeling van Europese voorstellen is nagenoeg hetzelfde als de behandeling van nationale voorstellen. De behandeling begint zodra de Kamercommissie een nieuw Commissievoorstel heeft ontvangen; de commissie wacht niet langer op een BNC-fiche van de regering. De Kamercommissie neemt het voorstel in behandeling waarbij het voorstel, net zoals nationale voorstellen, integraal wordt getoetst. Vervolgens besluit zij tot een 'voorbe-

166 Website Eerste Kamer, Europese voorstellen.

167 Kamerstukken I 2009/10, 30953, H, p. 4.

168 Ibid., p. 5. 
reidend onderzoek' en stelt een datum vast voor een inbrengvergadering voor een schriftelijk overleg met de regering. Wanneer dit overleg heeft plaatsgevonden volgt, indien nodig, een nadere inbreng door middel van schriftelijke vragen, óf een mondeling overleg, óf een plenaire behandeling in de Kamer. De procedure is opgenomen in Bijlage I van dit boek. Op elk moment tijdens de behandeling kan de commissie de behandeling afronden door het voorstel 'voor kennisgeving aan te nemen'. ${ }^{169}$ Geprobeerd wordt om de behandeling zo veel mogelijk overeen te laten stemmen met de behandeling van een nationaal wetsvoorstel.

Bij Europese voorstellen zijn echter drie extra stappen mogelijk, namelijk de subsidiariteitstoets, het instemmingsrecht en het parlementair behandelvoorbehoud. De Eerste Kamer vindt zich geen verlengstuk van de Tweede Kamer voor wat betreft Europese zaken. Wat betreft bijvoorbeeld de bevoegdheid tot de gele kaart heeft de Eerste Kamer haar eigen stem en kan zij onafhankelijk van de Tweede Kamer een subsidiariteitstoets uitvoeren en bezwaar maken tegen een voorstel van de Europese Commissie. In dit kader is relevant dat op initiatief van de Eerste Kamer in september 2009 de Tijdelijke Gemengde Commissie Subsidiariteitstoets (gemengde slaat op het feit dat leden van de Tweede en Eerste Kamer lid waren van deze commissie) is opgeheven. Dit had te maken met het feit dat de Eerste Kamer(leden) een grotere rol speelde(n) in deze commissie dan de Tweede Kamer(leden). De Eerste Kamer was van mening dat dit niet zo hoorde. Ook meende de Eerste Kamer dat ze door deze commissie te veel werd gedwongen in het keurslijf van een beperkte toets terwijl per dossier bekeken zou moeten worden welke toets moest worden uitgevoerd (beperkt of brede, integrale toets). Ook verschilden de meningen van de Tweede en Eerste Kamer te veel waardoor de commissie niet goed werkte. Tot slot was het bureaucratische gehalte van de commissie te hoog hetgeen leidde tot tijdsverlies. Dit was zeer nadelig voor beide Kamers omdat de tijdsperiode van acht weken waarin een subsidiariteitsbezwaar opgesteld dient te worden, al krap was. ${ }^{170}$

Net zoals de Tweede Kamer heeft ook de Eerste Kamer een commissie voor Europese Zaken (EUZA) (tot november 2012 commissie voor Europese Samenwerkingsorganisaties (ESO) genaamd). De EUZA houdt zich nauwelijks bezig met nationale wetgeving. De reden hiervoor is dat Europese wetsvoorstellen worden behandeld door de Kamercommissie die daarvoor verantwoordelijk is. De commissie EUZA behandelt met name de overkoepelende Europese thema's die niet tot het beleidsterrein van een van de andere Kamercommissies behoren. ${ }^{171}$ De commissie EUZA heeft, net zoals in de Tweede Kamer, een coördinerende rol met betrekking tot Europese aangelegenheden. Voorheen had de toenmalige

169 Ibid.

170 Kamerstukken I 2008/09, 30953, F, p. 2.

171 Eerste Kamercommissie Europese Zaken (2015), Introductiedossier, Den Haag: Eerste Kamer 12 juni 2015, p. 6. 
commissie ESO een poortwachtersfunctie waarbij zij alle Europese voorstellen besprak. Voorts werd besloten om een voorstel onder de aandacht te brengen van een specifieke Kamercommissie. Door de nieuwe werkwijze kan thans elke Kamercommissie zelf voorstellen agenderen zonder tussenkomt van de commissie EUZA. ${ }^{172}$ De functie van de commissie EUZA is daarmee verschoven van een poortwachtersfunctie naar een coördinerende functie voor wat betreft commissie-overstijgende activiteiten. Een van die activiteiten is deelnemen aan de Conferentie van Commissies van Europese Zaken (COSAC). ${ }^{173}$

Tijdens de behandeling van een voorstel gaat de betrokken Kamercommissie in debat met de regering. Tijdens deze debatten kunnen ministers toezeggingen doen aan de Eerste Kamer. Ieder half jaar wordt de minister herinnerd aan de openstaande toezeggingen waarvan de deadline is verstreken en aan die waarvan de deadline het komend halfjaar zal verstrijken. De reactie van de minister op deze herinnering wordt in de commissie besproken. Wanneer de commissie een brief ontvangt ter nakoming van een toezegging wordt ook deze in de commissie besproken; met name wordt nagegaan of daadwerkelijk aan de toezegging is voldaan. ${ }^{174}$ Op de website van de Eerste Kamer worden alle toezeggingen bijgehouden en daarbij wordt de status van de toezegging aangegeven. ${ }^{175}$ De meeste toezeggingen hebben de status 'voldaan', een enkele toezegging is nog 'openstaand' en een klein aantal heeft de status 'deels voldaan' of 'afgevoerd'.

Het is evenwel mogelijk dat een Kamercommissie het debat breder trekt dan enkel de regering en ook met de Europese Commissie, het Europees Parlement of met nationale parlementen uit andere lidstaten in discussie gaat. Geprobeerd wordt om de behandeling zo veel mogelijk overeen te laten stemmen met de behandeling van een nationaal wetsvoorstel.

In 2011 is de nieuwe werkwijze geëvalueerd en dit resulteerde in enkele aanbevelingen ter versterking ervan. De aanbevelingen betroffen het gebied van (interne) processen die door de Kamercommissies worden gevolgd en het contact tussen de Kamer en de regering. De Kamer vroeg om een tijdigere informatievoorziening en doelde met name op de aanbieding van BNC-fiches. Het belang hiervan voor de Kamer is om zich zo tijdig een oordeel te kunnen vormen omtrent het eventueel inroepen van een parlementair behandelvoorbehoud of het oordeel van de regering mee te kunnen nemen in de dialoog met de Europese Commissie. Naar aanleiding van de evaluatie van de werkwijze is de informatievoorziening

172 De commissie ESO is opgericht op 23 juni 1973, jaren voordat de Tweede Kamer een commissie voor Europese Zaken oprichtte.

173 Eerste Kamercommissie Europese Zaken (2015), Introductiedossier, Den Haag: Eerste Kamer 12 juni 2015, p. 6.

174 Ibid., p. 11.

175 Website Eerste Kamer, toezeggingen. 
door de regering aan de Eerste Kamer verbeterd, maar desondanks blijft dit een aandachtspunt. $^{176}$

De afgelopen jaren is het aantal geselecteerde dossiers uit het werkprogramma van de Europese Commissie gedaald. De verklaring hiervoor ligt in het feit dat het werkprogramma van de Commissie is geslonken. Daarnaast wil de Kamer zich beter concentreren op de geselecteerde dossiers en daarom selecteert zij minder dossiers. Kamerleden richten met name hun aandacht op dossier waarvan kan worden verwacht dat met de inbreng van de Kamerleden een verschil kan worden gemaakt en waar de politieke invloed het grootst is. ${ }^{177}$ Hierin is overigens geen rode draad te herkennen. De geselecteerde voorstellen betreffen vele verschillende onderwerpen. De Eerste Kamer heeft een voorstel voor wijziging van de verordening tot afschaffing van visumplicht voor Oekraïne geselecteerd evenals een voorstel voor een verordening betreffende grensoverschrijdende pakketbezorgdiensten. Alle geselecteerde voorstellen zijn op de website EuropaPoort van de Eerste Kamer te vinden. ${ }^{178}$

Wanneer een nieuw Commissievoorstel is gepubliceerd en een Kamercommissie besluit hiermee aan de slag te gaan beschikt deze over meerdere controle-instrumenten. Daarbij valt op dat in de meerderheid van de gevallen de handelingen van de Kamercommissie gericht zijn op het verkrijgen van antwoorden op vragen die het voorstel oproept. In plaats van deze vragen voor te leggen aan de Commissie via bijvoorbeeld de politieke dialoog, worden deze vragen voorgelegd aan de Nederlandse regering. Hoewel de Kamer op grond van artikel 4 van de Goedkeuringswet van het Verdrag van Lissabon een parlementair behandelvoorbehoud kan plaatsen bij een Commissievoorstel, wordt doorgaans gekozen voor de inlichtingenplicht van de regering op grond van artikel 68 van de Grondwet. De Kamer is van mening dat zij op basis van deze inlichtingenplicht voldoende over het Commissievoorstel wordt geïnformeerd. Tot op heden heeft de Eerste Kamer geen gebruik gemaakt van het parlementair behandelvoorbehoud. ${ }^{179}$

De afgelopen jaren zijn veel brieven aan de Commissie gestuurd. De ervaring van de Eerste Kamer daarmee is dat de beantwoording van de Commissie te wensen overlaat. Zowel de tijdigheid als de kwaliteit van de antwoorden is voor verbetering vatbaar. Het gevolg hiervan is dat Kamerleden sneller geneigd zijn hun vragen aan de Nederlandse regering te stellen in plaats van aan de Commissie. De regering reageert doorgaans binnen vier tot zes weken, de Commissie streeft ernaar om binnen drie maanden te antwoorden.

176 Kamerstukken I 2009/10, 30953, H.

177 F. Bergman \& I. van den Driessche, 'De Eerste Kamer en "Europa”, Internationale Spectator 2015, nr. 8, p. 2.

178 Website Eerste Kamer, geselecteerde voorstellen.

179 F. Bergman \& I. van den Driessche, 'De Eerste Kamer en "Europa”, Internationale Spectator 2015, nr. 8, p. $2-3$. 
De Eerste Kamer is actief ten aanzien van EU-aangelegenheden dus met name via de eigen regering. ${ }^{180}$

Een Europees voorstel dat de Eerste Kamer nauwlettend in de gaten heeft gehouden is het voorstel van de Commissie tot instelling van het Europees Openbaar Ministerie. ${ }^{181}$ Dit bekende voorstel werd op 17 juli 2013 gepubliceerd en is vanaf het begin door de Eerste Kamer gevolgd. Het voorstel werd om te beginnen door de commissies voor Veiligheid en Justitie (V\&J) en voor Immigratie en Asiel/JBZ-Raad (I\&A/JBZ) als prioriteit geselecteerd uit het werkprogramma van de Europese Commissie van 2013. ${ }^{182} \mathrm{Na}$ publicatie werd de procedure voor behandeling van het voorstel binnen de commissies V\&J en I\&A/JBZ besproken. Daar werd onder andere besproken om inbreng te leveren voor een schriftelijk overleg. Verschillende partijen gaven aan subsidiariteitsbezwaren te hebben met betrekking tot het voorstel. Van de voorzitter van de commissie voor Europese Zaken van de Tweede Kamer ontving de Eerste Kamer het bericht dat de commissie van Veiligheid en Justitie van de Tweede Kamer een subsidiariteitstoets had uitgevoerd en dat daaruit een negatief oordeel kwam. Een meerderheid van de fracties van de Eerste Kamer kon zich vinden in de argumentatie van het negatieve subsidiariteitsoordeel van de Tweede Kamer. Daarop heeft een meerderheid van de Eerste Kamer ingestemd met een gemotiveerd advies aan de Europese Commissie dat is opgesteld door de voorzitters van de commissie I\&A/JBZ en V\&J. Op 17 oktober 2013 werd de brief aan de Europese Commissie verzonden. Binnen een maand, namelijk op 12 november 2013, ontving de Eerste Kamer een reactie van de Europese Commissie. In die brief gaf de Commissie aan dat de drempel voor een gele kaart was gehaald en dat de Commissie het voorstel zou heroverwegen.

Eind november 2013 ontvingen alle nationale parlementen het bericht van de Europese Commissie dat zij van mening was dat het voorstel niet in strijd was met het subsidiariteitsbeginsel. Het voorstel zou daarom niet worden gewijzigd of ingetrokken. De commissies I\&A/JBZ en V\&J besloten daarop hun pijlen te richten op de regering en een inbreng te leveren voor een schriftelijk overleg met de regering. De commissies wilden van de regering weten welke positie de regering zou innemen tijdens de onderhandelingen, gegeven de subsidiariteitsbezwaren door beide Kamers van het parlement. In een reactie gaf de minister van Veiligheid en Justitie aan niet in te stemmen met het voorstel daar een meerderheid van de Tweede Kamer dit wenste. Na het schriftelijk overleg besloot de Eerste Kamer de rapporteur voor het Europees Openbaar Ministerie van de Tweede Kamer, VVD-Kamerlid Van der Steur, uit te nodigen in de Eerste Kamer om zijn aanstelling en mandaat toe te lichten.

180 Ibid., p. 5-6.

181 Voorstel voor een Verordening tot instelling van het Europees Openbaar Ministerie, COM(2013)534.

182 Zie nr. 19 van de 'Prioritaire selectie uit het WP2013 van de Europese Commissie' via website Eerste Kamer, prioritaire selectie. 
Op 1 april 2014 bracht de rapporteur een bezoek aan de Eerste Kamer en informeerde de Kamer over zijn aanstelling en mandaat, over een alternatief voorstel van het Griekse voorzitterschap en over zijn voornemen een position paper op te stellen. In april besloten de commissies I\&A/JBZ en V\&J, naar aanleiding van de position paper, te willen samenwerken met de rapporteur EOM van de Tweede Kamer. Ook wenste de Eerste Kamer zich aan te sluiten bij een kritische brief die de Tweede Kamer aan de Europese Commissie wilde sturen naar aanleiding van de reactie van de Commissie op de subsidiariteitsbezwaren. In oktober 2014 besloot de commissie I\&A/JBZ schriftelijke vragen te stellen aan de regering naar aanleiding van haar geannoteerde agenda van de JBZ-Raad in oktober. In het voorjaar van 2015 voerde de commissie I\&A/JBZ mondeling overleg met de minister van Veiligheid en Justitie over de stand van zaken met betrekking tot de onderhandelingen over het voorstel. Ook hield de minister de Eerste Kamer via brieven op de hoogte van de ontwikkelingen. Na vele briefwisselingen tussen de minister van Veiligheid en Justitie en de commissies I\&A/JBZ en V\&J volgde in het voorjaar van 2016 wederom een mondeling overleg waarin de minister de commissies op de hoogte bracht van de stand van zaken van de onderhandelingen over het voorstel.

De commissies I\&A/JBZ en V\&J hechtten veel waarde aan de geannoteerde agenda die voor elke JBZ-Raad aan de Kamer wordt gestuurd. Doorgaans werd deze geannoteerde agenda besproken binnen de commissies, een enkele keer werd deze voor kennisgeving aangenomen. Naar aanleiding van een brief van de minister van Veiligheid en Justitie over de stand van zaken voor wat betreft de onderhandelingen binnen de Raad werd een plenair debat aangevraagd en gehouden op 6 december $2016 .{ }^{183}$ Tijdens dit debat werd wederom de stand van zaken voor wat betreft het voorstel besproken evenals de procedurele gang van zaken. ${ }^{184}$ Ook in 2017 bleef het voorstel hoog op de agenda van de commissies I\&A/JBZ en V\&J staan, werd het vrijwel maandelijks besproken binnen de commissies en stelden de commissies schriftelijk vragen aan de minister van Veiligheid en Justitie die ook schriftelijk werden beantwoord. De minister heeft herhaaldelijk aangegeven niet te zullen instemmen met het voorstel in de Raad gezien het negatieve oordeel over het voorstel van beide Kamers van het parlement. Dit geeft mooi weer dat het effectief kan zijn om de eigen regering onder druk te zetten. Ook al betreft het een Europees voorstel en ligt het voor de hand om de 'Europese' bevoegdheden in te zetten zoals de subsidiariteitstoets, het is ook dan nuttig (en effectief) om de nationale bevoegdheden in te zetten om de eigen regering te bestoken.

Per brief van 7 april 2017 informeerde de minister van Veiligheid en Justitie de Eerste Kamer over het voornemen van zestien lidstaten om een nauwere samenwerking aan te

183 Kamerstukken I 2016/17, 33709, W, brief van de minister van Veiligheid en Justitie d.d. 25 november 2016.

184 Verslag van de plenaire vergadering van dinsdag 6 december 2016, 2016-2017, $10^{\mathrm{e}}$ vergadering. 
gaan voor wat betreft het Europees Openbaar Ministerie (EOM) ${ }^{185}$ In een latere brief, van 2 juni 2017, informeerde de minister wederom de Kamer over de stand van zaken voor wat betreft het voorstel. Ook gaf de minister aan geen definitief standpunt binnen de Raad in te nemen over de deelname aan het EOM. Dit zal Nederland pas doen wanneer de tekst van het voorstel definitief is en beide Kamers van het parlement een oordeel daarover hebben kunnen vormen. Het kabinet heeft echter de Eerste Kamer in november 2016 al geïnformeerd over de voor- en nadelen van deelname aan de nauwere samenwerking en is voor deelname aan het Europees Openbaar Ministerie. ${ }^{186}$

Tussen zomer 2017 en januari 2018 is er vrijwel geen contact geweest tussen de regering en de Kamer over het voorstel in verband met de formatie van een nieuw kabinet na de Tweede Kamerverkiezingen van 15 maart 2017. Op 3 april 2018 voerde de Eerste Kamer een debat met de minister van Justitie en Veiligheid over een eventuele deelname aan de nauwere samenwerking met betrekking tot het Europees Openbaar Ministerie. ${ }^{187}$ Tijdens dit debat heeft de Kamer echter geen definitief oordeel over deze deelname gegeven. ${ }^{188}$ In het debat van 17 april 2018 vond een derde termijn plaats en vond de stemming over alle ingediende moties plaats. De motie-Van Hattem ${ }^{189}$ c.s. waarin de regering wordt opgeroepen af te zien van deelname aan het Europees Openbaar Ministerie, werd verworpen en de gewijzigde motie-Duthler c.s. over een Nederlandse deelname werd aangenomen, waarmee besloten werd dat Nederland zou meedoen aan het Europees Openbaar Ministerie. ${ }^{190}$

Het bovenstaande voorbeeld illustreert hoe de Eerste Kamer met (belangrijke) Europese voorstellen omgaat. Zo is te lezen dat de Kamer vele mogelijkheden aangrijpt om op de hoogte te blijven van alle ontwikkelingen omtrent het voorstel. Er zijn vele schriftelijke debatten gevoerd, er is een subsidiariteitstoets uitgevoerd, er zijn schriftelijke vragen gesteld en zelfs mondelinge overleggen en debatten gehouden. Dit laatste komt niet vaak voor aangezien de Kamer doorgaans schriftelijk contact houdt met de regering. De Eerste Kamer doet niet enkel een beroep op de eigen regering maar ook op de Europese Commissie.

Ook illustreert het voorbeeld hoe beide Kamers van het parlement bij belangrijke voorstellen samenwerken. Door samen te werken kunnen de Kamers elkaar versterken en kan voorkomen worden dat iedere Kamer afzonderlijk het wiel moet uitvinden. Denk bijvoorbeeld aan een gezamenlijke reactie aan de Europese Commissie. Vele brieven aan de Europese Commissie zijn door de Tweede en Eerste Kamer gezamenlijk verstuurd. Op

185 Kamerstukken I 2016/17, 33709, AB, Brief van de minister van Veiligheid en justitie d.d. 7 april 2017.

186 Kamerstukken I 2016/17, 33709, W.

187 Sinds kabinet Rutte-III is de naam van de minister van Veiligheid en Justitie gewijzigd in minister van Justitie en Veiligheid.

188 Verslag van de plenaire vergadering van dinsdag 3 april 2018, 2017-2018, $25^{\mathrm{e}}$ vergadering; Website Eerste Kamer, Voorstel EOM.

189 Kamerstukken I 2017/18, 33709, AF.

190 Kamerstukken I 2017/18, 33709, AH. 
vele wijzen heeft de regering beide Kamers van het parlement op de hoogte gehouden over de ontwikkelingen rond het Europees Openbaar Ministerie. Deze uitgebreide en nauwkeurige inlichtingenstroom heeft wellicht ook te maken met het behandelvoorbehoud dat door de Tweede Kamer is geplaatst en waar ook de Eerste Kamer van heeft kunnen profiteren. De Eerste Kamer kan de berichtgeving van de minister aan de Tweede Kamer volgen waardoor een 'eigen' behandelvoorbehoud wellicht overbodig is. Tot slot, de Eerste Kamer documenteert op haar website 'Europapoort' (www.eerstekamer.nl/eu) het gehele voorstel met alle stappen, documenten en andere relevante informatie zeer nauwkeurig. Hier wordt niet enkel de weg beschreven die het voorstel in de Eerste Kamer heeft afgelegd maar ook die in de Tweede Kamer. ${ }^{191}$ Dit is van groot belang voor onderzoekers en geïnteresseerde burgers. Een dergelijke documentatie wordt (helaas) niet door de Tweede Kamer gedaan.

\subsubsection{Nieuwe nationale bevoegdheden na Lissabon}

De Rijkswet houdende goedkeuring van het Verdrag van Lissabon tot wijziging van het Verdrag bevat twee (nieuwe) bevoegdheden voor het Nederlandse parlement, het zogenoemde instemmingsrecht (art. 3) en het behandelvoorbehoud (art. 4). ${ }^{192}$ Beide instrumenten worden gebruikt om de regering te controleren in het kader van Europese besluitvorming. Verdere uitwerking van deze bevoegdheden is te vinden in het Reglement van Orde van de Tweede Kamer en de Procedureregeling parlementair behandelvoorbehoud.

\subsubsection{Instemmingsrecht}

Bepaalde EU-besluiten op het gebied van Justitie en Binnenlandse Zaken behoeven instemming van het Nederlandse parlement. Het gaat om besluiten over paspoorten, familierecht en bepaalde vormen van politiesamenwerking. Deze bevoegdheid is opgenomen in artikel 3 van de Goedkeuringswet van het Verdrag van Lissabon. Geheel nieuw is het instemmingsrecht niet. Het bestond namelijk al voor het Verdrag van Lissabon ten aanzien van Europese besluiten in het kader van de derde pijler. ${ }^{193}$ Bij de Goedkeuringswet heeft het parlement echter besloten om een groot gedeelte van zijn bevoegdheid op te geven door het instemmingsrecht op minder besluiten van toepassing te laten zijn. Door het Verdrag van Lissabon werd het Europees Parlement een volledig bevoegde medewetgever. De Raad van State redeneerde dat het instemmingsrecht voor die besluiten waarbij het Europees Parlement medewetgever werd, overbodig en onwenselijk was. De meerderheid

191 Het voorstel tot oprichting van het Europees Openbaar Ministerie is op de website Europapoort terug te vinden onder nummer E130041 (www.eerstekamer.nl/eu/edossier/e130041_voorstel_voor_een).

192 Art. 3 en 4 Rijkswet houdende goedkeuring van het Verdrag van Lissabon tot wijziging van het Verdrag betreffende de Europese Unie en het Verdrag tot oprichting van de Europese Gemeenschap.

193 De derde pijler omvatte beleid op het gebied van Justitie en Binnenlandse Zaken (JBZ). 
van de Tweede Kamer ging hierin mee. ${ }^{194}$ Wanneer het gaat om besluiten op het terrein van strafrecht, asiel en politiesamenwerking waarover de Raad met eenparigheid van stemmen moet beslissen, is een uitzondering gemaakt. ${ }^{195}$ Deze onderwerpen zijn zo politiek gevoelig dat, hoewel ook hier de Raad medewetgever is geworden, het handhaven van het instemmingsrecht voor deze besluiten nodig werd geacht. Artikel 3 van de Goedkeuringswet geeft aan dat ontwerpbesluiten overeenkomstig artikel 77 lid 3 (vaststellen bepalingen over paspoorten, identiteitskaarten, verblijfsvergunningen e.d.), artikel 87 lid 3 (maatregelen over operationele samenwerking tussen politie, douane en andere wetshandhavingsdiensten) en artikel 89 (voorwaarden voor optreden van politiële autoriteiten op het grondgebied van een andere lidstaat) instemming van het parlement vereisen voordat de vertegenwoordiger van het Koninkrijk zijn medewerking kan verlenen aan de totstandkoming van het besluit. De drie onderdelen vallen onder titel V over de ruimte van vrijheid, veiligheid en recht van het Verdrag betreffende de werking van de Europese Unie. Ook voor besluiten op het terrein van grensoverschrijdend familierecht blijft het instemmingsrecht van beide Kamers gelden (art. 81 lid 3 VWEU).

Zodra de ontwerptekst van een voorstel dat Nederland beoogt te binden openbaar wordt gemaakt, dient de tekst ter instemming te worden voorgelegd aan de Tweede en de Eerste Kamer. Instemming kan zowel op stilzwijgende als uitdrukkelijke manier gebeuren. Stilzwijgende instemming vindt plaats wanneer niet binnen vijftien dagen na het overleggen van het ontwerpbesluit aan de Tweede en Eerste Kamer, een of beide Kamers heeft/hebben aangegeven dat uitdrukkelijke instemming wordt gewenst. ${ }^{196}$ Omdat de onderhandelingen binnen de Raad vaak doorgaan tot kort, soms daags, voor de raadsvergadering, is het echter niet altijd mogelijk om gebruik te maken van het stilzwijgende instemmingsrecht. De finale tekst wordt pas na de onderhandelingen openbaar gemaakt en dan zitten er geen vijftien dagen meer tussen het openbaar maken en de raadsvergadering. Het parlement en de regering zijn zich hiervan bewust en de regering doet er alles aan om de Kamer zo goed en snel mogelijk te informeren. Hiertoe heeft de regering een drietal afspraken met het parlement gemaakt. Ten eerste zal door Nederland een parlementair behandelvoorbehoud worden geplaatst op alle voorstellen waarvoor instemming is vereist. Ten tweede zal de regering in het overzicht van JBZ-dossiers dat zij per kwartaal aan de Kamers stuurt, aangeven welke dossiers instemming vereisen. En tot slot legt de verantwoordelijke minister de finale tekst van een voorstel waarvoor op grond van artikel 81 lid 3 VWEU unanimiteit in de Raad is vereist, voor aan beide Kamers met het verzoek om schriftelijke

194 Kamerstukken II 2007/08, 31374 (R 1850), 4, p. 20.

195 Art. 3 Rijkswet houdende goedkeuring van het Verdrag van Lissabon tot wijziging van het Verdrag betreffende de Europese Unie en het Verdrag tot oprichting van de Europese Gemeenschap.

196 Procedureregeling parlementaire instemming Verdrag van Lissabon (het Verdrag betreffende de werking van de Europese Unie) via website Tweede Kamer, JBZ-procedure. 
instemming. ${ }^{197}$ De eerste afspraak is enigszins vreemd omdat volgens artikel 4 lid 4 van de Goedkeuringswet van het Verdrag van Lissabon, het parlementair behandelvoorbehoud niet kan worden ingezet op voorstellen waarvoor parlementaire instemming is vereist. Desondanks gebeurt dit dus toch maar dit zal naar alle waarschijnlijkheid geen negatieve gevolgen hebben voor zowel het parlement als de regering. Dit kan worden gezien als een positief gebaar van de regering aan het parlement. De procedure voor instemming is enigszins gewijzigd over de jaren. In eerste instantie werd het instemmingsverzoek via een aanbiedingsbrief bekend gemaakt. Op een gegeven moment is besloten om dit via de geannoteerde agenda van de JBZ-Raad te doen. Voor de behandeling van het voorstel en de instemming heeft deze wijziging geen gevolgen gehad, in die zin dat alle voorgelegde verzoeken zijn behandeld en er uiteindelijk is ingestemd.

\subsection{Tweede Kamer en Eerste Kamer}

In de Tweede Kamer adviseert de vaste Kamercommissie voor Veiligheid en Justitie en in de Eerste Kamer de vaste Kamercommissie voor Immigratie \& Asiel en JBZ-Raad (I\&A/JBZ) over het al dan niet verlenen van instemming. Omdat het instemmingsrecht voor besluiten geldt op het gebied van de expertise ${ }^{198}$ van deze commissie, is niet de commissie voor Europese Zaken maar deze commissie belast met het geven van advies. Op basis van dit advies beslissen de beide Kamers. Deze commissie controleert of de binnengekomen voorstellen aan de formele eisen voldoen. De voorstellen moeten op tijd worden aangeleverd, dat wil zeggen ten minste vijftien dagen voor een raadsvergadering; daarnaast moeten ze openbaar zijn en in het Nederlands opgesteld zijn. ${ }^{199}$ Als een voorstel niet aan deze eisen voldoet, adviseert de commissie om de toestemming niet te verlenen op basis van formele gronden. Daarna volgt een inhoudelijke toets. ${ }^{200}$

In de periode 2010 tot en met 2016 heeft het parlement drie keer ingestemd met nieuwe Europese wetgeving op het terrein van paspoorten, familierecht en bepaalde vormen van politiesamenwerking. Instemming is nog nooit niet verleend. De instemming voor het voorstel van de toetreding van Peru, Zuid-Korea en Kazachstan tot het Haags Kinderontvoeringsverdrag vond stilzwijgend plaats. ${ }^{201}$ Met betrekking tot dit voorstel heeft de minister van Veiligheid en Justitie tweemaal instemming gevraagd omdat de tekst van het voorstel na de eerste instemming werd gewijzigd. De instemming met de twee voorstellen

197 Kamerstukken I 2015/16, 32317, FY, p. 3, brief van 4 maart 2016.

198 Het gaat om de besluiten inzake paspoorten, identiteitskaarten, verblijfsvergunningen (art. 77 lid 3 VWEU), politiële samenwerking (art. 87 lid 3 VWEU), optreden van o.a. politie, douane en andere gespecialiseerde wetshandhavingsdiensten in andere lidstaten (art. $89 \mathrm{VWEU})$.

199 Kamerstukken I 1995/96, 23490, nr. 90c.

200 Website Eerste Kamer, Instemmingsrecht.

201 Besluitenlijst van de procedurevergadering van woensdag 22 juni 2016, vaste commissie voor Veiligheid en Justitie, Tweede Kamer d.d. 23 juni 2016, agendapunt 56. 
voor nauwere samenwerking op het terrein van huwelijksvermogensrecht en geregistreerd partnerschap vond uitdrukkelijk plaats. ${ }^{202}$ Voorafgaand aan de uitdrukkelijke instemming is er een debat met de minister van Veiligheid en Justitie in de Tweede Kamer. Bij de instemming met de nauwere samenwerking met betrekking tot het huwelijksvermogensrecht en het geregistreerd partnerschap vond een versnelde instemming plaats omdat er tussen het overleggen van het ontwerpbesluit en de stemming in de Raad slechts enkele dagen zaten. Er was dus geen tijd om de termijn van vijftien dagen af te wachten en stilzwijgende toestemming te verlenen. Toestemming moest dus uitdrukkelijk en heel snel. ${ }^{203}$ Naar aanleiding van deze situatie heeft de vaste commissie voor Europese Zaken samen met de vaste commissie voor Veiligheid en Justitie, mede namens de commissies Veiligheid en Justitie en Immigratie en Asiel/JBZ-Raad in de Eerste Kamer, nieuwe werkafspraken gemaakt over het instemmingsrecht met de regering. ${ }^{204}$ Hierin is, als reactie op de versnelde instemming, de volgende tekst opgenomen: 'Indien de finale tekst niet uiterlijk 15 dagen voor de besluitvormende Raad aan de Kamers kan worden verzonden, bevat het instemmingsverzoek een toelichting hieromtrent en wordt tevens aangegeven op welke wijze de Kamers zijn geïnformeerd over de voortgang van het dossier. ${ }^{205}$ In 2015 is instemming gevraagd voor een voorstel inzake huwelijksvermogensrecht en geregistreerde partnerschappen. ${ }^{206}$ Het parlement heeft hiermee uitdrukkelijk ingestemd. ${ }^{207}$ De derde instemming betrof een voorstel tot herziening van Brussel IIbis. ${ }^{208}$

\subsubsection{Parlementair behandelvoorbehoud}

Het behandelvoorbehoud is strikt genomen niet gerelateerd aan het Verdrag van Lissabon. Het is door het amendement-Wiegman-van Meppelen Scheppink en Ten Broeke in de Goedkeuringswet opgenomen. ${ }^{209}$ Het parlementair voorbehoud, zoals het behandelvoorbehoud in de Goedkeuringswet wordt genoemd, is een extra informatievoorziening voor de Kamer. Zoals de Procedureregeling parlementair behandelvoorbehoud aangeeft: 'Het uitgangspunt van het behandelvoorbehoud is het versterken c.q. entameren van het politieke debat in de Tweede Kamer over Europese wetgevende voorstellen, teneinde de eigenstandige oordeelsvorming van de Kamer te stimuleren en te faciliteren. ${ }^{210} \mathrm{Nu}$ bestaat de grondwet-

202 Handelingen II 2015/16, 32, item 10; Handelingen II 2015/16, 32, item 11.

203 Kamerstukken II 2015/16, 32317, nr. 384, p. 2.

204 Kamerstukken II 2016/17, 32317, nr. 465.

205 Kamerstukken II 2016/17, 32317, nr. 465.

206 Kamerstukken I/II 2015/16, 32317, FO/nr. 365.

207 Kamerstukken II 2015/16, 32317, nr. 367.

208 Kamerstukken I 2015/16, 32317, GS.

209 Kamerstukken II 2007/08, 31384, nr. 23.

210 Procedureregeling voor de behandeling door de Kamer van wetgevende voorstellen van de Europese Unie in het kader van het parlementair behandelvoorbehoud en in het kader van de toetsing op aspecten van Europese rechtsgrondslag, subsidiariteiten, p. 2. 
telijke informatieplicht uit artikel 68 Grondwet ook ten aanzien van Europese aangelegenheden, waardoor het parlementair behandelvoorbehoud moet worden gezien als een 'bijzondere informatieplicht'. De Kamer wil met het plaatsen van een parlementair behandelvoorbehoud niet de behandeling van Europese ontwerpwetgeving in Brussel blokkeren of vertragen. Dit is het cruciale verschil met het instemmingsrecht, waarmee het parlement 'nee' kan zeggen tegen Europese ontwerpwetgeving. Het doel van deze bijzondere informatieplicht is het benadrukken van het politieke gewicht dat de Kamer verbindt aan het voorstel en om te voorkomen dat de regering voorbarig instemt met het voorstel. ${ }^{211}$ Beide Kamers hebben de mogelijkheid om binnen twee maanden nadat ze een wetsvoorstel van de Commissie hebben ontvangen een parlementair behandelvoorbehoud te plaatsen. ${ }^{212}$ Dat wil zeggen dat de Kamercommissie een oordeel wil opstellen over de noodzaak om een parlementair behandelvoorbehoud te plaatsen aangezien de commissie het voorstel van zodanig politiek belang acht dat zij over de behandeling daarvan op bijzondere wijze wenst te worden geïnformeerd door de regering. Daarnaast of apart zou de Kamercommissie een oordeel kunnen willen geven over de Europese rechtsgrondslag, de subsidiariteit en de proportionaliteit van het voorstel. ${ }^{213} \mathrm{Zij}$ deelt dit schriftelijk mede aan de regering waarna de regering de EU in kennis stelt van het parlementair voorbehoud.

Of een parlementair voorbehoud wordt geplaatst, wordt plenair beslist. Binnen vier weken na het plaatsen van het behandelvoorbehoud vindt een overleg plaats tussen de regering en de Kamer over het politieke belang van het voorstel. Tijdens dit overleg worden afspraken gemaakt over nadere informatievoorziening, prioriteiten, en strategieën met betrekking tot de onderhandelingen op Europees niveau. ${ }^{214}$ Artikel 4 lid 3 Goedkeuringswet geeft geen nadere invulling aan het overleg. De Kamer heeft daarmee de vrijheid om het debat naar eigen inzicht in te richten. Aangezien in het eerste lid wordt gesproken over maanden en in het derde lid over weken, mag worden aangenomen dat de twee maanden in het eerste lid meer zijn dan acht weken. Daarnaast wordt uitgegaan van ontvangst van de Nederlandstalige versie van het voorstel, hetgeen eveneens bij de subsidiariteitstoets het geval is. ${ }^{215}$ Tot slot worden de afspraken tussen de Kamer en de minister schriftelijk bevestigd door de minister. Hierna vervalt het voorbehoud in de Raad. De minister mag in de tussentijd in de Raad geen beslissingen nemen die onomkeerbaar zijn. Door het

211 Eerste Kamer, Memo 'Uitwerking procedure parlementair behandelvoorbehoud Eerste Kamer', Den Haag: Eerste Kamer 4 maart 2010, p. 4.

212 Het moet gaan om een voorstel als bedoeld in art. 2 van het Protocol betreffende de rol van de nationale parlementen in de Europese Unie.

213 Art. 5 Procedureregeling voor de behandeling door de Kamer van wetgevende voorstellen van de Europese Unie in het kader van het parlementair behandelvoorbehoud en in het kader van de toetsing op aspecten van Europese rechtsgrondslag, subsidiariteit en proportionaliteit (Kamerstukken II 2009/10, 32258).

214 Zie ook onderdeel 'Algemeen Overleg'.

215 Eerste Kamer, Memo ‘Uitwerking procedure parlementair behandelvoorbehoud Eerste Kamer’, Den Haag: Eerste Kamer 4 maart 2010, p. 6. 
behandelvoorbehoud worden de Kamers tijdens de onderhandelingen over nieuwe Europese wetgeving, tussen voorstel en besluit, op de hoogte gehouden. De Kamers blijven zo op de hoogte van de ontwikkelingen en kunnen wijzigende regeringsstandpunten met de regering bespreken. ${ }^{216}$ Het behandelvoorbehoud geldt voor alle EU-voorstellen met uitzondering van die voorstellen, zoals de Goedkeuringswet aangeeft, op het gebied van Justitie en Binnenlandse Zaken (JBZ) waarvoor de instemmingsprocedure geldt. ${ }^{217}$

De afspraken die gemaakt worden tijdens het behandelvoorbehoud zijn niet juridisch afdwingbaar maar het behandelvoorbehoud wordt desondanks gezien als een sterk instrument om de regering c.q. een minister te sturen en te controleren. ${ }^{218}$ Door het behandelvoorbehoud wordt de regering gedwongen vanaf het begin van het Europese besluitvormingsproces afspraken te maken met de Kamer over onder andere aandachtspunten en de wijze van informatieverstrekking tijdens het proces. ${ }^{219}$

In de Eerste Kamer kan het besluit om het parlementair voorbehoud in te zetten worden genomen op voorstel van de voorzitter, van een commissie of van een van de Kamerleden (art. $73 \mathrm{RvO}$ I). De vakcommissie op wier beleidsterrein het voorstel ligt, heeft de taak om te bepalen of het voorstel van zodanig politiek belang is dat zij over de behandeling daarvan op bijzondere wijze geïnformeerd wenst te worden en verlangt dat de regering een voorbehoud plaatst in Brussel. Indien de commissie hiervoor aanleiding ziet, zal het besluit plenair genomen moeten worden. Het debat dat binnen vier weken moet volgen kan mondeling of schriftelijk plaatsvinden. De werkwijze van de Eerste Kamer is om procedures schriftelijk af te handelen. In dit geval zou een mondeling debat het belang van het parlementair behandelvoorbehoud aangeven. Het is immers een speciale wijze van informatieverstrekking en wijkt af van de normale procedure van het totstandkomingsproces van wetten. ${ }^{220}$

\subsection{Tweede Kamer}

Zoals eerder beschreven heeft de Kamer de vrijheid om het overleg met de regering naar eigen wensen in te richten. De Tweede Kamer heeft gekozen voor de vorm van een speciaal algemeen overleg ( $\mathrm{AO}$ ). Omdat het om een $\mathrm{AO}$ gaat, is het mogelijk dat het verslag algemeen overleg plenair wordt behandeld zodat het indienen van moties mogelijk is.

216 J. Kester \& M. van Keulen, “De Tweede Kamermethode”: versterkte parlementaire invloed op Europese besluitvorming', RegelMaat 2011, afl. 6, p. 306.

217 Procedureregeling voor de behandeling door de Kamer van wetgevende voorstellen van de Europese Unie in het kader van het parlementair behandelvoorbehoud en in het kader van de toetsing op aspecten van Europese rechtsgrondslag, subsidiariteiten, p. 2.

218 W. Mastenbroek e.a., Engaging with Europe.Evaluating national parliamentary control of EU decision making after the Lisbon Treaty. Part I: Report of findings, Den Haag: Tweede Kamer der Staten-Generaal 2014, p. 14.

219 Tweede Kamer, 'Bovenop Europa: Evaluatie van de versterkte EU-ondersteuning van de Tweede Kamer 2007-2011', Den Haag: Tweede Kamer, p. 6.

220 B. van Mourik, Parlementaire controle op Europese besluitvorming. Een rechtsvergelijkend onderzoek naar mandaatsystemen en parlementaire behandelingsvoorbehouden, Nijmegen: Wolf Legal Publishers 2012, p. 57-58. 
De Tweede Kamer heeft in de periode 2010-2016 in totaal zo'n 86 behandelvoorbehouden geplaatst. In het jaar 2010, toen het behandelvoorbehoud net was geïntroduceerd, werden er vijf geplaatst. In de jaren erna werden het er meer en in 2016 werden er zelfs 25 geplaatst. In 2013 zijn er vergeleken met andere jaren veel behandelvoorbehouden geplaatst. In dat jaar waren het er 21. Het jaar ervoor, 2012, zijn slechts vier behandelvoorbehouden geplaatst. De aantallen in 2012 en 2013 kunnen verklaard worden door de verkiezingen die in 2012 werden gehouden. De Tweede Kamer ten tijde van het kabinet-Rutte I wist in april 2012 dat zij moest vertrekken. De behandelvoorbehouden in 2012 zijn dan ook in de eerste vier maanden van het jaar geplaatst. Later dat jaar zijn geen nieuwe voorbehouden geplaatst. Het kabinet-Rutte II werd in november 2012, na slechts 54 dagen formatieonderhandelingen, beëdigd. De nieuwe Tweede Kamer werd eind september geïnstalleerd. Prioriteit van de Kamer was de begroting van 2013.

Nog niet alle Kamercommissies maken gebruik van het behandelvoorbehoud. Het zijn met name de Kamercommissies voor Veiligheid en Justitie en Economische Zaken die de voorbehouden plaatsen. De Kamercommissie voor Veiligheid en Justitie plaatste ongeveer 35 voorbehouden in de onderzochte periode. De Kamercommissie voor Economische Zaken plaatste ongeveer 20 voorbehouden. Andere actieve commissies waren de commissie voor Infrastructuur en Milieu, de commissie voor Financiën en de commissie voor Sociale Zaken en Werkgelegenheid.

In tabel 9 is in de tweede kolom het aantal geplaatste behandelvoorbehouden per jaar opgenomen. In de derde kolom is opgenomen hoeveel behandelvoorbehouden de Tweede Kamer van plan was te plaatsen op basis van het wetgevings- en werkprogramma van de Europese Commissie. Een deel van de geplaatste behandelvoorbehouden is formeel beëindigd; andere voorbehouden niet, maar die zijn wel materieel uitgewerkt, wat betekent dat de informatievoorziening is gestopt of teruggebracht is naar het 'normale' niveau omdat er in de Raad gestemd is over het voorstel.

\section{Tabel 9 Behandelvoorbehouden}

\begin{tabular}{lll} 
Jaar & $\begin{array}{l}\text { Aantal geplaatste behandelvoorbehou- } \\
\text { den }\end{array}$ & $\begin{array}{l}\text { Voorgestelde behandelvoorbehouden } \\
\text { n.a.v. het wetgevings- en werkpro- } \\
\text { gramma EC }\end{array}$ \\
\hline $\mathbf{2 0 1 0}$ & 5 & 16 \\
\hline $\mathbf{2 0 1 1}$ & 8 & 10 \\
\hline $\mathbf{2 0 1 2}$ & 4 & 12 \\
\hline $\mathbf{2 0 1 3}$ & 21 & 9 \\
\hline $\mathbf{2 0 1 4}$ & 12 & 4 \\
\hline $\mathbf{2 0 1 5}$ & 11 & 3
\end{tabular}




\begin{tabular}{lll} 
Jaar & $\begin{array}{l}\text { Aantal geplaatste behandelvoorbehou- } \\
\text { den }\end{array}$ & $\begin{array}{l}\text { Voorgestelde behandelvoorbehouden } \\
\text { n.a.v. het wetgevings- en werkpro- } \\
\text { gramma EC }\end{array}$ \\
\hline 2016 & 25 & 12 \\
\hline Totaal & $\mathbf{8 6}$ & $\mathbf{6 6}$
\end{tabular}

Het overzicht is enigszins troebel omdat sommige wetgevingsvoorstellen van de Commissie pas een jaar later zijn gepubliceerd dan in het wetgevings- en werkprogramma van de Commissie was voorgesteld. Het behandelvoorbehoud is dus ook een jaar later geplaatst. Te verwachten was dat de aantallen daadwerkelijk geplaatste behandelvoorbehouden overeen zouden komen met de voorgestelde behandelvoorbehouden maar dit blijkt niet het geval. Ook komen wetgevingsvoorstellen in meerdere wetgevings- en werkprogramma's voor. Zo bevat het programma uit 2010 een 'Wetgevend pakket hervorming gemeenschappelijk visserijbeleid' evenals het programma van 2011 'Wetgevingsvoorstellen Gemeenschappelijk Visserijbeleid', zie bijlagen II en III voor de prioritaire voorstellen uit 2010 en 2011. In de eerste drie jaren van dit onderzoek blijkt het aantal voorgestelde behandelvoorbehouden vele malen hoger dan de daadwerkelijk geplaatste behandelvoorbehouden. Wellicht werd het zekere voor het onzekere genomen maar bleek het voorstel toch geen prioriteit te hebben of hadden Kamerleden geen tijd om het voorstel indringender te volgen en te controleren. In de jaren daarna gebeurt het omgekeerde en is het aantal daadwerkelijk geplaatste behandelvoorbehouden groter dan het aantal voorgestelde. Er worden meer 'ad hoc' behandelvoorbehouden geplaatst.

De Kamer heeft sinds een aantal jaren, zeker na haar eigen rapport 'Voorop in Europa' uit 2014, meer aandacht voor de Europese Unie. Dit rapport was het eindproduct van het rapporteurschap Democratische Legitimiteit dat in december 2013 startte. ${ }^{221}$ Het rapporteurschap had als doel om tot een Kamerbreed standpunt te komen over haar eigen positie en inbreng in Europa. Het rapport bespreekt onder meer de mogelijkheden die de Tweede Kamer heeft om invloed uit te oefenen op het Europese wetgevingsproces via de eigen regering en via Brussel. Dit zou een verklaring kunnen zijn voor het groeiende aantal geplaatste behandelvoorbehouden in de jaren 2013 tot en met 2016. Dat het aantal geplaatste behandelvoorbehouden groeit, kan als positief worden gezien omdat dit betekent dat er meer aandacht is voor Europa. De bevoegdheid behandelvoorbehouden te plaatsen is daarmee een levende bevoegdheid en wordt door Kamerleden als een nuttig instrument gezien. Een behandelvoorbehoud heeft niet alleen tot gevolg dat de Kamer beter wordt geïnformeerd - doorgaans is het een gedetailleerdere informatievoorziening waar de Kamer om vraagt - maar het behandelvoorbehoud zorgt ook voor snellere informatievoorziening.

221 Handelingen II 2013/14, 31, item 18. 
Zodra een behandelvoorbehoud wordt geplaatst wordt de regering verzocht om binnen drie weken een BNC-fiche aan de Kamer te sturen. Doorgaans worden BNC-fiches binnen zes weken na publicatie van het Europees voorstel aan de Kamer gestuurd met dien verstande dat een deel van de fiches ook na die termijn wordt gestuurd. Naast de extra informatievoorziening heeft het behandelvoorbehoud als voordeel dat het een duidelijk signaal afgeeft aan de regering. De Kamer zet het voorbehoud namelijk alleen in als het gaat om een voor de Kamer belangrijk voorstel. De regering weet dan dat ze te maken kan krijgen met een stellige Kamer die gehoord wil worden en niet (makkelijk) zal afwijken van haar standpunt. Het kan dus ook gezien worden als een waarschuwing aan de regering.

\subsection{Eerste Kamer}

Het parlementair behandelvoorbehoud is tot op heden niet door de Eerste Kamer gebruikt. ${ }^{222}$ De Kamer is terughoudend met het gebruik van het parlementair voorbehoud omdat zij van mening is dat haar andere 'normale' bevoegdheden voldoende zijn om de regering te controleren. ${ }^{223}$

\subsubsection{Ondersteuning}

De 150 leden van de Tweede Kamer en de 75 leden van de Eerste Kamer kunnen hun werk niet doen zonder (inhoudelijke) ondersteuning van ambtenaren. De mogelijkheid om Europese aangelegenheden te controleren is afhankelijk van de ondersteuning in het parlement. Het werk van Kamerleden is omvangrijk en complex. Het is dan ook niet vreemd dat de Kamerleden afhankelijk zijn van deze ondersteuning. De stafleden hebben verschillende taken waaronder het voorbereiden van debatten, zowel inhoudelijk als organisatorisch, het doen van onderzoek, het informeren van Kamerleden over mogelijkheden met betrekking tot het inzetten van bevoegdheden en het assisteren van Kamerleden bij binnenlandse en buitenlandse dienstreizen.

\subsubsection{Tweede Kamer}

Aan het hoofd van het ambtelijk apparaat van de Tweede Kamer staat de griffier. De taak van de griffier is het adviseren van de Kamer, de voorzitter en het Presidium over procedurele en staatsrechtelijke aspecten van het werk van de Tweede Kamer. ${ }^{224}$ Direct onder de griffier vallen allereerst de Stafdienst Communicatie, het Stafbureau Voorzitter en

222 Zomer 2021.

223 A.L. Högenauer, 'The Dutch Parliament and EU Affairs: Decentralizing Scrutiny', in: C. Hefftler e.a. (eds.), The Palgrave Handbook of National Parliaments and the European Union, Londen: Palgrave Macmillan 2015, p. 259.

224 Website Tweede Kamer, Griffier. 
Presidium en de Dienst Analyse en Onderzoek. Daarnaast zijn er een viertal griffies; Griffie commissies Bestuur en Onderwijs, Griffie commissies Internationaal en Ruimtelijk, Griffie commissies Sociaal en Financieel, Griffie plenair/Bureau Wetgeving. ${ }^{225}$ In totaal bevatten deze diensten en griffies ruim $100 \mathrm{fte}$. De Dienst Analyse en Onderzoek heeft als taak relevante kennis te vergaren en over te brengen op de Kamerleden. ${ }^{226}$ De kerntaak van de Griffiecommissies is het organiseren en ondersteunen van de Kamercommissies in hun werkzaamheden. Daarnaast ondersteunen de Griffiecommissies de plenaire behandeling van wetsvoorstellen en beleidsstukken, Eerste en Tweede Kamerleden bij deelname aan interparlementaire bijeenkomsten, ze bewaken de onderlinge samenhang tussen de Kamercommissies en de plenaire vergadering. ${ }^{227}$ Elke Kamercommissie wordt inhoudelijk ondersteund door een griffier, een of meer adjunct-griffiers, kenniscoördinator(en), EU-specialist(en), informatiespecialist(en) en een wetgevingsliaison. Deze werken doorgaans voor meerdere commissies. Het aantal ambtenaren dat ondersteuning biedt, verschilt per Kamercommissie. De Kamercommissie voor Economische Zaken en Klimaat wordt ondersteund door vier ambtenaren, terwijl de Kamercommissies voor Justitie en Veiligheid en Europese Zaken ondersteund worden door tien respectievelijk elf ambtenaren. De Kamercommissie Europese Zaken wordt ondersteund door zeven EU-specialisten waar andere Kamercommissies ondersteund worden door één of twee EU-specialisten, maar gezien de taken van de Kamercommissie Europese Zaken is dit niet vreemd. ${ }^{228}$

\subsubsection{Eerste Kamer}

De Eerste Kamerleden worden inhoudelijk ondersteund door ongeveer $25 \mathrm{fte}$ aan staf. Deze ambtenaren werken bij de afdeling 'Directie Inhoud'. De afdeling Directie Inhoud biedt hulp aan de vaste en bijzondere Kamercommissies en de Kamerleden in de vorm van beleidsvorming, informatievoorziening, agendabeheer, tekstverwerking, registratie en archivering. De ondersteuning van de Kamercommissies bestaat uit plaatsvervangend griffiers, stafmedewerkers (waarvan een specifiek voor Europa) en EU-informatiespecialisten. De plaatsvervangend griffiers hebben samen met de griffier de taak om het wetgevingsproces (procedureel) te begeleiden. Dit wordt met name gedaan door Kamerleden te ondersteunen in hun werk in de Kamercommissies. Daarnaast worden de griffier en de plaatsvervangend griffiers weer ondersteund in hun werk door stafmedewerkers en (EU-)informatiespecialisten. Zij zorgen voor wetgevingsrapporten, wetgevingsdossiers, de Kameragenda en tekstverwerking. ${ }^{229}$

225 Website Tweede Kamer, Organogram.

226 Website Tweede Kamer, Dienst Analyse en Onderzoek.

227 Website Tweede Kamer, Griffies commissies.

228 Website Tweede Kamer, commissie Europese Zaken.

229 Website Eerste Kamer, ambtelijke organisatie. 
Naast de voorgaande manieren van invloed uitoefenen via de weg van controle en wetgeving bestaan ook andere mogelijkheden om invloed uit te oefenen. De Staat van de Europese Unie is een middel voor het parlement om zijn mening over Europese wetgeving te delen zowel met de Nederlandse regering als officiële Europese instellingen waaronder de Europese Commissie. Ook de eigen parlementaire vertegenwoordiging in Brussel hoort bij de politieke wijze van informatie verkrijging en invloed uitoefenen.

\subsubsection{De parlementaire vertegenwoordiging van de Staten-Generaal bij de Europese Unie}

Sinds 2004 hebben de Tweede en Eerste Kamer een parlementaire vertegenwoordiger (liaison officer) in Brussel. Deze vertegenwoordiger is net als de vertegenwoordigers van alle andere lidstaten gehuisvest in het Europees Parlement. ${ }^{230}$ De vertegenwoordiger ondersteunt Nederlandse parlementariërs bij de uitoefening van parlementaire controle en invloed in het Europese besluitvormingsproces. De taak van de vertegenwoordiger is onder andere om in een vroeg stadium EU-ontwikkelingen te signaleren en hierover de Tweede en Eerste Kamer te informeren. Het gaat dan om onderwerpen uit het werkprogramma van de Europese Commissie die voor Nederland belangrijk zijn en die door de Kamers als prioriteit zijn aangemerkt. ${ }^{231}$ De vertegenwoordiger staat niet alleen in nauw contact met het Nederlandse parlement maar ook met andere Nederlandse organisaties en vertegenwoordigers (zoals het Huis van de Nederlandse Provinciën) en de vertegenwoordigers van de parlementen van de andere lidstaten. Het netwerk van vertegenwoordigers van nationale parlementen, waar de Nederlandse vertegenwoordiger lid van is, kan beste praktijken uitwisselen, er kan informatie worden uitgewisseld of standpunten van nationale parlementen met betrekking tot subsidiariteitstoetsen en het biedt een mogelijkheid voor nationale parlementen om samen te werken. ${ }^{232}$

Ongeveer twee keer per jaar spreekt de Kamercommissie voor Europese Zaken van de Tweede Kamer met de vertegenwoordiger. Tijdens dit gesprek worden met name de actuele zaken besproken. Nederlandse Kamerleden brengen werkbezoeken aan Brussel en nemen deel aan interparlementaire conferenties. De vertegenwoordiger is betrokken bij de voorbereidingen hiervoor. ${ }^{233}$ De vertegenwoordiger spreekt ook tweemaal per jaar met de commissie EUZA van de Eerste Kamer. Volgens de Eerste Kamer ligt de meerwaarde

230 Eerste Kamercommissie Europese Zaken, Introductiedossier, Den Haag: Eerste Kamer 12 juni 2015, p. 24.

231 Ibid., p. 25.

232 Kamerstukken I 2016/17, CXXIV, A, p. 35.

233 Eerste Kamercommissie Europese Zaken, Introductiedossier, Den Haag: Eerste Kamer 12 juni 2015, p. 25. 
van de vertegenwoordiger niet in het verstrekken van Europese informatie - daarvoor heeft de Eerste Kamer EU-informatiespecialisten - maar in het bruikbaar(der) maken van deze informatie door na te gaan wat de standpunten van andere nationale parlementen zijn over nieuwe regelgeving of het adviseren over het beste moment van beïnvloeding. Het gaat dan om 'inside information' die niet in documenten terug te vinden is. ${ }^{234}$ Daarnaast werkt in elke Kamer ook een ambtenaar die de Kamer vertegenwoordigt in de Europese Unie. Er zijn dus drie vertegenwoordigers, één in Brussel en twee in Den Haag bij de Tweede en de Eerste Kamer.

\subsubsection{Staat van de Europese Unie}

De Staat van de Europese Unie is een stuk dat jaarlijks door het kabinet wordt opgesteld. ${ }^{235}$ De Staat van de Europese Unie, ook wel Staat van Europa genoemd, is het jaarlijkse stuk waarin het kabinet terugkijkt op de belangrijkste ontwikkelingen in de Europese Unie van het afgelopen jaar en zijn visie op het komende jaar aangeeft. Het kabinet doet dit vanuit een Nederlands perspectief. Daarnaast wordt de visie van het kabinet op de Europese Unie en de Europese agenda van het kabinet voor het aankomend jaar erin opgenomen. Voor 2012 werd het stuk gepresenteerd op Prinsjesdag. Tegenwoordig wordt de Staat van de Europese Unie doorgaans in februari gepubliceerd en daarna behandeld in de Tweede Kamer. Het kabinet gaat hierover ook in debat met de Tweede Kamer. Ten eerste worden de politieke lijnen van het kabinet voor het Europese beleid gepresenteerd. Dit wordt gedaan door de minister-president en de minister van Buitenlandse Zaken. Hierna wordt per beleidsterrein ingegaan op de ontwikkelingen op het desbetreffende beleidsterrein. Bij het debat over de Staat van de Europese Unie zijn niet alleen Nederlandse parlementariërs aanwezig. Ook een aantal leden van het Europees Parlement en de Europese Commissie kunnen, op uitnodiging van de Tweede Kamer, aanwezig zijn. ${ }^{236}$ De leden van het Europees Parlement mogen het woord voeren. Zij zitten bij hun partijgenoten in de Tweede Kamer. Het is toegestaan dat zij de Tweede Kamer en de bewindsleden informeren. Daarnaast mogen zij de minister-president en de minister van Buitenlandse Zaken vragen stellen. Zij zijn echter niet verplicht antwoord te geven op die vragen. Interrupties door de leden van het Europees Parlement wanneer andere Europarlementariërs, Tweede Kamerleden of bewindslieden spreken, is niet toegestaan. Ook het indienen van moties of het ondertekenen van moties door Europarlementariërs is niet mogelijk. Deze grondwettelijke rechten zijn uitsluitend voorbehouden aan leden van de Tweede Kamer. Het doel van het betrekken van de Nederlandse Europarlementariërs bij het debat is om beide parlementen, de Staten-

234 Kamerstukken I 2016/17, CXXIV, A, p. 35.

235 De grondslag van dit stuk is art. 68 jo. 42 Grondwet.

236 Kamerstukken II 2007/08, 31202, nr. 4, p. 6. 
Generaal en het Europees Parlement, dichter bij elkaar te brengen en de Europarlementariërs op de hoogte te brengen van de Nederlandse belangen in de EU. Daarnaast is het voor de Tweede Kamer een kans om gebruik te maken van de inzichten, kennis en ervaringen van de Europarlementariërs. ${ }^{237}$ Het debat over de Staat van de Europese Unie is, zoals eerder beschreven, een notaoverleg, dat in de Tweede Kamer door de Commissie voor Europese Zaken wordt voorbereid. ${ }^{238}$

Zoals reeds vermeld vindt het debat tussen de Kamer en het kabinet doorgaans in februari plaats; in het vergaderjaar 2015-2016 heeft het debat echter al op 7 december 2015 plaatsgevonden. Dit had te maken met het EU-voorzitterschap van Nederland in de eerste helft van 2016. Het kabinet vond het passend om het debat over de Staat van de Europese Unie voorafgaand aan het voorzitterschap te houden. ${ }^{239}$

Ook de Eerste Kamer ontvangt de Staat van de Europese Unie. Hier wordt het stuk behandeld als onderdeel van de jaarlijkse Europese beschouwingen. Tijdens deze beschouwingen worden behalve de Staat van de Europese Unie, onder andere ook het Europees Semester, de Economische Monetaire Unie, de Raad(svergaderingen) en andere Europese aangelegenheden besproken. Enkele weken na de behandeling in de Tweede Kamer vindt de behandeling in de Eerste Kamer plaats. Het voltallige dossier van de Tweede Kamer wordt aan de Eerste Kamer gezonden waar tevens de vaste commissie voor Europese Zaken de plenaire behandeling voorbereidt. De behandeling in de Eerste Kamer kent geen bijzonderheden zoals de reeds beschreven behandeling in de Tweede Kamer. ${ }^{240}$ Ter voorbereiding van de jaarlijkse Europese beschouwingen brengt de commissie EUZA, doorgaans met leden van andere commissies, een werkbezoek aan Brussel. Zij spreekt dan met leden of vertegenwoordigers van de Commissie, de Raad, de Europese Raad en het Europees Parlement. ${ }^{241}$

De Staat van de Europese Unie ziet er elk jaar anders uit. Zo lag de focus van 2014 op subsidiariteit. Nederland moest strenger toetsen wat nationaal en wat Europees geregeld moest worden. ${ }^{242}$ Daarnaast moest gewerkt worden aan de tekortkomingen in het functioneren van de Europese Unie. Ook werd het belang van een betere focus en een betere werking van de Europese instituten benadrukt. Tevens was de regering op zoek naar mogelijkheden om de democratische legitimatie van de Europese besluitvorming te vergroten. Op nationaal niveau zou dat kunnen door meer contact met de Nederlandse Europarlementariërs en het vaker uitnodigen van Eurocommissarissen. Op Europees

237 Kamerstukken II 2007/08, 31202, nr. 4, p. 2.

238 L.F.M. Besselink \& B. van Mourik, 'The Parliamentary Legitimacy of the European Union: The Role of the States General within the European Union', Utrecht Law Review 2012, 8(1), p. 33.

239 Kamerstukken II 2015/16, 34166, nr. 43.

240 Website Eerste Kamer, Algemene Europese Beschouwingen 2016.

241 Eerste Kamercommissie Europese Zaken, Introductiedossier, Den Haag: Eerste Kamer 12 juni 2015, p. 19.

242 Kamerstukken II 2013/14, 33877, nr. 1, p. 7. 
niveau denkt men aan een versterking van de gelekaartprocedure en wellicht de invoering van een groene of rode kaart. ${ }^{243}$ Dit waren de belangrijke punten volgens de regering.

Opmerkelijk aan het debat met de Tweede Kamer was dat het debat, anders dan in niet-verkiezingsjaren, werd bepaald door de verkiezingen van het Europees Parlement. ${ }^{244}$ De fracties kwamen met vele onderwerpen en standpunten naar voren. Veel oneliners, het promoten van eigen partij en partijprogramma's passeerden de revue. Ook werd in het debat gesproken over onderwerpen uit de Staat van de Europese Unie. Zo voerden verschillende partijen aan dat de Europese Unie belangrijker voor de Nederlandse burger moest worden en dan met name in het herstel van de werkgelegenheid. Uit de bijdragen van de fracties valt af te leiden dat elke fractie stilstaat bij de invloed die de EU heeft op Nederland. De ene fractie heeft hier moeite mee, de andere fractie is er een voorstander van. Enkele moties werden ingediend. CDA-lid Omtzigt diende een motie in met het verzoek de invoering van een rode of groene kaart en versterking van de gelekaartprocedure te bewerkstelligen. ${ }^{245}$ Omtzigt diende de motie in aangezien de regering in de Staat van de Europese Unie had aangegeven de gelekaartprocedure te willen versterken en ook een verbetering van de positie van nationale parlementen te wensen. De motie vroeg om een concrete uitwerking van de regering. De Kamer verwierp de motie.

Het debat in de Eerste Kamer had een andere focus. Daar ging het hoofdzakelijk over de relatie tussen de Europese Unie en Rusland. Verschillende fracties waren van mening dat Europa moet inzetten op een gemeenschappelijk Europees defensiebeleid en dat Europa minder afhankelijk moet worden van Russisch gas. Daarmee hing samen dat gewerkt moest worden aan een betere energierelatie met Rusland en aan een Europees energiebeleid.

In tegenstelling tot het debat in de Tweede Kamer werd tijdens het debat in de Eerste Kamer 'slechts' één motie ingediend. Kamerlid Strik (GroenLinks) deed een oproep aan alle Europese lidstaten om een substantiële bijdrage te leveren aan de opvang van vluchtelingen uit Syrië. ${ }^{246}$ Deze motie werd verworpen.

Het debat over de Staat van Europa is over het algemeen weinig concreet. Knelpunten worden geconstateerd maar een verdere uitwerking of oplossing ontbreekt. Daarbij moet worden opgemerkt dat de Staat van Europa een visienota is waarbij een volledige (concrete) uitwerking van zaken niet mag worden verwacht. Ook speelt politiek een rol. Hoe concreter de regering haar plannen en visie maakt, hoe meer de regering daaraan is gebonden en hoe minder ruimte zij houdt om wijzigingen aan te brengen. Concreet werd het dus niet tijdens de debatten. Ook werden geen details besproken. Toch heeft de Staat van Europa een positieve waarde. Het is een uitgebreid stuk van de regering over haar visie op Europa

243 Kamerstukken II 2013/14, 33877, nr. 1, p. 10-12.

244 Kamerstukken II 2013/14, 33877, nr. 17.

245 Kamerstukken II 2013/14, 33877, nr. 6.

246 Kamerstukken I 2013/14, 33877, D. 
en het staat, weliswaar tijdelijk, hoog op de agenda van de Tweede en Eerste Kamer. Het geeft de Kamers een goed en breed overzicht van de plannen van de regering ten aanzien van Europa. Het debatteren over de visie, de interactie tussen het parlement en de regering en het bijstellen van de visie van de regering door de Kamers mag als positief worden gezien.

\subsubsection{Begrotingsrecht en Europees Semester}

Het budgetrecht, dat is geregeld in artikel 105 van de Grondwet, is een van de belangrijkste manieren van het parlement om invloed uit te oefenen op het beleid van de regering. ${ }^{247}$ Het Nederlandse budget wordt beïnvloed door het zogenoemde Europees Semester. Dit is sinds 2011een zes maanden durende cyclus van economische en budgettaire beleidscoördinatie door de EU. Tijdens en door deze cyclus houdt de Commissie toezicht op de budgetten van de lidstaten en kunnen budgettaire en structurele hervormingen besproken worden die nodig zijn om doelstellingen uit Europa 2020 en het stabiliteits- en groeipact (SGP) te behalen. ${ }^{248}$ Voordat de begroting op Prinsjesdag wordt ingediend bij de Tweede Kamer heeft deze het Europees Semester doorgelopen. Dit semester begint in november wanneer de Commissie haar jaarlijkse groeianalyse presenteert. Deze wordt na publicatie ontvangen door de nationale parlementen en regeringen. Doorgaans wordt van alle documenten die afkomstig zijn van de Commissie een BNC-fiche opgesteld over de inhoud van het document en het Nederlandse standpunt. Met betrekking tot de jaarlijkse groeianalyse van de Commissie wijkt de procedure sinds 2013 enigszins af. In plaats van een BNC-fiche op te stellen sturen de minister van Economische Zaken en de minister van Financiën gezamenlijk een brief aan de Tweede en Eerste Kamer. Hierin wordt, net zoals in een BNC-fiche, het document van de Commissie geanalyseerd.

De Tweede Kamer agendeert de jaarlijkse groeianalyse niet omdat het geen brief is aan de Kamer en de auteur (de Europese Commissie) geen verantwoording aflegt aan de Tweede Kamer. Zoals hierboven aangegeven ontvangt de Kamer wel de kabinetsappreciatie van de jaarlijkse groeianalyse. Hierover kan de Kamer in debat gaan met de regering. Deze wordt dan ook altijd geagendeerd. In de afgelopen jaren is de (kabinetsappreciatie van de) jaarlijkse groeianalyse doorgaans besproken tijdens de AO's van de Raad Concurrentievermogen (Kamercommissie Economische Zaken en Klimaat) en/of van de Ecofinraad (Kamercommissie Financiën). Andere stukken die verband houden met de begroting en het Europees Semester, zoals het Nationaal Hervormingsprogramma, het Stabiliteitspro-

247 M. Diamant \& M.L. van Emmerik, 'Het Nederlandse budgetrecht in Europees perspectief, TvCR 2013, afl. 2, p. 94.

248 P. Coenen, A.W. Heringa, H.T. Nguyen \& S. Wolf, Europees Semester (Montesquieu Policy Papers, nr. 6), Den Haag: Montesquieu Instituut 2015, p. 4. 
gramma, de kabinetsreacties op (concept)landenspecifieke aanbevelingen, worden ook in AO's en in plenaire debatten besproken. Nederland heeft van 2009 tot 2013 in de Buitensporigtekortprocedure gezeten aangezien de Nederlandse begroting niet voldeed aan de Europese budgetnormen. In die tijd was er binnen de Tweede Kamer, met name door de Kamercommissie Financiën, meer aandacht voor het onderwerp in verband met de eventuele Europese boetes wegens overschrijding van de EMU-norm.

De jaarlijkse groeianalyse is een breed document voor wat beleidsterreinen betreft. Binnen de regering wordt de groeianalyse gecoördineerd door de minister van Economische Zaken en Klimaat (EZK) maar in de Kamer wordt deze vaak door andere Kamercommissies behandeld dan door EZK. Ook wordt het document door meerdere Kamercommissies behandeld omdat het verschillende beleidsterreinen raakt. Door deze versnippering is het voor de Kamer moeilijk om het Europees Semester inhoudelijk te laten behandelen door de Kamercommissies die er inhoudelijk over gaan. Aangezien de minister van EZK op kabinetsniveau verantwoordelijk is, zou het logisch zijn dat de Kamercommissie voor EZK in de Kamer verantwoordelijk zou zijn maar in praktijk is dit niet het geval. In de afgelopen jaren is de jaarlijkse groeianalyse een aantal keren verhuisd van de commissie Europese Zaken naar de commissie Financiën (in verband met de buitensporigtekortprocedure) en weer terug. De commissie Financiën heeft echter vooral aandacht voor de EMU-normen en minder voor andere beleidsterreinen die de jaarlijkse groeianalyse kan bevatten. De Tweede Kamer is dus nog zoekende naar een goed werkende procedure om de jaarlijkse groeianalyse optimaal inhoudelijk te behandelen.

In de jaren 2013-2015 heeft de Tweede Kamer een rapporteur Europees Semester gehad met als doel de behandeling van de stukken die daarmee verband houden in de Kamer te coördineren. ${ }^{249}$ In haar rapport doet de rapporteur een drietal aanbevelingen. De eerste aanbeveling ziet op een actieve betrokkenheid van de relevante Kamercommissies bij de totstandkoming van de landenspecifieke aanbevelingen en de implementatie ervan in nationaal beleid. Het gaat dan met name om de Kamercommissies op wier terrein een dergelijke landenspecifieke aanbeveling van toepassing is. De Kamer dient niet alleen waakzaam en betrokken te zijn bij het Europese gedeelte van semester maar ook zeker bij het nationale gedeelte waar de landenspecifieke aanbeveling wordt verwerkt in de verschillende departementale begrotingen. Met andere woorden, de Kamer dient elke stap te controleren, van het begin - de opstelling van de landenspecifieke aanbevelingen - tot het eind - de implementatie van de aanbeveling - evenals het kabinetsbeleid door het jaar heen. De rapporteur beveelt dit aan om erzo voor te zorgen dat het parlement niet buitenspel komt te staan door het Europees Semester. ${ }^{250}$ De tweede aanbeveling ziet op het aanstellen

249 Kamerstukken II 2014/15, 33574, nr. 6.

250 Kamerstukken II 2014/15, 33574, nr. 6, p. 8. 
van een nieuwe rapporteur Europees Semester in $2015 .{ }^{251}$ De rapporteur schetst de vooren nadelen van het aanstellen van een nieuwe rapporteur en laat de uiteindelijk beslissing over aan de Kamer. In dat opzicht wordt er geen aanbeveling gedaan. Tot slot wordt aanbevolen een rapporteur voor de mid-term review Europa 2020-strategie aan te stellen. ${ }^{252}$ Gezien de complexiteit van het onderwerp, de uitwerking die het mogelijk kan hebben op het Europees Semester en de betrokkenheid van vrijwel alle Kamercommissies adviseert de rapporteur om hiervoor een aparte rapporteur aan te stellen die dit onderwerp nauwlettend in de gaten kan houden en de herziening van de strategie kan coördineren.

Tijdens een procedurevergadering van de Kamercommissie voor Europese Zaken wordt besloten om de eerste aanbeveling over te nemen en daarmee de relevante Kamercommissies actief te betrekken bij de totstandkoming en implementatie van de landenspecifieke aanbevelingen. Met betrekking tot een rapporteur Europees Semester 2015 wordt besloten om deze niet aan te stellen en over het aanstellen van een rapporteur mid-term review Europa 2020 wordt te zijner tijd een besluit genomen. ${ }^{253}$

\subsubsection{Wet informatiepositie Staten-Generaal inzake de Europese Unie}

Op 17 maart 2017 dienden toenmalige Kamerleden Marit Maij (PvdA) en Anne Mulder (VVD) een initiatiefwetsvoorstel in bij de Tweede Kamer. ${ }^{254}$ Het 'voorstel tot verbetering van de informatiepositie van de Staten-Generaal met betrekking tot de Europese Unie (Wet informatiepositie Staten-Generaal inzake de Europese Unie)' is een verzamelplaats van bevoegdheden en rechten van de beide Kamers. Het doel van deze wet is het verbeteren van de informatiepositie van de Staten-Generaal om zo de parlementaire controle te verbeteren tijdens de onderhandelingen die de regering uitvoert op Europees niveau, de invloed van het Nederlandse parlement in het Europese besluitvormingsproces te vergroten en daarbij de legitimiteit van dat besluitvormingsproces te doen toenemen. ${ }^{255}$

Het probleem van de huidige situatie is volgens de initiatiefnemers dat parlementaire controle op Europese besluitvorming complex en veelzijdig is. Omdat er tegelijkertijd vele onderhandelingsprocessen en besluitvormingsprocessen over verschillende onderwerpen lopen, moet het parlement op elk moment alert zijn omdat het doorlopend parlementaire controle moet uitvoeren. De complexiteit, veelzijdigheid en het feit dat het parlement continu alert moet zijn maakt het controleproces voor het parlement ingewikkeld en

251 Kamerstukken II 2014/15, 33574, nr. 6, p. 9.

252 Kamerstukken II 2014/15, 33574, nr. 6, p. 10.

253 Besluitenlijst van de procedurevergadering van donderdag 19 maart 2015, 2015D13191.

254 Kamerstukken II 2016/17, 34695, nr. 1 en 2; het voorstel is thans, zomer 2021, in behandeling bij de Tweede Kamer.

255 Kamerstukken II 2016/17, 34695, nr. 3, p. 1. 
moeilijk uit te voeren. Dit is met name het geval wanneer het parlement geen of in beperkte mate antwoord krijgt op cruciale controlevragen zoals: Wat was de inzet van de regering tijdens raadsonderhandelingen? en Welke rol heeft de regering gespeeld in het bereiken van het eindresultaat?

Het parlement kan zich hierdoor geen compleet beeld vormen van de situatie. Daarnaast krijgt het parlement geen inzicht in alle documenten die door de Europese onderhandelingspartners aan de regering zijn gestuurd. Dit is echter nodig voor een goede controle. Over de afgelopen jaren heeft het parlement toegang gekregen tot meer documenten. Toch zijn er nog documenten die het parlement niet kan inzien; dit zijn de zogeheten non-papers. De regering ontvangt deze documenten, die van informele aard zijn, van de verschillende onderhandelingspartners op Europees niveau, of levert ze zelf aan tijdens onderhandelingen, maar stuurt ze niet aan het parlement.

In het voorstel zijn het parlementair behandelvoorbehoud en het parlementair instemmingsrecht uit de Goedkeuringswet van het Verdrag van Lissabon terug te vinden in artikel 2 en $3 .{ }^{256}$ Daarnaast bevat het voorstel in het eerste artikel een algemene plicht voor de minister die het aangaat en de minister van Buitenlandse zaken om de Kamers tijdig, doorlopend en volledig in te lichten over aangelegenheden met betrekking tot de Europese Unie. Dit is niet veel meer dan een kopie van artikel 68 van de Grondwet. De inlichtingenplicht uit dit artikel ziet namelijk ook op Europese aangelegenheden. Wel is in het wetsvoorstel toegevoegd dat de minister die het aangaat deze plicht heeft, hetgeen niet meer dan logisch is, en daarnaast ook de minister van Buitenlandse Zaken (BuZa). Volgens de initiatiefnemers heeft de betrokkenheid van de minister van Buitenlandse Zaken het doel om de coördinatie tussen de ministeries te waarborgen, en wanneer inlichtingen meerdere ministeries aangaan dan zorgt de minister van Buitenlandse Zaken voor de inlichtingen. Daarnaast heeft de minister van BuZa de taak om de algehele kwaliteit te waarborgen. ${ }^{257}$

Naast deze algemene plicht is ook een inlichtingenplicht opgenomen voor dezelfde ministers als in het eerste artikel, om beide Kamers onverwijld te informeren over de bij het wetsvoorstel onder lijst I (EU-voorstellen) en II (EU-Documenten) opgenomen handelingen en ook over alle groenboeken of witboeken die de regering ontvangt. ${ }^{258}$ Wanneer de regering EU-voorstellen aan de Kamers stuurt, dient zij deze te doen vergezellen van een zogenoemde oplegbrief. Hierin wordt de volgende informatie opgenomen: 'de belangrijkste inhoud en doel van het EU-voorstel; de datum van het verschijnen van de

256 Beide bevoegdheden zijn geïntroduceerd in de Goedkeuringswet van het Verdrag van Lissabon in respectievelijk art. 3 en 4.

257 Kamerstukken II 2016/17, 34695, 3, p. 17.

258 Dit zijn onder andere wetgevingsvoorstellen, mededelingen, aanbevelingen, rapporten, verslagen en beleidsprogramma's van de instellingen van de Europese Unie. Zie art. 7 van het wetsvoorstel voor de plicht met betrekking tot groenboeken en witboeken. 
eerste versie alsook van het verschijnen van de eerste versie in de Nederlandse taal; de rechtsbasis van een voorgenomen besluit; de toepasselijke besluitvormingsprocedure; de naam van Onze Minister die het aangaat en tot slot de data ten behoeve van digitale verwerking'. ${ }^{259}$

Naast het wettelijk vastleggen van het BNC-fiche wordt ook een BUC-fiche geïntroduceerd. BUC staat voor 'Beoordeling Uitonderhandeld Commissievoorstel'. ${ }^{260}$ De bedoeling van dit BUC-fiche is dat de regering uitleg geeft over de verhouding tussen de vastgestelde wetgevingshandeling en de beginselen van subsidiariteit en proportionaliteit, en de gevolgen die de wetgevingshandeling heeft voor Nederland, waaronder de gevolgen voor implementatie hiervan; verder is het de bedoeling dat de regering een oordeel geeft over de uitkomst van de onderhandelingen, de onderhandelingen die door Nederland zijn ingezet en een verantwoording daarover.

Ook wordt in het wetsvoorstel vastgelegd dat de minister een agenda, de zogenoemde 'geannoteerde agenda' aan de Kamers zendt voor een bijeenkomst van de Europese Raad, de Raad, informele ministeriële bijeenkomsten, de Eurozone-top en bijeenkomsten van de Eurogroep. $\mathrm{Na}$ afloop van een bijeenkomst zendt de minister van Buitenlandse Zaken een verslag van de bijeenkomst aan beide Kamers. ${ }^{261}$ Waarom hier gekozen is voor de minister van Buitenlandse Zaken en niet de minister die het aangaat, is onduidelijk.

Tot slot wordt vastgelegd dat de minister van Buitenlandse Zaken viermaal per jaar een overzicht stuurt aan beide Kamers met daarin 'de actuele politieke ontwikkelingen over zaken die betrekking hebben op de Europese Unie; de voortgang van implementatie van Europese wetgevingsvoorstellen' ${ }^{262}$

\subsubsection{Voorstel tot verandering van de Grondwet strekkende tot toevoeging van bepalingen inzake het lidmaatschap van de Europese Unie}

Op 9 mei 2019 maakten D66-leden Kees Verhoeven en Rob Jetten een voorstel tot wijziging van de Grondwet aanhangig in de Tweede Kamer. ${ }^{263}$ Dit voorstel heeft als doel een bepaling inzake het lidmaatschap van de Europese Unie toe te voegen aan de Grondwet. Aan artikel 90 van de Grondwet worden drie leden toegevoegd. In het eerste lid wordt 'Het Koninkrijk is lid van de Europese Unie' opgenomen. ${ }^{264}$ De tweede toevoeging betreft de opzegging van het lidmaatschap van de Europese Unie. Het voorstel regelt met welke

259 Zie Lijst III - Leeswijzers onder sub a van Lijsten behorende bij het wetsvoorstel.

260 Ibid.

261 Art. 6 wetsvoorstel.

262 Art. 8 wetsvoorstel.

263 Kamerstukken II 2018/19, 35202 - (R2126), nr. 1.

264 Kamerstukken II 2018/19, 35202 - (R2126), nr. 2. 
procedure het lidmaatschap eventueel beëindigd kan worden. Verhoeven en Jetten nemen daarbij democratische legitimatie als uitgangspunt. Voorgesteld wordt namelijk om de procedure van grondwetswijziging van overeenkomstige toepassing te verklaren. Dit houdt in dat de procedure uit artikel 137 van de Grondwet gevolgd dient te worden. Indien Nederland uit de Europese Unie wil treden, dient in de zinsnede 'een verandering in de Grondwet' in artikel 137, 'de goedkeuring voor het opzeggen van het lidmaatschap van de Europese Unie' gelezen te worden. ${ }^{265}$ Tot slot wordt in een derde lid de betrokkenheid van de Staten-Generaal bij besluitvorming van de Europese Unie over wetgeving en verdragen vastgelegd. Hierbij kan volgens Verhoeven en Jetten worden aangesloten bij het voorstel van Maij en Mulder voor de Wet informatiepositie Staten-Generaal inzake de Europese Unie.

Het verankeren van de Europese Unie in de Nederlandse Grondwet brengt geen verplichtingen met zich. Wanneer men kijkt naar constituties van andere lidstaten valt op dat hierover overeenstemming bestaat. Er zijn landen, zoals Luxemburg en Denemarken, die in hun constituties geen verwijzing hebben naar de Europese Unie; daarnaast er zijn ook landen, zoals Frankrijk en Duitsland, die in hun constituties een (of meer) specifieke bepaling(en) over de Europese Unie hebben opgenomen. ${ }^{266}$ De lidstaten denken nu eenmaal verschillend over het opnemen van een bepaling over (het lidmaatschap van) de Europese Unie. Het voorstel van Verhoeven en Jetten is niet opvallend in vergelijking met andere lidstaten. Wel geeft het ondubbelzinnig aan dat Nederland lid is van de Europese Unie en geeft het een duidelijk 'pro-Europa' signaal af. Tot slot, gezien de chaos en problemen die Brexit met zich brengt, is het niet vreemd dat Verhoeven en Jetten een voorstel doen voor een duidelijke procedure indien ook Nederland de Europese Unie wil verlaten. Wil Nederland zijn lidmaatschap van de Europese Unie opzeggen dan dient dat via een grondwetswijziging te gaan. Een grondwetsherziening zorgt ervoor dat het Nederlandse volk, in verband met de tussentijdse verkiezingen, zich kan uitspreken over een eventuele Nexit. Daarnaast zorgt de procedure met twee lezingen en een twee derde meerderheid in beide Kamers in de tweede lezing ervoor dat het besluit om de Europese Unie te verlaten, weloverwogen wordt genomen en gesteund wordt door het volk. De drempel van een twee derde meerderheid in beide Kamers betekent echter ook dat de kans op een Nexit wordt verkleind. ${ }^{267}$ Met andere woorden, de initiatiefnemers wilden het moeilijker maken om het lidmaatschap op te zeggen.

Op 25 februari 2021 is het voorstel in eerste lezing verworpen. ${ }^{268}$

265 Kamerstukken II 2018/19, 35202 - (R2126), nr. 3, p. 10.

266 Art. 23 Duitse Grondwet en art. 88-1 e.v. Franse Grondwet.

267 H.T. Nguyen \& S. Wolf, 'Europa in de Grondwet: A reaffirmation of commitment', Nieuwsbrief De Hofvijver 2019, 9(97).

268 Handelingen II 2020/21, 59, item 26. 
Het onderwerp van dit hoofdstuk betrof de Nederlandse parlementaire activiteit aangaande Europese aangelegenheden en daarmee verbonden (vooral indirecte) invloed op Europese besluitvorming. De vraag daarbij is hoe het Nederlandse parlement een en ander doet en welke middelen dan wel bevoegdheden het parlement daarvoor tot zijn beschikking heeft en hoe (vaak) deze worden ingezet. Dit alles is bekeken vanuit een nationaal perspectief. Aan bod kwamen de bevoegdheden die het parlement heeft op basis van Nederlandse (constitutionele) wetgeving. Zoals beschreven verlopen de bedoelde activiteiten via het politieke controle- en verantwoordingsproces. De bevoegdheden die het parlement gebruikt, zien deels op de controle van de eigen regering en deels op acties richting de Europese Commissie.

Controle kan niet plaatsvinden zonder adequate informatievoorziening. In het eerste gedeelte van dit hoofdstuk is daarom ingegaan op de parlementaire controlemiddelen c.q. informatievoorziening. Deze middelen zijn niet specifiek voor controle van de regering inzake Europese aangelegenheden gecreëerd maar kunnen voor alle activiteiten van de regering, Europees of nationaal, worden ingezet. Het gaat dan om interpellaties, enquêtes, dertigledendebatten en schriftelijke en mondelinge vragen. Er zijn in de onderzoeksperiode van 2010 tot en met 2016 geen interpellaties en enquêtes geweest over Europa. Het percentage dertigledendebatten over Europa is met vijf procent het hoogste percentage van de in de vierde paragraaf van dit hoofdstuk genoemde controlemiddelen. Het percentage schriftelijke en mondelinge vragen ligt op vier procent, respectievelijk twee procent van het totaal. In de Eerste Kamer zijn er, net als in de Tweede Kamer, geen interpellaties of enquêtes geweest over Europa. Het percentage schriftelijke vragen aangaande EU-aangelegenheden is wel hoger dan in de Tweede Kamer, namelijk dertien procent. Als de regering ziet dat het parlement activiteit aangaande Europese aangelegenheden serieus neemt, zal de regering ook meer geneigd zijn om de standpunten van het parlement over te nemen/in aanmerking te nemen aangezien ook bij Europese aangelegenheden (politieke) sancties kunnen volgen. De tweede gele kaart inzake het voorstel voor een Europees Openbaar Ministerie is daarvan een goed voorbeeld. De Tweede Kamer zat daar 'bovenop' (via behandelvoorbehoud, rapporteurschap en gemotiveerde advies aan de Commissies) en de regering kon ook niet veel anders dan de Kamer daarin volgen, wat ze ook heeft gedaan.

Tot slot zijn er nog de ad hoc gemaakte afspraken tussen de regering en de Tweede Kamer. Bij nieuwe Europese wetgeving kan de Tweede Kamer een of meer 'Europese' bevoegdheden inzetten zoals het parlementair behandelvoorbehoud. Als het echter gaat om bijvoorbeeld handelsverdragen dan kan de Kamer deze bevoegdheden niet inzetten. Niets staat er dan aan in de weg om toch in lijn met de bevoegdheden van het behandelvoorbehoud (ad hoc procedure)afspraken te maken met de regering. Dit is gebeurd bij het 
CETA-verdrag en de ESM-besluiten. De afspraak die werd gemaakt ziet met name op een tijdelijke en adequate informatievoorziening en een debat tussen de regering en de Kamer voordat de regering zich ergens aan committeert op Europees niveau. Hetzelfde geldt voor de afspraak met betrekking tot Visserijakkoorden. Ook hier werd afgesproken om de Kamer meer, sneller en beter te informeren. Ook werd met de staatssecretaris afgesproken dat het standpunt van de Kamer zou worden meegenomen in de onderhandelingen in de Raad. Tot slot is er nog de afspraak om een behandelvoorbehoud te plaatsen op elk voorstel dat instemming van de Staten-Generaal vergt. Wederom zorgt dit voor een adequatere informatievoorziening.

Van deze afspraken zijn een paar voorbeelden gevonden. Aangezien er van deze afspraken geen overzicht wordt bijgehouden valt ook niet uit te sluiten dat er meer van dergelijke afspraken zijn gemaakt.

Het tweede gedeelte van het hoofdstuk behandelt de 'directe weg' om invloed uit te oefenen. Daarmee wordt bedoeld invloed op de Europese Commissie als initiatiefnemer van nieuwe Europese wetgeving. Voor het Barroso-initiatief was het Nederlandse parlement voor informatie vanuit de Europese Unie afhankelijk van de BNC-fiches van de regering. Dit is thans niet meer zo maar de BNC-fiches blijven van grote waarde voor het parlement aangezien het parlement zo door de regering wordt geïnformeerd over het standpunt van de regering betreffende nieuwe Europese wetsvoorstellen.

Naar aanleiding van het jaarlijkse wetgevings- en werkprogramma van de Europese Commissie stellen beide Kamers van het parlement een lijst samen met hun prioriteiten uit dit programma. Die prioriteiten worden door de desbetreffende Kamercommissie direct op de agenda gezet. Ook kunnen de Kamercommissies aangeven of ze van plan zijn een subsidiariteitstoets uit te voeren en/of een behandelvoorbehoud te plaatsen. Het feit dat beide Kamers selecteren en prioriteren is positief; in de eerste jaren na 2010 werden deze geplande behandelvoorbehouden echter niet geplaatst. In de jaren na 2013 loopt het aantal voorgestelde/geplande behandelvoorbehouden terug en de daadwerkelijk geplaatste behandelvoorbehouden nemen juist toe, maar nog altijd wordt niet elk voorgesteld behandelvoorbehoud geplaatst. Uiteindelijk is het belangrijk dat het aantal daadwerkelijk geplaatste behandelvoorbehouden toeneemt. Dat betekent namelijk dat de parlementaire bemoeienis met ook voor Nederland belangrijke Europese besluitvorming toeneemt. Bij een behandelvoorbehoud mag de minister namelijk in de Raad geen onomkeerbare beslissingen nemen voordat hij of zij de standpunten van de Kamer heeft gehoord.

De consultaties die de Europese Commissie verstuurt, de groenboeken en witboeken, staan niet hoog op de agenda van beide Kamers. Op vele groen- en witboeken wordt wel gereageerd naar de Commissie of de regering maar inhoudelijk zijn deze reacties niet erg indringend. Als de Kamer het niet eens is met de visie van de Commissie is dit een goed moment om dit te laten weten. Het zijn niet voor niets consultatiedocumenten, dus de 
Commissie verwacht er reacties op. Desondanks maken de Kamers door hun beknopte reacties slechts beperkt gebruik van deze mogelijkheid.

De Tweede Kamer kan een of meer van haar leden benoemen tot rapporteur voor een bepaald dossier. Hoe de Kamer tot die beslissing komt, is betrekkelijk onnavolgbaar. Het is onduidelijk waarom voor sommige onderwerpen een rapporteur wordt benoemd en voor andere niet. Zo is in 2015 een rapporteur aangesteld voor de begrotingscyclus. Onduidelijk is waarom er slechts één jaar een rapporteur is aangesteld terwijl de begrotingscyclus elk jaar terugkomt. Het eindigen van een rapporteurschap hangt vaak samen met het einde van de gestelde termijn. Dit kan ook zijn als over het wetgevingsvoorstel nog onderhandeld wordt. Juist dan zou een rapporteur nog steeds van belang zijn. De rapporteur kan de Kamer op de hoogte houden van de onderhandelingen waardoor het voor de Kamer makkelijker zou moeten zijn om greep op het onderwerp te houden. Het rapporteurschap zou pas moeten eindigen als het wetsvoorstel definitief wordt en niet als een termijn eindigt of als er nieuwe verkiezingen zijn van de Tweede Kamer. Het rapporteurschap is een effectief middel om enerzijds alle ontwikkelingen te volgen, informatie in te winnen en kennis bij te houden over een onderwerp of voorstel, en anderzijds is het ook een signaal aan de regering. De Kamer laat daarmee zien dat het gaat om een belangrijk onderwerp waarover zij alles wil weten en dat zij scherp in de gaten wil houden, maar met name dat het een onderwerp is waar de Kamer een sterke mening over heeft waarvan ze niet snel af zal wijken en waarmee ze de regering kritisch volgt.

Algemeen kan gesteld worden dat beide Kamers weliswaar hun bevoegdheden om controle en invloed uit te oefenen op Europese aangelegenheden gebruiken, maar dat dit een beperkt deel is van de vele andere activiteiten die de Kamers verrichten. Indien de Kamers meer invloed willen uitoefenen op Europese besluitvorming kan het nuttig zijn om vaker een behandelvoorbehoud te plaatsen bij nieuwe Europese wetgeving. Het voordeel hiervan is dat wanneer een van beide Kamers dit doet, de andere Kamer hierop kan meeliften. Daarnaast zou dit niet meer tijd van de Kamerleden kosten aangezien het de minister is die de Kamers moet informeren. De 'last' ligt dus bij de minister en niet bij de Kamers. Een dergelijk voorbehoud kost de Kamers weinig maar levert veel informatie op. De Kamers worden niet alleen over de inhoud op de hoogte gehouden maar ook over het proces, waardoor zij op het juiste moment actie kunnen ondernemen. Ook is het positief dat de minister geen onomkeerbare beslissingen in de Raad mag nemen zonder eerst de Kamers te hebben gehoord. Zo is voor de Kamers hun inbreng verzekerd. 



\section{Hoofdstuk 4 Duitsland}

\subsection{INLEIDING}

Zoals in het vorige hoofdstuk de Nederlandse parlementaire werkzaamheden met betrekking tot Europese besluitvorming zijn beschreven, zal in dit hoofdstuk op de Duitse parlementaire activiteiten met betrekking tot EU-aangelegenheden, wetgeving en bestuur worden ingegaan. In het eerste gedeelte van dit hoofdstuk wordt een korte beschrijving gegeven van de (constitutionele) geschiedenis van Duitsland, met nadruk op de naoorlogse periode. Vervolgens wordt, eveneens kort, de staatsstructuur besproken met de voor dit onderzoek belangrijke staatsorganen. Het gaat dan met name om de Bundestag (de bondsdag), de Bundesrat (de bondsraad), de federale regering en het Bundesverfassungsgericht (het constitutioneel hof). De Duitse staatsstructuur is anders dan die van Nederland. Om te beginnen is Duitsland een federale staat. Op federaal niveau heeft Duitsland andere organen dan Nederland op centraal niveau heeft. Om te begrijpen welke rol het Duitse parlement speelt in Europese aangelegenheden is het nodig om een duidelijk beeld te hebben van de bestaande organen, de verhoudingen tussen de organen en de rollen en bevoegdheden die deze hebben. Aangezien de staatsstructuur verschilt, verschillen ook de regelingen van bevoegdheden en procedures. In het algemeen worden zowel in Duitsland als in Nederland bevoegdheden toegekend in de Grondwet. Het verschil tussen beide landen ligt in de uitwerking van deze bevoegdheden. In Duitsland is de uitwerking veel nauwkeuriger. De uitwerking betreft dan niet alleen de bevoegdheid zelf maar ook de procedure rondom de bevoegdheid. Welke procedure wanneer gevolgd moet worden en in welke volgorde bepaalde stappen genomen dienen te worden is vaak terug te vinden in een wet; zie daarvoor wat betreft het onderwerp van dit boek de drie 'Europawetten' die een uitwerking vormen van artikel 23 van de Duitse Grondwet, waar ik later in dit hoofdstuk op terugkom. Op dat punt is er een contrast zichtbaar met Nederland, waar de te volgen procedures vaker zijn bepaald door gewoonte, 'omdat men het altijd al zo doet', zoals ook bijvoorbeeld het geval is bij de vertrouwensregel.

Paragraaf 4.3 omvat een beschrijving van het wetgevingsproces. In paragraaf $4.4 \mathrm{komt}$ de controle van de regering door het parlement aan bod. Hierin zullen de bevoegdheden van het parlement worden besproken waarmee het de regering controleert, alsmede hoe vaak deze bevoegdheden tussen 2010 en 2016 zijn ingezet. De bevoegdheden die worden besproken, zijn de algemene controlebevoegdheden van de Bundestag en Bundesrat zoals die kunnen en worden ingezet in alle aangelegenheden. Daarmee wordt bedoeld dat het niet uitmaakt of het gaat om een nationale aangelegenheid of een Europese aangelegenheid, in tegenstelling tot de bevoegdheden die in paragraaf 4.5 worden besproken. Deze (bijzon- 
dere) bevoegdheden kunnen uitsluitend worden ingezet bij Europese aangelegenheden. Op de verhouding tussen deze twee bevoegdheden wordt eveneens in paragraaf 4.5 ingegaan. Deze paragraaf draagt de titel 'Duitsland en de Europese Unie'.

In paragraaf 4.5 wordt eveneens ingegaan op artikel 23 van de Duitse Grondwet. Dit is het artikel in de Grondwet waarin specifiek naar de Europese Unie wordt verwezen. Artikel 23 is uitgewerkt in de drie wetten die al aangeduid zijn en die ook in deze paragraaf aan bod komen. Ook zijn in deze paragraaf tabellen opgenomen die een overzicht geven van het aantal keren dat de Bundestag of Bundesrat zijn bevoegdheden op grond van artikel 23 Grondwet dan wel de drie specifieke wetten heeft ingezet. Daarbij hoort ook de vraag of deze 'bijzondere' bevoegdheden die alleen voor Europese aangelegenheden kunnen worden ingezet, iets toevoegen aan de algemene controlebevoegdheden, of dat deze laatste al voldoende zijn om de regering op Europees beleid te controleren.

\section{Historie}

Duitsland was in de naoorlogse periode lange tijd verdeeld. Daarom was de huidige Grondwet, die dateert uit 1949, tot de eenwording strikt genomen alleen de Grondwet van de Bondsrepubliek Duitsland (BRD). ${ }^{1}$ Het huidige Duitsland werd in 1949 verdeeld in twee staten; de in het Oosten gelegen Duitse Democratische Republiek (DDR) en de in het Westen gelegen Bondsrepubliek Duitsland (BRD). De voormalige hoofdstad Berlijn lag dan wel geheel in het oostelijke gedeelte maar behoorde voor de helft toe aan de DDR en voor de helft aan de BRD. ${ }^{2}$ De relaties tussen de DDR en de BRD werden pas geregeld in het Verdrag van 21 december 1972 inzake de grondslagen van de betrekkingen tussen de DDR en de BRD. Tussen het Oosten en het Westen liep een scheidingslijn, het IJzeren Gordijn. In Berlijn werden beide delen gescheiden door de Berlijnse Muur die in augustus 1961 klaar was. Dit bleef zo tot het najaar van 1989. De muur werd afgebroken en Duitsland was vanaf 3 oktober 1990 weer verenigd, doordat de DDR toetrad tot het 'Geltungsbereich des Grundgesetzes'. Met andere woorden, op het gebied van de DDR werd de Grondwet van de BRD van toepassing. Politiek, ideologisch en qua mentaliteit gezien bleef er echter nog enige tijd verdeeldheid bestaan tussen Oost en West (volgens sommigen is dat nog steeds het geval). Op papier was er sprake van één Duitsland, maar in de praktijk was dit niet het geval. ${ }^{3}$ In de tijd dat Oost en West gescheiden waren, had ieder deel zijn eigen wetten en regels. Na de val van de muur werd het Oosten bij het Westen gevoegd en werd

1 P. Badura, Staatsrecht. Systematische Erläuterung des Grundgesetzes, München: Verlag C.H. Beck 2018, p. 50-51; D. Willoweit, Reich und Staat. Eine kleine deutsche Verfassungsgeschichte, München: Verlag C.H. Beck 2013, p. 115.

2 P. Badura, Staatsrecht. Systematische Erläuterung des Grundgesetzes, München: Verlag C.H. Beck 2018, p. $70-72$.

3 D. Willoweit, Reich und Staat. Eine kleine deutsche Verfassungsgeschichte, München: Verlag C.H. Beck 2013, p. 117-118. 
de Grondwet van de Bondsrepubliek van toepassing op het gehele territorium. Hiertoe werden artikel 146 van de Grondwet en de preambule gewijzigd, zodat de Grondwet van het Westen ook van toepassing werd op het Oosten en zo de vereniging van Oost en West grondwettelijk vastgelegd werd. Artikel 23 van de toenmalige Grondwet over Duitse gebieden waarop de Grondwet niet van toepassing was, werd geschrapt omdat dit artikel niet langer nodig was. Artikel 23 van de huidige Grondwet is nu hét artikel over de Europese Unie. $^{4}$

Om de vereniging tussen Oost en West te realiseren werden drie verdragen tussen de DDR en de BRD gesloten, namelijk het 'Staatsvertrag' (Staatsverdrag) ${ }^{5}$ dat de gezamenlijke monetaire, economische en sociale unie regelde, het 'Wahlvertrag' (Verkiezingsverdrag) ${ }^{6}$ dat gemeenschappelijke verkiezingen regelde en het 'Einigungsvertrag' (Eenheidsverdrag) ${ }^{7}$ dat ervoor moest zorgen dat beide staten werden verenigd tot één staat. Tot slot werd het 'Vertrag über die abschließende Regelung in bezug auf Deutschland' (Verdrag inzake de afsluitende regeling met betrekking tot Duitsland, ook wel het 'Zwei-plus-Vier-Vertrag' (twee-plus-vier-verdrag) genoemd, ${ }^{8}$ gesloten tussen de DDR, BRD, de Verenigde Staten, het Verenigd Koninkrijk, de Sovjet-Unie en Frankrijk (de voormalige bezettingsmachten). Dit verdrag regelde dat deze vier machten hun rechten en verantwoordelijkheden met betrekking tot Duitsland beëindigden, waardoor Duitsland weer volledig soeverein werd. ${ }^{9}$

De Bondsrepubliek Duitsland ${ }^{10}$ ontwikkelde na de Tweede Wereldoorlog een systeem met checks and balances op federaal en deelstatenniveau. Daarnaast wilde Duitsland uitdrukkelijk aangeven dat het openstond voor internationale samenwerking. Wat daar toen ook bij hoorde, was het afstaan van bevoegdheden aan supranationale organisaties. Dit werd gedaan om te laten zien dat Duitsland wereldvrede wilde promoten als een gelijkwaardige en bevriende staat binnen een verenigd Europa. De bevoegdheid tot het overhevelen van bevoegdheden werd specifiek opgenomen in de Grondwet. ${ }^{11}$

4 P. Badura, Staatsrecht. Systematische Erläuterung des Grundgesetzes, München: Verlag C.H. Beck 2018, p. 72-73.

5 Staatsvertrag, 18 mei 1990.

6 Wahlvertrag, 2 december 1990.

7 Einigungsvertrag, 31 augustus 1990; R. Schmidt, Staatsorganisationsrecht: sowie Grundzüge des Verfassungsprozessrechts und des EU-rechts, Hannover: Druckhaus Pinkvoss GmbH 2018, p. 7.

8 Vertrag über die abschließende Regelung in bezug auf Deutschland, 12 september 1990.

9 R. Schmidt, Staatsorganisationsrecht: sowie Grundzüge des Verfassungsprozessrechts und des EU-rechts, Hannover: Druckhaus Pinkvoss GmbH 2018, p. 8.

10 Strikt genomen moet het Bondsrepubliek Duitsland zijn.

11 D. Thym, 'Parliamentary Control of EU decision-making in Germany', in: O. Tans, C. Zoethout \& J. Peters (eds.), National Parliaments and European Democracy: A Bottom-up Approach to European Constitutionalism, Groningen: Europa Law Publishing 2007, p. 49-50. 


\subsection{StaAtsstructuUr}

In deze paragraaf zal worden ingegaan op de staatsstructuur van Duitsland. Daarnaast worden de, voor dit onderzoek, belangrijkste staatsorganen beschreven evenals de verhouding tussen deze organen. Duitsland is een federale staat, een bondsstaat, en bestaat op federaal niveau uit de bond en op decentraal niveau uit zestien deelstaten, de Länder. Deze Länder hebben ieder zelf ook een constitutie waarin de organisatie van het Land is vastgelegd. ${ }^{12}$ In dit proefschrift zal niet verder worden ingegaan op de interne aangelegenheden van de Länder. ${ }^{13}$ De Länder worden op federaal niveau vertegenwoordigd in de Bundesrat, zie daarvoor paragraaf 4.2.2.

Artikel 20 van de Grondwet maakt duidelijk dat gekozen is voor een republiek en een democratische en sociale federale staat, gebaseerd op het rechtsstaatbeginsel. Het democratieprincipe uit zich in de volkssoevereiniteit waarbij het niet gaat om een directe democratie maar een representatieve democratie waar het volk kan stemmen voor de samenstelling van de vertegenwoordigende staatsorganen. Daarnaast moet het handelen van de overheid herleidbaar zijn naar het volk, met andere woorden, het handelen moet democratisch gelegitimeerd zijn. Zo kiest het volk de leden van de Bundestag, die op zijn beurt weer de Bondskanselier kiest, die daarna ministers benoemt die in het kabinet komen. Dit is de zogenoemde legitimatieketen. De Bundestag is het hoogste representatieve orgaan binnen de democratie en heeft als taak de regering te vormen en te controleren en wetten te maken. ${ }^{14}$ Zoals aan het begin is aangegeven is Duitsland een sociale staat. Dit komt niet enkel tot uiting in het feit dat de staat verplicht is om socialezekerheidswetten te maken en een bestaansminimum van het volk te waarborgen maar ook in het doel van de ontwikkeling van de Europese Unie in artikel 23 van de Grondwet. In dit artikel is vastgelegd dat Duitsland deelneemt aan de ontwikkeling van een democratische en sociale Europese Unie. $^{15}$

Een belangrijk aspect van deze bepaling is dat de Europese eenwording zich blijft ontwikkelen en dus geen voltooid project is. Hierdoor ontstaat ruimte voor verdere integratiestappen en overdracht van bevoegdheden, voor zover de overige bepalingen van de Grondwet deze toelaten.

12 P. Badura, Staatsrecht. Systematische Erläuterung des Grundgesetzes, München: Verlag C.H. Beck 2018, p. $452-453$.

13 Het is niet zo dat de Länder geen rol spelen in Europese aangelegenheden. Länder spelen bijvoorbeeld een rol bij de implementatie en uitvoering van EU-recht, maar dit gaat het bereik van dit proefschrift te buiten. De interne aangelegenheden en organisatie van Länder zullen daarom geen rol spelen in dit onderzoek.

14 R. Schmidt, Staatsorganisationsrecht: sowie Grundzüge des Verfassungsprozessrechts und des EU-rechts, Hannover: Druckhaus Pinkvoss GmbH 2018, p. 27; Ch. Degenhart, Staatsrecht I. Staatsorganistionsrecht. Mit Bezügen zum Europarecht, Heidelberg: C.F. Müller GmbH 2017, p. 11.

15 R. Schmidt, Staatsorganisationsrecht: sowie Grundzüge des Verfassungsprozessrechts und des EU-rechts, Hannover: Druckhaus Pinkvoss GmbH 2018, p. 142. 
Op federaal niveau kunnen meerdere organen worden onderscheiden: de bondspresident, de Bundestag (Bondsdag), de Bundesrat (Bondsraad) en de bondsregering (bestaande uit de bondskanselier en de bondsministers). Daarnaast zijn er enkele adviescolleges en rechterlijke instanties. De laatste twee zullen verder niet behandeld worden, met uitzondering van het Bundesverfassungsgericht. ${ }^{16}$

Binnen het Duitse stelsel is een duidelijke machtenscheiding terug te vinden. Er is gekozen voor de klassieke driedeling van wetgeving, bestuur en rechtspraak. De machtenscheiding is niet alleen terug te vinden in deze driedeling maar ook in de checks and balances die te vinden zijn in de gedeelde bevoegdheden en de controlebevoegdheden tussen de organen. Zo heeft de bondspresident op grond van artikel 82 van de Grondwet de opdracht om conceptwetten te ondertekenen en af te kondigen. Voordat de bondspresident dit doet, controleert hij of de conceptwet in lijn is met de Grondwet. Indien hij van mening is dat de conceptwet onconstitutioneel is dan heeft hij het recht om zijn handtekening eraan te onthouden. ${ }^{17}$ De wet komt hiermee niet tot stand. Artikel 82 moet in samenhang met artikel 78 gelezen worden. Hierin is de eis opgenomen dat de totstandkoming procedureel correct moet zijn en de president gehouden is de Grondwet na te leven. Er zijn twee benaderingen voor het al dan niet ondertekenen van een conceptwet die de Grondwet schendt. De ene benadering is dat wanneer de president vindt dat de Grondwet wordt geschonden, hij de handeling, het ondertekenen van de conceptwet, niet mag uitvoeren. Dit is in enkele evidente gevallen ook gebeurd in het verleden. ${ }^{18}$ De andere benadering is dat de president juist wel de onconstitutionele conceptwet moet tekenen zodat deze daarna aan het Bundesverfassungsgericht kan worden voorgelegd voor finale beslechting. ${ }^{19}$

De Duitse Grondwet van 1949 geeft duidelijk een federale republiek met een parlementaire democratie weer. De zestien Länder worden op nationaal niveau vertegenwoordigd in de Bundesrat. De Bundesrat vormt samen met de Bundestag het parlement. De regering wordt geleid door de kanselier.

De Duitse Grondwet is de hoogste regeling binnen Duitsland en heeft voorrang boven andere wetten en regelingen. ${ }^{20}$ De Grondwet kan slechts gewijzigd worden door een procedure te volgen die met bijzondere waarborgen is omkleed. Niet alle bepalingen in de Grondwet kunnen worden gewijzigd. Artikel 79 lid 3 bepaalt dat artikel 1 (menselijke

16 Ibid., p. 218.

17 Het komt niet vaak voor dat de bondspresident weigert een handtekening te zetten. In 2006 weigerde bondspresident Köhler zijn handtekening te zetten onder de conceptwet die privatisering van de luchtverkeersbeveiliging regelde.

18 Zie vorige voetnoot.

19 R. Schmidt, Staatsorganisationsrecht: sowie Grundzüge des Verfassungsprozessrechts und des EU-rechts, Hannover: Druckhaus Pinkvoss GmbH 2018, p. 286.

20 Art. 20 lid 3 Grondwet. 
waardigheid) en 20 (staatsrechtelijke beginselen) niet gewijzigd kunnen worden. ${ }^{21}$ De Grondwet regelt de organisatie van de staat, de inrichting daarvan, de samenstelling en bevoegdheden van organen van de staat, de grondrechten van de burgers, de verhouding tussen de bond en de Länder en de verhouding tussen de burgers en de overheid. ${ }^{22}$

\subsubsection{Bundestag}

Binnen de representatieve parlementaire democratie in Duitsland is de Bundestag het rechtstreeks gekozen orgaan dat het volk vertegenwoordigt. ${ }^{23}$ Andere federale organen worden via de Bundestag gelegitimeerd. ${ }^{24}$ De Bundestag heeft als parlement de taak om de regering te controleren. Deze behoeft dan ook het vertrouwen van de Bundestag. Daarnaast is de Bundestag, samen met de Bundesrat, wetgever. De leden van de Bundestag worden rechtstreeks gekozen door het volk. In beginsel bestaat de Bundestag uit 598 leden maar door het kiessysteem waarbij het aantal zetels in de Bundestag kan worden verhoogd, zitten er doorgaans (veel) meer leden meer in de Bundestag. ${ }^{25}$ In de negentiende Bundestag, die in 2017 werd gekozen, zitten 111 meer leden. ${ }^{26}$

De leden van de Bundestag zijn verdeeld in fracties. Deze fracties kunnen gebruikmaken van faciliteiten zoals vergader- en kantoorruimtes en daarnaast hebben ze bepaalde bevoegdheden die 'fractieloze' leden van de Bundestag niet hebben zoals een Große Anfrage of Aktuelle Stunde aanvragen. ${ }^{27}$

Net zoals in de Nederlandse Tweede Kamer vinden de werkzaamheden in de Bundestag in de plenaire vergadering en in Kamercommissies plaats. Sommige van deze commissies worden expliciet genoemd in de Grondwet. ${ }^{28}$ De commissies hebben elk een eigen terrein waarop ze werkzaam zijn; wanneer de plenaire vergadering binnen dat terrein valt, zal de

21 R. Schmidt, Staatsorganisationsrecht: sowie Grundzüge des Verfassungsprozessrechts und des EU-rechts, Hannover: Druckhaus Pinkvoss GmbH 2018, p. 219.

22 L.F.M. Besselink, P.P.T. Bovend'Eert, J.L.W. Broeksteeg \& R. de Lange, Het Staatsrecht van 7 Europese landen, Deventer: Kluwer 2018, p. 68.

23 Ch. Gröpl, Staatsrecht I. Staatsgrundlagen, Staatsorganisation, Verfassungsprozess mit Einführung in das juristische Lernen, München: C.H. Beck 2017, p. 246.

24 R. Schmidt, Staatsorganisationsrecht: sowie Grundzüge des Verfassungsprozessrechts und des EU-rechts, Hannover: Druckhaus Pinkvoss GmbH 2018, p. 219.

25 Ch. Gröpl, Staatsrecht I. Staatsgrundlagen, Staatsorganisation, Verfassungsprozess mit Einführung in das juristische Lernen, München: C.H. Beck 2017, p. 249-250.

26 E. Jesse, 'Die Bundestagswahl 2017 und die Regierungsbildung', ZfP Zeitschrift für Politik 2018, 65(2), p. 168. Gewerkt wordt aan wetswijzigingen om voor de toekomst dergelijke omvangrijke toevoegingen te voorkomen.

27 Ch. Degenhart, Staatsrecht I. Staatsorganistionsrecht. Mit Bezügen zum Europarecht, Heidelberg: C.F. Müller GmbH 2017, p. 257; Ch. Gröpl, Staatsrecht I. Staatsgrundlagen, Staatsorganisation, Verfassungsprozess mit Einführung in das juristische Lernen, München: C.H. Beck 2017, p. 272-273.

28 Onder andere de commissies voor Europese Zaken (art. 45), Buitenlandse Zaken en defensie (art. 45a) en de commissie voor Verzoekschriften (art. 45c). 
Kamercommissie die vergadering voorbereiden. Wat daar onder andere bij hoort, is het doen van voorstellen met betrekking tot besluiten die de Bundestag neemt. De omvang van elke politieke partij in de Bundestag wordt weerspiegeld in de samenstelling van de Kamercommissies. Grote partijen hebben dus meerdere zetels binnen een commissie, kleine partijen slechts één of enkele zetels. Zo hebben de Kamercommissies ongeveer dezelfde politieke afspiegeling als de gehele Bundestag. De taken van de Kamercommissies worden gedeeltelijk geregeld door het Reglement van Orde, gedeeltelijk door gebruik. De zittingen van de commissies zijn in beginsel openbaar. Van deze zittingen wordt doorgaans door een rapporteur een schriftelijk rapport opgesteld dat aan de Bundestag wordt gestuurd. In dat rapport wordt een meerderheidsstandpunt en eventueel een minderheidsstandpunt kenbaar gemaakt. Naast het feit dat de leden van de Bundestag in commissies samenwerken over de grenzen van de fracties, werken leden van eenzelfde partij in hun fracties samen.

Zoals eerder aangegeven is het de Bundestag als geheel, in de plenaire vergadering, die de besluiten neemt en waaraan de bevoegdheden toekomen. Hierop bestaat één uitzondering. De commissie voor Europese Zaken is als enige commissie bevoegd, voor zover daarvoor door de Bundestag mandaat is afgegeven, zelfstandig besluiten te nemen namens de gehele Bundestag. Hierop zal later in dit hoofdstuk worden ingegaan.

Het aantal bevoegdheden van de Bundestag is ruim. Een van de belangrijkste bevoegdheden van de Bundestag ligt in het wetgevingsproces. Naast de Bundesrat, de regering en de bondspresident heeft de Bundestag een (hoofd)rol in het wetgevingsproces. Artikel 77 van de Grondwet bepaalt dat wetten moeten worden aangenomen door de Bundestag. In dit wetgevingsproces heeft ook de Bundestag, naast de Bundesrat en de regering, het initiatiefrecht en het recht om te amenderen. ${ }^{29}$

De Bundestag kiest daarnaast (mede) de ambtsdragers van andere staatsorganen. Doordat de Bundestag deze kiest, worden deze staatsorganen, zoals de bondskanselier en de leden van het Bundesverfassungsgericht, democratisch gelegitimeerd. De bondspresident wordt gekozen door de zogenoemde Bundesversammlung (federale vergadering), bestaande uit leden van de Bundestag en hetzelfde aantal mannen en vrouwen die door de parlementen van de Länder worden gekozen. Via deze indirecte weg is ook de bondspresident democratisch gelegitimeerd. ${ }^{30}$

De volgende bevoegdheid van de Bundestag is het opstellen van de begroting van inkomsten en uitgaven van de staat. ${ }^{31}$ De begroting wordt bij wet vastgesteld. Het is dus

29 Ch. Gröpl, Staatsrecht I. Staatsgrundlagen, Staatsorganisation, Verfassungsprozess mit Einführung in das juristische Lernen, München: C.H. Beck 2017, p. 248.

30 R. Schmidt, Staatsorganisationsrecht: sowie Grundzüge des Verfassungsprozessrechts und des EU-rechts, Hannover: Druckhaus Pinkvoss GmbH 2018, p. 283.

31 Art. 114 lid 1 Grondwet. 
via het budgetrecht voor de Bundestag mogelijk om invloed uit te oefenen op het regeringsbeleid.

Een andere hoofdtaak van de Bundestag is het controleren van de regering en haar beleid. Om dit te kunnen doen verstrekt de regering informatie aan de Bundestag. Wanneer de Bundestag aanwezigheid van een of meer leden van de regering wenst in de vergadering, dan zijn deze leden verplicht om aanwezig te zijn en de vragen te beantwoorden die de Bundestag heeft. Wanneer het lid of de leden van de regering niet voldoet/voldoen aan deze plicht dan kan als sanctie de vertrouwensregel worden ingezet. ${ }^{32}$ In beginsel gaat het om een informatieplicht van de regering aan de Bundestag zodat deze laatste de regering en het binnenlands- en buitenlandsbeleid kan controleren. Een enkele keer is de informatie nodig omdat de Bundestag moet instemmen. Op basis van een uitspraak van het Bundesverfassungsgericht is dit het geval wanneer het Duitse leger wordt ingezet buiten het grondgebied van de NAVO. ${ }^{33}$ Ook een ander belangrijk onderwerp waarin de Bundestag instemmingsrecht heeft, heeft het Bundesverfassungsgericht beslist in het zogenoemde 'Maastricht-Urteil'. ${ }^{34}$ Het Bundesverfassungsgericht bepaalde dat voor uitbreiding van de taken en bevoegdheden van de Europese Unie een verdragswijziging plaats moest vinden. Voor een dergelijke wijziging is de instemming van de Bundestag nodig. Toen in 2009 het Verdrag van Lissabon in werking trad, dat voorzag in bepaalde procedures waarbij taken en bevoegdheden van de Europese Unie wel zonder verdragswijziging konden worden uitgebreid, kwam het Bundesverfassungsgericht wederom met een uitspraak, het 'LissabonUrteil'. ${ }^{35}$ Wanneer er sprake is van een dergelijke situatie, een zogenoemde 'passerelleprocedure' heeft elk nationaal parlement de mogelijkheid de procedure te stoppen door bezwaar te maken. Het Bundesverfassungsgericht bepaalde dat voor een dergelijke wijziging een stilzwijgende goedkeuring van nationale parlementen niet voldoende was. Goedkeuring dient in dit geval uitdrukkelijk te gebeuren. Dat betekent dat een minister pas op Europees niveau kan meewerken wanneer de Bundestag heeft ingestemd met de wijziging.

Naast het Maastricht-Urteil en het Lissabon-Urteil deed het Bundesverfassungsgericht nog een keer uitspraak in een zaak die betrekking had op de verhouding tussen de Europese Unie en Duitsland. In 2011 toetste het Bundesverfassungsgericht de grondwettigheid van het 'Euro-Stabilisieringsmechanismus-Gesetz'. Op basis van deze wet zou Duitsland $€ 170$ miljard bijdragen aan de Euro-reddingsoperatie. Het hof oordeelde dat een inbreuk op het kiesrecht wordt gemaakt wanneer de Bundestag niet langer zelfstandig zijn budgetrecht kan uitoefenen. In het geval van de Euro-reddingsoperatie was er echter geen sprake van een onaanvaardbare uitholling van het budgetrecht. ${ }^{36}$ Het hof noemt het budgetrecht wel

\footnotetext{
32 Art. 43 lid 1 Grondwet.

33 BVerfG 7 mei 2008 - 2 BvE 1/03.

34 BVerfG 12 oktober 1993 - 2 BvR 2134/92.

35 BVerfG 30 juni $2009-2$ BvE 2/08.

36 BVerfG 7 september 2011 - 2 BvR 987/10.
} 
een van de fundamentele rechten binnen de democratische structuur van Duitsland. Met betrekking tot het vaststellen van de begroting heeft de Bundestag een belangrijke positie en deze is naar aanleiding van de Euro-reddingsoperatie ${ }^{37}$ niet beperkt. Op basis van artikel 110 van de Grondwet is het vaststellen van de begroting uitsluitend een taak van de wetgever waar de Bundestag deel van uit maakt. De belangrijke positie van de Bundestag is ook terug te vinden in artikel 114 van de Grondwet waarin het recht van de Bundestag (en de Bundesrat) is neergelegd om de uitgaven van de regering te controleren. ${ }^{38}$ Het hof geeft aan dat de Bundestag 'Herr seiner Entschlüsse' (baas over zijn eigen besluiten) blijft. ${ }^{39}$ Daarom heeft de Bundestag eveneens een belangrijke positie bij een ESM-beslissing om steun te verlenen aan noodlijdende eurolanden. In zijn ESM-uitspraak heeft het Bundesverfassungsgericht namelijk bepaald dat de Duitse Bundestag hiermee iedere keer expliciet dient in te stemmen. ${ }^{40}$ Dat is dan ook gebeurd toen er steunpakketten werden toegekend aan Griekenland.

Wanneer sprake is van voorbereiding van besluitvorming op een belangrijk en omvangrijk onderwerp, waaronder ook een onderwerp met betrekking tot de Europese Unie kan vallen, heeft de Bundestag de mogelijkheid om een enquêtecommissie in te stellen. Dit is hij zelfs verplicht wanneer een vierde van zijn leden hierom verzoekt. ${ }^{41}$ Anders dan in Nederland is het enquêterecht in de Duitse Bundestag een minderheidsrecht. Het doel van een dergelijke enquêtecommissie is het adviseren van de Bundestag omtrent de technische, economische en maatschappelijke consequenties van de wetgeving die in ontwikkeling is, alsmede het verrichten van nader onderzoek, bijvoorbeeld in gevallen waar de oppositie vermoedt dat de regering of een overheidsorgaan de wet heeft geschonden. De commissie doet aanbevelingen voor de politieke beslissingen die genomen moeten worden. ${ }^{42}$

\subsubsection{Bundesrat en Länder}

De Bondsrepubliek Duitsland bestaat uit zestien deelstaten die 'Länder' worden genoemd. Elk Land heeft zijn eigen Grondwet en parlementair stelsel met een parlement bestaande uit één Kamer. De regering binnen het Land wordt voorgezeten door een minister-president die verantwoording schuldig is aan het parlement van de deelstaat. ${ }^{43}$ Aangezien de Länder

\footnotetext{
37 Het EFSF en het ESM.

38 BVerfG 7 september 2011 - 2 BvR 987/10, r.o. 122.

39 BVerfG 7 september 2011 - 2 BvR 987/10, r.o. 124.

40 BVerfG 12 september 2012 - 2 BvR 1390/12.

41 Par. 56 Reglement van Orde van de Bundestag.

42 C. Heyer \& S. Liening, Enquete-Kommissionen des Deutschen Bundestages. Schnittstellen zwischen Politik und Wissenschaft, Deutscher Bundestag Berlin 2004 via www.btg-bestellservice.de/pdf/20207000.pdf.

43 Ch. Gröpl, Staatsrecht I. Staatsgrundlagen, Staatsorganisation, Verfassungsprozess mit Einführung in das juristische Lernen, München: C.H. Beck 2017, p. 277-278.
} 
op federaal niveau worden vertegenwoordigd in de Bundesrat, hebben de Länder op basis van artikel 50 Grondwet via de Bundesrat invloed op federale wetgeving en aangelegenheden inzake de Europese Unie. ${ }^{44}$ Een uiteenzetting hiervan volgt in de paragrafen 4.4 (wetgevingsproces) en 4.6 (Duitsland en de Europese Unie).

De Bundesrat bestaat uit vertegenwoordigers van de regeringen van de zestien Länder. Deze vertegenwoordigers spreken namens de (regeringen van) de Länder. Het zijn ook die regeringen die de vertegenwoordigers in de Bundesrat benoemen en ontslaan. ${ }^{45}$ Op grond van artikel 51 Grondwet heeft elk Land ten minste drie stemmen in de Bundesrat. Länder met meer dan twee miljoen inwoners hebben vier stemmen, Länder met meer dan zes miljoen inwoners hebben vijf stemmen en Länder met meer dan zeven miljoen inwoners hebben zes stemmen. Het aantal vertegenwoordigers per Land mag maximaal hetzelfde zijn als het aantal stemmen dat een Land heeft. ${ }^{46}$ Het is gebruikelijk om minimaal de minister-president van het land af te vaardigen. De vertegenwoordigers in de Bundesrat hebben niet zoals de leden van de Bundestag een vrij mandaat. Het is namelijk zo dat de vertegenwoordigers aanwijzingen krijgen van hun regering. Daarnaast wordt in de Bundesrat als land in zijn geheel gestemd. Een vertegenwoordiger kan dus niet anders stemmen dan de rest van zijn of haar land. Wordt dit wel gedaan dan worden de uitgebrachte stemmen van dat land ongeldig verklaard. ${ }^{47}$

De Bundesrat is een permanent orgaan en kan niet worden ontbonden. Bij een nieuwe samenstelling van de regering op Landniveau zullen er nieuwe vertegenwoordigers, leden van deze nieuwe regering, in de Bundesrat komen. Er zullen dus slechts een paar vertegenwoordigers uit de Bundesrat weggaan en een paar nieuwe zullen zitting nemen. Gezien het feit dat de verkiezingen binnen de Länder niet op één moment plaatsvinden, wijzigt de samenstelling van de Bundesrat continu en geleidelijk. ${ }^{48}$ Wanneer er op Landniveau verkiezingen zijn geweest kan dit wel gevolgen hebben voor de meerderheid binnen de Bundesrat. Dit heeft op zijn beurt weer gevolgen voor de federale regering: die moet namelijk zekerstellen of er voor bepaalde nieuwe wetgeving een meerderheid in de Bundesrat is.

De Bundesrat vormt samen met de direct gekozen Bundestag de wetgever. Zoals hierboven aangegeven worden de (regeringen van de) Länder op federaal niveau vertegenwoordigd in de Bundesrat. Hierdoor spelen de Länder een rol in het wetgevingsproces. Daarnaast

\footnotetext{
$44 \quad$ Ibid., p. 276.

45 Art. 51 lid 1 Grondwet.

46 Art. 51 lid 3 Grondwet.

47 Ch. Degenhart, Staatsrecht I. Staatsorganistionsrecht. Mit Bezügen zum Europarecht, Heidelberg: C.F. Müller GmbH 2017, p. 290.

48 R. Schmidt, Staatsorganisationsrecht: sowie Grundzüge des Verfassungsprozessrechts und des EU-rechts, Hannover: Druckhaus Pinkvoss GmbH 2018, p. 261.
} 
zijn het de Länder die federale wetgeving uitvoeren. Dit maakt de Länder een belangrijk onderdeel van het Duitse staatsbestel. ${ }^{49}$

Een kanttekening moet worden gemaakt. In het federale wetgevingsproces, dat hierna nog wordt besproken, is het mogelijk dat de Bundesrat wordt overstemd door de Bundestag. Instemming van de Bundestag is altijd vereist, maar afstemming door de Bundesrat kan worden overstemd door de Bundestag. Dat geldt echter niet voor wetgeving waarvoor volgens de Grondwet instemming van de Bundesrat vereist is, maar alleen voor de overige wetgeving waarbij de Bundesrat 'slechts' bezwaar kan maken. De eerste categorie, de Zustimmungsgesetze, zijn die wetten die als zodanig in de Grondwet zijn genoemd. Deze categorie is in drie groepen te verdelen: (1) wetten die de Grondwet wijzigen, (2) wetten die op een manier invloed hebben op de financiën van de Länder en (3) wetten waarvan de uitvoering de organisatorische en administratieve soevereiniteit van de Länder betreft. ${ }^{50}$ Alle andere wetten behoren tot de tweede categorie, de Einspruchsgesetze. ${ }^{51}$

Bij de vaststelling van federale wetten heeft de Bundesrat het recht van initiatief. Hierdoor is het voor de Länder mogelijk om initiatieven op federaal niveau aan te brengen. ${ }^{52}$ Andere bevoegdheden van de Bundesrat zijn er met name ten opzichte van de Länder. Zo moet de Bundesrat toestemming geven voor regelingen die maatregelen voor de Länder inhouden. Het gaat dan om regelingen van de federale overheid of een federale minister betreffende de vergoedingen voor het gebruik van post- en telecommunicatiefaciliteiten, over het in rekening brengen van het gebruik van de federale spoorwegen, de aanleg en exploitatie van spoorwegen en andere regelingen die op basis van federale wetten de toestemming van de Bundesrat vereisen of die door de Länder worden uitgevoerd namens de federale overheid. Het initiatief voor dergelijke regelingen kan van de Bundesrat komen. ${ }^{53}$ Wanneer de bondsregering ingrijpt in een Land indien dat zijn verplichtingen niet nakomt, dient de Bundesrat toestemming te geven voor de zware maatregelen die de regering wil treffen. ${ }^{54}$ Daarnaast is de Bundesrat bevoegd een deel van de rechters voor het Bundesverfassungsgericht te benoemen. ${ }^{55}$ De Bundesrat heeft echter geen bevoegdheden om de regering te controleren. Ook werkt de vertrouwensregel niet ten opzichte van de Bundesrat. ${ }^{56}$ Toch moet de Bundesrat als een belangrijk orgaan worden beschouwd, niet

49 Art. 50 Grondwet.

50 Website Bundesrat, Zustimmungs- und Einspruchsgesetze.

51 Zie par. 4.3 voor het Duitse wetgevingsproces.

52 R. Schmidt, Staatsorganisationsrecht: sowie Grundzüge des Verfassungsprozessrechts und des EU-rechts, Hannover: Druckhaus Pinkvoss GmbH 2018, p. 262.

53 Art. 80 lid 2 Grondwet.

54 Art. 84 lid 3 Grondwet.

55 R. Schmidt, Staatsorganisationsrecht: sowie Grundzüge des Verfassungsprozessrechts und des EU-rechts, Hannover: Druckhaus Pinkvoss GmbH 2018, p. 264.

56 L.F.M. Besselink, P.P.T. Bovend'Eert, J.L.W. Broeksteeg \& R. de Lange, Het Staatsrecht van 7 Europese landen, Deventer: Kluwer 2018, p. 78. 
alleen door het feit dat de Länder via de Bundesrat een rol spelen op federaal niveau. Door zijn rol in het wetgevingsproces kan de Bundesrat besluitvorming beïnvloeden en op belangrijke gebieden ook blokkeren (zie par. 4.3).

\subsubsection{Vertegenwoordiger Länder bij de EU}

De zestien Länder hebben een gezamenlijke waarnemer bij de Europese Unie in Brussel. Deze Länderbeobachter, zoals de waarnemer in het Duits heet, is een instituut dat de Bundesrat ondersteunt bij de uitoefening van zijn rechten met betrekking tot Europese aangelegenheden. Daarnaast houdt de waarnemer de Bundesrat op de hoogte van alle gebeurtenissen in de EU. De belangrijkste taak is het bijwonen van de vergaderingen van de Raad van de Europese Unie en hierover verslag uitbrengen aan de Bundesrat. Hierdoor kan de Bundesrat controleren of de regering de besluiten van de Bundesrat heeft meegenomen in de onderhandelingen in de Raad. Ook heeft de vertegenwoordiger als taak de Bundesrat continu op de hoogte te houden van en te betrekken bij de discussies en beslissingen die op Europees niveau worden genomen.

De waarnemer rapporteert over alle beleidsterreinen, ook over de terreinen waarop de Länder geen wetgevende bevoegdheid hebben. Daarnaast werkt de waarnemer nauw samen met de permanente vertegenwoordiger van Duitsland in de EU. ${ }^{57}$ De vertegenwoordiger bij de EU is van groot belang aangezien de Bundesrat hierdoor op de hoogte blijft van alle gebeurtenissen in de EU. Het is niet zo dat de vertegenwoordiger zelf invloed heeft op hetgeen in de EU gebeurt maar door de vertegenwoordiger kan de Bundesrat zijn bevoegdheden op het juiste moment en in een vroeg stadium inzetten. Zoals eerder in dit onderzoek is aangegeven is het van belang dat nationale parlementen in een vroeg stadium geïnformeerd worden en zo goed mogelijk geïnformeerd worden. Dat geldt natuurlijk ook voor de Bundesrat. Hoe eerder de Bundesrat op de hoogte is van onder andere nieuwe voorstellen, hoe eerder de Bundesrat bevoegdheden kan inzetten om invloed uit te oefenen op deze nieuwe voorstellen.

\subsubsection{Bondsregering; bondskanselier en de bondsministers}

Op federaal niveau bestaat de regering uit de bondskanselier en de bondsministers. De regering wordt geleid door de bondskanselier en de ministers hebben ieder hun eigen werkterrein. De bondskanselier wordt na verkiezing van de Bundestag door de nieuwe Bundestag gekozen. De kandidaat wordt voorgedragen door de bondspresident. De bondspresident maakt zijn keuze op basis van de wensen van de fractieleiders in de Bundestag en niet op basis van zijn eigen politieke voorkeuren. De voorgedragen kandidaat

57 Website Duitse permanente vertegenwoordiger in de EU. 
heeft minimaal het aantal stemmen van de meerderheid van het aantal leden van de Bundestag nodig. Wordt deze meerderheid niet gehaald dan heeft de Bundestag veertien dagen de tijd om zijn eigen kandidaat te verkiezen. De bondspresident benoemt uiteindelijk de gekozen kandidaat tot bondskanselier, tenzij de bondspresident ervoor kiest om de Bundestag te ontbinden. ${ }^{58}$

Wanneer de bondskanselier is benoemd worden de bondsministers benoemd. Zij worden op voordracht van de bondskanselier door de bondspresident benoemd. ${ }^{59}$ Ook worden de ministers op voordracht van de bondskanselier door de president ontslagen maar daarbij kan de bondspresident dit verzoek niet weigeren. ${ }^{60}$ Ministers zijn doorgaans naast minister ook nog lid van de Bundestag.

Ook kent Duitsland het ambt van staatssecretaris. Hierin zijn twee vormen te onderscheiden, de Beamtete Staatssekretär (ambtelijke staatssecretaris), of kortweg Staatssekretär, en de Parlamentarischer Staatssekretär (parlementaire staatssecretaris). De Beamtete Staatssekretär is de hoogste ambtenaar binnen het ministerie. Hij is verantwoordelijk voor de werkzaamheden binnen het ministerie en handelt in opdracht en volgens de richtlijnen van de minister. ${ }^{61}$ De Parlamentarischer Staatssekretär ondersteunt de minister in zijn politieke werkzaamheden, waaronder contact houden met de Bundestag. Deze staatssecretarissen zijn geen lid van de regering maar worden wel aan een ministerie gekoppeld. ${ }^{62}$ Tegelijkertijd moeten ze lid zijn van de Bundestag, wat overigens niet geldt voor de minister. ${ }^{63}$ Wanneer het lidmaatschap van de Bundestag of het ministerschap van zijn minister eindigt, dan zal ook het ambt van staatssecretaris eindigen.

De bondskanselier bepaalt, binnen de marges van het politiek mogelijke en de coalitie, het nationale politieke beleid. Dit beleid vormt voor de ministers een kader waarbinnen zij zelfstandig kunnen opereren en verantwoordelijk zijn voor hun werk. Ook zet de bondskanselier de hoofdlijnen uit van het Duitse buitenlands en Europees beleid. Daarnaast heeft de bondskanselier de bevoegdheid om een ministersploeg samen te stellen en te wijzigen, aanwijzingen te geven aan die ministers en de agenda voor de ministerraadsvergadering vast te stellen. De bondskanselier heeft een sterke positie door zijn vele bevoegdheden, maar de uitoefening daarvan wordt uiteraard beperkt door de realiteit in een coalitie. Zo is het de bondskanselier die de algemene beleidslijnen van de regering bepaalt en daar ook verantwoordelijk voor is. ${ }^{64}$ Ten opzichte van de bondspresident heeft de bondskanselier

58 Ch. Degenhart, Staatsrecht I. Staatsorganistionsrecht. Mit Bezügen zum Europarecht, Heidelberg: C.F. Müller GmbH 2017, p. 302-303.

59 Art. 64 lid 1 Grondwet.

60 Ch. Gröpl, Staatsrecht I. Staatsgrundlagen, Staatsorganisation, Verfassungsprozess mit Einführung in das juristische Lernen, München: C.H. Beck 2017, p. 337.

61 Website Ministerie van Binnenlandse Zaken, Beamtete Staatssekretär.

62 Art. 62 Grondwet.

63 Website Ministerie van Binnenlandse Zaken, Parlamentarischer Staatssekretär.

64 Art. 65 Grondwet. 
geen vertrouwensrelatie, wel ten opzichte van de Bundestag. ${ }^{65}$ Hierop wordt later in dit hoofdstuk ingegaan.

De ministers geven ieder leiding aan hun eigen departement. Daarnaast bepalen ze binnen hun werkterrein hun eigen beleid, binnen de kaders gesteld door de bondskanselier. Besluiten op het eigen werkterrein dient de minister, naast de bondspresident, te ondertekenen. Voor het handelen als minister is deze verantwoording schuldig aan de Bundestag. Wanneer binnen de regering meningsverschillen bestaan, beslist de regering als geheel daarover. Daarnaast heeft de regering de bevoegdheid om wetsvoorstellen in te dienen. De bondsregering als geheel heeft met name een coördinerende functie over aangelegenheden van het algemene regeringsbeleid. ${ }^{66}$

\subsubsection{Verhouding tussen de Bundestag en de regering}

De bondskanselier neemt een speciale plaats in voor wat betreft de verhouding tussen de Bundestag en de regering. De bondskanselier is de enige functionaris die door de Bundestag wordt gekozen. ${ }^{67}$ Tussen de regering en de Bundestag bestaat een vertrouwensrelatie. Dat wil zeggen dat de regering het vertrouwen van de Bundestag nodig heeft om te regeren. De vertrouwensregel is, anders dan in Nederland, gecodificeerd in de artikelen 67 en 68 van de Grondwet. Centraal daarin staat de zogenoemde constructieve motie van wantrouwen. Het vertrouwen kan alleen worden opgezegd zodra de Bundestag een nieuwe bondskanselier kiest. Hiermee wordt een continuïteit van het staatsbestuur beoogd. De Bundestag vraagt de bondspresident om de zittende bondskanselier te ontslaan en de gekozen opvolger te benoemen. De bondspresident heeft de plicht dit te doen wanneer de Bundestag hierom vraagt. Deze constructieve motie van wantrouwen is gericht tot de bondskanselier; wanneer echter de meerderheid van de Bundestag de motie steunt, zal niet alleen de bondskanselier worden ontslagen maar zal de gehele regering opstappen. Het is niet mogelijk om een motie van wantrouwen tegen een enkele minister aan te nemen. Ministers hebben namelijk het vertrouwen van de bondskanselier nodig en niet van de Bundestag. ${ }^{68}$ Er is sprake van een collectieve motie van wantrouwen dan wel van een collectieve vertrouwensregel. Opgemerkt moet worden dat het staatsrechtelijk mogelijk is om het vertrouwen op te zeggen in een minister maar dat vormt voor de minister dan geen verplichting om af te treden. In de naoorlogse Duitse geschiedenis is de constructieve

65 R. Schmidt, Staatsorganisationsrecht: sowie Grundzüge des Verfassungsprozessrechts und des EU-rechts, Hannover: Druckhaus Pinkvoss GmbH 2018, p. 265.

66 Ch. Gröpl, Staatsrecht I. Staatsgrundlagen, Staatsorganisation, Verfassungsprozess mit Einführung in das juristische Lernen, München: C.H. Beck 2017, p. 339.

67 Ibid., p. 330.

68 Ibid., p. 333-334. 
motie van wantrouwen twee keer ingezet, waarvan één keer succesvol. In 1972 probeerde oppositieleider Barzel (CDU/CSU) bondskanselier Willy Brandt naar huis te sturen. Hij zag zichzelf als nieuwe bondskanselier. Dit lukte niet omdat een meerderheid tegen stemde. ${ }^{69}$ Tien jaar later, in 1982, lukte het op die manier wel om Helmut Kohl als opvolger van Helmut Schmidt te kiezen. ${ }^{70}$

Het initiatief om een vertrouwenskwestie te beginnen kan ook bij de bondskanselier liggen. Op grond van artikel 68 van de Grondwet kan de bondskanselier de Bundestag verzoeken om het vertrouwen uit te spreken. Dit vertrouwen moet worden uitgesproken door een meerderheid van de leden van de Bundestag. Wanneer dit niet gebeurt, kan de bondskanselier de bondspresident verzoeken de Bundestag te ontbinden. De Bundestag kan dit tegengaan door met een meerderheid een nieuwe bondskanselier te kiezen. De bondskanselier kan ook zelf zijn ontslag indienen. ${ }^{71}$ De vertrouwensvraag op grond van artikel 68 Grondwet om het vertrouwen in de bondskanselier uit te spreken is in de naoorlogse geschiedenis vijf keren gesteld. ${ }^{72}$ In 1972 kreeg die vraag van bondskanselier Brandt niet de benodigde meerderheid. In $1982 \mathrm{kreeg}$ bondskanselier Schmidt wel het vertrouwen van de meerderheid van de Bundestag voor hem en zijn regering. Ook in 1982 stelde bondskanselier Kohl de vertrouwensvraag om nog voor het einde van de regeerperiode nieuwe verkiezingen van de Bundestag uit te kunnen schrijven. De meerderheid stemde tegen waarmee Kohl het vertrouwen dus niet kreeg van de Bundestag. Bijna twintig jaar later, in 2001, stelde bondskanselier Schröder de vertrouwensvraag aan de Bundestag. De vraag werd gecombineerd met het verzoek om Duitse gewapende troepen in te zetten in Afghanistan. Een meerderheid stemde voor waardoor Schröder het vertrouwen kreeg en de instemming voor de inzet van gewapende troepen in Afghanistan. Tot slot stelde wederom bondskanselier Schröder in 2005 de vertrouwensvraag. Deze keer, net zoals Kohl in1982, voor het uitschrijven van nieuwe verkiezingen voor de Bundestag. De vertrouwensvraag leidde uiteindelijk tot ontbinding van de Bundestag. ${ }^{73}$

69 Website Bundestag, Das Misstrauensvotum gegen Willy Brandt (1972).

70 Website Bundestag, Das Misstrauensvotum gegen Helmut Schmidt.

71 Ch. Degenhart, Staatsrecht I. Staatsorganistionsrecht. Mit Bezügen zum Europarecht, Heidelberg: C.F. Müller GmbH 2017, p. 307-210.

72 Das Datenhandbuch zur Geschichte des Deutschen Bundestages, 6.14. Vertrauensfrage des Bundeskanzlers, p. 1.

73 Das Datenhandbuch zur Geschichte des Deutschen Bundestages, 6.14. Vertrauensfrage des Bundeskanzlers, p. 8-18. 


\subsubsection{Bondspresident}

Duitsland kent een bondspresident als staatshoofd. De positie van het staatshoofd is onder de Weimarrepubliek ingevoerd als tegenwicht tegen de bondskanselier en de Bundestag. Hij bezat destijds bevoegdheden die inmiddels bij andere organen terechtgekomen zijn waardoor de bondspresident niet langer een sterke maar eerder een zwakke positie heeft. ${ }^{74}$

Artikel 54 Grondwet bepaalt dat de bondspresident wordt gekozen voor een periode van vijf jaar. Dit wordt zonder voorafgaand debat gedaan door een ad-hockiescollege, de Bundesversammlung (federale vergadering), die bestaat uit leden van de Bundestag en een gelijk aantal leden gekozen door de parlementen van de Länder. Voor het kiezen van de bondspresident is een meerderheid van de leden van de Bundesversammlung nodig. Wanneer na twee stemmingen geen bondspresident is gekozen kan worden volstaan met een relatieve meerderheid van de uitgebrachte stemmen. ${ }^{75}$ Doorgaans kan de bondspresident zelfstandig geen beslissingen nemen en behoeft elk besluit of elke rechtshandeling van de bondspresident op grond van artikel 58 Grondwet het contraseign van een lid van de regering: de bondskanselier of de verantwoordelijke minister. ${ }^{76}$ Uitzonderingen hierop zijn de besluiten tot benoeming en ontslag van de bondskanselier, de ontbinding van de Bundestag op grond van artikel 63 Grondwet en het verzoek op grond van artikel 69 Grondwet van de bondspresident aan de bondskanselier of een minister om in zijn ambt te blijven tot een opvolger is aangewezen. ${ }^{77}$ Tot de taken van de bondspresident horen het vertegenwoordigen van de bondsrepubliek buiten Duitsland, het sluiten van verdragen in naam van de bondsrepubliek en het in ontvangst nemen van geloofsbrieven van ambassadeurs van andere staten. ${ }^{78}$ Daarnaast behoren het ontslaan en benoemen van bondsrechters, bondsambtenaren en (onder)officieren tot zijn taken. ${ }^{79}$ Hij heeft tevens de mogelijkheid om gratie te verlenen. ${ }^{80}$ Ook heeft hij de bevoegdheid de noodtoestand af te kondigen en wetten uit te vaardigen. ${ }^{81}$

Niet onbelangrijk zijn de volgende bevoegdheden die de bondspresident heeft met betrekking tot het functioneren van het parlementaire stelsel. De bondskanselier wordt op voorstel van de bondspresident door de Bundestag gekozen. Wanneer de Bundestag

74 R. Schmidt, Staatsorganisationsrecht: sowie Grundzüge des Verfassungsprozessrechts und des EU-rechts, Hannover: Druckhaus Pinkvoss GmbH 2018, p. 280.

75 Ibid., p. 283-284.

76 Met uitzonderering van een drietal besluiten: benoeming of ontslag van de bondskanselier, ontbinding van de Bundestag op grond van art. 63 Grondwet en het verzoek van de bondspresident aan de bondskanselier om in een demissionaire periode zaken te behartigen; R. Schmidt, Staatsorganisationsrecht: sowie Grundzüge des Verfassungsprozessrechts und des EU-rechts, Hannover: Druckhaus Pinkvoss GmbH 2018, p. 281.

77 Art. 58 Grondwet.

78 Art. 59 lid 1 Grondwet.

79 Art. 60 lid 1 Grondwet.

80 Art. 60 lid 2 Grondwet.

81 Art. 82 lid 1 en 115a Grondwet. 
de kanselier heeft gekozen wordt deze weer door de bondspresident benoemd. Het voorstel dat de bondspresident doet, moet het vertrouwen hebben van het parlement. Voorafgaand aan het voorstel doet de bondspresident namelijk onderzoek bij de politieke partijen om te bepalen welke persoon de geschiktste kandidaat is. De bondspresident richt zich naar de wens van het parlement. Er kan dus niet gesproken worden over een zelfstandig en onafhankelijk recht van de bondspresident. Hetzelfde geldt voor zijn bevoegdheid om ministers te benoemen en te ontslaan aangezien dit gebeurt op voordracht van de bondskanselier. $^{82}$ Theoretisch heeft de bondspresident nog een politieke rol. Wanneer de Bundestag er niet in slaagt om met een meerderheid een bondskanselier te kiezen maar toch met een andere stemverhouding een bondskanselier kiest, heeft de bondspresident te mogelijkheid deze bondskanselier te benoemen of de Bundestag te ontbinden. ${ }^{83}$ Een ander theoretisch scenario is wanneer de bondskanselier te weinig vertrouwensstemmen krijgt van de Bundestag. Indien dit het geval is, kan de bondspresident, op voorstel van de bondskanselier, de Bundestag ontbinden. ${ }^{84}$

\subsubsection{Bundesverfassungsgericht}

Het Duitse constitutionele systeem berust op de Duitse federale Grondwet. Daarin is, naast de grondrechten, de organisatie van de staat opgenomen. De eerste negentien bepalingen zien op de grondrechten. ${ }^{85}$ Daarbij speelt het Bundesverfassungsgericht een grote rol. Het Bundesverfassungsgericht, het constitutionele hof, geniet een groot aanzien binnen Duitsland. Het hof is een grondwettelijk orgaan op federaal niveau en staat daarmee op hetzelfde niveau als de Bundestag, Bundesrat en de federale regering. ${ }^{86}$ Deze andere federale organen volgen zonder enige aarzeling de uitspraken van het hof, want de uitspraken van het hof binden alle staatsorganen en publieke functies.

De uitspraken worden gekenmerkt door een systematische dogmatische stijl van argumentatie en rechtvaardiging waardoor ze vaak veel verder gaan dan de concrete aangelegenheid. ${ }^{87}$ Dit heeft ook daarmee te maken dat uitspraken vaak over de grondwettigheid van regels gaan en kracht van wet hebben. Het hof draagt via zijn uitspraken bij aan de

82 Ch. Gröpl, Staatsrecht I. Staatsgrundlagen, Staatsorganisation, Verfassungsprozess mit Einführung in das juristische Lernen, München: C.H. Beck 2017, p. 344.

83 Art. 63 lid 4 Grondwet.

84 Art. 68 Grondwet.

85 M. Jestaedt, 'Die Europäische Integration und das Grundgesetz: Die Rechtsprechung des BVerfG zwischen Integrationsbeförderung und Integrationsbegrenzung', Osaka University Law Review 2017, 64, p. 53.

86 M. Höreth, 'Wenn Richter mitregieren wollen: Selbstautorisierung beim BVerfG und dem EuGH im Vergleich', in: R.Chr. van Ooyen \& M.H.W. Möllers (hrsg.), Handbuch Bundesverfassungsgericht im politischen System, Wiesbaden: Springer Fachmedien 2015, p. 878.

87 M. Jestaedt, 'Die Europäische Integration und das Grundgesetz: Die Rechtsprechung des BVerfG zwischen Integrationasbeförderung und Integrationsbegrenzung’, Osaka University Law Review 2017, 64, p. 53. 
ontwikkeling van het staatsrecht. De brede acceptatie van het hof komt onder andere omdat het hof bij grote politieke vragen externe deskundigen betrekt en de rechters niet in een ivoren toren verblijven waar zij enkel rechtspreken; zij maken hun oordelen ook kenbaar via publicaties en interviews. Het oordeel van het hof geniet zelfs meer aanzien dan de standpunten van het parlement of die van individuele politieke partijen. ${ }^{88}$ Het aanzien en de invloed van het Bundesverfassungsgericht stopt niet bij de Duitse grens, maar ook andere (constitutionele) hoven en gerechten binnen de Europese Unie worden beïnvloed door het Bundesverfassungsgericht. ${ }^{89}$ Zo speelde de uitspraak Solange I, die in paragraaf 4.2.6.1 verder wordt behandeld, een rol bij de grondrechtenbescherming door het Hof van Justitie. Die bescherming was in eerste instantie afwezig waardoor het Bundesverfassungsgericht zich genoodzaakt voelde om deze taak op zich te nemen tot het Hof van Justitie het stokje overnam. In de uitspraak Weiss, zie daarvoor eveneens paragraaf 4.2.6.1, fungeerde het Bundesverfassungsgericht als een controleur van het Hof van Justitie door na te gaan of het Hof van Justitie al dan niet buiten zijn mandaat handelde.

De zaken waarover het hof oordeelt, kunnen worden samengevat met 'Verfassungsstreitigkeiten' (vertaald: constitutionele geschillen). De bevoegdheid van het hof correspondeert met zijn verantwoordelijkheden die in de Grondwet of andere wetgeving zijn opgenomen. ${ }^{90}$ Het hof beslist niet alleen over grondrechten, maar ook in geschillen over de grondwettelijke rechten en plichten van de verschillende constitutionele organen. Alle organen zijn namelijk gebonden aan de Grondwet en moeten deze volgen, en het hof heeft nu eenmaal de exclusieve bevoegdheid tot gezaghebbende uitleg en toepassing van de grondwet, waarbij het handelen van die organen op grondwettigheid gecontroleerd wordt door het hof. Partijen in dergelijke zaken zijn de Bundestag, Bundesrat of leden van het parlement, de federale regering of een politieke partij, of ook de Länder. Het hof beslist of een maatregel, wet of besluit of handeling constitutioneel was. ${ }^{91}$ Zo kan wetgeving in abstracto of in concreto beoordeeld worden, kan de begroting getoetst worden, evenals het aangaan van een verdrag of de ontbinding van het parlement door de bondspresident.

Het Bundesverfassungsgericht heeft een hybride rol. Enerzijds is het een gerecht en doet het juridische uitspraken, anderzijds is het een orgaan van de overheid dat de Grondwet beschermt. Het hof begeeft zich daarmee ook op de grens van recht en politiek. Het Bundesverfassungsgericht is in staat om politieke vragen om te zetten in juridische

88 R. Zippelius \& T. Würtenberger, Deutsches Staatsrecht. Ein Studienbuch, München: Verlag C.H. Beck 2018, p. 534.

89 M. Jestaedt, 'Die Europäische Integration und das Grundgesetz: Die Rechtsprechung des BVerfG zwischen Integrationasbeförderung und Integrationsbegrenzung', Osaka University Law Review 2017, 64, p. 45.

90 Zie bijvoorbeeld art. 93 lid 1 Grondwet en art. 100 lid 1 Grondwet.

91 K. Schlaich \& S. Korioth, Das Bundesverfassungsgericht. Stellung, Verfahren, Entscheidungen. Ein Studienbuch, München: Verlag C.H. Beck 2018, p. 5-6. 
vragen. Het gevolg hiervan is dat bijna alle controversiële politieke vragen met een constitutionele component bij het Bundesverfassungsgericht terecht (kunnen) komen en aldaar, binnen de constitutionele grenzen, worden beantwoord. ${ }^{92}$ Niet alleen de politiek maar ook het positieve recht wordt daarmee geconstitutionaliseerd. Dat wil zeggen dat vragen over het positieve recht worden omgevormd tot vragen over de Grondwet. Men kan stellen dat de Duitse constitutionele cultuur bestaat uit (1) de juridisering van de politiek, (2) de constitutionalisering van het rechtsstelsel door de grondwettelijke interpretatie van het recht en de brede werking van de Grondwet en (3) de juridisering van het constitutionele recht door de uitgebreide mogelijkheden constitutionele vragen voor te leggen aan de rechterlijke macht, in casu het Bundesverfassungsgericht. ${ }^{93}$

\subsubsection{Het Bundesverfassungsgericht en de Europese Unie}

Wanneer men kijkt naar de rol die nationale constitutionele hoven spelen in de Europese integratie, dan valt op dat er een bijzondere rol is weggelegd voor het Duitse Bundesverfassungsgericht. Het hof heeft niet enkel voor Duitsland, maar ook indirect voor de andere lidstaten binnen de Europese Unie een grote rol gespeeld. De ontwikkeling van het gemeenschapsrecht en het Unierecht werden namelijk vanaf het begin begeleid door uitspraken van het hof. ${ }^{94}$ Dit heeft onder andere te maken met de Europese politieke consensus (als neergelegd in art. 23 Grondwet) die heerst onder de Duitse regeringspartijen waardoor zij geen vragen stellen over of kritiek leveren op de Europese integratie en de Europese Unie. Het gevolg hiervan is dat eventuele vragen of kritiek over de Europese Unie aan het hof worden voorgelegd omdat ze daar gehoord en beantwoord worden. Het hof wordt daarmee geconfronteerd met politieke vragen die niet in de politieke arena worden beantwoord. Dit maakt het hof zogezegd een vervanger van de politieke arena. ${ }^{95}$

Het hof is naar Duits recht ook bevoegd uitspraken te doen over de grondwettelijkheid van Europese wetgeving. Zo begrensde het hof in 1974 de voorrang van het gemeenschapsrecht (tegenwoordig EU-recht) boven het Duitse recht in de uitspraak Solange $I .{ }^{96}$ Het hof bepaalde dat zolang de Europese Gemeenschap (EG) niet over voldoende grondrechtenbescherming beschikte, die (mede) tot stand is gekomen door een door inwoners gekozen parlement en vergelijkbaar is met de Duitse grondrechtenbescherming in de Grondwet, het hof het recht zou behouden om de verenigbaarheid van het EG-recht met de grondrechten uit de Duitse Grondwet te beoordelen. Indien het hof zou bepalen dat het EG-

92 M. Jestaedt, 'Die Europäische Integration und das Grundgesetz: Die Rechtsprechung des BVerfG zwischen Integrationasbeförderung und Integrationsbegrenzung', Osaka University Law Review 2017, 64, p. 53.

93 Ibid., p. 54.

94 Ibid., p. 66-67.

95 Ibid., p. 67.

96 BVerfG 29 mei 1974 - BvR 37/271 (Solange I). 
recht niet verenigbaar was met het Duitse recht, zou de EG-wetgeving niet van toepassing zijn in Duitsland.

Zo'n twaalf jaar later, in 1986, kreeg de Solange I-uitspraak een vervolg. In de uitspraak Solange II ging het wederom om de vraag of het EG-recht voorrang had op de fundamentele rechten zoals neergelegd in de Duitse Grondwet. ${ }^{97}$ Hierin verlaat het hof de eerdere visie uit Solange I. Het hof verklaart in Solange II dat zolang de Europese Gemeenschap, en dan met name het Hof van Justitie, voor een effectieve grondrechtenbescherming zorgde, het hof zou afzien van de beoordeling over de verenigbaarheid van EG-wetgeving met de grondrechten uit de Duitse Grondwet. ${ }^{98}$ Het hof vertrouwde dus op het Europese Hof om zich uit te spreken over eventuele strijdigheid van EG-wetgeving met grondrechten.

Daarna oordeelde het hof in 1993 over de rechtmatigheid van het Verdrag van Maastricht. ${ }^{99}$ Het hof kwam tot het oordeel dat het Verdrag van Maastricht verenigbaar was met de Duitse Grondwet. Daarbij benadrukte het hof dat elke overdracht van bevoegdheden aan de EU goedkeuring van het Duitse parlement vereist en dat het hof daarom het recht houdt om te oordelen of de EU-instellingen de bevoegdheden die op grond van de verdragen aan de instellingen zijn toegekend, hebben overschreden. Het hof geeft daarbij aan dat de overdracht van bevoegdheden aan de EU nog steeds voldoende bevoegdheden met een aanzienlijk politiek gewicht overlaat aan de Duitse Bundestag. ${ }^{100}$

De bevoegdheid van het hof om te oordelen over de grondwettelijkheid van Europese verdragen valt onder de zelf ontwikkelde en uit de Grondwet afgeleide 'ultra-vires-controle'. Het hof controleert dan bij Europese secundaire wetgeving of de EU-wetgever niet buiten zijn bevoegdheden is getreden. ${ }^{101}$ Het hof controleert daarmee ook de uitoefening van de bevoegdheden van de Europese organen. ${ }^{102}$ Indien het hof constateert dat de EU-instellingen buiten hun bevoegdheden zijn getreden dan is Duitsland niet gebonden aan de handelingen van die EU-instellingen. ${ }^{103}$ In de uitspraak over het Verdrag van Maastricht bevestigde het hof dat het Europese Hof van Justitie de primaire verantwoordelijkheid heeft voor de bescherming van fundamentele rechten. Daarbij liet het Duitse hof doorschemeren dat het Bundesverfassungsgericht deze taak alleen zelf zou uitoefenen als het Europese Hof van Justitie de taak niet naar behoren zou vervullen (volgens Solange II).

In 2008 werd het hof door enkele parlementariërs gevraagd om ook een oordeel te geven over de rechtmatigheid van het Verdrag van Lissabon. ${ }^{104}$ Het hof oordeelde dat ook

\footnotetext{
97 BVerfG 22 oktober 1986 - 2 BvR 197/83 (Solange II).

98 BVerfG 22 oktober 1986 - 2 BvR 197/83, r.o. 132.

99 BVerfG 12 oktober 1993 - 2 BvR 2134/92 (Maastricht).

100 BVerfG 12 oktober 1993 - 2 BvR 2134/92, r.o. 94.

101 De Latijnse term 'ultra vires' betekent 'zonder bevoegdheid'.

102 Chr. Calliess, 'Die Rolle des Grundgesetzes und des Bundesverfassungsgericht', in: K. Böttger \& M. Jopp (Hrsg.), Handbuch zur deutschen Europapolitik, Baden-Baden: Nomos Verlagsgesellschaft 2017, p. 159.

103 BVerfG 12 oktober 1993 - 2 BvR 2134/92, r.o. 49.

104 BVerfG 30 juni 2009 - 2 BvE 2/08 (Lissabon).
} 
dit verdrag geen grondwettelijke problemen opwierp, en tevens zag het hof geen obstakels in een deelname van Duitsland aan het verdrag. Volgens het hof is het overhevelen van bevoegdheden naar de EU toegestaan, zolang de grondwettelijke identiteit van Duitsland niet in het gedrang komt. Het hof herhaalde de visie uit de uitspraak over het Verdrag van Maastricht, namelijk dat het hof de bevoegdheid houdt te toetsen of Europese instellingen hun bevoegdheden te buiten gaan (ultra vires). Verder stelt het hof dat de Europese instellingen niet de bevoegdheid hebben gekregen om hun verkregen bevoegdheden uit te breiden (Kompetenz-Kompetenz). ${ }^{105}$

Een jaar na de uitspraak over het Verdrag van Lissabon gaf het Bundesverfassungsgericht nadere voorwaarden aan de ultra vires-toets in de Honeywell-uitspraak van 6 juli $2010 .^{106}$ In deze uitspraak beperkte het Bundesverfassungsgericht zijn eigen toetsingsbevoegdheid. Het hof oordeelde namelijk dat een handeling als een ultra vires-handeling bestempeld kon worden, als een schending van bevoegdheden door Europese instellingen voldoende gekwalificeerd is. ${ }^{107}$ Een handeling moet in zo'n geval kennelijk in strijd met bevoegdheden van de lidstaten zijn en de handeling moet tevens leiden tot een significante verschuiving in de bevoegdheidsverdeling tussen de EU en de lidstaten, en wel ten nadele van de lidstaten. ${ }^{108}$ Daarnaast bepaalde het hof dat het de ultra vires-toets op een 'Europarechtsfreundliche' manier zal en mag uitoefenen. ${ }^{109}$ Daarmee wordt bedoeld dat het primaat van het EU-recht erkend dient te worden en dat de toetsing door het Bundesverfassungsgericht terughoudend moet zijn. De Honeywell-uitspraak was geen unanieme uitspraak. Rechter Landau meende in zijn dissenting opinion dat de meerderheid van het Bundesverfassungsgericht bovenmatige eisen aan de ultra vires-toets stelde. Door de voorwaarde te stellen dat er sprake moet zijn van een significante verschuiving in bevoegdheden, werd in zijn opvatting afgeweken van het oordeel uit de Lissabon-zaak. Landau meende namelijk dat ook een kleine verschuiving grote gevolgen kon hebben. Daarnaast verweet hij (de meerderheid van) het hof dat het de bevoegdheidsverdeling tussen de EU en de lidstaten enkel op papier verdedigde zonder deze in de praktijk toe te passen. ${ }^{110}$

Naast de voornoemde controle kent het hof ook een zogenoemde 'identiteitscontrole'. De Duitse staat is gegrondvest op een drietal beginselen. Het gaat om de waarborging van de democratie, de rechtsstaat en de grond- en mensenrechten. Deze drie beginselen dienen te allen tijde gewaarborgd te worden en de Grondwet kan op die punten niet gewijzigd worden. ${ }^{111}$ Het hof heeft als taak te beoordelen of Europese wetgeving deze beginselen

\footnotetext{
105 BVerfG 30 juni $2009-2$ BvE 2/08, r.o. 233.

106 BVerfG 6 juli 2010 - 2 BvR 2661/06 (Honeywell).

107 BVerfG 6 juli 2010 - 2 BvR 2661/06, r.o. 61.

108 BVerfG 6 juli 2010 - 2 BvR 2661/06, r.o. 64 .

109 BVerfG 6 juli 2010 - 2 BvR 2661/06, r.o. 58.

110 BVerfG 6 juli 2010 - 2 BvR 2661/06, r.o. 94-116.

111 Art. 79 lid 3 Grondwet.
} 
waarborgt en controleert in feite dus of de identiteit van Duitsland niet wordt aangetast door nieuwe wetgeving. Het hof controleert dus niet alleen of het overhevelen van bevoegdheden naar de EU is toegestaan, maar ook de wijze van uitoefening van deze bevoegdheden door EU-organen. ${ }^{112}$ Thiele heeft in 2017 een derde overkoepelende wijze van controleren erkend. ${ }^{113}$ Op grond van artikel 23 lid 1 van de Grondwet introduceert hij de zogenoemde 'integratiecontrole. ${ }^{114}$ Deze omvat alle controles binnen het raamwerk van de Europese integratie. De reeds genoemde ultra vires-controle en identiteitscontrole zijn specifiekere vormen van controle. ${ }^{115}$ De integratiecontrole is meer gericht op de uitkomst indien er strijd bestaat tussen het EU-recht en de Duitse Grondwet(telijke bepalingen). In een dergelijk geval gaat bij uitzondering de Duitse Grondwet voor. ${ }^{116}$ Hiervan is sprake wanneer er een schending van het rechtsstaatbeginsel in de zin van artikel 23 lid 1, eerste zin, van de Grondwet plaatsvindt, met name wanneer de EU buiten haar bevoegdheden treedt, met andere woorden ultra vires handelt en daarmee in strijd met artikel 5 lid 2 VEU, of wanneer zij in strijd met de waarborgen uit artikel 79 lid 3 van de Grondwet handelt. ${ }^{117}$ Het EU-recht heeft weliswaar voorrang maar het Bundesverfassungsgericht heeft duidelijk gemaakt dat hieraan grenzen zijn. ${ }^{118}$

Bijzonder is de uitspraak van het Bundesverfassungsgericht inzake het Europees Stabiliteitsmechanisme (ESM). ${ }^{119}$ Het hof legt hierin nadruk op de rol van het Duitse parlement in de ESM-beslissing om noodlijdende eurolanden te redden. Via uitleg van artikel 38 van de Grondwet en het democratiebeginsel beslist het hof dat Duitsland enkel kan deelnemen aan het ESM-verdrag nadat is overeengekomen dat de Bundestag, als gekozen volksvertegenwoordiger, betrokken is bij iedere beslissing van ESM om steun te verlenen aan noodlijdende eurolanden en hiermee ook heeft ingestemd. ${ }^{120}$ Hiermee is Duitsland de enige lidstaat die een dergelijk voorbehoud op het ESM-verdrag heeft gemaakt en daarmee parlementaire betrokkenheid heeft afgedwongen. Concreet bepaalde het hof dat grondwettelijke budgettaire bevoegdheden van de Bundestag niet kunnen worden overgeheveld naar instituten van de Europese Unie of instituten verwant aan de Unie. ${ }^{121}$ Volgens het Bundesverfassungsgericht vallen grondwettelijke budgettaire bevoegdheden onder de

112 Chr. Calliess, 'Die Rolle des Grundgesetzes und des Bundesverfassungsgericht', in: K. Böttger \& M. Jopp (Hrsg.), Handbuch zur deutschen Europapolitik, Baden-Baden: Nomos Verlagsgesellschaft 2017, p. 152.

113 A. Thiele, 'Die Integrationsidentität des Art. 23 Abs. 1 GG als (einzige) Grenze des Vorrangs des Europarechts', Europarecht 2017, 52, p. 368.

114 In zijn bijdrage noemt Thiele deze controle 'Integrationsidentität'.

115 A. Thiele, 'Die Integrationsidentität des Art. 23 Abs. 1 GG als (einzige) Grenze des Vorrangs des Europarechts', Europarecht 2017, 52, p. 368.

116 Ibid., p. 369.

117 Ibid., p. 373.

118 Ibid., p. 369.

119 BVerfG 12 september 2012 - 2 BvR 1390/12.

120 BVerfG 12 september 2012 - 2 BvR 1390/12, r.o. 111.

121 BVerfG 12 september 2012 - 2 BvR 1390/12, r.o. 132. 
zogenoemde core-sovereignty, een set aan bevoegdheden van het Duitse parlement die niet overgeheveld mogen worden naar Europees niveau. De inhoud en omvang van deze coresovereignty is overigens niet van tevoren duidelijk.

De ESM-uitspraak van het hof betekende ook dat de manoeuvreerruimte van de regering om zelfstandig besluiten te nemen met betrekking tot het Europees beleid werd beperkt. Het hof bepaalt namelijk duidelijk de (grenzen van de) bevoegdheden van de regering en van het parlement. ${ }^{122}$ Duidelijk is dat het Bundesverfassungsgericht vanaf het begin van de Europese integratie grenzen heeft gesteld aan de integratie en de voorrang van Europees recht op nationaal Duits recht. ${ }^{123}$

Zes jaren na de ESM-uitspraak, deed het Bundesverfassungsgericht uitspraak in de zogenoemde OMT-uitspraak. ${ }^{124}$ De vraag die hierin centraal stond, was of de Duitse centrale bank (Bundesbank) mocht deelnemen aan het OMT-programma (Outright Monetary Transaction) van de Europese Centrale Bank (ECB). In feite ging het om de vraag of het OMT-programma een ultra vires-handeling was en of de ECB dus buiten haar bevoegdheden had gehandeld door in te grijpen in het economische beleid. In eerdere jurisprudentie van het hof (zie o.a. Maastricht) was reeds bepaald dat de ultra vires-handelingen van Europese instellingen binnen de jurisdictie van het Bundesverfassungsgericht vallen. In de OMT-uitspraak oordeelde het hof dat het programma niet in strijd is met de Duitse Grondwet zolang de ECB zou voldoen aan de eisen gesteld door het Hof van Justitie. ${ }^{125}$ Indien de ECB die voorwaarden schendt, is er sprake van een ultra vires-handeling en is het aan de regering en de Bundestag om in te grijpen. ${ }^{126}$ Dit betekent echter wel dat wanneer het OMT-programma geïmplementeerd wordt, de regering en de Bundestag de taak hebben om de werking van het programma strikt te volgen en vroeg in te grijpen indien de voorwaarden worden geschonden. ${ }^{127}$

Tot slot hoort de uitspraak Weiss in dit rijtje thuis. ${ }^{128}$ Ook in deze uitspraak ging het om de vraag of er sprake was van een ultra vires-handeling. Dit keer stond een handeling (uitspraak) van het Hof van Justitie van de Europese Unie centraal. Het Bundesverfassungsgericht verklaarde voor het eerst een uitspraak van het Hof van Justitie ultra vires. ${ }^{129}$ Het ging in die uitspraak om het Public Sector Purchase Programme (PSPP) van de ECB. Het Bundesverfassungsgericht oordeelde dat het besluit van de ECB het mandaat van de ECB

122 D. Göler \& M. Jopp, 'Deutschlands konstitutionelle Europapolitik', in: K. Böttger \& M. Jopp (Hrsg.), Handbuch zur deutschen Europapolitik, Baden-Baden: Nomos Verlagsgesellschaft 2017, p. 51.

123 A. Thiele, 'Die Integrationsidentität des Art. 23 Abs. 1 GG als (einzige) Grenze des Vorrangs des Europarechts', Europarecht 2017, 52, p. 367.

124 BVerfG 21 juni 2016 - 2 BvR 2728/13 (OMT).

125 BVerfG 21 juni 2016 - 2 BvR 2728/13, r.o. 206.

126 BVerfG 21 juni 2016 - 2 BvR 2728/13, r.o. 174.

127 BVerfG 21 juni 2016 - 2 BvR 2728/13, r.o. 174.

128 BVerfG 5 mei 2020 - 2 BvR 859/15 (Weiss).

129 BVerfG 5 mei 2020 - 2 BvR 859/15, r.o. 119. 
te buiten ging, omdat daarin een behoorlijke evenredigheidsbeoordeling ontbrak. Omdat het Hof van Justitie het PSPP als proportioneel beschouwde, ging ook het Hof van Justitie daarmee zijn mandaat te buiten. ${ }^{130}$ Het gevolg hiervan was dat de handeling die door het Bundesverfassungsgericht ultra vires was verklaard, geen toepassing kon vinden in het Duitse rechtssysteem. ${ }^{131}$ Met andere woorden, de Duitse Bundesbank mocht niet deelnemen aan het programma van de ECB. Het Bundesverfassungsgericht hield echter nog een optie open: het gaf namelijk aan dat indien de ECB binnen drie maanden een betere onderbouwing van de proportionaliteit van het programma zou geven, de Duitse Bundesbank wel kon deelnemen. De ECB heeft uiteindelijk een betere onderbouwing gegeven waardoor de Bundesbank kon deelnemen aan het PSPP.

In de afgelopen decennia heeft het Bundesverfassungsgericht meerdere malen herhaald dat het zou optreden indien de bevoegdheden van Europese instellingen overschreden werden. In die gevallen waarin dat gebeurt, zou het EU-recht geen voorrang hebben op het Duitse recht. ${ }^{132}$ Tot de uitspraak Weiss had het Bundesverfassungsgericht dit echter nooit gedaan. ${ }^{133} \mathrm{Nu}$ het Bundesverfassungsgericht deze uitspraak heeft gedaan is het niet ondenkbaar dat het hof in de toekomst ook besluiten of handelingen van de Europese Commissie ultra vires verklaart en daarbij de Bundestag verwijt niet te hebben opgetreden door bijvoorbeeld een met redenen omkleed advies in te dienen in de gelekaartprocedure. Het Bundesverfassungsgericht zegt daarmee dat de Bundestag zijn taak niet heeft uitgevoerd omdat de Bundestag dient in te grijpen wanneer een Europese instelling haar bevoegdheden overschrijdt.

In de uitspraak Weiss komen de visies van het hof uit eerdere zaken terug. Zoals eerder is gesteld in Solange II dient het Hof van Justitie te oordelen over de vraag of handelingen van EU-instellingen binnen de bevoegdheden passen van die EU-instellingen en dient het Hof van Justitie de fundamentele rechten van burgers te waarborgen. Indien het Hof van Justitie faalt, zal het Bundesverfassungsgericht optreden (Solange II en Maastricht). Ook de regering en Bundestag hebben de taak om op te treden wanneer zij vaststellen dat een Europese instelling ultra vires handelt. ${ }^{134}$ Het Bundesverfassungsgericht stelt dat in de gevallen waarin een duidelijke en structureel significante overschrijding van bevoegdheden plaatsvindt (Honeywell), de Duitse constitutionele organen (lees: de regering en Bundestag) de middelen waarover zij beschikken om op te treden tegen deze overschrijding, dienen

130 BVerfG 5 mei 2020 - 2 BvR 859/15, r.o. 163.

131 BVerfG 5 mei 2020 - 2 BvR 859/15, r.o. 234.

132 H.T. Nguyen \& M. Chamon, The ultra vires decision of the German Constitutional Court. Time to fight fire with fire? (Policy Paper), Jacques Delors Centre 2020, p. 4.

133 Ibid., p. II.

134 BVerfG 5 mei 2020 - 2 BvR 859/15, r.o. 231. 
in te zetten $(O M T) .{ }^{135}$ Het waarborgen van de democratie ligt dus niet alleen bij het Bundesverfassungsgericht.

Meer concreet heeft het Bundesverfassungsgericht bepaald dat er voor de Bundestag een taak is weggelegd bij de beslissing om noodlijdende landen te steunen. ESM-besluiten dienen namelijk van instemming van de Bundestag te zijn voorzien. Hiermee bepaalt het Bundesverfassungsgericht niet alleen dat deze bevoegdheid aan de Bundestag toekomt, maar tegelijkertijd beperkt het hof ook de bevoegdheden van de regering om met betrekking tot ESM-besluiten zelfstandig beslissingen te doen. Ook bij het overhevelen van bevoegdheden naar Europees niveau dient het Duitse parlement in te stemmen (Maastricht). Het overhevelen is echter alleen toegestaan als daarmee de grondwettelijke identiteit van Duitsland niet in het gedrang komt (Lissabon). Het komt erop neer dat het hof grenzen stelt om ervoor te zorgen dat het Duitse parlement, en dan met name de Bundestag, zijn taken uitvoert en de taken vormgeeft. Hiermee heeft het Bundesverfassungsgericht een taak in de EU gecreëerd voor de Bundestag. Daarnaast heeft het Bundesverfassungsgericht door het doen van deze uitspraken ook voor zichzelf een rol gecreëerd in de EU. Door de beide Solange-uitspraken heeft het Hof van Justitie oog gekregen voor de bescherming van grondrechten. Later is deze grondrechtenbescherming gecodificeerd in het Handvest van de grondrechten van de Europese Unie en artikel 6 VEU. Hoewel het Bundesverfassungsgericht na de Solange-uitspraken meer vertrouwen kreeg in het Hof van Justitie, is het blijven controleren of er niet te veel bevoegdheden naar de EU gaan. Dat is in principe een taak voor het Hof van Justitie, maar het Bundesverfassungsgericht blijft dit toch controleren met als grondslag daarvoor artikel 38 Grondwet over het kiesrecht (lees: de macht van het parlement en de nationale democratie). Men kan dus zeggen dat het Bundesverfassungsgericht van groot belang is voor de bewaking van de rol van het Duitse parlement in de EU.

\subsubsection{Ondersteuning}

De Bundestag en Bundesrat worden in hun werkzaamheden ondersteund door vele ambtenaren. Aangezien het parlement met veel onderwerpen en vele verschillende en complexe onderwerpen te maken heeft, is het afhankelijk van deze ambtenaren. Deze zijn onder andere werkzaam bij de juridische afdeling en de onderzoeksafdeling. Het aantal ambtenaren dat werkt voor het parlement is groter dan het aantal leden van de Bundestag en Bundesrat samen. ${ }^{136}$ Högenauer en Christiansen menen dat het werk van de (verkozen)

135 BVerfG 5 mei 2020 - 2 BvR 859/15, r.o. 231.

136 A. Högenauer \& T. Christiansen, 'Parliamentary Administrations in the Scrutiny of EU Decision-Making', in: C. Hefftler e.a. (eds.), The Palgrave Handbook of National Parliaments and the European Union, Londen: Palgrave Macmillan 2015, p. 116. 
leden van het parlement afhankelijk is van het werk van de (niet verkozen) ambtenaren. Hierbij wordt opgemerkt dat dit de vraag oproept of de representatieve vertegenwoordiging van het volk helemaal tot zijn recht komt wanneer het werk van de volksvertegenwoordiging zo sterk afhangt van de niet gekozen ambtenaren. ${ }^{137}$ De Bundestag beschikt over ongeveer drieduizend ambtenaren die de parlementsleden ondersteunen in hun werk. ${ }^{138}$ Dit betekent, gelet op het wisselende aantal leden van de Bundestag na elke verkiezing, dat ieder lid van de Bundestag ongeveer vier of vijf ambtenaren tot zijn beschikking heeft. Deze ambtenaren werken op een van de vier afdelingen: Parlament und Abgeordnete (parlement en parlementsleden), Wissenschaft und Außenbeziehungen (wetenschap en externe betrekkingen), Information und Dokumentation (informatie en documentatie) en Zentralabteilung (centrale afdeling).

Onder de afdeling Parlament und Abgeordnete valt sinds 1 januari 2013 de afdeling Europese aangelegenheden. Deze afdeling is onderverdeeld in zes subdivisies; het secretariaat voor de Kamercommissie voor Europese Zaken, het Liaison Office, de onderzoeksafdeling voor Europese aangelegenheden en een EU-documentatiecentrum. De overige twee divisies houden zich bezig met de analyse en het prioriteren van Europese aangelegenheden en met algemene fundamentele Europese en EMU-aangelegenheden. Ook worden binnen deze afdeling (juridisch-)wetenschappelijke adviezen over Europees recht en politiek voorbereid en de actuele politieke ontwikkelingen, met name met betrekking tot wetsvoorstellen, binnen de EU-instellingen bijgehouden. ${ }^{139}$

Naast de bovengenoemde ambtenaren kunnen de leden van de Bundestag ook persoonlijke ondersteuning inhuren. ${ }^{140}$ Daarvoor krijgen ze maandelijks een bedrag van $€ 22.795$. ${ }^{141}$

In de Bundesrat zelf zijn ongeveer tweehonderd ambtenaren werkzaam. Deze ambtenaren werken met name voor de Kamercommissies. Zij ondersteunen de voorzitters van de commissies bij de organisatie van de vergaderingen, het notuleren van vergaderingen en het opstellen van besluiten. Het secretariaat van de Kamercommissie Europese Zaken is ook verantwoordelijk voor de Europakammer. ${ }^{142}$ Dit secretariaat zorgt ervoor dat de informatie die door de regering wordt verstrekt over Europese aangelegenheden, correct en tijdig terechtkomt bij de Länder. ${ }^{143}$

137 Ibid., p. 117.

138 Website Bundestag, Verwaltung.

139 Ibid.

140 Website Bundestag, Mitartbeiter.

141 Per 1 april 2021.

142 De 'Europakammer' is een commissie binnen de Bundesrat met afgevaardigden van elk Land. Wanneer een snelle reactie of beslissing met betrekking tot Europese aangelegenheden wordt verwacht van de Bundesrat is de Europakammer bevoegd deze namens de gehele Bundesrat te geven (art. 52 lid 3a Grondwet).

143 Website Bundesrat, Ausschüsse. 
Binnen de Bundesrat bestaan vier afdelingen: (1) Parlamentsdienst, Parlamentsrecht (parlementaire dienst, parlementsrecht), (2) Parlamentarische Beziehungen, Besucherdienst (parlementaire betrekkingen, bezoekersdienst), (3) Präsidialbüro, Protokoll, Verantstaltungen (presidentschap, protocol, evenementen) en (4) Presse und Kommunikation (pers en communicatie). De tweede afdeling, Parlamentarische Beziehungen, Besucherdienst, is de afdeling die de voorzitter en leden van de Bundesrat voorbereidt op interparlementaire conferenties. Ook houdt deze afdeling contact met andere parlementen over de hele wereld en is ze verantwoordelijk voor de bezoeken van buitenlandse delegaties aan de Bundesrat. ${ }^{144}$

Behalve door de ambtenaren die voor de Bundesrat werken, worden de vertegenwoordigers van de Bundesrat ook ondersteund door de ambtenaren uit de verschillende Länder die werken voor de regeringen van die Länder. Dat zijn er talloze met vele relevante kennis en expertise, juist ook omdat de Länder federale wetgeving uitvoeren en dus zeer ter zake kundig zijn en de ervaring hebben met (de uitvoering van) federale wetten. De echte expertise zit dus in de Länder en in mindere mate op federaal niveau doordat de uitvoering van wetten veelal een taak is van de Länder. Denk bij de expertise aan onderwerpen als het milieu, veiligheid, verantwoordelijkheden van de politie, scholing en landbouw. Dat zijn zaken die op het niveau van de Länder worden uitgevoerd.

Veel van het werk in de Bundestag en Bundesrat wordt met name door de vele ambtenaren voorbereid en ondersteund. Kortom, de ambtelijke ondersteuning van het parlement is van groot belang bij de uitvoering van de werkzaamheden van de parlementsleden. Een groot deel van het werk wordt door hen uitgevoerd. De ambtelijke ondersteuning heeft expertise op meerdere gebieden waardoor de parlementsleden grondig geïnformeerd kunnen worden. Gezien het aantal ambtenaren werkzaam voor de Bundestag en Bundesrat kan men stellen dat het Duitse parlement goed ondersteund wordt.

\subsection{WETGEVINGSPROCES}

Een manier om als parlement zeggenschap te hebben is via de rol van het parlement in de wetgevingsprocedure. Het parlement kan wetten al dan niet aannemen. Op federaal niveau vormen de Bundestag en Bundesrat de federale wetgever. De federale wetgever is bevoegd om federale wetgeving te maken voor zover dit binnen de federale bevoegdheden valt als aangegeven in de Grondwet. Wanneer dit niet het geval is, dan zijn de Länder bevoegd. ${ }^{145}$ Voor wat betreft de federale wetgevende bevoegdheid dient er onderscheid gemaakt te worden tussen de exclusieve en de gedeelde wetgevende bevoegdheid. Exclusieve wetgevende bevoegdheid houdt in dat alleen de federale wetgever nieuwe wetgeving kan maken met

144 Website Bundesrat, Parlamentsabteilung.

145 Art. 70 Grondwet. 
betrekking tot bepaalde onderwerpen. ${ }^{146}$ Buitenlandse zaken, defensie, nationaliteit, valuta en luchtvaart zijn onderwerpen die tot de exclusieve bevoegdheid van de federale wetgever behoren. ${ }^{147}$ Bij een gedeelde bevoegdheid kunnen de Länder wetgeving opstellen voor zover de federale wetgever dit (nog) niet heeft gedaan. ${ }^{148}$ Onderwerpen zoals de registratie van geboorte, sterfgevallen en huwelijken, arbeidsrecht en de jacht zijn gedeelde bevoegdheden. ${ }^{149}$

Zowel de leden van de Bundestag als die van de Bundesrat in zijn geheel (na een meerderheidsbeslissing) hebben op grond van artikel 76 van de Grondwet het recht van initiatief voor wat betreft bondswetten. Ook kunnen wetten worden voorgesteld door de regering. Voordat de regering het voorstel voor advies voorlegt aan de Bundesrat, dient het voorstel in de vergadering van de regering besproken te worden. Via het advies van de Bundesrat hebben de Länder de mogelijkheid om op het voorstel invloed uit te oefenen. De Bundesrat heeft echter geen recht van amendement. Na het advies van de Bundesrat wordt het voorstel ingediend bij de Bundestag. ${ }^{150}$

De Bundestag kan zelf een wetsvoorstel initiëren door minimaal vijf procent van de leden van de Bundestag of door een politieke partij binnen de Bundestag. ${ }^{151}$ In de Bundestag wordt een wetsvoorstel in drie lezingen behandeld. De Bundestag heeft ook het recht om voorstellen te amenderen. Wanneer de Bundestag het voorstel heeft aangenomen wordt het voorstel aan de Bundesrat voorgelegd. Hier moet een onderscheid gemaakt worden tussen de Zustimmungsgesetze (wetten die instemming behoeven) en de Einspruchsgesetze (wetten waartegen de Bundesrat bezwaar kan maken). Wil de Bundesrat bezwaar maken tegen een Einspruchsgesetze, dan dient een conciliatiecommissie gevormd te worden waarin zestien leden van de Bundestag en zestien leden van de Bundesrat zitting nemen. De commissie zal een compromis moeten voorstellen waarin zowel de Bundesrat als de Bundestag zich kan vinden. Wanneer de conciliatie mislukt, kan de Bundesrat bezwaar maken. Wanneer er wel een compromis tot stand is gekomen en de Bundestag hierover heeft gestemd, wordt het wetsvoorstel wederom aan de Bundesrat gezonden. De Bundesrat heeft dan de mogelijkheid om voor het voorstel te stemmen of bezwaar te maken. Indien dit laatste het geval is of wanneer de conciliatie mislukt, kan de Bundestag met een meerderheid, die afhankelijk is van de meerderheid waarmee de Bundesrat bezwaar heeft gemaakt, het bezwaar van de Bundesrat afwijzen en komt de wet tot stand. Met andere

146 Art. 71 jo. 73 Grondwet.

147 Art. 73 lid 1 sub 1, 2, 4 en 6 Grondwet.

148 Art. 72 jo. 74 Grondwet.

149 Art. 74 lid 1 sub 2, 12 en 28 Grondwet.

150 L.F.M. Besselink, P.P.T. Bovend'Eert, J.L.W. Broeksteeg \& R. de Lange, Het Staatsrecht van 7 Europese landen, Deventer: Kluwer 2018, p. 90-91.

151 R. Schmidt, Staatsorganisationsrecht: sowie Grundzüge des Verfassungsprozessrechts und des EU-rechts, Hannover: Druckhaus Pinkvoss GmbH 2018, p. 401-404. 
woorden, de Bundesrat kan overstemd worden door de Bundestag. ${ }^{152}$ In de periode 20102016 heeft de Bundesrat slechts één keer bezwaar gemaakt. Die ene keer is het bezwaar door de Bundestag afgewezen, wat betekent dat de Bundesrat overstemd werd door de Bundestag. ${ }^{153}$

Wanneer sprake is van een Zustimmungsgesetze is instemming van de Bundesrat nodig om een wet tot stand te laten komen. Hiervan is sprake wanneer de Grondwet expliciet aangeeft dat instemming van de Bundesrat vereist is. Wanneer onenigheid bestaat tussen de Bundesrat en de Bundestag kan een conciliatiecommissie worden ingesteld om een compromis op te stellen; dit is echter niet verplicht. In dit geval heeft de Bundesrat immers een vetorecht. Zonder de instemming van de Bundesrat komt geen wet tot stand.

Nadat beide Kamers hebben ingestemd met het voorstel wordt de wet door de bondspresident uitgevaardigd en afgekondigd. Behalve de bondspresident dienen ook de bondskanselier en de verantwoordelijke minister de wet te ondertekenen. ${ }^{154}$ Kortom, beide Kamers kunnen wetgeving initiëren; dit is een recht van de leden van de Bundestag en van de Bundesrat in zijn geheel. De Bundestag kan via het recht van amendement wetgeving wijzigen en de Bundesrat heeft een grote stem, maar dan vooral bij Zustimmungsgesetze.

Ook wetten over Europese aangelegenheden kunnen geïnitieerd worden, denk aan het omzetten van Europese wetgeving naar Duits recht. Als de Bundestag of de Bundesrat hiertoe het initiatief neemt, kunnen zij bepalen hoe de wet eruit komt te zien. Aangezien Zustimmungsgesetze instemming van Bundestag én Bundesrat vereisen, kan de Bundesrat deze instemming onthouden wanneer de wet bijvoorbeeld niet de standpunten van de Bundesrat bevat.

Een voorbeeld van een wet die instemming van de Bundesrat vereist, is wetgeving die de Europese Verordening (EU) 2019/1157 over de nieuwe vereisten voor identiteitskaarten en paspoorten integreert. ${ }^{155}$ Deze verordening, en dus ook de Duitse integratiewet, maakt het mogelijk om twee vingerafdrukken op te nemen in de chip van de identiteitskaart. Daarnaast zullen ook nieuwe strengere eisen worden gesteld aan de verzending van de pasfoto op identiteitskaarten en paspoorten. Dit wordt gedaan om het risico op vervalsing en manipulatie te verhinderen. ${ }^{156}$

152 Ch. Degenhart, Staatsrecht I. Staatsorganistionsrecht. Mit Bezügen zum Europarecht, Heidelberg: C.F. Müller GmbH 2017, p. 87-93.

153 Das Datenhandbuch zur Geschichte des Deutschen Bundestages, 10.3 Bundestag und Bundesrat, p. 2.

154 Ch. Degenhart, Staatsrecht I. Staatsorganistionsrecht. Mit Bezügen zum Europarecht, Heidelberg: C.F. Müller GmbH 2017, p. 95.

155 Deutscher Bundestag 19. Wahlperiode, Drucksache 19/21986, 31 augustus 2020; Website Bundesrat, Personalausweis.

156 Verordening (EU) 2019/1157 van het Europees Parlement en de Raad van 20 juni 2019 betreffende de versterking van de beveiliging van identiteitskaarten van burgers van de Unie en van verblijfsdocumenten afgegeven aan burgers van de Unie en hun familieleden die hun recht van vrij verkeer uitoefenen. 


\subsection{Controle VAN DE REgering}

Deze paragraaf vormt samen met de volgende paragrafen de kern van dit hoofdstuk. Als eerste worden de bevoegdheden behandeld die kunnen worden ingezet bij zowel nationale als Europese aangelegenheden. Het gaat hier om de 'gewone' controlebevoegdheden. De volgende paragraaf bevat de controlebevoegdheden die speciaal gecreëerd en inzetbaar zijn voor Europese aangelegenheden.

Lange tijd werden EU-aangelegenheden nauwelijks besproken in het parlement. Er bestond een zogenoemde stilzwijgende instemming tussen de partijen voor wat betreft EU-zaken. Het parlement was van mening dat zaken met betrekking tot de Europese Unie behoorden tot de aangelegenheden van de regering. Dit inzicht is door de jaren heen gewijzigd. Met name sinds de economische en financiële crisis binnen Europa worden EU-aangelegenheden niet slechts marginaal plenair besproken maar uitvoerig en binnen de fracties. ${ }^{157}$ Checks and balances voorkomen dat politieke beslissingen door slechts één orgaan worden genomen. Deze checks and balances zorgen ervoor dat het beslissing nemende orgaan kan worden gecontroleerd door andere organen. ${ }^{158}$ Controle wordt met name uitgeoefend door de oppositie in de Bundestag. Dit heeft te maken met de nauwe samenwerking tussen de regering en de coalitiepartijen in deze Kamer. Door deze nauwe samenwerking zijn de coalitiepartijen minder geneigd om de regering te controleren en laten zij dit over aan de oppositie.

De andere Kamer binnen het Duitse parlement, de Bundesrat, heeft met name de taak om de Länder te vertegenwoordigen op federaal niveau en niet de taak om de regering te controleren. Deze verdeling in en opstelling van het parlement moet men in het achterhoofd houden wanneer een analyse wordt gemaakt van parlementaire controle van het Duitse parlement in de context van het wetgevingsproces van de Europese Unie. ${ }^{159}$

Uit het oude of oorspronkelijke begrip 'dualisme' binnen een staat volgt de idee van checks and balances waarbij de regering door het parlement als geheel wordt gecontroleerd. Het begrip dualisme is door de jaren heen ontwikkeld en het 'nieuwe' dualisme kenmerkt zich door de uitwerkingen in de praktijk. De regering en de coalitiefracties uit het parlement worden als één gezien en het is de oppositie die de regering controleert met betrekking tot buitenlands beleid terwijl de coalitiefracties de regering controleren met betrekking tot nationale aangelegenheden. ${ }^{160}$

157 S. Kropp \& A. Buzogány, 'Europäisierung informaler Regierungskontrolle. Informationsgewinnung im deutschen, schwedischen und ungarischen Parlament', Z Politikwiss 2016 (Suppl.) 26, p. 225.

158 Ibid., p. 216.

159 Ch. Degenhart, Staatsrecht I. Staatsorganistionsrecht. Mit Bezügen zum Europarecht, Heidelberg: C.F. Müller GmbH 2017, p. 289.

160 S. Kropp \& A. Buzogány, 'Europäisierung informaler Regierungskontrolle. Informationsgewinnung im deutschen, schwedischen und ungarischen Parlament', Z Politikwiss 2016 (Suppl.) 26, p. 218. 
Controle door coalitiefracties vindt op een informelere manier plaats dan controle door de oppositie. Deze laatste vindt namelijk plaats via de officiële controlebevoegdheden en wordt op een transparante manier gedaan. De controle door de coalitiefracties is niet transparant aangezien de leden van de regering niet publiekelijk kritiek willen ontvangen van hun eigen fracties. ${ }^{161}$ Daarnaast vindt er binnen de controle door coalitiepartijen een zogenoemde kruiscontrole plaats. Deze houdt in dat de verschillende coalitiepartijen meer controle uitoefenen op de ministers van de andere partijen dan op de ministers van de eigen partij. ${ }^{162}$

Het is niet vreemd dat bij buitenlandse aangelegenheden het nieuwe begrip dualisme wordt 'toegepast'. Het gaat dan om de gevallen waarin het hele parlement achter de regering staat en instemt met de handelswijze van de regering in Brussel. ${ }^{163}$ Beide vormen van dualisme zijn terug te vinden in Duitsland.

Om effectief te kunnen controleren verlangt het parlement van de regering onafhankelijke informatie. Onder het nieuwe dualisme wordt een onderscheid gemaakt tussen de oppositie- en coalitiepartijen in het parlement aangezien zij in bepaalde situaties op verschillende manieren informatie verkrijgen. Zo hebben de coalitiepartijen regelmatig contact met de ministeries. De oppositiepartijen die voorheen tot de coalitie behoorden, hebben dit ook (nog) maar in mindere mate dan de coalitiepartijen. Zowel coalitie- als oppositiepartijen hebben contact met ngo's en andere verenigingen of bonden die in Brussel actief zijn. De coalitiepartijen hebben contact met een brede selectie van ngo's en verenigingen, terwijl de oppositie contact houdt met de ngo's en verenigingen waarmee zij ideologisch op één lijn zitten. Het uitwisselen van informatie met leden van het Europees Parlement gebeurt door zowel de oppositiepartijen als de coalitiepartijen. ${ }^{164}$ Ook hebben ze contact met vergelijkbare politieke partijen uit andere lidstaten. Oppositiepartijen zoeken met name contact met de partijen die in de andere lidstaten in de regering zitten. Men is dan vooral geïnteresseerd in de informatie die zij wellicht kunnen krijgen over de onderhandelingen in Brussel. ${ }^{165}$

Grote verschillen zitten in de aanwezigheid van ministers en/of ambtenaren van de ministeries bij de fractievergaderingen van de coalitiepartijen. Bij deze vergaderingen van de oppositiepartijen zijn ministers en ambtenaren niet aanwezig, wel kunnen ze worden uitgenodigd om aanwezig te zijn. De informatievoorziening door de minister binnen een vergadering van coalitiepartijen is uitgebreider dan bij vergaderingen van oppositiepartijen, waar alles via het boekje gaat en de minister geen woord te veel zegt. De informatievoor-

161 Ibid., p. 218.

162 Ibid., p. 218.

163 Ibid, p. 218.

164 Ibid., p. 222.

165 Ibid., p. 225. 
ziening is dan erg terughoudend. ${ }^{166}$ Uit het voorgaande blijkt duidelijk dat politieke partijen een belangrijke plaats innemen in het Duitse staatsrecht. Controle van de regering is niet zozeer een taak van het parlement als geheel maar wordt gedaan door de verschillende politieke partijen. De representatiedemocratie in Duitsland staat dan ook voor partijendemocratie. Het zijn de partijen die de link vormen tussen het volk en de staatsorganen. ${ }^{167}$

\subsubsection{Controlebevoegdheden}

Controle van de regering is nauw verbonden met de invloed van het parlement op regeringsbeleid. Door vragen te stellen of de regering ter verantwoording te roepen is het mogelijk om de regering te beïnvloeden. Door het stellen van vragen kan het parlement zijn standpunten overbrengen en aangeven in hoeverre het het eens of juist oneens is met de regering. Het controleren van de regering is een van de primaire taken van de Bundestag. Ook is dit nauw verbonden met de wetgevende taak omdat controle kan leiden tot nieuwe of verbeterde wetgeving. Van belang voor de parlementaire taken is uiteraard ook de begroting. Zonder goedkeuring van de Bundestag kan de begroting niet worden vastgesteld. Dit kan grote gevolgen hebben. De begroting is dan ook geen gewone wet en wordt daarom doorgaans gedurende enkele dagen in de Bundestag behandeld.

Maar los van wetgeving en begroting heeft de Bundestag als geheel en hebben de leden individueel enkele bevoegdheden in de context van de controlefunctie. ${ }^{168}$

Het ontvangen en hebben van informatie is het startpunt van regeringscontrole. ${ }^{169} \mathrm{Om}$ informatie te krijgen heeft de Bundestag een viertal bevoegdheden. Dit zijn de Kleine und Große Anfragen (kleine en grote interpellaties); Schriftliche Fragen, Mündliche Fragen und Fragestunden (schriftelijke vragen, mondelinge vragen en vragenuur); Aktuelle Stunde (spoeddebat), Regierungsbefragungen (regeringsdebat) en Untersuchung (enquête). ${ }^{170} \mathrm{Het}$ gaat hier om algemene controlebevoegdheden die zowel worden ingezet voor nationale als Europese aangelegenheden. Daarnaast bestaat voor de regering de plicht om aanwezig te zijn in de Bundestag wanneer deze dat verlangt. ${ }^{171}$

166 Ibid., p. 223

167 Ch. Degenhart, Staatsrecht I. Staatsorganistionsrecht. Mit Bezügen zum Europarecht, Heidelberg: C.F. Müller GmbH 2017, p. 22-23.

168 Website Bundestag, Vielfalt der Kontrolle.

169 R. Zippelius \& T. Würtenberger, Deutsches Staatsrecht. Ein Studienbuch, München: Verlag C.H. Beck 2018, p. 399.

170 Website Bundestag, Instrumente der Kontrolle.

171 R. Zippelius \& T. Würtenberger, Deutsches Staatsrecht. Ein Studienbuch, München: Verlag C.H. Beck 2018, p. 400. 


\subsubsection{Kleine und Große Anfragen}

De Kleine und Große Anfragen (kleine en grote interpellaties) zijn twee van de meest gebruikte vormen van controle. Om een dergelijke interpellatie over een bepaald onderwerp te plaatsen dient vijf procent van de leden van de Bundestag of een fractie uit de Bundestag een verzoek daartoe te steunen. De vragen worden aan de voorzitter van de Bundestag gestuurd, die ze daarna aan de regering doorstuurt met de opdracht de vragen te beantwoorden. Op Kleine Anfragen wordt door de regering alleen schriftelijk en binnen twee weken gereageerd. Große Anfragen worden doorgaans tijdens een debat in de Bundestag behandeld. Dit heeft te maken met de grotere politieke belangen. In een debat heeft de oppositie de kans om kritische vragen te stellen over het probleem en ook haar mening naar voor te brengen. ${ }^{172}$

Een voorbeeld van een Kleine Anfrage is die van 22 november 2016, opgenomen in bijlage IV. ${ }^{173}$ Samen met enkele leden van de Bundestag had de fractie 'Die Linke' een Kleine Anfrage ingediend over vluchtelingen in Griekenland. De interpellatie is opgebouwd uit een beschrijving van de situatie en 38 vragen, met enkele subvragen, aan de regering. Het antwoord van de regering, bijlage $\mathrm{V}$, is bij de meeste vragen kort en heel gericht. Uit bestudering van meerdere Kleine Anfragen blijkt dat dit een normale opzet van een Kleine Anfrage is. Er is geen wezenlijk verschil tussen Kleine Anfragen over een nationaal onderwerp of een Europees onderwerp.

De opzet van een Große Anfrage is gelijk aan die van een Kleine Anfrage. Allereerst wordt de situatie uiteengezet en vervolgens volgen er concrete vragen. Het verschil zit in het aantal vragen. Doorgaans bevat een Große Anfrage veel meer vragen dan een Kleine Anfrage. Het aantal kan wel oplopen tot 250 vragen in één Große Anfrage. Er zijn maar weinig Große Anfrage die minder dan honderd vragen hebben terwijl het aantal vragen van een Kleine Anfrage doorgaans tussen één en vijftig ligt. Een ander verschil is dat de regering bij een Große Anfrage de vragen mondeling beantwoordt tijdens een plenair debat. Omdat leden van de Bundestag tijdens dit debat in discussie kunnen gaan met de regering, wat bij een Kleine Anfrage niet mogelijk is, wordt de Große Anfrage als een van de belangrijkste controlemogelijkheden gezien.

Zoals al eerder aangegeven worden controlebevoegdheden met name ingezet door de oppositie. In de onderzoeksperiode 2010-2016 heeft geen enkele coalitiepartij (CDU/SCU, FDP, SPD) een Große Anfrage ingezet. Wel hebben de coalitiepartijen Kleine Anfragen aangevraagd. Tijdens het kabinet-Merkel III (2013-2017) hebben de coalitiepartijen gezamenlijk 43 Kleine Anfragen ingediend. Dit is slechts een gering aantal afgezet tegen het

172 Kleine und Große Anfragen via www.Bundestag.de/parlament/aufgaben/regierungskontrolle_neu/kon trolle/instru/255462.

173 Deutscher Bundestag Drucksache 18/10394 18. Wahlperiode 22 november 2016. 
totale aantal Kleine Anfragen, dat 3119 bedroeg. ${ }^{174}$ Ook zijn er mondelinge en schriftelijke vragen gesteld door de coalitiepartijen, maar wel in veel mindere mate dan door de oppositiepartijen. ${ }^{175}$ De schriftelijke en mondelinge vragen worden hierna behandeld.

Kleine en Große Anfragen zijn van grote waarde voor de Bundestag om controle uit te oefenen op de regering. Met relatief weinig moeite is het mogelijk om een Kleine of Große Anfrage in te dienen. Het zijn met name de Kleine Anfragen die het meest aangevraagd worden. Dit heeft ermee te maken dat Kleine Anfragen over 'normale' onderwerpen gaan die geen spoed hebben. Große Anfragen gaan juist over grote politieke vraagstukken, en komen daarom minder voor.

\subsubsection{Schriftliche Fragen, Mündliche Fragen en Fragestunden}

Waar de kleine en grote interpellaties een recht zijn van de fracties, hebben individuele leden ook rechten. Dit zijn de schriftelijke vragen, mondelinge vragen en het vragenuur.

Elk lid van de Bundestag heeft het recht om per maand maximaal vier vragen aan de regering te stellen. De vragen moeten binnen een week worden beantwoord door de regering. Indien de regering niet binnen een week antwoordt, heeft de vragensteller het recht om de regering te verzoeken mondeling op de vragen te reageren tijdens het eerstvolgende vragenuur (Fragestunde). De vragen en antwoorden worden ook wekelijks gepubliceerd.

Naast de vier vragen die maandelijks schriftelijk mogen worden gesteld heeft elk lid van de Bundestag ook het recht om tijdens het wekelijkse vragenuur maximaal twee vragen te stellen; dit zijn de mondelinge vragen. Om te voorkomen dat vele vragen in twee vragen worden verpakt mag elke vraag bestaan uit maximaal twee subvragen. Tijdens het vragenuur worden de vragen mondeling door de regering beantwoord. Wanneer het lid dat de vragen heeft gesteld niet aanwezig is bij het vragenuur, kunnen op diens verzoek de vragen schriftelijk worden beantwoord. Tijdens dit vragenuur kunnen leden van de Bundestag vervolgvragen stellen. Het vragenuur kan maximaal drie uur duren. ${ }^{176}$ Zowel de grote en kleine interpellaties als de schriftelijke vragen en het vragenuur worden niet als zodanig in de Grondwet genoemd maar vallen onder het recht om geïnformeerd te worden. De bevoegdheden zijn wel uitgewerkt in het Reglement van Orde van de Bundestag. ${ }^{177}$

Zoals in de vorige paragraaf aangegeven worden mondelinge en schriftelijke vragen niet alleen door de oppositie gesteld maar ook door de coalitiepartijen. Het merendeel van de mondelinge en schriftelijke vragen wordt echter door de oppositie gesteld. In het kabinet-

174 Overzicht van de Bundestag d.d. 27 februari 2018 via Website Bundestag, Anfragen.

175 Ibid.

176 Schriftliche Fragen und Fragestunde via website Bundestag, Instrumente der Kontrolle.

177 R. Zippelius \& T. Würtenberger, Deutsches Staatsrecht. Ein Studienbuch, München: Verlag C.H. Beck 2018, p. 400; par. 100 e.v. Reglement van Orde van de Bundestag. 
Merkel II werden 6.057 mondelinge en 20.141 schriftelijke vragen gesteld. ${ }^{178}$ De meeste mondelinge en schriftelijke vragen kwamen van de oppositiepartijen SPD, Bündnis 90/Die Grünen en Die Linke. ${ }^{179}$ Ook in het kabinet-Merkel III waren het Bündnis 90/Die Grünen en Die Linke die de meeste vragen stelden. ${ }^{180}$ De SPD behoorde in deze periode tot de coalitie en stelde daardoor veel minder vragen dan in de vorige kabinetsperiode.

Schriftelijke vragen zijn doorgaans korte vragen met korte antwoorden. Alle schriftelijke vragen worden per week gepubliceerd. Per week worden ongeveer honderd schriftelijke vragen gesteld. Van die vragen heeft een klein aantal, ongeveer zeven vragen per week, betrekking op de Europese Unie. Hieronder zijn twee voorbeelden opgenomen. Het stellen van schriftelijke vragen is er met name op gericht om binnen een kort tijdsbestek bondige informatie te ontvangen.

De volgende twee vragen van de leden Ostendorff en Wilms zijn als voorbeeld opgenomen. Duidelijk is te zien dat het gaat om korte vragen en korte antwoorden. Mochten de leden dieper willen ingaan op een onderwerp dan ligt het meer voor de hand om een mondelinge vraag te stellen.

\section{Abgeordneter Friedrich Ostendorff (BÜNDNIS 90/ DIE GRÜNEN)}

Ist der Bundesregierung bekannt, ob vonseiten der Europäischen Union oder internationaler Finanzorganisationen, an denen Deutschland beteiligt ist, eine direkte oder indirekte Förderung der o. g. Investitionen erfolgt oder geplant ist?

\section{Antwort des Parlamentarischen Staatssekretärs Dr. Gerd Müller vom 16. Oktober 2013}

Nach Kenntnis der Bundesregierung wurden die Investitionen durch die genannten Institutionen weder gefördert, noch ist eine Förderung geplant. ${ }^{181}$

\section{Abgeordnete Dr. Valerie Wilms (BÜNDNIS 90/ DIE GRÜNEN)}

Welche Maßnahmen werden nach Kenntnis der Bundesregierung durch die Europäische Union ergriffen, um die Umsetzung der internationalen Ballastwasser-Konvention zur Behandlung von Ballastwasser von Seeschiffen in allen EU-Mitgliedstaaten voranzutreiben (zum Beispiel Einrichtung von Umweltschutzmaßnahmen durch Gemeinschaftskompetenz),

178 Het kabinet-Merkel II regeerde van 28 oktober 2009 tot 17 december 2013.

179 Overzicht van de Bundestag d.d. 27 februari 2018 via website Bundestag, Anfragen.

180 Het kabinet-Merkel III regeerde van 17 december 2013 tot 14 maart 2018.

181 Deutscher Bundestag, Drucksache 17/14837, 17. Wahlperiode 21 oktober 2013, Nummer der Frage 39. 
und inwieweit sieht die Bun- desregierung (abgesehen von der EU-Verordnung (EU), Nr. 1143/2014) zu invasiven Arten aus dem Jahr 2014 einen Widerspruch der nicht EUweiten Umsetzung der Konvention zu EU-weit geltenden Umweltvorschriften wie z. B. der Mee- resstrategie-Rahmenrichtlinie?

Antwort des Parlamentarischen Staatssekretärs Enak Ferlemann vom 18. November 2016

Der Bundesregierung sind keine weiteren Maßnahmen der Europäischen Union bekannt. Von Seiten der Bundesregierung wird keine Notwendigkeit für solche Maßnahmen und auch kein Widerspruch zu EU-weit geltenden Umweltvorschriften gesehen.

Schriftelijke vragen en Kleine Anfragen lijken enigszins op elkaar. Beide soorten worden schriftelijk gesteld en beide kunnen ook schriftelijk beantwoord worden. Het verschil zit enerzijds in het aantal vragen dat gesteld mag worden en anderzijds toch in de beantwoording door de regering. Een schriftelijke vraag mag uit maximaal vier vragen bestaan met ieder twee subvragen; een dergelijk limiet zit niet op een Kleine Anfrage. Daarnaast worden Kleine Anfragen binnen twee weken beantwoord terwijl schriftelijke vragen in dezelfde week mondeling door de regering worden beantwoord. Dus wanneer (een lid van) de Bundestag meer dan vier vragen heeft over een onderwerp, wordt gekozen voor een Kleine Anfrage en niet voor een schriftelijke vraag. Daarnaast is ook van belang hoe snel de Bundestag antwoord wil hebben. Indien dat zo snel mogelijk wordt gewenst dan ligt het voor de hand om een schriftelijke vraag te stellen. Daarnaast is voor het aanvragen van Kleine of Große Anfragen de steun nodig van vijf procent van de leden van de Bundestag of een fractie uit de Bundestag. Indien één lid van de Bundestag niet op één lijn zit met de rest van zijn partij of met de rest van de Bundestag zal dat lid geen steun krijgen voor een Anfrage. In dat geval ligt het voor de hand dat dat lid schriftelijk en mondelinge vragen stelt.

\subsubsection{Aktuelle Stunde}

De Aktuelle Stunde (spoeddebat), letterlijk vertaald Actueel Uur en te vergelijken met een dertigledendebat in Nederland, is een vervolg op het vragenuur. Het spoeddebat wordt met name door de oppositiepartijen binnen de Bundestag gebruikt. Wanneer de leden van de Bundestag niet tevreden zijn met de antwoorden van de regering in het vragenuur kunnen zij direct aansluitend aan het vragenuur een spoeddebat houden. De aanvraag hiervoor dient door vijf procent van de leden of een fractie te worden gesteund. De aanvraag wordt ingediend bij de president van de Bundestag. Een spoeddebat kan echter ook onafhankelijk van een vragenuur worden aangevraagd. Ook deze aanvraag moet gesteund 
worden door minimaal vijf procent van de leden van de Bundestag of door de 'Ältestenrat', een orgaan binnen de Bundestag te vergelijken met het presidium van de Tweede Kamer. Elk lid heeft vijf minuten spreektijd tijdens de Aktuelle Stunde en het aantal sprekers wordt aan het begin van een regeringsperiode per partij bepaald. ${ }^{182}$ Doorgaans zijn er twaalf sprekers en duurt het 'Actueel Uur' ongeveer een uur tenzij de regering mondeling wil reageren, dan duurt het geheel langer dan een uur. ${ }^{183}$

Het is de gewoonte dat de regering voorafgaand aan een bijeenkomst van de Europese Raad de Bundestag informeert over haar standpunten via een zogenoemde 'Regierungserklärung' (verklaring van de regering over haar beleid en standpunten). Dit wordt gedaan door de bondskanselier voordat zij naar de bijeenkomst van de Europese Raad gaat. Wanneer dit niet gebeurt, komt de oppositie binnen de Bundestag in actie. Dit kan gedaan worden door een Aktuelle Stunde aan te vragen, wat gezien de spoed en actualiteit van de zaak hiervoor een geschikt instrument is. De oppositie in de Bundestag deed dit dan ook toen de regering zonder gegronde reden, aldus de oppositie, geen Regierungserklärung afgaf voorafgaande aan een bijeenkomst van de Europese Raad. ${ }^{184}$ De oppositie wilde dit niet door de vingers zien omdat de onderwerpen van de desbetreffende bijeenkomst, te weten Brexit en de crisis in Griekenland, belangrijke onderwerpen waren die besproken hoorden te worden tussen de regering en de Bundestag. De oppositie reageerde teleurgesteld en verbaasd en vond het onacceptabel dat de regering haar standpunten over deze onderwerpen niet met de Bundestag deelde. Als eerste sprak de fractie die de Aktuelle Stunde had aangevraagd, in dit geval was dat Bündnis 90/Die Grünen. Er volgde een betoog waarin de teleurstelling in de bondskanselier werd uitgesproken en vervolgens de eigen standpunten over de Brexit en de crisis in Griekenland uiteen werden gezet. Vervolgens kwam de regeringsfractie CDU/CSU aan het woord. Deze fractie verdedigde de regering en was van mening dat over Brexit en de crisis al zo vaak binnen de Bundestag was gedebatteerd, zowel plenair als in commissies, dat een Regierungserklärung overbodig zou zijn aangezien de standpunten van de regering al lang duidelijk en openbaar waren. ${ }^{185}$ Oppositiefractie Die Linke was net zoals Bündnis 90/Die Grünen van mening dat een Aktuelle Stunde nodig was omdat de bondskanselier geen discussie met de Bundestag was aangegaan voorafgaande aan de bijeenkomst van de Europese Raad. De SPD nam als regeringsfractie een mildere toon aan en meende dat de 'Staatsminister für Europa ${ }^{\text {'186 }}$ de Bundestag had ingelicht over de standpunten van de regering, maar was ook enigszins teleurgesteld dat de bondskanselier

182 Aktuelle Stunde via Website Bundestag, Instrumente der Kontrolle.

183 Website Bundestag, Mediathek.

184 Plenarprotokoll 18/240, Deutscher Bundestag, Stenografischer Bericht, 240. Sitzung, Berlin, Donnerstag, den 22. Juni 2017, p. 24536 (C).

185 Plenarprotokoll 18/240, Deutscher Bundestag, Stenografischer Bericht, 240. Sitzung, Berlin, Donnerstag, den 22. Juni 2017, p. 24539.

186 In sommige ministeries wordt de parlamentarischer Staatssekretär ook wel staatsminister genoemd. 
niet in debat was gegaan met de Bundestag. Hierna kwamen alle fracties nogmaals aan het woord. Uiteindelijk was de Aktuelle Stunde niet meer dan een debat tussen de oppositieen coalitiepartijen en niet, zoals de aanvrager gehoopt had, een debat tussen de (oppositie van de) Bundestag en de bondskanselier.

De Aktuelle Stunde geeft de mogelijkheid om langer en dieper op een onderwerp in te gaan. De meerwaarde van een Aktuelle Stunde zit in de aanwezigheid van de regering. Wanneer deze afwezig is, is het 'slechts' een uur waarin alle partijen hun standpunten over bepaalde onderwerpen benadrukken. Wanneer de regering afwezig is, krijgen de leden van de Bundestag geen antwoorden op hun vragen en dat is jammer want dat is wat de leden willen tijdens een Aktuelle Stunde.

\subsubsection{Regierungsbefragung}

Elke woensdag heeft de federale regering een 'Kabinettssitzung' (kabinetsvergadering), een soort ministerraad. Aansluitend aan deze bijeenkomst hebben de leden van de Bundestag de mogelijkheid vragen te stellen aan de regering over actuele aangelegenheden, de zogenoemde 'Regierungsbefragung'. Dit wordt gedaan in de vorm van een debat in de Bundestag dat elke woensdag om 13.00 uur plaatsvindt. Het debat duurt ongeveer dertig minuten en is daarmee een zeer compacte vorm van informatieverstrekking. De regering deelt de uitkomsten van de Kabinettssitzung. Tijdens de Kabinettssitzung wordt voor het eerst nieuwe informatie over een onderwerp gedeeld. Hierna kunnen de hiervoor beschreven debatten plaatsvinden. ${ }^{187}$

Tijdens dergelijke Regierungsbefragungen krijgt de aanwezige minister als eerste het woord. Hij deelt de uitkomsten van de Kabinettssitzung. Dit vormt de basis voor alle vragen die volgen. Na elke vraag van een lid van de Bundestag geeft de minister antwoord. Vervolgvragen door hetzelfde lid zijn niet gebruikelijk. Slechts een enkele keer komt het voor dat een lid twee vragen stelt. De minister kan ondersteund worden door een van zijn parlementaire staatssecretarissen. Deze kan ook vragen van de leden beantwoorden. De Regierungsbefragung is een goede manier om (actuele) informatie te verstrekken. Omdat de Regierungsbefragung direct na de Kabinettssitzung plaatsvindt, is de Bundestag snel op de hoogte van de zaken waarmee de regering zich op dat moment bezighoudt. Het moet gezien worden als het startpunt van de informatievoorziening vanuit de regering aan de Bundestag.

\subsubsection{Aanwezigheidsplicht}

Naast het bovenstaande heeft de Bundestag het recht de aanwezigheid van de federale regering bij debatten te verlangen. ${ }^{188}$ Aangezien leden van de regering ook lid zijn van de

187 Regierungsbefragungen via Website Bundestag, Instrumente der Kontrolle.

188 Art. 43 lid 1 Grondwet. 
Bundestag, zijn zij doorgaans aanwezig bij de debatten over de terreinen die hen aangaan. Indien de Bundestag zijn aanwezigheid verlangt, is de minister verplicht persoonlijk te verschijnen en de vragen te beantwoorden. ${ }^{189}$ Dit mag hij weigeren op basis van de gronden vermeld in de Grondwet, bijvoorbeeld wanneer er binnen de regering nog geen beslissing is genomen over het onderwerp. Omgekeerd hebben de leden van de regering het recht te verlangen aanwezig te zijn bij alle debatten van de Bundestag en Kamercommissies en aldaar gehoord te worden. ${ }^{190}$ Het recht om aanwezigheid van de regering te verlangen verschilt met de voorgaande rechten zoals het interpellatierecht, in zoverre dat voor de aanwezigheid een besluit van de meerderheid van de Bundestag nodig is terwijl dat bij het interpellatierecht niet zo is. Het laatste is een minderheidsrecht.

\subsubsection{Overzicht}

Tabel 10 hieronder geeft een overzicht van het aantal keren dat de Bundestag zijn controlebevoegdheden heeft ingezet. De aantallen zijn opgevraagd bij de Bundestag en ontvangen per e-mail. ${ }^{191}$ Een overzicht van de inzet van controlebevoegdheden per regeringsperiode is te vinden op de website van de Bundestag. Onder 'Statistik der Parlamentarischen Kontrolltätigkeit' publiceert de Bundestag deze overzichten. Er is een splitsing gemaakt tussen het totale aantal keren dat de controlebevoegdheden zijn ingezet, ongeacht waarvoor, en de keren dat dit is gebeurd voor controle op het Europees beleid van de regering. Tot slot is een percentage opgenomen dat aangeeft in hoeveel procent van het totaal de Bundestag zijn bevoegdheden gebruikt om het Europees beleid van de regering te controleren. Aan het 'totale aantal' valt te zien dat de Bundestag een actieve Kamer is. De gegeven getallen zijn de aantallen voor een periode van zeven jaar (2010-2016) samen, maar indien dit per jaar bekeken wordt, is te zien dat er per jaar duizenden interpellaties worden geplaatst en vragen worden gesteld. Het percentage Große Anfrage over Europa is 29,4 procent. De andere percentages liggen lager. Kleine Anfragen over Europa hebben een percentage van 15,9 procent. Schriftliche Fragen, Mündliche Fragen, Aktuelle Stunden en Regierungsbefragungen liggen alle onder 10 procent. Dit betekent dat de Bundestag die controlebevoegdheden met name inzet voor nationale aangelegenheden en dus in mindere mate voor Europese aangelegenheden. Een van de redenen hiervoor kan zijn dat er voor de Europese aangelegenheden specifieke bevoegdheden bestaan (waarover hierna meer). Daarnaast, zoals in paragraaf 4.4.2.1 te lezen zal zijn, heeft de federale regering de plicht haar standpunten omtrent Europese wetgeving met de Bundestag te coördineren alvorens de regering haar standpunt deelt op Europees niveau. Daarnaast heeft het Bundesverfassungsgericht

189 R. Zippelius \& T. Würtenberger, Deutsches Staatsrecht. Ein Studienbuch, München: Verlag C.H. Beck 2018, p. 400.

190 Art. 43 lid 2 Grondwet.

191 De aantallen zijn opgevraagd bij de Bundestag en via e-mail ontvangen op 30 november 2017 en 7 december 2017. 
bepaald dat de informatieplicht van de regering inhoudt dat de regering de Bundestag tijdig en van voldoende informatie voorziet zodat de Bundestag effectief invloed kan uitoefenen op Europees beleid. ${ }^{192}$ Er ís dus al contact tussen de regering en de Bundestag over elk Europees wetsvoorstel waardoor parlementariërs minder genoodzaakt zijn om via vragen of andere wegen om informatie te vragen.

De specifieke Europese bevoegdheden zijn in tabel 10 niet meegenomen maar worden in paragraaf 4.5 en verder besproken. Uit onderzoek naar de activiteiten in de Duitse politiek blijkt overigens dat Duitsland de afgelopen 25 jaren meer gefocust is geraakt op binnenlandse aangelegenheden en in mindere mate op Europese aangelegenheden. ${ }^{193} \mathrm{Bij}$ de uitkomsten van dit onderzoek kunnen enige kanttekeningen geplaatst worden. Het kan zo zijn dat in het parlement procentueel meer gesproken wordt over nationale aangelegenheden, maar dat zal zijn omdat er nog altijd meer zaken nationaal dan Europees geregeld worden. Of men ook een duidelijkere focus heeft op nationale aangelegenheden valt op basis van de data uit dit onderzoek niet te concluderen. Juist in Duitsland bestaan er wetten die bevoegdheden bevatten die specifiek gericht zijn op de Europese Unie. Dat alleen al geeft aan dat er (ook) een duidelijke focus op de EU bestaat. Daarnaast zorgt het Bundesverfassungsgericht via de jurisprudentie ervoor dat de Bundestag zijn bevoegdheden behoudt en benut. Kortom, het blijft lastig om uit te maken of de focus met name op nationale aangelegenheden ligt dan wel op Europese onderwerpen.

\section{Tabel 10 Controlebevoegdheden van de Bundestag}

\begin{tabular}{llll}
$\begin{array}{l}\text { Controlebevoegdheid } \\
\text { Bundestag }\end{array}$ & Totale aantal & $\begin{array}{l}\text { Over/verwant aan } \\
\text { de Europese Unie }\end{array}$ & $\begin{array}{l}\text { Percentage EU van } \\
\text { totaal }\end{array}$ \\
\hline Kleine Anfragen & 7529 & 1195 & 15,9 \\
\hline Große Anfragen & 68 & 20 & 29,4 \\
\hline Schriftliche Fragen & 33779 & 2722 & 8,1 \\
\hline Mündliche Fragen & 9176 & 870 & 9,5 \\
\hline Aktuelle Stunden & 218 & 19 & 8,7 \\
\hline Regierungsbefragungen & 131 & 12 & 9,2 \\
\hline Totaal controlebevoegdheden & $\mathbf{5 0 9 0 1}$ & $\mathbf{4 8 3 8}$ & $\mathbf{9 , 5}$
\end{tabular}

192 BVerfG 19 juni 2012 - 2 BvE 4/11, r.o. 107.

193 D. Göler \& M. Jopp, 'Deutschlands konstitutionelle Europapolitik', in: K. Böttger \& M. Jopp (Hrsg.), Handbuch zur deutschen Europapolitik, Baden-Baden: Nomos Verlagsgesellschaft 2017, p. 57. 


\subsubsection{Kamercommissies}

Controle door de Bundestag vindt met name plaats door de Kamercommissies. Daarvoor heeft de Bundestag de permanente commissies, waarvan de primaire taak is om deel te nemen aan de totstandkoming van wetgeving. Daarnaast bestaan er ook commissies die uitsluitend de taak hebben om de regering te controleren, bijvoorbeeld de Enquêtecommissie. ${ }^{194}$ Op basis van de Grondwet is de Bundestag verplicht bepaalde commissies op te richten. Dit zijn onder andere een commissie voor aangelegenheden van de Europese Unie (commissie voor Europese Zaken), ${ }^{195}$ een commissie voor Buitenlandse Zaken, ${ }^{196}$ een commissie voor Defensie ${ }^{197}$ en een commissie voor petities. ${ }^{198}$ Het instellen van andere (facultatieve) commissies is aan de Bundestag zelf om te besluiten. ${ }^{199}$ De commissies binnen de Bundestag zijn verder onder te verdelen in permanente commissies, controlecommissies en onderzoekcommissies. ${ }^{200}$

\subsubsection{Permanente commissies}

Bij de permanente commissies geldt doorgaans dat zij aan een bepaald ministerie gekoppeld zijn. Deze commissies hebben daarmee een duidelijk vakgebied dat zij dienen te controleren en waarop zij invloed uitoefenen. Deze invloed oefenen zij met name uit via hun deelname aan het wetgevingsproces. Naast deze indirecte controle hebben de commissies ook bevoegdheden om directe controle uit te oefenen. De commissies zijn bevoegd om vertegenwoordigers (de ministers) van de regering naar de actuele stand van (concept)wetgeving te vragen en aanbevelingen te verlangen buiten de plenaire vergadering om. Dit zogenoemde 'Selbstbefassungsrecht' (vrij vertaald: recht op betrokkenheid) heeft zich ontwikkeld tot een van de belangrijkste controlebevoegdheden. ${ }^{201}$

Binnen de vaste commissies hebben twee commissies een bijzondere positie. Dit zijn de begrotingscommissie en de commissie voor Europese Zaken. De begrotingscommissie wordt gezien als de belangrijkste commissie aangezien deze een belangrijke bijdrage levert aan de goedkeuring van de begrotingen.

Ook de commissie voor Europese Zaken heeft een speciale rol binnen de Bundestag. De commissie is namelijk bevoegd om namens de Bundestag adviezen uit te brengen over

194 Website Bundestag, Kontrolle der Regierung.

195 Art. 45 Grondwet.

196 Art. 45a Grondwet.

197 Art. 45a Grondwet.

198 Art. 45c Grondwet.

199 R. Zippelius \& T. Würtenberger, Deutsches Staatsrecht. Ein Studienbuch, München: Verlag C.H. Beck 2018, p. 407.

200 Website Bundestag, Gremien zur Kontrolle.

201 Website Bundestag, Gremien zur Kontrolle. 
Europese conceptwetgevingsvoorstellen. Artikel 45 van de Grondwet bepaalt dat de Bundestag een commissie Europese Zaken moet instellen. Door deze bepaling is de Bundestag in elke kabinetsperiode verzekerd van een commissie voor Europese Zaken. ${ }^{202}$ Artikel 23 lid 2 en 3 van de Grondwet bepaalt dan weer dat de Bundestag het recht heeft om mee te werken aan Europese aangelegenheden. ${ }^{203}$ Dit houdt in dat de federale regering haar standpunten dient te coördineren met de Bundestag (lees: de commissie Europese Zaken) alvorens zij een standpunt mag innemen op Europees niveau.

De standpunten van de commissie gelden als standpunten van de gehele Bundestag. Het is niet nodig om deze eerst plenair vast te leggen. Op basis van artikel 45 van de Grondwet is het wel aan de plenaire Bundestag om te bepalen in hoeverre de commissie wordt gemachtigd om de Bundestag te vertegenwoordigen. Dit houdt in dat de commissie gemachtigd kan worden om de bevoegdheden die de Bundestag heeft ten aanzien van de regering op grond van artikel 23 van de Grondwet uit te oefenen evenals de bevoegdheden die de Bundestag heeft op grond van de Europese verdragen. De Bundestag is verplicht een commissie Europese Zaken in te stellen maar het machtigen van de commissie om namens de Bundestag te handelen is optioneel. Het Reglement van Orde van de Bundestag bepaalt dat de commissie ook zonder deze machtiging de rechten van de Bundestag kan uitoefenen, mits geen van de overige commissies hiertegen bezwaar maakt en het niet gaat om het gemeenschappelijk buitenlands en veiligheidsbeleid. ${ }^{204}$ Het doel van artikel 45 Grondwet is om de Bundestag in staat te stellen een Stellungnahme te nemen ook wanneer er geen plenaire zittingen zijn. ${ }^{205}$ In de praktijk speelt artikel 45 Grondwet nauwelijks een rol, want de commissie maakt vrijwel geen gebruik van deze bevoegdheid. ${ }^{206}$

De commissie voor Europese Zaken is de grootste commissie binnen de Bundestag. In deze commissie hebben namelijk niet alleen leden uit de Bundestag zitting maar ook veertien leden uit het Europees Parlement. Om dit in perspectief te plaatsen: omdat ook leden van het Europees Parlement zitting hebben in de commissie Europese Zaken kan het totale aantal leden ervan oplopen tot meer dan 50, waar andere commissies doorgaans 25 tot 40 leden hebben. Deze leden van het Europees Parlement hebben het recht om deel te nemen aan het werk van de commissie. Dit houdt in dat ze kunnen voorstellen om bepaalde punten te bespreken, ze kunnen informatie verstrekken en hun standpunten

202 P. Badura, Staatsrecht. Systematische Erläuterung des Grundgesetzes, München: Verlag C.H. Beck 2018, p. 645; R. Zippelius \& T. Würtenberger, Deutsches Staatsrecht. Ein Studienbuch, München: Verlag C.H. Beck 2018, p. 407.

203 T. Maunz \& G. Dürig, Grundgesetz Kommentar, Band IV art. 23-53a, München: Verlag C.H. Beck 2009, art. 45 , p. 1.

204 Par. 93b (2) Reglement van Orde van de Bundestag.

205 H. Schröder, 'Die Mitwirkung des bundestages in EU-Angelegenheiten nach dem EUZbbG in der Praxis - ein Kurzkommentar', Zeitschrift für Parlamentsfragen (ZParl) 2012, 2, p. 250-277, p. 273.

206 Ibid., p. 273. 
delen. De leden van het Europees Parlement hebben geen stemrecht in de commissie, dat recht is enkel voor de leden van de Bundestag. ${ }^{207}$

Dit contact tussen leden van de commissie voor Europese Zaken van de Bundestag en leden van het Europees Parlement komt de informatievoorziening van de Bundestag ten goede. Daarnaast hebben leden van de commissie voor Europese Zaken ook zelfstandig contact met de verschillende Europese instituten, hetgeen wederom de informatievoorziening ten goede komt. ${ }^{208}$ Het aantal leden per fractie in de commissie hangt af van de grootte van de fractie in de Bundestag. ${ }^{209}$

De speciale rol van de commissie voor Europese Zaken komt ook naar voren in het feit dat de commissie niet vergadert in de commissievergaderzalen van de Bundestag maar in haar eigen vergaderzaal, de zogenoemde Europazaal. Als overkoepelende commissie is de commissie primair verantwoordelijk voor alle vraagstukken met betrekking tot Europese integratie en andere zaken die de EU betreffen, mits deze niet onder de verantwoordelijkheid vallen van andere commissies. ${ }^{210}$ Daarbij moet onder andere gedacht worden aan institutionele hervormingen, verdragswijzigingen maar ook het Europees Semester en de Brexit. ${ }^{211}$ Bij onderwerpen die tot de verantwoordelijkheid van andere commissies behoren, treedt de commissie voor Europese Zaken adviserend op. ${ }^{212}$ Net zoals de andere commissies binnen de Bundestag bereidt de commissie voor Europese Zaken de besluiten van de plenaire vergadering voor over voorstellen die aan de Bundestag zijn voorgelegd. Op basis van het 'Selbstbefassungsrecht' pakt de commissie met enige regelmaat ook zelfstandig Europese beleidskwesties op. ${ }^{213}$

Het Reglement van Orde van de Bundestag bevat regelingen voor de behandeling van EU-documenten en de verdeling van EU-documenten door de commissie voor Europese Zaken. Paragraaf 93 van het Reglement legt de procedure vast voor het overdragen van documenten aan de verschillende commissies van de Bundestag.

Paragraaf 93a bepaalt vervolgens dat EU-documenten worden getoetst op naleving van de beginselen van subsidiariteit en evenredigheid. Indien een commissie van plan is om een bezwaar in te dienen dan dient zij de commissie voor Europese Zaken hiervan op de

207 P. Badura, Staatsrecht. Systematische Erläuterung des Grundgesetzes, München: Verlag C.H. Beck 2018, p. 647.

208 A. Benz \& J. Broschek, 'Nationale Parlamente in der Europäischen Politik - Funktionen, Probleme und Lösungen', Internationale Politikanalyse 2010, Friedrich-Ebert-Stiftung, p. 8.

209 P. Badura, Staatsrecht. Systematische Erläuterung des Grundgesetzes, München: Verlag C.H. Beck 2018, p. 645; art. 45 Grondwet.

210 A. Benz \& J. Broschek, 'Nationale Parlamente in der Europäischen Politik - Funktionen, Probleme und Lösungen', Internationale Politikanalyse 2010, Friedrich-Ebert-Stiftung, p. 9.

211 Deutscher Bundestag, Der Ausschuss für die Angelegenheiten der Europäischen Union, juli 2018, p. 6 en 9.

212 A. Benz \& J. Broschek, 'Nationale Parlamente in der Europäischen Politik - Funktionen, Probleme und Lösungen', Internationale Politikanalyse 2010, Friedrich-Ebert-Stiftung, p. 9.

213 Deutscher Bundestag, Der Ausschuss für die Angelegenheiten der Europäischen Union, juli 2018, p. 6. 
hoogte te stellen zodat deze in de gelegenheid wordt gesteld commentaar te geven. ${ }^{214}$ Ook kan de commissie voor Europese Zaken, indien zij om advies is gevraagd met betrekking tot een EU-document door een andere commissie, wijzigingen aanbrengen in de aanbeveling voor een besluit van die andere commissie. ${ }^{215}$

De commissie voor Europese Zaken vormt een belangrijk onderdeel van het systeem om de federale overheid te controleren op Europese aangelegenheden. Zij heeft namelijk de nodige expertise om de activiteiten van de regering op EU-niveau effectief te volgen, iets wat andere commissies niet hebben. Daarnaast houdt zij als overkoepelende commissie toezicht op de inkomende EU-documenten en de verspreiding daarvan naar de verschillende andere commissies van de Bundestag. Zij adviseert de Bundestag over Europese aangelegenheden en kan zelfs in bepaalde gevallen de rechten van de Bundestag zelfstandig uitoefenen. Tot slot heeft de commissie een belangrijke taak in het filteren en verwerken van de grote hoeveelheid EU-documenten en -informatie die de Bundestag ontvangt. ${ }^{216}$

In de zeventiende verkiezingsperiode (2009-2013) heeft de commissie voor Europese Zaken 93 vergaderingen gehouden waarvan er negentien niet-openbaar waren en 64 (gedeeltelijk) openbaar. ${ }^{217}$ Van deze 93 vergaderingen hebben er drie in Brussel plaatsgevonden. Tijdens de zeventiende verkiezingsperiode heeft de commissie 1558 documenten behandeld die aan haar waren voorgelegd. Het werk van de commissie draaide met name om de uitdagingen van de economische en financiële crisis en de daarmee samenhangende hervormingen, de ontwikkeling van de Eurozone, de uitbreiding van de EU en het subsidiariteitsbeginsel en de betrokkenheid van de Bundestag bij Europese aangelegenheden. Daarnaast heeft de commissie de toetredingsonderhandelingen tussen de EU en Kroatië intensief begeleid. ${ }^{218}$

Men kan stellen dat de commissie voor Europese Zaken met de bevoegdheid om voor de gehele Bundestag op te treden (hoewel deze weinig wordt gebruikt) én de deelnemende parlementariërs van het Europees Parlement, de interessantste commissie van de Bundestag is.

Ook de Commissie voor Petities van het Volk heeft een bijzondere positie. Via deze vaste commissie kan het volk invloed uitoefenen op de regering. Volgens de Grondwet heeft iedereen het recht om een verzoek of klacht schriftelijk aan het parlement te richten. ${ }^{219}$ De bondspresident ontvangt de brieven van de burgers en stuurt ze door aan de Commissie

214 Par. 93a (1) Reglement van Orde van de Bundestag.

215 Par. 93b (7) Reglement van Orde van de Bundestag.

216 H.T. Nguyen, An uneven balance? A legal analysis of power asymmetries between national parliaments in the EU, The Hague: Eleven International Publishing 2018, p. 109.

217 Website archief Bundestag.

218 Website archief Bundestag.

219 Art. 17 Grondwet. 
voor Petities van het Volk. Deze commissie heeft bijzondere rechten. Zo kan zij overheidsorganen vragen naar bepaalde documenten of om toegang tot hun systemen. De commissie heeft geen bevoegdheden tot het maken van richtlijnen of beleid maar uit de praktijk blijkt dat de aanbevelingen van de commissie grote invloed hebben.

\subsubsection{Controlecommissies}

De controlecommissies zijn ook permanente commissies binnen de Bundestag maar hebben, zoals de naam al aangeeft, als hoofdtaak controle uitoefenen. Elke commissie controleert een bepaald beleidsterrein. Zo bestaat er een commissie die toeziet op douanecriminaliteit, een commissie die toeziet op georganiseerde criminaliteit en een commissie die toeziet op de naleving van de regelgeving voor wat betreft brief- en postgeheim evenals dergelijke geheimhouding binnen andere telecommunicatie. Deze controlecommissies kunnen de federale regering verzoeken informatie te verstrekken die zij nodig hebben van de overheidsdiensten. De regering is verplicht om de commissie informatie te verstrekken. Daarnaast moet zij ook toestaan dat de commissie bezoeken brengt aan de diensten en medewerkers van die diensten hoort.

\subsubsection{Onderzoekcommissies}

In tegenstelling tot de voorgaande twee categorieën commissies worden onderzoekcommissies alleen ad hoc naar aanleiding van een actuele situatie ingesteld. Dit kan worden vergeleken met het Nederlandse parlementair enquêterecht. Het instellen van een onderzoekscommissie wordt gedaan wanneer minimaal 25 procent van de leden van de Bundestag hiermee instemt. ${ }^{220}$ Het is dus een recht van de parlementaire minderheid. Het wordt doorgaans gebruikt door de oppositie binnen de Bundestag. ${ }^{221}$ Een onderzoekcommissie heeft als taak om politieke en bureaucratische misstanden binnen de regering, de Bundestag of een regeringsperiode te onderzoeken en oplossingen aan te reiken. Om onderzoek te doen naar de misstanden heeft de commissie de mogelijkheid om getuigen en deskundigen (onder ede) te horen, dossiers in te zien en hulp in te roepen van rechtbanken en andere autoriteiten. Aan het einde van het onderzoek maakt de commissie een rapport op dat besproken zal worden tijdens een debat in de Bundestag. Het onderzoek is openbaar tenzij dit uitdrukkelijk wordt uitgesloten. ${ }^{222}$

Het meeste onderzoek wordt gedaan naar onderwerpen die binnen de bevoegdheid van de federale regering liggen, waardoor onderzoekcommissies met name een middel zijn voor controle van de federale regering. ${ }^{223}$ Van de onderzoekcommissie moet de

220 Art. 44 Grondwet.

221 R. Zippelius \& T. Würtenberger, Deutsches Staatsrecht. Ein Studienbuch, München: Verlag C.H. Beck 2018, p. 407-408.

222 Art. 44 lid 1 Grondwet.

223 Website Bundestag, Gremien zur Kontrolle. 
enquêtecommissie worden onderscheiden. De laatste houdt zich bezig met complexe politieke vraagstukken. De Bundestag kan besluiten een dergelijke enquêtecommissie in te stellen ter voorbereiding op een complex besluit. De commissie doet onderzoek naar de materie en bereidt het besluit voor. Naast leden van de Bundestag kunnen ook externen, zoals wetenschappers en experts, zitting hebben. ${ }^{24}$

\subsection{Duitsland en de Europese Unie}

De Europese integratie heeft binnen de federale staat van de Bondsrepubliek Duitsland enige veranderingen teweeggebracht met betrekking tot de Duitse Grondwet. Met het Verdrag van Maastricht is artikel 24 van de Duitse Grondwet gewijzigd. Dat artikel bepaalt tegenwoordig dat soevereine rechten kunnen worden overgedragen aan internationale organisaties (lees: de Europese Unie). Duitsland erkent daarmee dat Europees recht van een hogere rangorde kan zijn dan zijn nationale recht. Toch heeft het Bundesverfassungsgericht gedurende lange tijd de rangorde van Europees recht in Duitsland van voorbehouden voorzien. Volgens het Hof van Justitie van de Europese Unie prevaleert het EU-recht boven het nationale recht en werkt het EU-recht rechtstreeks door in de lidstaten. In 1992 stemden de Bundestag en de Bundesrat in met het Verdrag van Maastricht, waarna enkele Grondwetswijzigingen zijn doorgevoerd. Naast de wijziging van artikel 24 werd ook artikel 23 opgenomen. Dit is een van de belangrijkste wijzigingen van de Grondwet met betrekking tot Europese aangelegenheden. Het oude artikel 23 was vervallen na de vereniging van Oost- en West-Duitsland door middel van het 'Einigungsvertrag. ${ }^{225}$

Niet alleen Duitsland als geheel, maar ook de Länder, die een grote rol spelen binnen het staatsrechtelijk systeem aangezien Duitsland een federale staat is, hebben te maken gehad met de Europese integratie. De Europese Unie erkent alleen lidstaten als geheel en dus niet de individuele Länder. Het gevolg hiervan is dat de Länder weinig invloed kunnen uitoefenen op Europese wetgeving terwijl Europese wetgeving vaak op het niveau van de Länder moet worden uitgevoerd. Om de Länder enigszins tegemoet te komen worden zij op bepaalde onderwerpen vertegenwoordigd in de Raad van Ministers. ${ }^{226}$ Artikel 23 sub 6 van de Grondwet bepaalt namelijk dat wanneer het gaat om de exclusieve wetgevende bevoegdheid van de Länder op het gebied van onderwijs, cultuur of omroep, de uitoefening van de rechten van de Bondsrepubliek Duitsland door de federale regering wordt overge-

224 R. Zippelius \& T. Würtenberger, Deutsches Staatsrecht. Ein Studienbuch, München: Verlag C.H. Beck 2018, p. 409.

225 Ibid., p. 25.

226 Art. 23 sub 6 Grundgesetz für die Bundesrepublik Deutschland; W. Heun, The Constitution of Germany. A contextual analysis (Constitutional Systems of the World), Oxford/Portland Oregon: Hart Publishing 2011, p. 79-81. 
dragen aan een door de Bundesrat aangewezen vertegenwoordiger van de Länder. De rechten worden dan uitgeoefend door de vertegenwoordiger met deelname van en in coördinatie met de federale regering.

Naast de verschuiving van soevereine federale bevoegdheden naar internationale organisaties is de verschuiving van bevoegdheden van de Länder naar de federale staat een prominente ontwikkeling (geweest). Voor dit verlies worden de Länder gecompenseerd door een sterke rol van de Bundesrat in het wetgevingsproces. ${ }^{227}$ De Bundesrat vertegenwoordigt de Länder en is naast de direct gekozen Bundestag medewetgever. ${ }^{228}$ In 2006 vonden grote grondwettelijke hervormingen van het federalisme plaats waarvan kan worden gezegd dat het gaat om de meest verstrekkende wijzigingen van het Duitse federale systeem sinds 1949. Het doel van de hervormingen was om bepaalde regelgevende bevoegdheden van de federale overheid weer onder te brengen bij de Länder en in ruil daarvoor de sterke rol van de Bundesrat in de wetgevingsprocedure te verminderen. Meer concreet werd het aantal goed te keuren wetten door de Bundesrat aanzienlijk verminderd; daarnaast werden de bevoegdheden van de Länder uitgebreid waardoor de Länder voortaan zelf konden beslissen over normen in zorginstellingen, uitvoering van straffen en sluitingstijden van winkels. De toelating tot en de uitgifte van diploma's van universiteiten bleven een verantwoordelijkheid van de federale regering maar de Länder kregen de mogelijkheid om van de federale regels af te wijken met eigen wetten. Hetzelfde geldt voor milieubescherming. Ook dit is een verantwoordelijkheid van de federale regering maar de Länder kunnen wederom van federale regels afwijken via eigen wetten. Tot slot is bepaald dat de Länder zelf mochten beslissen over bepaalde aangelegenheden met betrekking tot ambtenaren, zoals het loon. ${ }^{229}$ In het algemeen zagen de hervormingen dus met name op de relatie tussen de federale overheid en de Länder, waarbij de Länder enerzijds iets meer bevoegdheden hebben gekregen maar anderzijds ook bevoegdheden hebben verloren, namelijk in het wetgevingsproces.

In het tijdperk na de hervormingen kwamen de Länder erachter dat in Europa veel nieuwe wetgeving werd gemaakt waarop zij echter nauwelijks invloed konden uitoefenen. Op federaal niveau speelde Duitsland een rol in het Europese besluitvormingsproces via de Raad maar voor de Länder was op Europees niveau geen rol weggelegd. Om toch enige invloed uit te oefenen waren de Länder van mening dat de Bundesrat een rol zou moeten

227 D. Thym, 'Parliamentary Control of EU decision-making in Germany', in: O. Tans, C. Zoethout \& J. Peters (eds.), National Parliaments and European Democracy: A Bottom-up Approach to European Constitutionalism, Groningen: Europa Law Publishing 2007, p. 51.

228 A.W. Heringa, Constitutions Compared. An Introduction to Comparative Constitutional Law, Antwerpen: Intersentia 2016, p. 78-79.

229 F.W. Scharpf, Föderalismusreform. Kein Ausweg aus der Politikverflechtungsfalle?, Frankfurt/New York: Campus Verlag GmbH 2009, p. 106-110. 
krijgen in Europese aangelegenheden. Hiertoe werd in 1989 een Grondwetswijziging aangenomen en werd artikel 23 geïntroduceerd. ${ }^{230}$ Artikel 23 is de basis voor parlementaire invloed op Europese besluitvorming. Bij de totstandkoming van het Verdrag van Lissabon gaf het Bundesverfassungsgericht een oordeel over dat verdrag.

Het hof gaf in zijn 'Lissabon-Urteil' weliswaar aan dat het verdrag niet in strijd was met de Duitse Grondwet maar legde wel op dat de rechten van de Bundestag en Bundesrat met betrekking tot Europese aangelegenheden eerst moesten worden vastgelegd alvorens Duitsland het Verdrag van Lissabon mocht ratificeren. ${ }^{231}$ Hieruit zijn de volgende drie wetten voortgekomen: Gesetz über die Zusammenarbeit von Bundesregierung und Deutschem Bundestag in Angelegenheiten der Europäischen Union (EUZBBG) (Wet op de samenwerking tussen de federale regering en de Duitse Bondsdag in Europese Unie-aangelegenheden); Gesetz über die Wahrnehmung der Integrationsverantwortung des Bundestages und des Bundesrates in Angelegenheiten der Europäischen Union (IntVG) (Wet op de Verantwoordelijkheid voor de Integratie van de Bondsdag en de Bondsraad in Europese Unie-aangelegenheden); Gesetz über die Zusammenarbeit von Bund und Ländern in Angelegenheiten der Europäischen Union (EUZBLG) (Wet op de Samenwerking tussen de Federatie en de Landen in Europese Unie-aangelegenheden).

In deze wetten wordt artikel 23 van de Grondwet uitgewerkt. Dat artikel 23 wordt uitgewerkt in 'gewone' wetten heeft ermee te maken dat voor het wijzigen van een gewone wet de gewone wetgevingsprocedure gevolgd kan worden terwijl voor het wijzigen van de Grondwet een twee derde meerderheid nodig is in zowel de Bundestag als de Bundesrat. In de volgende paragrafen zal artikel 23 van de Grondwet meer in detail worden besproken evenals de wetten waarin artikel 23 is uitgewerkt.

\subsubsection{Artikel 23 Grundgesetz für die Bundesrepublik Deutschland}

Zoals al eerder aangegeven wordt in de Duitse Grondwet, in tegenstelling tot de Nederlandse Grondwet, naar de Europese Unie verwezen. Dat wordt onder andere gedaan in artikel 50 van de Grondwet, waarin staat dat de Länder via de Bundesrat een rol spelen in de aangelegenheden met betrekking tot de Europese Unie. Artikel 23 van de Grondwet is hét artikel met betrekking tot de Europese Unie. In dit artikel is opgenomen hoe de Bundesrat en de Bundestag een rol kunnen spelen in Europese aangelegenheden. Artikel 23 zal hieronder per lid worden behandeld.

230 P. Badura, Staatsrecht. Systematische Erläuterung des Grundgesetzes, München: Verlag C.H. Beck 2018, p. 64-65.

231 C. Hofmann, 'Die Lissabon-Begleitgesetze', in: M. Arbeiter, W. Bühring, H. Stihl, S. Schwab \& R. Höche, Die Zukunft aktiv gestalten II, Herbolzheim: Centaurus Verlag \& Media 2012, p. 53. 
'(1) Zur Verwirklichung eines vereinten Europas wirkt die Bundesrepublik Deutschland bei der Entwicklung der Europäischen Union mit, die demokratischen, rechtsstaatlichen, sozialen und föderativen Grundsätzen und dem Grundsatz der Subsidiarität verpflichtet ist und einen diesem Grundgesetz im wesentlichen vergleichbaren Grundrechtsschutz gewährleistet. Der Bund kann hierzu durch Gesetz mit Zustimmung des Bundesrates Hoheitsrechte übertragen. Für die Begründung der Europäischen Union sowie für Änderungen ihrer vertraglichen Grundlagen und vergleichbare Regelungen, durch die dieses Grundgesetz seinem Inhalt nach geändert oder ergänzt wird oder solche Änderungen oder Ergänzungen ermöglicht werden, gilt Artikel 79 Abs. 2 und 3.'

Dit eerste lid van artikel 23 bepaalt dat de Bondsrepubliek Duitsland zal meewerken aan de realisatie van de Europese Unie die democratisch, rechtstatelijk, sociaal zal zijn en op federale grondslagen zal rusten. Daarnaast dient de Europese Unie gebonden te zijn aan het beginsel van subsidiariteit en dient zij grondrechten te beschermen op hetzelfde niveau als in de Grondwet van Duitsland. Indien hiervan sprake is, mag Duitsland bevoegdheden overdragen aan de Europese Unie, met toestemming van de Bundesrat, indien voor die overdracht een Zustimmungsgesetze nodig is. Wanneer hiervoor de Grondwet gewijzigd dient te worden moet artikel 79 lid 2 en lid 3 in acht worden genomen, met andere woorden, dan dient de 'normale' procedure voor het wijzigen van de Grondwet te worden gevolgd.

'1a. Der Bundestag und der Bundesrat haben das Recht, wegen Verstoßes eines Gesetzgebungsakts der Europäischen Union gegen das Subsidiaritätsprinzip vor dem Gerichtshof der Europäischen Union Klage zu erheben. Der Bundestag ist hierzu auf Antrag eines Viertels seiner Mitglieder verpflichtet. Durch Gesetz, das der Zustimmung des Bundesrates bedarf, können für die Wahrnehmung der Rechte, die dem Bundestag und dem Bundesrat in den vertraglichen Grundlagen der Europäischen Union eingeräumt sind, Ausnahmen von Artikel 42 Abs. 2 Satz 1 und Artikel 52 Abs. 3 Satz 1 zugelassen werden.'

In 2008 is lid 1a toegevoegd aan artikel 23. Dit heeft te maken met de totstandkoming van het Verdrag van Lissabon. Lid la geeft de Bundestag en de Bundesrat de mogelijkheid om een klacht in te dienen bij het Hof van Justitie van de Europese Unie wanneer een wetgevingsbesluit van de Europese Unie in strijd is met het beginsel van subsidiariteit. Wanneer een kwart van de leden van de Bundestag hierom verzoekt, is de Bundestag verplicht een 
klacht in te dienen. ${ }^{232}$ Paragraaf 12 lid 2 IntVG bepaalt dat de Bundesrat in het Reglement van Orde kan bepalen hoe de Bundesrat een besluit tot het indienen van een klacht dient te nemen. In het Reglement van Orde is hierover geen specifieke bepaling opgenomen. Dat betekent dat op basis van artikel 52 lid 3 van de Grondwet een dergelijk besluit met steun van minimaal de meerderheid genomen dient te worden. Paragraaf 28 lid 1 van het Reglement van Orde voegt daar wel aan toe dat een besluit pas genomen mag worden indien de meerderheid van de stemmen vertegenwoordigd is. Artikel 8 van Protocol nr. 2 betreffende de toepassing van de beginselen van subsidiariteit en evenredigheid geeft deze bevoegdheid inzake een beroep dat wordt ingesteld door 'een lidstaat, of door een lidstaat overeenkomstig zijn rechtsorde wordt toegezonden namens zijn nationaal parlement of een Kamer van dat parlement'. ${ }^{233}$

'2. In Angelegenheiten der Europäischen Union wirken der Bundestag und durch den Bundesrat die Länder mit. Die Bundesregierung hat den Bundestag und den Bundesrat umfassend und zum frühestmöglichen Zeitpunkt zu unterrichten.'

Dat ook de Länder een rol in de Europese Unie spelen, en wel via de Bundesrat, wordt verder vermeld in artikel 50 van de Grondwet. Zowel de Bundestag als de Bundesrat wordt door de regering, en daartoe behoort ook de vertegenwoordiging van de regering in Brussel, zo vroeg mogelijk én zo uitgebreid mogelijk geïnformeerd. Deze plicht van de regering wordt verder uitgewerkt in paragraaf 13 van IntVG en paragraaf 3 lid 1 van EUZBBG. De laatste paragraaf voegt toe dat de regering de Bundestag voortdurend dient te informeren. Zodra de regering relevante (officiële en inofficiële) informatie krijgt, hoort zij dit met de Bundestag en Bundesrat te delen. ${ }^{234}$ Zoals eerder aangegeven, is, volgens het Bundesverfassungsgericht, de kern van de informatieplicht dat de Bundestag in een vroeg stadium effectief invloed kan uitoefenen op het besluitvormingsproces van de regering. Alleen wanneer de Bundestag voldoende informatie krijgt, kan hij invloed uitoefenen. Het is niet de bedoeling dat de Bundestag alleen informatie ontvangt maar er verder niets mee kan doen. Het Bundesverfassungsgericht geeft aan dat de Bundestag op basis van de informatie de voor- en nadelen moet kunnen bespreken en een eigen standpunt moet

232 L.F.M. Besselink, P.P.T. Bovend'Eert, J.L.W. Broeksteeg \& R. de Lange, Het Staatsrecht van 7 Europese landen, Deventer: Kluwer 2018, p. 72.

233 Art. 8 eerste alinea Protocol nr. 2 betreffende de toepassing van de beginselen van subsidiariteit en evenredigheid.

234 R. Zippelius \& T. Würtenberger, Deutsches Staatsrecht. Ein Studienbuch, München: Verlag C.H. Beck 2018, p. $399-400$. 
kunnen opstellen. ${ }^{235}$ Deze invloed van de Bundestag is van belang omdat Europese wetgeving bindend is voor Duitsland en voorrang kan hebben op Duits recht. ${ }^{236}$

Naast deze informatievoorziening door de regering houdt dit artikellid ook een recht in van de Bundestag en de Bundesrat. Om een rol te spelen in de EU hebben de Bundestag en Bundesrat het recht om een standpunt in te nemen ('Stellungnahme') en dit kenbaar te maken aan de regering. Dit recht kan worden ingezet bij elke Europese aangelegenheid zoals bijvoorbeeld een mededeling of groen- of witboek. Het standpunt van de Bundestag is echter niet bindend voor de regering. ${ }^{237}$

'3. Die Bundesregierung gibt dem Bundestag Gelegenheit zur Stellungnahme vor ihrer Mitwirkung an Rechtsetzungsakten der Europäischen Union. Die Bundesregierung berücksichtigt die Stellungnahme des Bundestages bei den Verhandlungen. Das Nähere regelt ein Gesetz.'

Met die informatie die de regering verplicht is te geven op grond van lid 3 kan de Bundestag een standpunt innemen over nieuwe Europese wetgeving. In tegenstelling tot het tweede lid gaat het hier alleen om Europese wetgeving (Rechtsetzungsakten). Het begrip 'Rechtsetzungakt' moet in de ruimste zin van het woord worden opgevat. Het standpunt van de Bundestag wordt door de regering in acht genomen voorafgaand aan onderhandelingen op Europees niveau, maar bindt de regering juridisch niet. Wanneer de regering echter besluit het standpunt van de Bundestag niet mee te nemen in de onderhandelingen zal zij dit moeten motiveren. Wanneer de Bundestag een Stellungnahme inneemt, dient de regering op Europees niveau een zogenoemd parlementair voorbehoud (Parlamentsvorbehalt) te plaatsen. ${ }^{238}$ Voordat er in de Raad over het wetgevingsvoorstel gestemd wordt, dient de Duitse regering eerst te onderhandelen met de Bundestag. Wanneer het echter gaat over de terreinen buitenlands beleid en integratiebeleid is de voorgaande procedure niet nodig en mag de regering afwijken van de standpunten van de Bundestag en de uiteindelijke beslissing nemen. Hierover dient de regering de Bundestag schriftelijk te informeren. ${ }^{239}$ Dit parlementair voorbehoud wordt verder uitgewerkt in paragrafen 8 en 9 EUZBBG.

Zoals eerder besproken, is, om deze bevoegdheid van de Bundestag te behartigen, op grond van artikel 45 van de Grondwet een Kamercommissie voor Europese Zaken opgericht.

235 BVerfG 19 juni 2012 - 2 BvE 4/11, r.o. 107.

236 L. Michael \& M. Morlok, Staatsorganisationsrecht, Baden-Baden: Nomos Verlagsgesellschaft 2017, p. 256257.

237 Uit correspondentie met mw. M. Swanson van de afdeling 'Referat PE 5 Europa-Dokumentation' van de Bundestag via e-mail d.d. 1 november 2018.

238 Par. 9 lid 4 EUZBBG; Deutscher Bundestag 17. Wahlperiode, Drucksache 17/14601, 30 augustus 2013, p. 26.

239 Website Bundestag, Mitwirkungsrechte. 
Deze commissie kan door de Bundestag gemachtigd worden om de bevoegdheid uit artikel 23 uit te oefenen. ${ }^{240}$ De derde zin uit dit lid - 'Das Nähere regelt ein Gesetz' - ziet op de Gesetz über die Zusammenarbeit von Bundesregierung und Deutschem Bundestag in Angelegenheiten der Europäischen Union (EUZBBG), die in een van de volgende paragrafen zal worden behandeld.

'4. Der Bundesrat ist an der Willensbildung des Bundes zu beteiligen, soweit er an einer entsprechenden innerstaatlichen Maßnahme mitzuwirken hätte oder soweit die Länder innerstaatlich zuständig wären.'

Lid 4 tot en met 6 hebben betrekking op de Bundesrat. Lid 4 bepaalt dat de regering de Bundesrat bij besluitvorming moet betrekken wanneer de besluitvorming betrekking heeft op de Länder. Er moet dan sprake zijn van een van de volgende twee situaties. Wanneer de belangen van de Länder in het geding zijn en als het gaat om een exclusieve wetgevingsbevoegdheid van de federale overheid - denk bijvoorbeeld aan onderwerpen op het gebied van milieurecht of een gedeelde bevoegdheid van de federale overheid en de Länder - dient de federale overheid het standpunt van de Bundesrat in acht te nemen als de belangen van de Lander in het geding zijn. ${ }^{241}$ Dit kan vergeleken worden met het recht van de Bundestag om zijn standpunt kenbaar te maken aan de federale regering waarbij de regering dit in acht moet nemen. Beide rechten, dus die van de Bundestag en de Bundesrat, zijn juridisch gelijk. Ze zijn beide niet juridisch af te dwingen maar wanneer de federale regering de standpunten van een van beide Kamers niet in overweging neemt, kunnen politieke consequenties volgen. ${ }^{242}$ Wanneer het gaat over een terrein waarop uitsluitend de Länder wetgeving kunnen maken, dan dient het standpunt van de Bundesrat leidend te zijn. Met andere woorden, in de laatste situatie weegt het standpunt van de Bundesrat zwaarder dan in de eerste situatie. Op grond van artikel 52 lid 3a van de Grondwet is de Bundesrat bevoegd een zogenoemde 'Europakammer' (Europakamer) in te stellen die de bevoegdheden van de Bundesrat voor wat betreft een Europese aangelegenheid kan uitoefenen. De besluiten van deze Europakammer gelden dan als besluiten van de Bundesrat. Dit wordt met name gedaan wanneer er met spoed een besluit genomen moet worden. De Europa-

240 L. Michael \& M. Morlok, Staatsorganisationsrecht, Baden-Baden: Nomos Verlagsgesellschaft 2017, p. 257.

241 D. Thym, 'Parliamentary Control of EU decision-making in Germany', in: O. Tans, C. Zoethout \& J. Peters (eds.), National Parliaments and European Democracy: A Bottom-up Approach to European Constitutionalism, Groningen: Europa Law Publishing 2007, p. 66.

242 Niet zozeer vanuit de Bundesrat omdat er geen vertrouwensregel bestaat tussen de federale regering en de Bundesrat. 
kammer kan pas een besluit nemen wanneer minimaal de meerderheid van de stemmen vertegenwoordigd is. ${ }^{243}$

'5. Soweit in einem Bereich ausschließlicher Zuständigkeiten des Bundes Interessen der Länder berührt sind oder soweit im übrigen der Bund das Recht zur Gesetzgebung hat, berücksichtigt die Bundesregierung die Stellungnahme des Bundesrates. Wenn im Schwerpunkt Gesetzgebungsbefugnisse der Länder, die Einrichtung ihrer Behörden oder ihre Verwaltungsverfahren betroffen sind, ist bei der Willensbildung des Bundes insoweit die Auffassung des Bundesrates maßgeblich zu berücksichtigen; dabei ist die gesamtstaatliche Verantwortung des Bundes zu wahren. In Angelegenheiten, die zu Ausgabenerhöhungen oder Einnahmeminderungen für den Bund führen können, ist die Zustimmung der Bundesregierung erforderlich.'

De positie van de Länder is versterkt door lid 5. Dit lid geeft aan dat wanneer de belangen van de Länder worden geraakt door een exclusieve wetgevingsbevoegdheid van de federale overheid of wanneer er sprake is van een andere wetgevende bevoegdheid van de federale overheid, de federale regering het standpunt van de Bundesrat zal meenemen in de besluitvorming, hetgeen ook in het vorige lid staat vermeld. Het vijfde lid voegt daaraan toe dat wanneer de wetgevende bevoegdheid van de Länder, de overheidsstructuur van de Länder of de bestuurlijke procedures binnen de Länder in het geding zijn, het standpunt van de Bundesrat van zeer groot belang is bij de bepaling van het standpunt van de federale overheid. Daarbij moet de federale overheid het standpunt van de Bundesrat afwegen tegen de verantwoordelijkheden van de gehele federatie. De federale regering kan alleen van het standpunt van de Bundesrat afwijken wanneer het gaat om de verantwoordelijkheid voor de federatie als geheel (die gesamtstaatliche Verantwortung des Bundes zu wahren). ${ }^{244}$ Wanneer het gaat om situaties waarbij de uitgaven van de federatie stijgen of de inkomsten afnemen, dan is weliswaar het standpunt van de Bundesrat leidend maar dient de federale regering hiermee in te stemmen. In dat geval moeten de Bundesrat en de federale regering dus samenwerken. ${ }^{245}$

243 R. Schmidt, Staatsorganisationsrecht: sowie Grundzüge des Verfassungsprozessrechts und des EU-rechts, Hannover: Druckhaus Pinkvoss GmbH 2018, p. 263.

244 D. Thym, 'Parliamentary Control of EU decision-making in Germany', in: O. Tans, C. Zoethout \& J. Peters (eds.), National Parliaments and European Democracy: A Bottom-up Approach to European Constitutionalism, Groningen: Europa Law Publishing 2007, p. 66.

245 T. Maunz \& G. Dürig, Grundgesetz Kommentar, Band IV art. 23-53a, München: Verlag C.H. Beck 2014, art. 23, Rn. 162. 
Met betrekking tot de leden 4 en 5 het volgende. De betrokkenheid van de Länder via de Bundesrat in Europese aangelegenheden is in de volgende drie fases opgebouwd. Ten eerste is er de informatieplicht van de regering om de Bundesrat op een zo vroeg mogelijk tijdstip uitputtend te informeren. De (inzet van de) bevoegdheden van de Bundesrat (hangt) hangen hier namelijk van af. Ten tweede volgt de betrokkenheid van de Bundesrat bij de besluitvorming van de federale regering. De Bundesrat wordt op grond van artikel 23 lid 4 Grondwet betrokken bij de besluitvorming en wordt daarom in de gelegenheid gesteld zijn standpunten over te brengen. Als derde dient het standpunt van de Bundesrat te worden meegenomen in de besluitvorming. Dat houdt in eerste instantie in dat ervan kennisgenomen wordt en dat erover gedebatteerd wordt. Het betekent niet dat de regering aan het standpunt gebonden is.

In geval van lid 5 tweede zin wordt het standpunt van de Bundesrat door de federale regering als leidend genomen (maßgeblich zu berücksichtigen). ${ }^{246}$ Wat maßgeblich berücksichtigen precies betekent, wordt niet in de Grondwet uitgewerkt. Paragraaf 5 tweede lid Gesetz über die Zusammenarbeit von Bund und Ländern in Angelegenheiten der Europäischen Union (EUZZBLG) kan meer duidelijkheid bieden. 'Stimmt die Auffassung der Bundesregierung nicht mit der Stellungnahme des Bundesrates überein, ist ein Einvernehmen anzustreben', met andere woorden, wanneer de standpunten van de Bundesrat en de regering niet overeenkomen, dan dient overeenstemming te worden bewerkstelligd. Wanneer deze niet wordt bereikt, dan kan de Bundesrat een nieuw standpunt innemen dan wel bij zijn standpunt blijven. Wanneer dit gebeurt met een twee derde meerderheid van de stemmen, dan geeft paragraaf 5 lid 2 vijfde zin EUZBLG aan dat het standpunt van de Bundesrat bindend is voor de federale regering. Dit geldt ook voor de besluiten inzake het buitenlands, defensie- en integratiebeleid. ${ }^{247}$

‘6. Wenn im Schwerpunkt ausschließliche Gesetzgebungsbefugnisse der Länder auf den Gebieten der schulischen Bildung, der Kultur oder des Rundfunks betroffen sind, wird die Wahrnehmung der Rechte, die der Bundesrepublik Deutschland als Mitgliedstaat der Europäischen Union zustehen, vom Bund auf einen vom Bundesrat benannten Vertreter der Länder übertragen. Die Wahrnehmung der Rechte erfolgt unter Beteiligung und in Abstimmung mit der Bundesregierung; dabei ist die gesamtstaatliche Verantwortung des Bundes zu wahren.'

246 Ch. Degenhart, Staatsrecht I. Staatsorganistionsrecht. Mit Bezügen zum Europarecht, Heidelberg: C.F. Müller GmbH 2017, p. 295.

247 Ibid., p. 296. 
Het zesde lid van artikel 23 geeft aan dat wanneer het gaat om de exclusieve wetgevende bevoegdheid van de Länder met betrekking tot 'Hausgut' (de Duitse verzamelnaam voor de onderwerpen onderwijs, cultuur, radio- en tv-uitzendingen) een vertegenwoordiger van de Länder de bevoegdheden van de bondsrepubliek als lid van de Europese Unie zal uitoefenen. Deze vertegenwoordiger wordt door de Bundesrat aangewezen en zal dan deelnemen aan de beraadslaging van de Raad van de Europese Unie. Het optreden van de vertegenwoordiger vindt plaats in overleg met en met medewerking van de federale regering om zo de belangen van de gehele staat te waarborgen. De betekenis van dit lid is beperkt aangezien de genoemde bevoegdheden niet behoren tot de exclusieve of gedeelde bevoegdheden van de Europese Unie. De EU kan de lidstaten alleen ondersteunen of aanvullen of coördinerend optreden bij de uitoefening van haar bevoegdheden in deze onderwerpen. $^{248}$

'7. Das Nähere zu den Absätzen 4 bis 6 regelt ein Gesetz, das der Zustimmung des Bundesrates bedarf.'

Nadere uitwerking van de leden 4 tot en met 6 wordt geregeld bij wet. Het gaat dan om de wetten $E U Z B L G, E U Z B B G$ en Int $V G$, die hierna worden behandeld.

\subsubsection{Gesetz über die Zusammenarbeit von Bundesregierung und Deutschem Bundestag in Angelegenheiten der Europäischen Union}

Het Gesetz über die Zusammenarbeit von Bundesregierung und Deutschem Bundestag in Angelegenheiten der Europäischen Union (EUZBBG) (Wet op de samenwerking tussen de federale regering en de Duitse Bondsdag in Europese Unie-aangelegenheden) bestond al voordat het Bundesverfassungsgericht het Lissabon-Urteil gaf. De oorspronkelijke EUZBBG stamt uit 1993 en regelde de rol van de Bundestag in Europese aangelegenheden via een overeenkomst tussen de Bundestag en de federale overheid. Het Bundesverfassungsgericht gaf echter in zijn Lissabon-Urteil aan dat de inhoud van de EUZBBG niet concreet en duidelijk genoeg was. Een en ander moest dus gewijzigd worden. ${ }^{249}$ De huidige wet werkt de plicht van de federale regering uit artikel 23 lid 2 tweede volzin van de Grondwet om de Bundestag te informeren met betrekking tot Europese aangelegenheden verder uit. Daarnaast wordt het derde lid van artikel 23 van de Grondwet, het recht van de Bundestag om een standpunt in te nemen voor wat betreft Europese aangelegenheden, geconcretiseerd.

248 Art. 6 VWEU.

249 C. Hofmann, 'Die Lissabon-Begleitgesetze', in: M. Arbeiter, W. Bühring, H. Stihl, S. Schwab \& R. Höche, Die Zukunft aktiv gestalten II, Herbolzheim: Centaurus Verlag \& Media 2012, p. 70. 
Ook geeft de wet een weergave van de documenten die de federale regering aan de Bundestag moet sturen. ${ }^{250}$

Zoals eerder in paragraaf 4.4.2.1 is aangegeven, is de Bundestag verplicht bepaalde Kamercommissies in te stellen. De Kamercommissie voor aangelegenheden van de Europese Unie is er hier een van. Paragraaf 2 EUZBBG geeft dit aan en regelt daarbij dat de Kamercommissie door de Bundestag gemandateerd kan worden een standpunt in te nemen voor de Bundestag. Ook de andere bevoegdheden die de Bundestag toekomen met betrekking tot de Europese Unie kunnen aan de commissie gemandateerd worden.

Op grond van Paragraaf 3 EUZBBG is de federale regering verplicht de Bundestag uitgebreid, zo vroeg mogelijk, continu en het liefst schriftelijk te informeren over Europese aangelegenheden. Het gaat dan met name om wetgevingsvoorstellen voor richtlijnen en verordeningen. Dit wordt in beginsel schriftelijk gedaan door de relevante (Europese) documenten en de eventuele eigen rapporten aan de Bundestag te zenden. Indien nodig wordt de Bundestag ook mondeling geïnformeerd waarbij deze mondelinge informatievoorziening met name supplementair en verhelderend van aard moet zijn. Uiteindelijk is het doel dat de Bundestag in debat gaat over de ontvangen informatie. Gezien de bewoordingen van de paragraaf heeft de federale regering de plicht om de Bundestag te informeren en mag zij geen informatie achterhouden, ook niet de (Raads)documenten over politiële en justitiële samenwerking binnen de Europese Unie. Het gaat met name om de documenten die gewisseld en opgesteld worden in het wetgevingsproces, de discussies binnen de organen van de Europese Unie, het standpunt van het Europees Parlement, de Europese Commissie, de andere lidstaten van de EU en tot slot de besluiten die in en tussen de organen zijn genomen. Hetzelfde geldt voor de documenten van de organen die voorbereidend werk verrichten en de documenten van werkgroepen. ${ }^{251}$

Paragrafen 4 tot en met 7 EUZBBG geven een uitgebreider overzicht van de documenten en rapportages die de federale overheid aan de Bundestag dient te sturen. Naast deze algemene regel over alle documenten met betrekking tot Europese aangelegenheden bestaat ook het reeds genoemde artikel 23 van de Grondwet dat ziet op de documenten binnen het Europese wetgevingsproces. In paragraaf 5 EUZBBG staat de verplichting voor de federale regering om gedetailleerdere informatie over het onderhandelingsproces binnen de Raad en de onderhandelingen tussen de EU-organen aan de Bundestag te geven. Wanneer de federale regering (wetgevings)documenten aan de Bundestag stuurt, is zij verplicht binnen vijf dagen na het toezenden van de documenten een samenvatting van de inhoud en het doel van het voorstel, de toepasselijke wetgevingsprocedure en de datum waarop het voorstel in de Raad zal worden behandeld, aan de Bundestag te sturen. Daar hoort ook bij dat de federale regering de Bundestag informeert over haar eigen standpunt,

250 Par. 4 EUZBBG.

251 Par. 3 lid 2 EUZBBG. 
haar positie in de onderhandelingen, de consequenties van het voorstel voor Duitsland, of het voorstel in overeenstemming is met het subsidiariteitsbeginsel en alle andere relevante informatie. Ook een overzicht van de standpunten van andere lidstaten wordt met de Bundestag gedeeld. Het doel van deze informatieplicht ligt in de betrokkenheid van het parlement bij Europese besluitvorming. Wanneer de Bundestag tijdig wordt geïnformeerd, dat wil zeggen, zodra een nieuw commissievoorstel wordt gepubliceerd of zolang de onderhandelingen nog gaande zijn, kan de Bundestag nog invloed uitoefenen op het voorstel. Daarbij is het noodzakelijk dat de Bundestag alle informatie krijgt, dus niet alleen het commissievoorstel maar ook alle informatie over de onderhandelingen en informatie die tijdens de onderhandelingen wordt gebruikt.

Op grond van artikel 23 lid 3 Grondwet en paragraaf 9 EUZBBG heeft de Bundestag het recht om zijn standpunt over wetgevingsvoorstellen aan de regering duidelijk te maken, de zogenoemde 'Stellungnahme', en de regering heeft de (grondwettelijke) plicht om dit standpunt in de onderhandelingen op Europees niveau mee te nemen. Wat opvalt, is dat in het grondwettelijk artikel alleen gesproken wordt over de Bundestag en niet over de Bundesrat. Deze laatste heeft dit recht dus niet. De federale regering is verplicht om het standpunt van de Bundestag mee te nemen in de onderhandelingen op Europees niveau maar dit betekent niet dat de Bundestag de federale regering kan mandateren.

Er bestaat geen juridische basis op grond waarvan de Bundestag de federale regering kan dwingen tot het nemen van bepaalde beslissingen of het uitbrengen van bepaalde stemmen. Juridisch gezien bepaalt de federale regering het Duitse standpunt. Politieke gevolgen bestaan wel. Het is aan te raden dat de federale regering het standpunt van de meerderheid van de Bundestag volgt. Informatie wordt doorgaans door de federale regering aan de Bundestag verstrekt, maar via de regering heeft de Bundestag ook toegang tot databanken van de Europese Unie. De Bundestag kan op deze manier zelf informatie uit de systemen halen. ${ }^{252}$ Om zo dicht mogelijk bij de bron te zitten kan de Bundestag via vertegenwoordigers contact leggen en houden met de instellingen van de Europese Unie. ${ }^{253}$

De Bundesrat wordt doorgaans niet zo gedetailleerd geïnformeerd als de Bundestag; dit wordt gecompenseerd door zijn betrokkenheid in het nationale wetgevingsproces. ${ }^{254}$ Het is dus ook niet voor niets dat er een speciale wet is om de relatie tussen de federale regering en de Bundestag te regelen waarbij de Bundesrat niet wordt genoemd. Indien de Bundestag of zijn commissies meer informatie wenst van de federale regering kan dit verlangd worden op grond van de gewone controlebevoegdheden. Bovenstaande documenten worden in de Bundestag ontvangen in de secretariaten van de verschillende Kamer-

252 Par. 10 EUZBBG.

253 Par. 11 EUZBBG.

254 D. Thym, 'Parliamentary Control of EU decision-making in Germany', in: O. Tans, C. Zoethout \& J. Peters (eds.), National Parliaments and European Democracy: A Bottom-up Approach to European Constitutionalism, Groningen: Europa Law Publishing 2007, p. 54-55. 
commissies. Door de hoeveelheid aan nieuwe commissievoorstellen kan niet elk voorstel grondig, tot in detail, worden bestudeerd. In de praktijk betekent dit dat het merendeel van de commissievoorstellen als hamerstuk wordt afgedaan. ${ }^{255}$

\subsubsection{Gesetz über die Wahrnehmung der Integrationsverantwortung des Bundestages und des Bundesrates in Angelegenheiten der Europäischen Union}

De Wet op de verantwoordelijkheid voor de integratie van de Bondsdag en de Bondsraad in Europese Unie-aangelegenheden ( $\mathrm{IntVG}$ ) is een uitbreiding en versterking van de rechten van de Bundestag en Bundesrat voor wat betreft Europese aangelegenheden. Deze wet is opgesteld naar aanleiding van het Lissabon-Urteil en werkt, net zoals de voorgaande wet, de deelname van de Bundestag en de Bundesrat in Europese aangelegenheden uit.

Deze dertien paragrafen tellende wet geeft in de eerste paragraaf aan dat de Bundestag en de Bundesrat hun bevoegdheden correct zullen uitoefenen en hun verantwoording in het Europese integratieproces moeten nemen. Dit houdt in dat de Bundestag en de Bundesrat, als democratisch gelegitimeerde organen, het Europese integratieproces continu in de gaten moeten houden en begeleiden om te voorkomen dat de verdragen van de Europese Unie worden gewijzigd zonder inmenging van nationale parlementen. ${ }^{256}$ In artikel 48 VEU wordt geregeld hoe verdragen kunnen worden herzien. De tweede alinea van het vierde lid geeft aan dat een wijziging pas kan intreden wanneer deze door alle lidstaten volgens hun grondwettelijke bepalingen bekrachtigd is. Het zesde lid van dit artikel geeft de mogelijkheid tot een vereenvoudigde wijzigingsprocedure voor wat betreft de bepalingen van het derde deel van het Verdrag betreffende de werking van de Europese Unie (VWEU) over het intern beleid en optreden van de Unie. Het verschil met de gewone wijzigingsprocedure is dat bij de eenvoudige procedure slechts een besluit van de Europese Raad nodig is in plaats van een Conferentie van vertegenwoordigers van de regeringen van de lidstaten. Het besluit van de Europese Raad treedt pas in werking wanneer alle lidstaten toestemming hebben gegeven op de manier waarop hun Grondwet het voorschrijft.

De tweede paragraaf van IntVG schrijft voor dat de vertegenwoordiger van de federatie Duitsland pas in de Europese Raad mag instemmen met de wijziging wanneer de Bundestag en Bundesrat hiermee ingestemd hebben. Dit wordt gedaan via een wet in de zin van artikel 23 lid 1 van de Grondwet. ${ }^{257}$ Van geval tot geval wordt gekeken of de Bundestag en Bundesrat kunnen instemmen, met andere woorden, er bestaat geen wet die een algemene toestemming geeft voor meerdere wijzigingen. Het voorgaande geldt ook indien sprake is

255 Ibid., p. 56.

256 Par. 1 IntVG.

257 Par. 2 IntVG. 
van een wijziging van artikel 218 lid 8 VWEU (toetreding van de Unie tot het Europees Verdrag tot bescherming van de rechten van de mens en de fundamentele vrijheden), artikel 311 VWEU (het stelsel van eigen middelen van de Unie), artikel 25 VWEU (ontwikkeling van de Unie), artikel 223 VWEU (verkiezingen Europees Parlement), artikel 262 VWEU (geschillen met betrekking tot Europese intellectuele-eigendomsrechten). Voor wat betreft een besluit volgens artikel $42 \mathrm{VEU}$ (gemeenschappelijke defensie) geeft het derde lid van paragraaf 3 IntVG een strengere procedure die bestaat uit twee stappen. Ten eerste mag de vertegenwoordiger van Duitsland in de Europese Raad alleen de besluitvorming steunen wanneer de Bundestag hiervoor toestemming heeft gegeven. Om deze beslissing te krijgen kan de federale regering een motie indienen in de Bundestag. Wanneer de Bundestag geen beslissing neemt, moet de vertegenwoordiger van de federale regering tegen het voorstel stemmen in de Europese Raad. Wanneer dan een besluit tot stand komt, dienen de Bundestag en Bundesrat toestemming te geven via een wet als genoemd in artikel 23 lid 1 Grondwet.

Op grond van artikel 48 lid 7 VEU is het mogelijk dat wanneer het VEU of het VWEU voorschrijft dat de Raad met eenparigheid van stemmen moet besluiten, de Europese Raad bij besluit zal bepalen dat de Raad in bepaalde gevallen ook met gekwalificeerde meerderheid kan besluiten. ${ }^{258}$ Dit is de zogenoemde passerelleprocedure. Hetzelfde geldt wanneer het VWEU voorschrijft dat voor bepaalde onderwerpen een bijzondere wetgevingsprocedure gevolgd moet worden. In dat geval kan wederom door de Europese Raad, op voorstel van de Commissie, worden bepaald dat de gewone wetgevingsprocedure gevolgd mag worden. Dit betekent dat de invloed van de lidstaat wordt verkleind. In het eerste geval raakt de lidstaat zijn vetorecht kwijt. De vertegenwoordiger van Duitsland in de Europese Raad mag alleen aan de besluitvorming deelnemen wanneer de Bundestag en Bundesrat via een wet als genoemd in artikel 23 lid 1 van de Grondwet toestemming hebben gegeven. Wanneer de Europese Raad voornemens is een besluit te nemen om de stemming te wijzigen wordt het initiatief daartoe aan de parlementen van de lidstaten gezonden. Zij kunnen hiertegen binnen zes weken bezwaar maken. Gebeurt dit, dan wordt het besluit niet vastgesteld. De nationale parlementen hebben dus een veto. Een enkel parlement kan voorkomen dat de Europese Raad een dergelijk besluit neemt. ${ }^{259}$ Maakt geen enkele lidstaat binnen zes weken bezwaar dan kan de Europese Raad het besluit vaststellen. ${ }^{260}$ Voor wat betreft het vetorecht geeft paragraaf 10 IntVG een uitwerking. Indien het om een voorstel gaat op het gebied waarop de federale overheid exclusieve wetgevingsbevoegdheid bezit, dan is alleen de Bundestag bevoegd om het initiatief van de Europese Raad af te wijzen. In alle andere

258 Par. 4 IntVG.

259 C. Hofmann, 'Die Lissabon-Begleitgesetze', in: M. Arbeiter, W. Bühring, H. Stihl, S. Schwab \& R. Höche, Die Zukunft aktiv gestalten II, Herbolzheim: Centaurus Verlag \& Media 2012, p. 62.

260 Art. 48 lid 7 derde alinea VEU. 
zaken is zowel de Bundestag als de Bundesrat hiertoe bevoegd. De vertegenwoordiger van Duitsland in de Europese Raad kan pas instemmen nadat hierover op nationaal niveau een wet in de zin van artikel 23 lid 1 Grondwet is vastgesteld. Indien er geen wet tot stand komt, dient de vertegenwoordiger in de Europese Raad tegen het besluit te stemmen. ${ }^{261}$

Indien de Europese Raad op grond van artikel 31 lid 3 derde alinea VEU (het gemeenschappelijk veiligheids- en defensiebeleid) ${ }^{262}$ en artikel 312 lid 2 tweede alinea VWEU (meerjarig financieel kader) ${ }^{263}$ wil besluiten dat de Raad een andere stemverhouding kan aannemen, dient hiervoor geen toestemmingswet in de zin van artikel 23 lid 1 Grondwet te worden gemaakt maar dient de Bundestag hiertoe een besluit te nemen. Naast een besluit van de Bundestag is ook een (corresponderend) besluit van de Bundesrat nodig wanneer het gaat om onderwerpen waarop de federale overheid geen wetgevende bevoegdheid heeft, wanneer de Länder (gedeelde) wetgevingsbevoegdheid bezitten op grond van artikel 72 lid 2 of 3 of artikel 84 van de Grondwet of wanneer het federale wetgevingsvoorstel instemming van de Bundesrat behoeft. ${ }^{264}$ Dat had ook via een toestemmingswet gekund maar het Bundesverfassungsgericht vindt in dit geval een wet overbodig. ${ }^{265}$ Het voorgaande geldt eveneens voor besluiten van de Raad betreffende artikel 153 lid 2 vierde alinea VWEU (de bescherming van werknemers bij beëindiging van de arbeidsovereenkomst, vertegenwoordiging en collectief onderhoud van werknemers en werkgeversbelangen, arbeidsvoorwaarden van onderdanen van derde landen), ${ }^{266}$ artikel 192 lid 2 tweede alinea VWEU (maatregelen voor het milieu), ${ }^{267}$ artikel 333 lid 1 en 2 VWEU (regels voor een nauwere samenwerking). ${ }^{268}$

Het Werkingsverdrag geeft de Europese Unie in bepaalde artikelen de mogelijkheid om haar bevoegdheden zelfstandig uit te breiden. Zo bevat artikel 83 lid 1 derde alinea VWEU de zin 'Afhankelijk van de ontwikkelingen in de criminaliteit kan de Raad bij besluit vaststellen, welke andere vormen van criminaliteit aan de in dit lid genoemde criteria voldoen'. Op het gebied van criminaliteit heeft de EU dus de mogelijkheid om haar bevoegdheden uit te breiden. Er zijn echter wel enkele beperkingen. De andere vormen van criminaliteit staan in de tweede alinea van artikel 83 lid 1 VWEU. Voordat de vertegenwoordiger van Duitsland in de Raad mag instemmen met het voorgenomen besluit dient op grond van paragraaf 7 IntVG een wet als genoemd in artikel 23 lid 1 van de Grondwet in werking te zijn getreden. Hetzelfde geldt voor een besluit als genoemd in

261 Par. 4 IntVG.

262 Par. 5 lid 1 IntVG.

263 Par. 5 lid 1 IntVG.

264 Par. 5 lid 2 IntVG.

265 C. Hofmann, 'Die Lissabon-Begleitgesetze', in: M. Arbeiter, W. Bühring, H. Stihl, S. Schwab \& R. Höche, Die Zukunft aktiv gestalten II, Herbolzheim: Centaurus Verlag \& Media 2012, p. 61.

266 Par. 6 lid 1 IntVG.

267 Par. 6 lid 1 IntVG.

268 Par. 6 lid 1 IntVG. 
artikel 86 lid 4 VWEU op grond waarvan de EU de bevoegdheden met betrekking tot het Openbaar Europees Ministerie kan uitbreiden en artikel 308 derde alinea VWEU over de wijziging van de statuten van de Europese Investeringsbank. ${ }^{269}$

Alle voorgaande mogelijkheden van de Raad, de Europese Raad en de invloed van het Duitse parlement worden ook wel 'zondagswetten' genoemd omdat er in de praktijk weinig gebruik wordt gemaakt van deze bevoegdheden en de invloed ervan gering is. ${ }^{270}$ Het in paragraaf 8 IntVG genoemde artikel $352 \mathrm{VWEU}$ is echter anders. Op basis van dit artikel heeft de Europese Unie de mogelijkheid om een bevoegdheid voor zichzelf te creëren zonder dat de Verdragen in deze bevoegdheid voorzien. 'Indien een optreden van de Unie in het kader van de beleidsgebieden van de Verdragen nodig blijkt om een van de doelstellingen van de Verdragen te verwezenlijken (...)'. Volgens het Bundesverfassungsgericht schuurt dit met het beginsel van bevoegdheidstoedeling. Volgens het hof mag artikel 352 VWEU in geen geval een blanco machtiging of Kompetenz-Kompetenz-bevoegdheid inhouden. Om dit te voorkomen mag de vertegenwoordiger van Duitsland in de Raad pas instemmen met een besluit inzake artikel $352 \mathrm{VWEU}$ indien een wet als bedoeld in artikel 23 lid 1 van de Grondwet van kracht is. ${ }^{271}$

Verder schrijft de IntVG voor dat bij maatregelen op het gebied van de sociale zekerheid die noodzakelijk zijn voor de totstandkoming van het vrije verkeer van werknemers (art. 48 lid 2 eerste zin VWEU) of wanneer (concept)richtlijnen volgens een lid van de Raad afbreuk doen aan de fundamentele aspecten van het strafrechtstelsel (art. 82 lid 3 eerste alinea VWEU) of wanneer een richtlijn als bedoeld in artikel 83 lid 1 of 2 VWEU afbreuk zou doen aan fundamentele aspecten van zijn strafrechtstelsel (art. 83 lid 3 eerste alinea, eerste zin VWEU), de vertegenwoordiger van de federale regering een motie dient in te dienen in de Raad, indien de Bundestag hiertoe de beslissing heeft genomen dat de aangelegenheid naar de Europese Raad verwezen moet worden. ${ }^{272}$

Aan het einde geeft de IntVG aan dat uitwerkingen omtrent de subsidiariteitstoets en de met redenen omklede adviezen in de zin van paragraaf 6 van het Protocol betreffende de toepassing van de beginselen van subsidiariteit en evenredigheid (mogen) worden opgenomen in de Reglementen van de Bundestag en Bundesrat. ${ }^{273}$ De laatste paragraaf van de wet vormt een opsomming van de aangelegenheden waarin de federale overheid de Bundestag en de Bundesrat dient te informeren. ${ }^{274}$

269 Par. 7 lid 2 IntVG.

270 C. Hofmann, 'Die Lissabon-Begleitgesetze', in: M. Arbeiter, W. Bühring, H. Stihl, S. Schwab \& R. Höche, Die Zukunft aktiv gestalten II, Herbolzheim: Centaurus Verlag \& Media 2012, p. 63.

271 Par. 8 IntVG.

272 Par. 9 IntVG.

273 Par. 11 en 12 IntVG.

274 Par. 13 IntVG. 
De kern van deze wet is dat zij de instemming van de Bundestag en/of Bundesrat regelt wanneer op Europees niveau een besluit door de Raad of de Europese Raad wordt genomen met betrekking tot de verschuiving van bevoegdheden zonder een verdragswijziging met een andere stemverhouding dan in beginsel is voorgeschreven. ${ }^{275}$ Het is met name de Bundestag die de bevoegdheden in de IntVG bezit. Een enkele keer is de instemming van ook de Bundesrat vereist. De verhouding tussen de IntVG, de EUZBBG en de hierna te bespreken EUZBLG is dat de IntVG speciale gevallen uitwerkt. Daarmee is de IntVG een zogenoemde lex specialis. Een duidelijke scheiding tussen de drie wetten is echter niet mogelijk omdat ze met elkaar verbonden zijn. ${ }^{276}$

\subsubsection{Gesetz über die Zusammenarbeit von Bund und Ländern in Angelegenheiten der Europäischen Union}

Deze Wet op de samenwerking tussen de Federatie en de Landen in Europese Unie-aangelegenheden (EUZBLG) is een verdere uitwerking van artikel 23 lid 2 van de Grondwet. Hierin wordt aangegeven dat de Länder via de Bundesrat een rol spelen in Europese aangelegenheden. Leden vier tot en met zes van artikel 23 geven concreter aan wat de rol van de Bundesrat is. Het zevende lid bepaalt dat leden vier tot en met zes worden uitgewerkt in een wet: de EUZBLG. De twee hierboven besproken wetten, EUZBBG en IntVG, komen voort uit het Lissabon-Urteil van het Bundesverfassungsgericht dat de wetgever heeft opgedragen deze wetten te maken. De EUZBLG was geen opdracht van het Bundesverfassungsgericht maar de wetgever vond het noodzakelijk om de rol van de Länder in Europese aangelegenheden vast te leggen, gezien de gevoeligheid van dit onderwerp. ${ }^{277}$ Dat is te herkennen aan het feit dat de EUZBLG artikel 23 Grondwet eerder herhaalt dan dat ze dit artikel uitwerkt. Door enkele uitwerkingen die de EUZBLG bevat, is het echter geen overbodige wet. ${ }^{278}$

In de eerste paragraaf van de EUZBLG wordt herhaald dat de Länder via de Bundesrat een rol spelen in Europese aangelegenheden. De regering hoort hen zo vroeg en volledig mogelijk te informeren over Europese aangelegenheden die de belangen van de Länder raken. ${ }^{279}$ Hiervan is sprake wanneer het gaat om een onderwerp waarin de Länder op

275 J. Müller Gómez \& W. Wessels, Die deutsche Verwaltung und die Europäische Union. Deutsche Beamte im EU-Mehrebenensystem. Bundesakademie für öffentliche Verwaltung im Bundesministerium des Innern, Brühl 2016, p. 237.

276 C. Hofmann, 'Die Lissabon-Begleitgesetze', in: M. Arbeiter, W. Bühring, H. Stihl, S. Schwab \& R. Höche, Die Zukunft aktiv gestalten II, Herbolzheim: Centaurus Verlag \& Media 2012, p. 71.

277 Ibid., p. 74.

278 Ibid., p. 76.

279 Par. 2 EUZBLG. 
nationaal niveau een rol spelen. Het gaat hier om een ruim begrip. ${ }^{280}$ Indien de belangen van de Länder worden geraakt dient de federale regering de Bundesrat de tijd te geven om te reageren alvorens de federale regering haar onderhandelingspositie inneemt op Europees niveau. ${ }^{281}$ Het vijfde lid van paragraaf 23 van de Grondwet geeft aan dat de belangen van de Länder worden geraakt wanneer het gaat om de exclusieve wetgevingsbevoegdheid van de Länder, de overheidsstructuur van de Länder of de bestuurlijke procedures binnen de Länder. Daarnaast zal in deze gevallen een vertegenwoordiger van de Länder deelnemen aan de beraadslagingen van de federale regering om invloed uit te oefenen op de onderhandelingspositie van de regering. Over de invulling van de onderhandelingspositie dienen beide partijen het eens te zijn. ${ }^{282}$ Artikel 23 lid 5 van de Grondwet geef aan dat de federale regering rekening dient te houden met het standpunt van de Länder. Paragraaf 5 EUZBLG geeft aan in hoeverre de federale regering dit dient te doen. Zoals eerder beschreven dienen twee situaties onderscheiden te worden. In de eerste situatie heeft de federale overheid een exclusieve wetgevingsbevoegdheid of is er sprake van een gedeelde wetgevingsbevoegdheid tussen de Länder en de federale overheid. In dit geval dient de federale overheid het standpunt van de Länder in acht te nemen maar is zij niet verplicht dit over te nemen. De federale regering heeft het laatste woord. Dit is anders wanneer de Länder exclusieve wetgevende bevoegdheid bezitten. Dan heeft de Bundesrat het laatste woord. De federale regering dient dan het standpunt over te nemen. De zesde paragraaf van EUZBLG bepaalt dat wanneer het gaat om onderwijs, cultuur of radio- of tv-uitzendingen een vertegenwoordiger van de Länder de bevoegdheden van de bondsrepubliek op Europees niveau zal uitoefenen. In alle andere gevallen waarin de Länder een exclusieve wetgevende bevoegdheid hebben, kan de vertegenwoordiger van de Länder in samenspraak met de vertegenwoordiger van de federale overheid, uitspraken doen. De onderhandelingen zullen in dat geval worden gedaan door een vertegenwoordiger van de federale regering. Paragraaf zeven EUZBLG verplicht de federale regering een klachtprocedure zoals genoemd in het Verdrag van de Europese Unie te starten bij het Hof van Justitie van de Europese Unie wanneer de Bundesrat hierom verzoekt wanneer de Länder door een handelen of nalaten van organen van de Europese Unie worden getroffen in hun wetgevingsbevoegdheden.

Er zijn wel enkele Stellungnahmen op grond van de EUZBLG te vinden. Zo nam de Bundesrat in 2011 een Stellungnahme aan ten aanzien van een groenboek van de Commissie betreffende de onlinedistributie van audiovisuele werken in de EU: mogelijkheden en uit-

280 C. Hofmann, 'Die Lissabon-Begleitgesetze,' in: M. Arbeiter, W. Bühring, H. Stihl, S. Schwab \& R. Höche, Die Zukunft aktiv gestalten II, Herbolzheim: Centaurus Verlag \& Media 2012, p. 75.

281 Par. 3 EUZBLG.

282 Par. 4 EUZBLG. 
dagingen voor een digitale eengemaakte markt. ${ }^{283}$ Het groenboek werd binnen de Bundesrat behandeld door vier Kamercommissies: de commissie Juridische zaken, de commissie Europese Unie, de commissie Cultuur en media en de commissie Economische en technologische zaken. Deze Kamercommissies hebben gezamenlijk - met uitzondering van de commissie Economische en technologische zaken - geadviseerd om ten aanzien van dit groenboek een Stellungnahme te nemen en zij hebben daarbij ook de daadwerkelijke Stellungnahme opgesteld. ${ }^{284}$ Hierover werd plenair gestemd en uiteindelijk werd daartoe besloten. ${ }^{285}$ Andere voorbeelden zijn Stellungnahmen ten aanzien van het voorstel voor een richtlijn betreffende verspreiding van gegevens van aardobservatiesatellieten voor commerciële doeleinden of de mededeling van de Commissie 'Naar een integrale aanpak voor cultureel erfgoed in Europa'. ${ }^{286}$

Zoals in het overzicht in de volgende paragraaf te zien is, neemt de Bundesrat gemiddeld 184 Stellungnahmen per jaar. Het merendeel is op basis van de EUZBLG. Zoals hierboven beschreven vinden er nauwelijks Stellungnahmen plaats op grond van IntVG. Deze wet regelt de bijzondere gevallen, die niet vaak voorkomen. Met een gemiddelde van bijna 184 Stellungnahmen op grond van de EUZBLG per jaar, worden tijdens elke vergadering van de Bundesrat een of meer Stellungnahmen vastgesteld en vormt dit een vast onderdeel van de agenda.

\subsubsection{Stellungnahme}

Wanneer de Bundesrat een nieuw Europees wetgevingsvoorstel heeft getoetst op subsidiariteit en/of proportionaliteit kan hij beslissen om de plenair vastgestelde uitkomst hiervan aan de regering en de Europese Commissie te sturen. De Bundesrat stuurt deze besluiten dan op grond van de EUZBLG. Besluiten worden niet op basis van artikel 23 Grondwet gestuurd maar alleen op basis van de verschillende artikelen in de EUZBLG. Deze Stellungnahmen kunnen en worden naast de voorgaande bevoegdheden ingezet. Het kan dus zijn dat de Bundestag of Bundesrat een met redenen omkleed advies aan de Europese Commissie stuurt en tegelijkertijd een Stellungnahme inneemt die door de Duitse regering in acht dient te worden genomen. Het is waarschijnlijk dat een onderwerp eerst in een

283 Bundesrat Plenarprotokoll 889. Sitzung, 4 november 2011; Groenboek betreffende de onlinedistributie van audiovisuele werken in de Europese Unie: mogelijkheden en uitdagingen voor een digitale eengemaakte markt, $\operatorname{COM}(2011) 427$.

284 Bundesrat, Drucksache 413/1/11, 24 oktober 2011.

285 Bundesrat Plenarprotokoll 889. Sitzung, 4 november 2011, p. 515-516.

286 Voorstel voor een Richtlijn betreffende de verspreiding van gegevens van aardobservatiesatellieten voor commerciële doeleinden, $\mathrm{COM}(2014) 344$; Mededeling 'Naar een geïntegreerde aanpak van cultureel erfgoed voor Europa', $\operatorname{COM}(2014) 477$. 
debat wordt besproken of dat er schriftelijke dan wel mondelinge vragen over gesteld worden alvorens de Bundestag of Bundesrat een Stellungnahme inneemt. Dit ligt natuurlijk voor de hand aangezien het parlement eerst van alle informatie dient te zijn voorzien voordat het een standpunt kan innemen. Stellungnahmen zijn wellicht de meest dwingende mogelijkheden om invloed uit te oefenen op Europese angelegenheden. Wanneer de Bundestag of Bundesrat een Stellungnahme aanneemt, kan de regering dit niet negeren. De regering zal dit standpunt van de Bundestag of Bundesrat in overweging moeten nemen en meenemen in de beslissing of onderhandeling. Doet zij dit niet dan zal zij met gegronde redenen moeten uitleggen waarom zij dit niet doet. De regering komt dan met een zogenoemde 'Gegenäußerung' (strikt vertaald: tegenuitdrukking) met daarin argumenten tegen de Stellungnahme. ${ }^{287}$

In de praktijk ziet een dergelijke Stellungnahme er als volgt uit. Een voorbeeld is het voorstel voor een richtlijn betreffende het gebruik van persoonsgegevens van passagiers voor het voorkomen, opsporen, onderzoeken en vervolgen van terroristische misdrijven en zware criminaliteit. ${ }^{288}$ Nadat de Commissie dit voorstel had gepubliceerd heeft de Duitse regering de Bundestag en Bundesrat, op basis van artikel 23 van de Grondwet en specifiek artikel 3 EUZBBG (Bundestag) en artikel 2 EUZBLG (Bundesrat), hierover geïnformeerd. Dit werd schriftelijk gedaan door het verstrekken van de documenten van de Commissie en de eventuele documenten met daarin het standpunt van de regering verwoord. De documenten werden begeleid door een brief waarin is opgenomen wat het doel en de essentie is van de nieuwe wetgeving, de datum waarop de Duitstalige versie van het document is verschenen, de rechtsgrondslag, de toepasselijke wetgevingsprocedure en welk ministerie de leiding heeft over de behandeling van het voorstel. Deze brief is te vergelijken met het Nederlandse BNC-fiche. Het voorstel is daarnaast ook door de Commissie aan het Duitse parlement gezonden. Binnen de Bundestag en de Bundesrat worden Europese voorstellen behandeld door verschillende Kamercommissies. Binnen de Bundestag is het voorstel doorgeleid naar de Kamercommissies Binnenlandse zaken, Europese Unie, Toerisme, Vervoer, bouw en stedelijke zaken, Buitenlandse zaken en Juridische zaken. ${ }^{289}$ Binnen de Bundesrat waren dit de Kamercommissies voor Vragen over de Europese Unie, Financiën, Binnenlandse zaken, Juridische zaken en Vervoer. ${ }^{290}$ De Bundesrat heeft bij zijn behandeling de standpunten van enkele belangenvertegenwoordigers, zoals de Europese

287 Zie bijvoorbeeld Drucksache 19/22783 (Bundestag), voor de Stellungnahme van de Bundesrat en de Gegenäußerung van de regering op een wet over versterking van de veiligheid van paspoorten en identiteitsdocumenten.

288 Voorstel voor een Richtlijn betreffende het gebruik van persoonsgegevens van passagiers voor het voorkomen, opsporen, onderzoeken en vervolgen van terroristische misdrijven en zware criminaliteit, COM(2011)32.

289 Deutscher Bundestag 17. Wahlperiode, Drucksache 17/4927, 25 februari 2011, p. 2.

290 Bundesrat, Unterrichtung durch die Europäische Kommission, Drucksache 73/11, 3 februari 2011. 
privacytoezichthouder, in acht genomen. ${ }^{291}$ Dat is niet vreemd aangezien de Commissie het wetgevingsvoorstel ook aan de Europese privacytoezichthouder had gezonden. ${ }^{292}$

Aangezien het gaat om een wetgevingsvoorstel hebben de Bundestag en Bundesrat op grond van artikel 23 lid 3 van de Grondwet het recht om een standpunt in te nemen. De Bundestag heeft dit op grond van artikel 23 lid 3 van de Grondwet juncto artikel 9 lid 4 EUZBBG gedaan. ${ }^{293}$ In casu kwam het initiatief van de Kamercommissies maar in het algemeen kan dit ook afkomstig zijn van fracties. ${ }^{294}$ In de Stellungnahme, die is opgesteld door de Kamercommissies, geeft de Bundestag op een zeer duidelijke manier aan wat zijn kritiekpunten zijn ten aanzien van het voorstel van de Commissie en geeft hij puntsgewijs aan wat hij van de regering verwacht.

Ook de Bundesrat besluit op aanraden van de Kamercommissies tot Stellungnahme. Dit doet hij op basis van artikel 23 Grondwet juncto artikel 3 en 5 EUZBLG.${ }^{295}$ De Bundesrat stuurde zijn Stellungnahme niet alleen aan de regering maar direct aan de Europese Commissie. ${ }^{296}$ Een reactie van de Commissie in het kader van de politieke dialoog bleef echter uit. De Stellungnahme van de Bundesrat zag er anders uit dan die van de Bundestag. Waar die van de laatste één geheel vormde, bestond die van de Bundesrat uit genummerde alinea's waarbij werd aangegeven van welke Kamercommissie de alinea afkomstig is. Uiteindelijk was van zowel de Bundestag als de Bundesrat duidelijk wat hun standpunten waren. In het geval van de bovengenoemde richtlijn lagen beide standpunten op één lijn, wat gunstig was voor de regering.

De Stellungnahmen van de Bundestag en Bundesrat hadden betrekking op het voorstel voor een richtlijn over gebruik van persoonsgegevens van passagiers voor het voorkomen, opsporen, onderzoeken en vervolgen van terroristische misdrijven en zware criminaliteit. ${ }^{297}$ Zowel de Bundesrat als de Bundestag heeft problemen met het oprichten van een zogenoemd PNR-systeem (Passenger Name Record) waarin persoonsgegevens van passagiers worden opgeslagen omdat dit volgens beide grondwettelijk niet toelaatbaar is. Daarnaast doet noch de inhoud van de richtlijn, noch de rechtvaardiging voor de richtlijn, recht aan het feit dat bewaring van passagiersgegevens als uitzondering moet worden gezien. Ten slotte wordt getwijfeld aan de uitvoerbaarheid van de richtlijn.

291 Ibid.

292 Website EUR-Lex, Procedure 2011/0023/COD.

293 Deutscher Bundestag 17. Wahlperiode, Drucksache 17/5490, 13 april 2011.

294 Zie bijvoorbeeld de Stellungnahme van de FDP-fractie naar aanleiding van Richtlijn COM(2016)593 inzake auteursrechten in de digitale eengemaakte markt, Deutscher Bundestag 19. Wahlperiode, Drucksache 19/8959, 03 april 2019.

295 Bundesrat, Drucksache 73/1/11, 7 maart 2011.

296 Website ipex, COM/2011/0032/FIN.

$297 \operatorname{COM}(2011) 32$. 
Een Stellungnahme is een recht van het parlement en de uitoefening ervan dient door de federale regering gerespecteerd te worden. Het reikt echter niet zo ver dat men kan zeggen dat het een dwingend mandaat is. De regering dient in de Raad enige onderhandelingsmogelijkheden te behouden evenals het recht om andere beslissingen te nemen dan in lijn met de Stellungnahme(n) van het parlement. ${ }^{298}$

Onderstaande tabel 11 bevat een overzicht van het aantal Stellungnahme door de Bundestag, terwijl in tabel 12 de aantallen van de Bundesrat zijn opgenomen. ${ }^{299}$ In de tabel met Stellungnahmen van de Bundestag is alleen het aantal aangenomen Stellungnahmen door de Bundestag in de periode 2010-2016 opgenomen. In de praktijk worden veel meer Stellungnahmen opgesteld, maar een groot deel wordt uiteindelijk niet aangenomen of wordt weer ingetrokken.

Tabel 11 Aantal Stellungnahmen door de Bundestag ${ }^{300}$

\begin{tabular}{ll} 
& $\begin{array}{l}\text { Aantal Stellungnahmen door de Bundestag } \\
\mathbf{2 0 1 0 - 2 0 1 6}\end{array}$ \\
\hline $\begin{array}{l}\text { Wetgevingsbesluiten o.g.v. art. 23 lid 1 jo. } \\
\text { IntVG }\end{array}$ & 15 \\
\hline Stellungnahmen o.b.v. art. 23 lid 2 & 116 \\
\hline Stellungnahmen o.b.v. art. 23 lid 3 & 75 \\
\hline Gemiddelde per jaar & 29 \\
\hline Totaal & $\mathbf{2 0 6}$
\end{tabular}

Tabel 12 Aantal Stellungnahmen door de Bundesrat

\begin{tabular}{ll} 
Jaar & Aantal Stellungnahmen door de Bundesrat \\
\hline $\mathbf{2 0 1 0}$ & 158 \\
\hline $\mathbf{2 0 1 1}$ & 208 \\
\hline $\mathbf{2 0 1 2}$ & 256 \\
\hline $\mathbf{2 0 1 3}$ & 229 \\
\hline $\mathbf{2 0 1 4}$ & 144 \\
\hline $\mathbf{2 0 1 5}$ & 87
\end{tabular}

298 H. Schröder, 'Die Mitwirkung des bundestages in EU-Angelegenheiten nach dem EUZbbG in der Praxis - ein Kurzkommentar', Zeitschrift für Parlamentsfragen (ZParl) 2012, 2, p. 250-277, p. 274-274.

299 De aantallen zijn opgevraagd bij de Bundestag en Bundesrat en via e-mail ontvangen in augustus en september 2018.

300 De aantallen Stellungnahmen van de Bundestag zijn niet per jaar ontvangen maar per regeerperiode waardoor er geen splitsing per jaar te maken is. 


\begin{tabular}{ll} 
Jaar & Aantal Stellungnahmen door de Bundesrat \\
\hline $\mathbf{2 0 1 6}$ & 177 \\
\hline Totaal 2010-2016 & $\mathbf{1 2 5 9}$ \\
\hline Gemiddelde per jaar & 180
\end{tabular}

\subsubsection{Overzicht}

De hiervoor beschreven drie wetten danken hun ontstaan aan het oordeel van het Bundesverfassungsgericht over het Verdrag van Lissabon in het zogenoemde Lissabon-Urteil. Hierin gaf het hof aan dat het verdrag weliswaar niet in strijd was met de Duitse Grondwet maar legde wel op dat de rechten van de Bundestag en Bundesrat met betrekking tot Europese aangelegenheden eerst moesten worden vastgelegd alvorens Duitsland het Verdrag van Lissabon mocht ratificeren. In deze drie wetten zijn de rechten van de Bundestag en Bundesrat vastgelegd.

Deze drie wetten vormen een belangrijke grond voor de Bundesrat om invloed uit te oefenen op Europese aangelegenheden door de zogenoemde Stellungnahme, een officieel standpunt. Zoals hierboven beschreven vinden de Stellungnahmen van de Bundestag plaats op basis van artikel 23 lid 1, 2 en 3 van de Grondwet in combinatie met de EUZBBG en IntVG. Stellungnahme door de Bundesrat gebeurt op grond van de afzonderlijke wetten en niet op grond van artikel 23 van de Grondwet. Uit tabel 11 blijkt dat de Bundestag in de jaren 2010 tot en met 2016 in totaal 206 Stellungnahmen heeft aangenomen. In tabel 12 is opgenomen hoe vaak de Bundesrat een Stellungnahme heeft ingenomen en deze heeft gedeeld met de regering. Dit gebeurt met een gemiddelde van 180 keer per jaar, in totaal 1259 keer in de periode 2010-2016. Als het aantal Stellungnahmen door de Bundesrat wordt vergeleken met dat door de Bundestag is te zien dat het aantal door de Bundesrat vele malen hoger is dan dat van de Bundestag. De bevoegdheid tot Stellungnahme wordt in praktijk vaker gebruikt door de Bundesrat dan de Bundestag. De reden hiervan zal zijn dat de Bundesrat door de parlementen en regeringen in de Länder wordt 'gedwongen' hierin actief te zijn. De leden van de Bundesrat hebben namelijk geen vrij mandaat zoals de leden van de Bundestag. De regeringen van de Länder kunnen aanwijzingen geven aan de leden van de Bundesrat die deze moeten opvolgen. Dit is, naast de rol in het wetgevingsproces, de enige manier om invloed uit te oefenen op Europese aangelegenheden. Daar waar de Bundestag zijn stem kan laten horen via de algemene controlebevoegdheden is de Stellungnahme de manier voor de Bundesrat. In dit geval is het handig om de Bundesrat niet als parlementaire Kamer te zien, maar als een verzameling van regeringen van de Länder die allemaal de eigen belangen van hun Land vertegenwoordigen. 
Welke weerslag artikel 23 Grondwet en de drie bovenstaande wetten precies hebben, is moeilijk te zeggen. Uiteindelijk is het doel dat de Bundesrat en de Bundestag via een Stellungnahme of via de federale regering in de Raad, invloed kunnen uitoefenen op Europese besluitvorming. Daarvoor dient gekeken te worden naar de onderhandelingen in de Raad, maar deze onderhandelingen zijn niet openbaar waardoor niet te achterhalen is wat precies het standpunt van de Duitse regering is tijdens de onderhandelingen. Daarnaast moet ook rekening gehouden worden met de manier van besluitenvorming op Europees niveau. Meer en meer wordt nieuwe over Europese wetgeving besloten in de zogenoemde 'trilogen'. Ook daarvan zijn de onderhandelingen niet openbaar. Het is dus niet mogelijk om concreet aan te geven wat de regering precies met elke Stellungnahme heeft gedaan.

\subsection{Tussenconclusie}

Dit hoofdstuk is gericht op de rol van het Duitse parlement in Europese aangelegenheden. Gekeken is naar de nationale bevoegdheden van het parlement die vastgelegd zijn in Duitse wetgeving en daarbij is onderzocht hoe vaak deze bevoegdheden zijn ingezet. Aan bod kwamen allereerst de geschiedenis en de staatsstructuur van Duitsland om het geheel in context te plaatsen en zo duidelijk te maken welke staatsorganen bestaan binnen de Duitse structuur, wat de functie is van deze organen en hoe de verhoudingen tussen de organen liggen.

De belangrijkste organen voor dit onderzoek zijn de Bundestag, de Bundesrat, de regering en het Bundesverfassungsgericht.

Het Bundesverfassungsgericht heeft sinds 1974 veel betekend voor de rol van het Duitse parlement in de Europese Unie evenals voor de rol van de Republiek Duitsland in de Europese Unie. Het hof beoordeelt namelijk of handelingen van Europese instellingen binnen de bevoegdheden passen, met andere woorden of deze al dan niet ultra vires zijn. Hiermee beschermt het hof de Duitse staat tegen handelingen die buiten de bevoegdheid zijn genomen door deze niet van toepassing te verklaren op Duitsland. Dit doet het Bundesverfassungsgericht onder de noemer 'waarborging van de democratie' en bescherming van de 'core' van de Duitse soevereiniteit. Voor het Duitse parlement heeft het hof, meer concreet, bepaald dat het parlement dient op te treden wanneer een EU-instelling ultra vires handelt. Ook heeft het hof bepaald dat de Bundestag een rol heeft bij de ESMbesluiten. Met andere woorden, het Bundesverfassungsgericht zorgt ervoor dat de bevoegdheden en rollen van het Duitse parlement bij het Duitse parlement blijven, geeft een oordeel over de reikwijdte van de bevoegdheden van het parlement en zorgt ervoor dat het parlement zijn taken uitvoert. Het Bundesverfassungsgericht is als het ware een beschermer van het parlement. 
Vervolgens is ingegaan op de invloed op Europese aangelegenheden. Deze vindt onder andere plaats via controle van de regering door de Bundestag. Controle van de regering is een van de hoofdtaken van de Bundestag, maar is geen taak van de Bundesrat. Om deze taak uit te voeren heeft de Bundestag allereerst informatie nodig. Zonder correcte en deugdelijke informatie kan de Bundestag de regering niet of nauwelijks controleren. Om de informatie van de regering te krijgen heeft de Bundestag enkele algemene bevoegdheden. Dit zijn de Kleine Anfragen, Große Anfragen, Schriftliche Fragen, Mündliche Fragen, Fragestunden, Aktuelle Stunden en Regierungsbefragungen. Het sluitstuk wordt gevormd door de verplichte aanwezigheid van de regering bij debatten wanneer de Bundestag hierom verzoekt. Kleine en Große Anfragen worden het meest ingezet. Dit heeft te maken met het feit dat het aanvragen van een Kleine of Große Anfrage relatief makkelijk is. Vijf procent van de leden van de Bundestag of een fractie uit de Bundestag moet het verzoek steunen. Dit blijkt geen hoge drempel te zijn. Daarnaast worden beide soorten Anfragen relatief snel beantwoord. De Kleine Anfragen worden binnen twee weken schriftelijk beantwoord en de Große Anfragen mondeling in een debat. Wanneer Kleine en Große Anfragen over Europese aangelegenheden worden afgezet tegen Kleine en Große Anfragen over nationale aangelegenheden blijkt dat bijna 30 procent van de Große Anfragen en bijna 16 procent van de Kleine Anfragen over Europa gaat. Große Anfragen worden gebruikt bij onderwerpen die van groot politiek belang zijn.

Schriftelijke en mondelinge vragen worden in mindere mate ingezet voor Europese aangelegenheden. 8,1 procent van de schriftelijke vragen en 9,5 procent van de mondelinge vragen gaat over een Europees onderwerp. Per week worden ongeveer honderd schriftelijke vragen gesteld. Ongeveer zeven vragen per week hebben betrekking op de Europese Unie. Het stellen van schriftelijke en mondelinge vragen wordt gedaan om in een kort tijdsbestek een bondig antwoord te krijgen. Wellicht lenen Europese onderwerpen zich niet voor korte vragen en korte antwoorden aangezien Europese onderwerpen door de Bundestag als meer complex worden gezien, waardoor men eerder geneigd is een Kleine Anfrage in te dienen. Een schriftelijke vraag mag immers maar uit vier vragen met ieder twee subvragen bestaan terwijl een Kleine Anfrage geen limiet heeft op het aantal vragen. Het is ook goed mogelijk dat de Bundestag al voldoende informatie ontvangt van de regering via de uitgebreide informatieplicht die geldt voor Europese aangelegenheden op basis van artikel 23 lid 2 Grondwet. Ook zijn de leden van de regering tevens lid van de Bundestag. De ministers nemen daardoor deel aan de debatten. Daarnaast zijn de ministers aanwezig bij de fractievergaderingen waarin informatie kan worden gedeeld en antwoorden kunnen worden gegeven. De coalitiefracties in de Bundestag hebben daardoor wellicht minder de behoefte om vragen te stellen via de officiële weg van mondelinge en schriftelijke vragen, Kleine en Große Anfragen. 
Een Aktuelle Stunde wordt ingezet wanneer de Bundestag van mening is dat de regering onvoldoende antwoord heeft gegeven op de mondelinge vragen die gesteld zijn tijdens het wekelijkse vragenuur. Van de Aktuelle Stunden gaat 8,7 procent over Europa. Tot slot zijn er nog de Regierungsbefragungen. Deze korte debatten van slechts 30 minuten vinden elke woensdag aansluitend aan de kabinetsvergadering plaats. Dit is vaak de eerste informatieverstrekking door de regering over een bepaald onderwerp. Het percentage Regierungsbefragungen over een Europees onderwerp is 9,2. De Bundestag heeft geen invloed op het onderwerp dat wordt besproken aangezien dat door de regering wordt bepaald.

In het algemeen kan worden gesteld dat de Bundestag de algemene controlebevoegdheden met name inzet voor controle van nationale aangelegenheden. De reden hiervoor is dat voor controle van of invloed op Europese aangelegenheden speciale bevoegdheden bestaan op grond van artikel 23 van de Grondwet en de daaruit voortvloeiende wetten.

Artikel 23 van de Grondwet is voor zowel de Bundestag als de Bundesrat belangrijk. Het artikel bepaalt namelijk dat beide een rol spelen in Europese aangelegenheden of, zoals het artikel het verwoordt, 'In Angelegenheiten der Europäischen Union (...)'.

Op basis van de leden 1, 2 en 3 heeft de Bundestag de mogelijkheid tot Stellungnahme. De Bundestag neemt dan een standpunt in en deelt dit standpunt met de regering. De regering hoort dit standpunt dan mee te nemen in haar beslissingen en in de onderhandelingen op Europees niveau. Doet de regering dit niet dan dient zij dit te motiveren. Het speciale aan de Stellungnahme van de Bundestag is dat deze opgesteld kan worden door de commissie voor Europese Zaken. De Grondwet bepaalt dat de Bundestag een dergelijke commissie moet instellen en geeft daarna de mogelijkheid om deze commissie te mandateren om namens de Bundestag op te treden. Daarnaast geeft lid 2, zoals net ook aangegeven, de Bundestag concreet het recht op informatie over Europese aangelegenheden. Zodra de regering of haar vertegenwoordiging in Brussel nieuwe informatie krijgt, dient zij deze informatie met de Bundestag te delen. Deze informatieplicht van de regering is uitgewerkt in de wet Gesetz über die Zusammenarbeit von Bundesregierung und Deutschem Bundestag in Angelegenheiten der Europäischen Union (Wet op de samenwerking tussen de federale regering en de Duitse Bondsdag in Europese Unie-aangelegenheden).

De Bundesrat heeft niet de taak om de regering te controleren (op nationale aangelegenheden). Toch is de Bundesrat een belangrijk orgaan omdat hij de Länder op federaal niveau vertegenwoordigt en op basis van artikel 23 van de Grondwet een rol speelt in (controle van) Europese aangelegenheden. Ook heeft hij een rol in het wetgevingsproces. In deze laatste rol kan de Bundesrat (Europese) besluitvorming beïnvloeden. De Bundesrat heeft niet zoals de Bundestag algemene controlebevoegdheden maar is op grond van artikel 23 van de Grondwet wel betrokken bij Europese aangelegenheden. Net zoals de Bundestag wordt de Bundesrat op grond van lid 2 van het voorgenoemde artikel geïnformeerd over 
nieuwe informatie met betrekking tot Europa. Op basis van de leden 4, 5 en 6 neemt de Bundesrat deel aan Europese aangelegenheden. Op basis van lid 4 dient de regering de Bundesrat bij besluitvorming te betrekken wanneer deze betrekking heeft op de Länder. Dit kan vergeleken worden met het recht van de Bundestag om zijn standpunt kenbaar te maken aan de regering waarna dit standpunt meegenomen moet worden in de besluitvorming en in de onderhandelingen. Op grond van artikel 52 lid 3a van de Grondwet is de Bundesrat bevoegd een zogenoemde Europakammer in te stellen die net zoals de commissie voor Europese Zaken van de Bundestag, de bevoegdheden van de Bundesrat kan uitoefenen voor wat betreft Europese aangelegenheden. In de praktijk komt dit weinig voor.

Het vijfde lid van artikel 23 heeft de positie van de Länder in de besluitvorming versterkt. Hierin wordt namelijk bepaald dat wanneer het gaat om de wetgevende bevoegdheid van de Länder, de overheidsstructuur van de Länder of de bestuurlijke procedures binnen de Länder, de regering het standpunt van de Bundesrat als leidend moet nemen bij het opstellen van haar eigen standpunt. Wanneer beide standpunten niet overeenkomen, dient overeenstemming te worden bereikt. Is dit niet mogelijk dan kan de Bundesrat een nieuw standpunt innemen of bij zijn oude standpunt blijven. Wanneer twee derde van de Bundesrat instemt met dit (nieuwe) standpunt, is dit standpunt bindend voor de federale overheid. Dit betekent dus dat de Bundesrat een zeer sterke positie heeft wanneer de besluitvorming gaat over een van de voornoemde situaties. Tot slot wordt in het zesde lid bepaald dat een vertegenwoordiger van de Länder wordt aangewezen die de belangen van de Bondsrepubliek zal behartigen in de Raad van de Europese Unie wanneer het gaat om een exclusieve wetgevende bevoegdheid van de Länder op het gebeid van 'Hausgut' (de Duitse verzamelnaam voor de onderwerpen onderwijs, cultuur, radio- of tv-uitzendingen). De concrete Stellungnahme door de Bundesrat vindt plaats op basis van de verschillende paragrafen in de EUZBLG.

Als gekeken wordt naar het aantal Stellungnahmen door de Bundesrat en de Bundestag valt op dat de Bundesrat veel actiever is dan de Bundestag. De Bundesrat neemt gemiddeld 180 Stellungnahmen per jaar terwijl de Bundestag in dezelfde periode 2010-2016 gemiddeld 29 Stellungnahmen heeft genomen. De Bundesrat is actiever hierin omdat hij door de regeringen van de Länder wordt gedwongen dit te doen. Leden van de Bundesrat hebben geen vrij mandaat en dienen te doen wat hun regeringen in de Länder voorschrijven. Bovendien is het nemen van een Stellungnahme, naast de rol in het wetgevingsproces, de enige manier voor de Bundesrat om invloed uit te oefenen op het Europese beleid van de regering. Daar waar de Bundestag zijn algemene controlebevoegdheden kan inzetten om de regering te controleren, kan de Bundesrat dit niet, simpelweg omdat de Bundesrat deze bevoegdheden niet heeft.

De Bundestag heeft overigens nog de algemene controlebevoegdheden, zoals besproken in paragraaf 4.4.1, om invloed uit te oefenen. 
In hoeverre de Stellungnahmen op basis van artikel 23 Grondwet en verwante wetten het standpunt van de regering hebben beïnvloed is moeilijk te zeggen. Het is namelijk niet te achterhalen welk standpunt de regering precies heeft ingenomen in de Raad, maar er zijn geen aanwijzingen om aan te nemen dat dit standpunt niet overeenkomt met hetgeen op nationaal niveau is bediscussieerd. 



\title{
HoOfdTUK 5 NeDERLAND EN DUITSLAND
}

\author{
VE R G E L E K E N
}

\subsection{INLEIDING}

In de voorgaande drie hoofdstukken zijn de bevoegdheden met betrekking tot Europese aangelegenheden van het Nederlandse en Duitse parlement besproken. De kern van dit onderzoek is het vergelijken van de bevoegdheden en de inzet daarvan door het Nederlandse parlement met die van het Duitse parlement. Zoals in de inleiding is besproken heeft de rol van Duitsland in de Europese Unie een andere dynamiek dan de Nederlandse omdat de stem van Duitsland in de Raad zwaarder weegt. ${ }^{1}$ Daarnaast hebben beide landen een andere staatsvorm. Met betrekking tot de bevoegdheden vastgelegd in Europese verdragen is de staatsvorm van een lidstaat en hoe het staatsrecht binnen een lidstaat is ingericht voor de Europese Unie niet relevant. De bevoegdheden komen aan alle lidstaten toe, ongeacht welke staatsvorm een lidstaat heeft. ${ }^{2}$ Met betrekking tot de (interne) uitoefening van deze bevoegdheden, hetgeen een nationale aangelegenheid is, zijn de staatsvorm en inrichting van de staat wel bepalend. Duitsland is een federatie waar als gevolg van het staatsbestel ook de Länder, via de Bundesrat, een rol spelen in Europese aangelegenheden. Nederland is een gedecentraliseerde eenheidsstaat. De gedecentraliseerde overheden spelen geen rol op Europees niveau, althans niet op dezelfde manier als de Länder in Duitsland. De grootte van de parlementen is wel een bepalende factor. De Duitse Bundestag heeft gemiddeld 626 leden, de Nederlandse Tweede Kamer heeft altijd 150 leden. ${ }^{3}$ Dit betekent dat de Bundestag qua ledenaantal meer dan vier keer groter is dan de Tweede Kamer en daardoor meer werk kan verzetten; het grote verschil in ambtelijke ondersteuning (zie par. 5.4.4) komt hier nog bij.

In dit hoofdstuk zal dezelfde volgorde worden aangehouden als die van de opzet van dit onderzoek. Ten eerste zullen de bevoegdheden worden besproken die de parlementen hebben op basis van Europese wetgeving (par. 5.2: Van Europees naar nationaal). Daarna zullen de nationale bevoegdheden van beide parlementen worden behandeld, die reeds in

1 Soms weegt de Nederlandse stem vaak zwaarder dan zijn eigen stemgewicht, omdat Nederland vaak optreedt als woordvoerder van de 'frugal four' (Nederland, Zweden, Denenmarken en Oostenrijk).

2 Ch. Degenhart, Staatsrecht I. Staatsorganistionsrecht. Mit Bezügen zum Europarecht, Heidelberg: C.F. Müller GmbH 2017, p. 294.

3 Het aantal leden van de Bundestag wisselt per verkiezingsperiode. In de zeventiende verkiezingsperiode (2009-2013) had de Bundestag 622 leden, in de achttiende verkiezingsperiode (2013-2017) waren het er 630. Voor dit onderzoek is daarvan het gemiddelde genomen, wat 626 leden is. 
hoofdstuk 3 over Nederland en hoofdstuk 4 over Duitsland zijn besproken. Deze bevoegdheden zijn neergelegd in de Grondwetten van beide landen en ook in andere formele wetten en regelingen. Naast bevoegdheden worden in dit onderzoek ook bepaalde processen beschreven. Het gaat dan om de manier waarop bevoegdheden worden ingezet. Deze manieren zijn vaak ontstaan door gewoonte en niet terug te vinden in formele wetgeving. Deze vergelijking en de analyse gaan ook hierop in.

De bevoegdheden van beide parlementen zijn niet identiek maar komen wel grotendeels overeen en zullen in dit hoofdstuk met elkaar vergeleken worden. In de gevallen waarin de bevoegdheden op elkaar lijken, is het de vraag of de Nederlandse versie verbeterd kan worden aan de hand van de Duitse versie en zal naar de inzet van de bevoegdheden gekeken worden. Ook wordt bekeken of een bevoegdheid die in Duitsland wel bestaat en in Nederland niet, van toegevoegde waarde kan zijn in Nederland. Het antwoord op deze vragen en een uiteindelijke waardering van de bevoegdheden en processen zal worden gegeven in het laatste, concluderende hoofdstuk. Door de vergelijking zullen ook verschillen naar voren komen, want hoewel de parlementaire stelsels van beide landen op elkaar lijken, zijn ze niet hetzelfde. Die verschillen geven in principe het antwoord op de vraag of Nederland bepaalde bevoegdheden en/of processen die in Duitsland bestaan, zou moeten creëren. ${ }^{4}$

\subsection{VAN Europees NAAR NationaAl}

In hoofdstuk 2, Van Europees naar nationaal, zijn de bevoegdheden besproken die de parlementen toekomen op basis van Europees recht. Daarnaast wordt ook de Europese interparlementaire samenwerking genoemd.

\subsubsection{Het Barroso-initiatief en de politieke dialoog}

In het Duitse en in het Nederlandse parlement wordt ten aanzien van de politieke dialoog op min of meer dezelfde wijze gehandeld. De documenten van de Europese Commissie worden opgepakt door de Kamercommissies op het beleidsterrein van het onderwerp van het document. In de Bundestag en Bundesrat hebben de Kamercommissies voor Europese

4 Voor de mogelijkheden en zin van 'constitutional transplants' zie onder andere W.J.M. Voermans, 'From Legal Imposition to Legal Invitation: From Transplants to Mutual Learning, Benchmarks and Best-PracticeInspiration', European Journal of Law Reform 2018, 20, p. 8-19; V. Perju, 'Constitutional Transplants, Borrowing and Migrations', in: M. Rosenfeld \& A. Sajo (eds.), Oxford Handbook of Comparative Constitutional Law, Oxford: Oxford University Press 2012; F. Jacobs, 'Comparative Law and European Union Law', in: M. Reinmann \& R. Zimmermann, The Oxford Handbook of Comparative Law, Oxford: Oxford University Press 2019. 
Zaken daarentegen wel een overkoepelende rol. Deze commissies wijzen de documenten aan de Kamercommissies toe en houden daarnaast een oogje in het zeil. Samen met de Kamercommissie waaraan het document is toegewezen stelt de Kamercommissie voor Europese Zaken een behandelplan op. Het feit dat de Kamercommissies voor Europese Zaken worden betrokken heeft te maken met hun expertise op het gebied van Europese aangelegenheden en die ontbreekt bij andere commissies. In de Tweede Kamer heeft de Kamercommissie voor Europese Zaken deze rol niet (meer). Daar zijn het de individuele Kamercommissies die bepalen of een dialoog met de Europese Commissie gestart wordt en op welke manier. Uit dit onderzoek is echter niet gebleken dat een van de twee stelsels, het Duitse of het Nederlandse, effectiever is dan het andere.

Doorgaans wordt de politieke dialoog in beide parlementen schriftelijk gevoerd. Met betrekking tot het aantal gevoerde politieke dialogen zijn grote verschillen te zien. Het gemiddelde aantal politieke dialogen per jaar in de onderzoeksperiode van 2010 tot en met 2016 is voor de Tweede Kamer 36, voor de Eerste Kamer 41, voor de Bundestag 23 en voor de Bundesrat 246. Het is het aantal politieke dialogen door de Bundesrat dat opvalt. Zoals in Hoofdstuk 4 Duitsland is beschreven heeft dit te maken met de druk van de regeringen en parlementen uit de Länder. Daarnaast heeft elk van de zestien Länder ook een eigen vertegenwoordiger in Brussel die aldaar behoorlijk wat informatie kan verzamelen en terug aan het Land kan geven. Ook hebben sommige Länder een eigen ministerie voor Europese Zaken (zoals Noordrijn-Westfalen). Hieruit volgt dan dat de Bundesrat, als parlementaire Kamer begrepen, althans in theorie heel goed geïnformeerd is over Europese aangelegenheden.

Via de Bundesrat kan vanuit de Länder invloed worden uitgeoefend op Europese aangelegenheden. Van die stem die de Länder hebben, wordt veel gebruikgemaakt, omdat dit een van de weinige mogelijkheden is van de Länder om invloed uit te oefenen op Europees niveau. Een ander verschil tussen de gevoerde politieke dialogen is het aantal vragen en antwoorden. Het Nederlandse parlement is niet geneigd lange of veel vragen te stellen in de politieke dialoog, in tegenstelling tot het Duitse parlement. De brieven van zowel de Tweede als de Eerste Kamer zijn één tot drie pagina's lang en hierin wordt doorgaans op één onderwerp ingegaan. De Bundestag en Bundesrat snijden veel meer onderwerpen aan in hun brieven aan de Commissie. Vaak is zo'n brief een opsomming van vele verschillende vragen. Ten slotte voert het Nederlandse parlement graag de dialoog met de eigen regering. Gezien het feit dat de Europese Commissie op basis van de politieke dialoog niet of nauwelijks geneigd is om haar beleid of wetgevingsvoorstellen aan te passen is het voeren van een dialoog met de eigen regering, zoals het Nederlands parlement doet, het effectiefst. Aan de eigen regering kan men het standpunt van het parlement met meer nadruk meegeven via bijvoorbeeld een motie of een Stellungnahme. In zulke gevallen is de ernst van de zaak duidelijker dan wanneer een parlement een advies in de politieke dialoog stuurt. 
Het feit dat zowel het Nederlandse als het Duitse parlement deelneemt aan de politieke dialoog zorgt voor een grotere legitimiteit van de Europese Unie. Het is niet zo dat er een getal kan worden gezet op het aantal adviezen dat een nationaal parlement ten minste aan de Europese Commissie moet sturen om zijn legitimiteit te vergroten, maar het gaat erom dát er gebruik wordt gemaakt van de politieke dialoog.

\subsubsection{De gelekaartprocedure}

Een andere mogelijkheid om nationale parlementen te betrekken bij Europese aangelegenheden is de gelekaartprocedure. Tot op heden, zomer 2021, zijn drie gele kaarten maar geen oranje kaart getrokken.

De procedures binnen het Nederlandse en Duitse parlement om tot een met redenen omkleed advies te komen zijn gelijk aan die van een advies inzake de politieke dialoog. Dit is ook niet vreemd aangezien de Europese Commissie bepaalt of het gaat om een advies in de gelekaartprocedure of in de politieke dialoog. Nationale parlementen kunnen wel de bedoeling hebben om een advies in een van de twee procedures op te stellen maar het is de Commissie die op basis van de inhoud van het advies bepaalt in welke procedure het advies wordt behandeld. Op dat gebied doen het Nederlandse en Duitse parlement het goed. Het feit dat al hun subsidiariteitsbezwaren als zodanig door de Europese Commissies worden gezien betekent dat beide parlementen genoeg kennis van zaken hebben op dit gebied.

Binnen de gelekaartprocedure is het Nederlandse parlement, en dan met name de Tweede Kamer, actiever dan het Duitse parlement. De Tweede Kamer is het actiefst van alle Kamers (van het Nederlandse en Duitse parlement samen). Dit zou verband kunnen houden met het feit dat Nederland minder machtig is in de Raad waardoor het parlement andere mogelijkheden aangrijpt om invloed uit te oefenen. In de periode 2010-2016 diende de Kamer zestien met redenen omklede adviezen in bij de Europese Commissie. De Bundestag diende drie adviezen in, de Bundesrat tien, de Eerste Kamer vijf en de Tweede en Eerste Kamer gezamenlijk dienden er ook vijf in (in de periode 2010-2012). In het laatste geval telt het advies voor twee stemmen mee in de gelekaartprocedure aangezien het advies van beide Kamers afkomstig is. De Bundestag heeft na 2012 geen advies meer ingediend, en hetzelfde geldt voor de Bundesrat na 2013. Dit kan te maken hebben met de verkiezingen van de Bundestag (en in het Land Hessen) in 2013. In die nieuwe Bundestag namen veel nieuwe, onervaren, leden zitting wat ervoor heeft kunnen zorgen dat er geen adviezen meer zijn ingediend omdat de nieuwe leden niet bekend waren met deze mogelijkheid. Ook werden in 2014 verkiezingen voor het Europees Parlement gehouden. In die periode ligt het Europese wetgevingsproces voor een deel stil. De bestaande wetgevingsvoorstellen worden afgerond maar er komen vrijwel geen nieuwe plannen. Wanneer de 
verkiezingen voor het Europees Parlement eenmaal geweest zijn, moet een nieuwe Europese Commissie op gang komen. De Commissie-Juncker (2014-2019) gaf bij haar aantreden bovendien aan minder nieuwe wetgeving te willen maken. Kennelijk speelde ook het soort wetgevingsvoorstellen een rol: mogelijk ging het om wetsvoorstellen waarbij het Duitse parlement minder of geen subsidiariteitsproblemen zag of het parlement geen toegevoegde waarde zag in het instrument van de gelekaartprocedure. Dat de Bundestag en Bundesrat minder tot geen adviezen zijn gaan insturen heeft dus te maken met een combinatie van factoren.

De Tweede Kamer heeft elk jaar minimaal één met redenen omkleed advies ingediend maar nooit meer dan vijf per jaar. De Eerste Kamer heeft alleen in de jaren 2012, 2013 en 2016 een of meer adviezen ingediend. Het feit dat de aantallen in de eerste jaren na 2010 oplopen en daarna weer aflopen is niet verrassend. Dit is een gebruikelijk fenomeen bij nieuwe bevoegdheden. De afname heeft ook te maken met het feit dat de Europese Commissie steeds minder wetgevingsvoorstellen publiceerde. Er zijn dus minder voorstellen om op te reageren. Vergeleken met andere EU-lidstaten zijn de aantallen adviezen van het Nederlandse en Duitse parlement gemiddeld. De Zweedse Riksdag stuurt elk jaar vele subsidiariteitsbezwaren en vormt hiermee een uitzondering, maar het Europese gemiddelde ligt op een paar bezwaren per jaar. Het feit dat het Nederlandse en Duitse parlement gemiddeld presteren betekent niet dat het niet beter kan. Het aantal met redenen omklede adviezen is op zichzelf geen indicator voor de mate van tevredenheid van een Kamer met betrekking tot subsidiariteit. Daarvan zou alleen sprake kunnen zijn als alle Europese voorstellen op subsidiariteit getoetst zouden worden, maar dat gebeurt niet. Men kan daarom concluderen dat beide parlementen hun taak uit artikel 12 VEU maar gedeeltelijk nakomen.

Zoals hierboven kort aangehaald worden de meeste subsidiariteitsbezwaren ingediend door het Zweedse parlement. Dit maakt de rol van het Zweedse parlement in de gelekaartprocedure een onderwerp voor onderzoek. ${ }^{5}$ Zweden wordt gezien als een bijzonder sterke democratie. De elementen die daaraan bijdragen, zijn het hoge aantal subsidiariteitsbezwaren, de gedelegeerde behandeling van controle door de verschillende Kamercommissies en de jaarlijkse 'follow-up' rapporten en analyses van het controleproces door de Kamercommissie voor de Grondwet. ${ }^{6}$ In Zweden is er geen sprake van een overkoepelende

5 Zie o.a. A. Jonsson Cornell, 'The Swedish Riksdag as Scrutiniser of the Principle of Subsidiarity', European Constitutional Law Review 2016, 12(2), p. 294-317; I. Cooper, 'The Nordic Parliaments and the EU', in: C. Howard Grøn e.a., Still the other European Community? The Nordic Countries and the European Union, Londen/New York: Routledge 2015; A. Jonsson Cornell \& M. Goldoni, National and Regional Parliaments in the EU-legislative Procedure post-Lisbon. The Impact of the Early Warning System, Oxford: Hart Publishing 2016.

6 A. Jonsson Cornell, 'The Swedish Riksdag as Scrutiniser of the Principle of Subsidiarity', European Constitutional Law Review 2016, 12(2), p. 296. 
commissie die zicht houdt op controle van Europese wetgeving en beleid, zoals in Duitsland het geval is. Iedere Kamercommissie is verantwoordelijk voor controle op haar eigen beleidsterrein. Dit komt overeen met het Nederlandse model. Het valt niet binnen de reikwijdte van dit onderzoek om de behandeling van Europese wetgeving door de Zweedse Riksdag hier te bespreken, maar uit onderzoek naar het Zweeds model komt naar voren dat bij gedecentraliseerde controle meer wetgeving gecontroleerd wordt dan bij een centrale controle. Bij deze laatste vervult een Kamercommissie een filterfunctie, terwijl het Zweedse gedecentraliseerde model zonder uitzondering zorgt voor controle van álle Europese wetgeving. ${ }^{7}$ Uit dit onderzoek blijkt weliswaar niet dat het gedecentraliseerde model (Nederland) zorgt voor meer controle dan het gecentraliseerde model (Duitsland).

\subsection{Nationale BeVOEgDhEDEN}

Zoals in de vorige twee hoofdstukken over Nederland en Duitsland is beschreven kunnen en worden nationale bevoegdheden ingezet voor parlementaire controle op Europese besluitvorming. In Nederland bestaan er twee nationale bevoegdheden die uitsluitend gericht zijn op controle van Europese aangelegenheden. Dit zijn het parlementair behandelvoorbehoud en het instemmingsrecht. Deze twee bevoegdheden zijn neergelegd in de Goedkeuringswet van het Verdrag van Lissabon. ${ }^{8}$ Alle andere nationale bevoegdheden kunnen worden ingezet voor zowel nationale als Europese aangelegenheden. Ook in Duitsland worden de nationale bevoegdheden gebruikt voor controle van Europese aangelegenheden. Daarnaast bestaan er in Duitsland, in tegenstelling tot in Nederland, meerdere wetten die de rol van de Bundestag en de Bundesrat in Europese aangelegenheden vastleggen. Om te beginnen is dit de Grondwet waar in artikel 23 is opgenomen dat de Bundestag en Bundesrat een rol spelen in Europese aangelegenheden. Deze rol wordt verder uitgewerkt in een drietal in paragraaf 4.5 besproken wetten. ${ }^{9}$

$7 \quad$ Ibid., p. 303.

8 Rijkswet van 10 juli 2008, houdende goedkeuring van het op 13 december 2007 te Lissabon totstandgekomen Verdrag van Lissabon tot wijziging van het Verdrag betreffende de Europese Unie en het Verdrag tot oprichting van de Europese Gemeenschap, Stb. 2008, 301.

9 Deze drie wetten zijn: Gesetz über die Zusammenarbeit von Bundesregierung und Deutschem Bundestag in Angelegenheiten der Europäischen Union (EUZBBG) (Wet op de samenwerking tussen de federale regering en de Duitse Bondsdag in Europese Unie-aangelegenheden); Gesetz über die Wahrnehmung der Integrationsverantwortung des Bundestages und des Bundesrates in Angelegenheiten der Europäischen Union (IntVG) (Wet op de Verantwoordelijkheid voor de Integratie van de Bondsdag en de Bondsraad in Europese Unie-aangelegenheden); Gesetz über die Zusammenarbeit von Bund und Ländern in Angelegenheiten der Europäischen Union (EUZBLG) (Wet op de Samenwerking tussen de Federatie en de Landen in Europese Unie-aangelegenheden). 
De nationale controlebevoegdheden van beide parlementen komen het meest met elkaar overeen. Dit zijn de bevoegdheden om de eigen regering te controleren. Denk daarbij aan het recht om vragen te stellen en om in debat te gaan met de regering.

\subsubsection{Controlebevoegdheden}

\subsubsection{Inlichtingenplicht}

Controle van de regering staat of valt bij goede informatievoorziening. Zonder goede en volledige inlichtingen kunnen parlementen hun werk niet doen. Hiertoe bestaat in Nederland de inlichtingenplicht van de regering, ook wel parlementair inlichtingenrecht genoemd. Inlichtingen kunnen zowel mondeling als schriftelijk worden gegeven, aan beide Kamers gezamenlijk (in een verenigde vergadering) of de Kamers afzonderlijk. Hetgeen hiermee samenhangt, zijn de vertrouwensregel en de ministeriële verantwoordelijkheid. Zonder adequate inlichtingen stelt de ministeriële verantwoordelijkheid weinig voor want zonder deze inlichtingen kan het parlement de regering c.q. de minister niet controleren en verantwoordelijk houden voor zijn handelen.

Ook in Duitsland heeft de regering de plicht om het parlement te informeren. De algemene informatieplicht staat in artikel 43 van de Grondwet maar er is ook een informatieplicht die speciaal gericht is op Europese informatie. Deze laatste is te vinden in artikel 23 lid 2 van de Grondwet. Het feit dat in Duitsland een aparte inlichtingenplicht ten aanzien van Europese aangelegenheden bestaat, verandert de situatie niet. Wanneer de Duitse regering het parlement informeert over nationale aangelegenheden doet zij dit op grond van artikel 43 van de Grondwet en ten aanzien van Europese aangelegenheden op basis van artikel 23 van de Grondwet. Er zit geen verschil in beide plichten. Wat precies wordt verstaan onder Europese informatie of op basis van welk artikel een minister het parlement informeert, is een keuze van de minister zelf. In Nederland bestaat er één inlichtingenplicht (art. 68 Grondwet), of het nu gaat om nationale of Europese aangelegenheden. In de praktijk zit er geen verschil tussen de plichten in Nederland en Duitsland. Het resultaat is hetzelfde. Het parlement wordt over alle aangelegenheden geïnformeerd door de regering. Het hebben van een aparte inlichtingenplicht voor Europese aangelegenheden is dan ook niet noodzakelijk.

\subsubsection{Recht van interpellatie, debat en vragen}

De Tweede Kamer en Eerste Kamer komt beide het recht van interpellatie toe. Dit houdt in dat een Kamerlid een debat kan aanvragen over een onderwerp dat niet reeds op de agenda staat. Naast dit interpellatierecht kent de Tweede Kamer ook het dertigledendebat. Naast deze twee mogelijkheden om in debat te treden met een of meer ministers is het ook mogelijk om vragen te stellen. Dit gebeurt in beide Kamers schriftelijk. De Tweede Kamer 
heeft daarnaast ook de mogelijkheid om mondelinge vragen te stellen tijdens het wekelijks vragenuurtje. In de periode 2010-2016 hebben in de Tweede Kamer negen interpellaties plaatsgevonden. Geen van deze interpellaties ging over Europese aangelegenheden. Het aantal dertigledendebatten over Europese aangelegenheden bedroeg ook negen. Wanneer dit wordt afgezet tegen het totale aantal dertigledendebatten in dezelfde tijd, 201, gaat een percentage van vijf procent over Europa. Een verklaring voor het feit dat er veel meer dertigledendebatten over nationale aangelegenheden gaan dan over Europese aangelegenheden kan zijn dat Europese onderwerpen reeds op de agenda van de Kamer staan en dat het dus niet nodig is om ad hoc een debat te organiseren. Een andere verklaring is dat Europese onderwerpen met name in algemene overleggen (AO's) worden besproken, voorafgaand aan een Raadsvergadering, waardoor er weinig behoefte is om Europese onderwerpen tijdens een dertigledendebat te bespreken. Het aantal schriftelijke en mondelinge vragen over Europese aangelegenheden bedroeg 718 respectievelijk 25. Dit is vier procent en twee procent van het totale aantal schriftelijke en mondelinge vragen. Voor wat betreft de Eerste Kamer gelden de volgende cijfers. In de periode 2010-2016 hebben twee interpellaties plaatsgevonden waarvan geen over Europese aangelegenheden. Slechts dertien procent van de schriftelijke vragen die de Eerste Kamer stelt, gaat over Europa.

Binnen het Duitse parlement wordt controle met name uitgeoefend door de oppositiefracties. De coalitiefracties hebben doorgaans een nauwe band met de regering, mede doordat de ministers ook leden van de Bundestag zijn, waardoor de coalitiefracties minder geneigd zijn om de regering te controleren of openlijk kritiek te uiten. Er zijn in het Duitse parlement echter ook leden van de coalitiepartijen te vinden die de regering lang niet altijd steunen. ${ }^{10}$ Met name de leden die een veilig Direktmandat hebben, kunnen zich dat beter en langer veroorloven dan Nederlandse dissidenten, omdat de centrale partijleiding weinig invloed heeft op wie districtkandidaat wordt. ${ }^{11}$ Omdat de fracties in Duitsland betrekkelijk groot zijn, is het voor de regering niet meteen een probleem wanneer een lid (of twee) zich afzet van de partij. De regering zal hierdoor niet zo snel vallen. Daarnaast kan het hebben van dissidenten binnen de partij ook een voordeel zijn. Hierdoor kan de partij namelijk een veelheid van kiezers aanspreken. Bovendien is het niet vreemd dat er binnen een partij verschillen bestaan voor wat betreft ideeën en standpunten. Fracties worden samengesteld op basis van een partijlijst op Landsniveau en niet op federaalniveau. Die mensen uit de verschillende Länder kunnen verschillende belangen, ideeën en standpunten hebben. Dit is anders in het Nederlandse parlement. Er bestaat weinig verschil tussen controle door coalitie- of oppositiefracties in het Nederlandse parlement. Controle wordt namelijk niet overgelaten aan de oppositie zoals in Duitsland het geval is. Uit de analyse van verschillende

10 Bijvoorbeeld de leden Bosbach (CDU) en Gauweiler (CSU) bij onderwerpen van de financiële crisis en het ESM en meer recent CDU-lid Maaßen, die vaak tegen het beleid van de regering is.

11 S. Hardt, 'Vrijdenkers en dwarsliggers in de Duitse Bundestag', Nieuwsbrief De Hofvijver 2021, 11(121). 
debatten valt op te maken dat coalitiefracties net zo 'hard' kunnen debatteren als oppositiefracties. Er bestaat uiteraard een band tussen de coalitiefracties en de regering maar deze zorgt er niet voor dat coalitiefracties milder zijn naar de regering dan oppositiefracties. Net zoals het Nederlandse parlement beschikt ook het Duitse parlement over meerdere controlebevoegdheden. Om te beginnen kan de Bundestag, de kamer die de regering controleert, gebruikmaken van twee vormen van het recht van interpellatie, namelijk grote (Große) en kleine (Kleine) interpellaties (Anfragen). Dit zijn de meest gebruikte vormen van controle. Op Kleine Anfragen wordt door de regering schriftelijk en binnen twee weken gereageerd. Große Anfragen worden doorgaans in een debat in de Bundestag behandeld. In 2010-2016 ging bijna zestien procent van de Kleine Anfragen en bijna dertig procent van de Große Anfragen over Europese aangelegenheden.

Net zoals in Nederland kunnen Duitse parlementsleden schriftelijke en mondelinge vragen stellen. Dit zijn individuele rechten van de leden, in tegenstelling tot de interpellaties; deze komen toe aan de Bundestag als geheel. Elk lid heeft het recht om per maand vier vragen te stellen. Per week mogen leden maximaal twee vragen stellen tijdens het vragenuur (Fragestunde). Aan het aantal schriftelijke en mondelinge vragen in de Bundestag is te zien dat hiervan veel gebruikgemaakt wordt. In 2010-2016 werden er in totaal 33.779 schriftelijke en 9.176 mondelinge vragen gesteld. Daarvan gingen er 2.722 respectievelijk 870 over Europese aangelegenheden. Dit is in beide gevallen nog geen tien procent van het totaal.

De Aktuelle Stunde, die met het Nederlandse dertigledendebat vergeleken kan worden, is een vervolg op het vragenuur. In de onderzoeksperiode hebben er 218 Aktuelle Stunden plaatsgevonden. Negentien hiervan hadden te maken met de Europese Unie. Procentueel is dit 8,7 procent. Het percentage ligt iets hoger dan bij het Nederlandse dertigledendebat. Tot slot is er nog de Regierungsbefragung (vragen aan de regering na het wekelijks kabinetsoverleg). In dit debat komt de minister met nieuwe informatie die daarvoor binnen het kabinet is besproken. Het is een kort debat van ongeveer 30 minuten waar slechts enkele vragen worden gesteld. Van de 131 Regierungsbefragungen tussen 2010 en 2016 gingen er twaalf over Europa. Dit ligt, met een percentage van 9,2, in de buurt van de schriftelijke en mondelinge vragen en de Aktuelle Stunde. Opgemerkt moet worden dat controle van de regering via specifieke controle-instrumenten, zoals hiervoor beschreven, wordt gedaan door de Bundestag en niet door de Bundesrat.

Wanneer strikt naar de cijfers wordt gekeken in relatie tot het aantal Kamerleden dan blijkt dat een lid van de Bundestag gemiddeld 11,6 keer per jaar gebruikmaakt van een (nationale) bevoegdheid om het Europees beleid van de regering te controleren. Een lid van de Tweede Kamer doet dit gemiddeld 18,7 keer per jaar. Het Nederlandse parlement is relatief gezien, beoordeeld naar het totaal van alle activiteiten, minder actief dan het Duitse parlement, maar per Kamerlid juist actiever. In het Duitse parlement wordt in totaal meer gebruik gemaakt van de controlebevoegdheden, maar dat is simpelweg te verklaren 
doordat het Duitse parlement meer leden heeft en meer ondersteuning. Uit deze statistische bevindingen volgt dat het Nederlandse parlement met betrekking tot Europese zaken een capaciteitstekort heeft.

Duidelijk is te zien dan het Duitse parlement twee van zijn nationale bevoegdheden vaker inzet voor Europese aangelegenheden dan het Nederlandse parlement. Dit zijn de Kleine en Große Anfragen. Daarbij moet in acht worden genomen dat het Duitse parlement meer dan vier keer zo groot is als het Nederlandse parlement. Procentueel wordt in Duitsland meer aandacht geschonken aan Europa dan in Nederland. Inzet van de andere bevoegdheden ligt ook hoger in Duitsland dan in Nederland maar niet veel.

Het gebruik van nationale bevoegdheden voor Europese aangelegenheden door beide parlementen is laag. Voor bijna alle bevoegdheden geldt dat het percentage over Europa niet boven de tien procent uitkomt met als uitzondering de Kleine en Große Anfragen binnen de Bundestag en de schriftelijke vragen binnen de Eerste Kamer. Voor Duitsland is dit te verklaren doordat er voor Europese aangelegenheden aparte bevoegdheden bestaan. Controle op dat gebied gebeurt met name op grond van deze daarvoor speciaal gecreëerde bevoegdheden en niet zozeer via algemene controlebevoegdheden. Zoals al aangegeven is het Duitse parlement veel groter dan het Nederlandse. Dit zou kunnen verklaren waarom in Duitsland vaker gebruik wordt gemaakt van controlebevoegdheden dan in Nederland. Meer parlementsleden, meer ambtenaren en meer expertise kunnen uiteindelijk meer werk verzetten.

\subsubsection{Enquêterecht}

Het recht op enquête komt beide Kamers van het Nederlandse parlement zowel gezamenlijk als afzonderlijk toe. Het enquêterecht is verwant aan het recht van interpellatie. Bij het laatste recht speelt de regering een actieve rol door inlichtingen te verstrekken. Bij het enquêterecht kunnen de Kamers zonder tussenkomst van de regering informatie verzamelen en daarbij burgers dwingen te verschijnen en antwoord te geven op vragen van de commissie. Ook bestaat er sinds 2016 de parlementaire ondervraging. Dit is een kortlopende parlementaire enquête gericht op het krijgen van mondelinge informatie. Het aantal enquêtes in zowel de Tweede Kamer als de Eerste Kamer over een Europees onderwerp bedraagt nul. Het aantal enquêtes in de Tweede Kamer in het algemeen is vrij laag met drie enquêtes in zeven jaar. Binnen de Duitse Bundestag kan een zogenoemde Untersuchungsausschuss (onderzoekscommissie) worden ingesteld naar aanleiding van een actuele situatie. Deze commissie doet onderzoek naar misstanden binnen de regering, de Bundestag of een regeringsperiode. Tussen 2010 en 2016 heeft de Bundestag negen onderzoekscommissies ingesteld. Geen van deze onderzoeken had Europese wetgeving tot onderwerp. Dus zowel in Nederland als in Duitsland wordt de parlementaire enquête of een onderzoekscommissie niet ingezet voor Europese aangelegenheden. Vermeld moet worden dat het Duitse 
enquêterecht een recht is van de parlementaire minderheid, in tegenstelling tot in Nederland, waar het een recht is van de meerderheid. Slechts 25 procent van de leden van de Bundestag hoeft een verzoek tot instelling van een Untersuchungsausschuss te ondersteunen. Daarnaast heeft het onderzoek een actueler karakter dan in Nederland. Doordat een minderheid het verzoek dient te steunen kan sneller naar (aanleiding van) een actuele gebeurtenis een onderzoek worden ingesteld. Desondanks worden er niet aan de lopende band onderzoekscommissies ingesteld en is het enquêterecht in Duitsland, net zoals in Nederland, een sporadisch gebruikt recht. Het recht wordt met name ingezet bij grote(re) onderwerpen, dan wel misstanden die ook daadwerkelijk onderzoek vergen. Als een Kamerlid informatie wil van de regering ligt het niet voor de hand om een enquête in te stellen. Als een Kamerlid snel antwoorden wil ontvangen of invloed wil uitoefenen ligt een enquête evenmin voor de hand, maar zijn er andere rechten die daarvoor kunnen worden ingezet.

\subsubsection{Parlementair voorbehoud}

Zowel het Nederlandse als het Duitse parlement kent een parlementair voorbehoud. Beide zijn gericht op Europese aangelegenheden. In Nederland komt het initiatief voor dergelijke voorbehouden vanuit de Kamer(commissie)s. Wanneer de Tweede Kamer of de Eerste Kamer een parlementair behandelvoorbehoud wenst te plaatsen dan deelt zij dit mede aan de regering c.q. de minister die deelneemt aan de beraadslaging in de Raad. De minister zal dit voorbehoud dan uitvoeren door geen onomkeerbare handelingen uit te voeren in de Raad alvorens in debat te gaan met het parlement. In Duitsland hangt het parlementair behandelvoorbehoud samen met een Stellungnahme van de Bundestag. Wanneer de Bundestag een Stellungnahme op grond van artikel 23 lid 3 van de Grondwet aanneemt of hiertoe voornemens is dan dient de minister een parlementair voorbehoud te plaatsen op Europees niveau. De minister dient eerst de Stellungnahme van de Bundestag af te wachten alvorens op Europees niveau te handelen. Kortom, in Nederland hangt de inzet van het voorbehoud af van de wens van de Kamer, in Duitsland is het een vereiste wanneer de Bundestag een Stellungnahme aanneemt. Een Stellungnahme is ook de wens van de Kamer maar het gaat erom dat het parlementair voorbehoud in het ene land een vereiste binnen een procedure is en in het andere land niet.

In de periode 2010-2016 heeft de Tweede Kamer 86 parlementaire behandelvoorbehouden geplaatst. In diezelfde periode heeft de Bundestag 75 Stellungnahmen op grond van artikel 23 lid 3 van de Grondwet aangenomen en daarmee heeft de regering ook 75 voorbehouden geplaatst. Qua aantal liggen de Tweede Kamer en Bundestag dicht bij elkaar.

De Eerste Kamer heeft nog geen gebruik gemaakt van het parlementair behandelvoorbehoud omdat zij vindt dat de 'normale' bevoegdheden toereikend zijn. De Bundesrat heeft een dergelijke bevoegdheid niet. 
Het behandelvoorbehoud is in beide landen een goed middel om het standpunt van het parlement over te brengen op de regering. In Nederland kan het parlementair behandelvoorbehoud worden gezien als een extra informatievoorziening. Wanneer het behandelvoorbehoud door de Kamer(s) wordt ingezet worden met de minister afspraken gemaakt over de informatie die de Kamer wenst te ontvangen. De Kamer wil hiermee aangeven dat het onderwerp van groot belang is. Het is niet zo dat de Kamer(s) kan (kunnen) bepalen wat de minister op Europees niveau moet doen maar zij kan (kunnen) de minister wel haar (hun) standpunt meegeven. Let wel, puur theoretisch is het behandelvoorbehoud een extra informatievoorziening maar in de praktijk wil de Kamer hiermee ook een signaal afgeven. De Kamer zegt met een dergelijk behandelvoorbehoud dat zij over het voorstel een sterkte mening heeft en graag zou zien dat de minister die mening meeneemt in het regeringsstandpunt. Uiteindelijk heeft de Kamer geen vetorecht en is het ook niet juridisch afdwingbaar dat de minister het standpunt meeneemt, maar wanneer dit laatste niet gebeurt, kunnen daar politieke consequenties aan verbonden worden.

De inzet van het behandelvoorbehoud kent geen duidelijke vereisten. Het is aan de Kamer(commissie)s zelf om te bepalen wanneer het voorbehoud wordt ingezet. Hierin is (voor buitenstaanders) niet altijd een rode draad te vinden. In Duitsland is dit overzichtelijker en een automatisch gevolg bij een Stellungnahme. Ook zijn de gevolgen van het voorbehoud positiever voor het Duitse parlement. De Duitse regering dient namelijk eerst in debat te gaan met de Bundestag en het officiële standpunt in acht te nemen bij de onderhandelingen en stemming op Europees niveau. De regering is niet verplicht het standpunt van de Bundestag over te nemen maar dient rekening te houden met het standpunt van de Bundestag bij de onderhandelingen. Indien de regering dit niet zal doen, zal zij de Bundestag hierover moeten informeren. Het Duitse behandelvoorbehoud is daarmee sterker dan het Nederlandse en ook de inzet ervan is duidelijker.

\subsubsection{Artikel 23 Duitse Grondwet en verwante wetten}

Het grote verschil tussen Nederland en Duitsland zit in wetgeving met betrekking tot de Europese Unie. In Nederlandse wetgeving komt de Europese Unie summier voor. De erkenning van het bestaan van de Europese Unie is terug te vinden in de Goedkeuringswet van het Verdrag van Lissabon, waarin in artikel 1 het Verdrag van Lissabon voor het gehele Koninkrijk wordt goedgekeurd. In de Grondwet is echter niets te vinden over de Europese Unie. De EU wordt daarin niet (als zodanig) genoemd. In maart 2017 hadden Tweede Kamerleden Marit Maij en Anne Mulder het voorstel van wet tot verbetering van de informatiepositie van de Staten-Generaal met betrekking tot de Europese Unie (Wet informatiepositie Staten-Generaal inzake de Europese Unie) ingediend. Na inwerkingtreding zou dit een van de weinige wetten zijn die in zijn geheel gericht is op de Europese Unie. De wet bevat geen nieuwe bevoegdheden voor het parlement maar kan worden gezien als een verzamelplaats van de bevoegdheden die het parlement heeft met betrekking tot de 
Europese Unie. De Duitse Grondwet kent een duidelijke verwijzing naar de Europese Unie. Naast artikel 50 van de Grondwet, waarin is opgenomen dat Länder via de Bundesrat een rol spelen in Europese aangelegenheden, bevat artikel 23 van de Grondwet de bevoegdheden en rechten van de Bundestag en Bundesrat met betrekking tot de EU. Zo is opgenomen dat de Bundestag en de Bundesrat het recht hebben een klacht in te dienen bij het Hof van Justitie van de Europese Unie wanneer wetgevingsbeleid in strijd is met het subsidiariteitsprincipe. Dat recht komt overigens ook het Nederlandse parlement toe op grond van artikel 8 Protocol nr. 2. ${ }^{12}$ Dit recht is dus opgenomen in Europese wetgeving maar voor de volledigheid ook in de Duitse Grondwet. ${ }^{13}$ Verder hebben de Bundestag en Bundesrat het recht om zo vroeg en volledig mogelijk geïnformeerd te worden over Europese aangelegenheden. Het belangrijkste recht van zowel de Bundestag als de Bundesrat is het recht om een standpunt (Stellungnahme) in te nemen dat door de regering in acht genomen dient te worden (en in sommige gevallen als leidend geldt). Een dergelijk sterk recht heeft het Nederlandse parlement niet. Ook het automatisme dat bij een Stellungnahme met betrekking tot nieuwe Europese wetgeving een parlementair behandelvoorbehoud geplaatst wordt door de regering, is niet terug te vinden in Nederland. Deze twee sterke onderdelen van het Duitse systeem zorgen ervoor dat het Duitse parlement een sterke positie heeft binnen Europese aangelegenheden. Het grote verschil zit met name in het feit dat een parlementair voorbehoud niet automatisch wordt ingezet in Nederland. Een van de Kamerleden moet de stap nemen om dit te initiëren; gebeurt dit niet dan zal er ook geen parlementair behandelvoorbehoud komen, wat weer betekent dat het parlement niet de extra informatie krijgt.

Artikel 23 van de Grondwet wordt in een drietal wetten verder uitgewerkt. Hierin wordt aangegeven hoe de bevoegdheden ingezet moeten worden en welke voorwaarden en procedures er gelden. Daar waar in Nederland procedures op verschillende plaatsen worden vastgelegd, zoals de ESM-afspraak in een brief of de procedure omtrent het parlementair behandelvoorbehoud, wordt in Duitsland alles op 'één' plaats verzameld.

Een dergelijke bepaling in de Grondwet geeft, samen met de drie formele wetten, duidelijkheid. Voor de Duitse parlementsleden vormt dit een houvast. Alle bevoegdheden met betrekking tot Europese aangelegenheden, met uitzondering van de algemene nationale bevoegdheden, zijn terug te vinden in deze wetgeving. Ook de procedures en voorwaarden zijn vastgelegd. Dit vergemakkelijkt de inzet van de bevoegdheden.

Daarnaast kent deze wetgeving een sterke bevoegdheid, namelijk de mogelijkheid tot een Stellungnahme (standpunt). Het Nederlandse parlement kent geen dergelijke sterke bevoegdheid, het instemmingsrecht en de motie daargelaten. Het Nederlandse parlement

12 Protocol nr. 2 betreffende de toepassing van de beginselen van subsidiariteit en evenredigheid (Verdrag van Lissabon).

13 Art. 8 Protocol nr. 2. 
kan zijn standpunten via onder andere vragen, debatten en moties kenbaar maken aan de minister. Het is uiteindelijk aan de minister en de regering gezamenlijk om het Nederlandse standpunt en de onderhandelingen in de Raad te bepalen. De Duitse Stellungnahme is een document waarin de Bundestag of de Bundesrat zijn standpunt uiteenzet. Deze Stellungnahme is juridisch niet af te dwingen maar het niet in acht nemen ervan kan tot politieke gevolgen leiden. Indien de regering deze niet meeneemt in haar standpunt en onderhandelingen dient zij dit te motiveren. Indien de Stellungnahme afkomstig is van de Bundesrat over een onderwerp waarop uitsluitend de Länder wetgevende bevoegdheid hebben, is de Stellungnahme leidend en moet de regering deze volgen. Op het gebied van buitenlands beleid en defensie- en integratiebeleid is de Stellungnahme van de Bundesrat bindend voor de federale regering. In dit laatste geval, maar dit geldt eigenlijk voor alle Stellungnahmen, komt de sterke positie van de Bundestag en Bundesrat naar voren. Via de Stellungnahme wordt namelijk het standpunt van de minister in de Raad bepaald.

De Duitse Stellungnahme lijkt op het eerste gezicht op de Nederlandse motie. Een motie is doorgaans een korte stelling van de Kamer. In één of twee zinnen wordt het standpunt van de Kamer kenbaar gemaakt. Een Stellungnahme daarentegen is weliswaar ook het standpunt van de Kamer, maar is veel meer uitgewerkt. Een Stellungnahme bevat een inleiding, een middelstuk met argumenten en overwegingen, met voors en tegens en details over het onderwerp en uiteindelijk een uitgebreid concreet standpunt. Daarnaast zijn er Stellungnahmen die bindend zijn voor de regering. Met andere woorden, de regering kan zelf geen afwijkend standpunt innemen. Alles samengenomen maakt dit de Duitse Stellungnahme een dwingender middel dan de Nederlandse motie.

\subsubsection{Gewone controlebevoegdheden vs. bijzondere controlebevoegdheden}

In Duitsland zijn er zogezegd twee soorten controlebevoegdheden, de gewone en de bijzondere. Onder de gewone vallen de kleine en Große Anfragen, schriftliche Fragen, mündliche Fragen, de Aktuelle Stunde en de Regierungsbefragungen. Onder de bijzondere vallen de rechten van de Bundestag en Bundesrat op grond van artikel 23 Grondwet en de drie verwante wetten.

Tabel 13 Bevoegdheden van de Bundestag ten aanzien van Europees beleid

\section{Controlebevoegdheid Bundestag Over/verwant aan de Euro- Percentage} pese Unie

\begin{tabular}{lll}
\hline Kleine Anfragen & 1195 & $23,7 \%$ \\
\hline Große Anfragen & 20 & $0,4 \%$ \\
\hline Schriftliche Fragen & 2722 & $54,0 \%$ \\
\hline Mündliche Fragen & 870 & $17,2 \%$ \\
\hline Aktuelle Stunden & 19 & $0,4 \%$
\end{tabular}




\section{Controlebevoegdheid Bundestag Over/verwant aan de Euro- Percentage pese Unie}

\begin{tabular}{lll}
\hline Regierungsbefragungen & 12 & $0,2 \%$ \\
\hline Stellungnahme o.g.v. art. 23 Gw & 206 & $4,1 \%$ \\
\hline Totaal & $\mathbf{5 0 4 4}$ & $\mathbf{1 0 0} \%$
\end{tabular}

In tabel 13 zijn de bevoegdheden van de Bundestag ten aanzien van Europees beleid opgenomen. De aantallen in de tweede kolom vormen samen honderd procent inzet van bevoegdheden om Europees beleid te controleren. Zoals te zien worden naar verhouding veel vaker de gewone bevoegdheden ingezet dan de bijzondere (de Stellungnahme). Dat is ook niet vreemd. De Stellungnahme is niet voor alles inzetbaar. Als een lid van de Bundestag informatie wil van de regering is het niet logisch om een Stellungnahme in te zetten.

Tabel 13 geeft aan dat controle van Europees beleid met name via Schriftliche Fragen en Kleine Anfragen gebeurt. Voor een Stellungnahme is een concreet document nodig zoals een wetgevingsvoorstel of een groen- of witboek maar het komt vaker voor dat de leden van de Bundestag vragen hebben of meer informatie willen over een concreet document of over beleid.

Zonder deze informatie kan de Bundestag ook geen Stellungnahme opstellen. Kortom, controle van Europese aangelegenheden is dus vaak een combinatie van verschillende controlebevoegdheden.

\subsection{OVERIGE ELEMENTEN VAN CONTROLE}

Of nationale parlementen invloed op Europees niveau kunnen uitoefenen en in welke mate hangt niet enkel af van de bevoegdheden die de nationale parlementen kunnen inzetten. Eveneens van groot belang zijn de processen die binnen de nationale parlementen worden gevolgd, hoe de nationale parlementen zijn ingericht en in hoeverre en in welke mate Kamerleden ondersteund worden. Deze paragraaf gaat in op deze aspecten. Allereerst zal worden ingegaan op het Bundesverfassungsgericht, daarna op de overleggen voorafgaand aan vergaderingen van de Raad en Europese Raad, de Kamercommissies binnen beide parlementen en de 'ambtelijke ondersteuning' en tot slot op interparlementaire samenwerking.

\subsubsection{Bundesverfassungsgericht}

Een groot verschil tussen de twee landen is dat Duitsland in tegenstelling tot Nederland een constitutioneel hof heeft. Dit constitutionele hof, het Bundesverfassungsgericht, is van 
belang voor de relatie tussen Duitsland en de EU. Zoals beschreven doet het hof uitspraken over de verenigbaarheid van Europees recht met de Duitse Grondwet, over de taken van de Bundestag zoals het optreden tegen ultra vires-handelingen van EU-instellingen en over de (reikwijdte van de) bevoegdheden van de Bundestag, denk daarbij aan het budgetrecht. Het al dan niet bestaan van een constitutioneel hof kan dus een verschil uitmaken voor nationale parlementen. Het hof bewaakt de rol van de parlementen. Concreet is dit tot uiting gekomen in de uitspraken Lissabon, ESM, OMT en Weiss. Met name door de ESM-uitspraak heeft de Bundestag een speciale positie gekregen binnen de EU, althans binnen het kader van ESM-besluiten.

Ook bij nieuwe Europese verdragen zal het Bundesverfassungsgericht bekijken in hoeverre die verdragen verenigbaar zijn met het Duitse recht, maar ook in hoeverre de bevoegdheden van de Bundestag in gedrang komen en dus juist de aandacht vestigen op bevoegdheden van de Bundestag in Europese aangelegenheden. Kortom, het Duitse parlement heeft een beschermer die met enige regelmaat aan de bel trekt.

Wanneer een land, zoals Nederland, geen constitutioneel hof heeft, moet het parlement zelf zijn eigen beschermer zijn. Het punt in Nederland is dan dat het Nederlandse parlement dit niet of nauwelijks is. Het Nederlandse parlement had eenzelfde rol als het Duitse parlement in de ESM-besluiten kunnen afdwingen maar heeft dat niet gedaan. Ook de reikwijdte van de bevoegdheden van het parlement dient door het parlement zelf te worden bepaald. Er is niemand anders die dit voor het parlement doet.

Wat het Nederlandse parlement wel heeft gedaan is enkele ad-hocafspraken maken met de regering. Dit zijn de afspraken die verwacht kunnen worden van een parlement als er geen constitutioneel hof is. Het gaat dan met name om de afspraak om een parlementair behandelvoorbehoud in te zetten bij toekomstige ESM-besluiten en de inspraak bij toekomstige handelsverdragen zoals het CETA-verdrag. Met betrekking tot de afspraak over toekomstige handelsverdragen is de rol van het Nederlandse parlement niet heel sterk. De minister zal het standpunt van de Kamer meenemen op Europees niveau maar de minister is niet gebonden aan dat standpunt. Kijken we naar de afspraak omtrent ESM-besluiten dan is de rol van het Duitse parlement vele malen sterker. Het Duitse parlement dient goedkeuring te verlenen, het Nederlandse parlement dient door de regering alleen uitvoerig geïnformeerd te worden maar heeft geen veto. Het Bundesverfassungsgericht heeft voor de Bundestag een sterke rol opgeëist. Een rol die door de Bundestag moet worden uitgevoerd en die door de regering moet worden geaccepteerd, opgelegd door een 'derde', namelijk het Bundesverfassungsgericht. Dat laatste is van belang omdat in Nederland een dergelijke rol door het parlement zelf dient te worden gecreëerd, via wetgeving of een afspraak, maar daarbij dient de regering in te stemmen. In Duitsland heeft de regering geen keuze en wordt een en ander door het Bundesverfassungsgericht opgelegd. Het wel of niet hebben van een constitutioneel hof maakt hier een groot verschil voor de rol en plaats en bevoegdheden van nationale parlementen. 


\subsubsection{Overleg voorafgaand aan vergadering van de Raad en Europese Raad}

In Nederland speelt het algemeen overleg een belangrijke rol bij de controle van Europees beleid. Het is ondenkbaar dat een minister naar een vergadering van de Raad gaat zonder eerst met de Kamer te hebben gesproken in de vorm van een AO. In Duitsland worden de debatten niet in zoveel verschillende soorten (commissie)debatten onderverdeeld als in Nederland. Er is dan ook geen Duits equivalent van het algemeen overleg. Wel bestaat er overleg tussen de minister die deelneemt aan de Raadsvergadering en de Kamercommissie. Dit gebeurt echter niet in dezelfde strakke vorm als in Nederland, dus áltijd voorafgaand aan een Raadsvergadering. In Duitsland is er wel degelijk aandacht voor de Raadsvergaderingen maar dat gebeurt, anders dan in Nederland, door inzet van de controlebevoegdheden van de Bundestag enerzijds en de informatieplicht van de regering anderzijds. Wat daarmee bedoeld wordt, is dat de regering de plicht heeft om de Bundestag, doorgaans via de Kamercommissie, te informeren over de Raadsvergaderingen en alles wat daarbij speelt. De Bundestag kan daarop reageren door gebruik te maken van de verschillende controlebevoegdheden, zoals het vragenrecht.

Met betrekking tot een Raadsvergadering is de Nederlandse procedure strakker dan de Duitse maar dat betekent niet dat het Duitse parlement geen invloed probeert uit te oefenen. In Nederland gebeurt dat in het algemeen overleg door te debatteren, in Duitsland gebeurt dat door de inzet van de verschillende controlebevoegdheden. Daarbij hangt het ervan af wat de leden van de Bundestag op dat moment de geschiktste controlevorm achten.

Met betrekking tot de vergaderingen van de Europese Raad zijn meer gelijkenissen te zien. Voorafgaand aan een dergelijke vergadering gaat in Nederland de minister-president in debat met de Tweede Kamer. Debatten in de Tweede Kamer volgen een strikt stramien. Allereerst krijgen de verschillende fracties tijd voor hun eerste termijn met eventuele interrupties, daarna volgt de termijn van de minister-president waarin de Kamer over het kabinetsstandpunt en de onderhandelingspositie wordt geïnformeerd en waarin de minister-president reageert op de eerste termijn van de fracties. Daarna volgt een tweede termijn op dezelfde wijze. In Duitsland gebeurt ongeveer hetzelfde wanneer de bondskanselier de Bundestag informeert via de Regierungserklärung. Dit gebeurt ook in de vorm van een debat waarin alle fracties de mogelijkheid hebben om te reageren op de Regierungserklärung. In Duitsland begint het debat dus met de inbreng, de Regierungserklärung, van de bondskanselier en zijn daarna de verschillende fracties aan de beurt. Debatteren gebeurt in Duitsland in mindere mate via interrupties maar door eigen inbreng van elke fractie.

Hoe precies gedebatteerd wordt in beide landen is verschillend maar van belang is dat zowel de Nederlandse minister-president als de Duitse bondskanselier voorafgaand aan een vergadering van de Europese Raad in debat gaat met het parlement. 


\subsubsection{Kamercommissies}

De bevoegdheden die de nationale parlementen toekomen, komen toe aan het parlement in zijn geheel, dus de gehele Tweede Kamer, Eerste Kamer (en soms de gezamenlijke vergadering), Bundestag en Bundesrat, in tegenstelling tot de rechten voor individuele parlementsleden. De uitoefening van de bevoegdheid binnen de parlementen gebeurt echter door de Kamercommissies. Parlementen zijn verdeeld in meerdere permanente en ad hocKamercommissies. De jure worden alle besluiten plenair genomen. De facto wordt controle op Europees beleid uitgevoerd door de Kamercommissies. Dit geldt in zowel het Nederlandse als het Duitse parlement.

Een groot verschil tussen Nederland en Duitsland is de commissie voor Europese Zaken. Alle vier de Kamers van het Nederlandse en Duitse parlement hebben een dergelijke commissie maar alleen in Duitsland hebben deze commissies een bijzondere positie. Zij zijn namelijk bevoegd om zelfstandig besluiten te nemen ten aanzien van het innemen van Stellungnahmen, waarover plenair niet gestemd hoeft te worden. Een dergelijk sterke positie die de commissie voor Europese Zaken in de Bundestag of Bundesrat heeft, heeft de Nederlandse variant niet. Binnen het Nederlandse parlement worden uiteindelijk alle besluiten plenair genomen.

Een ander opvallend punt van de commissie voor Europese Zaken van de Bundestag, is dat naast leden van de Bundestag ook leden van het Europees Parlement zitting hebben in de commissie. De leden van het Europees Parlement nemen actief deel aan de werkzaamheden van de commissie maar hebben geen stemrecht.

Een ander verschil tussen de Kamercommissies van beide parlementen is het aantal Kamercommissies. In Nederland ligt het aantal tussen twaalf en vijftien per Kamer. Dat komt overeen met het aantal Kamercommissies van de Bundesrat. De Bundestag daarentegen heeft er meer dan twintig. De reden hiervan is dat de Bundestag veel meer leden heeft dan de Tweede Kamer waardoor er voor meer onderwerpen commissies kunnen worden ingesteld en bemenst. De fracties in de Bundestag zijn in het algemeen groter waardoor een fractie in meerdere (ofwel alle) commissies kan zitten. In de Tweede Kamer is daar geen capaciteit voor. Dat betekent niet dat bepaalde onderwerpen niet worden besproken in de Tweede Kamer maar de Kamercommissies in de Tweede Kamer behandelen ieder meerdere onderwerpen.

\subsubsection{Ambtelijke ondersteuning}

Ambtelijke ondersteuning is van groot belang voor parlementsleden om hun taken uit te voeren. Ambtenaren ondersteunen parlementsleden op alle mogelijk vlakken: bij de 
voorbereiding van debatten, werkbezoeken, behandeling van nieuwe wetgeving, op juridisch gebied, politiek gebied, onderzoek en nog veel meer. Naast de mensen die in dienst zijn van politieke partijen zijn in het Nederlandse en Duitse parlement een groot aantal ambtenaren in dienst. De Tweede Kamer heeft ongeveer $100 \mathrm{fte}$. beschikbaar voor inhoudelijke ondersteuning, de Eerste Kamer ongeveer $25 \mathrm{fte}$. Dit betekent in beide gevallen dat er minder ambtenaren werkzaam zijn dan er parlementsleden zijn. In de Duitse Bundestag is sprake van het omgekeerde. De Bundestag heeft ongeveer drieduizend ambtenaren in dienst die de parlementsleden ondersteunen in hun werk. Dit komt neer op vier of vijf ambtenaren per lid van de Bundestag. In totaal werken er zo'n zesduizend mensen voor de Bundestag dus de voornoemde drieduizend ambtenaren zijn alleen ter (inhoudelijke) ondersteuning van de leden. Voor de Bundesrat geldt ook dat er meer ambtenaren zijn dan leden. De Bundesrat heeft ongeveer tweehonderd ambtenaren in dienst. Dat zijn ongeveer drie ambtenaren per lid van de Bundesrat. Daarnaast worden de leden van de Bundesrat ook ondersteund door hun eigen ambtenaren die in de verschillende Länder werkzaam zijn. Het ambtenarenapparaat van de Bundesrat is dus nog vele malen groter dan de tweehonderd ambtenaren die in dienst zijn van de Bundesrat.

Aangezien er zoveel ambtenaren in de Bundestag en Bundesrat werkzaam zijn, is het in het Duitse parlement mogelijk om meerdere onderwerpen in de gaten te houden, een grote onderzoeksafdeling te hebben, meer expertise in huis te hebben en een documentatiecentrum te runnen, wat zou kunnen bijdragen aan meer en gedetailleerdere controle van de regering en Europese Commissie. Dit is voor het Nederlandse parlement niet mogelijk. Het aantal ambtenaren per parlementslid in het Nederlandse parlement ligt beduidend lager dan in het Duitse parlement. In de Eerste en Tweede Kamer werken zelfs minder ambtenaren voor inhoudelijke ondersteuning dan dat er Kamerleden zijn. ${ }^{14}$

De omvang van de ondersteuning van de parlementen verschilt aanzienlijk. In Duitsland werken in de Bundestag meer ambtenaren dan parlementsleden. Daarbij krijgen de leden van de Bundestag maandelijks een bedrag van $€ 22.795$ om externe krachten in te huren. Voor de Bundesrat komt daar nog bij dat de vertegenwoordigers in de Bundesrat niet alleen ondersteund worden door ambtenaren van de Bundesrat maar ook uit de Länder. Zoals aangegeven, elke vertegenwoordiger brengt nog een aantal 'eigen' ambtenaren mee. Die omvang van ondersteuning en daarmee expertise, is iets waarvan men in de Nederlandse Eerste en Tweede Kamer alleen maar kan dromen.

Een groot ambtenarenapparaat kan ook nadelen hebben. Zo is het voor te stellen dat het zeer complex is en bureaucratisch maar de voordelen wegen zwaarder. Hoe meer

14 Ook op decentraal niveau is er weinig ondersteuning. Bijna alle fracties van de gemeenteraad van Amsterdam hebben daarom gezamenlijk een motie ingediend om het budget voor ondersteuning met vijftig procent te verhogen, zie website Nederlandse Vereniging voor Raadsleden. 
expertise er is, hoe beter de leden van de Bundestag tegenwicht kunnen bieden aan de minister. In Nederland moet de expertise met name bij de Kamerleden zelf zitten en komt de inzet daarvan neer op de bereidheid van Kamerleden om zich te verdiepen in bepaalde zaken en/of misstanden. Zij moeten dit doen zonder (veel) ondersteuning van ambtenaren. De voor- en nadelen overziend zorgt een groter ambtenarenapparaat voor meer uitoefening van bevoegdheden.

\subsubsection{Interparlementaire samenwerking}

Interparlementaire samenwerking vormt een van de manieren om Europese besluitvorming te beïnvloeden. Uit onderzoek komt naar voren dat de belangenbehartiging van nationale standpunten door Nederlandse parlementariërs positief is. Dat wil zeggen dat de belangenbehartiging consistent is, zeer transparant en dat alle belangen worden meegenomen in de onderhandelingen tijdens interparlementaire bijeenkomsten. ${ }^{15}$ Hetzelfde geldt voor Duitsland, alleen wordt de belangenbehartiging door Duitse parlementariërs als succesvoller gezien dan die door de Nederlandse parlementariërs. ${ }^{16}$ Ook blijkt uit onderzoek dat leden van de Tweede Kamer te weinig afreizen naar Brussel. Een verklaring hiervoor is de geringe ambtelijke ondersteuning voor de leden. De leden van de Duitse Bundestag zijn vaker in Brussel te vinden, wat juist te maken heeft met de ruimhartige ambtelijke ondersteuning van de leden. ${ }^{17}$

Interparlementaire samenwerking tussen nationale parlementariërs en parlementariërs van het Europees parlement zorgt ervoor dat ook nationale standpunten in het Europees Parlement worden gehoord. Het zetelaantal van een lidstaat in het Europees Parlement speelt echter een rol. Daarin verschillen Nederland en Duitsland veel van elkaar. Ook de posities van individuele leden van het EP zijn van belang. Rapporteurs in het Europees Parlement hebben namelijk veel invloed op de Europese besluitvorming. Het is dus voordelig voor nationale parlementen wanneer een van hun Europarlementariërs een rapporteurschap bekleedt. ${ }^{18}$

Zowel leden als ambtenaren van beide parlementen nemen deel aan de bijeenkomsten van COSAC. De delegatie van de Bundestag bestaat doorgaans uit een zestal mensen: vier leden van de commissie voor Europese Zaken en twee ambtenaren. ${ }^{19}$ Vanuit de Bundesrat worden

15 B. Dekker e.a., Weinig empathisch, wel effectief. Percepties van Nederlandse belangenbehartiging in de Europese Unie (Clingendael Rapport), Den Haag: Nederlands Instituut voor Internationale Betrekkingen Clingendael 2019, p. 13.

16 Ibid., p. 12.

17 Ibid., p. 12.

18 Ibid., p. 17-18.

19 De lijst met vertegenwoordigers per parlement kan voor elke COSAC-bijeenkomst op ipex worden gevonden. 
meestal twee personen afgevaardigd: een vertegenwoordiger van de Bundesrat en een ambtenaar. Ook vanuit de Tweede Kamer nemen elke keer zo'n zes personen deel aan de bijeenkomsten. Daarvan zijn er doorgaans vier lid van de commissie voor Europese Zaken en twee zijn staflid. De grootte van de delegatie van de Eerste Kamer ligt rond de drie personen betstaande uit twee leden van de commissie voor Europese Zaken en één staflid. In de periode 2010-2016 zijn alle kamers vertegenwoordigd geweest bij elke COSAC-bijeenkomst. Voor andere interparlementaire samenwerkingsverbanden zijn geen aanwezigheidslijsten te vinden. Wel is er hier en daar een schriftelijke inbreng van een (kamer van een) parlement te vinden, maar dat betekent niet automatisch dat er vanuit dat parlement ook vertegenwoordigers aanwezig waren. Kortom, alleenl voor COSAC is vast te stellen dat vertegenwoordigers van zowel het Nederlandse als het Duitse parlement aanwezig zijn geweest bij alle bijeenkomsten.

\subsection{TusSENCONCLUSIE}

De vergelijking tussen het Nederlandse en het Duitse parlement is opgesplitst in drie elementen: Europese bevoegdheden, nationale bevoegdheden en overige elementen. Voor wat betreft de inzet van Europese bevoegdheden kan worden geconcludeerd dat in beide parlementen ongeveer op dezelfde wijze wordt gehandeld. Nieuwe Europese wetgeving of andere documenten worden in de Kamercommissies behandeld. Daar wordt besloten welke bevoegdheden er ten aanzien van de nieuwe wetgeving of documenten worden ingezet. Indien wordt besloten tot het aangaan van een politieke dialoog is te zien dat de Nederlandse Tweede Kamer en Eerste Kamer en de Duitse Bundestag qua aantallen op één lijn zitten. In de periode 2010-2016 hebben deze drie Kamers 23 tot 41 politieke dialogen gestart. Buitenbeentje vormt, door zijn eigen specifieke positie en samenstelling en rol, de Duitse Bundesrat met 246 politieke dialogen.

De andere 'Europese bevoegdheid' is de gelekaartprocedure. In deze procedure is het Nederlandse parlement actiever dan het Duitse. De Bundestag heeft vanaf 2013 tot 2016 geen met redenen omklede adviezen gestuurd. Hetzelfde geldt voor de Bundesrat maar dan vanaf 2014. Dit heeft met een aantal factoren te maken, te weten de verkiezingen van de Bundestag in 2013, de verkiezingen van het Europees Parlement in 2014 en de daaraan gekoppelde nieuwe Europese Commissie. Ook het soort nieuwe wetgevingsvoorstellen speelt mee. Het Duitse parlement zag en ziet hierin geen of weinig subsidiariteitsproblemen. Tot slot zijn de Bundesrat en Bundestag vermoedelijk minder gecharmeerd van de gelekaartprocedure en vinden zij dit geen effectief middel (meer) om invloed uit te oefenen.

Beide parlementen kennen ongeveer dezelfde nationale controlebevoegdheden. Er zit wel enig verschil in het parlementair inlichtingenrecht, maar dat verschil lijkt materieel geen 
gevolgen te hebben. Beide landen kennen een algemeen recht van het parlement om geïnformeerd te worden door de regering. Duitsland kent daarnaast ook een specifiek inlichtingenrecht voor wat betreft Europese aangelegenheden. De inhoud is niet anders dan het algemene recht. In beide gevallen geldt dat de regering het parlement volledig en zo vroeg mogelijk hoort te informeren.

Met betrekking tot de inzet van de nationale controlebevoegdheden zijn enkele kleine verschillen te ontdekken. Het Nederlandse interpellatierecht en de dertigledendebatten zijn te vergelijken met de Duitse Große en Kleine Anfragen. In Nederland wordt het interpellatierecht nauwelijks gebruikt omdat dertigledendebatten meer ruimte geven voor controle. Er zijn in Nederland dan ook geen interpellaties geweest over Europa. Vijf procent van de dertigledendebatten heeft een Europees onderwerp. In Duitsland gaat bijna zestien procent van de Kleine Anfragen en bijna dertig procent van de Große Anfragen over Europa. Het verschil tussen het aantal Große en Kleine Anfragen heeft te maken met de mogelijkheid om invloed uit te oefenen. Een Kleine Anfrage is niets meer dan het stellen van vragen aan de regering waardoor de mogelijkheid om invloed uit te oefenen beperkt is. Große Anfragen worden tijdens een debat behandeld. Het is dan voor leden van de Bundestag mogelijk om hun standpunten kenbaar te maken via die Anfrage en daarbij kunnen tijdens het debat kritische vragen worden gesteld aan de regering. Er zijn dan dus meer mogelijkheden om invloed uit te oefenen. Ook zegt de Bundestag met een Große Anfrage zelf al dat het gaat om een belangrijk onderwerp (anders zou men het in een Kleine Anfrage hebben verpakt). Uiteindelijk heeft de Bundestag het onderwerp 'Europa' veel vaker op de agenda staan dan het Nederlandse parlement. Daarbij komt dat een Große Anfrage wordt gezien als het belangrijkste controlemiddel dat wordt ingezet bij grote politieke vraagstukken.

Het aantal schriftelijke en mondelinge vragen van de Tweede Kamer over Europa bedraagt vier respectievelijk twee procent van het totaal. In de Eerste Kamer ligt het percentage iets hoger. Dertien procent van de schriftelijke vragen gaat over Europa. Daar heeft acht procent van de schriftelijke vragen en 9,5 procent van de mondelinge vragen een Europees onderwerp. In de Bundestag gaat 8,1 procent van alle schriftelijke vragen over Europa en 9,5 procent van de mondelinge vragen. Er wordt in beide parlementen dus meer gebruikgemaakt van deze vormen van vragen stellen voor nationale aangelegenheden dan voor Europese aangelegenheden.

Het parlementair enquêterecht is in beide landen niet ingezet voor controle op Europees beleid. Dit wordt kennelijk binnen beide parlementen niet als een geschikt middel gezien om Europees beleid te controleren. Het enquêterecht wordt in beide parlementen ingezet voor controle achteraf van grote onderwerpen of misstanden. Het is dus geen middel om vooraf invloed uit te oefenen op Europees beleid en dat is wel waar het om draait. Daarbij moet wel vermeld worden dat het enquêterecht in beide landen voor verschillende doelen wordt ingezet. Het instrument is, ondanks dezelfde naam, niet hetzelfde. 
Verder is er nog het parlementair behandelvoorbehoud. Het grote verschil hierin zit in diegene die het initiatief neemt tot het plaatsen van een behandelvoorbehoud. In Nederland komt het initiatief van (de Kamercommissies binnen) de Tweede Kamer of Eerste Kamer. In Duitsland is een parlementair behandelvoorbehoud een gevolg wanneer de Bundestag een Stellungnahme neemt op basis van artikel 23 lid 3 van de Grondwet. Het initiatief tot een Stellungnahme komt weliswaar van de Bundestag maar het is de minister die het parlementair behandelvoorbehoud dient te plaatsen. Buiten dit verschil zijn er geen grote andere verschillen waar te nemen aangezien het aantal geplaatste voorbehouden niet ver uit elkaar ligt. De Tweede Kamer plaatste namelijk 86 behandelvoorbehouden. De Bundestag nam 75 Stellungnahmen aan waardoor de regering ook 75 behandelvoorbehouden heeft moeten plaatsen. Materieel gezien maakt dit dus weinig verschil.

Tot slot zijn er nog de overige elementen van controle. In dat verband werd het Bundesverfassungsgericht behandeld. Het bestaan van een constitutioneel hof heeft voordelen voor het nationale parlement. Het Duitse Bundesverfassungsgericht is duidelijk een beschermer van het Duitse parlement. Het waakt over de bevoegdheden van het parlement en geeft via uitspraken uitleg over de reikwijdte en invulling van die bevoegdheden. Deze uitspraken moeten worden gevolgd door de regering, ook als ze nadelig zijn voor de regering. Nederland heeft geen constitutioneel hof, wat betekent dat het parlement zelf over de bevoegdheden moet waken. Hierdoor bestaat er een verschil tussen het Nederlandse en het Duitse parlement. Het Duitse parlement (lees: de Bundestag) heeft op bepaalde gebieden, denk aan de ESM-besluiten, een vele sterkere positie binnen de EU dan het Nederlandse parlement en dat heeft de Bundestag te danken aan het Bundesverfassungsgericht. Kortom, uit dit onderzoek blijkt dat het bestaan van een constitutioneel hof een positieve uitwerking heeft voor de rol van nationale parlementen ten opzichte van de eigen regering in de EU en ten aanzien van EU-gerelateerde besluiten.

Ook de debatten tussen de minister(-president) of de bondskanselier en het parlement voorafgaand aan een vergadering van de Europese Raad of Raad vormen een onderdeel binnen de controle van Europese aangelegenheden. Voor wat betreft de vergaderingen van de Europese Raad zien we tussen Duitsland en Nederland weinig verschil. In beide landen gaat de regeringsleider in debat met het parlement. Met betrekking tot de vergadering van de Raad zijn er wel verschillen op te merken. In Nederland wordt een strakke procedure gevolgd. De minister gaat altijd voorafgaand in debat, een algemeen overleg, met de Kamer; bij uitzondering gebeurt dit schriftelijk. Het is in Nederland dan ook ondenkbaar dat dit niet gebeurt. In Duitsland gebeurt de controle voorafgaand aan een Raadsvergadering minder strikt. De regering is weliswaar verplicht om de Kamer over de vergadering te informeren maar er is geen strikte procedure zoals in Nederland. Het is mogelijk dat leden van de Bundestag vragen stellen over een Raadsvergadering maar dat 
hoeft niet. Het hoeft dus niet zo te zijn dat de minister uitvoerig met de Bundestag heeft gesproken alvorens hij naar de Raad gaat.

Aangaande de Kamercommissies is veel gelijkenis te zien. Kamercommissies zijn in het algemeen hetzelfde opgebouwd, de leden zijn een afspiegeling van het parlement en hebben dezelfde werkzaamheden. In beginsel wordt het werk in beide parlementen door Kamercommissies gedaan en worden de uiteindelijke besluiten plenair genomen. Er is één groot verschil waar te nemen en dat zit in de Kamercommissie voor Europese Zaken in de Bundestag. Dit is de enige commissie die zelfstandig besluiten mag nemen namens de gehele Bundestag zonder dat daar plenair over gestemd hoeft te worden. Dit recht heeft geen enkele andere Kamercommissie binnen de Bundestag, Tweede Kamer of Eerste Kamer. Wel moet daarbij worden opgemerkt dat in de praktijk de commissie voor Europese Zaken van de Bundestag nauwelijks gebruik maakt van deze mogelijkheid om namens de Bundestag besluiten te nemen.

Beide parlementen worden ondersteund door ambtenaren. Voor wat betreft het aantal ambtenaren zijn er echter grote verschillen tussen de parlementen. Het Duitse parlement heeft veel meer ambtenaren in dienst dan het Nederlandse parlement, niet alleen qua aantallen maar ook naar aantal ambtenaren dat per parlementslid beschikbaar is. In Nederland zijn in beide Kamers minder ambtenaren in dienst dan het aantal Kamerleden. In Duitsland is sprake van het omgekeerde. Aan ieder lid van de Bundestag staan vier tot vijf ambtenaren ter beschikking en per lid van de Bundesrat zijn dit drie ambtenaren. In vergelijking met het Duitse parlement heeft het Nederlandse parlement weinig ondersteuning. Daarnaast is de ondersteuning in het Nederlandse parlement vaak werkzaam op meerder beleidsterreinen en voor meerdere Kamercommissies.

Omdat het Duitse parlement meer ambtenaren in dienst heeft, kunnen de parlementsleden meer werk verzetten. Neem alleen al het aantal Stellungnahmen door de Bundesrat. Voor het nemen van gemiddeld 180 Stellungnahmen per jaar is veel ondersteuning nodig. Dit kunnen parlementsleden niet alleen doen.

Interparlementaire samenwerking is een belangrijke taak van nationale parlementen. Uit onderzoek blijkt dat beide landen hierin enigszins verschillen. De aanpak van Duitsland wordt als succesvoller gezien. Dit ligt waarschijnlijk daaraan dat Duitse parlementsleden actiever zijn in parlementaire samenwerking, met andere woorden, zij reizen vaker naar Brussel dan de Nederlandse parlementariërs. 


\section{Hoofdstuk 6 ConCLUSie}

Dit onderzoek richt zich op de verschillen en overeenkomsten tussen het Nederlandse en het Duitse parlement in Europese aangelegenheden. De onderzoeksvraag die daaraan voorafging, is: In welke mate maakt het Nederlandse parlement van de hem toekomende bevoegdheden naar nationaal en Europees recht gebruik voor wat betreft Europese aangelegenheden? Om deze vraag te beantwoorden is in dit onderzoek een vergelijking gemaakt met Duitsland. Hierdoor kan ook de volgende centrale vraag worden beantwoord, namelijk: Kan het Nederlandse parlement zijn controle ten aanzien van Europese aangelegenheden verbeteren, al dan niet naar Duits voorbeeld, teneinde recht te doen aan het VEU, en de eigen nationale rol die het heeft ten aanzien van controle en vertegenwoordiging?

Bij de centrale vraag gaat het onder andere om de wenselijkheid of het Nederlandse parlement zijn bevoegdheden ten aanzien van Europese aangelegenheden dient vast te leggen in wetgeving naar Duits voorbeeld en/of de bestaande bevoegdheden dient te versterken of uit te breiden. Op basis van de vergelijking tussen het Nederlandse en het Duitse parlement worden aan het einde van dit onderzoek enkele aanbevelingen gedaan aan het Nederlandse parlement. Deze kunnen deels worden gezien als de zaken die het Nederlandse parlement kan leren van het Duitse parlement en deels als zelfstandige bevindingen van het Nederlandse onderzoek.

\section{Artikel 12 VEU}

Om enig perspectief te bieden aan de vraag of en, zo ja, hoe het parlement controle op Europese aangelegenheden dient te verbeteren of versterken, is het van belang om te weten wat een nationaal parlement in de Europese Unie naar EU-recht zou mogen en moeten doen. Hierbij wordt gekeken naar de taak van nationale parlementen die in Europees verdragsrecht en secundair recht is vastgelegd. Zoals in de inleiding van dit boek is besproken, hebben nationale parlementen immers naast nationale taken ook Europese taken. Met andere woorden, nationale parlementen dienen zich te bemoeien met Europese aangelegenheden. Dit is niet zozeer een opdracht die hun is opgelegd, maar zij hebben zichzelf deze taak toegewezen door akkoord te gaan met het Verdrag betreffende de Europese Unie. In artikel 12 van dit verdrag is de Europese taak van nationale parlementen vastgelegd.

Het is niet voor niets dat deze taak is gecreëerd. Voorheen (voor de totstandkoming van VEU en VWEU) werd gesproken over een democratisch tekort van de EU en over de kleine rol of zelfs de afwezigheid van nationale parlementen in de EU. Met het opnemen van deze taak in artikel $12 \mathrm{VEU}$ is een poging gedaan om dit tekort te verkleinen en de rol van nationale parlementen te vergroten. In artikel $12 \mathrm{VEU}$ is vrij dwingend geformuleerd 
dat nationale parlementen deze rol moeten oppakken: 'De nationale parlementen dragen actief bij tot de goede werking van de Unie'. Het is dus niet vrijblijvend geformuleerd met woorden als 'mogen bijdragen' of 'kunnen bijdragen'. Met andere woorden: artikel 12 schept geen bevoegdheid voor nationale parlementen om het goede functioneren van de Europese Unie te monitoren, maar de opdracht om er actief aan bij te dragen. Deze opdracht wordt gefaciliteerd doordat in een tweetal protocollen de gelekaartprocedure is gecreëerd alsmede de informatieverstrekking aan de nationale parlementen is geregeld. Het minste dat dan van nationale parlementen kan worden verwacht is deze taak serieus uit te oefenen en zich dus daadwerkelijk met Europese aangelegenheden te bemoeien.

$\mathrm{Nu}$ is de vraag wat concreet van een nationaal parlement kan en moet worden verwacht bij de uitoefening van zijn taak om actief bij te dragen aan het goede functioneren van de Europese Unie. Zoals in artikel $12 \mathrm{VEU}$ is opgenomen zien nationale parlementen toe op eerbiediging van het beginsel van subsidiariteit. Dat betekent niet dat elk nieuw wetsvoorstel een subsidiariteitsprobleem heeft maar wel dat nationale parlementen nieuwe wetsvoorstellen dienen te controleren op subsidiariteit. Gezien het belang van subsidiariteit is het noodzakelijk dat nationale parlementen in beginsel alle nieuwe voorstellen controleren met het oog op de vraag: 'Regelen we dit als lidstaat zelf of is dit een onderwerp dat door de EU geregeld dient te worden en geven we het dus uit handen?'. Dit betekent echter niet dat nationale parlementen meer met redenen omklede adviezen in de gelekaartprocedure moeten indienen dan nu gebeurt. Of hier noodzaak toe is, hangt af van de gevallen die zich voordoen waarin nationale parlementen oordelen dat het subsidiariteitsbeginsel wordt geschonden.

Wat samenhangt met de subsidiariteitscontrole en de gelekaartprocedure is deelname aan interparlementaire samenwerkingsverbanden. Ook die deelname is volgens artikel 12 VEU niet vrijblijvend. Deelname hieraan is namelijk te bezien in het licht van de (gezamenlijke) rol van nationale parlementen in hun plaats op het EU-niveau en van de versterking van hun democratische controle op de nationale executieve. Interparlementaire samenwerking kent immers vele voordelen. Denk bijvoorbeeld aan een goede werking van de gelekaartprocedure en de uitwisseling van informatie en beste praktijken tussen nationale parlementen. Ook draagt interparlementaire samenwerking bij aan de verbetering van de informatiepositie van de parlementen en de mogelijkheden tot nationale controle. Daardoor zou elk nationaal parlement moeten deelnemen aan deze verschillende samenwerkingsverbanden: zowel ter versterking van hun Europese rol als neergelegd in artikel 12 VEU als ter versterking van hun nationale controlefunctie, en tezamen genomen ter verbetering van de democratische legitimiteit van de EU. Europese samenwerking en de subsidiariteitscontrole vormen samen de twee randvoorwaarden voor nationale parlementen om hun EUtaak uit te oefenen. Uiteraard dient een nationaal parlement ook het gedrag van de eigen 
ministers met betrekking tot Europese aangelegenheden te controleren. Dit volgt niet uit Europese maar uit nationale wetgeving, maar dit is ook een belangrijk puzzelstukje in de bestrijding van het democratietekort.

\subsection{BEVINDINGEN}

Om de onderzoeksvraag en de centrale vraag te beantwoorden is allereerst gekeken naar de taken en bevoegdheden van parlementen die zijn neergelegd in Europese wetgeving (hoofdstuk 2). Deze taken en bevoegdheden zijn voor alle parlementen in de Europese Unie gelijk. Hoe en of deze worden uitgeoefend is een nationale zaak. Daarin kunnen verschillen worden ontdekt.

\section{Politieke dialoog}

Als eerste is gekeken naar de politieke dialoog. Uit dit onderzoek blijkt dat toepassing van dit instrument er nauwelijks toe leidt dat wetgevingsvoorstellen worden aangepast. Op basis van de politieke dialoog is de Commissie niet snel geneigd haar standpunten te wijzigen of de standpunten van nationale parlementen over te nemen. De antwoorden van de Commissie zijn veelal vaag en niet meer dan een herhaling van haar standpunten. Dat is vooral het geval als er geen grote eenstemmigheid is onder de nationale parlementen. Maar de invloed is anders wanneer een grote groep nationale parlementen gezamenlijk een dialoog met de Commissie start, zoals gebeurt wanneer een groene kaart wordt getrokken. In een dergelijk geval is de Commissie eerder geneigd om het standpunt van de nationale parlementen in acht te nemen. Daarbij moet worden opgemerkt dat er tot nu toe 'slechts' één groene kaart getrokken is. In dit geval verzochten de parlementen de Commissie een voorstel op te stellen om voedselverspilling binnen de Europese Unie tegen te gaan. In het pakket 'Circulaire energie' heeft de Commissie uiteindelijk regels opgenomen om voedselverspilling te voorkomen.

De groene kaart is niet officieel vastgelegd in Europese wetgeving maar desondanks is hiervan één keer succesvol gebruikgemaakt. Het is wellicht ook niet nodig om deze groene kaart vast te leggen, want het gaat hier om een gezamenlijk advies in de zin van de politieke dialoog. Dit betekent dat een groene kaart al sinds het ontstaan van de politieke dialoog bestaat.

Het is natuurlijk niet vreemd dat als er veel nationale parlementen achter een voorstel staan zoals bij de groene kaart (of zoals we hierna zullen zien bij de drie voorbeelden van de gele kaart), er ook veel regeringen achter het voorstel staan. In een dergelijk geval is het dus redelijk eenvoudig om van een voorstel een wet te maken omdat het op weinig verzet kan rekenen in de Raad; of om in de context van de gelekaartprocedure een voorstel te 
laten struikelen in de Raad of substantieel te wijzigen (al dan niet na discussie in en met het Europees Parlement).

In de onderzoeksperiode 2010-2016 stuurden nationale parlementen gemiddeld negentien adviezen per jaar aan de Commissie. De Duitse Bundesrat zat met een gemiddelde van 34 adviezen per jaar ver boven het gemiddelde. Dit heeft te maken met de druk die door de regeringen en parlementen uit de Länder wordt uitgeoefend via de Bundesrat. De bevoegdheid van de Bundesrat wordt kennelijk door de deelstaten gezien als een mogelijkheid om invloed uit te oefenen op Europese aangelegenheden. Dit is een uitdrukking van het Duitse federalisme, en vanuit Europees perspectief gezien, van regionalisme. Deze verwevenheid tussen de deelstaten en de Bundesrat (de Bundesrat wordt immers gevormd door vertegenwoordigers uit de deelstaten) is niet terug te vinden in Nederland. De Nederlandse Tweede Kamer en Eerste Kamer en de Duitse Bundestag liggen qua aantal adviezen dichter bij elkaar, met gemiddeld vijf, respectievelijk zes en drie adviezen per jaar. Vergeleken met de andere nationale parlementen binnen de Europese Unie behoren deze Kamers tot de middenmoot. Beide parlementen maken dus met enige regelmaat gebruik van de mogelijkheid om met de Europese Commissie in dialoog te gaan.

Wellicht kunnen bepaalde aspecten van de dialoog worden verbeterd, zoals de inhoud van de antwoorden van de Commissie. De dialoog neigt nu meer naar een monoloog van de Commissie omdat de antwoorden vaak herhalingen zijn, maar door het gebruik ervan laten nationale parlementen zien dat het toch een goed middel is om informatie uit te wisselen. Nationale parlement halen er vermoedelijk dus nog genoeg informatie uit om gebruik te maken van de politieke dialoog. Was dat niet het geval, dan zouden nationale parlementen er wellicht geen gebruik van maken. Wat betreft beïnvloeding van Europese aangelegenheden kan geconcludeerd worden dat argumenten succesvol kunnen zijn wanneer zij via parlementaire samenwerking met meerdere nationale parlementen worden gedaan.

De politieke dialoog mag dan een manier zijn voor nationale parlementen om te proberen om invloed uit te oefenen, in de praktijk is het een nuttig middel om informatie uit te wisselen tussen de Europese Commissie en nationale parlementen. Op dat gebied werkt de politieke dialoog zoals het is bedoeld, een dialoog. Nationale parlementen krijgen informatie van de Europese Commissie als ze erom vragen en ze kunnen zelf ook hun standpunten kenbaar maken aan de Commissie. De nationale parlementen zijn echter van mening dat de beantwoording door de Commissie voor verbetering vatbaar is. $\mathrm{Zij}$ geven aan dat de antwoorden vaag zijn en een herhaling van eerdere teksten. Wel zijn de nationale parlementen tevreden over de snelheid waarmee de Europese Commissie antwoordt. Kortom, de politieke dialoog heeft als doel informatie uitwisselen tussen nationale parlementen en de Europese Commissie en die functie vervult de dialoog ook. De politieke dialoog is dus niet gemaakt als instrument om invloed uit te oefenen door nationale parle- 
menten op de Europese Commissie. Dit laatste is wel eens gebeurd, denk bijvoorbeeld aan de groene kaart, en is ook een van de redenen waarom nationale parlementen een dialoog aangaan met de Europese Commissie. Toch is dit niet het doel van de politieke dialoog. Het is natuurlijk voor de controlefunctie van nationale parlementen wel van belang om goed geïnformeerd te zijn, want zonder informatie kan een parlement niet controleren.

\section{Gelekaartprocedure}

In de tweede plaats is gekeken naar de gelekaartprocedure. In de aanloop naar het Verdrag van Lissabon, waarin deze procedure is vastgelegd, en ook daarna is veel onderzoek gedaan naar de gelekaartprocedure. Onderzoekers komen tot de conclusie dat dit een nuttige bevoegdheid kan zijn en dat nationale parlementen daadwerkelijk invloed kunnen uitoefenen op Europese besluitvorming, maar dat dit alleen lukt wanneer meerdere nationale parlementen samenwerken. Deze samenwerking hoeft niet EU-breed te zijn maar kan op bilateraal niveau plaatsvinden, bijvoorbeeld tussen twee aangrenzende lidstaten. Dit gebeurt ook op regeringsniveau, denk aan de Duits-Franse samenwerking op basis van een vriendschapsverdrag, het Élysée-verdrag, waarin is bepaald dat op bepaalde beleidsterrein eerst met elkaar wordt afgestemd alvorens op Europees niveau wordt onderhandeld en gestemd.

Ondanks dit voorbeeld ontbreekt de samenwerking thans nog te vaak, waardoor er geen sprake is van een optimale werking van de procedure. Dit heeft onder andere te maken met de verschillende belangen van de verschillende lidstaten. Vaak zitten de parlementen van de verschillende lidstaten gewoonweg niet op één lijn. Nationale parlementen vinden ook de termijn van acht weken te kort om een deugdelijk advies op te stellen, en vooral ook samenwerking met andere parlementen te zoeken, hoewel juist in die samenwerking de sleutel lijkt te zitten.

Het Nederlandse parlement maakt gebruik van de gelekaartprocedure. De Tweede Kamer zendt ieder jaar minimaal één met redenen omkleed advies aan de Europese Commissie. De Eerste Kamer is iets minder actief daarin maar heeft in de periode 2010-2016 in totaal vijf adviezen gestuurd. Het Nederlandse parlement was bij twee van de drie gele kaarten betrokken (Monti II en Europees OM). Alle drie de kaarten die tot op heden zijn getrokken, zijn ook daadwerkelijk succesvol geweest.

Voor het Duitse parlement ziet het er qua aantallen niet veel anders uit. De Bundestag heeft in de periode 2010-2016 drie adviezen gestuurd en de Bundesrat tien adviezen. Het Duitse parlement was bij geen van de gele kaarten betrokken. Het Duitse parlement, in het bijzonder de Bundesrat, concentreert zich met name op de politieke dialoog en zijn 
nationale bevoegdheden om de Duitse regering te sturen in de Raad en om de positie van de Länder in de EU te versterken.

In beide parlementen worden niet alle wetgevingsvoorstellen gecontroleerd op subsidiariteit. Dit betekent dat beide parlementen op de Europese Commissie moeten vertrouwen voor wat betreft de subsidiariteit van wetsvoorstellen die niet gecontroleerd worden. Dit betekent strikt genomen ook dat beide parlement hun taak uit artikel 12 VEU niet uitvoeren. Het is namelijk aan de nationale parlementen om de subsidiariteit te controleren.

De Europese Commissie bepaalt of een advies van een lidstaat daadwerkelijk een advies is in de gelekaartprocedure, een zogenoemd subsidiariteitsbezwaar, of dat het gaat om een advies in de politieke dialoog. Het Nederlandse en Duitse parlement zijn zich er duidelijk van bewust aan welke eisen een advies in de gelekaartprocedure moet voldoen. Elk advies dat vanuit een van deze parlementen is verstuurd als subsidiariteitsbezwaar werd als zodanig opgevat door de Commissie. Daarbij moet worden vermeld dat wanneer de drempels van de gelekaartprocedure niet worden gehaald een subsidiariteitsbezwaar wordt behandeld in de politieke dialoog.

Ondanks de verbeterpunten van de gelekaartprocedure zijn tot op heden drie gele kaarten getrokken. Deze drie kaarten zijn allemaal succesvol geweest. Deze gele kaarten hebben ervoor gezorgd dat de wetgevingsvoorstellen uiteindelijk zijn ingetrokken of gewijzigd. Daarmee kan gezegd worden dat de gelekaartprocedure een middel is om invloed uit te oefenen op wetgeving van de Commissie en dat nationale parlementen daadwerkelijk een rol (kunnen) spelen in het Europese wetgevingsproces. Voor de een zal drie kaarten veel zijn, voor de ander weinig, maar waar het in dit onderzoek om gaat, is dat gebruik wordt gemaakt van de procedure, want dat is immers onderdeel van de taak van nationale parlementen, en dat ook is bereikt wat men bij het opstellen van de procedure voor ogen had. Met dat laatste wordt niets meer bedoeld dan dat nationale parlementen een stem hebben op Europees niveau.

\section{Interparlementaire samenwerking}

Zoals hierboven is beschreven speelt samenwerking tussen nationale parlementen een grote rol bij de (effectieve) uitoefening van taken en bevoegdheden. Samenwerking vindt onder andere plaats in de vele interparlementaire conferenties. Deze conferenties hebben als doel het uitwisselen van informatie en beste praktijken en het bevorderen van samenwerking met derde landen. Het bestaan van interparlementaire samenwerking en de plicht van nationale parlementen om hieraan deel te nemen is neergelegd in artikel 12 VEU. 
Volgens het verdrag dienen nationale parlementen actief bij te dragen aan de goede werking van de Unie en dat doen zij onder andere door deel te nemen aan interparlementaire samenwerking. De samenwerking op het gebied van subsidiariteitsbezwaren en adviezen binnen de politieke dialoog is echter niet optimaal, met andere woorden, op dat gebied wordt te weinig samengewerkt om een duidelijke positie in te kunnen nemen richting de Europese Commissie. Dit ligt niet aan het aantal verschillende samenwerkingsverbanden waaraan nationale parlementen kunnen deelnemen. Er bestaan bijna tien verschillende conferenties waaraan deelgenomen kan worden. De één heeft een breed onderwerp, COSAC bijvoorbeeld, de ander heeft een meer specifiek onderwerp, zoals de Artikel 13-conferentie. Wat wel meespeelt, zijn tijdgebrek (zoals de achtwekentermijn voor een gele kaart), nationale parlementaire kennis en expertise en nationale prioriteiten, en de verschillende belangen van de lidstaten. Het komt zodoende niet vaak voor dat voldoende lidstaten (lees: nationale parlementen) op één lijn zitten om de drempel van de gelekaartprocedure te halen.

Wellicht dient de werkwijze voor wat betreft het opstellen van subsidiariteitsbezwaren en adviezen binnen de politieke dialoog gewijzigd te worden. Een idee zou kunnen zijn dat per wetgevingsvoorstel één Kamer van een nationaal parlement het voortouw neemt en een subsidiariteitsbezwaar opstelt dat door andere parlementen kan worden overgenomen. Niet elk(e Kamer van een) nationaal parlement dient dan zelf een bezwaar op te stellen maar ze zouden elkaars voorbeeld kunnen overnemen en eventueel aanpassen naar eigen wens. Dit zou wellicht ook een oplossing kunnen zijn voor de krappe achtwekentermijn die de gelekaartprocedure kent. Nationale parlementen vinden deze termijn nu te kort om een subsidiariteitstoets uit te voeren en een bezwaar aan de Commissie te sturen. Wanneer nationale parlementen een gedeelte van het werk niet hoeven te doen omdat een ander parlement dit al heeft gedaan, is het voor nationale parlementen eerder mogelijk om binnen acht weken een subsidiariteitsbezwaar op te sturen. Een verlenging van de achtwekentermijn zou volgens parlementariërs en onderzoekers ook een oplossing kunnen zijn. Acht weken blijkt een (te) korte termijn te zijn om een subsidiariteitstoets uit te voeren en een met redenen omkleed advies op te stellen, hoewel de termijn effectief langer is dan acht weken aangezien deze pas begint te lopen na de laatste vertaling.

\section{Alternatieve bronnen}

Tot slot zijn er nog alternatieve bronnen van informatie die een belangrijke factor vormen. IPEX en ECPRD dragen bij aan een goede uitoefening van de bevoegdheden en aan de samenwerking tussen nationale parlementen. Het nadeel van IPEX is dat het niet voor 
actuele zaken gebruikt kan worden. Nationale parlementen plaatsen hun documenten namelijk pas op IPEX wanneer de nationale procedure is afgerond.

\section{Het Nederlandse parlement}

In de hoofdstukken 3 en 4 zijn de bevoegdheden die zijn neergelegd in nationale wetgeving van het Nederlandse respectievelijk het Duitse parlement besproken. In het viffde hoofdstuk is hiervan een vergelijking gemaakt.

\section{Instemmingsrecht en behandelvoorbehoud}

Het Nederlandse parlement heeft slechts twee bevoegdheden die speciaal gericht zijn op de Europese Unie. Dit zijn het instemmingsrecht en het parlementair behandelvoorbehoud.

Keuze voor het gebruik van het instemmingsrecht kan het parlement niet zelf bepalen. Alleen wanneer de Europese Commissie nieuwe wetgeving maakt op het beleidsterrein ruimte van vrijheid, veiligheid en recht, kan en moet de Nederlandse regering het parlement om instemming vragen. Het is dus niet aan de Kamers om te bepalen wanneer om instemming moet worden gevraagd. Wel kan bepaald worden hoe instemming wordt verleend, stilzwijgend of uitdrukkelijk, en ó instemming wordt verleend. Indien wordt besloten tot uitdrukkelijke instemming zal er een overleg plaatsvinden tussen de Kamer(s) en de regering. In dit overleg kan de Kamer haar standpunten ten aanzien van het voorstel (nogmaals) overbrengen aan de regering. Wordt voor stilzwijgende instemming gekozen dan heeft de Kamer deze mogelijkheid niet.

De inzet van het behandelvoorbehoud hebben de Kamers wel zelf in de hand. Het startpunt hiervoor is het jaarlijkse wetgevings- en werkprogramma van de Europese Commissie. Op basis hiervan bepalen Kamerleden op welke wetgevingsvoorstellen van de Commissie een behandelvoorbehoud geplaatst zal worden. Dit is geen eenvoudige taak. In het jaarlijkse wetgevings- en werkprogramma worden namelijk geen concrete voorstellen opgenomen maar enkel titels of onderwerpen waarover de Commissie voornemens is om nieuwe wetgeving te publiceren. De Kamer kan daarom alleen maar een inschatting maken van wat haar belangrijk voorkomt. Zekerheid komt pas wanneer het concrete voorstel wordt gepubliceerd. Aan de inzet van het behandelvoorbehoud zijn geen criteria verbonden. Kamerleden kunnen zelf bepalen wanneer en op welke gronden een behandelvoorbehoud wordt geplaatst. Dit betekent in de praktijk dat de inzet zeer afhankelijk is van een Kamerlid met een interesse voor een bepaald onderwerp. Er was in de Tweede Kamer bijvoorbeeld veel aandacht voor het Europees Openbaar Ministerie (EOM). Niet alleen werd het behandelvoorbehoud ingezet, maar ook werd een subsidiariteitstoets gedaan, een met redenen omkleed advies naar de Europese Commissie gestuurd in de gelekaart- 
procedure en er werd een rapporteurschap gekoppeld aan het voorstel. Dat juist dit voorstel zoveel aandacht kreeg en andere voorstellen minder tot geen aandacht, komt voornamelijk doordat het voorstel voor het EOM de interesse had van een of meer Kamerleden. Die interesse nam overigens na een tijdje weer af, wat bleek uit het feit dat het rapporteurschap niet werd verlengd of overgenomen door een ander Kamerlid. Ook bij de uiteindelijke deelname aan het EOM was het parlement niet bijzonder betrokken.

\section{Controlemiddelen}

Naast deze twee bevoegdheden, die specifiek gericht zijn op Europese aangelegenheden, kan het Nederlandse parlement ook al zijn andere 'nationale' controlemiddelen inzetten om de regering te controleren op haar Europees beleid. Hiervoor kunnen de Kamers gebruikmaken van het parlementair recht op inlichtingen, het recht van interpellatie, debat (zoals de AO's) en vragen en het enquêterecht. Onderzocht is in hoeverre het parlement gebruikmaakte van deze bevoegdheden voor controle van Europese aangelegenheden. Uit de verzamelde data blijkt dat er in de Tweede Kamer geen enkele interpellatie heeft plaatsgevonden of enquête is gehouden over Europa en dat vijf procent van de dertigledendebatten een Europees onderwerp had. Vier procent van de schriftelijke vragen en twee procent van de mondelinge vragen had betrekking op Europese aangelegenheden.

Nationale bevoegdheden worden dus met name ingezet voor nationale aangelegenheden. Als ze worden ingezet voor Europese aangelegenheden is het voornamelijk met het doel om informatie in te winnen. Het maakt daarbij weinig uit welk instrument wordt ingezet. De keuze voor het instrument dat wordt ingezet zit in de snelheid waarmee Kamerleden antwoord willen en hoe complex het onderwerp is. Complexe vragen worden eerder in een dertigledendebat of commissievergadering gesteld dan via een schriftelijke vraag. Een schriftelijke vraagt leent zich meer voor een korte en eenvoudige vraag.

Het percentage algemene overleggen ( $\mathrm{AO}$ ) met een Europees onderwerp ligt hoger dan bij de andere instrumenten. Bijna 22 procent van de AO's gaat over Europa. Dat relatief hoge percentage heeft te maken met het feit dat er altijd een AO plaatsvindt voor een vergadering van de Raad en tot 2011 ook voorafgaand aan een vergadering van de Europese Raad. Deze AO's hoeven niet aangevraagd te worden maar horen bij het controleproces.

Als men kijkt naar de manier waarop debatten worden gevoerd dan is er weinig verschil op te merken tussen bijvoorbeeld een dertigledendebat en een AO. Voor alle debatten geldt dat Kamerleden geïnformeerd willen worden, dat ze antwoorden willen op hun vragen en dat ze eigen standpunten kenbaar kunnen maken. In hoeverre de Kamerleden de ministers kunnen sturen is moeilijk te zeggen. Dat hangt zeer af van de minister. De ene is tot meer bereid dan de andere, maar in het algemeen kan gezegd worden dat ministers het niet prettig vinden wanneer hun wordt gevraagd om op een bepaalde manier te handelen of om toezeggingen te doen. Een uitzondering vormt het plenaire debat met de minister- 
president voorafgaand aan de Europese Raad. Men ziet dat de Kamer daarbij meer probeert om de minister-president te sturen dan in andere debatten, maar dit heeft wellicht te maken met de bereidheid van de minister-president (ten opzichte van andere ministers) om te handelen naar het standpunt van de Kamer.

$\mathrm{Al}$ met al is het $\mathrm{AO}$ een goed controlemiddel. Dit komt niet alleen door de inhoud, maar ook door de frequentie waarmee de AO's gehouden worden. Ook de grondigheid waarmee de Kamer omgaat met AO's is positief. De Kamer zorgt er namelijk voor dat voor elke Raadsvergadering een AO plaatsvindt. Door deze structuur blijft de Kamer op de hoogte van en gefocust op Europese aangelegenheden.

Verder vindt er jaarlijks een debat plaats in zowel de Tweede Kamer als de Eerste Kamer over het beleidsstuk de Staat van de Europese Unie dat door de regering wordt opgesteld. In de Tweede Kamer worden voor dit (nota)debat Europarlementariërs en leden van de Europese Commissie uitgenodigd. In de Eerste Kamer wordt het beleidsstuk besproken als onderdeel van de jaarlijkse Europese beschouwingen. De Staat van de Europese Unie geeft veel informatie aan de Kamerleden. De regering kijkt namelijk terug op de belangrijkste Europese ontwikkelingen en geeft haar visie op het komende jaar. Dit geeft de Kamerleden een overzicht van de standpunten (per beleidsterrein) van de regering en zo wordt duidelijk wat het parlement van de regering kan verwachten op Europees niveau. Heel concreet maakt de regering haar plannen niet kenbaar, want als zij dit wel doet dan is zij daar ook aan gebonden. De regering houdt graag nog enige vrijheid. Het positieve aan de Staat van de Europese Unie is dat het parlement goed geïnformeerd wordt over de visie en de plannen van de regering met betrekking tot Europa. Dit komt niet alleen door het stuk zelf, maar ook door de debatten die in de Tweede en Eerste Kamer hierover worden gevoerd, evenals door de aanwezigheid van Europarlementariërs en leden van de Europese Commissie bij het debat in de Tweede Kamer. Zoals al eerder in dit boek is gezegd, is een kanttekening bij dit alles dat het parlement zijn controlerende taak alleen goed kan uitvoeren wanneer het wordt geïnformeerd. Zonder informatie is het parlement machteloos.

Een andere nationale werkwijze die wordt gebruikt om de regering te controleren op Europees beleid is het rapporteurschap. Dit rapporteurschap vormt in beginsel een goed middel om de regering te controleren door parlementaire informatie en betrokkenheid te verzekeren. Het wordt ook daadwerkelijk ingezet voor het controleren van de regering, maar de uitvoering is regelmatig zwak. Wat namelijk gebeurt, is dat het rapporteurschap wordt ingezet op een bepaald Europees dossier dat de Kamer belangrijk vindt, maar dat het rapporteurschap eindigt voordat het dossier eindigt. Daarmee mist de Kamer een deel van de controle die zij kan uitoefenen. Dit is een gemiste kans. Een rapporteurschap hoort namelijk niet te eindigen op een vooraf vastgestelde (willekeurige) datum of bij nieuwe verkiezingen, maar het einde hoort samen te vallen met het einde van het Europese dossier. 
Als het wel eerder eindigt, dan dient dit weloverwogen te worden bepaald. De uitvoering van het rapporteurschap is dus wat dat betreft onder de maat. Ook mag een rapporteurschap structureler worden ingezet op grote Europese dossiers. De keuze van onderwerpen oogt namelijk nogal willekeurig. Het rapporteurschap is wel een goed controlemiddel dat enerzijds zorgt voor een goede informatievoorziening aan de Kamer en voor een goede opvolging van een dossier en anderzijds een goed signaal afgeeft aan de regering over het belang van het dossier.

\section{Afspraken}

Tot slot bestaat de mogelijkheid om afspraken te maken tussen de regering en het parlement. Een viertal afspraken is gevonden. Dat zijn de afspraken over visserijakkoorden, het CETAverdrag, de ESM-besluiten en de inzet van het parlementair behandelvoorbehoud op dossiers waarvoor het instemmingsrecht geldt. Hierbij moet worden opgemerkt dat deze afspraken niet worden opgenomen in een openbaar register waardoor het niet uitgesloten is dat er meer afspraken bestaan dan deze vier. Voor wat betreft de eerste drie afspraken is aangesloten bij het parlementair behandelvoorbehoud. Dit houdt in dat de Tweede Kamer in feite de wens te kennen geeft tijdiger te willen worden geïnformeerd en betrokken wil worden bij de Europese besluitvorming, dan wel erop uit is dat de minister meer aandacht heeft voor het standpunt van de Kamer.

De afspraken, zoals die gemaakt zijn, zorgen ervoor dat de Kamer meer betrokken wordt bij Europese aangelegenheden. Wat blijkt, is dat de Kamer afspraken met de minister dient te maken om nauwer betrokken te worden bij bepaalde dossiers. Daartoe spreekt de Kamer met de minister een procedure af over informatievoorziening en parlementaire betrokkenheid voordat op EU-niveau stappen worden gezet. Voor een aantal Europese besluiten, zoals handelsverdragen, is het niet mogelijk om de reguliere Europese bevoegdheden als het behandelvoorbehoud in te zetten. Nationale controlemiddelen zijn wel mogelijk, want door afspraken te maken met de regering laat de Kamer ten eerste zien dat het gaat om een belangrijk dossier. Daarnaast is het mogelijk om betrokkenheid vast te leggen op basis van toezeggingen door de minister. De Kamer is zo meer betrokken. Voor parlementaire betrokkenheid is het goed dat de Kamer haar standpunten duidelijk kan maken. Het zou dan ook niet verkeerd zijn wanneer de Kamer meer afspraken maakt met de regering om zo vaker en (volgens de Kamer zelf) beter betrokken te worden bij Europese besluitvorming.

Daarnaast bestaat de afspraak tussen het parlement en de regering dat op elk dossier waarvoor het instemmingsrecht geldt het parlementair behandelvoorbehoud wordt ingezet. Dit is op grond van de Goedkeuringswet van het Verdrag van Lissabon strikt genomen niet mogelijk maar desondanks is deze afspraak gemaakt. Vanuit het perspectief van parlementaire betrokkenheid is dit een goede afspraak, omdat het parlement hierdoor beter geïnformeerd wordt door de regering dan wanneer alleen het instemmingsrecht wordt 
ingezet. Er vindt op basis van deze afspraak namelijk altijd een debat plaats. Dit zou niet noodzakelijkerwijs het geval zijn wanneer er geen parlementair behandelvoorbehoud wordt geplaatst; denk hierbij aan stilzwijgende instemming.

De data over de Eerste Kamer tonen dat er geen interpellaties of enquêtes over Europa zijn geweest en dertien procent van de mondelinge vragen had een Europees onderwerp. Hierbij moet wel worden aangegeven dat de Eerste Kamer tot op heden geen gebruik heeft gemaakt van het enquêterecht. Op basis hiervan kan worden geconcludeerd dat de Eerste Kamer weinig oog heeft voor Europese aangelegenheden.

Het Nederlandse parlement bestaat uit de Tweede en Eerste Kamer met ieder haar eigen mogelijkheden om Europese aangelegenheden te beïnvloeden. Als men kijkt naar de activiteiten van beide Kamers valt op dat de Tweede Kamer actiever is (geworden) dan de Eerste Kamer. Dat geldt op vrijwel alle vlakken. De Eerste Kamer was in het begin van de onderzoeksperiode (2010-2016) nog actiever in de politieke dialoog maar vanaf $2013 \mathrm{heeft}$ de Tweede Kamer vaker een dialoog gevoerd met de Europese Commissie dan de Eerste Kamer. In de gelekaartprocedure is de Tweede Kamer altijd actiever geweest dan de Eerste Kamer. Dit is ook het geval voor wat betreft reacties op groen- en witboeken, het aanstellen van rapporteurs en het inzetten van het behandelvoorbehoud. Dat laatste heeft de Eerste Kamer nog nooit gedaan.

Het is niet heel vreemd dat de Tweede Kamer actiever is. Het lidmaatschap van de Eerste Kamer is namelijk een deeltijdfunctie en er moet veel werk worden verricht op die ene dinsdag in de week. Daarnaast heeft de Eerste Kamer de gewoonte om met de regering in overleg te treden en in mindere mate met de Europese Commissie. Tot slot hangt het af van de persoonlijke aandacht van de leden voor Europa. In de ene zittingsperiode zitten er meer leden in de Eerste Kamer met aandacht voor Europa dan in de andere verkiezingsperiode.

\section{Het Duitse parlement}

Wanneer gekeken wordt naar de inzet van nationale bevoegdheden voor Europese aangelegenheden door het Duitse parlement is het volgende te zien en te concluderen. De algemene nationale bevoegdheden van het Duitse parlement zijn de Kleine Anfragen, Große Anfragen, Schriftliche Fragen, Mündliche Fragen, Fragestunden en Regierungsbefragungen. De percentages hiervan liggen hoger dan in Nederland: 15,9 procent van de Kleine Anfragen en 29,4 procent van de Große Anfragen heeft een Europees onderwerp. De percentages van de overige bevoegdheden liggen alle onder tien procent (Schriftlichte Fragen 8,1 procent, Mündliche Fragen 9,5 procent, Aktuelle Stunden 8,7 procent en Regierungs- 
befragungen 9,2 procent). Ook hiervoor geldt dat de nationale bevoegdheden met name worden ingezet voor nationale aangelegenheden. Deze percentages zijn te verklaren doordat Duitsland aparte wetgeving heeft over de bevoegdheden voor het parlement die specifiek inzetbaar zijn voor Europese aangelegenheden.

Artikel 23 van de Grondwet geeft aan dat de Bundestag en de Länder via de Bundesrat meewerken aan Europese aangelegenheden en dat ze dit kunnen doen via het nemen van een zogenoemde Stellungnahme (standpunt). Hoe dit in zijn werk gaat en hoe een dergelijke Stellungnahme genomen kan worden is uitgewerkt in een drietal wetten: Gesetz über die Zusammenarbeit von Bundesregierung und Deutschem Bundestag in Angelegenheiten der Europäischen Union (EUZBBG) (Wet op de samenwerking tussen de federale regering en de Duitse Bondsdag in Europese Unie-aangelegenheden); Gesetz über die Wahrnehmung der Integrationsverantwortung des Bundestages und des Bundesrates in Angelegenheiten der Europäischen Union (IntVG) (Wet op de verantwoordelijkheid voor de integratie van de Bondsdag en de Bondsraad in Europese Unie-aangelegenheden); en Gesetz über die Zusammenarbeit von Bund und Ländern in Angelegenheiten der Europäischen Union (EUZBLG) (Wet op de samenwerking tussen de Federatie en de Landen in Europese Unieaangelegenheden).

De Bundestag neemt gemiddeld dertig Stellungnahmen per jaar. De Bundesrat is veel actiever dan de Bundestag en neemt gemiddeld 180 Stellungnahmen per jaar. De reden hiervoor is dat deze Stellungnahme hét middel voor de Bundesrat, oftewel de Länder, is om invloed uit te oefenen. Deze Stellungnahme is voor de Länder de enige manier, naast de rol in het wetgevingsproces, om invloed uit te oefenen op Europees beleid. Aangezien Europese besluitvorming ook, of misschien wel met name, van invloed is op de Länder, zijn deze Länder zeer actief op dit gebied.

\section{Overige elementen van invloed}

Zoals in de inleiding aangegeven is niet alleen gekeken naar de formele bevoegdheden van beide parlementen. Ook andere elementen kunnen invloed hebben op de rol die nationale parlementen spelen in Europese aangelegenheden. Op de vraag welke elementen een rol spelen, wordt hieronder een antwoord gegeven.

\section{Bundesverfassungsgericht}

In Duitsland speelt het Bundesverfassungsgericht een grote rol bij de uitleg van de bevoegdheden van de Bundestag en de rol van Duitsland in de Europese Unie. Het hof is bevoegd om uitspraken te doen over de grondwettelijkheid van Europese wetgeving en bepaalt daarmee of die Europese wetgeving van toepassing is in Duitsland of niet. Maar 
het is met name belangrijk dat het hof waakt over de bevoegdheden van de Bundestag. Zo heeft het hof bepaald dat er voor de Bundestag een rol moet zijn weggelegd bij de ESMbesluiten. Het hof zorgde er zo voor dat de bevoegdheden en rollen van de Bundestag ook bij de Bundestag blijven. Daarnaast bepaalt het hof ook de reikwijdte van de bevoegdheden en zorgt ervoor dat de Bundestag zijn taken uitvoert.

Een dergelijke onafhankelijk beschermer van het Nederlandse parlement bestaat niet. Het Nederlandse parlement dient zichzelf te beschermen. Indien het parlement meent dat hem een bepaalde bevoegdheid toekomt, dan zal het daar zelf voor moeten strijden. Dit is niet eenvoudig aangezien daarvoor afspraken gemaakt dienen te worden tussen de regering en het parlement. Denk daarbij aan de vier afspraken die gemaakt zijn omtrent visserijakkoorden, het CETA-verdrag, de ESM-besluiten en de inzet van het parlementair behandelvoorbehoud wanneer het instemmingsrecht geldt. Het parlement dient dan zelf aan te geven dat er een rol voor hem is weggelegd en de regering dient daarmee in te stemmen. Voor de duidelijkheid van de afspraken en om ervoor te zorgen dat ze niet in de vergetelheid raken, zou het goed zijn wanneer dergelijke afspraken in een wet worden vastgelegd of in ieder geval in het Reglement van Orde. Het maken van deze afspraken is vele malen moeilijker, omdat parlement en regering het hierover eens moeten zijn. Dergelijke overeenstemming is niet nodig wanneer een constitutioneel hof bepaalt wat (de reikwijdte van) de bevoegdheden (is) zijn. Dat is ook te zien aan de rol van beide parlementen in het ESM. Het Duitse parlement dient namelijk in te stemmen met ESM-besluiten, terwijl het Nederlandse parlement enkel wordt geïnformeerd en alleen wanneer daar een afspraak over is gemaakt. Het bestaan van een constitutioneel hof kan voor een parlement dus voordelen hebben aangezien zo'n hof de rol van het parlement bewaakt en bepaalt.

\section{Ondersteuning}

Voor beide parlementen geldt dat ze afhankelijk zijn van de ambtenaren die ondersteuning bieden aan de Kamerleden bij de uitoefening van hun bevoegdheden, maar er zijn grote verschil te zien in dat ambtenarenapparaat. Om te beginnen de omvang. Het Duitse parlement is ongeveer 3,5 keer groter dan het Nederlandse parlement. Het aantal ambtenaren dat als taak heeft inhoudelijke ondersteuning te bieden aan het Duitse parlement is groter dan het aantal leden van het parlement zelf. Zo zijn er in de Bundestag zo'n drieduizend ambtenaren (ten opzichte van momenteel 709 leden) werkzaam en in de Bundesrat tweehonderd (ten opzichte van 69 vertegenwoordigers). Dat betekent dat elk lid van de Bundestag vier tot vijf ambtenaren ter beschikking heeft en een lid van de Bundesrat bijna drie ambtenaren.

Het beeld in Nederland ziet er behoorlijk anders uit. De Tweede Kamer wordt ondersteund door ruim $100 \mathrm{fte}$ en de Eerste Kamer door ongeveer $25 \mathrm{fte}$. Dit betekent zowel voor de leden van de Tweede Kamer als die van de Eerste Kamer dat zij ieder minder dan één ambtenaar ter beschikking hebben. Het is dan ook niet vreemd dat bijvoorbeeld 
ambtenaren met als functie EU-informatiespecialist niet voor Kamerleden afzonderlijk werken maar voor Kamercommissies in zijn geheel. Zij doen dit dan ook nog eens voor meerdere Kamercommissies tegelijkertijd. De leden van het Nederlandse parlement hebben dus minder ondersteuning dan hun collega's in het Duitse parlement, waardoor (in theorie) het Nederlandse parlement minder werk kan verzetten.

Er is in het Nederlandse parlement naar mijn mening te weinig ondersteuning om de taken van het parlement goed en volledig uit te voeren. Denk met name aan het controleren van Europese wetgevingsvoorstellen op subsidiariteit. Het grote aantal pagina's van Europese voorstellen dat gelezen, besproken en beoordeeld dient te worden kost tijd. Dit probleem klemt temeer door het grote aantal Tweede Kamerfracties (inmiddels achttien). Kamerleden (vooral van de vele kleinere fracties) moeten hun expertise en aandacht spreiden. Meer ondersteuning, vooral ook op langlopende en complexe Europese dossiers, zou hier kunnen helpen.

\section{Kamercommissies}

Kamercommissies spelen in beide parlementen een grote rol. Zowel in het Nederlandse als het Duitse parlement zijn het de Kamercommissies die schriftelijke en mondelinge vragen stellen, debatten (AO's en NO's) voeren met de minister, besluiten om een subsidiariteittoets uit te voeren of een behandelvoorbehoud te plaatsen. Enkele bevoegdheden dienen plenair te worden vastgesteld, maar dat is vaak niet meer dan een formaliteit. Het grote verschil tussen het Nederlandse en het Duitse parlement zit in de Kamercommissie voor Europese Zaken. De Duitse variant is bevoegd besluiten te nemen namens de Bundestag. Deze besluiten hoeven dus niet plenair genomen te worden. In hoeverre en welke besluiten deze commissie kan nemen namens de Bundestag wordt wel plenair vastgesteld. De Bundestag is overigens grondwettelijk verplicht een Kamercommissie voor Europese zaken in te stellen. Hetzelfde geldt voor de Kamercommissie voor Europese Zaken van de Bundesrat. Deze wordt de 'Europakammer' genoemd. Van de bevoegdheid van beide Kamercommissies wordt met name gebruikgemaakt wanneer met spoed een besluit (Stellungnahme) genomen dient te worden.

Uit dit onderzoek blijkt niet dat het nodig is om ook de Nederlandse Kamercommissies voor Europese Zaken de bevoegdheid te geven om besluiten te nemen namens de gehele Kamer zonder dat dit plenair hoeft te worden afgestemd. In Duitsland wordt niet tot nauwelijks gebruikgemaakt van deze bevoegdheid. Er is daarom geen sprake van een bevoegdheid die zorgt voor snellere en betere besluitvorming. Ook blijkt dat het ontbreken van deze bevoegdheid in Nederland niet leidt tot grote vertragingen in de besluitvorming. Bovendien is evenmin naar voren gekomen dat deze bevoegdheid een wens is van de Kamerleden.

Anders dan in Nederland hebben in Duitsland leden van het Europees Parlement zitting (zonder stemrecht) in de Kamercommissie voor Europese Zaken. Zij kunnen debatteren 
en zaken aandragen voor de agenda maar kunnen niet stemmen. Het voordeel is dat deze Europarlementariërs direct informatie kunnen delen over standpunten binnen het Europees Parlement, de stand van zaken binnen Europese processen en informatie over Europese aangelegenheden. Hierdoor zijn de leden van het Duitse parlement meteen op de hoogte van hetgeen in Europa speelt.

Nationale parlementen zijn gediend bij een snelle informatievoorziening. Een van de manieren waarop nationale parlementen informatie ontvangen, is via de vertegenwoordigers die in Brussel zitten. Het Nederlandse parlement heeft sinds 2004 een vertegenwoordiger in Brussel. Deze is, net zoals andere vertegenwoordigers, gehuisvest in het Europees Parlement. De vertegenwoordiger informeert de Tweede en Eerste Kamer in een vroeg stadium over Europese gebeurtenissen. De Kamercommissies voor Europese Zaken uit beide Kamers spreken tweemaal per jaar met de vertegenwoordiger. Dit kan plaatsvinden in Den Haag maar parlementariërs brengen ook bezoeken aan Brussel. De vertegenwoordiger informeert niet alleen de Kamers maar adviseert ook over het beste moment van beïnvloeding. Eenzelfde constructie is te vinden in Duitsland. Zowel de Bundestag als de Bundesrat heeft een vertegenwoordiging in Brussel. De vertegenwoordiging van de Bundesrat is een gezamenlijke waarnemer voor alle zestien Länder. De verschillende vertegenwoordigers van de verschillende lidstaten hebben onderling contact om zo informatie, standpunten en beste praktijken uit te wisselen.

\section{De beoordeling}

Uiteindelijk is nu de vraag hoe het Nederlandse parlement beoordeeld dient te worden op de uitoefening van werkzaamheden in Europese kwesties, en dat ook in vergelijking met het Duitse parlement. Geconcludeerd mag worden dat het Nederlandse parlement minder actief is dan het Duitse parlement. Dit is echter te verklaren. Ten eerste spelen de grootte van het parlement en het ambtelijk apparaat een rol. Het Duitse parlement is ongeveer 3,5 keer groter dan het Nederlandse parlement. Ook het aantal ambtenaren dat werkzaam is voor het parlement is in Duitsland vele malen groter. Dit betekent simpelweg dat meer werk verzet kan worden. Daarnaast kent de inzet van bepaalde bevoegdheden enig automatisme. Wanneer de Bundestag een Stellungnahme inneemt, plaatst de minister automatisch een parlementair voorbehoud in de Raad. Dat wordt pas weer opgeheven als de minister die Stellungnahme in acht heeft genomen. Dat betekent dat er eventueel nog een debat plaatsvindt tussen de minister en de Bundestag maar ook dat de minister moet bepalen of hij de Stellungnahme (deels) overneemt of niet. 
Het feit dat de Kamercommissies voor Europese Zaken in de Bundestag en Bundesrat zelfstandig besluiten kunnen nemen die als besluiten voor de gehele Bundestag of Bundesrat gelden, is een groot verschil met de bevoegdheden van de Nederlandse Kamercommissies. Op basis van dit onderzoek is niet naar voren gekomen dat deze bevoegdheid wordt gemist binnen het Nederlandse parlement en dat die daarom ook in Nederland gecreëerd dient te worden. Hetgeen wellicht wel een rol speelt bij de Kamercommissie voor Europese Zaken, is dat in Duitsland leden van het Europees Parlement zitting hebben in deze commissie. Er is daardoor meer contact tussen nationale parlementariërs en Europarlementariërs. Dit kan een groot voordeel zijn in de informatievoorziening. Europarlementariërs mogen onderwerpen op de agenda van de commissie plaatsen en daarmee aangeven wat op Europees niveau speelt. Ook brengt het nauwe contact tussen parlementariërs van het nationale en Europese parlement mee dat informatie snel uitgewisseld kan worden. Denk dan aan informatie over de verschillende standpunten binnen het Europees parlement, de stand van zaken van nieuwe wetgeving die behandeld wordt in het Europees parlement en informatie over andere Europese aangelegenheden. Dit zorgt voor een goede en complete informatievoorziening voor het Duitse parlement.

Ook is er nog de Duitse wetgeving waarin alle bevoegdheden van het parlement ten aanzien van Europese aangelegenheden is vastgelegd. Het grote voordeel hiervan is dat dit duidelijkheid creëert voor zowel het parlement als de regering. Dit overzicht van de rechten van het parlement en de plichten van de regering kan zorgen voor een beter en veelvuldiger gebruik ervan. De kans dat er iets wordt vergeten is zo kleiner, omdat het duidelijker is wat er van het parlement wordt verwacht. In Nederland worden afspraken gemaakt tussen regering en parlement in een brief of in een debat. Hiermee worden de afspraken bedoeld over de visserijakkoorden, het CETA-verdrag, de ESM-besluiten en de inzet van het parlementair behandelvoorbehoud indien het instemmingsrecht geldt. Aangezien deze afspraken niet verzameld zijn in een wet of regeling maar her en der verspreid staan, zorgt dit voor onduidelijkheid. Ook bestaat de kans dat een afspraak wordt vergeten en in het ongerede raakt. Daarnaast kan het zo zijn dat een eerder gemaakte afspraak niet in een nieuwe casus wordt toegepast of opnieuw wordt uitgevonden. Als het een en ander als regel in het RvO of een wet is opgenomen, dan is het eenvoudiger erop terug te vallen wanneer het gaat om grote Europese dossiers. Doordat dit niet het geval is, wordt niet gewerkt vanuit een automatisme dat voor efficiëntie zorgt en ontstaat er willekeur. Waarom is er bijvoorbeeld wel een afspraak gemaakt ten aanzien van ESM en niet ten aanzien van het coronanoodsteunpakket van de EU?

Kortom, het Nederlandse parlement maakt in mindere mate gebruik van de hem toekomende bevoegdheden dan het Duitse parlement. Dat lag, onder andere vanwege de omvang van het Duitse parlement, wellicht in de lijn der verwachtingen. Er zijn echter ook duidelijke 
redenen aan te wijzen die gerelateerd zijn aan de manier waarop verschillende processen zijn ingericht. Hierdoor is de hogere activiteit van het Duitse parlement niet alleen te relateren aan de grotere mankracht die er is, maar ook aan de efficiëntie in de werkprocessen.

Tot slot. Nationale parlementen voeren controle met name uit door gebruik te maken van nationale bevoegdheden. Dit is in beginsel niet problematisch. Ook door controle van de eigen minister, die zitting heeft in de Raad, kan invloed worden uitgeoefend op Europese besluitvorming. Hierbij geldt, net zoals bij de Europese bevoegdheden, dat nationale parlementen ook daadwerkelijk gebruik moeten maken van de bevoegdheden. Uit dit onderzoek blijkt dat de nationale bevoegdheden met name worden gebruikt om de eigen regering te controleren op nationale aangelegenheden. Dat heeft ermee te maken dat op nationaal niveau meer bereikt kan worden. Op Europees niveau hangt de invloed van nationale parlementen af van de stemming in de Raad. Door het toenemend gebruik van stemmen met een gekwalificeerde meerderheid in de Raad kan één stem van een minister niet veel veranderen. Ook kan het weinig nut hebben om de minister te controleren omdat hij niets kan doen op Europees niveau. De situatie op Europees niveau wordt soms namelijk niet beheerst door EU-recht, maar bepaald door intergouvernementele samenwerking. In een dergelijk geval kunnen de Europese bevoegdheden niet worden ingezet. In andere situaties kan sprake zijn van handelsakkoorden waarop bijvoorbeeld het behandelvoorbehoud niet van toepassing is. Het een en ander betekent niet dat nationale parlementen, en dan in het bijzonder het Nederlandse en het Duitse parlement, niet vaker gebruik zouden kunnen maken van hun bevoegdheden. Het onderzoek heeft laten zien dat de percentages voor de inzet van de controlebevoegdheden voor beide parlementen in absolute zin aan de lage kant zijn. Deels is dit te verklaren doordat het, zoals gezegd, niet zinvol is om controlemiddelen in te zetten. Voor een ander deel zijn de lage percentages echter het resultaat van gebrek aan interesse voor, en wellicht ook kennis van, de (procedures van de) Europese Unie. Men kan stellen, en dan met name voor de gelekaartprocedure, dat de percentages laag zijn. Om de taak uit artikel 12 VEU uit te voeren dient het Nederlandse parlement mijns inziens elk Europees voorstel te controleren op subsidiariteit. Dit gebeurt niet waardoor gezegd kan worden dat het percentage te laag is omdat het daadwerkelijk hoger kan. Er kunnen en moeten namelijk meer subsidiariteitstoetsen worden uitgevoerd. Of de inzet van beide parlementen ook in relatieve zin laag is, is moeilijk te zeggen. Voor de gelekaartprocedure is het antwoord ja, maar voor de andere bevoegdheden is dat niet zo helder. Nationale parlementen kunnen meer vragen stellen over Europese aangelegenheden en kunnen ook vaker in debat met de eigen regering, maar of dit ook noodzakelijk en zinvol is, is een andere vraag waar geen eenduidig antwoord op gegeven kan worden.

Uiteindelijk geldt dat nationale parlementen meer invloed kunnen uitoefenen op Europees niveau en het democratisch tekort van de Europese Unie kleiner wordt als de 
nationale parlementen meer gebruikmaken van de nationale en Europese bevoegdheden die hun toekomen en daarbij onderling meer samenwerken.

\subsection{AanbeVElingen}

De centrale vraag is: Kan het Nederlandse parlement zijn controle ten aanzien van Europese aangelegenheden verbeteren, al dan niet naar Duits voorbeeld, teneinde recht te doen aan het VEU, en de eigen nationale rol die het heeft ten aanzien van controle en vertegenwoordiging?

Het onderzoek heeft aangetoond dat er verbeterpunten zijn voor het Nederlandse parlement. Deze zijn deels geïnspireerd door sterkere onderdelen uit het Duitse stelsel, maar volgen ook uit onvolkomenheden die bij de bestudering van het Nederlandse stelsel naar voren zijn gekomen. Sommige van deze aanbevelingen zijn daarom geïnspireerd door Duitsland. Dit geldt echter niet voor alle aanbevelingen.

\subsubsection{Verzamelen en vastleggen van bevoegdheden}

In 2017 hebben de toenmalige Kamerleden Marit Maij en Anne Mulder het voorstel voor de Wet informatiepositie Staten-Generaal inzake de Europese Unie ingediend bij de Tweede Kamer. Dit voorstel heeft als doel het verbeteren van de informatiepositie van het parlement en daardoor het verbeteren van de parlementaire controle. De wet verzamelt de bevoegdheden die de Kamer heeft om de regering te controleren op haar Europees beleid.

Deze wet heeft iets weg van de Duitse 'Europawetten'. Het feit dat Duitsland alle bevoegdheden en bijbehorende procedures vastlegt in wetgeving is niet vreemd. Het zit in de Duitse cultuur om dingen goed en duidelijk vast te leggen - althans, dat is een alom bekend cliché en ook veel Duitsers zien er een preußische Tugend in. In Nederland is dit minder voor de hand liggend. Toch is het de vraag of Nederland ook wetgeving moet maken waarin bevoegdheden ten aanzien van Europese aangelegenheden worden vastgelegd. Het idee om alle bevoegdheden te verzamelen en op een gestructureerde wijze uiteen te zetten, is in beginsel een goed voornemen en zou ook daadwerkelijk de parlementaire controle verbeteren. Omdat het Nederlandse parlement over minder wetenschappelijke en ondersteunende staf beschikt alsmede veel kleinere fracties heeft (met eveneens minder staf), is aannemelijk dat het 'institutionele geheugen' van de Staten-Generaal minder sterk is dan in het Duitse parlement. Het vastleggen en daardoor beter kenbaar maken van taken en bevoegdheden in wetgeving zou dit probleem kunnen verhelpen. Met het ingediende wetsvoorstel zal dit echter niet worden bereikt. Het voorstel kent een tweetal nieuwe plichten die in feite overbodig zijn. Ten eerste de plicht van de minister van Buitenlandse Zaken om de Kamers te informeren. Deze plicht staat al in artikel 68 van de Grondwet. 
Op basis hiervan dienen alle ministers de Kamers te informeren. Wanneer deze taak voor wat betreft Europese aangelegenheden bij de minister van Buitenlandse Zaken komt te liggen dan kan dat tot miscommunicatie, vertraging en onduidelijkheid leiden. De informatie moet dan namelijk eerst naar de minister van Buitenlandse Zaken en gaat dan pas naar de Kamers, in plaats van dat de informatie direct naar de Kamers gaat. Ten tweede wordt voorgesteld om nieuwe EU-voorstellen te vergezellen van een zogenoemde oplegbrief. In deze brief wordt informatie opgenomen over onder andere de belangrijkste inhoud en het doel van het voorstel, de toepasselijke besluitvormingsprocedure en de publicatie van de Nederlandstalige versie. Nieuwe Europese wetgeving van de Commissie wordt echter al rechtstreeks aan parlementen gezonden. Er is dus geen noodzaak om deze wetgeving ook van de nationale regering te ontvangen. De informatie in de oplegbrief is af te leiden uit de wetsvoorstellen zelf, waardoor de oplegbrief overbodig is. Daarnaast zal het toevoegen van een extra document aan de al grote hoeveelheden documenten die de Kamers ontvangen, niet bijdragen aan de transparantie van het proces. Bovendien zou de informatie van de oplegbrief verwerkt kunnen worden in de BNC-fiches. Deze ontvangen de Kamers weliswaar niet op hetzelfde moment als het EU-voorstel, maar wel binnen zes weken na publicatie van het EU-voorstel.

Positief aan het wetsvoorstel is echter de introductie van het BUC-fiche. In dit fiche geeft de regering uitleg over de voorgestelde wetgeving. Dit fiche komt, in tegenstelling tot het BNC-fiche, aan het einde van het wetgevingsproces. Het nut van dit fiche zit in de uitleg van de gevolgen van de nieuwe wetgeving voor Nederland. Op basis van deze informatie weten de Kamers bijvoorbeeld wat ze kunnen verwachten aan nieuwe nationale wetgeving zoals implementatie- of uitvoeringswetten.

In het algemeen is het verzamelen en vastleggen van de bevoegdheden om de regering te controleren op haar Europees beleid wenselijk. Dat is dan ook een van de aanbevelingen op basis van dit onderzoek. Momenteel staan de bevoegdheden van de Kamers in verschillende wetten en regelingen en is niet een één oogopslag duidelijk welke bevoegdheden de Kamers toekomen. Hetzelfde geldt voor de afspraken (visserijakkoorden, CETA-verdrag, ESM-besluiten en inzet parlementair behandelvoorbehoud bij instemmingsrecht) die zijn gemaakt tussen de Kamers en de regering. Deze zijn veelal in verschillende brieven of handelingen te vinden.

Het verzamelen van bevoegdheden en afspraken kan worden gedaan in een wet in formele zin zoals het hierboven aangehaalde voorstel voor de Wet informatiepositie Staten-Generaal inzake de Europese Unie. Voor het maken van een wet in formele zin en het wijzigen van een wet in formele zin dient echter een tijdrovende procedure gevolgd te worden. Het is daarom aan te raden om de bevoegdheden vast te leggen in (een addendum bij) het 
Reglement van Orde van beide Kamers. De regering is weliswaar niet gebonden aan de Reglementen van beide Kamers maar dat lijkt niet zozeer een probleem. De afspraken die in het Reglement worden opgenomen zijn al eerder door de regering en het parlement gemaakt. De regering wordt dus gebonden door de afspraak, niet door het document waarin de afspraak wordt opgenomen. Het opnemen van de afspraken in het Reglement van Orde zorgt wel voor duidelijkheid en voor een overzichtelijke vindplaats. Dus ook al staat de afspraak opgenomen in een Reglement, de regering wordt toch politiek gebonden aan die afspraak voor alle dossiers waarvoor regering en Kamer besluiten dat de afspraak geldt. De Kamer kan bij het nakomen van deze afspraak verwijzen naar het debat of de brief waarin de afspraak is gemaakt.

Kamerleden zijn gebaat bij een goed overzicht van alle mogelijkheden die ingezet kunnen worden. Daarbij dienen niet alleen bevoegdheden te worden verzameld maar ook de afspraken die zijn gemaakt tussen de Kamers en de regering. Er moet dus een compleet plaatje worden geschetst van alle mogelijkheden van de Kamers en de daarbij horende afspraken en procedures. Dit is met name van belang omdat afspraken meestal ad hoc worden gemaakt en niet terug te vinden zijn in een wet of reglement, maar wel ontzettend belangrijk zijn. Denk bijvoorbeeld aan de afspraak die is gemaakt bij het CETA-verdrag. De Tweede Kamer werd hier nu op gewezen doordat de minister voor Buitenlandse Handel en Ontwikkelingssamenwerking in een brief liet weten dat de Kamer zich kan uitspreken over het CETA-verdrag voordat de regering een standpunt inneemt in de Raad. Deze afspraak is van belang omdat het parlement zo betrokken wordt bij Europese besluitvorming in de gevallen waarin de gelekaartprocedure, het instemmingsrecht en het behandelvoorbehoud niet van toepassing zijn. Het is de vraag of de Kamer de afspraak scherp voor ogen zou hebben gehad als de minister er niet op had gewezen. Deze afhankelijkheid kan worden weggenomen door een duidelijk overzicht van afspraken te creëren waar makkelijk op kan worden teruggevallen. Denk bijvoorbeeld aan de afspraak omtrent de inzet van het behandelvoorbehoud. De afspraak is dat de minister in de Raad een voorbehoud plaatst op elk voorstel waarop het instemmingsrecht van toepassing is. Volgens de goedkeuringswet bij het Verdrag van Lissabon is dit niet nodig of zelfs niet mogelijk, maar nu deze afspraak is gemaakt dient deze te worden nagekomen.

Het vastleggen en verzamelen van alle bevoegdheden, procedures en afspraken moet zorgen voor duidelijkheid en zekerheid voor de Kamerleden. Het gaat er namelijk om dat voor hen duidelijk is welke bevoegdheden ze kunnen, mogen en moeten inzetten, welke procedures daarvoor gevolgd dienen te worden en welke andere afspraken er in het verleden zijn gemaakt. Het initiatief voor de inzet van de bevoegdheden en de uitvoering van de afspraken komt namelijk van de Kamerleden. Zij moeten de bevoegdheden inzetten of de minister attenderen op de gemaakte afspraken. 


\subsubsection{Betere procedures voor inzetten en beëindigen bevoegdheden}

De Tweede Kamer zet haar bevoegdheden vaak op onnavolgbare wijze in. Het is niet te voorspellen wanneer een bevoegdheid wordt ingezet. Dit hangt er vaak van af of een Kamerlid interesse heeft in een onderwerp. Ook het beëindigen van de inzet gebeurt niet altijd op een logisch moment en heeft niet altijd voordelen voor de Kamer. De aanbeveling is daarom een betere procedure voor het inzetten en beëindigen van bevoegdheden te creëren. Hieronder wordt dit voor het rapporteurschap, de subsidiariteitstoets en het parlementair behandelvoorbehoud uiteengezet.

\subsubsection{Rapporteur}

In de Tweede Kamer kunnen een of meer leden worden aangewezen als rapporteur. Deze rapporteur zal zich meer verdiepen in een onderwerp of dossier om de Kamer daarna te informeren. Met name voor Europese dossiers is een rapporteur belangrijk omdat deze dossiers vaak complex zijn. De Kamer zet hiervoor dan ook met enige regelmaat een rapporteur in. Het vreemde aan het rapporteurschap in de Tweede Kamer is de beëindiging ervan. Voorafgaand aan de benoeming wordt vastgesteld wanneer het rapporteurschap ten einde komt. Het is niet vreemd dat er een einde aan de termijn zit, maar het is onnodig dat deze termijn zo strikt vooraf wordt bepaald. Bij het aangaan van het rapporteurschap is namelijk moeilijk te zeggen wat er precies gaat gebeuren. Het is dan nog onduidelijk hoe de wetgevingsprocedure op Europees niveau zal verlopen. Gaat deze snel en wijzen de neuzen allemaal dezelfde kant op of verloopt de procedure langzaam omdat er veel obstakels zijn? Met name in het laatste geval kan het zijn dat het rapporteurschap eindigt voordat het wetgevingsproces op Europees niveau geëindigd is. Deze situatie deed zich voor bij het voorstel voor het Europees Openbaar Ministerie. De Kamer vond dit een belangrijk onderwerp en stelde daarom een rapporteur aan, maar ging ook akkoord met de bepaling waarin stond wanneer het rapporteurschap zou eindigen. Het rapporteurschap eindigde daardoor veel eerder dan het proces op Europees niveau. Dit gaat voorbij aan het doel van een rapporteurschap. Een rapporteur wordt benoemd om belangrijke dossiers in de gaten te houden en de Kamer daarover te informeren. Dit hoort niet te stoppen op een vooraf bepaalde datum of bij verkiezingen van de Tweede Kamer, maar wanneer de Europese wetgevingsprocedure ten einde is. De Tweede Kamer dient dus een betere en logischere procedure met betrekking tot het einde van een rapporteurschap op te stellen. Het rapporteurschap dient niet automatisch te eindigen op een vooraf gestelde datum. Ook mag het rapporteurschap niet eindigen omdat het Kamerlid na verkiezingen niet meer terugkeert in de Kamer. Wel kan een datum worden bepaald waarop geëvalueerd wordt of het rapporteurschap nog nodig is of dat dit kan worden beëindigd. Tot slot dienen de procedures voor de inzet en beëindiging van rapporteurschappen te worden vastgelegd. Hiervoor kan worden aangesloten bij de voorgaande aanbeveling over het vastleggen van 
bevoegdheden en procedures. Ook verdient het de aanbeveling om meer, dan wel alle, rapporteurschappen over meerdere leden te verdelen zodat het werk niet bij slechts bij één Kamerlid terechtkomt.

Het parlement dient ervoor te zorgen dat wanneer er gewerkt wordt met een rapporteur, dit rapporteurschap gecontinueerd wordt tot het einde van het dossier. Wanneer het rapporteurschap eerder eindigt dan het dossier, dan doet dit af aan de sterkte van het rapporteurschap (in algemene zin). Hiermee geeft de Kamer als het ware aan het dossier niet langer belangrijk te vinden, wat niet zo is en wat ook niet zou moeten zijn. Het rapporteurschap is een sterk controlemiddel, maar de Kamer gaat er te zwak mee om. Een rapporteurschap kan en mag voor lange tijd worden ingezet. Het is ook aan te raden om dit te doen. Tot slot zou het rapporteurschap kunnen worden opgenomen in de Europese werkwijze van de Kamers. Met andere woorden, doe hetzelfde als met het subsidiariteitsbezwaar en het parlementair voorbehoud. Zodra het werkprogramma van de Europese Commissie binnenkomt, moet niet alleen gekeken worden of er bij voorstellen een subsidiariteitstoets zal worden gedaan of dat er een parlementair behandelvoorbehoud wordt geplaatst, maar ook of er een rapporteur (of twee) wordt aangesteld voor bepaalde voorstellen. Op deze manier kan op het moment dat het voorstel door de Commissie gepubliceerd wordt, en aan het parlement wordt gezonden, gekeken worden of een rapporteurschap ook daadwerkelijk gewenst is.

\subsubsection{Subsidiariteitstoets}

Zoals in dit onderzoek aangehaald bepalen de Tweede en de Eerste Kamer op basis van het jaarlijkse wetgevings- en werkprogramma van de Europese Commissie op welke nieuwe wetgevingsvoorstellen zij een subsidiariteitstoets willen uitvoeren. Waarom bepaalde voorstellen worden uitgekozen is onduidelijk. Kamerleden hoeven voor de selectie alleen een kruis te zetten achter het voorstel. Wanneer het voorstel gepubliceerd wordt, kunnen Kamerleden bepalen om daadwerkelijk de toets uit te voeren zoals aangegeven, maar ook om geen toets uit te voeren. Ook kunnen zij besluiten alsnog een toets uit te voeren op de voorstellen waarvoor dat niet gepland was. De aanbeveling is om op alle voorstellen uit het jaarlijkse wetgevings- en werkprogramma van de Europese Commissie een subsidiariteitstoets te plaatsen. Zodra het voorstel gepubliceerd wordt, dient de Kamer de toets uit te voeren om er zo zeker van te zijn dat het voorstel niet in strijd is met het subsidiariteitsbeginsel. Het plannen van een subsidiariteitstoets op alle voorstellen heeft als voordeel dat geen voorstel wordt gemist en de Kamer ook zeker weet dat er geen strijd bestaat met het subsidiariteitsbeginsel. Bestaat er wel strijd dan dient de Kamer een met redenen omkleed advies op te stellen in de gelekaartprocedure. De termijn om de toets uit te voeren en eventueel een subsidiariteitsbezwaar aan de Commissie te sturen is slechts acht weken. Geen van deze weken mag verloren gaan omdat men een voorstel heeft gemist. Naast het plannen van een subsidiariteitstoets op alle voorstellen in het algemeen verdient het daarom 
in het bijzonder aanbeveling om hiervoor een duidelijke, in wezen simpele en helder gecommuniceerde procedure voor in te voeren. Toezicht op de inachtneming van het subsidiariteitsbeginsel in Europese wetgeving is krachtens artikel 12 VEU een taak van de nationale parlementen. Het dient daarom onderdeel van de parlementaire routine te worden.

\subsubsection{Parlementair behandelvoorbehoud}

Een andere bevoegdheid die een betere procedure nodig heeft, is het parlementair behandelvoorbehoud. Ook hiervoor geldt, net zoals bij de subsidiariteitstoets, dat het aan de verschillende Kamercommissies is om te besluiten om dit instrument in te zetten. Welke criteria en redenen daarvoor worden gebruikt, is niet te achterhalen. Met betrekking tot het parlementair behandelvoorbehoud wordt aanbevolen om criteria en richtlijnen op te stellen om effectieve inzet te bevorderen. Daarbij kan worden gedacht aan een automatisch behandelvoorbehoud bij bepaalde onderwerpen of een behandelvoorbehoud op alle Europese voorstellen. In dit laatste geval kan dan bij publicatie van het voorstel worden bepaald of het voorbehoud wordt doorgezet of geannuleerd. Het verschil met de huidige situatie is dat er over het voorstel nagedacht dient te worden en het dus niet onbehandeld kan blijven. Momenteel is de inzet zeer willekeurig en wordt er bij Europese onderwerpen meestal geen behandelvoorbehoud ingezet. Als er duidelijke richtlijnen en criteria komen over wanneer de Kamers het behandelvoorbehoud zo effectief mogelijk in kunnen zetten, dan zal het behandelvoorbehoud mogelijk vaker worden gebruikt en beter zijn werk doen. Er zou een voorbeeld genomen kunnen worden aan de Duitse Bundestag. De Bundestag heeft het wettelijke recht om via de Duitse regering deel te nemen aan het Europese wetgevingsproces. Dit kan hij doen door een officieel standpunt, een Stellungnahme, in te nemen. Wanneer de Bundestag dit doet, wordt er automatisch een behandelvoorbehoud geplaatst. De minister dient eerst met de Bundestag te overleggen en te onderhandelen alvorens hij mag stemmen binnen de Raad. De Tweede Kamer kent weliswaar geen equivalent van de Duitse Stellungnahme maar zou wel criteria kunnen opstellen voor situaties waarin een behandelvoorbehoud automatisch wordt ingezet. Eventueel kunnen daarbij ook afspraken tussen de Tweede Kamer en de regering worden gemaakt over een soortgelijke Stellungnahme. Indien de Tweede Kamer een officieel standpunt inneemt, volgt de regering de Kamer hierin zoals de Duitse regering de Bundestag volgt.

\subsubsection{Leden Europees Parlement zitting in Kamercommissie Europese Zaken}

Parlementaire controle staat of valt bij een goede informatievoorziening. Het Nederlandse parlement krijgt informatie via vele kanalen. Dit kunnen de formele kanalen zijn van de regering en de Europese Commissie, maar informatie kan bijvoorbeeld ook worden ver- 
kregen via werkbezoeken. Om goed op de hoogte te zijn en blijven van hetgeen op Europees niveau gebeurt, is het zinvol om contact te hebben met de bron. Deze aanbeveling ziet op het contact tussen de leden van de Tweede en Eerste Kamer en de leden van het Europees Parlement. Concreet wordt aanbevolen om, net zoals in Duitsland, enkele leden van het Europees Parlement zitting te laten nemen in de Kamercommissies voor Europese Zaken. In principe zouden alle Nederlandse parlementariërs zitting mogen nemen in deze Kamercommissies, maar in de praktijk zal dit gebeuren naar onderwerpen die op de agenda staan. De aanwezigheid van Europarlementariërs komt de informatievoorziening van het Nederlandse parlement ten goede. Duitsland laat zien dat dit nuttig is. Deelname aan de vergaderingen van de Kamercommissie zou fysiek kunnen, maar om reistijd te voorkomen zou dit ook digitaal kunnen. Omdat deze leden van het Europees Parlement niet gekozen zijn in het Nederlands parlement zouden ze geen stemrecht hebben, maar wel andere mogelijkheden om actief deel te nemen aan de vergaderingen. De Europarlementariërs kunnen namelijk agendapunten inbrengen, ze kunnen de leden van het Nederlandse parlement op de hoogte brengen van de stand van zaken op Europees niveau, informatie kan gedeeld worden, enzovoort. Het grote voordeel is dat de lijn tussen nationaal en Europees daarmee verkleind wordt en dat informatie makkelijker en sneller uitgewisseld kan worden. Wat van belang is, is dat de Europarlementariër(s) die deelnemen aan de vergaderingen informatie delen met de gehele Kamercommissie dus niet alleen met de partijgenoten. Het maakt dus niet uit bij welke partij de Europarlementariër is aangesloten en bovendien is dit voordelig voor die (kleine) partijen die geen Europarlementariërs hebben.

Ten aanzien van deze aanbeveling kan worden tegengeworpen dat dit de ongelijkheid tussen lidstaten en parlementen in de hand werkt. Kleine lidstaten hebben weinig leden in het Europees Parlement en die krijgen er nog een extra taak bij in hun reeds volle agenda. Wellicht is dit ook het geval, maar ook zonder de aanwezigheid van Europarlementariërs in de Kamercommissies voor Europese Zaken is er contact tussen nationale parlementariërs en Europarlementariërs. Er is niets op tegen om dit in een gestructureerdere vorm te doen, dus door Europarlementariërs zitting te laten hebben in de nationale Kamercommissies. De ongelijkheid kan ook niet door grote(re) landen worden weggenomen. Er is nu eenmaal vastgesteld dat het aantal Europarlementariërs dat een lidstaat kan afvaardigen afhangt van het aantal inwoners van de lidstaat.

\subsubsection{Parlementaire betrokkenheid bij handelsverdragen}

Voor de totstandkoming van handelsverdragen tussen de Europese Unie en derde landen wordt niet het 'normale' wetgevingsproces gevolgd maar een apart proces dat specifiek is ingericht voor handelsverdragen. De belangrijkste speler daarin is de Raad. Deze geeft 
namelijk de Europese Commissie de opdracht om over een handelsverdrag te onderhandelen en waarover onderhandeld dient te worden. Pas aan het einde van het proces dient het Europees Parlement in te stemmen met het verdrag. Voor nationale parlement is doorgaans geen rol weggelegd in dit proces, tenzij er onderwerpen in het verdrag staan opgenomen waarover de EU niet de exclusieve bevoegdheid heeft. In dergelijke gevallen spreken we over een 'gemengd akkoord'. In zo'n geval dienen de nationale parlementen goedkeuring te geven aan het onderwerp. Het gevoel van de Tweede Kamer is echter dat zij in de andere gevallen, dus wanneer het niet gaat om een gemend akkoord maar om een zogenoemd 'EU-only' akkoord, geen stem heeft en dus niets te zeggen heeft over een dergelijk akkoord. ${ }^{1}$ Deze aanname is niet correct. De Nederlandse ministers van Buitenlandse Zaken en van Buitenlandse Handel en Ontwikkelingssamenwerking zijn degenen die de Nederlandse belangen op Europees niveau behartigen en zij zullen dus ook met het Nederlandse parlement moeten debatteren over handelsakkoorden. Er staat de Tweede Kamer dan niets in de weg om de 'gewone' controlemiddelen, zoals bijvoorbeeld het vragenrecht of een motie, in te zetten om hun standpunten over te brengen en eventueel de minister te sturen. De Tweede Kamer staat dus niet met lege handen als het gaat om handelsakkoorden. Het is toch aan te raden om bij handelsverdragen een (strakke) procedure op te stellen over de rol van het parlement bij deze handelsverdragen. Aan de ene kant maakt dit duidelijk dat er een rol is voor het parlement en wat deze rol inhoudt. Aan de andere kant zorgt dit ervoor dat het parlement ook daadwerkelijk deze taak uitvoert (mits het parlement dat ook wil op dat moment).

De bovenstaande aanbeveling zou ook kunnen (moeten) gelden voor andere grote dossiers, zoals klimaatverdragen, dossiers als het Brexit-dossier en Europese monetaire dossiers zoals het Europese Coronafonds. Het gaat dan om de dossiers die, zoals in Duitsland, de 'core-sovereignty' van het parlement raken. Het parlement, met name de Tweede Kamer, wil bij zulke grote dossiers inspraak hebben. Het is daarom aan te bevelen om afspraken te maken met de regering om bij grote dossiers het parlement te betrekken door bijvoorbeeld het parlementair behandelvoorbehoud van toepassing te verklaren. Uiteraard dienen deze afspraken opgenomen te worden in het Reglement van Orde zoals bij de eerste aanbeveling is geadviseerd.

\subsubsection{Uitbreiding van het ambtenarenapparaat}

Om de bovenstaande aanbevelingen uit te voeren is meer capaciteit in het Nederlandse parlement nodig. De aanbeveling is dan ook een uitbreiding van het ambtenarenapparaat.

1 NOS.nl, 'Kamer voelt zich voor het blok gezet met brexit-deal', 28 december 2020. 
In vergelijking met het Duitse parlement heeft het Nederlandse parlement een klein ambtenarenapparaat. Waar de leden van de Bundestag ieder ongeveer vier ambtenaren ter beschikking hebben, heeft een lid van de Tweede Kamer nog niet één ambtenaar ter beschikking. Het feit dat het parlement niet toekomt aan bepaalde onderwerpen of het inzetten van bepaalde bevoegdheden kan te maken hebben met het kleine ambtenarenapparaat. Er is gewoonweg geen capaciteit om alles uit te voeren. Bij uitbreiding van het aantal ambtenaren dient niet alleen gedacht te worden aan politiek-neutrale ambtenaren, maar ook aan ambtenaren voor politieke ondersteuning van de verschillende fracties binnen de Kamers. Politieke standpunten zijn immers de drijfveren van de partijen en bepalend binnen het parlement.

\subsubsection{Openbare statistieken Tweede Kamer}

De aanbeveling over het openbaar maken van statistieken komt voort uit de ervaring die is opgedaan bij de uitvoering van dit onderzoek. Voor dit onderzoek was het nodig om data te verzamelen van de beide parlementen. Data van het Duitse parlement zijn per e-mail opgevraagd en ontvangen. Het Duitse parlement houdt van alle activiteiten statistieken bij. Deze worden openbaar gemaakt via publicatie op de websites van de Bundestag en Bundesrat. Er kan precies worden aangegeven wanneer, hoe vaak en waarvoor een bevoegdheid is ingezet. Dit is niet alleen nuttig voor het parlement zelf om zijn eigen activiteiten te waarderen, maar ook voor de wetenschap om onderzoek te doen en voor de burgers om vertegenwoordiging te controleren. De Nederlandse Eerste Kamer houdt haar eigen activiteiten ook bij en publiceert overzichten op haar website. De Tweede Kamer houdt geen overzichten bij, althans geen openbare. Het is voor onderzoekers moeilijk te achterhalen welke bevoegdheden de Kamer inzet en voor welke onderwerpen. Daar komt bij dat de Kamer dus zelf ook geen weet heeft van de inzet van haar bevoegdheden voor Europese aangelegenheden. Het is daarom de Tweede Kamer aan te bevelen om statistieken bij te houden en deze openbaar te maken. Hierdoor kan de Kamer een beeld krijgen van haar eigen handelen en kunnen onderzoekers en andere geïnteresseerde burgers de Kamer controleren. Het bijhouden van gegevens over activiteiten van het parlement en het hebben heldere procedures, helpt parlementariërs bij hun werk. Wanneer de eigen activiteiten niet worden bijgehouden is het ook niet mogelijk om deze te evalueren.

\subsubsection{Betere samenwerking tussen nationale parlementen}

Strikt genomen komt ook de aanbeveling tot betere samenwerking tussen nationale parlementen niet voort uit de vergelijking tussen het Nederlandse en het Duitse parlement, maar volgt deze naar aanleiding van dit onderzoek in algemene zin. Interparlementaire 
samenwerking is van wezenlijk belang voor de goede werking van de gelekaartprocedure. Alleen wanneer een derde van alle stemmen uitgebracht is, wordt een zogenoemde gele kaart getrokken. Een gele kaart vergroot de invloed van nationale parlementen op Europese besluitvorming. Uit onderzoek is gebleken dat de Europese Commissie pas geneigd is de standpunten van nationale parlementen in overweging te nemen wanneer een groot aantal nationale parlementen deze standpunten naar voren brengt. Dit geldt niet alleen voor de gelekaartprocedure maar ook voor de politieke dialoog. Binnen de gelekaartprocedure is een dergelijke drempel ingebouwd maar bij de politieke dialoog niet. Er is geen minimumaantal landen vastgesteld dat bij een politiek dialoog voldoende is voor de Europese Commissie om de standpunten in overweging te nemen; de drempels binnen de gelekaartprocedure zouden daarvoor echter leidend kunnen zijn. Tot op heden zijn drie gele kaarten getrokken. Nationale parlementen stellen ieder zelf een subsidiariteitsbezwaar op en sturen dat aan de Commissie. Dit bezwaar wordt daarna in de databank IPEX geplaatst, maar veelal is dit na de achtwekentermijn waarbinnen nationale parlementen een subsidiariteitsbezwaar kunnen sturen. Om het aantal ingediende subsidiariteitsbezwaren te vergroten zou een van de (Kamers van) nationale parlementen het voortouw kunnen nemen en een subsidiariteitsbezwaar opstellen dat door alle andere nationale parlementen kan worden overgenomen. Op deze manier hoeft niet elk parlement individueel veel tijd en energie te investeren in elk voorstel. Subsidiariteitsbezwaren zien immers allemaal op hetzelfde, namelijk subsidiariteit. Nationale parlementen kunnen aan het format van het land dat het bezwaar heeft opgesteld nog een eigen zienswijze toevoegen, maar de kern van het bezwaar blijft hetzelfde. Dit zou ook een aanbeveling aan het Duitse parlement kunnen zijn. Na 2013 heeft noch de Bundestag noch de Bundesrat met redenen omklede adviezen in het kader van de gelekaartprocedure ingediend. Beide Kamers gebruiken andere mogelijkheden om invloed uit te oefenen op Europese aangelegenheden. Voor een effectieve gelekaartprocedure is het echter van belang dat zo veel mogelijk (Kamers van) nationale parlementen met redenen omklede adviezen insturen. De adviezen van het Duitse parlement zijn daarin dus van belang.

Tot slot. De kracht van nationale parlementen zit in de samenwerking met andere nationale parlementen. Door die samenwerking kan optimaal gebruik worden gemaakt van de Europese bevoegdheden die nationale parlementen hebben. De gelekaartprocedure en de politieke dialoog zijn gecreëerd om nationale parlementen een grote(re) rol te geven in de Europese Unie. Enerzijds om de democratische legitimatie van de EU te vergroten en het democratisch tekort te verkleinen, anderzijds omdat controle van de nationale én de Europese executieve hoort bij de primaire rol van nationale parlementen. Ook al hebben nationale parlementen bevoegdheden overgedragen, dat betekent niet dat ze achterover kunnen leunen. Het hoort bij de taak van nationale parlementen om ook de besluitvorming op Europees niveau te controleren. Dat kunnen en mogen ze niet uitsluitend aan hun 
regeringen overlaten. Nationale parlementen kunnen door besluitvorming op Europees niveau te controleren niet alleen laten zien dat ze Europese aangelegenheden en de Europese instellingen serieus nemen, maar ook zichzelf. Daarnaast zijn ze dit verplicht aan de burgers die zij vertegenwoordigen. Het is dus in het belang van de nationale parlementen zelf de executieve te controleren en zich te bemoeien met nationale en Europese wetgeving. Het is daarom ook van belang dat nationale parlementen samenwerken. Het creëren van bevoegdheden voor nationale parlementen werd en wordt gedaan om nationale parlementen een grotere rol te geven op Europees niveau. Als daarvan geen gebruik wordt gemaakt, dan hebben deze bevoegdheden geen nut. Nationale parlementen moeten zelf ook laten zien dat zij een rol willen spelen op Europees niveau en dat het niet hebben van invloed ook daadwerkelijk een probleem is. Dit kunnen zij alleen doen door gebruik te maken van de bevoegdheden. Het is daarom voor het Nederlandse en het Duitse parlement van belang dat zij gebruikmaken van hun bevoegdheden en dat ze samenwerken met andere nationale parlementen.

De aanbevelingen in het kort:

- Verzamel alle bevoegdheden, procedures en afspraken en leg deze vast in één document.

- Maak een duidelijke procedure voor (het beëindigen van) een rapporteurschap.

- Toets alle Europese wetgevingsvoorstellen op subsidiariteit.

- Stel criteria en richtlijnen op om de inzet van rapporteurs en het parlementair behandelvoorbehoud te bevorderen.

- Laat leden van het Europees Parlement zitting nemen (zonder stemrecht) in de Kamercommissies voor Europese Zaken.

- Zorg voor parlementaire betrokkenheid bij handelsverdragen en andere grote dossiers.

- Breid het ambtenarenapparaat van de Staten-Generaal uit.

- Houd statistieken bij en maak deze openbaar.

- Zorg voor een betere samenwerking tussen nationale parlementen. 



\section{B I B L I O GRA A I E}

\subsection{LiterATUUR}

K. Auel \& Th. Christiansen, 'After Lisbon: National Parliaments in the European Union', West European Politics 2015, 38(2), p. 261-281.

K. Auel, O. Eisele \& L. Kinski, 'What Happens in Parliament Stays in Parliament? Newspaper Coverage of National Parliaments in EU Affairs', Journal of Common Market Studies 2018, 56(3), p. 628-645.

K. Auel \& Ch. Neuhold, 'Multi-arena players in the making? Conceptualizing the role of national parliaments since the Lisbon Treaty', Journal of European Public Policy 2017, 24(10), p. 1547-1561.

K. Auel \& T. Raunio, 'Introduction: Connecting with the Electorate? Parliamentary Communication in EU Affairs', The Journal of Legislative Studies 2014, 20(1), p. 1-12.

K. Auel, O. Rozenberg \& A. Tacea, 'To Scrutinise or Not to Scrutinise? Explaining Variation in EU-Related Activities in National Parliaments', West European Politics 2015, 38(2), p. 282-304.

P. Badura, Staatsrecht. Systematische Erläuterung des Grundgesetzes, 7. Auflage, München: Verlag C.H. Beck 2018.

A. Benz \& J. Broschek, 'Nationale Parlamente in der Europäischen Politik - Funktionen, Probleme und Lösungen', Internationale Politikanalyse 2010, Friedrich-Ebert-Stiftung.

F. Bergman \& I. van den Driessche, 'De Eerste Kamer en "Europa”', Internationale Spectator 2015, nr. 8 .

L. Besselink, 'EU Constitutionalism and National Parliaments. Insiders or Outsiders?', in:

C. Fasone \& N. Lupo, Interparliamentary Cooperation in the Composite European Constitution, Oxford: Hart Publishing 2016. 
L.F.M. Besselink \& B. van Mourik, 'The Parliamentary Legitimacy of the European Union: The Role of the States General within the European Union', Utrecht Law Review 2012, 8(1), p. 28-50.

L.F.M. Besselink, P.P.T. Bovend'Eert, J.L.W. Broeksteeg \& R. de Lange, Het Staatsrecht van 7 Europese landen, Deventer: Kluwer 2018.

P.P.T. Bovend'Eert \& H.R.B.M. Kummeling, Het Nederlandse parlement, twaalfde druk, Deventer: Kluwer 2017.

P. Bovend'Eert, H. Kummeling, S. Munneke \& W. Voermans, Factsheet Reikwijdte van artikel 68 Grondwet, Den Haag: Tweede Kamer der Staten-Generaal 2020.

B. van den Braak, De Eerste Kamer. Geschiedenis, samenstelling en betekenis 1815-1995, Den Haag: Sdu Uitgevers 1998.

Chr. Calliess, 'Die Rolle des Grundgesetzes und des Bundesverfassungsgericht', in: K. Böttger \& M. Jopp (Hrsg.), Handbuch zur deutschen Europapolitik, Baden-Baden: Nomos Verlagsgesellschaft 2017, p. 149-170.

P.J. Cardwell \& D. Jančić, 'The European Parliament and development cooperation: democratic participation in the "low politics" of EU external relations', Journal of European Integration 2019, 41(3), p. 365-381.

F. Cheneval, S. Lavenex \& F. Schimmelfennig, 'Demoi-cracy in the European Union: principles, institutions, policies, Journal of European Public Policy 2015, 22(1), p. 1-18.

P. Coenen, A.W. Heringa, H.T. Nguyen \& S. Wolf, Europees Semester (Montesquieu Policy Papers, nr. 6), Den Haag: Montesquieu Instituut 2015.

I. Cooper, 'Deliberation in the multileverl parliamentary field: the seasonal workers directive as a test case', in: B. Crum \& J. Fossum (eds.), Practices of Inter-Parliamentary Coordination in International Politics. The European Union and Beyond, Colchester: ECPR Press 2013.

I. Cooper, 'The Nordic Parliaments and the EU', in: C. Howard Grøn e.a., Still the other European Community? The Nordic Countries and the European Union, Londen/New York: Routledge 2015. 
P. Craig \& G. de Burca, EU Law: Text, Cases, and Materials, third edition, Oxford: Oxford University Press 2015.

A. Cygan, 'The parliamentarisation of EU decision-making? The impact of the Treaty of Lisbon on national parliaments', European Law Review 2011, 36(4), p. 480-499.

Ch. Degenhart, Staatsrecht I. Staatsorganistionsrecht. Mit Bezügen zum Europarecht, 33. Auflage, Heidelberg: C.F. Müller GmbH 2017.

B. Dekker e.a., Weinig empathisch, wel effectief. Percepties van Nederlandse belangenbehartiging in de Europese Unie (Clingendael Rapport), Den Haag: Nederlands Instituut voor Internationale Betrekkingen Clingendael 2019.

M. Diamant \& M.L. van Emmerik, 'Het Nederlandse budgetrecht in Europees perspectief, TvCR 2013, afl. 2, p. 94-129.

D.J. Elzinga, 'De politieke ministeriële verantwoordelijkheid', in: D.J. Elzinga (red.), Ministeriële verantwoordelijkheid in Nederland, Zwolle: W.E.J. Tjeenk Willink 1994.

C. Fasone \& N. Lupo, 'Constitutional Review and the Powers of National Parliaments in EU Affairs. Erosion or Protection?', in: D. Jančić, National Parliaments after the Lisbon Treaty and the Euro Crisis. Resilience or Resignation?, Oxford: Oxford University Press 2017.

D. Fromage, The New Joint Parliamentary Scrutiny Group for Europol: Old Wine in New Bottles?, EU TARN, Blog 17 juni 2017.

A. Gostyńska-Jakubowska, The role of national parliaments in the EU: Building or stumbling blocks, Centre for European Reform 2016.

D. Göler \& M. Jopp, 'Deutschlands konstitutionelle Europapolitik', in: K. Böttger \& M. Jopp (Hrsg.), Handbuch zur deutschen Europapolitik, Baden-Baden: Nomos Verlagsgesellschaft 2017, p. 45-60.

K. Granat, The Principle of Subsidiarity and its Enforcement in the EU Legal Order. The Role of National Parliaments in the Early Warning System, Oxford: Hart Publishing 2018.

A. Groen \& T. Christiansen, 'National Parliaments in the European Union: Conceptual Choices in the European Union's Constitutional Debate', in: C. Hefftler e.a. (eds.), The 
Palgrave Handbook of National Parliaments and the European Union, Londen: Palgrave Macmillan 2015, p. 43-59.

Ch. Gröpl, Staatsrecht I. Staatsgrundlagen, Staatsorganisation Verfassungsprozess mit Einführung in dat juristisch Lernen, 9. Auflage, München: C.H. Beck 2017.

S. Hardt, 'Vrijdenkers en dwarsliggers in de Duitse Bundestag', Nieuwsbrief De Hofvijver 2021, 11(121).

C. Hefftler \& K. Gattermann, 'Interparliamentary Cooperation in the European Union: Patterns, Problems and Potential', in: C. Hefftler e.a. (eds.), The Palgrave Handbook of National Parliaments and the European Union, Londen: Palgrave Macmillan 2015, p. 94 115.

A.W. Heringa, Europees Nederlands Staatsrecht. Het Nederlands staatsrecht beïnvloed door internationaal en Europees recht, Den Haag: Boom juridisch 2019.

A.W. Heringa, Constitutions Compared. An Introduction to Comparative Constitutional Law, 4th edition, Antwerpen: Intersentia 2016.

A.W. Heringa, J. van der Velde, L.F.M. Verhey \& W. van der Woude, Staatsrecht, dertiende druk, Deventer: Wolters Kluwer 2018.

W. Heun, The Constitution of Germany. A Contextual Analysis (Constitutional Systems of the world), Oxford/Portland Oregon: Hart Publishing 2011.

C. Heyer \& S. Liening, Enquete-Kommissionen des Deutschen Bundestages. Schnittstellen zwischen Politik und Wissenschaft, Berlin: Deutscher Bundestag 2004.

C. Hofmann, 'Die Lissabon-Begleitgesetze', in: M. Arbeiter, W. Bühring, H. Stihl, S. Schwab \& R. Höche, Die Zukunft aktiv gestalten II, Herbolzheim: Centaurus Verlag \& Media 2012.

M. Horspool \& M. Humphreys, European Union Law, $7^{\text {th }}$ edition, Oxford: Oxford University Press 2012.

A.L. Högenauer \& G. Abels, 'Conclusion: regional parliaments - a distinct role in the EU?', The Journal of Legislative Studies 2017, 23(2), p. 260-273. 
A.L. Högenauer, 'The Dutch Parliament and EU Affairs: Decentralizing Scrutiny', in: C. Hefftler e.a. (eds.), The Palgrave Handbook of National Parliaments and the European Union, Londen: Palgrave Macmillan 2015, p. 252-274.

A. Högenauer \& T. Christiansen, 'Parliamentary Administrations in the Scrutiny of EU Decision-Making', in: C. Hefftler e.a. (eds.), The Palgrave Handbook of National Parliaments and the European Union, Londen: Palgrave Macmillan 2015, p. 116-132.

M. Höreth, Wenn Richter mitregieren wollen: Selbstautorisierung beim BVerfG und dem EuGH im Vergleich, in: R.Chr. van Ooyen \& M.H.W. Möllers (hrsg.), Handbuch Bundesverfassungsgericht im politischen System, 2. Auflage, Wiesbaden: Springer Fachmedien 2015, p. 875-887.

F. Jacobs, 'Comparative Law and European Union Law', in: M. Reinmann \& R. Zimmermann, The Oxford Handbook of Comparative Law, Oxford: Oxford University Press 2019.

D. Jančić, 'The Barroso Initiative: Window Dressing or Democracy Boost?', Utrecht Law Review 2012, 8(1), p. 78-91.

D. Jančić, 'The Legacy of an Evolving Polity: Democracy, National Identity, and the Good Functioning of the EU', in: D. Jančić, National Parliaments after the Lisbon Treaty and the Euro Crisis. Resilience or Resignation?, Oxford: Oxford University Press 2017.

E. Jesse, 'Die Bundestagswahl 2017 und die Regierungsbildung', ZfP Zeitschrift für Politik 2018, 65(2), p. 168-194.

M. Jestaedt, 'Die Europäische Integration und das Grundgesetz: Die Rechtsprechung des BVerfG zwischen Integrationasbeförderung und Integrationsbegrenzung', Osaka University Law Review 2017, 64, p. 43-110.

A. Jonsson Cornell, 'The Swedish Riksdag as Scrutiniser of the Principle of Subsidiarity', European Constitutional Law Review 2016, 12(2), p. 294-317.

A. Jonsson Cornell \& M. Goldoni, National and Regional Parliaments in the EU-legislative Procedure post-Lisbon. The Impact of the Early Warning System, Oxford: Hart Publishing 2016.

J. Kester \& M. van Keulen, “'De Tweede Kamermethode”: versterkte parlementaire invloed op Europese besluitvorming', RegelMaat 2011, afl. 6, p. 303-314. 
P. Kiiver, 'The early-warning system for the principle of subsidiarity: the national parliament as a Conseil d'Etat for Europe', European Law Review 2011, 36(1), p. 98-108.

P. Kiiver, The National Parliaments in the European Union. A Critical View on EU Constitution-Building, Alphen aan den Rijn: Kluwer Law International 2006.

J.H. Klok \& H.M.B. Breunese, 'Het dubbelmandaat: tussen droom en daad...', TvCR 2014, afl. 4, p. 303-372.

V. Knutelská, 'Cooperation among national parliaments: an effective contribution to EU legitimation?', in: B. Crum \& J. Fossum (eds.), Practices of Interparliamentary Coordination in International Politics: The European Union and Beyond, Colchester: ECPR Press 2013, p. 33-50.

V. Kreilinger, A Watchdog for Europe's Policemen: The Joint Parliamentary Scrutiny Group for Europol (Policy Paper), Jacques Delors Institute 2017.

V. Kreilinger, The new inter-parliamentary conference for economic and financial government (Policy Paper), Jacques Delors Institute 2013.

S. Kropp \& A. Buzogány, 'Europäisierung informaler Regierungskontrolle. Informationsgewinnung im deutschen, schwedischen und ungarischen Parlament', Z Politikwiss 2016 (Suppl.) 26.

H.R.B.M. Kummeling, B. van Mourik \& R. Nehmelman, Enkele staatsrechtelijk reflecties op de positie van de Eerste Kamer in het kader van de Europese Unie, Den Haag: Eerste Kamer.

S.C. Loeffen, Parlementair onderzoek. Een studie van het onderzoeksrecht in Nederland, het Verenigd Koninkrijk en de Verenigde Staten, Den Haag: Sdu Uitgevers 2013.

G. Majone, 'Europe's “Democratic Deficit”: The Question of Standards', European Law Journal 1998, 4(1), p. 5-28.

E. Mastenbroek e.a., Gericht op Europa. Nationale parlementaire controle op Europese besluitvorming na het Verdrag van Lissabon, Institute for Management Research Radboud Universiteit Nijmegen 2014. 
W. Mastenbroek e.a., Engaging with Europe. Evaluating national parliamentary control of EU decision making after the Lisbon Treaty. Part I: Report of findings, Den Haag: Tweede Kamer der Staten-Generaal 2014.

A. Maurer, 'National Parliaments in the European Architecture: From Latecomers' Adaptation towards Permanent Institutional Change?', in: A. Maurer \& W. Wessels, National Parliaments on their Ways to Europe: Losers or Latecomers?, Baden-Baden: Nomos Verlagsgesellschaft 2001.

T. Maunz \& G. Dürig, Grundgesetz Kommentar, Band IV art. 23-53a, München: Verlag C.H. Beck 2009.

T. Maunz \& G. Dürig, Grundgesetz Kommentar, Band IV art. 23-53a, München: Verlag C.H. Beck 2014.

L. Michael \& M. Morlok, Staatsorganisationsrecht, 3. Auflage, Baden-Baden: Nomos Verlagsgesellschaft 2017.

E. Miklin, 'EU Politicisation and National Parliaments: Visibility of Choices and Better Aligned Ministers?', The Journal of Legislative Studies 2014, 20(1), p. 78-92.

E. Miklin, 'Beyond subsidiarity: the indirect effect of the Early Warning System on national parliamentary scutiny in European Union affairs', Journal of European Public Policy 2017, 24(3), p. 366-385.

B. van Mourik, Parlementaire controle op Europese besluitvorming. Een rechtsvergelijkend onderzoek naar mandaatsystemen en parlementaire behandelingsvoorbehouden, Nijmegen: Wolf Legal Publishers 2012.

J. Müller Gómez \& W. Wessels, Die deutsche Verwaltung und die Europäische Union. Deutsche Beamte im EU-Mehrebenensystem, Brühl: Bundesakademie für öffentliche Verwaltung im Bundesministerium des Innern 2016.

H.T. Nguyen, An uneven balance? A legal analysis of power asymmetries between national parliaments in the EU, The Hague: Eleven International Publishing 2018.

H.T. Nguyen \& S. Wolf, 'Europa in de Grondwet: A reaffirmation of commitment', Nieuwsbrief De Hofvijver 2019, 9(97). 
H.T. Nguyen \& M. Chamon, The ultra vires decision of the German Constitutional Court. Time to fight fire with fire? (Policy Paper), Jacques Delors Centre 2020.

N. Nugent \& M. Rhinard, 'Is the European Commission Really in Decline?', Journal of Common Market Studies 2016, 54(5), p. 1199-1215.

V. Perju, 'Constitutional Transplants, Borrowing and Migrations', in: M. Rosenfeld \& A. Sajo (eds.), Oxford Handbook of Comparative Constitutional Law, Oxford: Oxford University Press 2012.

F.W. Scharpf, Föderalismusreform. Kein Ausweg aus der Politikverflechtungsfalle?, Frankfurt/New York: Campus Verlag GmbH 2009.

K. Schlaich \& S. Korioth, Das Bundesverfassungsgericht. Stellung, Verfahren, Entscheidungen. Ein Studienbuch, 11. Auflage, München: Verlag C.H. Beck 2018.

R. Schmidt, Staatsorganisationsrecht, sowie Grundzüge des Verfassungsprozessrechts und des EU-rechts, 19. Auflage, Hannover: Druckhaus Pinkvoss GmbH 2018.

H. Schröder, 'Die Mitwirkung des bundestages in EU-Angelegenheiten nach dem EUZbbG in der Praxis - ein Kurzkommentar', Zeitschrift für Parlamentsfragen (ZParl) 2012, 2, p. 250-277.

M. Sorace, 'The European Union democratic deficit: Substantive representation in the European Parliament at the input stage', European Union Politics 2018, 19(1), p. 3-4.

A. Thiele, 'Die Integrationsidentität des Art. 23 Abs. 1 GG als (einzige) Grenze des Vorrangs des Europarechts', Europarecht 2017, 52, p. 367-380.

Ch. Rauh \& P. de Wilde, 'The opposition deficit in EU accountability: Evidence from over 20 years of plenary debate in four member states', European Journal of Political Research 2018, 57(1), p. 194-216.

T. Raunio, National Parliaments and European Integration. What we know and what we should know, Working Paper No. 2, ARENA Centre for European Studies University of Oslo 2009. 
C. Sprungk, 'A New Type of Representative Democracy? Reconsidering the Role of National Parliaments in the European Union', Journal of European Integration 2013, 35(5), p. 547 563.

O. Tans, 'Introduction: National Parliaments and the European Union; In Search of Common Ground', in: O. Tans, C. Zoethout \& J. Peters (eds.), National Parliaments and European Democracy: A Bottom-up Approach to European Constitutionalism, Groningen: Europa Law Publishing 2007.

O. Tans, C. Zoethout \& J. Peters (eds.), National Parliaments and European Democracy: A Bottom-up Approach to European Constitutionalism, Groningen: Europa Law Publishing 2007.

D. Thym, 'Parliamentary Control of EU decision-making in Germany', in: O. Tans, C. Zoethout \& J. Peters (eds.), National Parliaments and European Democracy: A Bottomup Approach to European Constitutionalism, Groningen: Europa Law Publishing 2007, p. 49-69.

W.J.M. Voermans, 'From Legal Imposition to Legal Invitation: From Transplants to Mutual Learning, Benchmarks and Best-Practice-Inspiration', European Journal of Law Reform 2018, 20, p. 8-19.

W.J.M. Voermans, 'Delegeren is een kwestie van vertrouwen. De nieuwe EU-delegatiesystematiek onder het Verdrag van Lissabon', RegelMaat 2014, afl. 4.

H. Vollaard, 'How European Integration Has Continued, Despite the EU's Limited Lockingin Capacity', in: European Disintegration. Palgrave Studies in European Union Politics, Londen: Palgrave Macmillan 2018, p. 165-196.

D. Whelan, 'Assessing the Reasons and Options for Brexit: A Defence of the UK's Decision to Leave the EU', North East Law Review 2018, 6, p. 1-5.

D. Willoweit, Deutsche Verfassungsgeschichte. Vom Frankenreich bis zur Wiedervereinigung Deutschlands, 7. Auflage, München: Verlag C.H. Beck 2013.

D. Willoweit, Reich und Staat. Eine kleine deutsche Verfassungsgeschichte, München: Verlag C.H. Beck 2013. 
Th. Winzen, Ch. Roederer-Rynning \& F. Schimmelfennig, 'Parliamentary co-evolution: national parliamentary reactions to the empowerment of the European Parliament', Journal of European Public Policy 2015, 22(1), p. 75-93.

R. Zippelius \& T. Würtenberger, Deutsches Staatsrecht. Ein Studienbuch, 33. Auflage, München: Verlag C.H. Beck 2018.

\subsection{JURISPRUDENTIE}

Gerechtshof Den Haag 24 maart 2020, ECLI:NL:GHDHA:2020:509

BVerfG 29 mei 1974 - 2 BvR 37/271 (Solange I)

BVerfG 22 oktober 1986 - 2 BvR 197/83 (Solange II)

BVerfG 12 oktober 1993 - 2 BvR 2134/92 (Maastricht)

BVerfG 7 mei 2008 - 2 BvE 1/03

BVerfG 30 juni 2009 - 2 BvE 2/08 (Lissabon)

BVerfG 6 juli 2010 - 2 BvR 2661/06 (Honeywell)

BVerfG 7 september 2011 - 2 BvR 987/10

BVerfG 19 juni 2012 - 2 BvE 4/11

BVerfG 12 september 2012 - 2 BvR 1390/12

BVerfG 21 juni 2016 - 2 BvR 2728/13 (OMT)

BVerfG 5 mei 2020 - 2 BvR 859/15 (Weiss) 


\subsection{WeTgEVING}

\subsubsection{Nederlandse wetgeving}

Grondwet 1815, Stb. 1815, 45.

Grondwet, Stb. 2008, 272.

Rijkswet houdende goedkeuring van het Verdrag van Lissabon tot wijziging van het Verdrag betreffende de Europese Unie en het Verdrag tot oprichting van de Europese Gemeenschap, Trb. 2008, 11.

Reglement van Orde van de Tweede Kamer, vastgesteld op 22 juni 1993.

Reglement van Orde van de Eerste Kamer, vastgesteld op 6 juni 1995.

Procedureregeling parlementaire instemming Verdrag van Lissabon (het Verdrag betreffende de werking van de Europese Unie) als opgenomen in het Reglement van Orde van de Tweede Kamer.

Procedureregeling voor de behandeling door de Kamer van wetgevende voorstellen van de Europese Unie in het kader van het parlementair behandelvoorbehoud en in het kader van de toetsing op aspecten van Europese rechtsgrondslag, subsidiariteiten als opgenomen in het Reglement van Orde van de Tweede Kamer.

\subsubsection{Duitse wetgeving}

Grondwet

Grundgesetz für die Bundesrepublik Deutschland van 23 mei 1949 (Bundesgesetzblatt I, p. 1) laatst gewijzigd op 28 maart 2019 (Bundesgesetzblatt I, p. 404).

Reglement van Orde van de Duitse Bundestag

Geschäftsordnung des Deutschen Bundestages van 2 juli 1980 (Bundesgesetzblatt I, p. 1237), laatst gewijzigd op 1 maart 2019 (Bundesgesetzblatt I, p. 197).

Staatsvertrag van 18 mei 1990 (Bundesgesetzblatt II, p. 537). 
Wahlvertrag van 2 december 1990 (Bundesgesetzblatt II, p. 822).

Einigungsvertrag van 31 augustus 1990 (Bundesgesetzblatt II, p. 885, 889) laatst gewijzigd op 21 januari 2013 (Bundesgesetzblatt I, p. 91).

Vertrag über die abschließende Regelung in bezug auf Deutschland van 12 september 1990 (Bundesgesetzblatt II, p. 1317).

Wet op de samenwerking tussen de federale regering en de Duitse Bondsdag in Europese Unie-aangelegenheden

Gesetz über die Zusammenarbeit von Bundesregierung und Deutschem Bundestag in Angelegenheiten der Europäischen Union van 4 juli 2013 (Bundesgesetzblatt I, p. 2170).

Wet op de Verantwoordelijkheid voor de Integratie van de Bondsdag en de Bondsraad in Europese Unie-aangelegenheden Gesetz über die Wahrnehmung der Integrationsverantwortung des Bundestages und des Bundesrates in Angelegenheiten der Europäischen Union van 22 september 2009 (Bundesgesetzblatt I, p. 3022) laatst gewijzigd op 1 december 2009 (Bundesgesetzblatt I, p. 3822).

Wet op de Samenwerking tussen de Federatie en de Landen in Europese Unie-aangelegenheden Gesetz über die Zusammenarbeit von Bund und Ländern in Angelegenheiten der Europäischen Union van 12 maart 1993 (Bundesgesetzblatt I, p. 313) laatst gewijzigd op 22 september 2009 (Bundesgesetzblatt I, p. 3031).

\subsubsection{Europese wetgeving}

Verdrag van Lissabon van 13 december 2007.

Verdrag betreffende de Europese Unie van 7 februari 1992.

Verdrag betreffende de werking van de Europese Unie van 25 maart 1957.

Protocol nr. 1 betreffende de rol van de nationale parlementen in de Europese van 26 oktober 2012.

Protocol nr. 2 betreffende de toepassing van de beginselen van subsidiariteit en evenredigheid van 9 mei 2008 . 
Akte betreffende de rechtstreeks verkiezing van de leden van het Europees Parlement van 20 september 1976 .

Verdrag inzake stabiliteit, coördinatie en bestuur in de economische en monetaire unie van 2 maart 2012.

Rules of Procedure of the Inter-Parliamentary Conference for the Common Foreign and Security Policy and the Common Security and Defence Policy als vastgesteld tijdens de eerste bijeenkomst van 9-10 september 2012.

Reglement van Orde van de Europese Raad, PbEU 2009, L 325/35.

Richtlijn 2014/36/EU van het Europees Parlement en de Raad van 26 februari 2014 betreffende de voorwaarden voor de toegang en verblijf van onderdanen van derde landen met het oog op seizoenarbeid, PbEU 2014, L 94/375.

Voorstel voor een Verordening over het burgerinitiatief, $\operatorname{COM}(2010) 119$.

Richtlijn 2014/49/EU van het Europees Parlement en de Raad van 16 april 2014 inzake de depositogarantiestelsels, PbEU 2014, L 173/149.

Voorstel voor een Richtlijn betreffende het gebruik van persoonsgegevens van passagiers voor het voorkomen, opsporen, onderzoeken en vervolgen van terroristische misdrijven en zware criminaliteit, $\operatorname{COM}(2011) 32$.

Richtlijn 2014/40/EU van het Europees Parlement en de Raad van 3 april 2014 betreffende de onderlinge aanpassing van de wettelijke en bestuursrechtelijke bepalingen van de lidstaten inzake de productie, de presentatie en de verkoop van tabaks- en aanverwante producten tot intrekking van Richtlijn 2001/37/EG, PbEU 2014, L 127/1.

Voorstel voor een Verordening betreffende de uitoefening van het recht om collectieve actie te voeren in de context van de vrijheid van vestiging en de vrijheid van dienstverrichting, $\operatorname{COM}(2012) 130$.

Voorstel voor een Richtlijn tot vaststelling van een kader voor maritieme ruimtelijke ordening en geïntegreerd kustbeheer, $\operatorname{COM}(2013) 133$.

Voorstel voor een Verordening tot instelling van het Europees Openbaar Ministerie, COM(2013)534. 
Verordening (EU) 2017/352 van het Europees Parlement en de Raad van 15 februari 2017 tot vaststelling van een kader voor het verrichten van havendiensten en gemeenschappelijke regels inzake de financiële transparantie van havens, PbEU 2017, L 57/1.

Voorstel voor en Verordening betreffende het Agentschap van de Europese Unie voor samenwerking en opleiding op het gebied van rechtshandhaving (Europol) en tot intrekking van Besluiten 2009/371/JBZ en 2005/681/JBZ, COM(2013)173.

Voorstel voor een Richtlijn betreffende de verspreiding van gegevens van aardobservatiesatellieten voor commerciële doeleinden, $\operatorname{COM}(2014) 344$.

Voorstel voor een Richtlijn betreffende bepaalde aspecten van overeenkomsten voor de levering van digitale inhoud, $\operatorname{COM}(2015) 634$.

Voorstel voor een Richtlijn betreffende bepaalde aspecten van overeenkomsten voor de online-verkoop en andere verkoop op afstand van goederen, $\operatorname{COM}(2015) 635$.

Voorstel voor een Verordening tot vaststelling van de criteria en instrumenten om te bepalen welke lidstaat verantwoordelijk is voor de behandeling van een verzoek om internationale bescherming dat door een onderdaan van een derde land of een staatloze bij een van de lidstaten wordt ingediend (herschikking), COM(2016)270.

Voorstel voor een Richtlijn tot wijziging van Richtlijn 96/71/EG van het Europees Parlement en de Raad van 16 december 1996 betreffende de terbeschikkingstelling van werknemers met het oog op het verrichten van diensten, $\operatorname{COM}(2016) 128$.

Voorstel voor een Verordening tot instelling van een inreis-uitreissysteem (EES) voor de registratie van inreis- en uitreisgegevens en van gegevens over weigering van toegang ten aanzien van onderdanen van derde landen die de buitengrenzen van de Europese Unie overschrijden en tot vaststelling van de voorwaarden voor toegang tot het EES voor rechtshandhavingsdoeleinden en tot wijziging van Verordening (EG) nr. 767/2008 en Verordening (EU) nr. 1077/2011, COM(2016)194.

Voorstel voor een Verordening tot wijziging van Verordening (EU) 2016/399 in verband met het gebruik van het inreis-uitreissysteem (EES), COM(2016)196. 


\section{$7 \cdot 4$ OFFICIËLE DOCUMENTEN}

Verslag van de Commissie. Jaarverslag 2007 over de contacten tussen de Europese Commissie en de nationale parlementen, $\operatorname{COM}(2008) 237$.

Verslag van de Commissie. Jaarverslag 2010 over de betrekkingen tussen de Europese Commissie en de nationale parlementen, $\operatorname{COM}(2011) 345$.

Verslag van de Commissie. Jaarverslag 2013 over de betrekkingen tussen de Europese Commissie en de nationale parlementen, $\operatorname{COM}(2014) 507$.

Verslag van de Commissie. Jaarverslag 2016 over de betrekkingen tussen de Europese Commissie en de nationale parlementen, $\operatorname{COM}(2017) 601$.

Verslag van de Commissie. Jaarverslag 2007 over de contacten tussen de Europese Commissie en de nationale parlementen, $\operatorname{COM}(2008) 237$.

Werkdocument van de Commissie - Raadpleging over de toekomstige 'EU 2020' strategie, $\operatorname{COM}(2009) 647$.

Groenboek over een Europees burgerinitiatief, COM(2009)622.

Groenboek naar adequate, houdbare en zekere Europese pensioenstelsels, COM(2010)365.

Groenboek betreffende de onlinedistributie van audiovisuele werken in de Europese Unie: mogelijkheden en uitdagingen voor een digitale eengemaakte markt, COM(2011)427.

Mededeling 'Naar een intensivering van de economische beleidscoördinatie', $\operatorname{COM}(2010) 250$.

Mededeling 'Naar een intensivering van de economische beleidscoördinatie ten behoeve van stabiliteit, groei en werkgelegenheid - Instrumenten voor een krachtigere economische governance van de EU', $\operatorname{COM}(2010) 367$.

Mededeling 'EUROPA 2020. Een strategie voor slimme, duurzame en inclusieve groei', $\operatorname{COM}(2010) 2020$.

Mededeling 'Naar een geïntegreerde aanpak van cultureel erfgoed voor Europa', $\operatorname{COM}(2014) 477$. 
Mededeling 'Het werkprogramma van de Commissie voor 2016. Tijd voor verandering', $\operatorname{COM}(2015) 610$.

Mededeling 'Krachtigere en slimmere informatiesystemen voor grenzen en veiligheid', $\operatorname{COM}(2016) 205$.

Brief Europese Commissie van 17 november 2015, C(2015)7982 final.

Rapport 'Evaluatie strafrechtelijke aanpak eergerelateerd geweld', WODC 28 juni 2012.

Rapport 'Evaluatie Wet wederzijdse erkenning en tenuitvoerlegging vrijheidsbenemende en voorwaardelijke sancties (Wets)', WODC 1 juni 2018.

Rapport 'Op doel? Evaluatie van de Wet maatregelen bestrijding voetbalvandalisme en ernstige overlast', WODC 22 juni 2012.

Subsidiarity, National Parliaments and the Lisbon Treaty, House of Commons European Scrutiny Committee, HC 563, 2007-2008.

Reply of the European Commission to the Contribution of the XLVIII COSAC Nicosia, 14-16 October 2012 via www.cosac.eu/48-cyprus-2012/plenary-meeting-of-the-xlviiicosac-14-16-october-2012-nicos/ (laatst geraadpleegd 23 februari 2018).

EU Committee's report on The Role of National Parliaments in the EU, 9th Report of Session 2013-14, 24 March 2014, House of Lords.

Lord Boswell of Aynho, House of Lords, The 'Green Card': discussion paper, 19 January 2015 via www.google.com/url?sa $=$ t\&rct $=j \& q=\& e s r c=s \&$ source $=$ web\&cd $=1 \& v e d=2 a h U$ KEwj6kJHdvtfiAhVHUlAKHVtQCswQFjAAegQIAhAC\&url=https\%3A\%2F\%2Fwww.tweedekamer.nl\%2Fdownloads\%2Fdocument\%3Fid\%3D87c6d271-d5d7-4e7a-b42c90a83c05a48b\%26title\%3DThe\%2520\%25E2\%2580\%259CGreen\%2520Card\%25E2\%2580\%259D\%253A\%2520discussion\%2520paper.pdf\&usg=AOvVaw3X1sN9iN9e4aoVsxyoOBmi (laatst geraadpleegd 23 februari 2018).

Eerste Groene Kaart, advies van Lord Boswell, House of Lords 22 juli 2015 via www.parliament.uk/documents/lords-committees/eu-select/green-card/green-card-onfood-waste.pdf (laatst geraadpleegd 23 februari 2018). 
Contribution of the LIII COSAC, Riga 31 mei-2 juni 2015 via https://eur-lex.europa.eu/ legal-content/NL/TXT/PDF/?uri=CELEX:52015XP1016(01)\&from=EN (laatst geraadpleegd 23 februari 2018).

COSAC, 22nd Bi-annual Report: Developments in European Union Procedures and Practices Relevant to Parliamentary Scrutiny, Rome 4 november 2014 via www.cosac.eu/ documents/bi-annual-reports-of-cosac/ (laatst geraadpleegd 6 maart 2018).

COSAC, 23rd Bi-annual Report: Developments in European Union Procedures and Practices Relevant to Parliamentary Scrutiny via www.cosac.eu/documents/bi-annualreports-of-cosac/ (laatst geraadpleegd 6 maart 2018).

Conference of Speakers of the European Union Parliaments, Guidelines for Inter-Parliamentary Cooperation in the European Union (2008) via www.google.com/url?sa=t\&rct=

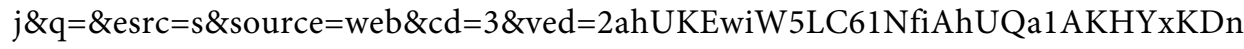
IQFjACegQIARAC\&url=http\%3A\%2F\%2Fwww.ipex.eu\%2FIPEXL-WEB\%2Fdossier \%2Ffiles\%2Fdownload\%2F082dbcc54b222e18014b53e6a34d399b.do\&usg= AOvVaw3qFV6wZyP6x4APJ1I0szRO (laatst geraadpleegd 24 april 2019).

The Stockholm Guidelines for the Conference of Speakers of EU als aangenomen op de EU Speakers' Conference in Stockholm op 15 mei 2010.

Eerste Kamercommissie Europese Zaken (2015), 'Introductiedossier', Den Haag: Eerste Kamer 12 juni 2015.

Reglement van de Conferentie van de commissies voor EU-aangelegenheden van de parlementen van de Europese Unie (2011/C 229/01) via www.google.com/url?sa=t\&rct= j\& $\mathrm{q}=\&$ esrc $=$ s\&source $=$ web \& $\mathrm{cd}=1 \& \mathrm{cad}=$ rja \&uact $=8 \& \mathrm{ved}=2 \mathrm{ahUKEwj} 3 \mathrm{nIuI} 2 \mathrm{NfiAhXFUl}$ AKHQLBDHkQFjAAegQIABAC\&url=https\%3A\%2F\%2Fwww.eerstekamer.nl\%2Fbijlage \%2F20150916\%2Fintroductiedossier_vaste_commissie_2\%2Fdocument3\%2Ff\%3D\%2F vjxdi2x0j5pi.pdf\&usg=AOvVaw2PidLp8q8o9iVa6kqREWn3 (laatst geraadpleegd 30 maart 2017).

Raad van State, Ministeriële verantwoordelijkheid. Een ongevraagd advies van de Afdeling advisering, Den Haag: juni 2020.

Rapport 'D8.4 Report: 'Do National Parliaments use their Rights to involve Themselves in EU Decision Making? What, if any, are the Constraints? A Comparison of Five EU Member States', (21 april 2016) van Petr Kaniok, Masaryk University via http:// 
beucitizen.eu/wp-content/uploads/D8.4-National-Parliaments-as-Collective-Actor-ofEuropean-Citizenship_FINAL.pdf (laatst geraadpleegd 15 februari 2018).

Rapport Staatscommissie Grondwet, november 2010.

Besluitenlijst van de procedurevergadering van woensdag 22 juni 2016, vaste commissie voor Veiligheid en Justitie, Tweede Kamer d.d. 23 juni 2016, agendapunt 56, activiteitnummer 2015A05068.

Verslag rapporteurs Single European Sky bij brief d.d. 15 september 2016 aan de vaste commissie voor Infrastructuur en Milieu van de Tweede Kamer via www.tweedekamer.nl/ kamerstukken/detail?id=2016Z17744\&did=2016D36547 (laatst geraadpleegd 6 juni 2017).

Eindverslag rapporteur EU-pakket Circulaire Economie, 13 februari 2017 via www.tweedekamer.nl/kamerstukken/detail?id=2017Z02611\&did=2017D05399 (laatst geraadpleegd 6 juni 2017).

Eerste Kamer (2010), Memo 'Uitwerking procedure parlementair behandelvoorbehoud Eerste Kamer’, Den Haag: Eerste Kamer, 4 maart 2010.

Eerste Kamer, verslag van de plenaire vergadering van dinsdag 6 december 2016, 2016/17, $10^{\mathrm{e}}$ vergadering.

Eerste Kamer, verslag van de plenaire vergadering van dinsdag 3 april 2018, 2017/18, 25 vergadering.

\subsection{Parlementaire StukKen}

\subsubsection{Tweede Kamer}

Kamerstukken II 2002/03, 28604, nr. 3.

Kamerstukken II 2003/04, 21501-02, nr. 560.

Kamerstukken II 2007/08, 31202, nr. 4.

Kamerstukken II 2007/08, 31374 (R 1850), nr. 4.

Kamerstukken II 2007/08, 31384, nr. 23.

Kamerstukken II 2008/09, 26488, nr. 169.

Kamerstukken II 2009/10, 32258.

Kamerstukken II 2010/11, 32726, nr. 1. 
Kamerstukken II 2010/11, 21501-02, nr. 490.

Kamerstukken II 2010/11, 21501-32, nr. 473.

Kamerstukken II 2011/12, 21501-07, nr. 877.

Kamerstukken II 2011/12, 21501-07, nr. 942.

Kamerstukken II 2011/12, 31980, nr. 61.

Kamerstukken II 2012/13, 23987, nr. 127.

Kamerstukken II 2012/13, 22112, nr. 1498.

Kamerstukken II 2013/14, 33877, nr. 1.

Kamerstukken II 2013/14, 21501-20, nr. 895.

Kamerstukken II 2014/15, 33606, nr. 4.

Kamerstukken II 2014/15, 21501-07, nr. 1217.

Kamerstukken II 2014/15, 32317, 302.

Kamerstukken II 2014/15, 33574, nr. 6.

Kamerstukken II 2015/16, 22112, nr. 2177.

Kamerstukken II 2015/16, 32317, nr. 384.

Kamerstukken II 2015/16, 33678, nr. 11.

Kamerstukken II 2015/16, 34166, nr. 43.

Kamerstukken II 2015/16, 34400.

Kamerstukken II 2015/16, 31985, nr. 27.

Kamerstukken II 2015/16, 22112, nr. 2124.

Kamerstukken II 2015/16, 32317, nr. 367.

Kamerstukken II 2016/17, 34566, nr. 3.

Kamerstukken II 2016/17, 34695, nr. 1.

Kamerstukken II 2016/17, 32317, nr. 465.

Kamerstukken II 2016/17, 21501-07, nr. 1406.

Kamerstukken II 2016/17, 21501-07, nr. 1408.

Kamerstukken II 2016/17, 34604, 10.

Kamerstukken II 2018/19, 25202 - (R2126).

Kamerstukken II 2018/19, 35228, nr. 1.

Kamerstukken II 2020/21, 35510, nr. 2.

Kamerstukken II 2020/21, 35228, nr. 35.

Kamerstukken II 21501-20 (documenten met betrekking tot de Europese Raad).

Kamerstukken II 22112 (BNC-fiches).

Handelingen II 2013/14, 31, item 18.

Handelingen II 2013/14, 98, item 8.

Handelingen II 2013/14, 98, item 9.

Handelingen II 2013/14, 100, item 2.

Handelingen II 2013/14, 103, item 11. 
Handelingen II 2013/14, 103, item 9.

Handelingen II 2013/14, 106, item 11.

Handelingen II 2014/15, 66, item 3.

Handelingen II 2014/15, 46, item 3.

Handelingen II 2014/15, 95, item 7.

Handelingen II 2015/16, 32, item 10.

Handelingen II 2015/16, 32, item 11.

Handelingen II 2016/17, 13, item 3.

Handelingen II 2016/17, 30, item 11.

Handelingen II 2017/18, 51, item 24.

Handelingen II 2020/21, 59, item 26.

Aanhangsel Handelingen II 2013/14, nr. 2420.

Aanhangsel Handelingen II 2013/14, nr. 2316.

Aanhangsel Handelingen II 2013/14, nr. 2140.

Besluitenlijst van de procedurevergadering van donderdag 19 maart 2015, 2015D13191.

\subsubsection{Eerste Kamer}

Kamerstukken I 1995/96, 23490, nr. 90c.

Kamerstukken I 2008/09, 30953, F.

Kamerstukken I 2009/10, 30953, H.

Kamerstukken I 2011/12, 22112, FJ.

Kamerstukken I 2012/13, C, A.

Kamerstukken I 2013/14, 33877, D.

Kamerstukken I 2015/16, 32317, FY.

Kamerstukken I 2015/16, 32317, GS.

Kamerstukken I 2016/17, 33709, W.

Kamerstukken I 2016/17, CXXIV, A.

Kamerstukken I 2020/21, CXLIII.

Handelingen I 1986/87, 30 september 1986, p. 21-58.

Handelingen I 2001/02, nr. 24, p. 1210-1213.

Handelingen I 2007/08, nr. 37, p. 1588.

Aanhangsel Handelingen I 2010/11, 2.

Aanhangsel Handelingen I 2010/11, 7. 
Aanhangsel Handelingen I 2011/12, 4. Aanhangsel Handelingen I 2011/12, 5. Aanhangsel Handelingen I 2011/12, 6. Aanhangsel Handelingen I 2013/14, 3. Aanhangsel Handelingen I 2013/14, 6. Aanhangsel Handelingen I 2014/15, 7.

\subsubsection{Tweede Kamer en Eerste Kamer}

Kamerstukken 30180 (Conferentie van Voorzitters van de parlementen van de Europese Unie).

Kamerstukken 2012/13, 33130, A/2.

Kamerstukken I/II 2015/16, 32317, FO/365.

\subsubsection{Bundestag}

Deutscher Bundestag 17. Wahlperiode, Drucksache 17/14837, 21 oktober 2013.

Deutscher Bundestag 17. Wahlperiode, Drucksache 17/4927, 25 februari 2011.

Deutscher Bundestag 17. Wahlperiode, Drucksache 17/5490, 13 april 2011.

Deutscher Bundestag 17. Wahlperiode, Drucksache 17/14601, 30 augustus 2013.

Deutscher Bundestag 18. Wahlperiode, Drucksache 18/10443, 25 november 2016.

Deutscher Bundestag 19. Wahlperiode, Drucksache 19/8959, 03 april 2019.

Deutscher Bundestag 19. Wahlperiode, Drucksache 19/21986, 31 augustus 2020.

Deutscher Bundestag, Plenarprotokoll 18/240, Stenografischer Bericht, 240. Sitzung, Berlin, Donnerstag, den 22. Juni 2017, p. 24536 (C).

Deutscher Bundestag, Plenarprotokoll 18/240, Stenografischer Bericht, 240. Sitzung, Berlin, Donnerstag, den 22. Juni 2017, p. 24539.

\subsubsection{Bundesrat}

Deutscher Bundesrat, Drucksache 73/11, 3 februari 2011.

Deutscher Bundesrat, Drucksache 73/1/11, 7 maart 2011.

Deutscher Bundesrat, Drucksache 413/1/11, 24 oktober 2011.

Deutscher Bundesrat Plenarprotokoll 889. Sitzung, 4 november 2011. 


\subsection{WeBsites}

\subsubsection{Europese websites}

Website Europese Commissie, Adviezen van nationale parlementen en antwoorden van de Commissie.

http://ec.europa.eu/dgs/secretariat_general/relations/relations_other/npo/index_en.htm (laatst geraadpleegd 7 februari 2018).

Website Europese Commissie, Dienst secretariaat-generaal http://ec.europa.eu/dgs/secretariat_general/relations/relations_other/npo/political_ dialogue_nl.htm (laatst geraadpleegd 7 februari 2018).

Website Europese Commissies, Betrekkingen met nationale parlementen https://ec.europa.eu/info/law/law-making-process/adopting-eu-law/relations-nationalparliaments_nl (laatst geraadpleegd 29 januari 2018).

Website Europese Commissie, Jaarverslagen https://ec.europa.eu/info/law/law-making-process/adopting-eu-law/relations-nationalparliaments/annual-reports-relations-national-parliaments_nl (laatst geraadpleegd 2 februari 2019).

Website Europese Commissie, brief voorzitter Tweede Kamer http://ec.europa.eu/dgs/secretariat_general/relations/relations_other/npo/docs/netherlands/ 2010/com20100521/com20100521_tweedekamer_opinion_en.pdf (laatst geraadpleegd op 7 februari 2018).

Website Europese Commissie, Naar een circulaire economie https://ec.europa.eu/commission/priorities/jobs-growth-and-investment/towards-circulareconomy_nl (laatst geraadpleegd 23 februari 2018).

Website Europese Commissie, Enhanced cooperation https://ec.europa.eu/commission/sites/beta-political/files/enhanced_cooperation_-_already_ a_reality_in_the_eu_1.pdf (laatst geraadpleegd 28 februari 2018).

Website Europese Commissie, De subsidiariteitscontrole https://ec.europa.eu/info/law/law-making-process/adopting-eu-law/relations-nationalparliaments/subsidiarity-control-mechanism_nl (laatst geraadpleegd 10 februari 2018). 
Website Europese Commissie, EU expenditure and revenue 2014-2020 https://ec.europa.eu/budget/graphs/revenue_expediture.html (laatst geraadpleegd 16 juli 2020).

Website Europese Raad en Raad van de Europese Unie, Europees Openbaar Ministerie http://www.consilium.europa.eu/nl/press/press-releases/2017/04/03/eppo/ (laatst geraadpleegd 28 februari 2018).

Website Europees Parlement, Relations with national parliaments http://www.europarl.europa.eu/webnp/cms/pid/8 (laatst geraadpleegd 10 maart 2018).

Website EUR-Lex, stand van zaken http://eur-lex.europa.eu/legal-content/EN/HIS/?uri=COM:2016:128:FIN (laatst geraadpleegd 28 februari 2018).

Website EUR-Lex, Procedure 2011/0023/COD https://eur-lex.europa.eu/legal-content/EN/HIS/?uri=CELEX:52011PC0032 (laatst geraadpleegd 22 november 2018).

Website ipex, COM/2011/0032/FIN www.ipex.eu/IPEXL-WEB/dossier/document/COM20110032FIN.do (laatst geraadpleegd 22 november 2018).

Website ipex, EU Speakers Conference www.ipex.eu/IPEXL-WEB/euspeakers/getspeakers.do?id=082dbcc530e432c20130e528 aff20134 (laatst geraadpleegd april 2019).

\subsubsection{Nederlandse websites}

Website Tweede Kamer www.tweedekamer.nl (laatst geraadpleegd 6 juni 2019).

Website Tweede Kamer, Vaste commissie voor Justitie en Veiligheid www.tweedekamer.nl/kamerleden_en_commissies/commissies/vj/vj-en-europa (laatst geraadpleegd op 7 februari 2018). 
Website Tweede Kamer, Artikel 13-conferentie www.tweedekamer.nl/vergaderingen/commissievergaderingen/details?id=2013A05820 (laatst geraadpleegd 6 maart 2015).

Website Tweede Kamer, Brochure Europese besluitvorming in de Tweede Kamer, www.tweedekamer.nl/sites/default/files/atoms/files/brochure_europese_besluitvorming.pdf (laatst geraadpleegd 4 augustus 2015).

Website Tweede Kamer, Bovenop Europa www.tweedekamer.nl/kamerleden/commissies/europese-zaken/bovenop-europa (laatst geraadpleegd 6 juni 2017).

Website Tweede Kamer, Rapporteurs Europees luchtruim www.tweedekamer.nl/nieuws/kamernieuws/rapporteurs-doen-verslag-overgemeenschappelijk-europees-luchtruim (laatst geraadpleegd op 6 juni 2017).

Website Tweede Kamer, Rapporteurs

www.tweedekamer.nl/kamerleden_en_commissies/commissies/vj/rapporteurs (laatst geraadpleegd 22 maart 2018).

Website Tweede Kamer, Rapporteur bespreekt in Parijs bezwaren Kamer tegen Europees $\mathrm{OM}$ www.tweedekamer.nl/nieuws/kamernieuws/newspage2947_bezwaren_tegen_europees_ om (laatst geraadpleegd 22 maart 2018).

Website Tweede Kamer, debat fiscale constructies www.tweedekamer.nl/nieuws/kamernieuws/parlementaire-ondervragingscommissiefiscale-constructies-presenteert-verslag (laatst geraadpleegd 18 maart 2018).

Website Tweede Kamer, JBZ-procedure www.tweedekamer.nl/sites/default/files/field_uploads/7RvO_JBZ-procedure_tcm181238565.pdf (laatst geraadpleegd 28 juni 2016).

Website Tweede Kamer, Griffier www.tweedekamer.nl/over_de_tweede_kamer/organogram/griffier (laatst geraadpleegd 21 juni 2018). 
Website Tweede Kamer, Organogram

www.tweedekamer.nl/over_de_tweede_kamer/organogram (laatst geraadpleegd 6 juli 2019).

Website Tweede Kamer, Dienst Analyse en Onderzoek

www.tweedekamer.nl/over_de_tweede_kamer/organogram/dienst_analyse_en_onderzoek (laatst geraadpleegd 21 juni 2018).

Website Tweede Kamer, Griffies Commissies

www.tweedekamer.nl/over_de_tweede_kamer/organogram/griffies_commissies (laatst geraadpleegd 21 juni 2018).

Website Tweede Kamer, Commissie Europese Zaken

www.tweedekamer.nl/kamerleden_en_commissies/commissies/eu/samenstelling (laatst geraadpleegd 21 juni 2018).

Website Tweede Kamer, Eurocommissaris Justitie spreekt met Kamerleden www.tweedekamer.nl/nieuws/kamernieuws/eurocommissaris-justitie-spreekt-metkamerleden (laatst geraadpleegd 14 oktober 2019).

Website Tweede Kamer, Parlementaire ondervragingscommissie kinderopvangtoeslag www.tweedekamer.nl/kamerleden_en_commissies/commissies/pok (laatst geraadpleegd 26 oktober 2020).

Website Eerste Kamer

www.eerstekamer.nl (laatst geraadpleegd 12 juli 2016).

Website Eerste Kamer, Parlementaire bevoegdheden Eerste Kamer met betrekking tot de Europese Unie

www.eerstekamer.nl/eu/thema/parlementaire_bevoegdheden_eerste (laatst geraadpleegd 10 augustus 2015).

Website Eerste Kamer, BNC

www.eerstekamer.nl/eu/bnc_fiches (laatst geraadpleegd 5 augustus 2015).

Website Eerste Kamer, Voorstel EOM

www.eerstekamer.nl/eu/edossier/e130041_voorstel_voor_een (laatst geraadpleegd 11 april 2018). 
Website Eerste Kamer, Witboek stappenplan www.eerstekamer.nl/eu/edossier/e110018_witboek_stappenplan_voor (laatst geraadpleegd 21 juni 2018).

Website Eerste Kamer, Europese voorstellen www.eerstekamer.nl/eu/europese_voorstellen (laatst geraadpleegd op 8 juli 2016).

Website Eerste Kamer, prioritaire selectie www.eerstekamer.nl/eu/overig/20121211/priorititaire_selectie_uit_het/f=/vj55h3bl4ezd.pdf (laatst geraadpleegd 11 april 2018).

Website Eerste Kamer, Instemmingsrecht www.eerstekamer.nl/eu/begrip/instemmingsrecht (laatst geraadpleegd 28 juni 2016).

Website Eerste Kamer, Ambtelijke organisatie www.eerstekamer.nl/begrip/ambtelijke_organisatie (laatst geraadpleegd 20 juni 2018).

Website Eerste Kamer, Algemene Europese Beschouwingen 2016 www.eerstekamer.nl/eu/thema/algemene_europese_beschouwingen_7 (laatst geraadpleegd 10 juli 2018).

Website Eerste Kamer, toezeggingen www.eerstekamer.nl/toezeggingen_2 (laatst geraadpleegd 28 oktober 2020).

Website Eerste Kamer, geselecteerde voorstellen. www.eerstekamer.nl/eu/edossiers (laatst geraadpleegd 28 oktober 2020).

Website parlement.com, Tweede Kamercommissies www.parlement.com/id/vh8lnhrogvuz/tweede_kamercommissie (laatst geraadpleegd januari 2019).

Website parlement.com, Eerste Kamercommissies www.parlement.com/id/vh8lnhrpmxvz/eerste_kamercommissies (laatst geraadpleegd januari 2019).

Website De Nederlandse Grondwet, BNC-fiche www.denederlandsegrondwet.nl/9353000/1/j9vvihlf299q0sr/vh8es07d69yp (laatst geraadpleegd 5 augustus 2015). 
Website Europa NU, BNC

www.europa-nu.nl/id/vh9gpltfvuzz/interdepartementale_werkgroep (laatst geraadpleegd 5 augustus 2015).

NOS.nl, 'Kamer voelt zich voor het blok gezet met brexit-deal' 28 december 2020.

https://nos.nl/collectie/13852/artikel/2362332-kamer-voelt-zich-voor-het-blok-gezet-metbrexit-deal (laatst geraadpleegd 15 januari 2021).

Website Nederlandse Vereniging voor Raadsleden

www.raadsleden.nl/actueel/nieuws/raad-amsterdam-wil-het-budget-ondersteuning-metminimaal-50-procent-verhogen (laatst geraadpleegd 9 juli 2021).

\subsubsection{Duitse websites}

Website Bundestag

www.bundestag.de (laatst geraadpleegd 3 februari 2019).

Website Bundesrat

www.bundesrat.de (laatst geraadpleegd 3 februari 2019).

Website Duitse permanente vertegenwoordiger in de EU

http://eu-lbde.webhosting.be (laatst geraadpleegd 21 september 2018).

Website Ministerie van Binnenlandse Zaken, Beamtete Staatssekretär www.bmi.bund.de/DE/ministerium/beamtete-staatssekretaere/beamtete-staatssekretaerenode.html (laatst geraadpleegd 12 september 2018).

Website Ministerie van Binnenlandse Zaken, Parlamentarischer Staatssekretär www.bmi.bund.de/DE/ministerium/parlamentarische-staatssekretaere/parlamentarischestaatssekretaere-node.html (laatst geraadpleegd 12 september 2018).

Website Bundestag, Verwaltung www.Bundestag.de/parlament/verwaltung/ (laatst geraadpleegd 26 juli 2018).

Website Bundestag, Instrumente der Kontrolle www.Bundestag.de/parlament/aufgaben/regierungskontrolle_neu/kontrolle/instru/255462 (laatst geraadpleegd 26 juli 2018). 
Website Bundestag, Kontrolle der Regierung www.Bundestag.de/parlament/aufgaben/regierungskontrolle_neu/kontrolle/kontrolle/ 212634 (laatst geraadpleegd 6 augustus 2018).

Website Bundestag, Gremien zur Kontrolle www.Bundestag.de/parlament/aufgaben/regierungskontrolle_neu/kontrolle/grem/255458 (laatst geraadpleegd 10 augustus 2018).

Website Bundestag, Mitwirkungsrechte www.Bundestag.de/europa_internationales/eu/mitwirkungsrechte (laatst geraadpleegd 15 november 2018).

Website Bundestag, Vielfalt der Kontrolle www.Bundestag.de/parlament/aufgaben/regierungskontrolle_neu/kontrolle/vielfalt/255456 (laatst geraadpleegd 27 juli 2018).

Website Bundestag, Anfragen www.Bundestag.de/blob/196220/6cb3e85de6b8d7377caa4fae8d05fcc4/kapitel_11_01_ anfragen-data.pdf (laatst geraadpleegd 21 september 2018).

Website Bundestag, Mediathek www.Bundestag.de/mediathek? videoid=6569827\# url=L211ZGlhdGhla292ZXJ $\mathrm{sYXk}=\& \bmod =$ mediathek (laatst geraadpleegd 25 september 2018).

Website Bundesrat, Ausschüsse www.bundesrat.de/DE/bundesrat/sekretariat/a/a-node.html (laatst geraadpleegd 26 juli 2018).

Website Bundesrat, Parlamentsabteilung www.bundesrat.de/DE/bundesrat/sekretariat/p/p-node.html (laatst geraadpleegd 26 juli 2018).

Website Bundestag, EU-Ausschuss diskutiert mit Kommissar Oettinger www.bundestag.de/dokumente/textarchiv/2014/kw39_pa_europa_oettinger-330632 (laatst geraadpleegd 14 oktober 2019).

Website Bundesrat, Zustimmungs- und Einspruchsgesetze www.bundesrat.de/DE/aufgaben/gesetzgebung/zust-einspr/zust-einsprnode.html\#doc4353672bodyText1 (laatst geraadpleegd 9 november 2020). 
Website Bundestag, Das Misstrauensvotum gegen Willy Brandt (1972) www.bundestag.de/dokumente/textarchiv/28290403_misstrauensvotum01-200574 (laatst geraadpleegd 10 november 2020).

Website Bundestag, Das Misstrauensvotum gegen Helmut Schmidt www.bundestag.de/webarchiv/textarchiv/2012/40797914_kw40_misstrauensvotum_ kalenderblatt-209576 (laatst geraadpleegd 10 november 2020).

Website Bundestag, Mitarbeiter www.bundestag.de/abgeordnete/mdb_diaeten/1334d-260806 (laatst geraadpleegd 9 juli 2021).

Website Bundesrat, Personalausweis www.bundesrat.de/DE/plenum/bundesrat-kompakt/16/946/946-node.html\#top-19 (laatst geraadpleegd 19 november 2020).

Website archief Bundestag http://webarchiv.bundestag.de/cgi/show.php?fileToLoad=2951\&id=1223 (laatst geraadpleegd 24 november 2020).

\subsubsection{Overige}

Website House of Lords www.parliament.uk/documents/lords-committees/eu-select/green-card/green-card-onfood-waste.pdf) (laatst geraadpleegd 23 februari 2018).

Website Hongaars parlement www.parlament.hu/web/house-of-the-national-assembly/conference-of-speakers-ofeuropean-union-parliaments (laatst geraadpleegd 15 februari 2018).

Website Beucitizen http://beucitizen.eu/wp-content/uploads/D8.4-National-Parliaments-as-Collective-Actorof-European-Citizenship_FINAL.pdf (laatst geraadpleegd 15 februari 2018).

Website Eurostat 2017

https://ec.europa.eu/eurostat/tgm/table.do?tab=table\&init=1\&plugin=1\&language=en \& pcode $=$ tps00001 (laatst geraadpleegd 29 november 2018). 
Deutscher Bundestag, Der Ausschuss für die Angelegenheiten der Europäischen Union, juli 2018

www.btg-bestellservice.de/pdf/20089100.pdf (laatst geraadpleegd 23 november 2020).

\subsection{OVERIGE BRONNEN}

H. Van Rompuy, 'Speech by President Herman Van Rompuy to the Interparliamentary Committee Meeting on the European Semester for Economic Policy Coordination', Brussels, 27 februari 2012, EUCO 31/12 (http://europa.eu/rapid/press-release_PRES-1268_en.htm?locale=en (laatst geraadpleegd 30 juni 2016).

Brief Tweede Kamer n.a.v. voorstel COM/2010/0521 (http://ec.europa.eu/dgs/secretariat_ general/relations/relations_other/npo/docs/netherlands/2010/com20100521/com20100521_ tweedekamer_opinion_en.pdf) (laatst geraadpleegd op 7 februari 2018).

Tweede Kamer, 'Bovenop Europa: Evaluatie van de versterkte EU-ondersteuning van de Tweede Kamer 2007-2011’, Den Haag: Tweede Kamer 2011.

Brochure Europese besluitvorming in de Tweede Kamer, www.tweedekamer.nl/sites/default/ files/atoms/files/brochure_europese_besluitvorming.pdf (laatst geraadpleegd 22 december 2017).

Position Paper House of Representatives of the States General in The Netherlands with regard to EU proposals regarding Smart Borders, position paper Slimme Grenzen, 29 oktober 2015 https://ec.europa.eu/home-affairs/sites/homeaffairs/files/what-is-new/ public-consultation/2015/docs/consultation_030/contribution_position_paper_smart_ borders_house_of_representatives_en.pdf (laatst geraadpleegd 6 juni 2017).

Onderzoek nieuwe Europese regelgeving: 'impact assessment', Eindrapport, PKMG, 5 oktober 2010 .

M. van Keulen, 'Kamerleden moeten hun kennistekort durven toegeven en agenderen', de Volkskrant 2 mei 2018.

B. Dekker e.a., Weinig empathisch, wel effectief. Percepties van Nederlandse belangenbehartiging in de Europese Unie (Clingendael Rapport), Den Haag: Nederlands Instituut voor Internationale Betrekkingen Clingendael 2019. 
Das Datenhandbuch zur Geschichte des Deutschen Bundestages via www.bundestag.de/datenhandbuch (laatst geraadpleegd 10 november 2020). 



\section{BiJlage I. PROCEDURE BEHANDELING Europese Voorstellen IN DE Eerste KA M E R ${ }^{1}$}

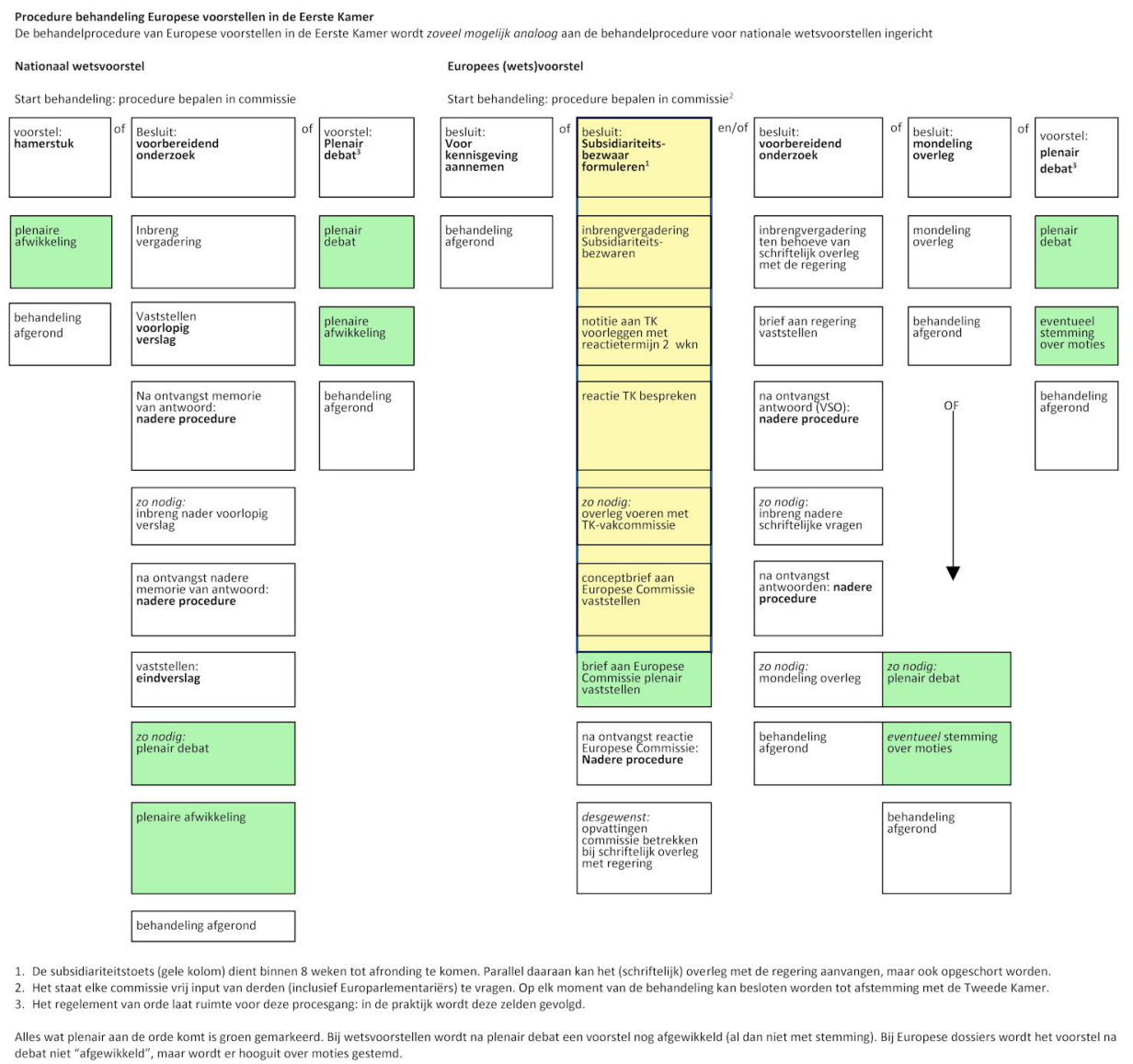

1 Eerste Kamercommissie Europese Zaken, Introductiedossier, Den Haag: Eerste Kamer 12 juni 2015. 



\section{BiJlage II. PRIORITAIRE VOORSTELLEN \\ UIT WETGEVINGS - EN WERKPROGRAMMA \\ 2010 VAN DE EUROPESE COMMISSIE \\ 1}

Alle voorstellen uit deze lijst zijn in overleg tussen regering en Kamer aangemerkt als voor Nederland prioritair. De Kamer zal extra aandacht besteden aan de behandeling van deze voorstellen.

Over de voorstellen waarbij in deze lijst is aangegeven dat er een subsidiariteitstoets of behandelvoorbehoud zal worden gemaakt, zal bovendien de regering binnen maximaal drie weken na publicatie een BNC-fiche naar de Kamer sturen.

\begin{tabular}{ll} 
Voorstel & $\begin{array}{l}\text { Subsidi- } \begin{array}{l}\text { Behan- } \\
\text { ari- } \\
\text { teits- } \\
\text { toets }\end{array} \\
\text { voorbe- } \\
\text { houd }\end{array}$ \\
\hline Commissie voor Buitenlandse Zaken & x \\
\hline Toekomst Europees Ontwikkelingsfonds (EOF) & \\
\hline Groenboek Begrotingssteun OS & \\
\hline Voorstel voor een nieuw partnerschap EU-Landen en Gebieden Overzee (LGO) & \\
\hline Mededeling over klimaatverandering en ontwikkeling & \\
\hline Commissie voor Binnenlandse Zaken en Koninkrijksrelaties & \\
\hline Mededeling interne veiligheidsstrategie & \\
\hline $\begin{array}{l}\text { Mededeling inzake de versterking van de reactiecapaciteit van de Europese } \\
\text { Unie bij rampen ('EU's Disaster Response Capacity') }\end{array}$ & \\
\hline Wetgevend voorstel inzake aanslagen tegen informatiesystemen & $\mathbf{x}$ \\
\hline Mededeling Interne Veiligheidsstrategie & $\mathbf{x}$ \\
\hline Commissie voor Economische Zaken & $\mathbf{x}$ \\
\hline $\begin{array}{l}\text { Verordening over de modernisering van het Europees Agentschap voor Net- } \\
\text { werk- en Informatiebeveiliging }\end{array}$ & $\mathbf{x}$ \\
\hline Een regelgevend kader voor Smart Energy Grids & \\
\hline $\begin{array}{l}\text { Wetgevend voorstel voor het Europees Fonds voor Regionale Ontwikkeling } \\
\text { (EFRO) en Cohesiefonds }\end{array}$ & \\
\hline Anti-Counterfeiting Trade Agreement (ACTA) & \\
\hline Kamerstukken II 2009/10, 22112, nr. 1012. & \\
\hline
\end{tabular}


Voorstel

Subsidi- Behan-

ari-

del-

teits-

voorbe-

toets

houd

Europese Digitale Agenda

Energie Infrastructuur Pakket

Voortgang implementatie Dienstenrichtlijn

Actieplan Energie Efficiëntie

Kaderprogramma voor Concurrentievermogen en Innovatie (CIP) 2014-2020

Voortgangsrapport Cohesiebeleid

Mededeling versterking van het Cohesiebeleid in het kader van de EU2020 strategie

Mededeling over Europees plan voor onderzoek en innovatie

Aanpassing van de milieurichtsnoeren inzake ETS

\section{Commissie voor Europese Zaken}

Budget Review 2007-2013

Jaarlijkse rapport inzake EU-uitbreiding

\section{Commissie Financiën}

Wetgevend voorstel Meerjarig Financieel Kader van de EU begroting (nieuwe Financiële Perspectieven)

Mededeling over Versterking van het Stabiliteit- en Groei Pact (surveillance)

Wetgevingsvoorstel over short selling/credit default swaps

Herziening van de Richtlijn Kapitaalvereisten

Omnibus II Richtlijn (financieel toezicht)

Mededeling over externe vertegenwoordiging in het IMF en de Wereldbank

Wetgevend voorstel over Macro-Financiële Assistentie (MFA)

Wetgevend voorstel voor een Common Consolidated Corporate Tax Base (CCCTB)

Wetgevend voorstel voor meer transparantie en stabiliteit in derivatenmarkten

Herziening Richtlijn Depositogarantiestelsel

Mededeling over opties voor bank resolution funds

\section{Commissie Justitie}

Herziening van Verordening (EG) 44/2001 inzake jurisdictie, erkenning en $\quad$ x afdwinging van rechterlijke uitspraken op civiel en handelsgebied (Brussel I verordening)

\begin{tabular}{lll}
\hline Voorstel voor een Richtlijn inzake de voorwaarden voor toegang en verblijf & $\mathbf{x}$ & $\mathbf{x}$
\end{tabular} van seizoensarbeiders uit derde landen

Nieuw alomvattend juridisch raamwerk voor dataprotectie

Voorstel tot aanpassing van Richtlijn 2003/86/EG inzake het recht op familiehereniging 
Voorstel

Subsidi- Behan-

ari- del-

teits- voorbe-

toets houd

Actieplan ter implementatie van het Stockholmprogramma

Rapportage inzake Immigratie en Asiel (implementatie van het Europese Pact en vanaf 2011 het Stockholmprogramma)

Mededeling inzake een Actieplan betreffende niet-begeleide minderjarige migranten

Groenboek inzake het recht op familiehereniging

Mededeling inzake een alomvattende aanpak van Passenger Name Record

(PNR) gegevens bij derde landen

Wetgevend voorstel inzake strafrechtelijke maatregelen gericht op het verzekeren van de handhaving van intellectuele eigendomsrechten

Mededeling inzake een geïntegreerde strategie voor de bestrijding van mensenhandel en inzake maatregelen ter bescherming en begeleiding van slachtoffers

EU Immigratie Code

Herziening van de handhavingsrichtlijn

Voorstel voor een aanbeveling tot goedkeuring van de onderhandelingen inzake een overeenkomst tussen de EU en de Verenigde Staten betreffende dataprotectie en delen van informatie voor rechtshandhavingsdoeleinden

Voorstel voor een Verordening inzake conflict van rechtsstelsels betreffende huwelijksgoederenrecht, met inbegrip van de vraag van jurisdictie en wederzijdse erkenning, alsmede een voorstel voor een Verordening inzake eigendomsgevolgen van scheidingen van gehuwden uit verschillende lidstaten

Mededeling inzake de strategie voor dataprotectie

Wetgevend voorstel inzake een alomvattend regime betreffende bewijsverkrij-

ging, gebaseerd op het beginsel van wederzijdse erkenning en betrekking heb-

bend op alle soorten bewijs

Wetgevend voorstel ter invoering van gemeenschappelijke normen voor bewijsverkrijging in strafzaken met het oog op de toelaatbaarheid van bewijs

Groenboek inzake detentie-aangelegenheden

\section{Commissie voor Landbouw, Natuur en Voedselkwaliteit}

Verordening voedselverstrekking aan minderbedeelden in de Gemeenschap $\quad \mathbf{x}$

\begin{tabular}{ll}
\hline Wetgeving volgend op de mededeling over het GLB na 2013 & $\mathbf{x}$ \\
\hline Nieuw beleid voor de teelt van GGO-gewassen & $\mathbf{x}$ \\
\hline Wetgevend pakket Hervorming gemeenschappelijk visserijbeleid & $\mathbf{x}$ \\
\hline
\end{tabular}

Mededeling over nieuwe biodiversiteitstrategie na 2010

Mededeling over de toekomst van het GLB

Wetgeving volgend op de mededeling over de Less Favoured Areas

Diergezondheidswet

Verslag over uitvoering verordening diertransport 
Voorstel

Subsidi- Behan-

ari-

del-

teits-

voorbe-

toets

houd

Mededeling over de tweede dierenwelzijnstrategie (2011-2015)

\section{Commissie voor Onderwijs, Cultuur en Wetenschap}

Youth on the Move-programma 2014-2020

Wetgevend voorstel voor 'verweesde werken' in digitale bibliotheken

Mededeling over een initiatief voor meer Europese competenties op onderwijsgebied

Europese Strategie voor Gendergelijkheid

Cultuur and Media Programma 2014-2020

Communicatie over de modernisering van hoger onderwijs

\section{Commissie voor de Rijksuitgaven}

Herziening van het Financieel Reglement van de EU begroting

Commissie voor Sociale Zaken en Werkgelegenheid

\begin{tabular}{lll}
\hline Herziening van de Richtlijn Arbeidstijden & $\mathbf{x}$ & $\mathbf{x}$ \\
\hline Ontwerprichtlijn bescherming werknemers tegen elektromagnetische velden & $\mathbf{x}$ & \\
\hline $\begin{array}{l}\text { Wetgevend voorstel ter verbetering verenigbaarheid arbeid en privéleven (o.m. } \\
\text { vaderschapsverlof) }\end{array}$ &
\end{tabular}

\begin{tabular}{ll}
\hline Herziening richtlijn pensioenfondsen & $\mathbf{x}$ \\
\hline $\begin{array}{l}\text { Herschikking richtlijn bescherming werknemers tegen de risico's van spier- } \\
\text { en gewrichtsaandoeningen (MSD) }\end{array}$ & $\mathbf{x}$
\end{tabular}

Wetgevend voorstel inzake de implementatie Detacheringsrichtlijn

Groenboek Pensioenen

Initiatief over pensioenen, gebaseerd op de uitkomst van het groenboek (mogelijk een Witboek)

Voorstel voor benchmarks over mobiliteit en over employability

\section{Commissie voor Volkshuisvesting, Ruimtelijke Ordening en Milieubeheer}

Voorstel voor herziening van bestaande wetgeving met het oog op integratie $\mathbf{x}$ daarin van mitigatie en adaptatie (in navolging op de Mededeling over adaptatie aan klimaatverandering)

Mogelijk wetgevend initiatief van de Commissie om de emissiereductiedoelstelling te verhogen boven $20 \%$ (20\% tot $30 \%$, klimaatverandering)

Mededeling over implementatie 'biofuel sustainability scheme'

Vereenvoudigingvoorstel voor verordening Nr. 2150/2002 over afvalstoffenstatistieken

\section{Commissie Verkeer en Waterstaat}

Witboek over de toekomst van vervoer 
Voorstel

Subsidi- Behan-

ari- del-

teits- voorbe-

toets

houd

Duurzaam vervoer pakket: Herziening van de Richtsnoeren voor trans-Europese vervoersnetwerken (TEN-T)

Interne markt pakket: Herziening van het Eerste Spoorpakket (reeds n.a.v.

WWP 2008 als prioritair aangemerkt)

\section{Commissie voor Volksgezondheid, Welzijn en Sport}

Herziening van de richtlijn tabaksproducten met betrekking tot de productie, $\mathbf{x}$ reclame en verkoop van tabaksproducten

Mededeling over de implementatie van de sportbepalingen in het Verdrag van

Lissabon

Herziening van de richtlijn met betrekking tot maatregelen voor het prijzen en vergoeden van geneesmiddelen

\section{Commissie voor Wonen, Wijken en Integratie}

Richtlijn Water Efficiëntie van Gebouwen 



\title{
Bijlage III. Overzicht VAN VOOR DE TWEEDE KAMER PRIORITAIRE
}

\author{
VOORSTELLEN UIT HET WETGEVINGS- EN \\ WERKPROGRAMMA VOOR 2011 VAN DE \\ EUROPESE COMMISSIE
}

NB Alle voorstellen op deze lijst zijn voor de Tweede Kamer prioritair. De Kamer zal extra aandacht besteden aan de behandeling van al deze voorstellen. Over de voorstellen waarbij in deze lijst is aangegeven dat er een subsidiariteitstoets of behandelvoorbehoud zal worden gemaakt, zal de regering binnen maximaal drie weken na publicatie een BNC-fiche naar de Kamer sturen.

$\mathrm{Nr} \quad$ Prioritaire voorstellen

Subsidi- Behan-

ari- del-

teits- voorbe-

toets houd

\begin{tabular}{ll}
\hline \multicolumn{2}{c}{ Commissie voor Binnenlandse Zaken } \\
\hline I-31 & 'Smart Borders'-initiatieven: \\
& - Wetgevingsvoorstel tot instelling van een inreis-uitreissysteem \\
& (EES) \\
& - Wetgevingsvoorstel tot instelling van een programma voor geregis- \\
& treerde reizigers (RTP) \\
& - Wetgevingsvoorstel tot wijziging van de Schengengrenscode \\
& - Mededeling over de mogelijke introductie van een ESTA (elektro- \\
& nisch systeem voor reisvergunningen) in de EU \\
\hline II-39 & Mededeling over een EU-agenda voor de integratie van onderdanen \\
& van derde landen, met inbegrip van de ontwikkeling van een coördi- \\
& natiemechanisme \\
\hline III-23 & Richtlijn 93/109/EG tot vaststelling van de wijze van uitoefening van \\
& het actief en passief kiesrecht bij de verkiezingen voor het Europees \\
& Parlement ten behoeve van de burgers van de Unie die verblijven in \\
een lidstaat waarvan zij geen onderdaan zijn
\end{tabular}

\begin{tabular}{ll}
\hline Commissie voor Buitenlandse Zaken \\
\hline I-38 & $\begin{array}{l}\text { Initiatief inzake modernisering van het EU-ontwikkelingsbeleid } \\
\text { inclusief de flankerende beleidsmaatregelen waaronder 'klimaatver- }\end{array}$
\end{tabular}

$1 \quad$ Kamerstukken II 2010/11, 22112, nr. 1109. 
$\mathrm{Nr} \quad$ Prioritaire voorstellen

Subsidi- Behan-

ari- del-

teits- voorbe-

toets

houd

\begin{tabular}{llc}
\hline & $\begin{array}{l}\text { andering en ontwikkeling' en voorstellen volgend op het 'Groenboek } \\
\text { EU-begrotingssteun' }\end{array}$ & X \\
\hline I-40 & Toekomst Europees Ontwikkelingsfonds & \\
\hline II-70 & Recht op consulaire bescherming & \\
\hline
\end{tabular}

\section{Commissie voor Defensie}

Geen prioritaire voorstellen

\begin{tabular}{lll}
\hline & Commissie voor Economische Zaken, Landbouw en Innovatie & \\
\hline I-13 & Roadmap energie 2050 & $\mathbf{X}$ \\
\hline I-40 & Wetgevingsvoorstellen Gemeenschappelijk Landbouwbeleid & $\mathbf{X}$ \\
\hline I-40 & Wetgevingsvoorstellen Gemeenschappelijk Visserijbeleid & $\mathbf{X}$ \\
\hline II-27 & $\begin{array}{l}\text { Initiatief om de invoering van slimme energienetwerken te ondersteu- } \\
\text { nen }\end{array}$ & \\
\hline II-82 & $\begin{array}{l}\text { Strategie en actieplan van de Europese Unie voor een duurzame bio- } \\
\text { economie in 2020 }\end{array}$ & \\
\hline
\end{tabular}

\begin{tabular}{|c|c|c|}
\hline & Commissie voor Europese Zaken & \\
\hline II-29 & Uitbreidingspakket 2011 & \\
\hline II-30 & $\begin{array}{l}\text { Advies van de Commissie over het verzoek om toetreding tot de EU } \\
\text { van Servië }\end{array}$ & \\
\hline $\mathrm{I}-40$ & $\begin{array}{l}\text { Financiële perspectieven: } \\
\text { 1) een Mededeling van de Commissie over het volgende meerjarig } \\
\text { financieel kader; } \\
\text { 2) een voorstel van de Commissie voor een verordening van de Raad } \\
\text { tot vaststelling van een nieuw meerjarig financieel kader; } \\
\text { 3) een voorstel van de Commissie voor een nieuw eigenmiddelenbe- } \\
\text { sluit; } \\
\text { 4) een voorstel van de Commissie voor een nieuw Interinstitutioneel } \\
\text { Akkoord inzake goed financieel beheer en samenwerking in begro- } \\
\text { tingszaken. }\end{array}$ & $\mathbf{X}$ \\
\hline
\end{tabular}

\begin{tabular}{ll}
\hline & Commissie voor Financiën \\
\hline I-2 & Versterking van de follow-up van de economic governance \\
\hline II-85 & Belasting op de financiële sector \\
\hline I-8 & Richtlijn inzake verantwoord lenen \\
\hline I-23 & $\begin{array}{l}\text { Wetgevend voorstel voor een gemeenschappelijke geconsolideerde } \\
\text { heffingsgrondslag voor de vennootschapsbelasting (CCCTB) }\end{array}$
\end{tabular}


BIJLAGE III. OVERZICHT VAN VOOR DE TWEEDE KAMER PRIORITAIRE VOORSTELLEN UIT HET WETGEVINGS- EN WERKPROGRAMMA VOOR 2011 VAN DE EUROPESE COMMISSIE

$\mathrm{Nr} \quad$ Prioritaire voorstellen

Subsidi- Behan-

ari- del-

teits- voorbe-

toets houd

\begin{tabular}{ll}
\hline II-62 & $\begin{array}{l}\text { EU-kader voor de onderlinge afstemming van sanctieregelingen in } \\
\text { de financiële sector }\end{array}$ \\
\hline I-3 & Wijziging van de verordening inzake ratingbureaus \\
\hline I-4 & $\begin{array}{l}\text { Wetgevend voorstel voor een kader voor crisisbeheersing en -afwik- } \\
\text { keling in de banksector }\end{array}$ \\
\hline II-5 & $\begin{array}{l}\text { Richtsnoeren voor het redden en herstructureren van financiële } \\
\text { instellingen }\end{array}$ \\
\hline & \\
\hline II-41 & Mededeling over grotere solidariteit binnen de EU \\
\hline II-43 & $\begin{array}{l}\text { Wetgevingsvoorstel betreffende de oprichting van een Europees } \\
\text { grensbewakingssysteem (Eurosur) }\end{array}$ \\
\hline III-19 & EU Immigratiecode \\
\hline &
\end{tabular}

\section{Commissie voor Infrastructuur en Milieu}

\begin{tabular}{ll}
\hline I-12 & Roadmap naar een koolstofarme economie in 2050 \\
\hline I-14 & Roadmap naar een efficiënt gebruik van hulpbronnen \\
\hline I-17 & Witboek over de toekomst van het vervoer (overgedragen van 2010) \\
\hline I-27 & $\begin{array}{l}\text { Luchthavenpakket: (1) Beoordeling en inventarisatie van de capaciteit } \\
\text { van luchthavens, (2) Herziening van de slotverordening, (3) Herzie- } \\
\text { ning van de grondafhandelingsrichtlijn, (4) Herziening van de } \\
\text { richtlijn inzake luchtvaartgeluid }\end{array}$ \\
\hline II-50 & $\begin{array}{l}\text { Voorstel voor een verordening betreffende het toegestane geluidsni- } \\
\text { veau motorvoertuigen }\end{array}$ \\
\hline II-92 & Pakket e-mobiliteit \\
\hline III-2 & $\begin{array}{l}\text { Herziening wetgeving monitoring en rapportage uitstoot van broei- } \\
\text { kasgassen }\end{array}$ \\
\hline III-33 & $\begin{array}{l}\text { Herschikking Verordening (EG) nr. 3821/85 betreffende het contro- } \\
\text { leapparaat in het wegvervoer (digitale tachograaf) }\end{array}$ \\
\hline
\end{tabular}

Commissie voor Onderwijs, Cultuur en Wetenschap

I-11 Mededeling over de modernisering van het hoger onderwijs

\section{Commissie voor de Rijksuitgaven}

Geen prioritaire voorstellen

\section{Commissie voor Sociale Zaken en Werkgelegenheid}


$\mathrm{Nr} \quad$ Prioritaire voorstellen

Subsidi- Behan-

ari-

teits-

del-

toets

voorbe-

houd

\begin{tabular}{lll}
\hline I-18 & Wetgevingsinitiatief inzake detachering van werknemers & \\
\hline I-19 & Herziening van de arbeidstijdenrichtlijn (Richtlijn 2003/88) & X \\
\hline I-21 & Witboek over pensioenen & $\mathbf{X}$ \\
\hline II-65 & $\begin{array}{l}\text { Herziening van de richtlijn inzake instellingen voor bedrijfspensioen- } \\
\text { voorzieningen (IBPV) }\end{array}$ & \\
\hline
\end{tabular}

\begin{tabular}{|c|c|}
\hline & Commissie Veiligheid en Justitie \\
\hline I-26 & $\begin{array}{l}\text { Wetgevingsvoorstel voor een alternatief geschillenregelingmecha- } \\
\text { nisme (ADR) in de EU }\end{array}$ \\
\hline $\mathrm{I}-30$ & Richtlijn inzake de rechten van en steun voor misdaadslachtoffers \\
\hline $\mathrm{I}-33$ & $\begin{array}{l}\text { Een nieuw alomvattend wettelijk kader voor de bescherming van } \\
\text { persoonsgegevens in de EU (overgedragen van 2010) }\end{array}$ \\
\hline II-40 & $\begin{array}{l}\text { Richtlijn inzake het gebruik van passagiersgegevens voor wetshand- } \\
\text { havingdoeleinden (Europees PNR) }\end{array}$ \\
\hline $\mathrm{II}-45$ & $\begin{array}{l}\text { Voorstel voor een herziening van Richtlijn 2006/24/EG (bewaring } \\
\text { van gegevens; dataretentie) }\end{array}$ \\
\hline II-76 & Herziening van het kaderbesluit inzake geldboetes \\
\hline III-22 & $\begin{array}{l}\text { Kaderbesluit 2004/757/JBZ van de Raad betreffende de vaststelling } \\
\text { van minimumvoorschriften met betrekking tot de bestanddelen van } \\
\text { strafbare feiten en met betrekking tot straffen op het gebied van de } \\
\text { illegale drugshandel (herziening) }\end{array}$ \\
\hline
\end{tabular}

\begin{tabular}{ll}
\hline \multicolumn{3}{c}{ Commissie voor Volksgezondheid, Welzijn en Sport } \\
\hline II-34 & $\begin{array}{l}\text { Voorstel voor een herziening van het besluit betreffende overdraag- } \\
\text { bare ziekten }\end{array}$ \\
\hline II-37 & $\begin{array}{l}\text { Voorstel voor een herziening van Richtlijn 2001/37/EG inzake de } \\
\text { productie, de presentatie en de verkoop van tabaksproducten }\end{array}$ \\
\hline II-48 & $\begin{array}{l}\text { Evaluatie van Richtlijn 89/105/EEG betreffende de doorzichtigheid } \\
\text { van maatregelen ter regeling van de prijsstelling van geneesmiddelen }\end{array}$
\end{tabular}




\title{
Bijlage IV. Kleine Anfrage
}

\author{
Deutscher Bundestag Drucksache 18/10394 18. Wahlperiode 22 november 2016
}

\author{
Kleine Anfrage
}

der Abgeordneten Ulla Jelpke, Wolfgang Gehrcke, Christine Buchholz, Sevim Dağdelen, Heike Hänsel, Inge Höger, Andrej Hunko, Jan Korte, Katrin Kunert, Kersten Steinke, Kathrin Vogler und der Fraktion DIE LINKE.

\section{Situation von Flüchtlingen in Griechenland}

Der sogenannte Flüchtlingsdeal zwischen der Europäischen Union (EU) und der Türkei sieht vor, dass türkische Behörden in Zusammenarbeit mit der NATO (Organisation des Nordantlantikvertrages), der griechischen Küstenwache und Frontex Flüchtlinge an der Überfahrt auf die griechischen Inseln hindern sollen. Diejenigen, denen die Überfahrt trotzdem gelingt, werden auf den Inseln in Hotspots festgehalten. Dort soll darüber entschieden werden, ob ihre Asylanträge zulässig und begründet sind. Anschließend ist entweder ihre Abschiebung geplant oder ihre Umsiedlung, auch in andere Länder der EU.

Die praktische Umsetzung dieses Abkommens geht aus Sicht der Fragesteller und nach Schilderungen von Menschenrechtsorganisationen eindeutig zu Lasten der Flüchtlinge. Deren Rechte werden auf teilweise gravierende Weise verletzt. Durch die nach wie vor schleppende Bearbeitung der Asylanträge in den Hotspots kommt es dort zu massiven Überbelegungen, die sich schon mehrfach in militanten Protesten der dort Festgehaltenen entladen haben.

Die von der EU zugesagte personelle Unterstützung der griechischen Asylbehörden reicht offenbar nicht aus, die Problematik zu lösen. Zum einen wird nicht so viel Personal bereitgestellt, wie aus Griechenland bzw. dem Europäischen Unterstützungsbüro für Asylfragen (EASO) angefordert, zum anderen weist das eingesetzte Personal häufig nicht die erforderlichen Qualifikationen auf. Auch nach Aussagen des griechischen Integrationsministers Ioannis Mouzalas geht es 'nur langsam voran, zu langsam' (vgl. 'Asylchaos in Griechenland', SPIEGEL ONLINE, 2. November 2016). Kurze Einsatzzeiten reduzieren die Effektivität dieser Art der Unterstützung weiter. Dementsprechend ist die Qualität der erstinstanzlichen Entscheidungen der Asylbehörden, die auch auf Anhörungen durch Personal aus den Mitgliedstaaten bzw. deren Empfehlungen beruhen, in Frage gestellt. 
Die Berufungsinstanzen in Griechenland haben in den meisten Fällen die erstinstanzlichen Entscheidungen revidiert. Von 311 bis zum 18. September 2016 ergangenen Rechtsbehelfsentscheidungen zur Zulässigkeit von Asylanträgen wurden in nur sechs Fällen die erstinstanzlichen Entscheidungen bestätigt (vgl. Mitteilung der Kommission: 'Dritter Bericht über die Fortschritte bei der Umsetzung der Erklärung EU-Türkei', Ratsdokument 12813/16).

Indiz für gravierende Verletzungen internationaler Flüchtlingsrechte ist zudem eine Meldung des Hohen Flüchtlingskommissars der Vereinten Nationen (UNHCR) vom 21. Oktober 2016, der zufolge mindestens zehn syrische Staatsangehörige von der griechischen Insel Leros ohne angemessene Beachtung ihres Asylwunsches in die Türkei abgeschoben worden sind. Dem UNHCR wurde zudem der Zugang zu 33 Flüchtlingen verweigert, die Anfang Oktober 2016 vom Peloponnes an einen 'unbekannten Ort' verbracht worden waren.

Soweit im Folgenden Kenntnisse der Bundesregierung erfragt werden, setzen die Fragesteller voraus, dass sich die Bundesregierung aktiv um entsprechende Kenntnisse auch bei den z. B. in Griechenland eingesetzten deutschen Beamtinnen und Beamten verschafft, unabhängig davon, ob diese im Rahmen von Frontex, EASO oder aufgrund bilateraler Vereinbarungen tätig sind.

Wir fragen die Bundesregierung:

1. Wie viele Flüchtlinge sind nach Kenntnis der Bundesregierung seit Juni 2016 von welchen Behörden welcher Länder beim Versuch, von der Türkei aus über die Ägäis auf die griechischen Inseln zu gelangen, unverzüglich (also ohne Gelegenheit, einen Asylantrag zu stellen, Anhörung und Rechtsbefehlsverfahren), in die Türkei zurückverbracht worden?

Und wie viele davon
a) aus türkischen Hoheitsgewässern,
b) aus griechischen Hoheitsgewässern,
c) von griechischen Inseln aus?

2. Welche Kenntnis hat die Bundesregierung darüber, inwiefern den aufgegriffenen Personen Gelegenheit gegeben wurde, Bedenken gegen ihre Abschiebung in die Türkei zu äußeren und inwiefern diese Bedenken unter Beachtung des Refoulement-Verbots geprüft wurden?

Falls die Bundesregierung nicht ausschließen kann, dass Personen ohne solche Prüfungen in die Türkei zurückverbracht worden sind, welche Schlussfolgerungen für 
ihre weitere Mitwirkung an der Umsetzung des EU-Türkei-Abkommens zieht sie aus einer solchen Verletzung internationaler Schutzstandards?

3. Wie viele Flüchtlinge sowie unbegleitete minderjährige Flüchtlinge (UMF) (bitte jeweils getrennt angeben) halten sich nach Kenntnis der Bundesregierung derzeit in den Hotspots sowie weiteren Einrichtungen in Griechenland auf (bitte getrennt darstellen), und für wie viele Flüchtlinge sind die einzelnen Einrichtungen bzw. Hotspots tatsächlich ausgelegt?

Worauf ist nach Kenntnis der Bundesregierung die allfällige Überbelegung der Hotspots zurückzuführen?

4. Wie viele dieser Flüchtlinge hatten nach Kenntnis der Bundesregierung bislang
a) Gelegenheit, einen Asylantrag zu stellen,
b) eine Anhörung (hier bitte zusätzlich angeben, wie viele Anhörungen von EASO- Personal durchgeführt wurden),
c) eine erstinstanzliche Entscheidung über ihren Asylantrag erhalten,
d) eine Entscheidung der Berufungsinstanz erhalten?

5. Bei wie vielen Anhörungen war nach Kenntnis der Bundesregierung keine Übersetzung in die Muttersprache bzw. in eine für die Asylsuchenden verständliche Sprache möglich?

6. In wiefern werden nach Kenntnis der Bundesregierung in Griechenland derzeit zusätzliche Aufnahmekapazitäten (bitte getrennt nach Inseln und Festland darstellen) geschaffen, und bis wann sollen diese bezugsbereit sein?

7. Wie viele Flüchtlinge leben nach Kenntnis der Bundesregierung derzeit in den Hotspots und anderen Einrichtungen, deren Asylanträge bereits rechtskräftig abgelehnt wurden?

8. Wie viel Zeit müssen die Insassen der Hotspots nach Kenntnis der Bundesregierung durchschnittlich in diesen verbringen?

9. Welche Defizite sieht die Bundesregierung derzeit hinsichtlich des griechischen Asylsystems, der Lage in den Hotspots und bei der Umsetzung des Flüchtlingsabkommens mit der Türkei, und auf welche Ursachen führt sie diese zurück (bitte jeweils einzeln und ausführlich beantworten)? 
10. Welche Defizite sieht die Bundesregierung hinsichtlich der technischen und materiellen Ausstattung der Hotspots?

11. Wie lange dauert nach Kenntnis der Bundesregierung ein Asylverfahren in den Hotspots, aufgeschlüsselt nach den Zeiträumen
a) von der Ankunft bis zur Stellung eines formellen Antrages,
b) bis zur Anhörung,
c) bis zur Entscheidung in erster Instanz,
d) bis zur Entscheidung in zweiter Instanz?

12. Wie gestalten sich die in der vorangegangenen Frage abgefragten Bearbeitungszeiten hinsichtlich unbegleiteter Minderjähriger oder anderer besonders schutzbedürftiger Flüchtlinge (bitte differenzieren)?

13. Inwiefern ist nach Kenntnis der Bundesregierung die volle Arbeitsfähigkeit der griechischen Rechtsbehelfsbehörde bzw. der Rechtsbehelfsausschüsse gewährleistet, und welche Defizite sind ihr diesbezüglich bekannt?

14. Welche Schlussfolgerungen in Hinblick auf die Qualität der Anhörungen bzw. der Eignung und Qualifikation des bei den Anhörungen eingesetzten Personals, das oftmals aus anderen EU-Mitgliedstaaten kommt und der von ihnen formulierten Empfehlungen zur Entscheidung über die (Un-)Zulässigkeit von Asylanträgen ziehen die Bundesregierung sowie nach ihrer Kenntnis die griechische Regierung aus dem Umstand, dass die Rechtsbehelfsausschüsse 98 Prozent der erstinstanzlichen Unzulässigkeitsentscheidungen aufheben (bitte ausführen)?

15. Inwiefern und in welchem Umfang werden dem griechischen bzw. von EU-Mitgliedstaaten bereitgestellten Personal, das zur Unterstützung der Asylverfahren eingesetzt wird, Supervisionen angeboten?

16. Welche Kenntnis hat die Bundesregierung über die Entscheidungspraxis der Rechtsbehelfsausschüsse hinsichtlich erstinstanzlicher Entscheidungen in Bezug auf die inhaltliche Unbegründetheit von Asylanträgen (bitte nach Möglichkeit konkrete Zahlen nennen), und welche Schlussfolgerungen zieht sie daraus?

17. Inwiefern haben Flüchtlinge in Griechenland nach Kenntnis der Bundesregierung gegenwärtig Zugang zu kostenfreier rechtlicher Beratung, und wie viele Rechtsanwälte oder andere Beratungsorganisationen stehen dafür zur Verfügung (bitte ggf. auf relevante örtliche Unterschiede hinweisen)? 
18. Inwieweit treffen Informationen der Fragesteller zu, wonach Angehörigen bestimmter Nationalitäten bislang noch keine Gelegenheit gegeben wurde, einen förmlichen Asylantrag zu stellen, und um welche Nationalitäten und wie viele Personen handelt es sich dabei im Einzelnen?

19. Welche Kritik an den in den Anhörungen der Asylantragsteller in Griechenland eingesetzten Befragungsbögen ist der Bundesregierung bekannt, und inwiefern hält sie selbst eine Überarbeitung für sinnvoll (bitte nach Möglichkeit den Wortlaut eines solchen Befragungsbogens in englischer Sprache übermitteln)?

20. Wie genau beziffern die europäischen Agenturen, die in Griechenland bzw. den Hotspots tätig sind, ihren materiellen und personellen Unterstützungsbedarf durch die Mitgliedstaaten (bitte getrennt und aufgeschlüsselt nach angeforderten Fähigkeitsprofilen und Einsatzbereichen wie etwa Anhörer, Dolmetscher u. a. darstellen)?

a) Wie hat sich nach Kenntnis der Bundesregierung die personelle Unterstützung durch die Mitgliedstaaten tatsächlich gestaltet?

b) Wie viele Unterstützungskräfte (bitte nach einzelnen Einsatzbereichen und Fähigkeitsprofilen darstellen) sind gegenwärtig aus welchen Mitgliedstaaten in Griechenland im Einsatz?

c) In welchem Umfang wurden die Einrichtung bzw. der Betrieb von Hotspots in Griechenland bislang aus Mitteln der EU gefördert, und welche Mittel wurden für die Zukunft zugesagt?

21. Welcher zeitliche Aufwand wird nach Kenntnis der Bundesregierung pro Anhörung betreffend Zulässigkeit und Begründetheit von Asylanträgen in den Hotspots kalkuliert?

22. Inwiefern sind die Anhörer nach Kenntnis der Bundesregierung dazu angehalten, sich an einen bestimmten Zeitrahmen bei der Anhörung zu halten?

23. Welchen künftigen personellen Unterstützungsbedarf prognostizieren die europäischen Agenturen?

24. Worauf führt die Bundesregierung die Untererfüllung des Unterstützungsbedarfs durch die Mitgliedstaaten zurück, und welche Maßnahmen sind nach ihrer Kenntnis in Deutschland, in Griechenland sowie in anderen Mitgliedstaaten getroffen worden, um die Defizite zu beseitigen? 
25. Wie lange ist im Schnitt die Einsatzzeit in Griechenland für das Unterstützungspersonal (bitte nach Agenturen, Zuständigkeitsbereichen und Fähigkeitsprofil untergliedern) nach Kenntnis der Bundesregierung, was kann sie insbesondere zu den Einsatzzeiten deutscher Bediensteter und zu etwaigen Problemen bei deren Einsatz Genaueres sagen?

Trifft es zu, dass einige Kräfte bereits nach zehn Tagen wieder abreisen (vgl. SPIEGEL ONLINE, 2. November 2016)?

26. Wie viele Flüchtlinge sind nach Kenntnis der Bundesregierung im Zeitraum seit Juni 2016 auf den Inseln angekommen, und wie viele Flüchtlinge wurden in diesem Zeitraum in die Türkei zurückverbracht, in welche weiteren Drittstaaten abgeschoben, in andere Unterbringungseinrichtungen auf dem griechischen Festland verbracht oder in andere Mitgliedstaaten (bitte einzeln angeben) umgesiedelt?

27. In welchem Umfang kommt es nach Kenntnis der Bundesregierung vor, dass Mitgliedstaaten Umsiedlungsbewerber ohne Angabe von Gründen ablehnen, und um welche Mitgliedstaaten handelt es sich dabei?

28. Welche Erkenntnisse (ggf. auch von dritter Seite) hat die Bundesregierung über die näheren Umstände der vom UNHCR in der Meldung vom 21. Oktober 2016 angesprochenen Abschiebung syrischer Staatsangehöriger?

a) Inwieweit trifft es zu, dass deren Asylwunsch nicht angemessen geprüft wurde? Hatten die Personen überhaupt Gelegenheit, einen formellen Asylantrag zu stellen?

b) Wie verhalten sich die griechischen Behörden zu den Vorwürfen des UNHCR, und inwiefern haben sie zu deren Klärung beigetragen?

c) Sollte sich der Vorwurf einer Abschiebung ohne angemessene Prüfung des Asylwunsches bestätigt haben, welche Konsequenzen ziehen die griechischen Behörden daraus?

Ist den betroffenen Flüchtlingen Gelegenheit gegeben worden, nach Griechenland zurückzukehren?

29. Wie viel Zeit nimmt derzeit nach Kenntnis der Bundesregierung ein Umsiedlungsverfahren in Anspruch (Zeitraum zwischen Datum des Umsiedlungsantrages und der tatsächlichen Umsiedlung)?

30. Wie viele Anträge auf Familienzusammenführung nach Deutschland bzgl.in Griechenland aufhältiger Flüchtlinge im Rahmen des Dublin-Verfahrens liegen derzeit dem Bundesamt für Migration und Flüchtlinge (BAMF) vor, und wie viele dieser 
Anträge wurden bislang wie entschieden, und wie viele Überstellungen zu Familienangehörigen haben bereits stattgefunden (bitte nach den fünf wichtigsten Staatsangehörigkeiten differenzieren)?

31. Welche Kenntnisse hat die Bundesregierung über einen weiteren, ebenfalls am 21. Oktober 2016 vom UNHCR gemeldeten Vorfall vom 8. Oktober 2016, demzufolge 33 Flüchtlinge an einen 'unbekannten Ort' verbracht wurden und dem UNHCR der Zugang zu diesen verweigert wurde?

Hat der UNHCR mittlerweile Zugang zu ihnen erhalten, und hatten die Personen Gelegenheit, einen Asylantrag zu stellen?

32. Auf welche Weise wird nach Kenntnis der Bundesregierung die Registrierung bei Flüchtlingen durchgesetzt, die hieran nicht mitwirken wollen, insbesondere nicht an erkennungsdienstlichen Maßnahmen?

33. Gibt es nach Kenntnis der Bundesregierung Klagen über Rechtsverletzungen oder Übergriffe im Rahmen dieses Verfahrens (falls ja, bitte Anzahl und Art der Verletzung angeben)?

34. Wie viele disziplinarrechtliche oder strafrechtliche Verfahren hat es bisher gegen Personal von Hotspots im Rahmen ihrer Tätigkeit nach Kenntnis der Bundesregierung gegeben?

35. Wie beurteilt die Bundesregierung die Sicherheitslage in Griechenland?

36. Welche Kenntnisse und Einschätzungen hat die Bundesregierung hinsichtlich der Zumutbarkeit der Lebensbedingungen in den Hotspots, nicht zuletzt angesichts der Berichte über deren Überfüllung?

Welche Maßnahmen sollen nach ihrer Kenntnis getroffen werden, um die Lebensbedingungen und die Sicherheitslage zu verbessern?

37. Welche Kenntnisse und Einschätzungen hat die Bundesregierung hinsichtlich der Sicherheitslage in den Hotspots?

Welche Maßnahmen sollen nach ihrer Kenntnis getroffen werden, um die Lebensbedingungen und die Sicherheitslage zu verbessern?

Wie viele Polizeibeamte und Mitarbeiter von Sicherheitsfirmen sind in den Hotspots im Einsatz, wie hat sich deren Zahl seit Einrichtung der Hotspots entwickelt, und inwiefern ist eine weitere Aufstockung beabsichtigt? 
NATIONALE PARLEMENTEN IN DE EUROPESE UNIE

38. Welche weiteren Konsequenzen und Schlussfolgerungen zieht die Bundesregierung aus den bisherigen Erfahrungen mit der Umsetzung des TürkeiEU-Abkommens?

Berlin, den 21. November 2016

Dr. Sahra Wagenknecht, Dr. Dietmar Bartsch und Fraktion 


\title{
Bijlage V. Antwoord Regering op Kleine Anfrage
}

\author{
Deutscher Bundestag Drucksache 18/10691 18. Wahlperiode 14 december 2016
}

Antwort der Bundesregierung auf die Kleine Anfrage der Abgeordneten Ulla Jelpke, Wolfgang Gehrcke, Christine Buchholz, weiterer Abgeordneter und der Fraktion DIE LINKE. - Drucksache 18/10394 -

\section{Situation von Flüchtlingen in Griechenland}

Vorbemerkung der Fragesteller

Der sogenannte Flüchtlingsdeal zwischen der Europäischen Union (EU) und der Türkei sieht vor, dass türkische Behörden in Zusammenarbeit mit der NATO (Organisation des Nordatlantikvertrages), der griechischen Küstenwache und Frontex Flüchtlinge an der Überfahrt auf die griechischen Inseln hindern sollen. Diejenigen, denen die Überfahrt trotzdem gelingt, werden auf den Inseln in Hotspots festgehalten. Dort soll darüber entschieden werden, ob ihre Asylanträge zulässig und begründet sind. Anschließend ist entweder ihre Abschiebung geplant oder ihre Umsiedlung, auch in andere Länder der EU.

Die praktische Umsetzung dieses Abkommens geht aus Sicht der Fragesteller und nach Schilderungen von Menschenrechtsorganisationen eindeutig zu Lasten der Flüchtlinge. Deren Rechte werden auf teilweise gravierende Weise verletzt. Durch die nach wie vor schleppende Bearbeitung der Asylanträge in den Hotspots kommt es dort zu massiven Überbelegungen, die sich schon mehrfach in militanten Protesten der dort Festgehaltenen entladen haben.

Die von der EU zugesagte personelle Unterstützung der griechischen Asylbehörden reicht offenbar nicht aus, die Problematik zu lösen. Zum einen wird nicht so viel Personal bereitgestellt, wie aus Griechenland bzw. dem Europäischen Unterstützungsbüro für Asylfragen (EASO) angefordert, zum anderen weist das eingesetzte Personal häufig nicht die erforderlichen Qualifikationen auf. Auch nach Aussagen des griechischen Integrationsministers Ioannis Mouzalas geht es 'nur langsam voran, zu langsam' (vgl. 'Asylchaos in Griechenland', SPIEGEL ONLINE, 2. November 2016). Kurze Einsatzzeiten reduzieren die Effektivität dieser Art der Unterstützung weiter. Dementsprechend ist die Qualität der erstinstanzlichen Entscheidungen der Asylbehörden, die auch auf Anhörungen durch 
Personal aus den Mitgliedstaaten bzw. deren Empfehlungen beruhen, in Frage gestellt. Die Berufungsinstanzen in Griechenland haben in den meisten Fällen die erstinstanzlichen Entscheidungen revidiert. Von 311 bis zum 18. September 2016 ergangenen Rechtsbehelfsentscheidungen zur Zulässigkeit von Asylanträgen wurden in nur sechs Fällen die erstinstanzlichen Entscheidungen bestätigt (vgl. Mitteilung der Kommission: 'Dritter Bericht über die Fortschritte bei der Umsetzung der Erklärung EU-Türkei', Ratsdokument 12813/16).

Die Antwort wurde namens der Bundesregierung mit Schreiben des Auswärtigen Amts vom 9. Dezember 2016 übermittelt.

Die Drucksache enthält zusätzlich - in kleinerer Schrifttype - den Fragetext.

Indiz für gravierende Verletzungen internationaler Flüchtlingsrechte ist zudem eine Meldung des Hohen Flüchtlingskommissars der Vereinten Nationen (UNHCR) vom 21. Oktober 2016, der zufolge mindestens zehn syrische Staatsangehörige von der griechischen Insel Leros ohne angemessene Beachtung ihres Asylwunsches in die Türkei abgeschoben worden sind. Dem UNHCR wurde zudem der Zugang zu 33 Flüchtlingen verweigert, die Anfang Oktober 2016 vom Peloponnes an einen „unbekannten Ort“ verbracht worden waren.

Soweit im Folgenden Kenntnisse der Bundesregierung erfragt werden, setzen die Fragesteller voraus, dass sich die Bundesregierung aktiv um entsprechende Kenntnisse auch bei den z. B. in Griechenland eingesetzten deutschen Beamtinnen und Beamten verschafft, unabhängig davon, ob diese im Rahmen von Frontex, EASO oder aufgrund bilateraler Vereinbarungen tätig sind.

1. Wie viele Flüchtlinge sind nach Kenntnis der Bundesregierung seit Juni 2016 von welchen Behörden welcher Länder beim Versuch, von der Türkei aus über die Ägäis auf die griechischen Inseln zu gelangen, unverzüglich (also ohne Gelegenheit, einen Asylantrag zu stellen, Anhörung und Rechtsbefehlsverfahren), in die Türkei zurückverbracht worden?

Und wie viele davon a) aus türkischen Hoheitsgewässern, b) aus griechischen Hoheitsgewässern, c) von griechischen Inseln aus?

Der Bundesregierung sind keine Fälle bekannt, in denen Flüchtlinge, die in die Türkei zurück verbracht worden sind, nicht Gelegenheit gehabt hätten, einen Asylantrag zu stellen oder dass Anhörung und Rechtsbehelfsverfahren nicht vorgenommen worden wären. 
2. Welche Kenntnis hat die Bundesregierung darüber, inwiefern den aufgegriffenen Personen Gelegenheit gegeben wurde, Bedenken gegen ihre Abschiebung in die Türkei zu äußeren und inwiefern diese Bedenken unter Beachtung des Refoulement-Verbots geprüft wurden?

Falls die Bundesregierung nicht ausschließen kann, dass Personen ohne solche Prüfungen in die Türkei zurückverbracht worden sind, welche Schlussfolgerungen für ihre weitere Mitwirkung an der Umsetzung des EU-Türkei-Abkommens zieht sie aus einer solchen Verletzung internationaler Schutzstandards?

Der Bundesregierung liegen keine Erkenntnisse über derartige Fälle vor.

3. Wie viele Flüchtlinge sowie unbegleitete minderjährige Flüchtlinge (UMF) (bitte jeweils getrennt angeben) halten sich nach Kenntnis der Bundesregierung derzeit in den Hotspots sowie weiteren Einrichtungen in Griechenland auf (bitte getrennt darstellen), und für wie viele Flüchtlinge sind die einzelnen Einrichtungen bzw. Hotspots tatsächlich ausgelegt?

Nach den aktuellen Zahlen der griechischen Behörden hielten sich zum 23. November 201611507 Personen in den fünf Hotspots auf den ostägäischen Inseln auf. Die Hotspots sind für eine Kapazität von 7450 Personen ausgelegt. Die Zahl unbegleiteter Minderjähriger in den Hotspots lag zum 2. November 2016 bei 344 Personen.

Bei einer Kapazität von 62323 Plätzen hielten sich nach Angaben der griechischen Behörden zum 23. November 201651041 Personen in den übrigen Einrichtungen in Griechenland auf. Die Zahl unbegleiteter Minderjähriger lag zum 2. November 2016 in Griechenland - inklusive Hotspots - bei geschätzt 2 400. Landesweit stehen 1191 Plätze in speziellen Einrichtungen für unbegleitete Minderjährige zur Verfügung.

Worauf ist nach Kenntnis der Bundesregierung die allfällige Überbelegung der Hotspots zurückzuführen?

Die Zahl der Neuankünfte übersteigt derzeit die Asyl-Verfahrenskapazitäten vor Ort. Mit dem angestrebten Ausbau der Asyl-Verfahrenskapazitäten und weiterer Unterkünfte soll der derzeitigen Überbelegung entgegengewirkt werden. Hierzu wird auf die Antwort zu Frage 6 verwiesen.

4. Wie viele dieser Flüchtlinge hatten nach Kenntnis der Bundesregierung bislang

a) Gelegenheit, einen Asylantrag zu stellen,

b) eine Anhörung (hier bitte zusätzlich angeben, wie viele Anhörungen von EASOPersonal durchgeführt wurden), 
c) eine erstinstanzliche Entscheidung über ihren Asylantrag erhalten,

d) eine Entscheidung der Berufungsinstanz erhalten?

Vom 20. März 2016 bis zum 22. November 2016

a) haben 8701 Flüchtlinge auf den ostägäischen Inseln einen Asylantrag gestellt;

b) wurden 5307 Anhörungen durchgeführt. Zahlen über das Personal, das die Anhörungen durchführt, liegen der Bundesregierung nicht vor;

c) wurden 2964 Entscheidungen der Asylbehörde getroffen;

d) wurden 871 Entscheidungen der Rechtsbehelfsausschüsse getroffen.

5. Bei wie vielen Anhörungen war nach Kenntnis der Bundesregierung keine Übersetzung in die Muttersprache bzw. in eine für die Asylsuchenden verständliche Sprache möglich?

Der Bundesregierung liegen hierzu keine Erkenntnisse vor.

6. Inwiefern werden nach Kenntnis der Bundesregierung in Griechenland derzeit zusätzliche Aufnahmekapazitäten (bitte getrennt nach Inseln und Festland darstellen) geschaffen, und bis wann sollen diese bezugsbereit sein?

Die griechische Regierung ist bestrebt, die Aufnahmekapazitäten auf den ostägäischen Inseln zu erweitern. Aufgrund von Widerständen in den lokalen Gemeinden ist bisher allerdings keine Erweiterung realisiert worden. Der UNHCR und die Nichtregierungsorganisation bemühen sich um weitere Aufnahmekapazitäten, z. B. durch die kurzfristige Anmietung von Hotelzimmern für Familien und vulnerable Personen. Auf dem Festland besteht kein grundsätzlicher Mangel an Aufnahmekapazitäten (siehe Antwort zu Frage 3).

Für den Bereich unbegleiteter Minderjähriger plant der UNHCR im Rahmen seiner Programme eine Aufstockung von derzeit 522 auf 726 Plätze. Zur Planung weiterer in diesem Bereich tätigen Organisationen liegen der Bundesregierung keine konkreten Zahlen vor.

7. Wie viele Flüchtlinge leben nach Kenntnis der Bundesregierung derzeit in den Hotspots und anderen Einrichtungen, deren Asylanträge bereits rechtskräftig abgelehnt wurden?

Offizielle Zahlen hierüber liegen der Bundesregierung nicht vor.

8. Wie viel Zeit müssen die Insassen der Hotspots nach Kenntnis der Bundesregierung durchschnittlich in diesen verbringen? 
Die Dauer des Aufenthalts ist abhängig von der Dauer der Bearbeitung der Asylanträge. Auf die Antwort zu den Fragen 11 und 12 wird verwiesen.

9. Welche Defizite sieht die Bundesregierung derzeit hinsichtlich des griechischen Asylsystems, der Lage in den Hotspots und bei der Umsetzung des Flüchtlingsabkommens mit der Türkei, und auf welche Ursachen führt sie diese zurück (bitte jeweils einzeln und ausführlich beantworten)?

Auf die Antworten zu den Fragen 3, 10, 13, 36, 37 und 38 wird verwiesen.

10. Welche Defizite sieht die Bundesregierung hinsichtlich der technischen und materiellen Ausstattung der Hotspots?

Die griechische Regierung hat im Jahr 2015 auf den Inseln Lesbos, Chios, Samos, Kos und Leros Registrierungs- und Erstaufnahmezentren (sogenannte Hotspots) eingerichtet, die ursprünglich für einen Aufenthalt von Migranten für eine Dauer von 48 bis 72 Stunden konzipiert waren. Die Unterbringungskapazitäten und damit einhergehend die technische und materielle Ausstattung der Hotspots sind derzeit teilweise unzureichend. Die griechische Regierung, UNHCR und Nicht-regierungsorganisationen sind bestrebt, weitere Unterbringungskapazitäten zu schaffen.

Seit Einrichtung der Hotspots wurden, soweit für die Bundesregierung feststellbar, große Fortschritte erreicht. Vor dem Hintergrund einzelner sicherheitsrelevanter Vorfälle wird aktiv in Zusammenarbeit mit den verantwortlichen griechischen Stellen und EASO an Maßnahmen zur Verbesserung der Sicherheit gearbeitet.

11.Wie lange dauert nach Kenntnis der Bundesregierung ein Asylverfahren in den Hotspots, aufgeschlüsselt nach den Zeiträumen

a) von der Ankunft bis zur Stellung eines formellen Antrages,

b) bis zur Anhörung,

c) bis zur Entscheidung in erster Instanz,

d) bis zur Entscheidung in zweiter Instanz?

12. Wie gestalten sich die in der vorangegangenen Frage abgefragten Bearbeitungszeiten hinsichtlich unbegleiteter Minderjähriger oder anderer besonders schutzbedürftiger Flüchtlinge (bitte differenzieren)?

Die Fragen 11 und 12 werden gemeinsam beantwortet. 
$\mathrm{Zu}$ den Fragestellungen liegen keine entsprechenden Statistiken der griechischen Behörden vor. Die griechische Regierung nimmt aufgrund begrenzter Kapazitäten eine Priorisierung unter den ankommenden Flüchtlingen und Migranten vor. Daher ist von einer von Fall zu Fall unterschiedlichen Verfahrensdauer auszugehen.

13. Inwiefern ist nach Kenntnis der Bundesregierung die volle Arbeitsfähigkeit der griechischen Rechtsbehelfsbehörde bzw. der Rechtsbehelfsausschüsse gewährleistet, und welche Defizite sind ihr diesbezüglich bekannt?

Die griechische Regierung erhöht derzeit die Zahl der Komitees, um die Asyl-Verfahrenskapazitäten auszubauen. Außerdem wurden bereits die Effizienz der Komitees erhöht und Entscheidungsabläufe standardisiert.

14. Welche Schlussfolgerungen in Hinblick auf die Qualität der Anhörungen bzw. der Eignung und Qualifikation des bei den Anhörungen eingesetzten Personals, das oftmals aus anderen EU-Mitgliedstaaten kommt und der von ihnen formulierten Empfehlungen zur Entscheidung über die (Un-)Zulässigkeit von Asylanträgen ziehen die Bundesregierung sowie nach ihrer Kenntnis die griechische Regierung aus dem Umstand, dass die Rechtsbehelfsausschüsse 98 Prozent der erstinstanzlichen Unzulässigkeitsentscheidungen aufheben (bitte ausführen)?

Die Auswahl des von den EU-Mitgliedstaaten vorgeschlagenen Personals für Anhörungen obliegt dem Europäischen Unterstützungsbüro für Asylfragen (EASO). Der Bundesregierung liegen keine Kenntnisse darüber vor, dass das von EASO ausgewählte Personal nicht den Eignungs- und Qualifikationsvorgaben für die durchzuführenden Anhörungen entspräche.

15. Inwiefern und in welchem Umfang werden dem griechischen bzw. von EU-Mitgliedstaaten bereitgestellten Personal, das zur Unterstützung der Asylverfahren eingesetzt wird, Supervisionen angeboten?

Der Bundesregierung liegen hierzu keine Erkenntnisse vor. Deutsches Personal nimmt im Regelfall vor dem Einsatz an einer Vorbereitungsschulung in Deutschland teil. Zudem wird das Personal während der Durchführung der Unterstützungsmaßnahme durch EASO begleitet und geschult.

16. Welche Kenntnis hat die Bundesregierung über die Entscheidungspraxis der Rechtsbehelfsausschüsse hinsichtlich erstinstanzlicher Entscheidungen in Bezug auf die inhaltliche 
Unbegründetheit von Asylanträgen (bitte nach Möglichkeit konkrete Zahlen nennen), und welche Schlussfolgerungen zieht sie daraus?

Begründetheitsprüfungen werden für Antragsteller aus anderen Staaten als Syrien durchgeführt. Mit Stand vom 22. November 2016 gab es 1450 Entscheidungen der Asylbehörden, in denen die Begründetheit der Anträge geprüft wurde. Davon wurden 1309 Anträge als unbegründet abgewiesen und 130 Anträge wurden als begründet anerkannt. In elf Fällen wurde auf subsidiären Schutz entschieden. Der hohe Anteil von unbegründeten Anträgen erklärt sich auch daraus, dass die griechischen Asylbehörden Anträge von Antragstellern aus Herkunftsstaaten mit einer niedrigen Schutzquote prioritär behandelt haben.

17. Inwiefern haben Flüchtlinge in Griechenland nach Kenntnis der Bundesregierung gegenwärtig Zugang zu kostenfreier rechtlicher Beratung, und wie viele Rechtsanwälte oder andere Beratungsorganisationen stehen dafür zur Verfügung (bitte ggf. auf relevante örtliche Unterschiede hinweisen)?

Der Zugang von Flüchtlingen (Asylsuchenden) zu kostenfreier rechtlicher Beratung ist seit April 2016 durch das Gesetz zum griechischen Asylverfahren Nr. 4375/206 geregelt.

Die griechische Asylbehörde hat zudem 2016 in Kooperation mit dem UNHCR ein Programm zur kostenfreien rechtlichen Beratung für Flüchtlinge gestartet. Im Rahmen des Programms findet eine Kooperation mit auf Rechtsberatung spezialisierten griechischen Nichtregierungsorganisationen wie dem Greek Refugee Council und ARSIS (Organisation für die Rechte von Kindern und Jugendlichen) statt. Letztere ist auf den Beistand unbegleiteter Minderjähriger spezialisiert.

Das Programm und die Gewinnung von Rechtsanwälten für dieses Programm befinden sich noch im Aufbau. Über die genaue Zahl der Rechtsanwälte und der Beratungsorganisationen liegen der Bundesregierung keine Kenntnisse vor.

18. Inwieweit treffen Informationen der Fragesteller zu, wonach Angehörigen bestimmter Nationalitäten bislang noch keine Gelegenheit gegeben wurde, einen förmlichen Asylantrag zu stellen, und um welche Nationalitäten und wie viele Personen handelt es sich dabei im Einzelnen?

Die griechischen Asylbehörden haben in den Hotspots nach Kenntnis der Bundesregierung bisher keine förmlichen Asylanträge von afghanischen, iranischen und irakischen Staatsbürgern angenommen. 
Über die genaue Anzahl an afghanischen, iranischen und irakischen Staatsbürgern, die in den Hotspots bisher keinen förmlichen Asylantrag stellen konnten, liegen der Bundesregierung keine Kenntnisse vor.

Im September 2016 haben nach Angaben der griechischen Asylbehörde 561 pakistanische, 380 afghanische und 69 iranische Staatsangehörige auf dem griechischen Festland einen förmlichen Asylantrag gestellt.

19. Welche Kritik an den in den Anhörungen der Asylantragsteller in Griechenland eingesetzten Befragungsbögen ist der Bundesregierung bekannt, und inwiefern hält sie selbst eine Überarbeitung für sinnvoll (bitte nach Möglichkeit den Wortlaut eines solchen Befragungsbogens in englischer Sprache übermitteln)?

Die Organisation und Durchführung der Anhörungen in Griechenland obliegt EASO sowie den griechischen Behörden. Die Bundesregierung nimmt keine Bewertung der Durchführung und der dabei verwendeten Arbeitsmittel vor. Der Bundesregierung liegen keine Erkenntnisse vor, dass rechtsstaatliche Vorgaben nicht eingehalten würden.

20. Wie genau beziffern die europäischen Agenturen, die in Griechenland bzw. den Hotspots tätig sind, ihren materiellen und personellen Unterstützungsbedarf durch die Mitgliedstaaten (bitte getrennt und aufgeschlüsselt nach angeforderten Fähigkeitsprofilen und Einsatzbereichen wie etwa Anhörer, Dolmetscher u. a. darstellen)?

a) Wie hat sich nach Kenntnis der Bundesregierung die personelle Unterstützung durch die Mitgliedstaaten tatsächlich gestaltet?

b) Wie viele Unterstützungskräfte (bitte nach einzelnen Einsatzbereichen und Fähigkeitsprofilen darstellen) sind gegenwärtig aus welchen Mitgliedstaaten in Griechenland im Einsatz?

Die Fragen 20 bis 20b werden gemeinsam beantwortet.

Zum materiellen Bedarf von EASO liegen der Bundesregierung keine Erkenntnisse vor. Der personelle Bedarf richtet sich nach den jeweiligen Kapazitäten vor Ort. Der aktuelle Aufruf von EASO vom 11. November 2016 sieht einen Bedarf an 150 Asylexperten sowie 40 Dolmetschern auf den griechischen Inseln sowie einen Bedarf von 28 Experten für Relocation und zehn Dolmetscher für das Festland vor. Nach Mitteilung der Europäischen Kommission sind mit Stand vom 21. November 2016 insgesamt 74 EASO-Experten eingesetzt, davon 37 in den Hotspots (Deutschland 23, Niederlande sechs, Österreich zwei, Großbritannien ein, Frankreich zwei, Rumänien ein, Tschechische Republik zwei). In Griechenland sind aktuell 101 Dolmetscher durch EASO eingesetzt, eine Aufteilung auf 
das Festland und die griechischen Inseln wurde von der Europäischen Kommission nicht mitgeteilt.

c) In welchem Umfang wurden die Einrichtung bzw. der Betrieb von Hotspots in Griechenland bislang aus Mitteln der EU gefördert, und welche Mittel wurden für die Zukunft zugesagt?

Griechenland hat bisher aus den Mehrjahresprogrammen des Asyl-, Migrationsund Integrationsfonds (AMIF) sowie des Fonds für innere Sicherheit (ISF) 70 Mio. Euro erhalten. Aus den Notfallmaßnahmen der beiden Fonds bisher 225 Mio. Euro (jeweils Mitteilung der EU-Kommission, Stand: 8. November 2016). Insgesamt stehen Griechenland für die Mehrjahresprogramme des AMIF und des ISF 505 Mio. Euro bis 2020 zur Verfügung, für die Notfallmaßnahmen insgesamt 352 Mio. Euro. Das ECHO Emergency Assistance Instrument sieht ein Gesamtbudget von 198 Mio. Euro vor.

21. Welcher zeitliche Aufwand wird nach Kenntnis der Bundesregierung pro Anhörung betreffend Zulässigkeit und Begründetheit von Asylanträgen in den Hotspots kalkuliert?

$\mathrm{Zu}$ der internen Ablauforganisation von EASO oder den griechischen Behörden liegen der Bundesregierung keine Erkenntnisse vor.

22. Inwiefern sind die Anhörer nach Kenntnis der Bundesregierung dazu angehalten, sich an einen bestimmten Zeitrahmen bei der Anhörung zu halten?

Über derartige Vorgaben liegen der Bundesregierung keine Erkenntnisse vor.

23. Welchen künftigen personellen Unterstützungsbedarf prognostizieren die europäischen Agenturen?

Auf die Antwort zu Frage 20 wird verwiesen.

24. Worauf führt die Bundesregierung die Untererfüllung des Unterstützungsbedarfs durch die Mitgliedstaaten zurück, und welche Maßnahmen sind nach ihrer Kenntnis in Deutschland, in Griechenland sowie in anderen Mitgliedstaaten getroffen worden, um die Defizite zu beseitigen?

Die Bundesregierung beteiligt sich seit Jahren an Unterstützungsmaßnahmen für EASO. Im Anschluss an die EU-Beschlüsse zur Umsiedlung von Schutzsuchenden aus Italien und Griechenland aus 2015 sowie die EU-Türkei-Vereinbarung vom März 2016 wurden die 
deutschen Unterstützungsmaßnahmen deutlich verstärkt. Bislang wurden rund 50 Mitarbeiterinnen und Mitarbeiter zur Unterstützung von EASO und der griechischen Asylbehörde entsandt. Vorbereitungen für weitere Entsendungen werden derzeit getroffen. Erkenntnisse zu den getroffen Maßnahmen in Griechenland und anderen Mitgliedstaaten liegen nicht vor.

25. Wie lange ist im Schnitt die Einsatzzeit in Griechenland für das Unterstützungspersonal (bitte nach Agenturen, Zuständigkeitsbereichen und Fähigkeitsprofil untergliedern) nach Kenntnis der Bundesregierung, was kann sie insbesondere zu den Einsatzzeiten deutscher Bediensteter und zu etwaigen Problemen bei deren Einsatz Genaueres sagen?

Trifft es zu, dass einige Kräfte bereits nach zehn Tagen wieder abreisen (vgl. SPIEGEL ONLINE, 2. November 2016)?

Beim Unterstützungspersonal der Bundesregierung handelt es sich in der Regel um Entscheider, welche EASO und die griechische Asylbehörde bei der Durchführung von Asylverfahren unterstützen.

Die Einsatzzeit von grenzpolizeilichen Unterstützungskräften auf der Grundlage bilateraler Abkommen beträgt drei bis zwölf Monate.

Die Einsatzzeit von Unterstützungspersonal im Rahmen von FRONTEX-koordinierten Einsätzen beträgt sechs bis acht Wochen. Dies gilt für alle Fähigkeitsprofile.

Weder aus den Einsatzzeiten noch aus den Einsatzbedingungen haben sich bisher Probleme ergeben. Es trifft deshalb nicht zu, dass Kräfte der Bundespolizei bereits nach zehn Tagen wieder abgereist wären.

Der Bundesregierung liegen keine Erkenntnisse zur Einsatzdauer der Mitarbeiter aus anderen Mitgliedstaaten vor.

26. Wie viele Flüchtlinge sind nach Kenntnis der Bundesregierung im Zeitraum seit Juni 2016 auf den Inseln angekommen, und wie viele Flüchtlinge wurden in diesem Zeitraum in die Türkei zurückverbracht, in welche weiteren Drittstaaten abgeschoben, in andere Unterbringungseinrichtungen auf dem griechischen Festland verbracht oder in andere Mitgliedstaaten (bitte einzeln angeben) umgesiedelt?

Zwischen 1. Juni 2016 und 20. November 2016 sind nach Angaben von UNHCR 14461 Personen auf den ostägäischen Inseln angekommen. Im gleichen Zeitraum wurden 280 Drittstaater von Griechenland in die Türkei zurückgeführt. Über Abschiebungen in weitere 
Drittstaaten liegen der Bundesregierung keine Kenntnisse vor. Zwischen dem 21. September 2016 und dem 27. Oktober 2016 wurden 266 Asylbewerber im regulären Verfahren in insgesamt sieben Transfers auf das Festland gebracht. Weitere Zahlen hierzu liegen der Bundesregierung nicht vor. Zwischen dem 15. Juni 2016 und dem 21. November 2016 wurden 4302 Umsiedlungen ('Relocation') aus Griechenland in andere EU-Mitgliedstaaten durchgeführt.

27. In welchem Umfang kommt es nach Kenntnis der Bundesregierung vor, dass Mitgliedstaaten Umsiedlungsbewerber ohne Angabe von Gründen ablehnen, und um welche Mitgliedstaaten handelt es sich dabei?

Der Bundesregierung liegen hierzu keine Erkenntnisse vor. Soweit Deutschland Asylsuchende im Rahmen des Relocation-Verfahrens ablehnt, werden die Ablehnungsgründe gegenüber Italien beziehungsweise Griechenland mitgeteilt.

28. Welche Erkenntnisse (ggf. auch von dritter Seite) hat die Bundesregierung über die näheren Umstände der vom UNHCR in der Meldung vom 21. Oktober 2016 angesprochenen Abschiebung syrischer Staatsangehöriger?

a) Inwieweit trifft es zu, dass deren Asylwunsch nicht angemessen geprüft wurde? Hatten die Personen überhaupt Gelegenheit, einen formellen Asylantrag zu stellen?

b) Wie verhalten sich die griechischen Behörden zu den Vorwürfen des UNHCR, und inwiefern haben sie zu deren Klärung beigetragen?

c) Sollte sich der Vorwurf einer Abschiebung ohne angemessene Prüfung des Asylwunsches bestätigt haben, welche Konsequenzen ziehen die griechischen Behörden daraus?

Ist den betroffenen Flüchtlingen Gelegenheit gegeben worden, nach Griechenland zurückzukehren?

Die Fragen 28 bis 28c werden gemeinsam beantwortet.

Nach Aussagen der griechischen Behörden wurde die Gruppe syrischer Staatsangehöriger von der griechischen Polizei mehrfach über ihr Recht informiert, einen Asylantrag zu stellen: sowohl bei ihrer Ankunft auf Milos am 9. Oktober 2016 als auch während ihres zehntägigen Aufenthalts im Hotspot von Leros sowie am Flughafen von Kos, unmittelbar vor ihrem Rückflug in die Türkei. Bei dieser Gelegenheit habe eine dreiköpfige Familie ihren Asylwunsch geäußert und sei deshalb in Griechenland verblieben. Die übrigen zehn Syrer hätten keinen Asylwunsch geäußert und seien zurück an die Türkei überstellt worden. 
Während der Überstellung seien Vertreter von FRONTEX und dem griechischen Ombudsmann für Menschenrechte anwesend gewesen.

Nach Auskunft des UNHCR hat das griechische Ministerium für Migration dennoch eine Untersuchung des Vorgangs durch den Generalinspekteur der Öffentlichen Verwaltung beantragt. Der UNHCR wird den Fall weiter verfolgen und erwartet das Ergebnis der Untersuchung.

29. Wie viel Zeit nimmt derzeit nach Kenntnis der Bundesregierung ein Umsiedlungsverfahren in Anspruch (Zeitraum zwischen Datum des Umsiedlungsantrages und der tatsächlichen Umsiedlung)?

Zwischen den Ersuchen bis zur tatsächlichen Umverteilung der Asylsuchenden nach Deutschland liegen durchschnittlich sieben bis acht Wochen, so dass das gesamte Umsiedlungsverfahren ab der Tranchenmeldung bis zur tatsächlichen Umsiedlung von jeweils 500 Personen derzeit rund zehn bis zwölf Wochen umfasst.

Zum zeitlichen Ablauf in anderen Mitgliedstaaten liegen der Bundesregierung keine Erkenntnisse vor.

30. Wie viele Anträge auf Familienzusammenführung nach Deutschland bzgl. in Griechenland aufhältiger Flüchtlinge im Rahmen des Dublin-Verfahrens liegen derzeit dem Bundesamt für Migration und Flüchtlinge (BAMF) vor, und wie viele dieser Anträge wurden bislang wie entschieden, und wie viele Überstellungen zu Familienangehörigen haben bereits stattgefunden (bitte nach den fünf wichtigsten Staatsangehörigkeiten differenzieren)?

Die Bundesregierung kann nur die Zahl der Übernahmeersuchen und der Überstellungen statistisch auswerten. Die Zahl der Übernahmeersuchen und Überstellungen im Zusammenhang mit Familienkonstellationen von Griechenland an Deutschland im Zeitraum vom 1. Januar 2016 bis zum 31. Oktober 2016 kann der folgenden Tabelle entnommen werden: 
Übernahmeersuchen von Griechen- Überstellungen aus Griechenland land an Deutschland nach Deutschland

\begin{tabular}{|c|c|c|}
\hline $\begin{array}{l}\text { Art. } 8 \text { Abs. } 1 \\
\text { Dublin-VO }\end{array}$ & 223 & 44 \\
\hline $\begin{array}{l}\text { Art. } 8 \text { Abs. } 2 \\
\text { Dublin-VO }\end{array}$ & 12 & 3 \\
\hline \multicolumn{3}{|l|}{$\begin{array}{l}\text { Art. } 8 \text { Abs. } 4 \\
\text { Dublin-VO }\end{array}$} \\
\hline Art. 9 Dublin-VO & 753 & 65 \\
\hline $\begin{array}{l}\text { Art. } 10 \text { Dublin- } \\
\text { VO }\end{array}$ & 1.158 & 165 \\
\hline \multicolumn{3}{|l|}{$\begin{array}{l}\text { Art. } 11 \text { Dublin- } \\
\text { VO }\end{array}$} \\
\hline $\begin{array}{l}\text { Art. } 16 \text { Abs. } 1 \\
\text { Dublin-VO }\end{array}$ & 58 & 4 \\
\hline $\begin{array}{l}\text { Art. } 16 \text { Abs. } 2 \\
\text { Dublin-VO }\end{array}$ & 2 & 1 \\
\hline $\begin{array}{l}\text { Art. } 17 \text { Abs. } 2 \\
\text { Unterabs. } 1 \\
\text { Dublin-VO }\end{array}$ & 83 & 12 \\
\hline Summe & 2.289 & 294 \\
\hline
\end{tabular}

Überstellungen von Griechenland nach Deutschland mit Abfragestand 23. Oktober 2016 nach den fünf häufigsten Herkunftsländern für den Zeitraum 1. Januar bis 30. September 2016:

Januar bis September 2016

\begin{tabular}{ll}
\hline Herkunftsländer gesamt & 240 \\
\hline darunter: & \\
\hline Syrien & 125 \\
\hline Afghanistan & 83 \\
\hline Irak & 22 \\
\hline Iran & 4 \\
\hline Staatenlos & 2
\end{tabular}

31. Welche Kenntnisse hat die Bundesregierung über einen weiteren, ebenfalls am 21. Oktober 2016 vom UNHCR gemeldeten Vorfall vom 8. Oktober 2016, demzufolge 33 Flüchtlinge an einen 'unbekannten Ort' verbracht wurden und dem UNHCR der Zugang zu diesen verweigert wurde? 
Hat der UNHCR mittlerweile Zugang zu ihnen erhalten, und hatten die Personen Gelegenheit, einen Asylantrag zu stellen?

Nach Auskunft des UNHCR hat das griechische Ministerium für Migration eine Untersuchung des Vorgangs durch den Generalinspekteur der Öffentlichen Verwaltung beantragt. Der UNHCR wird den Fall weiterverfolgen und erwartet das Ergebnis der Untersuchung.

Weitere Informationen liegen der Bundesregierung nicht vor.

32. Auf welche Weise wird nach Kenntnis der Bundesregierung die Registrierung bei Flüchtlingen durchgesetzt, die hieran nicht mitwirken wollen, insbesondere nicht an erkennungsdienstlichen Maßnahmen?

Das Verfahren zur Abnahme von Fingerabdrücken wird gemäß den innerstaatlichen Gepflogenheiten des betreffenden Mitgliedstaats und unter Beachtung der in der Europäischen Menschenrechtskonvention und im Übereinkommen der Vereinten Nationen über die Rechte des Kindes verankerten Schutzklauseln festgelegt.

33. Gibt es nach Kenntnis der Bundesregierung Klagen über Rechtsverletzungen oder Übergriffe im Rahmen dieses Verfahrens (falls ja, bitte Anzahl und Art der Verletzung angeben)?

Die Bundesregierung hat keine Kenntnis zu Klagen über Rechtsverletzungen oder Übergriffe im Sinne der Fragestellung.

34. Wie viele disziplinarrechtliche oder strafrechtliche Verfahren hat es bisher gegen Personal von Hotspots im Rahmen ihrer Tätigkeit nach Kenntnis der Bundesregierung gegeben?

Informationen über disziplinarrechtliche oder strafrechtliche Verfahren gegen Personal in den Hotspots liegen der Bundesregierung nicht vor.

35. Wie beurteilt die Bundesregierung die Sicherheitslage in Griechenland?

Grundsätzlich ist die Sicherheitslage in Griechenland gut. Allerdings sind weiterhin eine Reihe von anarchistischen Organisationen wie etwa 'Rubikon' sowie die Untergrundorganisation „Konspiration der Feuerzellen“ aktiv, wobei insbesondere letztere zu Aktionen gegen Interessen des griechischen Staates beziehungsweise gegen 'ausländische Interessen’ aufgerufen hat. 
36. Welche Kenntnisse und Einschätzungen hat die Bundesregierung hinsichtlich der Zumutbarkeit der Lebensbedingungen in den Hotspots, nicht zuletzt angesichts der Berichte über deren Überfüllung?

Welche Maßnahmen sollen nach ihrer Kenntnis getroffen werden, um die Lebensbedingungen und die Sicherheitslage zu verbessern?

37. Welche Kenntnisse und Einschätzungen hat die Bundesregierung hinsichtlich der Sicherheitslage in den Hotspots?

Welche Maßnahmen sollen nach ihrer Kenntnis getroffen werden, um die Lebensbedingungen und die Sicherheitslage zu verbessern?

Wie viele Polizeibeamte und Mitarbeiter von Sicherheitsfirmen sind in den Hotspots im Einsatz, wie hat sich deren Zahl seit Einrichtung der Hotspots entwickelt, und inwiefern ist eine weitere Aufstockung beabsichtigt?

Die Fragen 36 und 37 werden gemeinsam beantwortet.

Die Gewährleistung der öffentlichen Sicherheit in den Hotspots obliegt der griechischen Regierung. Nach mehreren gewaltsamen Protesten und Auseinandersetzungen zwischen verschiedenen Flüchtlings- und Migrantengruppen wie auch gegen die Arbeitsbereiche des Europäischen Asylunterstützungsbüros (EASO) hat die griechische Polizei ihre Präsenz, insbesondere auf Lesbos und Chios, seit Mitte November 2016 erhöht. Darüber hinaus wurden in den Hotspots durch bauliche Veränderungen Flucht- und Evakuierungswege für das eingesetzte Personal geschaffen. Ferner hat EASO für die in den Hotspots eingerichteten Asylarbeitsbereiche einen privaten Sicherheitsdienst beauftragt. Maßnahmen zur Verbesserung der Lebensbedingungen konzentrieren sich insbesondere auf eine Entlastung der Hotspots durch die Schaffung zusätzlicher Aufnahmekapazitäten auf den Inseln sowie durch die Beschleunigung der Asylverfahren.

Nach Angaben von FRONTEX sind derzeit 663 Beamte aus den EU-Mitgliedstaaten in der FRONTEX-Operation EPN Poseidon 2016 eingesetzt, davon 288 in den Hotspots. Angaben zum personellen Umfang des privaten Sicherheitspersonals liegen der Bundesregierung nicht vor.

Zur Erhöhung der Sicherheit in den Hotspots wird der Einsatz von 180 griechischen Polizeibeamten durch FRONTEX kofinanziert. 
Zur Gesamtzahl aller in den Hotspots eingesetzten Beamten sowie zu einer ggf. beabsichtigten Aufstockung des Sicherheitspersonals in den Hotspots liegen der Bundesregierung keine weiteren Erkenntnisse vor.

38. Welche weiteren Konsequenzen und Schlussfolgerungen zieht die Bundesregierung aus den bisherigen Erfahrungen mit der Umsetzung des Türkei-EU-Abkommens?

Die Bundesregierung sieht in der EU-Türkei-Erklärung ein wirksames Instrument, um Schleuserkriminalität in der Ostägäis zu bekämpfen, die Zahl der illegalen Grenzübertritte auf den griechischen Inseln maßgeblich zu senken und die Zahl der Todesfälle bei Überfahrten über das östliche Mittelmeer deutlich zu verringern sowie die Lebensbedingungen von Flüchtlingen in der Türkei zu verbessern. 


\section{S U M M A RY}

National parliaments in the European Union. A legal comparison between the Dutch and the German parliament in EU affairs.

The purpose of this dissertation is to compare the activities of the Dutch and German parliament in EU affairs. The role of national parliaments in the European Union has been extensively discussed in academic literature, particularly in relation to the EU's democratic deficit. This democratic deficit is supposedly a consequence of, among other things, the small role that national parliaments play(ed) in the EU. However, this role has shifted over time. National parliaments have received more and more powers in EU affairs, not lastly through the scrutiny of their own governments and the newly introduced possibilities to intervene in the legislative process at the European level. This dissertation focusses on the use of the powers of the Dutch Tweede Kamer and Eerste Kamer and the German Bundestag and Bundesrat to scrutinize their national governments and the European Commission in the legislative process, with a particular focus on the Dutch parliament.

The first question to be asked is: In what way does the Dutch parliament make use of its powers under national and European Law in EU affairs?

Based on the conclusions for this question, the research question is formulated to be able to make some recommendations to the Dutch parliament: Can the Dutch parliament improve its scrutiny of EU affairs, in order to do justice to its role under the EU Treaties and its own national role with regard to democratic control and representation?

According to article 12 TEU "national parliaments contribute actively to the good functioning of the Union". To fulfill this duty, national parliaments have several powers at their disposal. The first type of powers is laid down in EU law itself. The EU Treaties provide every parliament of an EU member state with the right to review draft legislation of the EU for its compatibility with the subsidiarity principle (Early Warning System), the right to start a political dialogue with the European Commission, as well as the possibility to take part in interparliamentary cooperation. The existence of these powers is the same for all member states. If, and how, they are used is, however, a national matter. As a consequence, national parliaments can and do differ in the application of the powers given to them by the EU Treaties. Afther the introduction in chapter 1, chapter 2 takes a closer look at these powers and their application by the German and Dutch parliaments. Firstly, the political dialogue is discussed. It is found that the political dialogue is not an instrument that provides national parliaments with much power to influence European decision- 
making. It is merely a dialogue, as the title indicates. The European Commission (EC) is not likely to change its opinion or draft legislative proposal based on the opinions sent to the EC by one or more national parliaments within the framework of the political dialogue. On the other hand, when a large group of national parliaments send a joint opinion to the EC, it is more willing to take the opinion of that group into account and act in accordance with that opinion. In the years that are included in this study, 2010 to 2016, national parliaments have sent an average of 19 reasoned opinions per year and per national parliament in the political dialogue. The Bundesrat, the upper house of the German parliament, has been one of the most active chambers of national parliaments by sending an average of 34 reasoned opinions per year. The reason for this is the fact that the Länder, the states of the German federation, prescribe the Bundesrat when to send a reasoned opinion. According to the Länder, the political dialogue is the main instrument for them to influence European decision-making. The German lower house, the Bundestag, the Dutch lower house, the Tweede Kamer, and the Dutch upper house, the Eerste Kamer, are less active than the Bundesrat, but their activities are average in comparison to other national parliaments in the EU.

Next to the political dialogue, national parliaments have the option to send a reasoned opinion in the context of the Early Warning System. When used correctly, this instrument can be effective for national parliaments in influencing European decision-making. The key to this instrument is interparliamentary cooperation. Each national parliament has two votes - in bicameral systems each chamber is allocated one vote - and when at least one third of such votes are cast, a so-called yellow card is triggered. National parliaments need to reach this threshold of one third of votes cast before the EC must consider whether to revise a draft legislation. There is, however, often a lack of cooperation between national parliaments to work together to reach this threshold and thus to make use of this instrument. None of the chambers of the German and Dutch parliaments is aiming to exercise this power extensively. Especially in Germany, this instrument is not seen by parliament as a useful instrument. Both the German and the Dutch parliament are more inclined use the powers under their own domestic legal framework to scrutinize their own government as opposed to using the powers laid down in EU law.

Lastly, chapter 2 discusses interparliamentary cooperation. According to article 12 TEU, national parliaments have a duty to contribute actively to the good functioning of the EU by also taking part in interparliamentary cooperation between national parliaments and with the European Parliament. There are several different forms of interparliamentary cooperation. Members of national parliaments are able to participate in one or more of the formal conferences. Next to that, members of national parliaments meet with other members of national parliaments in smaller, bilateral settings. 
In addition to the powers given to national parliaments at EU level, national parliaments have also been vested with powers at national level to participate in EU affairs. These powers can vary from one member state to another. Examples of this type of power include the existence of a scrutiny reserves or the right to ask questions to the government. Chapter 3 analyzes the powers of the Dutch parliament, whereas chapter 4 does the same for the German parliament. In chapter 5 the powers and their application by the German and Dutch parliament are compared.

It is found that the Dutch parliament has only two powers focusing on EU affairs. These powers are the right of consent and the scrutiny reserve. The right of consent can only be used when the EC drafts new legislation in the area of freedom, security and justice. This means that this power can only be invoked by the Dutch parliament as a response to specific actions by the EC. On the other hand, the power of scrutiny reserve can be applied at all times. Members of parliament are able to decide whether or not to place a scrutiny reserve on new draft legislation. However, the process of deciding to place a scrutiny reserve is unclear and its application largely depends on a member of parliament having an interest in the subject of the draft legislation.

Next to these aforementioned powers, the Dutch parliament, the Tweede Kamer and Eerste Kamer, has more general scrutiny powers, like the right to ask written or oral questions, enshrined in national law, which can be used to scrutinize the Dutch government both national and EU affairs. However, according to the collected data on the use of these powers, it can be concluded that these powers are only infrequently used to scrutinize the government in EU affairs. There are two main reasons for that. Firstly, there is little reason for parliament to use the powers in cases where the government, i.e. the minister in acting in Council negotations, has little to no power to affect a change in the matter at hand at EU level. Secondly, there is little focus on the European Union as a topic in the Dutch parliament in general as members of parliament are more concerned with national matters than European ones.

The German parliament has similar powers to the Dutch parliament when it comes to general national scrutiny powers vis-à-vis the government. Percentagewise the numbers of how often the German parliament used its powers to scrutinize the government in EU affairs are higher in Germany than in the Netherlands. However, the numbers still show that general national scrutiny powers are not often used in EU affairs. The reason for this is the fact that the German parliament has been vested with particular powers to scrutinize the government on EU affairs. So for scrutiny of EU affairs those particular powers are used and not so much the general national scrutiny powers. The German basic law assigns a role to the German parliament in EU affairs in article 23 GG. This article determines the right of parliament to state its position before the government participates in EU legislative acts. The Bundestag states an average of 30 positions a year and the Bundesrat an average 
of 180 a year. This right to state its position is the right most frequently used by the Bundesrat when it comes to its participation in EU affairs. Next to this right, the Bundestag also has several more options to participate in EU affairs, like the right ask questions (major interpellations and minor interpellations) and the right to hold a debate or put questions tot the government on 'matters of topical interest'.

Another factor that contributes to parliament's ability to scrutinize EU affairs is the size of its civil service. Both parliaments are very dependent on their civil servants. They support the members of parliament in their activities on every level. A large difference between both parliaments is noticeable in size of staffing. In general, the German parliament is 3.5 the size of the Dutch parliament. There are also more civil servants working in the German parliament than there are members of parliament. More than 3000 civil servants work for the Bundestag, which is four to five civil servants per member of parliament. The number of civil servants of the Bundesrat is around 200, which means almost three civil servants per member (not taking into account the civil servants working for the different governments of the states). The Dutch Tweede Kamer has approximately 100 fulltime employees available to support its members, which is less than one civil servant per member. Only twenty-five civil servants are working at the Dutch Eerste Kamer. The significantly smaller workforce of the Dutch parliament will most certainly have an impact on its productivity.

Overall it is found in this dissertation that while the Dutch parliament is less active than the German parliament when it comes to EU affairs, this difference can be explained by virtue of the differences between both parliaments. The German parliament is in every sense bigger than the Dutch. Not only in members but also in civil servants working for parliament. Next to that, some powers of the German parliament are used automatically. For example, when the Bundestag states its position to the government, the government will automatically put a scrutiny reserve on EU level.

Lastly, the role of the German parliament in EU affairs is laid down in legislation. The advantage of this is that it creates a clear overview of powers, procedures, rights and duties of parliament (and the government). Also, this provides clarity in the relationship between those two institutions and the procedures that have to be followed.

As mentioned before, the research question is formulated to be able to make some recommendations to the Dutch parliament. The question Can the Dutch parliament improve its scrutiny of EU affairs in order to do justice to its role under the EU Treaties and its own national role with regard to democratic control and representation? is answered in the following nine recommendations.

The first recommendation is to lay down all the powers of the Dutch parliament in EU affairs (i.e. the agreements between parliament and government and the procedures 
regulating the powers and agreements) in one document like the rules of procedure of parliament or a statutory act. Currently, there is no formal document or act in the Netherlands with all these aforementioned matters in it. This means that there is no overview of all the powers of parliament in EU affairs and agreements made between parliament and the government. The recommendation is to follow the German example and collect all the matters (right, obligations, agreements, powers) that play a role in EU affairs in one statutory act in order to to make it easier for parliamentarians to make use of it.

Second, the procedures for the use of such powers should be improved/elaborated. For some important powers, such as the scrutiny reserve, there are no formal procedures on how and when to use these powers. Such procedures could facilitate the members of parliament to make more and better use of their powers. This could then have the effect of a more solid and effective role of the Dutch parliament in the EU.

Third, the civil service of the Dutch parliament should be expanded. To improve the work of parliament and to implement the previous recommendations, the parliament requires more staff. Compared to other parliaments in the EU, Dutch members of parliament are supported by (too) few staff. This has an impact on the productivity of the Dutch parliament, making its members unable to participate in EU affairs even where they might wish to do so.

Fourth, statistics of the Tweede Kamer are not open to the public. There are no public records of activities of members of the Tweede Kamer. It is recommended to keep track of statistics and make them available for the public. Not only will researchers benefit from it but also the general public. Based on those statistics, the public can track the activities of their representatives and hold them accountable for it. Lastly, statistics are also needed for the Tweede Kamer itself in order to evaluate its own activities. Thus, keeping track of statistics is also in its own interest.

Fifth, in the Tweede Kamer one or more members can be appointed as rapporteur. This rapporteur will delve more deeply into a subject or dossier in order to inform the Tweede Kamer. A rapporteur is particularly important for European dossiers because of their complexity. The Tweede Kamer therefore regularly deploys a rapporteur for this purpose. However, already prior to the rapporteur's appointment, it is determined when the rapporteurschip will end, with the consequence that a rapporteur might have to relinquish their file even if the European dossier has not yet brought to an end. It is therefore recommended that the rapporteurschip only ends when the European dossier ends, or when the rapporteurship is no longer needed, instead of on a predetermined date.

Sixth, as mentioned before, "national parliaments contribute actively to the good functioning of the Union", according to article 12 TEU. To fullfil this duty national parliaments have the right to review draft legislation of the EU for its compatibility with the subsidiarity principle. To know whether or not draft legislations is compatible national 
parliaments should actually review the draft legislation. The recommendation for the Tweede Kamer is therefore to review all draft legislation for its compatibility with the subsidiarity principle. Only then one can know if it's compatible.

Seventh, in order to be able to exercise effective scrutiny parliaments need information. And in order to be well informed about the activities on European level it is useful to be well connected to the actors at EU level, in particular within the European Parliament. This recommendation concerns the contact between members of the Tweede Kamer and Eerste Kamer and members of the European Parliament. More concretely, it is recommended that a few members of the European Parliament sit on the parliamentary committees for European Affairs of the Tweede Kamer and Eerste Kamer, as is done in Germany. The advantage of this is the direct contact between the members of the different parliaments so information is easily and quickly passed.

Eighth, the 'normal' European legislative process is not followed for the conclusion of trade agreements between the EU and third countries. There is a separate process that is specifically designed for trade agreements. This means parliament (in practice, the Tweede Kamer) cannot use its competences laid down in EU law. This does not mean, however, that parliament is left empty handed since it can use its 'ordinary' scrutiny competences vis-à-vis the Dutch government, such as the right to ask questions. It is nevertheless recommended to create a procedure on the role of parliament with regard to trade agreements. On the one hand, this makes clear that there is a role for parliament and what this role entails. On the other hand, this ensures that parliament actually perfoms its scrutiny tasks.

Finally, the last recommendation is to establish better interparliamentary cooperation. The aim of better interparliamentary cooperation is to enhance the role of national parliaments in the EU. The Early Warning System and the Political Dialogue are two instruments that require cooperation between national parliaments to be effective. The more use is made of these instruments, the more likely it is the EC will take the opinion of the national parliaments into account. By that, national parliaments can have a say in the EU. 


\section{M PACT PA R A G R A A F}

\section{INLEIDING}

Het promotiereglement van de Universiteit Maastricht beschrijft de impactparagraaf als volgt; '(...) een reflectie in lekentaal over de wetenschappelijke impact van de resultaten uit het promotieonderzoek dat is beschreven in het proefschrift, en indien van toepassing ook de reeds behaalde of de te verwachten maatschappelijke impact.'. Aan de hand van een viertal vragen zal de impact van dit proefschrift worden uitgelegd. Ten eerste zal worden ingegaan op het hoofddoel van het onderzoek dat beschreven is in het proefschrift en wat de belangrijkste resultaten en conclusies zijn (paragraaf 2). Vervolgens wordt in paragraaf 3 (relevantie) beschreven wat de (potentiële) bijdrage van de resultaten uit het onderzoek aan de wetenschap zijn, en indien van toepassing aan maatschappelijke sectoren en maatschappelijke uitdagingen. In paragraaf 4 (doelgroep) wordt een antwoord gegeven op de vraag voor wie de onderzoeksresultaten interessant, dan wel relevant zijn. In de vijfde en laatste paragraaf (activiteit) gaat over de wijze waarop deze doelgroepen kunnen worden betrokken bij en geïnformeerd worden over de onderzoeksresultaten, zodat de opgedane kennis in de toekomst kan worden gebruikt?

\section{ONDERZOEK}

Het doel van het onderzoek is het achterhalen van de verschillen en overeenkomsten tussen het Nederlandse en het Duitse parlement waar het hun activiteiten in Europese aangelegenheden betreft. De onderzoeksvraag die hierbij is gesteld is als volgt: In welke mate maakt het Nederlandse parlement van de hem toekomende bevoegdheden naar nationaal en Europees recht gebruik voor wat betreft Europese aangelegenheden? Om de uitkomsten te vergelijken wordt deze vraag ook voor het Duitse parlement beantwoord. Tot slot wordt een antwoord op de centrale vraag gegeven, namelijk: Kan het Nederlandse parlement zijn controle ten aanzien van Europese aangelegenheden verbeteren, al dan niet naar Duits voorbeeld, teneinde recht te doen aan het VEU, en de eigen nationale rol die het heeft ten aanzien van controle en vertegenwoordiging?

De belangrijkste conclusies van dit onderzoek zijn dat het Nederlandse parlement in mindere mate gebruik maakt van de hem toekomende bevoegdheden dan het Duitse parlement. De redenen hiervoor zijn onder andere de grootte van het Duitse parlement. De Duitse Bundestag is ongeveer 4,5 keer groter dan de Nederlandse Tweede Kamer. Tevens 
zijn er in verhouding, maar ook in absolute zin, veel meer ambtenaren werkzaam in het Duitse parlement dan in het Nederlandse parlement. Dit brengt mee dat er simpelweg meer werk verzet kan worden in Duitsland dan in Nederland. Het verschil tussen beide parlementen komt ook door de manier waarop verschillende processen zijn ingericht. De hogere aantal activiteiten van het Duitse parlement ligt dus ook in de efficiëntie van de werkprocessen.

Beide parlementen maken echter het meest gebruikt van de hun naar nationaal recht toekomende bevoegdheden. Ook hiermee kunnen zij een rol spelen in Europese besluitvorming. Dit wordt gedaan door de eigen minister te controleren die zitting heeft in de Raad.

Het onderzoek toont tevens aan dat de inzet van controlebevoegdheden in beide parlementen in absolute zin aan de lage kant is. Dat heeft enerzijds daarmee te maken dat het niet altijd zinvol is om bevoegdheden in te zetten wanneer bijvoorbeeld de minister weinig kan doen op Europees niveau. Het ligt dan niet voor de hand om de minister te controleren. Anderzijds zijn deze percentages te verklaren door het gebrek aan interesse in, en kennis van, Europa.

Gesteld kan worden dat nationale parlementen, krachtens artikel 12 VEU, de taak hebben actief bij te dragen aan het goede functioneren van de Europese Unie. Het onderzoek laat zien dat nationale parlementen meer gebruik dienen te maken van hun bevoegdheden om deze taak uit te voeren. Voor het Nederlandse parlement kan de uitvoering verbeterd worden door enkele aanpassingen door te voeren. De aanbevelingen hiertoe zijn deels gebaseerd op het Duitse systeem. In het kort komen de aanbevelingen neer op:

- Verzamel alle bevoegdheden, procedures en afspraken en leg deze vast in één document.

- Maak een duidelijke procedure voor (het beëindigen van) een rapporteurschap.

- Toets alle Europese wetgevingsvoorstellen op subsidiariteit.

- Stel criteria en richtlijnen op om de inzet van rapporteurs en het parlementair behandelvoorbehoud te bevorderen.

- Laat leden van het Europees Parlement zitting nemen (zonder stemrecht) in de Kamercommissies voor Europese Zaken.

- Zorg voor parlementaire betrokkenheid bij handelsverdragen en andere grote dossiers.

- Breid het ambtenarenapparaat van de Staten-Generaal uit.

- Houd statistieken bij en maak deze openbaar.

- Zorg voor een betere samenwerking tussen nationale parlementen. 
De rol van nationale parlementen in de Europese Unie is een onderwerp dat met enige regelmaat onderzocht dient te worden. Dit onderzoek vormt een bijdrage aan het algemene grote onderzoek naar nationale parlementen omdat het een alomvattend onderzoek betreft en dus niet een deelaspect. Tevens betreft het een recent onderzoeken dat is gedaan na de inwerkingtreding van het Verdrag van Lissabon. De maatschappelijke relevantie van dit onderzoek ligt in de bijdrage aan het nationale en Europese debat over de rol van nationale parlementen in de Europese Unie. Dit debat zal mijns inziens nog lang aanhouden omdat de meningen en standpunten over dit onderwerp verschillend zijn. Dit onderzoek draagt bij aan de juridische kant van het debat. Het onderzoek naar deze twee specifieke nationale parlementen geeft een overzicht van de activiteiten van deze parlementen. Op basis van de verzamelde gegevens kan bepaald worden wat (in praktijk) de rol van het Nederlandse en het Duitse parlement is in de Europese Unie en hoe sterk of zwak deze rol is. Door deze analyse is het mogelijk om bepaalde verbeterpunten van nationale parlementen te achterhalen. Met betrekking tot deze zwaktes worden in dit onderzoek aanbevelingen gedaan. Deze aanbevelingen zien op het versterken van het Nederlandse parlement. Hierdoor zou het parlement zijn bevoegdheden beter kunnen uitoefenen en wellicht met een beter resultaat (dat wil zeggen meer invloed op Europese besluitvorming). Hetgeen daarnaast waardevol is, is dat de verzamelde data is gerangschikt waardoor een overzicht van de activiteiten van de nationale parlementen is gecreëerd. Een dergelijk overzicht is nog niet publiekelijk beschikbaar. Dit overzicht is van waarde voor parlementariërs, omdat ze hierdoor kunnen zien wat de impact is van hun eigen handelen en kunnen hiermee aan de bevolking die zijn representeren laten zien wat ze (niet) doen. Daarnaast is het ook in het belang van parlementariërs om te zien waar verbeteringen mogelijk zijn.

Het innovatieve karakter van dit onderzoek is dan ook gelegen in het feit dat ten aanzien van de activiteiten van de Tweede Kamer met betrekking tot Europese aangelegenheden tot op heden geen (openbaar) overzicht is, zoals zojuist aangegeven. In dit onderzoek is schematisch weergegeven hoe vaak de Tweede Kamer haar bevoegdheden inzet om de Europese Commissie of de Nederlandse regering te controleren op Europees beleid. Aan de hand van de vergelijking van dit overzicht met dat van Duitsland is inzichtelijk gemaakt hoe (in)actief het Nederlandse parlement is met betrekking tot controle van Europees beleid en waar verbeteringen kunnen worden doorgevoerd. 


\section{DOELGROEP}

De onderzoeksresultaten zijn uiteraard relevant voor de wetenschap omdat het, zoals hierboven beschreven, bijdraagt aan het debat over nationale parlementen. Daarnaast is dit onderzoek in de eerste plaats relevant voor parlementariërs van nationale parlementen. Dit betreft met name de parlementariërs van het Nederlandse en Duitse parlement. Op basis van dit onderzoek is voor parlementariërs te achterhalen hoe groot hun rol, dan wel hoe groot de rol van het nationale parlement, is in Europese aangelegenheden en op welke punten verbeteringen mogelijk zijn. Dit laatste geldt ook voor de ambtenaren die werkzaam zijn voor nationale parlementen. Zij ondersteunen de parlementariërs in hun werkzaamheden. Ambtenaren maken dus deel uit van de werking van het parlement. Sterker nog: de werking van het parlement is afhankelijk van ambtenaren. Het is niet voor niets dat een van de aanbevelingen ziet op de vergroting van het ambtenarenapparaat. Ook de ambtenaren van de regeringen van de lidstaten, als ook de ambtenaren die op Europees niveau werken, behoren tot de doelgroepen waarvoor dit onderzoek is gedaan. Tot slot is ook de Nederlandse en Duitse bevolking een doelgroep. De invloed van de Europese Unie op de lidstaten is een beladen onderwerp onder de bevolking. Dit onderzoek laat zien dat er ook invloed kan worden uitgeoefend op de Europese Unie door de lidstaten. Het onderzoek kan de bevolking van kennis voorzien om zo de plaats van nationale parlementen in de Europese Unie beter te begrijpen en om eventueel de gekozen parlementariërs ter verantwoording te roepen voor hun werkzaamheden.

\section{Activiteit}

Het onderzoek resulteert in negen concrete aanbevelingen aan het Nederlandse parlement. Deze kunnen worden overgenomen en geïmplementeerd in het Nederlandse systeem. Meer concreet wordt het volgende aanbevolen; (1) verzamel alle bevoegdheden, procedures en afspraken en leg deze vast in één document, (2) maak een duidelijke procedure voor (het beëindigen van) een rapporteurschap, (3) toets alle Europese wetgevingsvoorstellen op subsidiariteit, (4) stel criteria en richtlijnen op om de inzet van rapporteurs en het parlementair behandelvoorbehoud te bevorderen, (5) laat leden van het Europees Parlement zitting nemen (zonder stemrecht) in de Kamercommissies voor Europese Zaken, (6) zorg voor parlementaire betrokkenheid bij handelsverdragen en andere grote dossiers (7) breid het ambtenarenapparaat van de Staten-Generaal uit, (8) houd statistieken bij en maak deze openbaar en (9) zorg voor een betere samenwerking tussen nationale parlementen.

Deze laatste aanbeveling is gericht tot de parlementariërs en zou enigszins eenvoudig gerealiseerd kunnen worden. Voor de andere aanbevelingen is meer werk nodig en zijn 
meer partijen betrokken. Desondanks zijn het geen puur theoretische aanbevelingen maar kunnen deze allemaal in praktijk gerealiseerd worden. Daarnaast zijn de onderzoeksresultaten vertaald en vormgegeven in een aantal (bijdragen aan) publicaties. ${ }^{1}$

Of de aanbevelingen worden gerealiseerd is afhankelijk van het Nederlandse parlement en de regering. Mijns inziens zijn alle aanbevelingen te realiseren en is die realisatie ervan ook nodig. Een van de aanbeveling betreft het verzamelen en vastleggen van bevoegdheden. Hiervoor is een initiatiefvoorstel aanhangig in de Tweede Kamer. ${ }^{2}$ In dit voorstel wordt de informatievoorziening tussen de regering en het parlement vastgelegd. Dit zou uitgebreid kunnen worden tot een zogenoemde Europawet door alle bevoegdheden, procedures en afspraken met betrekking tot de EU op te nemen in deze wet. Voor de realisatie van de andere aanbevelingen is geen nieuwe wet nodig maar een wijziging in beleid. Het bijhouden en openbaren van statistieken van de Tweede Kamer moet mogelijk zijn. De Eerste Kamer is hierin al zeer actief. Nu zal het voor de Tweede Kamer meer tijd en energie kosten, maar deze investering is in het democratisch belang omdat de werkzaamheden van het parlement zo beter inzichtelijk zijn voor wetenschappers, journalisten en burgers. Het bijhouden en openbaren van statistieken is ook van belang voor de Tweede Kamer zelf om bijvoorbeeld een beeld te krijgen van het eigen handelen. Het uitbreiden van het ambtenarenapparaat is niet alleen een aanbeveling uit de wetenschap maar ook een wens van de Nederlandse parlementariërs. Hiervoor is niet alleen tijd maar ook geld nodig. Een dergelijke uitbreiding zal waarschijnlijk jaren duren. Ook wordt een betere samenwerking tussen nationale parlementen aanbevolen. De realisatie hiervan kan niet enkel door het Nederlandse en het Duitse parlement worden gedaan maar hiervoor zijn alle nationale parlementen in de Europese Unie nodig. Desondanks kunnen het Nederlandse en het Duitse parlement wel het initiatief nemen en een voorbeeld vormen voor andere nationale parlementen.

Tot slot zal dit onderzoek verder vorm krijgen in de publicatie van wetenschappelijke artikelen met het onderwerp nationale parlementen in de Europese Unie.

1 Zie onder andere: S. Wolf, De invloed van nationale parlementen op Europese besluitvorming: De mogelijkheden van het nationale parlement om invloed uit te oefenen op Europese besluitvorming: Het lijkt weinig maar het is veel. Den Haag: Montesquieu Instituut, De Hofvijver 6(70); S. Wolf, De kwestie-Mijer (1866). Hoe 'politieke zonden' mede resulteerden in een kernregel in het Nederlandse staatsrecht. In Zonden in de politiek: Jaarboek Parlementaire Geschiedenis 2016. Amsterdam: Boom. pp. 32-39; A.W.Heringa, H.T. Nguyen, S. Wolf, EU Legitimacy: Squaring the triangle. Den Haag: Montesquieu Instituut. (Montesquieu Policy Papers; 7); S. Wolf, Het nationale parlement ook als EU-parlement?. Den Haag: Montesquieu Instituut, De Hofvijver 9(97).

2 Kamerstukken II 2016/17, 34695, nr. 2. 



\section{DA N K WOOR D}

Het schrijven van een proefschrift doe je niet alleen. Weliswaar heb ik het boek geschreven maar er komt meer bij kijken dan alleen het schrijfwerk. Ik zou dan ook graag de mensen bedanken die een bijdrage hebben geleverd aan de totstandkoming van dit proefschrift.

In de eerste plaats zijn dat mijn promotor Aalt Willem Heringa en copromotor Sascha Hardt. Dank voor jullie commentaar, positieve feedback, jullie geduld (het heeft 'even' geduurd voordat dit boek af was) en vertrouwen in mij. Ondanks dat ik met mijn hart in mijn keel naar elk gesprek ging (dat lag aan mij en niet aan jullie), heb ik onze gesprekken als plezierig ervaren. Niet alleen bespraken we alle serieuze dingen, maar was er ook ruimte voor gezelligheid waardoor ik een stuk wijzer ben geworden op het gebied van hardlopen, wielrennen en tuinieren. Dank voor alles dat ik van jullie heb geleerd.

Daarnaast wil ik de leden van de beoordelingscommissie, prof. dr. B.H. van den Braak, prof. dr. J.Th.J. van den Berg, prof. mr. dr. A. van den Brink en prof. mr. dr. W. van der Woude hartelijk danken voor het lezen en beoordelen van het manuscript en het deelnemen aan de oppositie.

My friend, my partner in crime and my paranymph Thu, I could not have done this without you, thank you! Benthe, jij bent de paranimf van mijn leven! Jij steunt mij als het nodig is maar vertelt me ook wanneer ik me aanstel. Ga daar vooral mee door.

Ook ben ik dank verschuldigd aan mijn collega's van de rechtenfaculteit in Maastricht. Ik heb een hele plezierige tijd gehad in Maastricht en dat komt omdat ik zulke toffe collega's had. Mijn collega's van de Eerste Kamer mag ik niet vergeten. Ik ben blij dat ik met zoveel leuke collega's werk. Jullie zorgen ervoor dat ik mij thuis voel bij de Eerste Kamer.

Veel dank gaat ook uit naar al mijn vrienden. Ik zal geen namen noemen want wat als ik iemand vergeet?! Jullie zijn heel belangrijk voor mij en hebben een grote bijdrage geleverd aan de totstandkoming van dit boek zonder dat jullie dat zelf weten.

Tot slot wil ik mijn familie bedanken voor hun getoonde interesse en steun. Om te beginnen met Rob en Sandra, Marieke en Simon, Luuk, Jessie en Thijs. Ik had geen betere schoonfamilie kunnen wensen. Bedankt voor jullie betrokkenheid en dat jullie mij het gevoel geven altijd welkom te zijn. 
In het bijzonder dank ik mijn zus Charlotte, schoonbroer Samuel en broer Moritz voor jullie begrip en luisterend oor en Olivia, Max en Iris voor alle knuffels die ik heb gekregen.

Mijn ouders ben ik zeer veel dank verschuldigd. Aan jullie draag ik dit boek dan ook op. Dank voor jullie onvoorwaardelijke steun en liefde.

Mijn grootste steun en toeverlaat ben jij, Simon. Jij weet nu, misschien ongewild, ook het een en ander over nationale parlementen in de Europese Unie, maar je weet dat we daar, na vandaag, nooit meer over hoeven te spreken. Regelmatig zag ik het niet meer zitten en wilde ik het liefst het boek in de prullenbak gooien. Jij motiveerde mij telkens weer om door te gaan. Als jij dat niet had gedaan dan was dit boek er nooit gekomen. Dank je wel dat je er voor me bent! Tot slot nog een knuffel en een kus voor Isabella. 


\section{Curriculum Vitae}

Sofie Wolf (Roermond, 1985) studeerde Nederlands recht aan de Universiteit Maastricht en een semester aan de University of Glasgow in Schotland. Van 2011 tot 2013 volgde zij de master Nederlands recht met de profielen Staats- en Bestuursrecht en Privaatrecht. Tijdens haar master werkte ze als student-assistent bij de afdeling Juridische Zaken van de Universiteit Maastricht. Na haar studie werd Sofie aangesteld als juriste bij deze afdeling. Vanaf februari 2014 combineerde zij dit met de functie van docent Staats- en Bestuursrecht bij de capaciteitsgroep publiekrecht van de rechtenfaculteit van de Universiteit Maastricht. In 2015 kreeg zij een fulltime aanstelling als docent bij de rechtenfaculteit en werkte ze hier tevens aan haar proefschrift. Van juli 2019 tot april 2021 was Sofie werkzaam als universitair docent Staatsrecht aan de Erasmus Universiteit Rotterdam. Sinds mei 2021 werkt ze als stafmedewerker voor de Eerste Kamer der Staten-Generaal. 